"Approved for public release; distribution is unlimited."

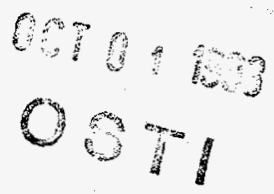

\title{
Bioavailability of Sediment-Bound \\ Contaminants to Marine Organisms
}

\author{
B. Brown \\ J. Neff
}

Battelle/Marine Sciences Laboratory

Sequim, Washington

September 1993

Prepared for

National Ocean Pollution Program Office

National Oceanic and Atmospheric Administration under a Related Services Agreement

with the U.S. Department of Energy

Contract DE-AC06-76RLO 1830

Pacific Northwest Laboratory

Operated for the U.S. Department of Energy

by Battelle Memorial Institute 


\title{
DISCLAIMER
}

This report was prepared as an account of work sponsored by an agency of the United States Government. Neither the United States Government nor any agency thereof, nor Battelle Memorial Institute, nor any of their employees, makes any warranty, expressed or implied, or assumes any legal liability or responsibility for the accuracy, completeness, or usefulness of any information, apparatus, product, or process disclosed, or represents that its use would not infringe privately owned rights. Reference herein to any specific commercial product, process, or service by trade name, trademark, manufacturer, or otherwise does not necessarily constitute or imply its endorsement, recommendation, or favoring by the United States Government or any agency thereof, or Battelle Memorial Institute. The views and opinions of authors expressed herein do not necessarily state or reflect those of the United States Government or any agency thereof.

\author{
PACIFIC NORTHWEST LABORATORY \\ operated by \\ BATTELLE MEMORIAL INSTITUTE \\ for the \\ UNITED STATES DEPARTMENT OF ENERGY. \\ under Contract DE-AC06-76RLO 1830
}

Printed in the United States of America

Available to DOE and DOE contractors from the

Office of Scientific and Technical Information, P.O. Box 62, Oak Ridge, TN 37831; prices available from (615) 576-8401. FTS 626-8401.

Available to the public from the National Technical Information Service, U.S. Department of Commerce, 5285 Port Royal Rd., Springfield, VA 22161. 


\section{DISCLAIMER}

Portions of this document may be illegible in electronic image products. Images are produced from the best available original document. 
BIOAVAILABILITY OF SEDIMENT-BOUND CONTAMINANTS TO MARINE ORGANISMS
B. Brown ${ }^{(a)}$
J. Neff $f^{(b)}$

Battelle/Marine Sciences Laboratory

Sequim, Washington

September 1993

Prepared for the

National Ocean Pollution Program Office

National Oceanic and Atmospheric Administration

under a Related Services Agreement

with the U.S. Department of Energy

Contract DE-ACO6-76RLO 1830

Pacific Northwest Laboratory

Richland, Washington 99352

(a) Colby College, Waterville. Maine.

(b) Battelle Ocean Sciences, Duxbury, Massachusetts. 
-

-

○ 


\section{CONTENTS}

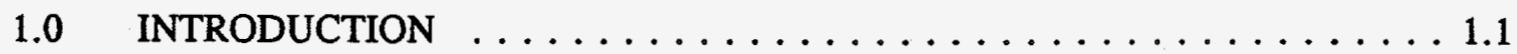

2.0 FORMS AND REACTIVITY OF CONTAMINANTS IN SEDIMENTS $\ldots \ldots 2.1$

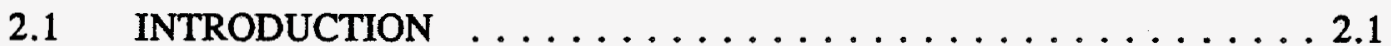

2.2 PHYSICAL PROPERTIES OF MARINE SEDIMENTS $\ldots \ldots \ldots \ldots \ldots . . . .4$

2.3 CHEMICAL REACTIONS IN SEDIMENTS . . . . . . . . . . 2.6

2.3.1 Changes in Redox Potential and $\mathrm{pH} \ldots \ldots \ldots \ldots \ldots \ldots$

2.3.2 Reduction/Dissolution of Iron and Manganese Hydrous Oxides . . 2.9

2.3 .3 Reduction of Sulfur $\ldots \ldots \ldots \ldots \ldots \ldots \ldots \ldots \ldots \ldots$

2.3.4 Oxidizable Organic Substrates in Sediments . . . . . . . . 2.12

3.0 METALS IN MARINE SEDIMENTS $\ldots \ldots \ldots \ldots \ldots \ldots \ldots \ldots \ldots$

3.1 INTRODUCTION $\ldots \ldots \ldots \ldots \ldots \ldots \ldots \ldots \ldots \ldots \ldots \ldots \ldots \ldots$

3.2 PHYSICAL AND CHEMICAL FORMS OF METALS IN

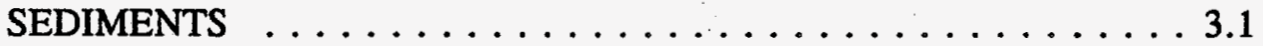

3.3 DETERMINATION OF THE FORMS OF METALS IN

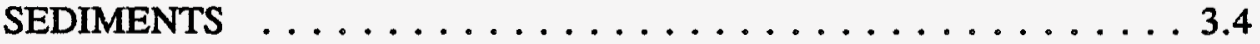

3.4 BEHAVIOR OF SELECTED METALS IN SEAWATER AND

MARINE SEDIMENTS $\ldots \ldots \ldots \ldots \ldots \ldots \ldots \ldots \ldots$

3.4 .1 Cadmium $\ldots \ldots \ldots \ldots \ldots \ldots \ldots \ldots \ldots \ldots \ldots \ldots \ldots \ldots$

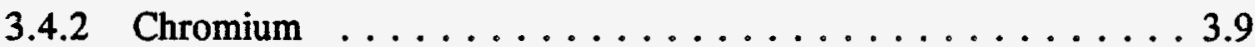

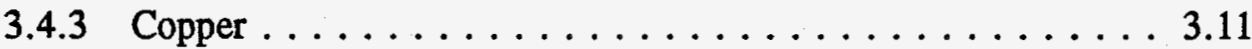

3.4 .4 Lead $\ldots \ldots \ldots \ldots \ldots \ldots \ldots \ldots \ldots \ldots \ldots \ldots \ldots \ldots \ldots \ldots$

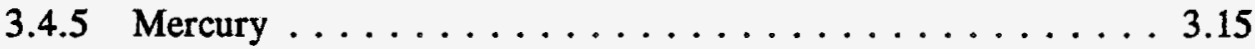

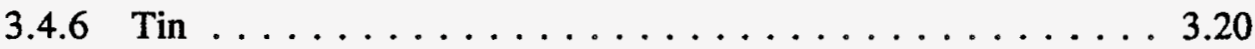

3.4 .7 Nickel $\ldots \ldots \ldots \ldots \ldots \ldots \ldots \ldots \ldots \ldots \ldots . \ldots \ldots \ldots$ 
3.4.8 Silver $\ldots \ldots \ldots \ldots \ldots \ldots \ldots \ldots \ldots \ldots \ldots \ldots . .24$

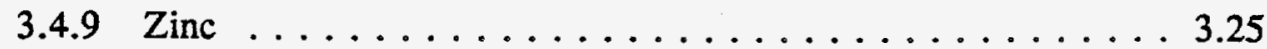

3.4.10 Arsenic . . . . . . . . . . . . . . . . . 3.27

3.4.11 Selenium $\ldots \ldots \ldots \ldots \ldots \ldots \ldots \ldots \ldots \ldots .3 .30$

3.5 DESORPTION OF METALS FROM MARINE SEDIMENTS $\ldots \ldots 3.32$

4.0 ORGANIC CONTAMINANTS IN MARINE SEDIMENTS $\ldots \ldots \ldots \ldots .1$

4.1 INTRODUCTION $\ldots \ldots \ldots \ldots \ldots \ldots \ldots \ldots \ldots \ldots .1$

4.2 NEUTRAL, NONPOLAR ORGANIC CHEMICALS $\ldots \ldots \ldots \ldots .2$

4.3 IONIZABLE, NONPOLAR ORGANIC COMPOUNDS $\ldots \ldots \ldots 4.11$

4.4 POLAR ORGANIC CHEMICALS $\ldots \ldots \ldots \ldots \ldots \ldots \ldots .12$

4.5 MASS-LOADING OF ORGANIC CONTAMINANTS

IN SEDIMENTS $\ldots \ldots \ldots \ldots \ldots \ldots \ldots \ldots \ldots \ldots \ldots .13$

4.6 BEHAVIOR OF SELECTED ORGANIC COMPOUNDS IN

SEAWATER AND MARINE SEDIMENTS $\ldots \ldots \ldots \ldots \ldots \ldots 4.14$

4.6.1 Polynuclear Aromatic Hydrocarbons $\ldots \ldots \ldots \ldots \ldots .4 .15$

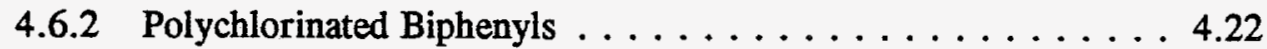

4.6.3 Chlorinated Phenols . . . . . . . . . . . . . . . 4.26

5.0 LIFE STYLES AND FEEDING HABITS OF BENTHIC ORGANISMS $\ldots \ldots 5.1$

5.1 INTRODUCTION $\ldots \ldots \ldots \ldots \ldots \ldots \ldots \ldots \ldots \ldots \ldots \ldots \ldots$

5.2 MORPHOLOGY AND BODY FORM $\ldots \ldots \ldots \ldots \ldots \ldots \ldots .1$

5.3 MOBILITY PATTERNS $\ldots \ldots \ldots \ldots \ldots \ldots \ldots \ldots .4$

5.4 FEEDING $\ldots \ldots \ldots \ldots \ldots \ldots \ldots \ldots \ldots \ldots \ldots \ldots \ldots \ldots \ldots \ldots \ldots$

5.4 .1 Deposit-Feeding $\ldots \ldots \ldots \ldots \ldots \ldots \ldots \ldots \ldots$

5.4 .2 Suspension-Feeding $\ldots \ldots \ldots \ldots \ldots \ldots \ldots \ldots \ldots \ldots$

5.4 .3 Predation $\ldots \ldots \ldots \ldots \ldots \ldots \ldots \ldots \ldots \ldots \ldots .10$ 
5.4 .4 Uptake of Dissolved Organic Matter . . . . . . . . 5.10

5.4 .5 Herbivory and Omnivory $\ldots \ldots \ldots \ldots \ldots \ldots \ldots \ldots \ldots \ldots$

5.5 BIOTURBATION/BIODEPOSITION ............ 5.13

5.5 .1 Biodeposition . . . . . . . . . . . . . . . 5.14

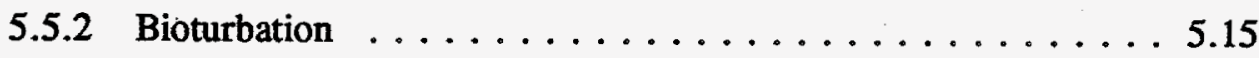

$5.6 \quad$ SEAGRASSES ...................... 5.22

5.6 .1 Introduction $\ldots \ldots \ldots \ldots \ldots \ldots \ldots \ldots \ldots \ldots \ldots \ldots \ldots \ldots$

5.6.2 Interactions Between Seagrasses and Marine Sediment ... . 5.23

6.0 BIOACCUMULATION AND BIOAVAILABILITY OF SEDIMENT-

BOUND METALS $\ldots \ldots \ldots \ldots \ldots \ldots \ldots \ldots \ldots \ldots \ldots \ldots \ldots \ldots \ldots$

6.1 INTRODUCTION $\ldots \ldots \ldots \ldots \ldots \ldots \ldots \ldots \ldots \ldots \ldots \ldots$

6.2 POTENTIAL SOURCES OF METALS FOR UPTAKE $\ldots \ldots \ldots \ldots .3$

6.3 FACTORS INFLUENCING BIOAVAILABILITY OF

SEDIMENT-BOUND METALS . . . . . . . . . . . . . 6.9

6.3 .1 Organic Matter $\ldots \ldots \ldots \ldots \ldots \ldots . \ldots \ldots . \ldots \ldots$

6.3.2 Sediment Grain Size and Type ............. . 6.11

6.3 .3 Seasons $\ldots \ldots \ldots \ldots \ldots \ldots . \ldots \ldots \ldots \ldots \ldots$

6.3.4 Salinity, Rainfall, and Temperature ..........6.13

6.3.5 Age/Size/Weight/Life Stage . . . . . . . . . . . 6.14

6.3.6 Sex or Reproductive Condition ............ 6.16

6.3.7 Species Differences and Feeding Types . . . . . . . . . 6.17

6.3 .8 Adaptation/Evolution . . . . . . . . . . . . 6.20

6.3 .9 Other Factors $\ldots \ldots \ldots \ldots \ldots . \ldots \ldots . \ldots \ldots$

6.4 METAL BIOAVAILABILITY AND BIOACCUMULATION . . . . 6.21

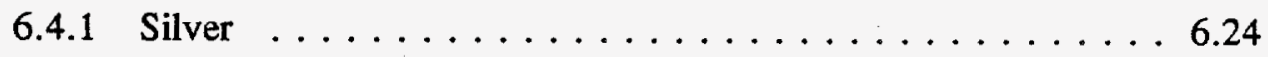


6.4 .2 Arsenic $\ldots \ldots \ldots \ldots \ldots \ldots \ldots \ldots \ldots \ldots .25$

6.4 .3 Cadmium $\ldots \ldots \ldots \ldots \ldots \ldots \ldots \ldots \ldots \ldots .26$

6.4.4 Chromium .................... 6.28

6.4 .5 Copper $\ldots \ldots \ldots \ldots \ldots \ldots \ldots \ldots \ldots \ldots .6 .28$

6.4 .6 Iron $\ldots \ldots \ldots \ldots \ldots \ldots \ldots \ldots \ldots \ldots .6 .30$

6.4 .7 Mercury $\ldots \ldots \ldots \ldots \ldots \ldots \ldots \ldots \ldots .6 .30$

6.4.8 Manganese $\ldots \ldots \ldots \ldots \ldots \ldots \ldots \ldots \ldots \ldots .6 .31$

6.4 .9 Lead $\ldots \ldots \ldots \ldots \ldots \ldots \ldots \ldots \ldots \ldots \ldots .32$

6.4 .10 Zinc $\ldots \ldots \ldots \ldots \ldots \ldots \ldots \ldots \ldots \ldots \ldots .32$

6.5 METALS IN TISSUES OF MARINE ANIMALS $\ldots \ldots \ldots \ldots \ldots .34$

6.5 .1 Molluscs . . . . . . . . . . . . . . . 6.34

6.5 .2 Crustaceans $\ldots \ldots \ldots \ldots \ldots \ldots \ldots \ldots \ldots .6 .37$

6.5.3 Polychaetes $\ldots \ldots \ldots \ldots \ldots \ldots \ldots \ldots \ldots \ldots .6 .38$

6.5 .4 Echinoderms $\ldots \ldots \ldots \ldots \ldots \ldots \ldots \ldots \ldots .6 .38$

6.5.5 Vertebrates . . . . . . . . . . . . . . . 6.39

6.5.6 Excretion and Storage of Metals . . . . . . . . . . 6.39

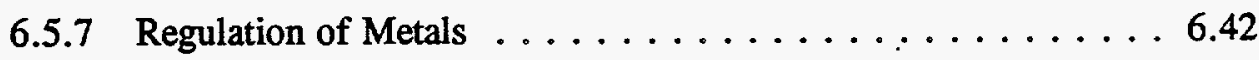

6.6 BIOACCUMULATION FACTORS FOR METALS

FROM SEDIMENTS $\ldots \ldots \ldots \ldots \ldots \ldots \ldots \ldots \ldots .45$

6.7 BIOAVAILABILITY AND BIOACCUMULATION OF METALS

BY SEAGRASSES $\ldots \ldots \ldots \ldots \ldots \ldots \ldots \ldots \ldots \ldots .47$

7.0 BIOACCUMULATION AND BIOAVAILABILITY OF

ORGANIC CONTAMINANTS $\ldots \ldots \ldots \ldots \ldots \ldots \ldots \ldots \ldots \ldots \ldots$

7.1 INTRODUCTION $\ldots \ldots \ldots \ldots \ldots \ldots \ldots \ldots \ldots \ldots \ldots \ldots \ldots$

7.2 POTENTIAL SOURCES OF ORGANIC CONTAMINANTS

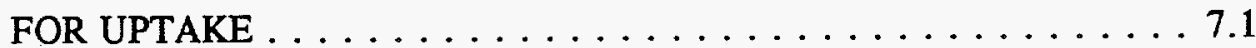


7.2.1 PAH and Other Petroleum Hydrocarbons $\ldots \ldots \ldots . \ldots .2$

7.2.2 Polychlorinated Biphenyls $\ldots \ldots \ldots \ldots \ldots \ldots \ldots$

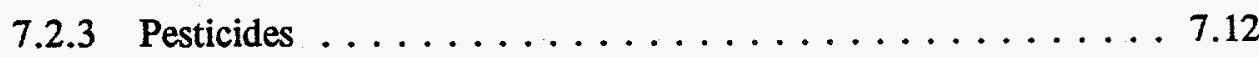

7.3 FACTORS INFLUENCING BIOAVAILABILITY AND

BIOACCUMULATION OF ORGANIC CONTAMINANTS $\ldots \ldots \ldots 7.16$

7.3 .1 Feeding Types $\ldots \ldots \ldots \ldots \ldots \ldots \ldots \ldots \ldots \ldots$

7.3.2 Concentration and Chemical Form . . . . . . . . 7.16

7.3.3 Acquired Tolerance and Adaption ............ 7.18

7.3.4 Sediment Grain Size . . . . . . . . . . . . . . 7.19

7.3.5 Total Organic Carbon $\ldots \ldots \ldots \ldots \ldots \ldots . \ldots \ldots$

7.3.6 Octanol-Water Partition Coefficients $\ldots \ldots \ldots \ldots \ldots . . \ldots 71$

7.3.7 Taxonomic Differences in Organic Contaminant Uptake, Especially as Related to Life Styles and Feeding Habits . . . 7.26

7.4 ORGANIC CONTAMINANTS IN TISSUES OF

MARINE ANIMALS $\ldots \ldots \ldots \ldots \ldots \ldots \ldots \ldots \ldots \ldots \ldots$

7.4 .1 Polychaetes $\ldots \ldots \ldots \ldots \ldots \ldots \ldots \ldots \ldots \ldots \ldots \ldots$

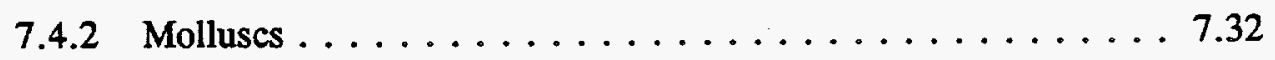

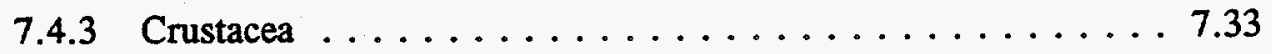

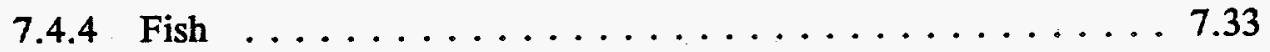

7.4.5 Marine Birds . . . . . . . . . . . . . 7.34

7.4.6 Excretion of Organic Contaminants .......... 7.35

7.5 SUMMARY OF BIOACCUMULATION OF ORGANIC CONTAMINANTS . . . . . . . . . 7.40

7.6 BIOAVAILABILITY AND BIOACCUMULATION OF ORGANIC CONTAMINANTS IN SEAGRASSES . . . . . . . . . . 7.41

8.0 FOOD CHAIN TRANSFER AND POSSIBLE BIOMAGNIFICATION OF METALS AND ORGANIC CONTAMINANTS IN MARINE FOOD WEBS LEADING TO HUMANS $\ldots \ldots \ldots \ldots \ldots \ldots \ldots \ldots . \ldots \ldots \ldots$ 
8.1 INTRODUCTION $\ldots \ldots \ldots \ldots \ldots \ldots \ldots \ldots \ldots \ldots .1$

8.2 TROPHIC TRANSFER AND BIOMAGNIFICATION $\ldots \ldots \ldots \ldots 8.1$

8.2.1 Food Webs $\ldots \ldots \ldots \ldots \ldots \ldots \ldots \ldots \ldots .4$

8.2.2 Methods of Documenting Biomagnification $\ldots \ldots \ldots \ldots .7$

8.2.3 Determination of Trophic Status $\ldots \ldots \ldots \ldots \ldots \ldots 8.8$

8.3 TROPHIC TRANSFER OF METALS $\ldots \ldots \ldots \ldots \ldots \ldots \ldots .11$

8.3.1 Natural Distribution of Metals in Marine Food Webs ... . . 8.11

8.3.2 Mechanisms for Accumulation of Metals from Food ... . 8 8.13

8.3.3 Feeding Studies $\ldots \ldots \ldots \ldots \ldots \ldots \ldots \ldots . \ldots .15$

8.3 .4 Field Studies $\ldots \ldots \ldots \ldots \ldots \ldots \ldots \ldots \ldots \ldots . .25$

8.4 TROPHIC TRANSFER OF ORGANIC COMPOUNDS $\ldots \ldots \ldots .32$

8.4.1 Mechanisms for Accumulation of Organic Contaminants from Food $\ldots \ldots \ldots \ldots \ldots \ldots \ldots \ldots . \ldots .32$

8.4.2 Polychlorinated Biphenyls . . . . . . . . . . . 8.37

8.4.3 Other Halogenated Organic Compounds $\ldots \ldots \ldots \ldots .8 .44$

8.4.4 Polycyclic Aromatic Hydrocarbons $\ldots \ldots \ldots \ldots \ldots .6 .52$

8.5 SUMMARY OF TROPHIC TRANSFER AND

BIOMAGNIFICATION . . . . . . . . . . . . . . . . . 8.59

9.0 SUMMARY AND CONCLUSIONS $\ldots \ldots \ldots \ldots \ldots \ldots \ldots \ldots \ldots$

9.1 INTRODUCTION $\ldots \ldots \ldots \ldots \ldots \ldots \ldots \ldots \ldots \ldots \ldots \ldots$

9.2 THE BENTHIC ENVIRONMENT $\ldots \ldots \ldots \ldots \ldots \ldots \ldots .2$

9.3 BINDING OF CONTAMINANTS TO SEDIMENTS $\ldots \ldots \ldots \ldots .5$

$9.3 .1 \quad$ Metals $\ldots \ldots \ldots \ldots \ldots \ldots \ldots \ldots \ldots \ldots .9 .5$

9.3.2 Organic Chemicals $\ldots \ldots \ldots \ldots \ldots \ldots \ldots \ldots .6$

9.4 BIOACCUMULATION AND BIOMAGNIFICATION OF

CONTAMINANTS FROM SEDIMENTS $\ldots \ldots \ldots \ldots \ldots \ldots .$.

viii 
9.4.1 Bioavailability and Bioaccumulation ........... 9.8

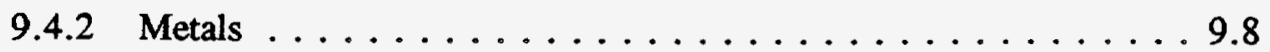

9.4.3 Organic Compounds $\ldots \ldots \ldots \ldots . \ldots \ldots$

9.5 RECOMMENDATIONS FOR ADDITIONAL RESEARCH $\ldots \ldots .9 .14$

9.5 .1 Bioavailability $\ldots \ldots \ldots \ldots \ldots \ldots \ldots \ldots \ldots \ldots \ldots \ldots$

9.5 .2 Metals . . . . . . . . . . . . . . . 9.17

9.5.3 Organic Contaminants $\ldots \ldots \ldots \ldots \ldots . \ldots . \ldots . \ldots . \ldots$

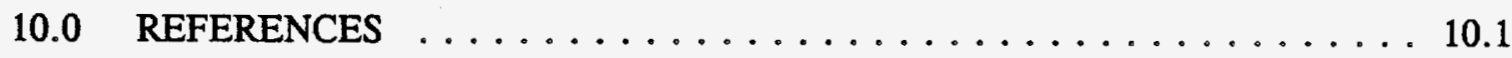




\section{FIGURES}

2.1 Relationship of Porosity to Particle Size in Modern Sediments . . . . . . . 2.18

2.2 Relationship Between $\mathrm{pH}$ and Eh in Natural Waters . . . . . . . . . . . 2.19

2.3 Influence of Ambient $\mathrm{pH}$ and Eh on distribution of Microorganisms in Sediments

2.4 Sequence of Redox Reactions in Water and Sediments $\ldots \ldots \ldots \ldots \ldots \ldots$

2.5 Example of a Proposed Structure for Freshwater Humic Acid . . . . . . . 2.22

2.6 Examples of the Proposed Structures of Marine Fulvic and Humic Acids . . . . 2.23

3.1 The Mercury Cycle in Marine and Freshwater Ecosystems . . . . . . . 3.38

3.2 The Arsenic Cycle in Marine and Freshwater Ecosystems . . . . . . . . . 3.39

3.3 The Biogeochemical Cycle of Selenium in Natural Waters . . . . . . . . 3.40

3.4 Schematic Diagram of a Typical Metal-Enriched Sediment Profile

Exhibiting Metal Migration Caused by Diagenic Reactions and

Bioturbation

5.1 Use of Siphons in Feeding by Bivalves $\ldots \ldots \ldots \ldots \ldots \ldots \ldots \ldots \ldots$

5.2 Distribution of Calcite (A) and Opal (B) Through Out the World's Oceans . . . 5.28

5.3 Zonation of Electron Acceptor Use in Sediments . . . . . . . . . . . . . . . 5.29

6.1 The Role of Metallothioneins and Lysosomes in Metal Homeostasis . . . . . . 6.59

6.2 Metal Reactions Affecting Bioavailability to Deposit-Feeders . . . . . . . . 6.60

6.3 Possible Mechanisms Explaining Fluxes of Ions Into Cells . . . . . . . 6.61

6.4 Possible Pathways of Accumulation of Mechanisms for Loss of heavy Metals in Bivalves .....................6.62

7.1 Schematic of Possible Sources of Organic Contaminants to Marine Animals . . 7.46

8.1 Summary of Trophic Relationships on the Palos Verdes Shelf, California . . 8.72

8.2 Values for $\delta^{13} \mathrm{C}$ in Tissues of Alaska Fauna From the Southwest Bering, Chukchi, and Eastern Beaufort Seas . . . . . . . . . . . . 8.73 
8.3 Relationship Between Body Mass and Concentrations of Cadmium in Tissues of the Clan Scrobicularia plana, From Five British Estuaries . . . . . . 8.74

8.4 Simplified Schematic Representation of the Mechanisms of Uptake of Metals Through Membranes into Tissues of Marine Animals . . . . . . . 8.75

8.5 Concentrations of Total and Organic Mercury in Tissues of Marine Animals From Three Marine Food Webs of the Pacific . . . . . . . . . . . 8.76

8.6 The Distribution of Total Mercury Concentrations in the Tissues of Major Consumer Groups of the Derwent Estuary, Australia, Food Web . . . . . . . 8.77

8.7 The Relationship Between $\log \mathrm{K}_{\mathrm{ow}}$ (a), Molecular Weight (b), and Molecular Volume, (c) of Nonpolar Organic Chemicals and the Efficiency of Absorption From the Gut of Salmonid Fish . . . . . . . . . . 8.78

8.8 Concentrations of Total PCBs and DDTs in Lipids of Marine Animals at Different Trophic Levels in the Coastal Pelagic Food Web of the Southern California Bight (a) and the Palos Verdes Shelf, California, Epibenthic Food Web (b) . . . . . . . . . . . . . . . . . . . . . . . . 8.79

8.9 Mean Concentrations Relative to the Concentrations in the Clam, Macoma balthica, or Group I and Group II PCB Congeners in a Simple Baltic Sea Food Chain ...................... 8.80

8.10 Relationship Between Tropic Level, as Indicated by $\delta^{13} \mathrm{C}$, and Mean Concentrations of Total DDTs in Tissues of Marine Animals From Food Chains Adjacent to the Santa Barbara Wastewater Treatment Plant Outfall and the Joint Water Pollution Control Plant . . . . . . . . .

8.11 Biomagnification Factors of Chlordane Isomers in Dall's Porpoise Phocoenoides dalli and Thick-Billed Murre Uria lomvia From the North Pacific Ocean and Bering Sea

8.12 Relationship Between Trophic Level, as Indicated by $\delta^{15} \mathrm{~N}$, and Concentrations of Polychlorinated Dibenzodioxins and Polychlorinated Dibenzofurans . . . . . . . . . . . . . . . .

8.13 Mean Concentrations of Several Chlorinated Hydrocarbons in the Tissues of Two Marine Animals and Three Marine Mammals from the Canadian Arctic

8.14 Mean Biomagnification Facts of Several Chlorinated Hydrocarbons for Three Trophic Steps in a Canadian Arctic Marine Food Chain

8.15 Mean Concentrations of Several Polycyclic Aromatic Hydrocarbons in Three Components of a Simple Marine Food Chain From the Baltic Sea: Seston, Blue Mussel, and Eider Dick 


\section{TABLES}

2.1 Average Abundance of Clay Mineral Classes in the Clay Fraction of

Sediments From Different Oceans . . . . . . . . . . . . . . . 2.17

2.2. Standard Size Classes of Sediment Particles . . . . . . . . . . . . 2.17

3.1 Typical Background Concentrations of Metals and Other Potentially

Toxic Elements in Clean Surface Seawater, Sediment Pore Water and

Sediments, and Dominant Adsorbed or Complexed Phases of Metals in

Oxic and Anoxic Sediments . . . . . . . . . . . . . . . . . 3.35

3.2 A Comparison of the Range of Binding Capacities for Several Substrates

in Typical Estuarine Sediments . . . . . . . . . . . . . . 3.36

4.1 Regression Equations From the Literature for the Estimation of

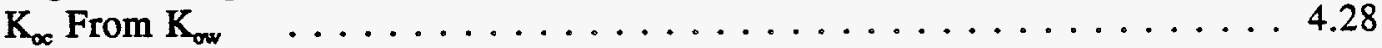

4.2 Physical Properties of Aromatic and Polynuclear Aromatic Hydrocarbons . . . 4.29

$4.3 \quad$ Physical Properties of Polychlorinated Biphenyls . . . . . . . . . . 4.30

4.4 Physical Properties of Selected Chlorinated Phenols . . . . . . . . . . . 4.30

5.1 Animal Types, Body Forms, and Areas of Uptake or Interaction

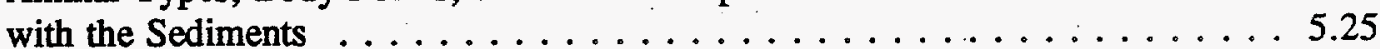

5.2 Feeding/Mobility Classifications and Associated Sediment Modifying

Processes

6.1 Considerations for Designing Experiments on Metal Bioavailability

From Sedimentary Material by Deposit Feeders . . . . . . . . . . 6.51

6.2 Factors with Potential to Affect Bioavailability of Sediment-Bound

Metals to Marine Animals . . . . . . . . . . . . . . . . . . . 6.52

6.3 Prediction of Metal Availability to Marine Benthic Organisms From

Sediment Characteristics . . . . . . . . . . . . . . . . . 6.53

6.4 Transfer Factors From the Literature $\ldots \ldots \ldots \ldots \ldots \ldots . \ldots \ldots$

6.5 Published Bioaccumulation Factors of Organic Contaminants for Marine Organisms ...................... 6.58

7.1 Compendium of Cytochrome 450 and BaP-hydroxylase Activities for Marine Organisms . . . . . . . . . . . . . . . . . 7.42 
7.2 Activity of in vitro Activity of Glutathione s-transerases in Marine Organisms

7.3 Comparison of Expoxide Hydrolase Activity of Marine Organisms Using in vitro Preparations of Liver, Hepatopancrease, or Digestive Gland Extracts

7.4

8.1 Essential Elements Known to Have Biochemical or Physiological Functions in Plants or Animals $\ldots \ldots \ldots \ldots \ldots \ldots \ldots . \ldots \ldots 2$

8.2 Efficiency of Absorption of Metals From Food by Marine Non-Marine Animals . . . . . . . . . . . . . . . 8.63

8.3 Concentrations of Several Metals in Muscle Tissues of Marine Animals at Different Trophic Levels in Three Southern California Food Chains . . . . . 8.64

8.4 Mean Concentrations of Several Metals in Whole Tissues of Marine Animals From a Loire Estuary, France, Food Chain

8.5 Transfer Factors for Metals in Five Species of Fish From the Loire Estuary, France . . . . . . . . . . . . . . . . . . 8.66

8.6 Efficiency of Absorption on Nonpolar Organic Chemicals From Food by Marine and Freshwater Animals . . . . . . . . . . . . 8.68

8.7 Contribution of Various Sources to the Bioaccumulation of Hexachlorobenzene by the Deposit-Feeding Clam, Macoma nasuta . . . . . . 8.70

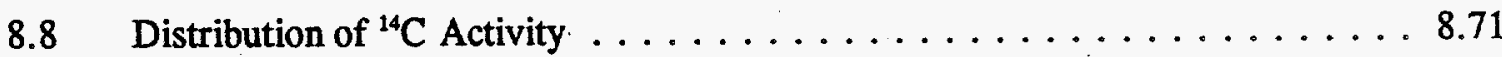




\subsection{INTRODUCTION}

Many solid and liquid wastes entering oceanic, coastal, and estuarine waters through disposal or discharge from point sources contain elevated concentrations of potentially toxic metals and organic chemicals. In addition, large amounts of pollutant chemicals enter coastal waters from non-point sources. Many of these chemicals are in particulate form or are adsorbed to particles. Organic compounds, not already adsorbed to particulate material, may quickly become adsorbed to suspended particles following discharge into the ocean. Metals may adsorb to suspended particles or precipitate with the salts or carbonate in seawater. These particulate chemicals eventually are deposited in bottom sediments where they may persist indefinitely.

Historically, marine sediments have been viewed primarily as sinks for chemical wastes. However, in recent years, a realization has grown that many of these chemicals are not permanently immobilized in the sediments, but may be released back to the overlying water column or be accumulated by marine organisms. The importance of contaminated sediments as a source of pollutant chemicals in the biota and in the water column has led to greater emphasis on the contribution of sediment quality to the overall quality of marine ecosystems (e.g., see Bolton et al. 1985, A.D. Little, Inc. 1987, NOAA 1988).

The growing body of literature dealing with various aspects of the bioavailability of sedimentbound contaminants to marine organisms indicates that there exists a potential for transfer of these contaminants through marine food webs to commercial fisheries products consumed by humans (Malins 1988). "Certain biological compartments such as ... sediment-water interfaces ... can be especially important in relation to bioavailability of pollutants because it appears that pollution can concentrate in these compartments" (NOAA 1988). However, there has been relatively little effort to combine and synthesize data on chemical/biological interactions between benthic animals and seagrasses and the sediments in which they reside on the one hand, and on the chemistry of bioaccumulation on the other. This report provides a conceptual basis for an approach to bioavailability and biomagnification of sediment-bound contaminants that reviews biological and chemical approaches.

"Bioaccumulation" is the uptake and retention by an organism of bioavailable chemicals from all possible external sources (water, food, substrate, air). Chemicals that are taken up from the external medium more rapidly than they are depurated will accumulate in the tissues as long as 
exposure to the chemical continues. The magnitude of bioaccumulation of a chemical, usually measured as the bioaccumulation factor (BAF), is a function of the ratio of the rate of uptake of the chemical to the rate of depuration of the chemical. Chemicals that tend to bind to tissue components or have a high affinity for some tissue component, such as lipids, will tend to have high BAFs.

"Bioavailability" is the degree to which a chemical can be taken up by a living organism by active (biological) or passive (physical or chemical) processes. A chemical is said to be bioavailable when it is in a form that can move through or bind to the surface coating (e.g., skin, gill epithelium, gut lining, cell membrane) of an organism and thereby elicit biological responses. The usual method for measuring the bioavailability of a chemical is to measure its accumulation by organisms exposed to it in the ambient water, food, or sediment. However, it should be recognized that, although a chemical must be bioavailable to be bioaccumulated, bioavailability is not the only determinant of the extent to which a chemical will accumulate in the tissues of an organism. To accumulate, the chemical must also be retained in the tissues of the organism; that is, the rate of uptake by the tissues must be greater than the rate of depuration from the tissues.

Many highly soluble chemicals, such as some inorganic ions, are highly bioavailable and rapidly penetrate into the tissues and cells or aquatic organisms. However, they are not retained, but are lost from the tissues by diffusion or active excretion. Their concentrations in tissues are equal to or lower than their concentrations in the ambient medium. Other bioavailable chemicals are taken up rapidly, but are rapidly transformed and/or excreted by active metabolic processes of the organism, and so are not retained. Chemicals of these sorts, though bioavailable, are not bioaccumulated. It is also possible that some chemicals may elicit toxic biological responses in organisms without being absorbed by or adsorbed to the tissues. However, evidence of this kind of interaction is lacking. These distinctions must be kept in mind in evaluating the bioavailability of different forms of chemicals in different environmental compartments to marine organisms.

Numerous laboratory studies have shown that aquatic organisms can accumulate polynuclear aromatic hydrocarbons, polychlorinated biphenyls, and halogenated hydrocarbons from the water column, sediments, and their diets (e.g., Neff 1979a,b). However, it is also clear from these studies that the bioavailability of toxic material from different sources is not equivalent. It is not sufficient to know the quantity of a contaminant in the marine environment. Proper management also requires an understanding of the form of the chemical and whether it is bioavailable. 
The process of accumulation from food is called trophic transfer. Many of the processes involved in accumulation of contaminants from sediment and water are also included in trophic transfer. However, accumulation occurs mainly or totally in the gut of the consumer.

Biomagnification is the process whereby a chemical is passed through the food chain or web by trophic transfer, its concentration increasing in tissues of organisms at each higher level. Two requirements for biomagnification are (1) the efficiency of uptake of a chemical through the digestive tract must be high and (2) after a chemical has been absorbed from the food by the organism, it must be retained in or bound tightly to the consumer's tissues so that its loss from the organism is low.

In addressing the question of bioavailability of sediment-bound contaminants, forms and reactivity of contaminants, metals and organic contaminants in sediments are reviewed in Chapters 2 , 3 and 4. Next, life styles and feeding habits of benthic animals are reviewed in Chapter 5. Chapters 6 and 7 address bioaccumulation and bioavailability of metals and organic contaminants. Food chain transfer and possible biomagnification are reviewed in Chapter 8. The report concludes with a summary summarizing the key issues in this report (Chapter 9) and provides the list of references used to prepare this report (Chapter 10). The issues discussed herein focus strictly on bioavailability of sediment-bound contaminants with few exceptions. Thus, related topics such as toxicology of these contaminants is not reviewed. 


\subsection{FORMS AND REACTIVITY OF CONTAMINANTS IN SEDIMENTS}

\subsection{INTRODUCTION}

The physical and chemical properties of marine and estuarine sediments have a profound influence on both the biota that live in association with them and the forms and amounts of chemical contaminants that they contain.

Sediments are composed of particles that have settled directly or indirectly from the overlying water column. There are two broad groups of sedimentary particles: (1) solid breakdown products of older deposits; and (2) materials that are not solid breakdown products (Freidman and Sanders 1978). Each of these broad groups can be subdivided further into several types of sedimentary particles.

Particles eroded as solids from land are called terrigenous or detrital particles. Terrigenous particles may be inorganic or carbonaceous (organic). Inorganic terrigenous particles are either rock fragments that have not been altered by weathering or the alteration products of chemical weathering of rocks, chiefly clay minerals. Because of its resistance to chemical weathering, quartz is the dominant mineral in terrigenous sediments. Feldspars, which are the dominant group of silicate minerals in igneous and metamorphic rocks, usually are converted by chemical weathering to clays and so rarely represent more than $10 \%$ to $15 \%$ of modern terrigenous sediments. Many terrigenous sediments also contain heavy minerals. These are minerals derived from igneous and, to a lesser extent, metamorphic rocks. They are resistant to chemical weathering and have densities greater than those of quartz (sp. gr., 2.65) and feldspars (sp. gr., 2.56 to 2.76). The heavy minerals include several silicate minerals as well as oxides, sulfides, and other ore minerals. Many heavy minerals contain high concentrations of one or more heavy metals and may contribute substantially to the heavy metal content of terrigenous sediments.

Clay minerals are fine-grained layer-lattice silicates, predominantly hydrous aluminosilicates. By definition, clays are particles with diameters smaller than $2 \mu \mathrm{m}$. However, the clay fraction of sediment contains not only clay minerals, but also clay-size particles of quartz, feldspar, pyrite, heavy minerals, volcanic glass, iron and manganese oxides, carbonates, and organic particles. The dominant clay minerals in marine sediments are illite, montmorillonite, chlorite, and kaolinite (Griffin et al. 1968). All four types of clay minerals may occur together in a sediment. However, each has a 
different distribution in marine sediments, reflecting the source rocks and the weathering processes to which the rocks have been subjected. For example, chlorite is most abundant in sediments from high latitudes, whereas kaolinite is more abundant in sediments from lower latitudes (Griffin et al. 1968). Montmorillonite is characteristic of a volcanic regime, though some montmorillonites are not derived from chemical weathering of volcanic ash. The most abundant clay minerals in most offshore sediments are montmorillonite and illite (Table 2.1). The dominant clay mineral in Atlantic sediments is illite, whereas the dominant clay mineral in sediments of the South Pacific and Indian Oceans is montmorillonite.

Carbonaceous organic particles in terrigenous sediments may be fossil or modern. Fossil particles include bituminous and anthracite coal, amber, waxes, and kerogens. Kerogens are early diagenic precursors of fossil fuels. They are solid hydrocarbon polymers that are extremely stable and refractory to chemical weathering. Their average abundance in sedimentary rocks is $0.3 \%$ (Freidman and Sanders 1978).

Modern carbonaceous material in sediment is derived primarily from decaying plant material. Plant detritus, including humic and fulvic acids, is abundant in near-shore sediments. Living and dead microbes (bacteria and fungi) and their exudates, meiofauna, and macrofauna usually do not contribute significantly to the total organic carbon of surficial sediments. However, in oxidized intertidal sediments, bacterial biomass may represent from $1 \%$ to $50 \%$ of the sediment total organic carbon (Dales 1974; Tunnicliffe and Risk 1977). They also make important contributions to the diagenic processes affecting metal and organic contaminant distributions and residence times in sediments.

The non-terrigenous components of sediments include pyroclastic particles, cosmogenous particles, and various solids (authigenic particles) derived from biological deposition or chemical precipitation. Pyroclastic particles are derived from volcanic activity and include rock fragments, single crystals, and volcanic glass (Freidman and Sanders 1978). Cosmogenous particles include all sorts of meteorites, tektites, cosmic dust, and magnetic spherules (Goldberg 1964; Brownlee 1981). Although pyroclastic and cosmogenous particles usually are not abundant, they are ubiquitous components of marine sediments.

Biogenic debris is an important component of most marine sediments, particularly deep sea pelagic sediments. Biogenic particles in marine sediments are derived from skeletal structures of many species of marine bacteria, plants, and animals. Most are calcium carbonate; some are silica. 
Important contributors to calcium carbonate deposits are reef-building algae and corals, byrozoans, molluscs, echinoderms, calcareous sponges, forminifera, and coccolithophorids. Most carbonate sediments are coarse-grained and are composed of eroded skeletal fragments. However, some carbonate sediments are very fine-grained, consisting primarily of silt- and clay-sized calcium carbonate particles. Lime muds along the Florida reef tract are derived from microscopic aragonite crystals produced by green algae of the genera, Penicillus, Udotea, and Rhipocephalus (Stockman et al. 1967). Calcareous oozes that cnver vast areas of the abyssal plain of the oceans are derived from the microscopic calcium carbonate skeletal structures of Globigerina (a foraminiferan), coccolithophorids (a chrysophycean alga), and pteropods (a gastropod) (Arrhenius 1963, Barron and Whitman 1981). Foraminiferal oozes cover one third of the earth's surface (Vincent and Berger 1981). Biogenic calcium carbonate does not appear to be an important source of metals in marine sediments (Collier and Edmond 1984a,b).

The contributors of biogenic siliceous particles to sediments include diatoms, radiolareans, dinoflagellates, and siliceous sponges. Siliceous oozes in pelagic sediments are derived primarily from the skeletal remains of planktonic radiolareans and diatoms. They occur primarily in areas of upwelling and high plankton productivity (Kastner 1981).

Seawater is essentially a saturated solution with respect to several minerals. Evaporation, ion exchange reactions, and some other processes may produce a variety of inorganic precipitates in seawater. Examples include ferromanganese minerals, glauconite, phosphorite, barite, porcelanite, and hydromagnesite (Arrhenius 1963, Goldberg 1964). In zones of seafloor spreading in the oceans, hydrothermal vents may discharge large volumes of heated seawater saturated with a wide variety of metals. As the water cools, a variety of metal salts precipitate out and accumulate around the vent (Bonatti 1981). Three types of deposits are common, oxide-hydroxides, silicates, and sulfides. The sulfide deposits may be particularly rich in several metals, including copper, iron, lead, and zinc (Rona 1983). These deposits may accumulate at rates as high as $2 \mathrm{~mm} / 1000$ y (Bonatti 1981). Because deep sea hydrothermal vent systems are a very recent discovery, the extent of vent systems and the polymetallic sulfide deposits associated with them is not well-known (Kaufman 1986).

Ferromanganese deposits are of two types (encrustacions and nodules) and accumulate much more slowly than hydrothermal vent deposits (Halbach 1984). Encrustations are produced by precipitation on the surface of exposed submarine elevations (e.g., the edge of seamounts) where bottom currents, rich in hydrous metal compounds prevent settling of sediment on exposed rock 
surfaces. Ferromanganese nodules accumulate on the surface of abyssal sediments where sedimentation is slow. The nodules grow very slowly by precipitation of metal ions and hydrated metal oxides onto nuclei of biogenic, pyroclastic, or cosmogenous particles.

Because of the tremendous diversity of sources and compositions of particles contributing to marine and estuarine sediments, the composition of sediments in most locations is quite heterogeneous. In addition, sediment composition, particularly in estuarine, coastal, and upper continental shelf areas, often variej substantially over small spacial scales. In estuarine and shallow coastal waters, sediment composition may vary seasonally due to seasonal variability of inputs of particles from different sources (Thomson-Becker and Luoma 1985, Watson et al. 1985). This variability and heterogeneity of sediment composition must be kept in mind in evaluating and predicting sediment/contaminant/biota interactions.

\subsection{PHYSICAL PROPERTIES OF MARINE SEDIMENTS}

Sediment grain size has an extremely important effect on the types of biological communities residing therein and the chemical interactions of the sediments with contaminants (Cauwet 1987). It is useful when studying sediment/contaminant/biota interactions, to subdivide sediments into the following two major groups (Salomons and Förstner 1984):

- Fine-grained sediments smaller than $63 \mu \mathrm{m}$, consisting of silts and clays;

- Coarse sediments larger than $63 \mu \mathrm{m}(0.06 \mathrm{~mm})$, consisting of sands and gravels.

Sediment grain size usually is classified according to either the Wentworth Scale (Wentworth 1922) or the Phi Scale (Table 2.2). In the Phi Scale developed by Krumbein (1936), phi equals the negative $\log$ to the base two of particle diameter in $\mathrm{mm}$. Thus, phi values increase as grain size decreases.

As a general rule, marine sands are composed of angular or rounded particles, depending on the extent of abrasion. The shape of fine-grained particles is more variable (Freidman and Sanders 1978). Clay-sized particles usually are charged, the strength of the charge depending on the size of the clay particles, ionic strength of the water, and the surface coatings on the particle. This surface charge has a strong influence on the cohesive properties of fine-grained sediments. During settling through marine or estuarine waters, clay particles tend to flocculate, forming loose aggregates. When 
deposited, these flocs form an open sediment structure with a large volume of included water (Salomons and Förstner 1984).

The porosity of sediment is dependent on the grain size distribution and the degree of compaction or consolidation of the sediment. Porosity is the volume of interstitial spaces among sediment particles, expressed as a percent of the total volume of the sediment. Thus, porosity is also a measure of the volume of pore water or interstitial water per volume of submerged sediment. For closely packed spheres of uniform diameter, the porosity is $26 \%$ irrespective of particle size (Figure 2.1). However, sediment particles are almost never spherical and most sediments are composed of particles with a range of grain sizes. As a general rule, there is a roughly inverse relationship between grain size and porosity (Figure 2.1). Unconsolidated clays can have porosities up to nearly 90\%. However, compacted clays, particularly if exposed intertidally, may have a porosity of less than $20 \%$. Admixtures of fine and coarse particles usually are less porous than sediments containing nearly pure fine or coarse particles.

Another important physical property of sediments is permeability. Permeability is the capacity of sediment to permit the passage of fluid. The permeability of a sediment to water depends on the size, shape, and degree of connection among pore spaces (Freidman and Sanders 1978), and so is indirectly related to porosity. For closely packed spheres of uniform diameter, the permeability is directly proportional to the diameter squared of the spheres. Although fine-grained sediments are fairly porous unless tightly compacted, they are not very permeable. Movement of water through the minute pore spaces of fine-grained sediments is inhibited by friction, capillary forces, ionic forces, and adsorption (Scheidegger 1957). Addition of even small amounts of fine-grained sediment to course sediment greatly decreases its permeability.

Porosity and permeability have a tremendous effect on the chemistry and biology of sediments. They affect the adsorption/desorption reactions of metal and organic chemicals, including contaminants, in the sediments. They also affect the rate of exchange or flux between pore water and the overlying water, thereby affecting equilibration times between adsorbed and aqueous phases of sediments. Permeable sediments usually remain oxidized to a greater depth than impermeable sediments, favoring habitation by obligate aerobic fauna.

Another physical property of sediments that is affected by grain size is surface area. The total surface area per unit mass of sediment particles, called the specific surface area, increases as sediment grain size decreases. Clays have very large specific surface areas, ranging from 10 to $50 \mathrm{~m}^{2} / \mathrm{g}$ dry wt 
for kaolinite to 50 to $150 \mathrm{~m}^{2} / \mathrm{g}$ for montmorillonite (Förstner and Wittmann 1981). Freshly precipitated iron hydrous oxides derived from Fe (II) have a specific surface area of about 97 to 120 $\mathrm{m}^{2} / \mathrm{g}$ (Crosby et al. 1983). The specific surface area of sediment organic materials (humic acids) may be as high as $1900 \mathrm{~m}^{2} / \mathrm{g}$ (Gapon 1947).

The surface charge of the clay or other fine particles increases with surface area. Thus, the capacity of a sediment to bind metals or organic compounds by cation exchange increases as sediment grain size decreases. Clays have cation exchange capacities of 3 to 120 milli-equivalents/100 g dry wt (Schaffer and Schachtschabel 1966).

In part because of their large binding capacity, fine-grained particles tend to have high-metal concentrations even in uncontaminated sediments (Mayer and Fink 1980, Salomons and Förstner 1984). The coarse fractions of sediment, particularly if they include heavy minerals, may also contain elevated concentrations of metals. The silt and sand fractions of sediment, particularly if they are dominated by quartz or calcium carbonate, generally have low metal concentrations.

Organic carbon and nitrogen, as well as bacteria and many species of meiofauna, are more abundant in fine grained silt/clay sediments than in coarse sediments (Zobell 1938, Newell 1965, Dales 1974). Much of the organic material in fine sediments is in the form of surface coatings on clay particles. Bacteria and meiofauna, and perhaps some macrofauna, utilize these surface coatings for nutrition.

\subsection{CHEMICAL REACTIONS IN SEDIMENTS}

Following deposition, sediment particles undergo a variety of chemical reactions. These chemical reactions, collectively termed early diagenesis, involve both biotic and abiotic reactions that alter the chemical form of many of the inorganic and organic constituents of the sediment. They include oxidation of organic matter, liberation of inorganic nutrients, and a variety of oxidation and reduction reactions. The oxidation and reduction reactions alter the chemical form of the organic and inorganic reactants, change the $\mathrm{pH}$ of the sediment pore water, and change concentrations of electron donors and acceptors. These reactions may result in precipitation or dissolution of various mineral phases at different depths within the sediment (Gardner 1979), resulting in vertical gradients of dissolved or colloidal chemicals in the pore water. Such gradients provide the motive force for diffusive exchange of dissolved substances between the sediment and overlying water. 


\subsubsection{Changes in Redox Potential and $\mathrm{pH}$}

The most intensive diagenic process affecting recently deposited or recently disturbed sediments is a change in the oxidation-reduction (redox) potential of the sediment. The redox potential (Eh) is a measure of the relative intensity of oxidation or reduction in solution or of the concentration of electrons in solution (Freidman and Sanders 1978). The Eh scale is based on the oxidation-reduction of hydrogen. Therefore, the Eh is the equilibrium electrical potential of an oxidation-reduction reaction relative to the electrical potential of a standard hydrogen electrode. Eh values greater than zero indicate oxidizing conditions; those less than zero indicate reducing conditions. Oxidation reactions involve a loss of orbital electrons from the participating elements and an increase in valence number; reduction reactions involve a gain in orbital electrons by participating elements and result in a decrease in the valence number of the cation.

The $\mathrm{Eh}$ and $\mathrm{pH}$ of sediments tend to covary because $\mathrm{Eh}$ is a measure of electron concentration and $\mathrm{pH}$ is a measure of proton (hydrogen ion) concentration. The extreme range of $\mathrm{pH}$ in sediment pore water is 2 to 11 (Figure 2.2). However, the extreme values are very rare. The pore water of marine and estuarine sediments, like the overlying seawater, is strongly buffered. Therefore, pore water of oxic marine sediments usually has a $\mathrm{pH}$ of about 7.0 to 7.5. The range of $\mathrm{pH}$ for deeper anoxic layers of marine and estuarine sediments may range from 5 to about 10 (Oppenheimer 1966). Pore water from peaty, waterlogged salt marsh sediments may have a $\mathrm{pH}$ as low as 4 (Giblin and Howarth 1984).

Salomons et al. (1987) considered that oxidation-reduction reactions control pore water $\mathrm{pH}$ in freshwater, estuarine, and marine sediments. They identified four scenarios involving different availability of the three most important reactive species: organic matter, trivalent iron, and sulfate. If both sulfate and reducible iron are present, iron is reduced to iron sulfide with a concomitant oxidation of organic material to bicarbonate, carbon dioxide, and water. The $\mathrm{pH}$ will be determined by the $8: 1$ ratio of bicarbonate to carbon dioxide and will be approximately 7.25 . This is the most common situation in surficial marine and estuarine sediments where both sulfate and iron are in abundant supply. If reducible iron is limited, then organic carbon will be oxidized to carbon dioxide, and water and sulfate will be reduced to sulfide. The resulting $\mathrm{pH}$ is about 6.75 . It is unlikely that sulfate will be limiting in marine sediment because of the high sulfate concentration in seawater. However, in deeper layers of anoxic sediment, all the sulfate may have been reduced to sulfide. Under such conditions, any iron present will be in the form of iron sulfide, and so methanogenesis 
(reduction of carbon dioxide to methane) is the only oxidation-reduction reaction available. Under these conditions, $\mathrm{pH}$ may drop to 6.2 to 6.5 . Organisms living in the sediments, can influence pore water $\mathrm{pH}$ and $\mathrm{Eh}$ in several ways. Several marine bacteria catalyze the oxidation-reduction reactions discussed above, reducing sulfate and oxidizing organic materials (Oppenheimer and Kornicker 1958). Microalgae and photosynthetic bacteria living at the sediment-water interface of intertidal and shallow subtidal sediments may alter sediment $\mathrm{pH}$ on a diurnal basis due to photosynthesis during the day and respiration at night. The $\mathrm{pH}$ at the sediment surface may range from about 7.4 at night to 9.2 during daylight hours. The $\mathrm{pH}$ and Eh limitations of the most important marine sediment microorganisms are summarized in Figure 2.3.

The most important redox reactions in water and sediment involve only a few elements - C, N, O, S, Fe, and Mn (Förstner and Wittmann 1981). Each reaction occurs over a particular range of Eh (Figure 2.4). The reduction sequence in the upper half of Figure 2.4 can be viewed as the gradient of reactions that occur in a vertical sediment column characterized by an oxidized surface layer and a gradient of decreasing Eh with depth. Alternatively, the sequence can be viewed as the events taking place in a layer of oxidized sediment over time after deposition or bioturbation. The reduction reactions above the horizontal dashed line also involve oxidation of organic matter (reaction L). All but possibly the reduction of manganese and iron oxides are mediated by the sediment microbiota depicted in Figure 2.3. The slope of the vertical Eh gradient in sediment, and therefore, the depth at which different reductions take place will depend on the oxygen concentration in the overlying water, the permeability of the sediment, and the availability of oxidizable organic material and reducible sulfate.

There often is a limited supply of sulfate in freshwater systems and low-salinity zones of estuaries. As a result, most of the available sulfate is used up in the reduction of iron hydroxides to iron sulfide (Salomons et al. 1987). Methanogenesis may occur fairly near the sediment surface and any unreduced Fe (III) is reduced to iron carbonate. Sulfate is abundant in seawater, so it is not generally limiting in surficial marine sediments. Most of the degradable organic matter is oxidized during reduction of all available iron to iron sulfide. Thus, in deeper layers of marine sediment, all oxidizable organic material and reducible iron are used up before sulfate is depleted and so methanogenesis does not occur until very deep in the sediment.

If the Eh of pore water increases at a particular depth in a sediment column due to disturbance or convective influx of oxygen, the oxidation reactions depicted in the lower half of Figure 2.4 will 
take place in the sequence shown, depending on the Eh of the pore water. All the reactions, except oxidation of organic matter, are reversible. Therefore, as the redoxocline (point in sediment where Eh is zero, also called the redox potential discontinuity) moves up or down in the sediment column due to changes in the dissolved oxygen concentration of the overlying water, deposition of new sediment layers, or bioturbation, different oxidation and reduction reactions appropriate to the local Eh and $\mathrm{pH}$, will take place.

\subsubsection{Reduction/Dissolution of Iron and Manganese Hydrous Oxides}

Several of these oxidation and reduction reactions have a profound influence on the chemical forms and mobility of contaminant metals and organic compounds in sediments. The most readily exchangeable (and therefore most bioavailable) metals are adsorbed to amorphous iron and manganese hydrous oxides, carbonates, organic matter, and clay minerals (Salomons et al. 1987). Oxidation or reduction of the transition metals directly affects their aqueous solubility. For example, oxidation of titanium, vanadium, and chromium, increases their aqueous solubilities. Reduction of manganese, iron, cobalt, nickel, and copper increases their aqueous solubilities.

The most important of these reactions with respect to diagenesis of marine sediments is the reductive dissolution of iron and manganese. Fe (III) and Mn (III, IV) hydrous oxides tend to form colloidal precipitates in the water column and are deposited as coatings on suspended inorganic particles (Burns and Burns 1981, Schoer 1985). Hydrous oxides include oxides, hydroxides, and oxide hydroxides (Schindler and Stumm 1987). Weathering and erosion of terrestrial rocks introduces several forms of colloidal Fe (III) oxides to the ocean in runoff from land (Burns and Burns 1981). These include amorphous or poorly crystalline geothite, hematite, and ferrihydrite. Schoer (1985) identified Fe (III) hydroxide (geothite: FeOOH) and Fe (III) oxide (ferrihydrite and hematite), probably as coatings on particles, and both Fe (III) and Fe (II) in silicate lattice positions. Manganese probably enters the ocean primarily as amorphous or poorly crystalline vernadite $\left(\delta-\mathrm{MnO}_{2}\right)$ and manganite ( $\tau-\mathrm{MnOOH}$ ) (Burns and Burns 1981). These suspended iron and manganese hydrous oxide particles have diameters of only tens of angstrom units. These small dimensions give them a large surface area per unit mass and a strong propensity to adsorb as surface films on larger particles. During initial weathering or estuarine mixing, the iron hydrous oxides seem to adsorb preferentially to clay-size particles, whereas manganese hydrous oxides tend to occur largely as discrete particles (Jenne 1977, Schoer 1985). The hydrous oxide coatings appear to be the most reactive forms of these metals in sediments (Froelich et al. 1979). 
When Fe and Mn hydrous oxide particles or coatings encounter reducing conditions in anoxic water or, more frequently, in sediments, they are reduced to the divalent species. This reduction is coupled to oxidation of organic material in the water or sediment. Stone and Morgan (1987) identified three steps in the reduction of metal hydrous oxides: (1) diffusion of the organic reductant molecules to the oxide surface; (2) surface chemical reaction involving electron transfer; and (3) release of reaction products [oxidized organic material and $\mathrm{Fe}(\mathrm{II})$ or $\mathrm{Mn}(\mathrm{II})$ ] from the oxide surface. Reduced iron and manganese are oxidized primarily by oxygen. They can also be oxidized by highly reduced metal species, such as pyrite. However, organic material, particularly low molecular weight organic compounds in pore water, may inhibit the kinetics of Fe(II) oxidation and Fe(III) reduction . Reduced iron species react with sulfate or sulfur to form several iron sulfides. These and other important reactions of iron are summarized in the following chemical equations:

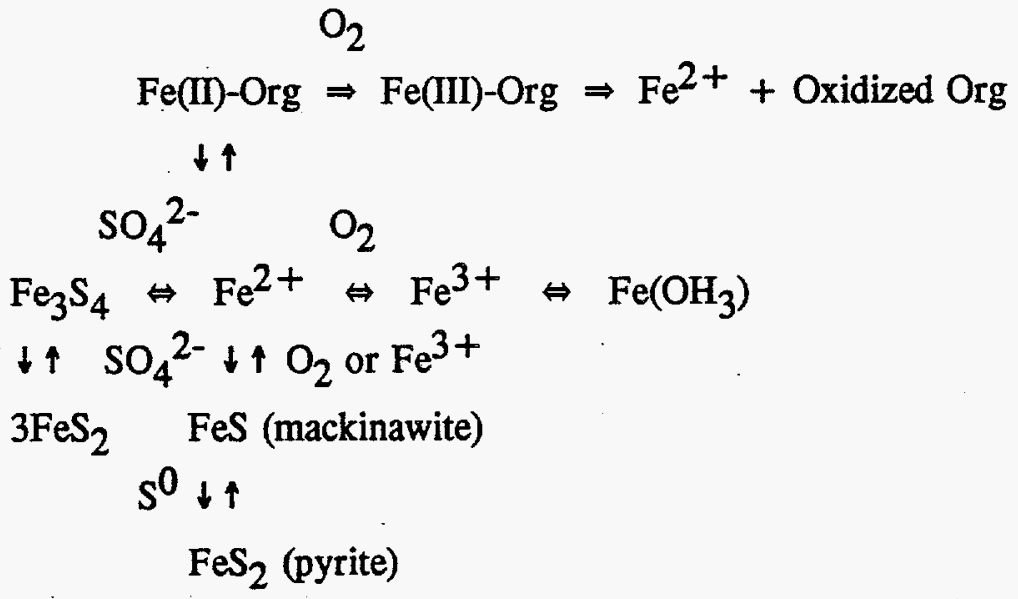

As indicated in Figure 2.4, reduction of manganese hydrous oxides occurs at higher Eh values (higher in the sediment column) than reduction of iron hydrous oxides. Because the reduced iron and manganese species are orders of magnitude more water-soluble than the oxidized species (Stone and Morgan 1987), they tend to go into solution in the sediment pore water. The $\mathrm{Mn}^{+2}$ ions tend to diffuse upward in the sediment column until they reach more strongly oxidizing conditions where they are oxidized and precipitate (Lynn and Bonatti 1965). Iron shows similar behavior. However, because iron is reduced at lower Eh values (more anoxic sediment), the $\mathrm{Fe}^{+2}$ solubilized by reduction of $\mathrm{Fe}^{+3}$ species may be trapped by concomitant reduction of sulfate to form highly insoluble iron sulfide (Salomons and Förstner 1984). Soluble $\mathrm{Fe}^{+2}$ and $\mathrm{Mn}^{+2}$ may be released into the overlying water column from the sediment pore water or by pore water convection. 
Less iron than manganese is released because iron is rapidly precipitated as iron sulfide or oxidized to insoluble iron hydrous oxides. The rate of oxidation of manganese (II) species is slow, so a significant fraction of the solubilized manganese can reach the overlying water column before it is oxidized (Balzer 1982). The rate at which manganese is redeposited onto particles in the water column is dependent on suspended particle load, salinity, $\mathrm{pH}$, and temperature (Morris et al. 1982). The rate of precipitation decreases with increasing salinity and decreasing $\mathrm{pH}$. Thus, manganese precipitation is most rapid in the low salinity regions of estuaries. However, in many salt wedge estuaries, suspended particulate manganese reaches a maximum concentration in the lower reaches of the estuary (Evans et al. 1977).

\subsubsection{Reduction of Sulfur}

Because of the high concentration of sulfate in the pore water of oxidized marine and estuarine sediments, microbially mediated sulfate reduction is the dominant process by which organic material in sediment is oxidized and decomposed (Gardner 1979). Sulfur occurs in pore waters of marine sediment in several oxidation states between the most oxidized (sulfate) and most reduced (sulfide) forms (Luther et al. 1985). These include thiosulfate, sulfite, bisulfide, and polysulfide. The partially oxidized sulfur species can be produced by oxidation of hydrogen sulfide, reductive dissolution of geothite, oxidation of sulfide minerals, and microbial metabolism. Secondary reactions of hydrogen sulfide and polysulfides with decomposing organic matter may produce a variety of thiols and organic polysulfides (Bouleque et al. 1982).

The major organic substrates oxidized during sulfate reduction in marine sediments appear to be low molecular weight organic acids, such as acetate, propionate, butyrate, and isobutyrate (Christensen 1984). Bacteria of the genus, Desulfovibrio, are the most important effectors of the coupled reduction of sulfate to sulfide and the oxidation of organic matter in sediment (Davies-Colley et al. 1985). Autotrophic bacteria such as the Thiobacteriaceae are able to use sulfides as an oxidizable energy source, producing elemental sulfur. The sulfur may be excreted in colloidal form (Trudinger 1979). Reaction of sulfides and bisulfides with elemental sulfur produces a variety of polysulfide ions that may be electroactive in sulfidic pore waters (Davies-Colley et al. 1985, Shea and Helz 1988). Alternatively, certain chemolithotrophic bacteria are able to use manganese oxides as reducible substrates for the oxidation of particulate and dissolved sulfides to sulfate (Aller and Rude 1988). Such reactions would occur only where physical or biological reworking of sediments brings oxidized surficial sediments into contact with deeper reduced sediment layers. 
There is growing evidence that, in transitional environments such as salt marshes and tidal flats that are intermittently exposed to anoxic and oxic conditions, concentrations of polysulfides in sediments are much higher than predicted from classical thermodynamic considerations (Lyons and Fitzgerald 1983). Partially oxidized sulfur compounds are important in the cycling of metals in sediments because many heavy metal polysulfides are slightly soluble (Gardner 1974, Boulegue et al. 1982).

The rate of sulfate reduction in highly organic, peaty salt marsh sediments is very high, accounting for the consumption of as much as $1800 \mathrm{~g}$ organic carbon per meter squared per year (Howarth and Teal 1979). Reduced sulfur is present primarily as stable pyrite $\left(\mathrm{FeS}_{2}\right)$. During the summer growing season, salt marsh grasses oxidize the sediment, and much of the pyrite is converted to oxidized mobile iron species with conversion of sulfide to sulfate (Giblin and Howarth 1984). During the non-growing season, the sediments become reduced again and oxidized iron salts are reduced to pyrite. In salt marsh sediments, pyrite formation appears to occur directly by reaction of polysulfides with iron and not by reaction of FeS with elemental sulfur.

In fine-grained subtidal marine sediments, less pyrite and more FeS is formed than in salt marsh sediments because of the limited supply of polysulfides and elemental sulfur in the former (Giblin and Howarth 1984). However, pyrite is nearly always more abundant than FeS. In coarsegrained subtidal sediments off the Georgia coast, the concentrations of $\mathrm{FeS}^{+}$and $\mathrm{HS}^{-}$are never greater than the concentration of $\mathrm{FeS}_{2}$ (Fallon 1987). At depths of 30 to $40 \mathrm{~cm}$ in these sediment cores, pyrite represents $0.21 \%$ to $0.34 \%$ by weight of the sediment. Nevertheless, a maximum of only $17.3 \%$ of the iron in these sediments is associated with pyrite and iron monosulfides. These results suggest that oxidized iron species predominate at all depths in the sediment cores.

\subsubsection{Oxididizable Organic Substrates in Sediments}

Organic matter is the most important oxidizable substrate available in sediments for the biotic or abiotic reduction of inorganic chemicals in the sediments. It is an important adsorbent for both inorganic and organic contaminants. It also provides, either directly or indirectly, essential nutrition for infaunal deposit-feeding organisms. The nonliving organic matier in marine and estuarine sediments is the degradation and excretory products of marine, freshwater, and terrestrial bacteria, plants, and animals (Morris and Eglinton 1977). In freshwater and estuarine systems, sediment organic matter, both dissolved and particulate, is derived in large part from terrestrial plant materials, and includes lignins, phenols, phenolic acids, cellulose, and xylose (Jednacak-Biscan and Juracic 
1987). Organic material in marine sediments is derived primarily from marine phytoplankton and sediment microbiota (Pocklington 1977). It consists primarily of complex aliphatic assemblages (Jednacak-Biscan and Juracic 1987).

The quantitatively most important organic materials in sediments are the humic substances. Four classes of humic substances can be differentiated, based on molecular weight and solubility behavior (Jonasson 1977, Aiken et al. 1985).

- Humins are high molecular weight polymers that are insoluble in water at any $\mathrm{pH}$.

- Humic acids are extremely complex medium molecular weight organics that are not water soluble at a pH of 2 or lower, but are soluble at higher $\mathrm{pH}$ values.

- Fulvic acids have molecular weights of about 700 to 1000 and are less condensed precursors of humic acids. They are completely water soluble at all $\mathrm{pH}$ values.

- Yellow organic acids are low molecular weight soluble acids, probably representing, in part, the final stages of microbial degradation of humic substances in sediments.

Humic and fulvic acids are polyelectrolytes with a strong tendency to adsorb to particles and to adsorb metal and organic molecules. Nissenbaum and Swaine (1976) suggested that marine humic acids are micellar, with a central hydrophilic cavity and an outer hydrophobic surface.

It is becoming increasingly apparent that terrestrial, freshwater, and marine humic substances, though they share some physical and chemical properties, have markedly different chemical structures (Pocklington 1977), reflecting their different origins. Humic substances from all three sources consist of a heterogeneous mixture of compounds for which no single structural formula can be given. Several generic structural formulas have been proposed (Stevenson 1985a, Harvey and Boran 1985, Malcolm 1985).

The generic molecular structure of a terrestrial (soil) humic acid is a micellar polymer consisting of di- and tri-hydroxyphenols, bridged by oxygen, methyl, amino, sulfur and other groups (Stevenson 1982; Figure 2.5). Quinones, carboxylic acid groups, and sugars are present. The main structural units of terrestrial fulvic acid appear to be phenols and benzene carboxylic acids. The subunits are held together by hydrogen bonds between hydroxyl and carboxylic acid groups to form a stable molecule (Schnitzer and Khan 1972). The great abundance of carboxylic acid and hydroxyl groups in humic and fulvic acids is responsible for their remarkable binding and ion exchange capacities. 
The structure of marine humic substances appears to be less variable than that of terrestrial humic substances (Harvey and Boran 1985). They have minimum molecular weights of about 900 to 1200 daltons. Harvey et al. (1983) proposed that marine humic acids are formed from the free radical autooxidative cross-linking of unsaturated lipids released by marine plankton. They are composed of two to four fatty acid chains (Figure 2.6). Diagenic reactions leading to marine humic acids may result in production of aromatic ring structures. However, unlike terrestrial humic substances, marine humic substances are predominantly aliphatic (Poutanen and Morris 1985). Crosslinking is primarily via hydroxyl groups. Some marine and estuarine humic substances may contain substantial amounts of carbohydrate in the form of several different monosaccharides (Kalinowski and Blondeau 1988) and polysaccharides with molecular weights greater than 1500 (Poutanen and Morris 1985). Carboxylic acid groups are abundant in marine humic acids and may be derived in part from uronic acids in polysaccharides (Hatcher et al. 1980).

Freshwater humic substances appear to be intermediate in structure between terrestrial and marine humic substances. Like marine humic substances, they are primarily aliphatic (Malcolm 1985). Approximately $16 \%$ to $20 \%$ of the carbon in stream fulvic acid is aromatic carbon. Stream humic acid may contain up to about $30 \%$ aromatic carbon. Stream fulvic and humic acids have molecular weights of approximately 1000 and 3000 daltons, respectively. The molecules contain abundant hydroxyl and carboxylic acid functional groups along the aliphatic chains.

Humic substances comprise $10 \%$ to $68 \%$ of the total organic carbon of typical estuarine sediments (Mayer 1985). In sediments from the vicinity of Los Angeles, California, humic acids represent $3.2 \%$ to $55.4 \%$ and fulvic acids represent $11.4 \%$ to $44.6 \%$ of the total organic carbon present (Knezevic and Chen 1977). Fulvic acids are more abundant than humic acids in most samples. However, the ratio of humic to fulvic acids in estuarine sediments varies widely from 0.4 to 3.4, with higher values being associated with sediments having a strong terrestrial influence (Mayer 1985). In strictly marine environments, the humic acid/fulvic acid ratio is about 0.1 indicating inefficient diagenesis of marine fulvic acids to humic acids (Harvey and Boran 1985). In marine sediment cores, the ratio of humic to fulvic acid increases with depth, suggesting either bacterial diagenesis or polymerization of fulvic acid to humic acid (Vandenbroucke et al. 1985).

The frequent observation of a direct correlation between percent silt/clay and concentration of total organic carbon in sediments appears to be related to the strong affinity of humic materials for 
clay particles (Choi and Chen 1976, Pocklington 1977). Clays adsorb about six times more organic matter in seawater than in freshwater.

A wide variety of soluble, low molecular weight organic compounds has been identified in marine and estuarine sediments. These compounds are major components of the dissolved organic matter in sediment pore water. Because the major inputs of organic matter to sediments are in the form of particulate material, the soluble organic matter in sediment pore water must be generated in situ (Barcelona 1980). This is accomplished primarily by the fermentative oxidation of complex organic precursors by bacteria in the sediments (Sansone 1986).

Miller et al. (1979) identified several organic acids, including acetic, propionic, butyric, valeric, lactic, and succinic acids, in pore water of sediments from Lock Eil, Scotland. Amino acids, methyl ketones, and long chain saturated fatty acids may also be abundant in marine and estuarine sediments (Morris and Eglinton 1977, Pocklington 1977). Pore water from organically enriched sediments from Loch Creran, Scotland contains acetic, propionic, iso-butyric, n-butyric, 2methylbutyric, iso-valeric, and n-valeric acids (Mueller-Harvey and Parkes 1987). Acetic acid is present at the highest concentration (up to $16,822 \mu \mathrm{M}$ ). These low molecular weight fatty acids probably are important ligands for binding metals and organic contaminants in pore water. They also are important substrates for bacterial sulfate reduction in anaerobic marine sediments (Sorensen et al. 1981, Winfrey and Ward 1983).

Concentrations of total nitrogen in sediments from the Gulf of Maine range from about 0.1 to $4.5 \mathrm{mg} / \mathrm{g}$ dry sediment, about $10 \%$ of the concentration of total organic carbon (Mayer et al. 1988). Hydrolyzable amino acids contribute from $12 \%$ to $81 \%$ and protein from $3 \%$ to $14 \%$ of the total nitrogen in the sediments. The organic nitrogen in estuaries is derived primarily from macroalgae, whereas that in offshore Gulf of Maine sediments is derived primarily from plankton.

Steinberg et al. (1987) and Venkatesan et al. (1987) identified a large variety of amino acids, carbohydrates, lignins, and lipids in relatively uncontaminated surficial sediments from the continental shelf, slope, and rise south of Cape Cod, Massachusetts. Amino acids, amino sugars, and sugars represent from $10 \%$ to $20 \%$ of the total organic carbon in the sediments. Lignin phenols represent no more than $10 \%$ of the total organic carbon in the sediments. Five classes of lipids are present; nalkanes, n-fatty acids, polycyclic aromatic hydrocarbons, alcohols, and sterols. Together, they represent about $0.1 \%$ to $0.2 \%$ of the total organic carbon in the sediments. The $n$-fatty acids and alcohols are the most abundant lipids in these marine sediments. 
Lipid concentrations in sediment pore waters vary widely, but generally are higher there than in the overlying water column (Saliot et al. 1988). Concentrations of fatty acids in pore water samples range from 0.7 to $47 \mu \mathrm{g} / \mathrm{L}, 1$ to 79 times higher than their concentrations in the overlying water column. Enrichment of n-alkanes and sterols in the pore water compared to the overlying water column is of a similar order of magnitude.

A variety of organo-sulfur compounds are produced in marine sediments during microbial reduction of sulfate and diagenesis of organic r.atter (Shea and MacCrehan 1988a). The most abundant organic thiols in sediment pore water samples analyzed by Shea and MacCrehan (1988b) are cysteine, 2-mecapto-propionate, monothioglycerol, mercaptopyruvate, and glutathione.

Concentrations of most thiols increase with depth in the sediment. 
Table 2.1. Average Abundance of Clay Mineral Classes in the Clay Fraction $(<2 \mu \mathrm{m})$ of Sediments From Different Oceans. (From Griffin et al. 1968).

Area

Average Percent Abundance

North Atlantic

South Atlantic

North Pacific

South Pacific

Indian1

\begin{tabular}{cr} 
Chlorite & \multicolumn{2}{c}{ Montmoril } \\
& \\
10 & 16 \\
11 & 26 \\
18 & 35 \\
13 & 53 \\
24 & 13
\end{tabular}

Illite

Kaolinite

Table 2.2. Standard Size Classes of Sediment Particles

Wentworth Class

Boulder

Cobble

Pebble

Very Coarse

Coarse

Medium

Fine

Granule

Sand

Silt

Very Coarse

Coarse

Medium

Fine

Very Fine

Clay
Phi Class

Range

$>-8$

$-6,-7$

$-5$

$-4$

$-3$

$-2$

$-1$

0

1

2

3

4

5-8

$\leq 9$
Particle Size (mm)

$>256$

64-256

32-64

16-32

8-16

4-8

2-4

1-2

0.5-1

$0.25-0.5$

$0.125-0.25$

$0.0625-0.125$

$0.0039-0.0625$

$<0.0039$ 


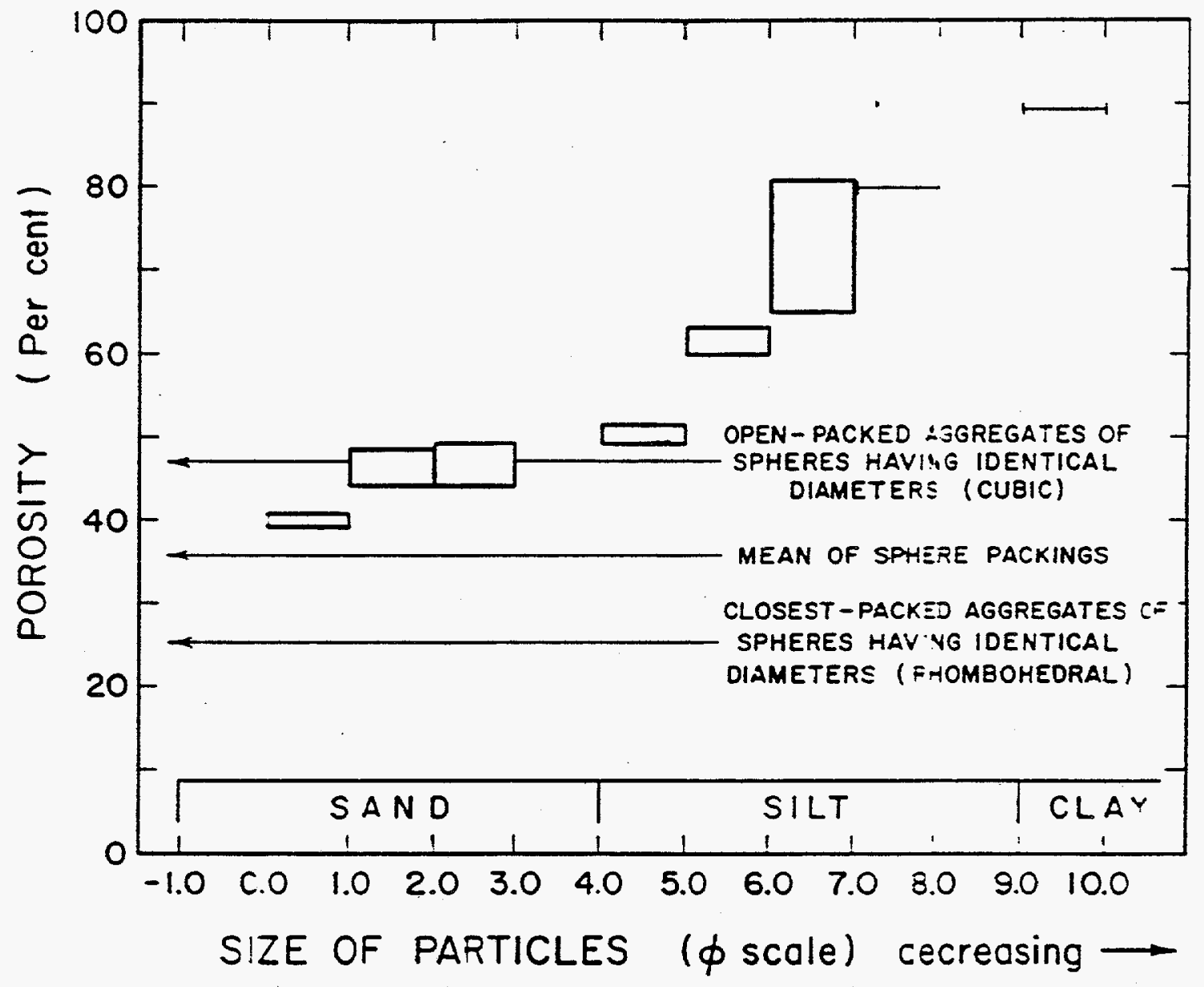

FIGURE 2.1. Relationship of Porosity to Particle Size in Modern Sediments 


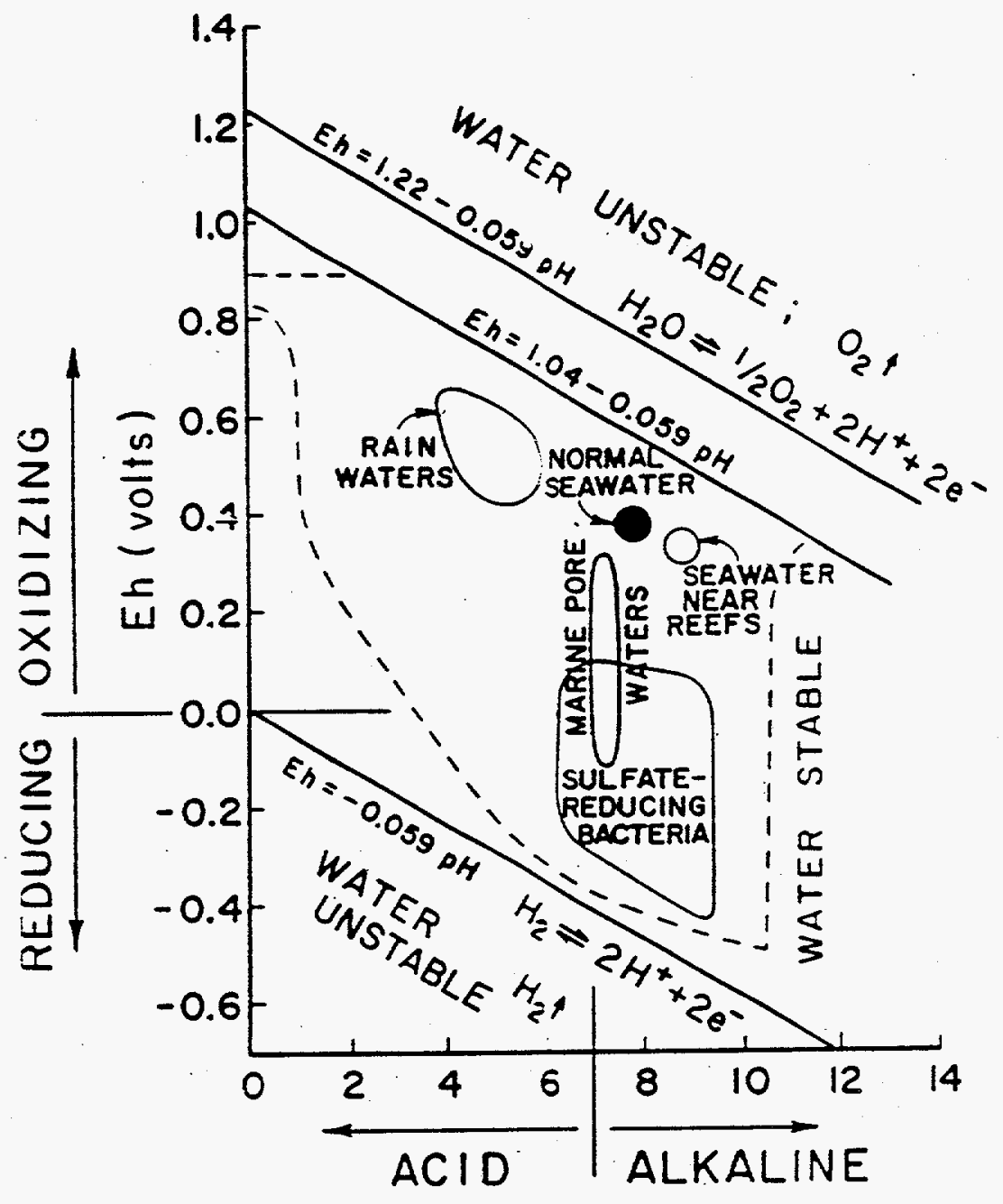

FIGURE 2.2. Relationship Between pH and Eh in Natural Waters. (Areas enclosed by dashed line is limite of measurements to date in sedimentary environments.) 


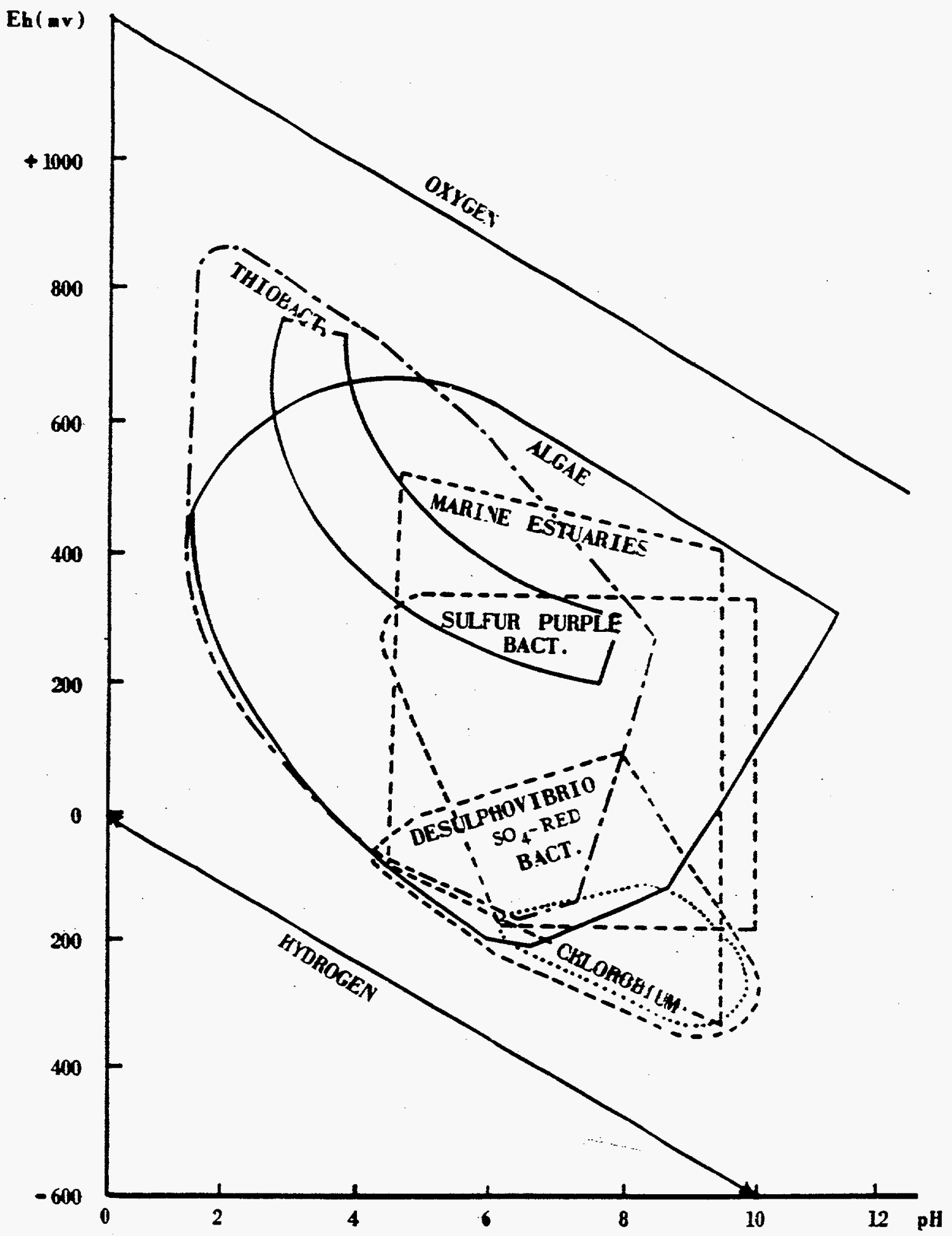

FIGURE 2.3. Influence of Ambient $\mathrm{pH}$ and Eh on Distribution of Microorganisms in Sediments 


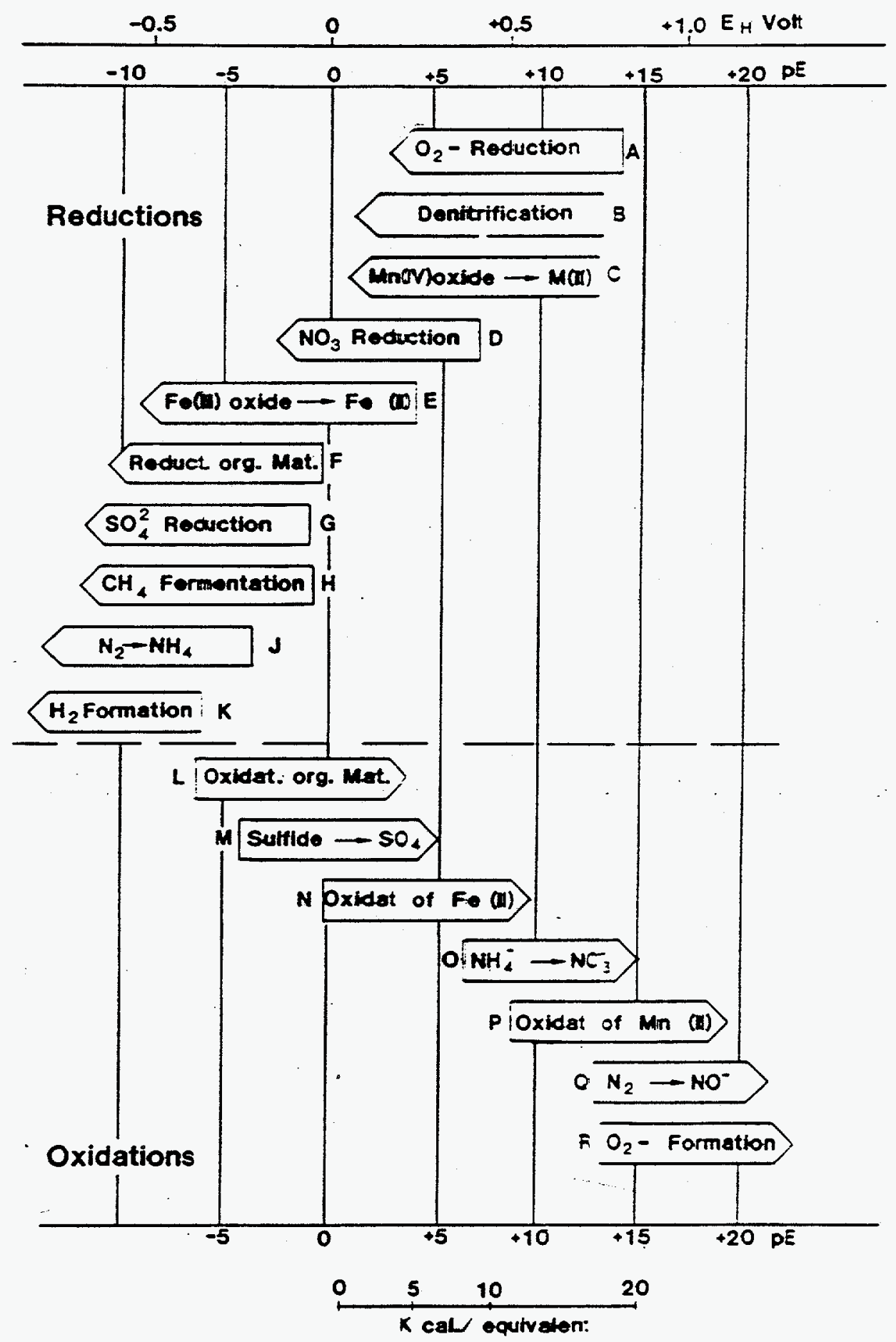

FIGURE 2.4. Sequence of Redox Reations in Water and Sediments (From Stumn and Baccini 1978) 


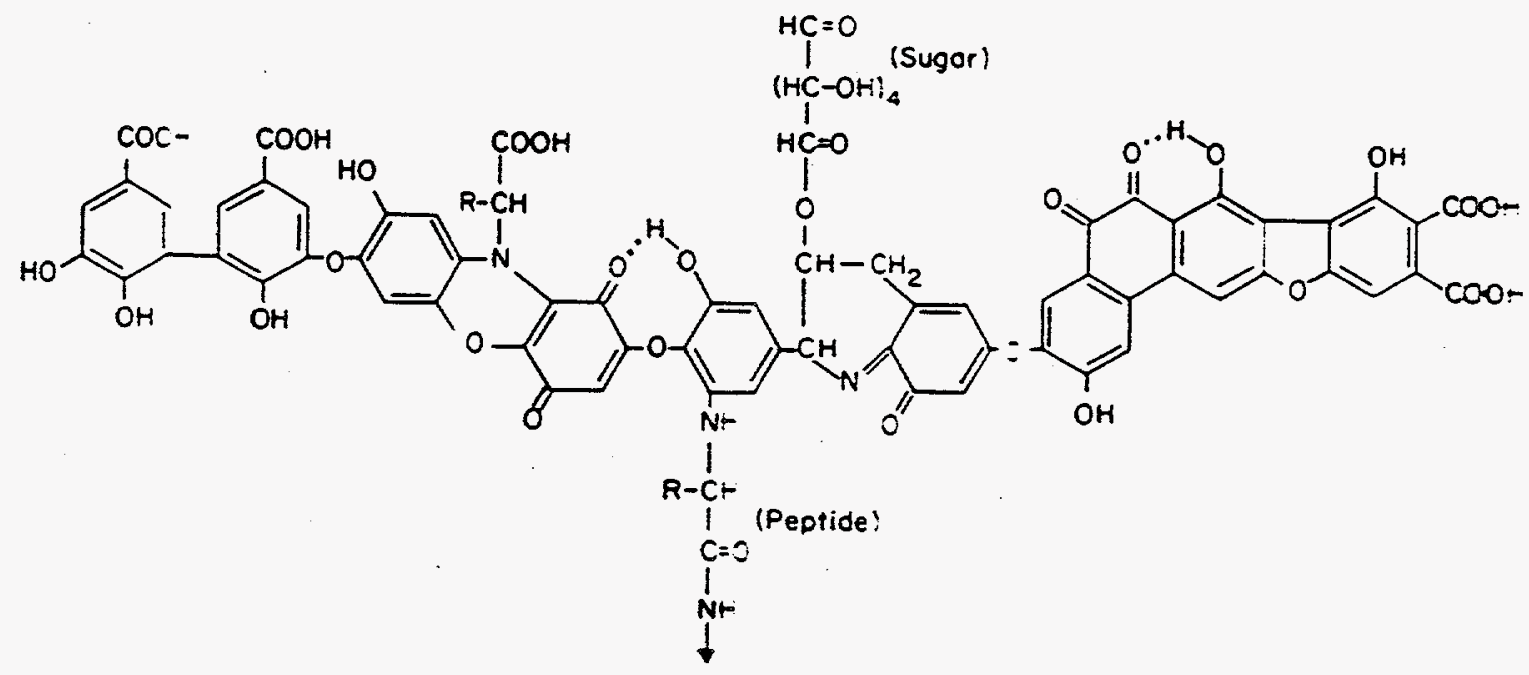

FIGURE 2.5. Example of a Proposed Structure for Freshwater Humic Acid (From Stevenson 1982) 

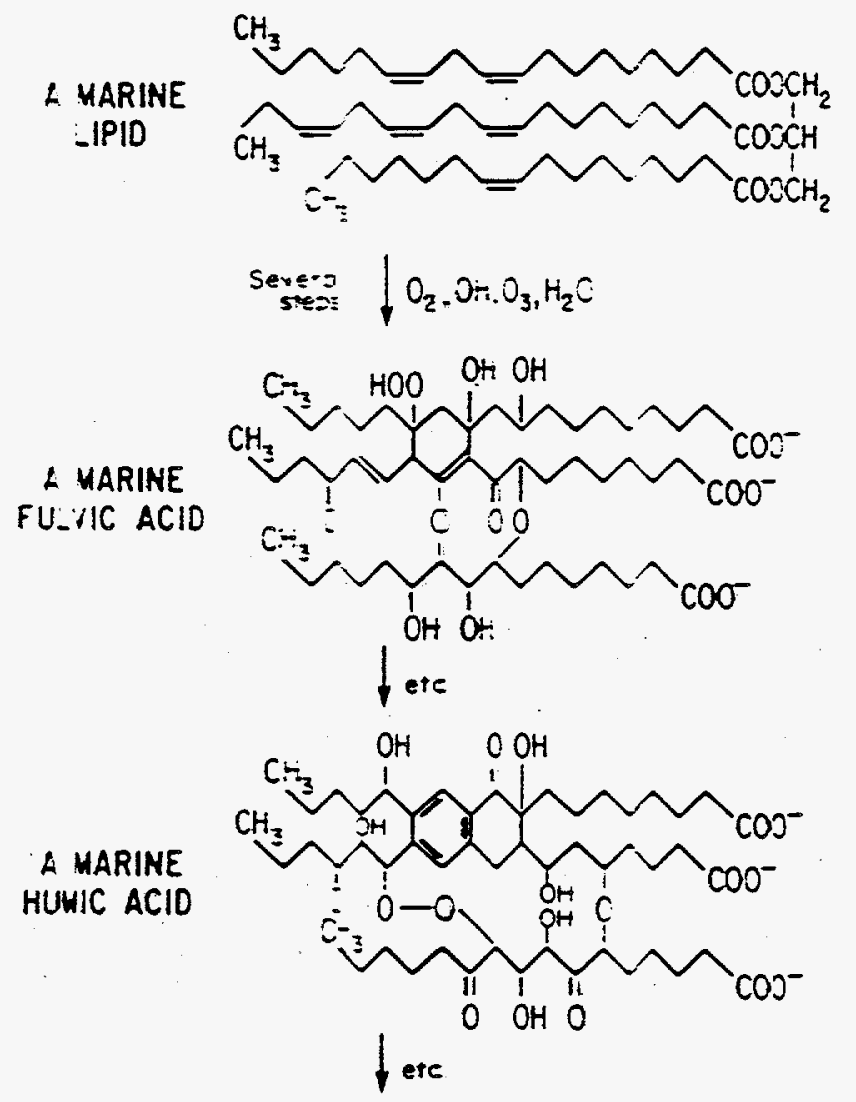

FIGURE 2.6. Examples of the Proposed Structures of Marine Fulvic and Humic Acids (From Harvey et al. 1983) 


\subsection{METALS IN MARINE SEDIMENTS}

\subsection{INTRODUCTION}

The metals in estuarine and marine sediments can originate from several sources and be present in several different forms (Goldberg 1954). The chemical species, complexes, adsorbed, and solid forms in which different metals occur in seawater and sediments have a profound effect on their bioavailability and toxicity to marine organisms (Nelson and Donkin 1985). The concentrations and forms of metals in seawater and marine pore water and sediments are summarized in Table 3.1 and reviewed in the sections that follow.

\subsection{PHYSICAL AND CHEMICAL FORMS OF METALS IN SEDIMENTS}

Inorganic detrital particles, derived from weathering of crustal rocks may contain a variety of metals, mostly in stable mineral lattice positions. Heavy minerals, in particular, and also many clay minerals are rich in one or more metals. Most of the metals in these solid, stable forms in coastal sediments are derived from natural weathering, erosion, and surface runoff from land. However, anthropogenic inputs from such sources as mine tailings, dredged material, and oil well drilling muds, may be important locally.

From an environmental perspective, a more important source of metals in sediments is physical and chemical reactions taking place in the water column. Metals introduced in soluble or colloidal form into estuaries and coastal waters tend to either precipitate or become bound to suspended particles and colloidal or dissolved organic matter (Salomons and Förstner 1984). These precipitated, adsorbed, or complexed metals tend to be deposited in more or less labile forms in surficial sediments. The diagenic reactions occurring in oxidized and reduced surficial sediments, discussed in Chapter 2, may result in remobilization of the deposited metals back into the overlying water column or into organisms living in the sediments, or they may result in transformation of the metals into more stable, immobile forms (Salomons 1985, Salomons et al. 1987).

Metal ions in seawater or sediment pore water tend to react with counterions in solution to form a variety of inorganic metal salts. The solubility of these salts varies widely and is defined by the solubility product. The solubility product is the product of the molar concentrations of the anion and cation in solution in equilibrium with the precipitated metal salt. The predominant inorganic anions in seawater and pore water are chloride, sulfate, bicarbonate, and, under reducing conditions, 
various sulfide anions (Förstner and Wittmann 1981). The chlorides (with the exception of silver, mercury, and lead chlorides) and sulfates of all heavy metals are readily soluble. However, the carbonates, hydroxides, and sulfides of most heavy metals have low solubilities. Among non-metals, barium (an alkaline earth element) is unusual in that its sulfate is much less soluble than its carbonate or sulfide (Trefry et al. 1986). The polysulfide salts of most metals are much more soluble than the sulfide salts. The presence of polysulfides may account in part for the higher than expected (based on solubility products of the sulfides) concentrations of some metals in pore waters of anoxic sediments (e.g., Lindberg and Harriss 1974). The other mechanism by which higher than expected concentrations of metals might exist in the pore water of sediments is through complexation of the metal to the dissolved organic matter of the sediment pore water (Lyons and Fitzgerald 1983).

Both $\mathrm{pH}$ and $\mathrm{Eh}$ of the water have an influence on what solid and dissolved forms of metals will be the most stable in seawater and pore water. Most divalent cations are stable in solution in oxygenated water at a pH less than 7 to 8 (Förstner and Wittmann 1981). At higher pH, first the carbonate, then the hydroxide becomes the most stable phase. In anoxic water, the sulfide is the most stable phase over a wide range of $\mathrm{pH}$.

Three types of sorption are encountered in binding of metals to solid particles in water or sediment. These are physical adsorption, chemisorption, and ion exchange (Salomons and Förstner 1984). A metal ion may be physically adsorbed to the surface of a particle by weak van der Waals forces of the ion-dipole or dipole-dipole type. Chemical adsorption involves the formation of chemical associations between ions or molecules in solution and on the particle surface.

Ion exchange is a chemical process in which fixed charges in the particle structure are compensated for by equivalent, but opposite charges on exchangeable molecules associated with the particles. These exchangeable molecules readily exchange with metal ions in solution. A majority of the fixed charges on marine particles are negative. Thus, the exchangeable species are predominantly cations. The fixed anionic sites include $\mathrm{SiOH}-, \mathrm{AlOH}_{2}^{-}$, and $\mathrm{AlOH}$-groups in clay minerals; $\mathrm{FeOH}-$ groups in iron hydroxides; and carboxyl, and phenolic OH-groups in organic substances (Förstner and Wittmann 1981). The abundance and configuration of the fixed anionic charges in the particle lattice gives the cation exchange process a degree of specificity for different cations in solution. Different metal and non-metal (e.g., $\mathrm{Ca}^{++}$and $\mathrm{Mg}^{++}$) cations have different affinities and different bonding strengths for exchange sites in the different types of particles and will tend to become distributed among the dissolved and different solid phases according to these different affinities. 
Because it involves interactions of electrically charged solutes and substrates, adsorption of metals onto sediment particles is very sensitive to $\mathrm{pH}$ (Benjamin et al. 1982, Lion et al. 1982, Schindler and Stumm 1987). For a system consisting of cationic metal ions and an adsorbing inorganic hydroxide surface, there is a range of one to two $\mathrm{pH}$ units over which adsorption rises from near $0 \%$ to near $100 \%$. The same is true for adsorption of anions. The adsorption of anions is coupled to uptake of protons or release of hydroxide ions and, therefore, is favored by low $\mathrm{pH}$ values (Davis and Leckie 1980, Schindler and Stumm 1987). For metals with several stable valency states in seawater or that may be present as anionic or cationic species, depending on $\mathrm{pH}$, such as vanadium (Shieh and Duedall 1988), the $\mathrm{pH} /$ adsorption curve may be complex. The slope of the $\mathrm{pH} / \mathrm{metal}$ adsorption curve tends to decrease with decreasing concentration of particles (Chang et al. 1987). The critical $\mathrm{pH}$ range or $\mathrm{pH}$ of adsorption is different for different metals and metal compounds. Leckie et al. (1980) reported that the $\mathrm{pH}$ of adsorption of metals onto amorphous iron hydrous oxides, alumina, and silica increases in the order $\mathrm{Pb}<\mathrm{Cu}<\mathrm{Zn}<\mathrm{Cd}<\mathrm{Ag}$ for cations and in the order $\mathrm{SeO}_{4}<\mathrm{CrO}_{4}<\mathrm{SeO}_{3}<\mathrm{AsO}_{4}$ for anions. In brackish water, seawater, and pore water with a $\mathrm{pH}$ in the range of 7 to 8 , lead and copper will tend to be bound more strongly than zinc and cadmium to inorganic hydrous oxide surfaces.

A similar pattern exists for adsorption of metals by organic compounds. However, in this case, cation adsorption changes over a much broader $\mathrm{pH}$ range (Nelson et al. 1981). For example, the adsorption of cadmium onto the surface of bacterial cells increases from about $60 \%$ to $80 \%$ as the $\mathrm{pH}$ is increased from 6.5 to 8.0 (Nelson et al. 1981). Fulvic and humic acids contain abundant carboxylic acid, phenolic hydroxyl, amino, and thiol groups that can participate in metal binding through electrostatic forces (attraction of a metal cation to an ionized carboxylic acid group) and by electron pair sharing (formation of a covalent bond) (Knezevic and Chen 1977, Olsen et al. 1982). The stability of divalent metal-humic acid complexes increases in the order $\mathrm{Mg}<\mathrm{Ca}<\mathrm{Cd} \approx \mathrm{Mn}$ $<\mathrm{Fe}<\mathrm{Co}<\mathrm{Pb}<\mathrm{Ni} \approx \mathrm{Zn}<\mathrm{Cu} \approx \mathrm{Hg}$ (Mantoura et al.-1978).

The capacity of different adsorbents to adsorb metal ions varies substantially and is dependent on specific surface area and the abundance of exchange sites on the particle surface. As seen in Table 3.2 exchange capacity is relatively low in freshly precipitated iron hydroxide, spans a wide range in different clay minerals, and is high in soil humic acids. Among the clay minerals, there is a good correlation between specific surface area and exchange sites on the particle surface. 
However, most clay particles acquire a coating of iron hydrous oxides or organic matter during settling through the water column. Therefore, the direct role of clay minerals in metal adsorption probably is less that expected from consideration of specific surface area and exchange capacity alone. In addition, the strength of the binding of metals to clay surfaces is much weaker than the strength of binding to other adsorbents. Thus, the major role of clay particles in metal binding is as a carrier for substrates that bind metals more strongly (Jenne 1977). In oceanic waters iron and manganese oxide particles also become coated with an organic film and it is this film that controls the adsorption of metal ions onto the particle surfaces (Balistrieri et al. 1981).

In anoxic marine and estuarine sediments, except those deficient in sulfur, sulfides control metal speciation and the forms of metals present. The processes controlling the speciation and forms of metals in oxidized surficial sediments are more complex (Luoma and Bryan 1981, Luoma and Davis 1983). In oxidized, fine-grained sediments, hydrous oxides of iron, aluminum, and manganese, clay minerals, carbonates, and organic matter all compete for binding of metals. The partitioning of metals among these sediment phases is influenced by:

- The relative binding capacity of each phase,

- The relative strength of the binding of each metal present to each sediment phase,

- The relative abundance of different sediment phases,

- Solution parameters such as pH, Eh and dissolved inorganic (e.g., chloride) and organic ligands that may complex with or influence speciation of dissolved metal ions, and

- The concentration of other metal ions, and non-metals (e.g., $\mathrm{Na}, \mathrm{Ca}, \mathrm{Mg}$ ) that may compete with the metals for available binding sites (Luoma and Davis 1983).

\subsection{DETERMINATION OF THE FORMS OF METALS IN SEDIMENTS}

The complexity of the metal-solid interactions in oxidized surficial sediments precludes direct measurement of the distribution of metals among different adsorbed and solid phases. Mathematical models may be the best approach to predicting the partitioning of metals among phases in sediments from different sources. Examples of such models are those of Oakley et al. (1981) and Davies-Colley et al. (1984). The Oakley et al. (1981) model predicts that the clay fraction is the major sink for copper and cadmium of the artificial geochemical phases used (clay, iron and manganese oxides, and humic acids). This prediction was based on the abundance of clays in the sediments modeled, without 
consideration of the availability of clay surfaces for binding metals. The model subsequently was modified (Davies-Colley et al. 1984) and predicted that copper and cadmium in oxidized estuarine sediments will be bound primarily to iron hydroxide and organic phases. For cadmium, the model predicts that iron oxides account for about $80 \%$ and humic substances account for about $10 \%$ of the total sediment binding capacity. Humic substances are slightly more important than iron hydroxide for binding copper.

From an environmental perspective, the most important forms of metals in sediments are those that are directly bioavailable to benthic organisms and those that can readily be transformed by diagenic processes in sediments to bioavailable forms. Sequential extraction or leaching schemes have been used extensively to partially characterize the phase associations of metals in sediments and to identify the fraction of the total metal that is or could become bioavailable. None of these selective extraction techniques is specific for a particular form of substrate and none adequately defines the bioavailable fraction of metals in sediments (Luoma and Bryan 1979, 1981; Salomons and Förstner 1984). These sequential extraction techniques are reasonably selective when used with oxidized, sulfide-poor sediments; however, they are not sufficiently selective when used with anoxic, sulfiderich sediments (Rapin et al. 1986). Salomons and Förstner (1984) provide a detailed description of different sequential extraction schemes. Great care must be taken in collection and handling of sediment samples to prevent changes in the chemical forms and associations of metals in the sediment samples (Kersten and Förstner 1986).

From three to six fractions usually are defined in sequential extraction schemes. The six fractions include the following:

1) exchangeable cations,

2) carbonates,

3) easily reducible phases,

4) moderately reducible phases,

5) an organic plus sulfide fraction, and

6) a residual fraction.

The exchangeable metal ions are extracted with an extractant containing cations that are more strongly bound than the metals to exchange positions. A solution of $1 \mathrm{M}$ ammonium acetate at $\mathrm{pH} 7$ is commonly used. This fraction is not well defined (Salomons and Förstner 1980). Metal ions bound to carbonates can be extracted with a weak acid (pH 5) sodium acetate buffer. Metals in this fraction 
might include those adsorbed to inorganic carbonate particles and those incorporated into the calcium carbonate crystal lattice during biodeposition of skeletal carbonates.

Reducible, amorphous, or poorly crystallized iron and manganese oxide phases can be dissolved by reducing the iron and manganese to lower valence states. The easily reducible phases, including manganese oxides and partly amorphous iron hydrous oxides can be extracted with an acidic (pH 2) ammonium hydroxide/nitric acid solution. The moderately reducible phases, including amorphous and poorly crystallized iron hydrous oxides, can be extracted with an acidic (pH 3) ammonium oxalate/oxalic acid solution.

Metals bound to the organic fraction of sediment can be extracted with a hot acidic ( $\mathrm{pH} 2$ ) solution of hydrogen peroxide and nitric acid. This extractant also extracts metal sulfides. The residual or detrital fraction contains metals tightly bound in clays or heavy minerals or adsorbed to crystalline iron oxides. These metals usually are extracted with mixtures of concentrated strong acids (e.g., aqua regia) at high temperature.

At least part of the metals in first five fractions may be or become bioavailable under some natural conditions. The metals in the residual fraction are considered inert and immobile. The extraction sequence roughly approximates the sequence of decreasing bioavailability of different bound forms of metals in sediments.

It has been widely assumed that, for benthic animals that reside in but do not ingest sediment to any great extent, the bioavailable fraction of the total metals in sediment is the fraction in solution in the pore water and the fraction in equilibrium with this soluble fraction (Campbell et al. 1988). For deposit-feeding infauna, additional metal phases may be bioavailable. These animals digest sediment organic matter as a source of nutrition. It is possible that metals adsorbed to digestible organic matter (e.g., bacterial cells) may become bioavailable when the organic matter is digested (Loutit et al. 1988).

Although no single extraction can adequately describe the bioavailable fraction of metals in sediments, dilute hydrochloric or nitric acid (1 to $3 \mathrm{M}$ ) is the most widely accepted extractant for the "bioavailable fraction" of metals in sediment (Luoma and Bryan 1982). These extractants tend to remove at least a portion of the metals from the first five fractions discussed above. Prediction of the metal concentration in benthic animals in apparent equilibrium with the sediments is improved when the concentrations of trace metals extracted from the sediments are normalized with respect to 
concentrations of iron hydrous oxides and total organic carbon in the sediment (Tessier and Campbell 1987).

\subsection{BEHAVIOR OF SELECTED METALS IN SEAWATER AND MARINE SEDIMENTS}

Of the large number of metals and heavy elements in the periodic table, only about a dozen or so are considered to be potential pollutants in the marine environment. A metal or heavy element is considered a potential marine pollutant if human use and disposal patterns result in a flux of the element to the marine environment that is large relative to the natural flux and if the element has substantial toxicity to marine organisms or consumers of marine organisms, including man. In the sections that follow, a brief overview is provided of the behavior of 11 elements that may be marine pollutants.

\subsubsection{Cadmium}

The mean concentrations of cadmium in surface waters of the open ocean are in the range of 4 to $20 \mathrm{ng} / \mathrm{kg}$ (Mart et al. 1982, 1984) (Table 3.1). In clean coastal waters, cadmium concentrations may increase to more than $200 \mathrm{ng} / \mathrm{kg}$.

Cadmium concentrations in uncontaminated marine sediments usually are in the range of 0.1 to $0.6 \mu \mathrm{g} / \mathrm{g}$ dry wt (Warren 1981). By comparison, contaminated sediment from New Bedford Harbor, Massachusetts, contains $52 \mu \mathrm{g} / \mathrm{g}$ cadmium (Stoffers et al. 1977). Contaminated sediments from 11 stations in San Francisco Bay contain 2.0 to $15.6 \mu \mathrm{g} / \mathrm{g}$ cadmium (Luoma and Phillips 1988). Concentrations of cadmium as high as $130 \mu \mathrm{g} / \mathrm{g}$ were reported in sediments from Corpus Christi Bay, Texas (Holmes et al. 1974), and sediments from the Derwent estuary, Tasmania, Australia contain up to $862 \mu \mathrm{g} / \mathrm{g}$ cadmium (Bloom and Ayling 1977).

Cadmium occurs in seawater in a variety of dissolved and solid forms. The dominant cadmium species in seawater, each accounting for about $30 \%$ of the total, are $\mathrm{CdCl}^{+}, \mathrm{CdCl}_{2}$ and $\mathrm{CdCl}_{3}^{-1}$ (Nürnberg 1983, Nürnberg and Valenta 1983, Salomons et al. 1987). Uncomplexed cadmium $\left(\mathrm{Cd}^{+2}\right)$ represents about $2 \%$ of the total (Zirino and Yamamoto 1972, Nürnberg and Valenta 1983). Cadmium has a strong affinity for adsorption to particles, particularly humic substances (Gardiner 1974). The affinity of cadmium for adsorption to particles decreases with increasing salinity, due to chloride complexation ( $\mathrm{Li}$ et al. 1984). Between $30 \%$ and $90 \%$ of the total cadmium in surface waters of the North Sea is adsorbed to particles (Jones and Jeffries 1983). Approximately $80 \%$ of the 
total cadmium associated with near-shore suspended particles from the southern North Sea is nearly equally distributed among the exchangeable, carbonate, and easily reducible fractions (Kersten and Förstner 1986). Most of the remainder is associated with the organic/sulfide fraction.

Cadmium in oxic sediments is associated primarily (50\% to $70 \%$ ) with the carbonate plus iron/manganese oxide fractions of the sediment (Luoma and Bryan 1981, Rapin et al. 1983, Rosental et al. 1986). Most of the remainder is associated with the organic/sulfide fraction. Only about $1 \%$ is in the residual fraction. These results are in reasonable agreement with the model predictions of Davies-Colley et al. (1984).

Cadmium in anoxic sediments appears to be associated almost exclusively with the sulfide phase (Salomons et al. 1987). Cadmium forms solid sulfides and strong complexes with sulfides. However, only at high concentrations of sulfide $\left(>10^{-3} \mathrm{M}\right)$ are soluble cadmium sulfide complexes formed (e.g., $\mathrm{Cd}(\mathrm{HS})_{x}{ }^{x-2}$ ). Bisulfide complexes appear to be the most important form of soluble cadmium in sulfidic pore water, assuming that $\mathrm{CdS}$ is the controlling solid phase (Davies-Colley et al. 1985). Lee and Kittrick (1984) examined individual sediment particles from a freshwater harbor by electron beam microprobe. They found that $89 \%$ of the cadmium is present as cadmium sulfide.

Metals may occur in sediment pore water in true solution or complexed to various dissolved organic or inorganic ligands. Reported concentrations of total cadmium in pore water range from 0.002 to $108 \mu \mathrm{g} / \mathrm{L}$ (Campbell et al. 1988). Concentrations usually are less than $1 \mu \mathrm{g} / \mathrm{L}$, except in pore water from heavily contaminated sediments. These concentrations are higher than those found in the overlying clean seawater (Table 3.1). In estuarine sediments, much of the pore water cadmium appears to be labile, as determined by anodic stripping voltammetry (Batley and Giles 1980a,b). Concentrations of cadmium in pore water from a sediment core from Villefranche Bay, France, decrease with depth to a minimum between 3 and $9 \mathrm{~cm}$, and then increase again with depth to $27 \mathrm{~cm}$ (Gaillard et al. 1986). Based on the profiles of total $\mathrm{H}_{2} \mathrm{~S}$ and $\mathrm{CO}_{2}$ in the core, the authors suggested that the decreasing gradient of dissolved cadmium in the upper part of the core is due to exchange with cadmium carbonates and precipitation of cadmium sulfide. The increase in concentrations of cadmium in pore water at greater depths probably is due to formation of soluble cadmium polysulfide complexes as the total hydrogen sulfide concentration increases. Cadmium forms a series of stable sulfide complexes, $\mathrm{Cd}(\mathrm{HS})_{2}{ }^{(\mathrm{n}-2)}$, where $\mathrm{n}=1$ or 4 , and a stable mixed complex, $\mathrm{Cd}(\mathrm{OH})(\mathrm{HS})^{0}$ (Boulegue 1983). The most abundant species of cadmium in anoxic pore water of sediments from Branford Harbor, Connecticut, are $\mathrm{CdHS}^{+}$and $\mathrm{Cd}(\mathrm{OH})^{+}$(Lyons and Fitzgerald 1983). These 
cadmium complexes are moderately soluble; therefore, the mobility of cadmium in reducing environments may be quite high (Boulegue 1983).

\subsubsection{Chromium}

Chromium may be present in seawater and marine sediments in two valency states: particleactive trivalent chromium, $\mathrm{Cr}(\mathrm{III})$, and more soluble hexavalent chromium, $\mathrm{Cr}(\mathrm{VI})$ (Murray et al. 1983). From a thermodynamic standpoint, only hexavalent chromium should be present in oxygenated seawater (Elderfield 1970). Most of the chromium in oceanic surface waters is, in fact, hexavalent (Van der Weijden and Reith 1982). However, in nearshore and estuarine waters and hypoxic ocean waters (e.g., the oxygen minimum layer in the ocean), a fraction (about $10 \%$, depending on suspended particle concentration) of the total dissolved chromium is trivalent (Cranston and Murray 1980, Murray et al. 1983). Chromium(VI) can be reduced readily to chromium(III) by marine organisms, dissolved organic material (Nakayama et al. 1981b) and possibly by reactive ferrous iron (FeII) (Eary and Rai 1988). Chromium(III) has a low solubility in seawater and tends to bind to suspended particles or complex with low molecular weight dissolved organics (Nakayama et al. 1981a,b; Eary and Rai 1987). Oxidation of chromium(III) to chromium(VI) by dissolved oxygen is very slow at the $\mathrm{pH}$ of seawater; however, particulate manganese oxides in seawater are able to oxidize chromium(III) (Nakayama et al. 1981b, Eary and Rai 1987). Hexavalent chromium does not readily adsorb to suspended estuarine sediment particles or model solid substrates (Cranston and Murray 1980, Mayer and Schick 1981). However, chromium(VI) may be removed from solution by a two-step reaction involving reduction to chromium(III) followed by adsorption.

The concentration of total dissolved chromium in open-ocean surface waters is about 100 to $500 \mathrm{ng} / \mathrm{L}$ (Table 3.1) and decreases with depth (Crecelius 1982, Murray et al. 1983, Mayer 1988). Fukai (1969) reported a concentration range of 208 to $432 \mathrm{ng} / \mathrm{L}$ for chromium in surface water of the Mediterranean.

Concentrations of chromium in uncontaminated marine and estuarine sediments are generally in the range of 50 to $100 \mu \mathrm{g} / \mathrm{g}$ dry wt (Salomons and Förstner 1984, Mayer 1988). Surficial sediments in estuaries receiving effluents from electroplating plants and leather tanneries may contain very high concentrations of chromium. For example, sediments in New Bedford Harbor, Massachusetts, (electroplating) and Otago Harbor, New Zealand, (tannery) contain more than 3000 $\mu \mathrm{g} / \mathrm{g}$ total chromium (Summerhayes et al. 1977, Johnson et al. 1981). Sediments from eight locations in San Francisco Bay contain 67 to $740 \mu \mathrm{g} / \mathrm{g}$ total chromium (Luoma and Phillips 1988). 
The distribution of chromium in sediment seems to depend in part on the source of the chromium. In estuaries receiving chromium from tanneries and electroplating operations, $80 \%$ or more of the total chromium in the sediment is associated with the organic/sulfide fraction (Capuzzo and Anderson 1973, Loutit et al. 1988). Because chromium is not known to form sulfides, carbonates, or phosphates (Schroeder and Lee 1975, Mayer 1988) and because of the stability of solid $\mathrm{Cr}(\mathrm{OH})_{3}$, it is probable that most of the chromium in these sediments is bound to organic matter or present as the hydroxide. Only $4 \%$ of the chromium is associated with reducible hydrous oxides.

Sediment bacteria are able to accumulate chromium(III) from contaminated sediment (Aislabie and Loutit 1986, Loutit and Pillidge 1986). Approximately $80 \%$ of the accumulated chromium is associated with an extracellular polysaccharide rich in uronic acid residues. Thus, a significant fraction of the organically bound chromium in sediment may be associated with polysaccharide exudates produced by bacteria. Chromium(III) bound to bacterial polysaccharide is bioavailable to infaunal invertebrates (Bremer and Loutit 1986).

Chromium in less contaminated sediments often is adsorbed primarily to the amorphous iron oxide (50\% to $70 \%)$ and organic/sulfide (25\% to $40 \%$ ) fractions of the sediments (Kersten and Förstner 1986, Rosental et al. 1986). Coarse-grained sediments contain a greater proportion of the total chromium in the residual fraction, and clayey, organic-rich sediments contain a greater proportion of the total chromium in the organic fraction.

In relatively uncontaminated sediments, $70 \%$ or more of the total chromium may be associated with the detrital fraction (Loring 1982, Prohic and Kniewald 1987). The detrital chromium is associated primarily with the heavy minerals chromite, chromiferous magnetite, and spinels, and with the aluminosilicate lattice of clay minerals (Mayer and Fink 1980).

The concentration of chromium in pore water of sediments from the Gulf of California, Mexico ranges from 0.4 to $7.0 \mu \mathrm{g} / \mathrm{L}$ and tends to increase with depth in the sediment (Brumsack and Gieskes 1983). The chromium appears to be bound to low molecular weight organics in the pore water. Even in sediments from Otago Harbor, heavily contaminated with chromium, the concentration of chromium in the pore water never exceeds $20 \mu \mathrm{g} / \mathrm{L}$ (Loutit et al. 1988).

The concentration of total chromium in pore water of Villefranche Bay, France, drops from $0.34 \mu \mathrm{g} / \mathrm{L}$ at the surface to $0.125 \mu \mathrm{g} / \mathrm{L}$ at 3 to $6 \mathrm{~cm}$ below the sediment surface, and remains near or below $0.1 \mu \mathrm{g} / \mathrm{L}$ at greater depths (Gaillard et al. 1986). The authors interpreted this chromium 
profile to indicate that the surficial sediments contain both chromium(III) and chromium(VI), the former complexed to organic matter and the latter in biota or derived from manganese oxide-mediated oxidation of chromium(III). Below the surficial layer of the sediment, all the chromium was in the trivalent state in the form of insoluble salts (e.g., hydroxide) or adsorbed to iron oxides and organic material.

A different distribution of chromium was observed in pore water of sediment cores from Narragansett Bay, Rhode Island (Douglas et al. 1986). In these cores, total soluble chromium in pore water increased from $0.05 \mu \mathrm{g} / \mathrm{L}$ at the surface to $2.1 \mu \mathrm{g} / \mathrm{L}$ at $14 \mathrm{~cm}$. In the same cores, organically bound chromium in the pore water increased from $0.005 \mu \mathrm{g} / \mathrm{L}$ at the surface to $0.88 \mu \mathrm{g} / \mathrm{L}$ at $14 \mathrm{~cm}$. Organic complexes of chromium represented $23 \%$ to $55 \%$ of the total chromium in pore water. As discussed above, the organic ligands could be low molecular weight organic compounds (e.g., fulvic acids and low molecular weight fatty acids) or bacterial exudates. At the $\mathrm{pH}$ and Eh of the pore water, all the chromium is present in the trivalent state.

\subsubsection{Copper}

The concentration of total copper in clean oceanic seawater is in the range of about 30 to 150 ng/L at the surface (Boyle et al. 1977, Schaule and Patterson 1981, Crecelius 1982, Mart et al. 1982), and increases to approximately $320 \mathrm{ng} / \mathrm{L}$ at abyssal depths (Bruland and Franks 1983). Concentrations of dissolved copper tend to be highest in the low salinity regions of estuaries and decrease with increasing salinity (Kerdijk and Salomons 1981, Windom et al. 1983). Copper concentrations in surface waters of San Francisco Bay range from about 1600 to $3500 \mathrm{ng} / \mathrm{L}$ (Luoma and Phillips 1988), reflecting substantial anthropogenic inputs of this metal to the bay.

Copper can occur in seawater in several forms. The most abundant inorganic complexes of copper at the $\mathrm{pH}$ and ionic composition of seawater are $\mathrm{CuCO}_{3}$ (Millero 1980), $\mathrm{CuHCO}_{3}^{-}$(Zuehlke and Kester 1983), $\mathrm{Cu}(\mathrm{OH})^{+}$, and $\mathrm{Cu}(\mathrm{OH})_{2}$ (Nelson et al. 1981, Zuehlke and Kester 1983). Very little copper ion $\left(\mathrm{Cu}^{+2}\right)$ is present in seawater (Millero 1980). The statistical analyses of Cowan et al. (1984) suggest that the various copper hydroxide species, not copper ion, are the most toxic species to aquatic fauna.

Copper has a strong affinity for complexation with organic ligands such as humic substances and dissolved organic matter (Oakley et al. 1981, Zuehlke and Kester 1983, Mills and Quinn 1984) 
and bacterial particles (Nelson et al. 1981), so little is present as toxic inorganic species. Nearly all the copper in seawater is present as the carbonate or as a metal-organic complex.

Zuehlke and Kester (1983) estimated that at a total copper concentration of $0.6 \mu \mathrm{g} / \mathrm{L}$ in seawater, in the presence of $0.7 \mathrm{mg} / \mathrm{L}$ dissolved organic matter, only about $1 \%$ of the total dissolved copper would be in a free ionic form.

Dissolved copper-organic complexes enter Narragansett Bay, Rhode Island, in sewage effluent and represent $14 \%$ to $70 \%$ of the total dissolved copper in Bay waters (Mills and Quinn 1984). In the New York Bight, the percent of total dissolved copper that is organically bound decreases from about $50 \%$ in bottom waters near the Bight apex to less than $10 \%$ in offshore surface waters (Hanson and Quinn 1983).

Concentrations of copper in uncontaminated marine and estuarine sediments usually are in the range of 10 to $50 \mu \mathrm{g} / \mathrm{g}$ dry wt (Salomons and Förstner 1984, Ridgway and Price 1987). Copper may reach very high concentrations in sediments from heavily contaminated estuaries. Copper concentrations of 6000 to $7500 \mu \mathrm{g} / \mathrm{g}$ were reported for the clay-size fraction of surficial sediments from inner New Bedford Harbor (Stoffers et al. 1977, Summerhayes et al. 1977). Surficial sediments in the vicinity of a refinery outfall in the Derwent Estuary, Tasmania, Australia, contain $10,000 \mu \mathrm{g} / \mathrm{g}$ copper (Bloom and Ayling 1977). Copper concentrations in sediments from San Francisco Bay, California, and the southern part of Puget Sound range from 13 to $580 \mu \mathrm{g} / \mathrm{g}$ (Schults et al. 1987, Luoma and Phillips 1988).

Much of the copper in deep sea sediments and coastal sediments containing low concentrations of organic matter is in the residual fraction associated with the silicate lattice of clays and siliceous oozes (Grieve and Fletcher 1976, Brannon et al. 1977, Förstner and Stoffers 1981, Chester et al. 1988).

In sediments containing high concentrations of organic matter, such as those from Corpus Christi Harbor, and Texas City Channel, Texas, False Bay, South Africa, and the Bay of Nice, France, copper is associated primarily with the organic/sulfide fraction or with extractable organic matter (Rapin 1983, Luoma and Davis 1983, Luoma 1986a, Rosental et al. 1986). Much of the remainder of the copper in sediments is associated with reducible iron and magnesium hydrous oxides (Brannon et al. 1977, Prohic et al. 1987). 
In anoxic, sulfidic sediments, copper may undergo a variety of reactions with different inorganic and organic sulfur species to form a variety of soluble and insoluble complexes (DaviesColley et al. 1985, Shea and Helz 1988). Polysulfide complexes with cuprous copper, $\mathrm{Cu}(\mathrm{I})$, are soluble. Because the formation of polysulfides is dependent on the availability of zero-valent sulfur, the solubility of copper in sulfidic pore water is also dependent on the concentration of zero-valent sulfur (Shea and Helz 1988). The dominant solid forms of copper in anoxic sediment are thought to be chalcocite $\left(\mathrm{Cu}_{2} \mathrm{~S}\right)$, covellite $(\mathrm{CuS})$, and possibly chalcopyrite $\left(\mathrm{CuFeS}_{2}\right)$. The dominant copper species in solution is thought to be $\mathrm{CuS}\left(\mathrm{S}_{\mathrm{s}}\right)^{-2}$. Copper in sulfidic salt marsh sediments may be complexed with organo-sulfur ligands (Boulegue et al. 1982). Shea and MacCrehan (1988) showed that the major copper complex in sulfidic pore water is that with cysteine, followed by that with polysulfides.

Concentrations of copper in pore water of sediment cores from Mobile Bay, Alabama, range from 1.00 to $2.27 \mu \mathrm{g} / \mathrm{L}$ (Brannon et al. 1977). There is no clear gradient with depth in the cores. Concentrations of copper in pore water of sediment cores from Narragansett Bay, Rhode Island, generally decrease with increasing depth in the core (Douglas et al. 1986). From $22 \%$ to $67 \%$ of the total copper in pore water is bound to dissolved organic matter. Maximum copper concentrations occur at 2 and $6 \mathrm{~cm}$ in the cores. The sharp gradient of total copper concentration from $1.3 \mu \mathrm{g} / \mathrm{L}$ at the sediment surface to $2.5 \mu \mathrm{g} / \mathrm{L}$ at $2 \mathrm{~cm}$ in the sediment suggests that the sediment could be supplying copper to the overlying water column. Manganese and iron oxides are reduced and dissolved in the 2 to $6 \mathrm{~cm}$ depth interval, possibly releasing copper adsorbed to these reducible phases. Below $10 \mathrm{~cm}$, the concentration of sulfide increases sharply. Nevertheless, the ratio of organically complexed copper to total copper does not change significantly in the pore water, suggesting that the organically complexed copper is in apparent equilibrium with the inorganic species and is not protected preferentially from sulfide mineral formation by its organic association. Below $10 \mathrm{~cm}$ in the sediment, the concentration of total copper in the pore water is about $0.3 \mu \mathrm{g} / \mathrm{L}$ and does not vary much with depth. In earlier investigations of sediment cores from Narragansett Bay, Elderfield et al. (1981) measured total copper concentrations of 1 to $22 \mu \mathrm{g} / \mathrm{L}$ in pore water. Approximately $80 \%$ of the copper was inorganic.

The concentration of copper is highest $(4.0 \mu \mathrm{g} / \mathrm{L})$ in pore water from the upper $3 \mathrm{~cm}$ of a sediment core from Villefranche Bay, France, and decreases to a minimum below $9 \mathrm{~cm}$ (Gaillard et al. 1986). The copper concentration in the overlying water is lower $(2.1 \mu \mathrm{g} / \mathrm{L})$ than in the pore water 
of surficial sediments. These results are similar to those of Douglas et al. (1986) for Narragansett Bay. Thermodynamic calculations based on concentrations of copper and sulfide in pore water in the depth range of 18 to $27 \mathrm{~cm}$ indicate that copper could precipitate as pure metal sulfide solid phases, as discussed above. However, it is more likely that copper was coprecipitated with iron sulfide as chalcopyrite $\left(\mathrm{CuFeS}_{2}\right)$.

\subsubsection{Lead}

Concentrations of dissolved lead in surface waters of the open Pacific and Atlantic Oceans are in the range of 5 to $15 \mathrm{ng} / \mathrm{kg}$ (Schaule and Patterson 1978) and 39 to $61 \mathrm{ng} / \mathrm{kg}$ (Mart et al. 1982), respectively. The concentration of dissolved lead in the Sargasso Sea drops from $33.2 \mathrm{ng} / \mathrm{kg}$ at the surface to about $5.4 \mathrm{ng} / \mathrm{kg}$ at a depth of $3000 \mathrm{~m}$. Along the Belgian and Dutch Coasts, concentrations of dissolved lead increase to the range of 41 to $857 \mathrm{ng} / \mathrm{kg}$ and total lead concentrations (dissolved plus particulate) are in the range of 364 to $1717 \mathrm{ng} / \mathrm{kg}$ (Mart et al. 1982). The particulate lead is present primarily as hydroxy and carbonato complexes that readily adsorb to particles (Valenta et al. 1987).

Nürnberg (1983) identified seven different species of inorganic lead in seawater. The carbonate $\left(\mathrm{PbCO}_{3}\right)$ and hydroxide $\left(\mathrm{PbOH}^{+}\right)$species are the most abundant, followed by the chloride complexes $\left(\mathrm{PbCl}_{2}\right.$ and $\left.\mathrm{Pb}(\mathrm{OH}) \mathrm{Cl}\right)$. The free metal ion $\left(\mathrm{Pb}^{+2}\right)$ represents only $1.8 \%$ of the total lead in seawater.

Concentrations of total lead in uncontaminated estuarine and near-shore marine sediments generally fall in the range of 5 to $30 \mu \mathrm{g} / \mathrm{g}$ dry wt (Warren 1981, Salomons and Förstner 1984). Major sources of lead in coastal waters are urban runoff and aerial deposition (Patterson and Settle 1987, Luoma and Phillips 1988). This lead is derived in large part from exhaust emissions from burning leaded gasoline in vehicles and from metal smelters. Thus, highest concentrations of lead often are found in sediments of urban bays and estuaries, such as San Francisco Bay where sediments contain 52 to $2900 \mu \mathrm{g} / \mathrm{g}$ total lead (Luoma and Phillips 1988)... Approximately $4.2 \%$ lead was reported in sediments near the wharf of a zinc refining company on the Derwent Estuary in Tasmania, Australia (Bloom and Ayling 1977). Sediments from large areas of the upper estuary contain more than $1000 \mu \mathrm{g} / \mathrm{g}$ lead.

The non-detrital fraction of lead in oxidized surficial estuarine and marine sediments appears to be associated primarily with reducible iron and manganese oxide fractions (Luoma and Bryan 1981, Lion et al. 1982, Rosental et al. 1986). Lead in sediments from the Krka River Estuary, Yugoslavia, 
is concentrated primarily in the carbonate and exchangeable fractions (Prohic and Kniewald 1987). About $20 \%$ of the non-detrital lead in salt marsh and basin sediments is associated with the organic/sulfide fraction of the sediment (Lion et al. 1982, Rosental et al. 1986).

The fraction of total lead in the residual fraction ranges from $2 \%$ to $82 \%$, depending on degree of contamination and organic carbon concentration of the sediment (Loring 1982, Rosental et al. 1986, Prohic and Kniewald 1987). The major carriers of the detrital lead appeared to be aluminosilicates, sulfide minerals, and barite.

In anoxic sediments, the most stable valence state of lead is the +II state (Harada and Tsunogai 1988). Divalent lead reacts with inorganic sulfide in sediment to form highly insoluble lead sulfide $(\mathrm{PbS})$. Sulfides appear to be the predominant form of lead in anoxic sediments (Kersten and Förstner 1986). Virtually all the non-residual lead in reducing sediments from Texas City Channel and Corpus Christi Harbor, Texas, is in the organic/sulfide fraction. At high concentrations of sulfide in sediment, lead may form a soluble bisulfide complex (Shea and MacCrehan 1988a,b). However, lead apparently does not form stable complexes with thiols.

Pore waters of estuarine and marine sediments contain 0.2 to $3.0 \mu \mathrm{g} / \mathrm{L}$ lead and exceptionally up to about $60 \mu \mathrm{g} / \mathrm{L}$ lead (Batley and Giles 1980a,b, Abdullah and Reusch-Berg 1981, Rapin et al. 1983). In pore water from anoxic mangrove swamp sediments from the Woronora River, New South Wales, Australia, $43 \%$ to $53 \%$ of the total lead is in labile forms (Batley and Giles 1980a,b). Only $6 \%$ of the lead in the pore water of the upper $2.5 \mathrm{~cm}$ of a sediment core examined by Abdullah and Reusch-Berg (1981) is in a labile form. However, in deeper anoxic strata from the same core, 25\% to $58 \%$ of the lead in pore water is labile, probably as bisulfide or organic complexes. The concentration of lead in pore water of a sediment core from Villefranche Bay, France, drops from 3.7

$\mu \mathrm{g} / \mathrm{L}$ in the upper $3 \mathrm{~cm}$ to $0.35 \mu \mathrm{g} / \mathrm{L}$ at 12 to $15 \mathrm{~cm}$ (Gaillard et al. 1986). The concentration of lead in the pore water remains relatively constant at 0.35 to $1.2 \mu \mathrm{g} / \mathrm{L}$ at core depths of 6 to $30 \mathrm{~cm}$. The overlying water contains $2.5 \mu \mathrm{g} / \mathrm{L}$ lead, slightly higher than the concentration in pore water of the surficial sediments.

\subsubsection{Mercury}

Mercury may occur in three valency states in seawater and marine sediments: zero (elemental mercury), +1 (mercurous compounds), and +2 (mercuric compounds) (Moore and Ramamoorthy $1984 \mathrm{a}, \mathrm{b})$. The +2 valency state is the most common in well-oxygenated water and sediments. The 
major species of inorganic mercury in seawater are the chloride, $\mathrm{HgCl}_{2}$, and other chloro complexes (Morel et al. 1973, Sibley and Morgan 1977). In low salinity (low chlorinity) estuarine waters, mercuric hydroxide, $\mathrm{Hg}(\mathrm{OH})_{2}$, becomes the dominant dissolved species (Lockwood and Chen 1973). Divalent mercury in seawater and sediments is subject to biological methylation, yielding a variety of highly toxic organo-mercury compounds (Wood 1987).

The average concentration of mercury in surface waters of the open ocean in the Southern Hemisphere is $11.2 \mathrm{ng} / \mathrm{L}$ and in the oceans of the Northern Hemisphere, $33.5 \mathrm{ng} / \mathrm{L}$ (Gardner 1975). The average concentration of mercury in the Gulf Stream is $4.0 \mathrm{ng} / \mathrm{L}$ (Mukheriji and Kester 1979). Olafsson (1983) reported concentrations of 2.2 to $3.2 \mathrm{ng} / \mathrm{L}$ total mercury in open ocean surface waters around Iceland. From one-quarter to three-quarters of the total mercury is reactive. Concentrations of total mercury in surface waters of the northwest Pacific Ocean are $14 \mathrm{ng} / \mathrm{L}$ and decrease to $6 \mathrm{ng} / \mathrm{L}$ at depths greater than $500 \mathrm{~m}$ (Miyake and Suzuki 1983). In the latter samples, one-third to one-half of the total mercury in surface waters were complexed to dissolved organic matter and $3 \%$ to $10 \%$ of the total mercury was in particulate form. Concentrations of methylmercury in oceanic surface waters nearly always are less than $1 \mathrm{ng} / \mathrm{L}$ (Moore and Ramamoorthy 1984a).

Concentrations of mercury in coastal waters and estuaries generally are much higher than those in the open ocean. Lindberg and Harriss (1977) reported a concentration of $200 \mathrm{ng} / \mathrm{L}$ total dissolved mercury in waters of Mobile Bay, Alabama. In the heavily contaminated Derwent Estuary, Tasmania, Australia, mercury concentrations in the water range from about 100 to $500 \mathrm{ng} / \mathrm{L}$ (Bloom and Ayling 1977). Concentrations of mercury associated with suspended particles in rivers and estuaries are in the range of 150 to $11,800 \mu \mathrm{g} / \mathrm{kg}$ and tend to decrease with increasing salinity, suggesting desorption of mercury from particles during estuarine mixing (Lindberg et al. 1975).

Concentrations of total mercury in uncontaminated estuarine and marine sediments generally are $0.2 \mu \mathrm{g} / \mathrm{g}$ dry wt or lower (Crecelius et al. 1975, Salomons and Förstner 1984), except in areas of natural mercuriferous deposits, such as the East Pacific Rise and the Mid-Atlantic Ridge (Jonasson and Boyle 1972). Surficial sediments from San Francisco Bay, California, Bellingham Bay, Washington, and lower Chesapeake Bay contain 0.4 to $10.7 \mu \mathrm{g} / \mathrm{g}$ total mercury (Huggett et al. 1972, Bothner et al. 1980a,b, Luoma and Phillips 1988). Chloralkali plants, and some pharmaceutical and other chemical plants, may be important local point sources of mercury to coastal waters. Sediments near wastewater outfalls from these industries may become heavily contaminated with mercury. Sediments in Berry's Creek, New Jersey, near the discharge from a mercury processing plant contain 
more than $1000 \mu \mathrm{g} / \mathrm{g}$ total mercury (Berman and Bartha 1986). Sediments of the Derwent Estuary, Tasmania, Australia, contain up to $1130 \mu \mathrm{g} / \mathrm{g}$ mercury (Bloom and Ayling 1977); those in Minimata Bay, Japan, contain up to $2010 \mu \mathrm{g} / \mathrm{g}$ mercury (Kitamura 1968).

Mercury forms stable complexes with a variety of organic ligands. Millward and Burton (1975) showed that freshwater humic substances readily complex with dissolved mercury in seawater. Both neutral and ionic organic mercury compounds adsorb strongly to humic acids in seawater (Dalland et al. 1986). There is little binding of neutral organo-mercury compounds to iron and manganese oxides.

Inorganic mercury salts form very strong and stable complexes with organic ligands in seawater and sediments (Moore and Ramamoorthy 1984a,b). Strongest complexes are formed with sulfhydroxyl-containing compounds, followed by amino acids and hydroxy carboxylic acids. Mercury associated with dissolved organic matter in surface waters of the northwest Pacific Ocean is complexed primarily to proteinaceous material with a molecular weight of approximately 9000 (Miyake and Suzuki 1983). Degradation of these stable inorganic mercury-organic matter complexes and remobilization of mercury is slow in the absence of biological activity (Wood 1987).

The major site of mercury methylation in aquatic ecosystems is the sediments (Callister and Winfrey 1986). A wide variety of reactions of organic and inorganic mercury compounds occur in sediments and the overlying water column (Figure 3.1). Several species of marine sediment bacteria can methylate mercury. Biomethylation of mercury involves the transfer of a methyl group to mercuric ion to produce a weak cation, methylmercury $\left(\mathrm{CH}_{3} \mathrm{Hg}+\right)$, that is more mobile than mercuric ion (Wood 1987). Mercury may also be methylated abiotically by natural methyl compounds (Thayer and Brinkman 1982) and humic substances (Weber et al. 1985). However, under natural conditions, biomethylation seems to predominate over abiotic methylation of mercury (Berman and Bartha 1986). Mercury methylation is used by bacteria to aid in detoxifying and excreting mercury (Hou-Pan and Imura 1982). In the presence of hydrogen sulfide, monomethylmercury undergoes a disproportionation reaction to yield highly insoluble mercuric sulfide and volatile dimethyl mercury (Craig and Moreton 1984). At high $\mathrm{pH}$ values, some microorganisms are able to convert methylmercury to dimethylmercury (Fagerstrom and Jernelov 1972). Because of its volatility, dimethylmercury is lost rapidly from surficial sediments. 
Mercuric ion may be reduced to elemental mercury by some sediment bacteria (Olson et al. 1979). Elemental mercury is volatile and is lost rapidly from sediments. Elemental mercury may be oxidized to mercuric ion by aerobic sediment bacteria.

Methylmercury may be demethylated by the enzyme, organomercurial lyase, present in many mercury-resistant bacteria (Summers 1985). Demethylation of organomercury compounds is nearly always followed by reduction of the mercuric ion to elemental mercury (Summers and Silver 1978).

A variety of environmental factors, particularly redox potential, affect the rates of different reactions controlling the relative abundance of different mercury compounds in sediments. Mercury methylation is most rapid in hypoxic or anoxic sediments (Olson and Cooper 1976, Bartlett and Craig 1981). In carefully controlled experiments, Compeau and Bartha (1984) showed that methylation predominated over demethylation of mercury in salt marsh sediments at a redox potential of $-220 \mathrm{mV}$ (reducing), whereas the opposite was true at a redox potential of $+110 \mathrm{mV}$ (oxidizing).

Subsequently, Compeau and Bartha (1985) provided evidence that production of methylmercury in anoxic sediment is mediated primarily by sulfate-reducing bacteria.

However, high concentrations of hydrogen sulfide may inhibit mercury methylation (Berman and Bartha 1986). This effect is thought to be due to formation of extremely insoluble mercuric sulfide (solubility product, $10^{-52.4}$ ). For example, in sediments from the Mersey River Estuary, England (Bartlett and Craig 1981) and the vicinity of a sewage sludge outfall in Santa Monica Bay, California (Eganhouse et al. 1978), the concentration of methylmercury is low wherever the concentration of hydrogen sulfide is high and is higher in nearby areas or strata where conditions are less anoxic.

Although mercuric sulfide can be methylated to methylmercury by sediment bacteria, the speed of this transformation is only one one-thousandth that of methylation of the mercuric ion (Fagerstrom and Jernelov 1971). Methylation of mercuric sulfide requires the oxidation of sulfide to sulfate (Gavis and Ferguson 1972), which can occur only under oxidizing conditions in the absence of other organic sulfides. However, under oxidizing conditions, demethylating bacteria are more abundant than methylating bacteria and demethylation predominates over methylation (Bartlett and Craig 1981). Thus, mercuric sulfide tends to be quite stable in anoxic and hypoxic marine sediments.

The predominant form of nonresidual mercury in oxidized sediments is as complexes with organic compounds (Lindberg et al. 1975, Campbell et al. 1988). In sediments from several British 
estuaries, between $47 \%$ and $71 \%$ of the total mercury $(1.2$ to $4.0 \mu \mathrm{g} / \mathrm{g})$ is associated with oxidizable organic matter (Langston 1982). Approximately $1 \%$ of the total mercury is associated with humic and fulvic acids. In sediments from the Tyrrhenian Sea, heavily contaminated with mercury from a chloralkali plant at Rosignano Solvay, Italy, $40 \%$ of the total mercury is bound to reactive organic matter (Baldi and Bargagli 1984). The remaining 60\% of the total mercury is in the residual fraction, probably as mercuric sulfide. In relatively uncontaminated sediments from the Bay of Fundy, Canada, most of the nonresidual mercury is associated with fine-grained organic material (Loring 1982). The residual mercury is associated with aluminosilicate minerals (clays) and metal sulfides. In highly reduced marine sediments, much of the mercury may be in the form of solid mercuric sulfide ( $\mathrm{Lu}$ and Chen $1977 \mathrm{a}, \mathrm{b})$.

Methylmercury almost never represents more than $1 \%$ of the total mercury in sediments. Lindberg et al. (1975) reported that methylmercury in sediments from the Mississippi River Delta, Louisiana, the Everglades, Florida, and Mobile Bay, Alabama, never represents more than $0.07 \%$ of the total mercury. On the average, methylmercury represents $0.46 \%$ of the total mercury in a large number of sediment samples from the Mersey River Estuary, England (Bartlett and Craig 1981). Only $0.0003 \%$ to $0.01 \%$ of the total mercury in highly sulfidic sediment from Barry's Creek, New Jersey, is methylmercury (Berman and Bartha 1986). However, in sediments from Kastela Bay, Yugoslavia, and the Yatsushiro Sea adjacent to Minemata Bay, Japan, contaminated with mercury from chloralkali or plastics manufacturing plants, from $1 \%$ to occasionally as high as $5 \%$ of the total mercury is methylmercury (Kudo et al. 1980, Mikac and Picer 1985).

Concentrations of mercury in sediment pore water in estuarine and marine sediments generally fall in the range of 100 to $3600 \mathrm{ng} / \mathrm{L}$ (Lindberg et al. 1975, Lu and Chen 1977a,b). Pore water in sediments from contaminated regions of San Francisco Bay contain up to $10,000 \mathrm{ng} / \mathrm{L}$ mercury (Serne 1977). Pore water from anoxic sediments from Bellingham Bay, Puget Sound, Washington, contain up to $3800 \mathrm{ng} / \mathrm{L}$ mercury, whereas pore water from oxygenated sediments in the same bay contain 10 to $60 \mathrm{ng} / \mathrm{L}$ mercury (Bothner et al. 1980a,b). These concentrations are substantially higher than the concentrations of mercury in surface waters, as discussed above.

Much of the pore water mercury in oxidized sediments appears to be complexed to dissolved organic matter, primarily fulvic acids (Lindberg and Harriss 1974, Lindberg et al. 1975). In uncontaminated sediments from the Everglades, most of the dissolved mercury in pore water is associated with a $<500$ molecular-weight fraction of dissolved organic matter. However, in 
contaminated sediments from Mobile Bay, most of the mercury is associated with the $>100,000$ molecular-weight organic fraction. Only $15 \%$ of the dissolved mercury in the pore water of these sediments is imethylmercury.

Concentrations of mercury in solution in anoxic pore waters are many orders of magnitude higher than predicted by equilibrium with solid-phase mercuric sulfide. Lu and Chen (1977) suggest that the dominant form of inorganic mercury (98\% in anoxic pore water) is $\mathrm{HgS}_{2}^{2}$. Mercury may also form soluble polysulfides. However, the predominant form of dissolved mercury in anoxic pore water probably is as complexes with dissolved organic matter.

\subsubsection{Tin}

Tin is present in the environment in a wide variety of inorganic and organic compounds. Organotin compounds always contain at least one carbon-tin covalent bond (Snoeij et al. 1987). Both divalent and trivalent tin are present in the environment. However, most organotins contain tetravalent tin covalently bonded to one to four organic substituents (Müller et al. 1989). Although inorganic tin compounds may be moderately toxic to marine organisms, contamination of marine ecosystems with inorganic tin is rarely perceived to be a problem, except possibly near some metal smelting and mining operations (e.g., Skei et al. 1972). However, various organotin compounds, some of which are extremely toxic to marine organisms, are used for a variety of commercial purposes that may favor their entry into the marine environment. Tripropyl-, tributyl-, and triphenyltins are extremely effective biocides that are used as wood preservatives, antifoulants for boat hulls and other submerged structures, and disinfectants and slimacides for cooling and paper mill waters (Snoeij et al. 1987). Tributyltin oxide is the most important organotin in antifouling paints (Müller et al. 1989). Because organotins must leach or be eroded from the surface being protected, use of organotins in antifouling paints results in the introduction of large amounts of dissolved organotins into coastal waters frequented by commercial and pleasure vessels.

The background concentration of total inorganic tin in estuarine and seawater is about 1 to 10 ng/L (Smith and Burton 1972, Andreae et al. 1983). When dissolved in seawater, tributyltin oxide speciates rapidly to tributyltin chloride (about 60\%), tributlytin hydroxide, tributyltin carbonate, and unspeciated tributyltin oxide (Guard et al. 1981b, Eng et al. 1986; Laughlin et al. 1986). The aqueous solubility of tributyltin chloride and tributyltin oxide at a pH of about 8 is $6 \mathrm{mg} / \mathrm{L}$ and 15 to $30 \mathrm{mg} / \mathrm{L}$, respectively (Maguire 1984), many orders of magnitude below the concentrations that are toxic to marine organisms. 
Tributyltins undergo sequential de-alkylation in seawater and sediments to yield dibutyltin, monobutyltin, and finally inorganic tin (Maguire et al. 1983, Maguire and Tkacz 1985). Dealkylation may occur abiotically, or it may be mediated by marine microorganisms (Olson and Brinkman 1986; Seligman et al. 1986). Because of these degradation processes, estuarine and marine ecosystems, particularly recreational boat marinas, that receive tributyltins often also contain elevated concentrations of dibutyltin, monobutyltin, and inorganic tin. The degradation half-life of tributyltin in seawater is about 7 to $15 \mathrm{~d}$ (Seligman et al. 1986), whereas that in oxidized marine sediments is approximately $162 \mathrm{~d}$ (Stang and Seligman 1986). Biodegradation of tributyltin in hypoxic and anoxic sediments is negligible. Because of the rapid rate of tributyltin degradation in seawater, tributyltin concentrations show marked seasonal variations in coastal waters. Highest concentrations are in spring and summer when use of pleasure boats with freshly painted bottoms is greatest (Waldock et al. 1987).

Inorganic tin, and possibly butyltins (Maguire 1984), can be methylated in sediments by microbial (Thayer and Brinkman 1982, Gilmour et al. 1985) and abiotic (Craig and Rapsomanikis $1984,1985)$ processes. Inorganic tin is methylated primarily to monomethyltin, with lesser amounts of dimethyl- and trimethyltin (Gilmour et al. 1985). Trimethyltin is slowly converted to tetramethyltin (Guard et al. 1981a). Tributylmethyltin and dibutymethyltin have been detected in sediments from Toronto Harbor, Canada, suggesting that butyltins from antifouling paints can be methylated (Maguire 1984). Sediment microorganisms may also be able to demethylate methyltin (Craig 1980). Some methyltins are quite volatile and are lost rapidly from sediment and water. Other methyltins readily adsorb to fulvic acid and iron oxide particles, decreasing their mobility in water and sediments (Donard and Weber 1985).

Concentrations of tributyltin in seawater at marinas along the California coast are in the range of 20 to $600 \mathrm{ng} / \mathrm{L}$ (Stallard et al. 1987). Lower concentrations are observed in seawater from harbors and the open coast. Dibutyltin and monobutyltin are found in nearly all water samples in which tributyltin is detected. In most cases, the concentration of tributyltin is higher than that of dibutyltin or monobutyltin. Similar results have been reported for the upper (Maryland) portion of Chesapeake Bay (Hall et al. 1987, Hall 1988). Concentrations of tributyltin up to $1801 \mathrm{ng} / \mathrm{L}$ were detected in the water column of marinas. Concentrations in the sea surface microlayer often are higher than those in the underlying water in Chesapeake Bay (Hall 1988) and estuaries in southwest England (Cleary and Stebbing 1987). Concentrations of total tin (including organotins) in the water column of Arcachon 
Bay, France, decreased from a mean of $5.05 \mu \mathrm{g} / \mathrm{L}$ in July, 1982, when use of organotin antifouling paints on boats less than $25-\mathrm{m}$ long was banned, to $1.00 \mu \mathrm{g} / \mathrm{L}$ two years later (Alzieu et al. 1986). Champ and Pugh (1987) recently summarized this literature on the concentrations of butyltins in waters and sediments of the United States, Canada, and Western Europe.

Most of the butyltins in seawater are in solution and not adsorbed to suspended particles. Valkirs et al. (1987) reported that $5 \%$ or less of butyltins in natural seawater samples are associated with particles. Mono- and tributyltin are adsorbed to a greater extent than dibutyltin. The fraction of total butyltins that adsorbs to suspended particles may increase (Harris and Cleary 1987) or decrease (Unger et al. 1988) with increasing salinity, depending on the types of suspended particles present.

The concentration of inorganic tin in clean marine sediments is about $2 \mu \mathrm{g} / \mathrm{g}$ dry wt. Although butyltins do not adsorb strongly to particles, they do tend to accumulate in sediments in the vicinity of major sources of butyltins in the water column.(e.g., marinas), though their concentrations are rarely as high as those of inorganic tin. Concentrations up to about $23 \mathrm{ng} / \mathrm{g}$ tributyltin were reported in surficial sediments of California marinas (Stallard et al. 1987). In many cases, concentrations of dibutyltin (up to $27 \mathrm{ng} / \mathrm{g}$ ) or monobutyitin (up to $60 \mathrm{ng} / \mathrm{g}$ ) are higher than those of tributyltin, providing circumstantial evidence for sequential demethylation of butyltins in sediments. Much higher concentrations of butyltins have been reported in sediments from Chesapeake Bay (Hall 1988) and Boston Harbor, Massachusetts (Makkar et al. 1989). Sediments from Back Creek on the Severn River, Maryland, contain 140 to $1390 \mathrm{ng} / \mathrm{g}$ tributyltin. Sediments from Sarah Creek, near Hampton Roads, Virginia, contain 920 to $1300 \mathrm{ng} / \mathrm{g}$ tributyltin, whereas those from Marina Bay Yacht Club in Boston contain up to $518 \mathrm{ng} / \mathrm{g}$ tributyltin and $375 \mathrm{ng} / \mathrm{g}$ monobutyl- and dibutyltin combined.

Tributyltin is present in aerobic sediment, primarily as tributyltin chloride, tributyltin hydroxide, and tributyltin carbamate (Guard et al. 1981a,b, Eng et al. 1986). In anaerobic sediment, the dominant chemical forms appear to be tributyltin sulfide, tributyltin hydroxide, and tributyltin carbonate. There are no published data on the concentrations or forms of butyltins in pore waters of marine sediments.

\subsubsection{Nickel}

The mean concentration of nickel in surface waters of the open ocean is in the range of 100 to $230 \mathrm{ng} / \mathrm{L}$ (Sclater et al. 1976, Bruland and Franks 1983, Crecelius 1984, Mart et al. 1982). Nickel 
concentrations tend to increase with water depth to a maximum of about $750 \mathrm{ng} / \mathrm{L}$ in the Atlantic (Sclater et al. 1976) and $600 \mathrm{ng} / \mathrm{L}$ in the Pacific (Bruland 1980, Mart et al. 1982). Concentrations of nickel in uncontaminated coastal waters generally are in the range of 600 to $5000 \mathrm{ng} / \mathrm{L}$, with a mean of about $1800 \mathrm{ng} / \mathrm{L}$ (Capelli et al. 1976, Snodgrass 1980). Concentrations near major point sources, such as metal smelters, may be substantially higher.

During estuarine mixing, nickel tends to become increasingly adsorbed to particles as salinity rises above about 10\% (Iierdijk and Salomons 1981). In Newark Bay, New Jersey, the particulate nickel is associated primarily with iron and manganese oxides and hydrous oxides (Luther et al. 1986). Nickel may also complex with dissolved organic compounds in seawater. Between $1 \%$ and $8 \%$ of the total dissolved nickel in the water column of the New York Bight is complexed to dissolved organic matter (Hanson and Quinn 1983).

The mean concentration of nickel in clean estuarine and marine sediments is about $50 \mu \mathrm{g} / \mathrm{g}$ (Bowen 1979), though much lower concentrations are common, particularly in coarse sediments. Sediments from Galveston Bay, Texas, contain 0.6 to $50 \mu \mathrm{g} / \mathrm{g}$ nickel (Trefry and Presley 1976) and those from Baltimore Harbor, Maryland, contain about $36 \mu \mathrm{g} / \mathrm{g}$ nickel (Helz 1976). Concentrations of nickel in surficial sediments off the Palos Verdes Peninsula, California, the site of a municipal wastewater outfall for Los Angeles County, ranged from 16 to $134 \mu \mathrm{g} / \mathrm{g}$ in 1975 (Hershelman et al. 1981). Concentrations of nickel in sediments of the New York Bight Apex near a dump site for sewage sludge range from 72 to $160 \mu \mathrm{g} / \mathrm{g}$ (Krom et al. 1985), whereas concentrations of nickel in surficial sediments from San Francisco Bay range from 31 to $343 \mu \mathrm{g} / \mathrm{g}$ (Luoma and Phillips 1988). These concentration ranges indicate that nickel is rarely present at substantially elevated concentrations in marine and estuarine sediments.

Nickel forms stable, insoluble complexes with sulfides and organic thiols in anoxic sediments (Wood 1987). In oxidized surficial sediments, nickel forms stable complexes with humic substances and iron/manganese oxides. Nickel also becomes tightly bound to anionic groups of bacterial polysaccharides (Wood 1987). However, most of the nickel in uncontaminated sediments is detrital. From $91 \%$ to $93 \%$ of the total nickel in sediments from the Bay of Fundy, Canada, is detrital (Loring 1982). Detrital nickel in Bay of Fundy sediments is associated primarily with oxide minerals, such as magnetite, spinels, and silicates.

Most of the nickel in sediments from the Baie de Nice, France, is associated with the detrital fraction (Rapin 1983). Most of the nondetrital nickel is associated with the reducible iron and 
manganese oxide fractions. Approximately $60 \%$ of the nickel in sediments from False Bay, South Africa, is associated with the organic/sulfide fraction (Rosental et al. 1986). Only about 10\% of the nickel is in the reducible/carbonate fraction, and about $30 \%$ is detrital. About $50 \%$ of the nondetrital nickel in marine sulfidic sediment analyzed by Kersten and Förstner (1986) is in the organic/sulfidic fraction. Virtually all the remainder is in the reducible fractions. Similar results were obtained for reducing sediments from Corpus Christi Harbor and Texas City Channel, Texas. It is uncertain how much of the nickel in the organic/sulfidic fraction of these sediments is associated with organic material. Knezevic and Chen (1977) reported that only $3 \%$ to $4 \%$ of the nickel in Los Angeles Harbor sediments is complexed to humic substances. Thus, a substantial fraction of the nondetrital nickel in sediments probably is in the form of nickel sulfide.

Somewhat different results were obtained for sediments from the Krka River estuary, Yugoslavia (Prohic and Kniewald 1987). From 16\% to 59\% of the nickel is associated with the carbonate and reducible fractions. From $13 \%$ to $31 \%$ is associated with the organic/sulfidic fraction, and $13 \%$ to $30 \%$ is detrital.

There are limited data on the concentrations of nickel in solution in pore waters of marine and estuarine sediments. Campbell et al. (1988) report values in the range of 600 to $25,000 \mathrm{ng} / \mathrm{L}$ for sediments from different sources. No speciation data are available. However, Lu and Chen (1977) predicted that the dominant soluble nickel complexes in interfacial seawater (and by inference interstitial seawater of oxidizing sediments) would be nickel ion (47\%) and nickel chlorides $\left(\mathrm{NiCl}_{2}\right.$ and $\mathrm{NiCl}^{+}, 48 \%$ ). Under reducing conditions, the dominant soluble complex would be with cysteine (99\%).

\subsubsection{Silver}

Monovalent silver ion is extremely toxic to marine organisms. However, it complexes readily with chloride in seawater and with sulfide in reducing sediments.(Morel et al. 1973) to form less toxic compounds. Virtually all the silver in solution in seawater is complexed to chloride (Simkiss and Taylor 1989). The background concentration of silver in seawater is about $10 \mathrm{ng} / \mathrm{L}$ (Robertson 1971). Its concentration may be substantially higher near major anthropogenic point sources (e.g., electroplating, photographic processing).

The typical background concentration of silver in sediments is approximately $0.06 \mu \mathrm{g} / \mathrm{g}$ dry wt (Bowen 1979), and it rarely exceeds $1 \mu \mathrm{g} / \mathrm{g}$ (Luoma and Bryan 1981), except in heavily 
contaminated sediments. Sediments from New Bedford, Massachusetts (electroplating wastes) contain up to $40 \mu \mathrm{g} / \mathrm{g}$ silver (Summerhayes et al. 1977). Sediments from the Sörfjord in western Norway contain up to $190 \mu \mathrm{g} / \mathrm{g}$ silver (Skei et al. 1972). Sediments from the South Bay portion of San Francisco Bay are contaminated with silver, with concentrations ranging from 2 to $66 \mu \mathrm{g} / \mathrm{g}$ (Luoma and Phillips 1988). By comparison, sediments from the northern reach of San Francisco Bay generally contain less than $0.5 \mu \mathrm{g} / \mathrm{g}$ silver.

Silver in oxidized marine sediments is partitioned primarily among iron hydrous oxides, humic substances, and possibly manganese oxides (Luoma and Bryan 1981). Harvey and Luoma $(1985 a, b)$ showed that silver adsorbs slowly to iron hydrous oxide particles in seawater.

Lyons and Fitzgerald (1983) reported that pore water from anoxic and suboxic estuarine sediments contains up to $1000 \mathrm{ng} / \mathrm{L}$ silver. Silver in anoxic pore water appears to be in the form of the silver bisulfide complex $\left(\mathrm{AgHS}^{\circ}\right)$. The concentration of silver in anoxic pore water is 100 -fold higher than the background concentration of silver in seawater, suggesting that silver might be mobilized readily from sediments. However, Lu and Chen (1977) could not demonstrate mobilization of silver from sediments under a variety of experimental conditions.

\subsubsection{Zinc}

Reported concentrations of zinc in seawater vary widely, probably due both to variability in concentrations actually present and to sample contamination. Crecelius (1982) reported a background concentration of $7 \mathrm{ng} / \mathrm{L}$ dissolved zinc in open ocean waters. Bruland and Franks (1983) reported concentrations ranging from 3.9 to $19.6 \mathrm{ng} / \mathrm{L}$ of zinc in the Sargasso Sea. Jones and Jeffries (1983) gave a concentration range of 300 to $4200 \mathrm{ng} / \mathrm{L}$ zinc for surface waters of the North Atlantic. Zinc concentrations tend to increase with depth in the ocean to maximum values below $1 \mathrm{~km}$ (Bruland 1980, Bruland and Franks 1983, Jones and Jeffries 1983). Dissolved zinc concentrations up to $1,500,000 \mathrm{ng} / \mathrm{L}$ have been reported in the water of a heavily contaminated estuary (Bloom and Ayling 1977).

A significant fraction of the total zinc in seawater is adsorbed to particles or complexed to dissolved organic matter. About $26 \%$ of the total zinc in surface waters of the Irish Sea and $54 \%$ of the total zinc in surface waters of the southern North Sea is adsorbed to suspended particles (Jones and Jeffries 1983). These particles contain 210 and $1158 \mu \mathrm{g} / \mathrm{g}$ zinc, respectively. Luther et al. (1986) showed that $4 \%$ to $50 \%$ of the dissolved zinc in seawater from Newark Bay, New Jersey, is 
nonlabile, and probably associated with inorganic and organic colloidal material. The dominant inorganic colloidal phase consists of particles $(<0.04 \mu \mathrm{m})$ of zinc sulfide. The organic colloidal phase includes zinc complexes with humic acids and organic material from municipal sewage discharges.

Zinc forms a variety of inorganic complexes in seawater, the relative proportion of different complexes depending on seawater salinity (Zirino and Yamamoto 1972, Bernhard et al. 1975, Amdurer et al. 1983). Uncomplexed zinc $\left(\mathrm{Zn}^{+2}\right)$ may represent $17 \%(\mathrm{pH}, 8.1)$ to $51 \%(\mathrm{pH}, 7.0)$ of the total dissolved zinc. The quantitatively most important zinc complexes at a pH of 8.1 are $\mathrm{Zn}(\mathrm{OH})_{2}, \mathrm{ZnCl}+\mathrm{ZnCl}_{2}$, and $\mathrm{ZnCO}_{3}$.

Concentrations of zinc in marine and estuarine sediments vary widely. Zinc concentrations in surficial sediments from the continental shelf of the southeastern United States are in the range of 3 to $10 \mu \mathrm{g} / \mathrm{g}$ (Bothner et al. 1980a). Concentrations of zinc in surficial sediments from Georges Bank off the New England coast range from 1.2 to $71 \mu \mathrm{g} / \mathrm{g}$, with the highest concentrations being associated with the finest-grained sediments (Bothner et al. 1985). Concentrations of zinc in sediments from Los Angeles Harbor are in the range of 98 to $325 \mu \mathrm{g} / \mathrm{g}$ (Emerson et al. 1976), whereas those in surficial sediments from the nearby Palos Verdes shelf, near the site of the wastewater discharge from the Los Angeles County sewage treatment plant, are in the range of 54 to $2880 \mu \mathrm{g} / \mathrm{g}$ (Hershelman et al. 1981). Sediments from San Francisco Bay contain 140 to $1890 \mu \mathrm{g} / \mathrm{g}$ zinc (Luoma and Phillips 1988). Very high concentrations of zinc may be found in sediments near major point sources. Zinc concentrations up to $10 \%$ were observed in sediments near the wharf of a zinc refining company on the Derwent Estuary, Tasmania (Bloom and Ayling 1977). Zinc concentrations up to $10,000 \mu \mathrm{g} / \mathrm{g}$ in sediments extend for several kilometers downstream from the wharf.

A large fraction of the zinc in contaminated and uncontaminated sediments may be residual (Warren 1981, Loring 1982). Zinc may be associated with the mineral lattice of clays or with a variety of heavy minerals. Chromite, ilmenite, and magnetite contain up to 8000,2400 , and 800 $\mu \mathrm{g} / \mathrm{g}$ zinc, respectively (Baker 1962). Zinc in sediments near mine tailings or zinc smelters may be present primarily as crystalline zinc sulfide (spalerite: $\mathrm{ZnS}$ ) (Dossis and Warren 1980). From 86\% to $91 \%$ of the total zinc (18 to $104 \mu \mathrm{g} / \mathrm{g}$ ) in Bay of Fundy sediments is residual (Loring 1982).

Sphalerite and zincite $(\mathrm{ZnO})$ are important detrital carriers of zinc in these sediments. Zinc in noncarbonate pelagic sediments (Förstner and Stoffers 1981) and surficial sediments from the Fraser 
River Estuary (Grieve and Fletcher 1976), Canada, is associated with the silicate (predominantly clay) fraction.

Nonresidual zinc in sediments from estuaries in southwest England (Luoma and Bryan 1981) and southern Louisiana (Feijtel et al. 1988) is associated primarily with the reducible iron, and to a lesser extent manganese oxide fractions. Organic material is also an important carrier of zinc in these sediments. In reducing sediments from Corpus Christi Channel, Texas, heavily contaminated with zinc ( $4547 \mu \mathrm{g} / \mathrm{g}$ total zinc), $35 \%$ uf the zinc is adsorbed to iron and manganese oxides, $48 \%$ is in the organic/sulfide fraction, and $17 \%$ is residual. Between $40 \%$ and $70 \%$ of the total zinc in sediments from Mobile Bay, Alabama, and False.Bay, South Africa, is associated with the organic/sulfide fraction and tends to increase with depth in the sediment (Brannon et al. 1977; Rosental et al. 1986). It is uncertain whether this zinc is complexed to organic matter or precipitated as zinc sulfide. Nissenbaum and Swaine (1976) quantified the fraction of total zinc associated with humic substances in marine sediments and concluded that virtually all the nonresidual zinc in reducing sediments is associated with organic matter. However, other investigators have identified significant quantities of zinc sulfides in reducing sediments (Loring 1982).

Concentrations of zinc in solution in sediment pore waters vary over a wide range (Campbell et al. 1988) and often are higher than concentrations in solution in the overlying water (Brannon et al. 1977). Pore water of surficial sediments $(0$ to $15 \mathrm{~cm})$ from Mobile Bay, Alabama, contains 26 to 35 $\mu \mathrm{g} / \mathrm{L}$ zinc, compared to 4 to $8 \mu \mathrm{g} / \mathrm{L}$ in the overlying water column (Brannon et al. 1977). Concentrations of zinc in pore water from these sediments increase with depth in the sediment core from $40 \mu \mathrm{g} / \mathrm{L}$ at the surface to $56 \mu \mathrm{g} / \mathrm{L}$ at 45 to $60 \mathrm{~cm}$. Virtually all the pore water zinc (5 to 20 $\mu \mathrm{g} / \mathrm{L})$ in reducing sediments from Saanich Inlet, Canada, is complexed with organic matter. However, as the sulfide concentration in reducing sediments increases, the solubility of zinc in the pore water increases, presumably by formation of polysulfide complexes ( $\mathrm{Zn}(\mathrm{HS})_{2}, \mathrm{ZnHSS}^{-}$, etc.) (Salomons et al. 1987). Lu and Chen $(1977 \mathrm{a}, \mathrm{b})$ predicted that the dominant form of inorganic zinc in solution in pore water of reducing sediments would be $\mathrm{Zn}(\mathrm{HS})_{3}^{-}$. In oxidizing sediments, most of the inorganic zinc in pore water is in the form of $\mathrm{Zn}^{+2}, \mathrm{Zn}(\mathrm{OH})_{2}, \mathrm{Zn} \mathrm{HCO}_{3}^{-}$, and $\mathrm{Zn} \mathrm{CO}$ ( $\mathrm{Lu}$ and Chen 1977a,b, Salomons 1985).

\subsubsection{Arsenic}

Arsenic can occur in estuarine and marine waters and sediments in four valency states, +5 , $+3,0,-3$ (Moore and Ramamoorthy 1984). Elemental arsenic is very rare and $\mathrm{As}^{-3}$ is found only at 
extremely low Eh values. Arsenate (As V) and arsenite (As III) are the dominant forms of arsenic in marine systems. Their ionic forms in solution are the oxyanions, $\mathrm{AsO}_{4}^{-3}$ and $\mathrm{AsO}_{2}^{-}$, respectively.

Phytoplankton in the water column (Sanders 1983) and bacteria in both aerobic and anaerobic sediments (Freeman et al. 1986, Brannon and Patrick 1987) are able to reduce As V to As III and methylate As III (Figure 3.2). Bacteria in aerobic sediments apparently can also oxidize As III to As V (Freeman et al. 1986). Thus, arsenate, arsenite, monomethylarsenic, and dimethylarsenic species may occur together in seawater and sediments. The relative proportions of the different forms depend on the redox conditions and the species composition and abundance of phytoplankton and bacteria present (Sanders 1983, 1985, Brannon and Patrick 1987).

The concentration of total arsenic in open-ocean waters is 2000 to $3000 \mathrm{ng} / \mathrm{L}$ (Johnson and Pilson 1972, Andreae 1979). In the Carnon/Restronguet Estuary system in southwest England, which drains a metal mining region, total arsenic concentrations decrease fromi 25 to $42 \mu \mathrm{g} / \mathrm{L}$ in the freshwater portion to 1.9 to $4.8 \mu \mathrm{g} / \mathrm{L}$ at the mouth of the estuary (Klumpp and Peterson 1979). The ratio of arsenite to arsenate in the water decreases from the head to the mouth of the estuary. A different pattern occurs in Chesapeake Bay (Sanders 1985). Freshwater entering the Bay from the Susquehanna River contains an average of $180 \mathrm{ng} / \mathrm{L}$ total arsenic. Concentrations of total arsenic in surface water increase with distance down the Bay and with increasing salinity to an average of 1130 $\mathrm{ng} / \mathrm{L}$ at the mouth of the Bay and immediately offshore. In the summer, all the arsenic in the Susquehanna River water is arsenate. Surface waters offshore the mouth of the estuary contain predominantly arsenate, with traces of arsenite and dimethylarsenic. Surface waters in the middle reaches of the Bay contain up to $62 \%$ arsenic as reduced or methylated arsenic species. Arsenite is most abundant at low salinities; monomethylarsenic is present primarily in the region of the estuary with salinities between $8 \%$ and $20 \%$; and dimethylarsenic occurs irregularly at salinities greater than $7 \%$. This pattern of arsenic distribution is attributed to a combination of reduction of arsenate in anoxic bottom waters during summer and presence in surface waters of large numbers of arsenicmethylating species of phytoplankton, particularly algae of the genus Chroomonas. In the Tejo River Estuary, Portugal, concentrations of total arsenic vary irregularly between 3.56 and $6.65 \mu \mathrm{g} / \mathrm{L}$ along the length of the estuary, compared to a mean of $2.7 \mu \mathrm{g} / \mathrm{L}$ at the mouth of the estuary (Andreae et al. 1983). The ratio of arsenite to arsenate increases from the head to the mouth of the estuary as salinity increases. Thus, the patterns of arsenic concentration and species distribution are complex and variable in different estuaries. 
Byrd (1988) identified a seasonal cycle of dissolved arsenic concentrations in surface waters of the continental shelf off South Carolina and Georgia. During late winter and spring, concentrations of arsenic in surface waters increase with distance from shore from 0.5 to $0.7 \mu \mathrm{g} / \mathrm{L}$, $10 \mathrm{~km}$ offshore to 1.1 to $1.2 \mu \mathrm{g} / \mathrm{L}, 50$ to $60 \mathrm{~km}$ offshore (background). Depletion of dissolved arsenic in nearshore waters is due to scavenging by resuspended sediments during winter storms and removal by phytoplankton during spring blooms. The arsenic adsorbed to particles or associated with phytoplankton is deposited in bottom sediments.

During summer, a reversed gradient develops of arsenic concentrations in surface waters. Total arsenic concentrations of 1.5 to $2.4 \mu \mathrm{g} / \mathrm{L}$ occur 2 to $6 \mathrm{~km}$ from shore and decrease with distance from shore to about $1.3 \mu \mathrm{g} / \mathrm{L}, 20$ to $23 \mathrm{~km}$ from shore. The excess arsenic in nearshore waters probably is derived from arsenic remobilized from bottom sediments. The behavior of arsenic resembles that of phosphate (Maher 1984), which is known to undergo seasonal remineralization and mobilization, with peak remobilization off Georgia occurring in August to October (Hopkinson 1987). Thus, off the southeast coast of the United States, arsenic appears to be deposited in nearshore sediments in early spring and then remobilized back into the water column in late summer.

Arsenate is the dominant form of arsenic in oxidized surficial sediments, whereas arsenite is the dominant dissolved and solid species in reduced sediment (Brannon and Patrick 1987, Riedel et al. 1987). In the oxidized layers of the sediment, much of the arsenic is associated (coprecipitated or adsorbed) with the hydrous iron and manganese oxide fractions (Maher 1984, Moore et al. 1988). Sediment organic matter may also bind some arsenic (Maher 1984). Knezevic and Chen (1977) reported that between $4 \%$ and $13.6 \%$ of the total arsenic in Los Angeles Harbor sediment is bound to humic substances. In reducing sediments, most of the arsenic is associated with sulfides as either inclusions in copper and zinc sulfides or as $\mathrm{As}_{2} \mathrm{~S}_{3}$ (Loring 1982, Moore et al. 1988). In such a system, arsenite remains quite mobile and tends to diffuse upward to be released into the overlying water column as either arsenite or arsenate (Brannon and Patrick 1987, Riedel et al. 1987, Moore et al. 1988). Infaunal organisms, such as the burrowing polychaete, Nereis succinea, increase the rate of flux to the overlying water by as much as five-fold (Riedel et al. 1987). Anion-exchangeable arsenic may also be abundant in surficial marine sediments (Neal et al. 1979).

Concentrations of total arsenic in uncontaminated marine sediments usually fall in the range of 5 to $15 \mu \mathrm{g} / \mathrm{g}$ (Moore and Ramamoorthy 1984a,b). Sediments from estuaries receiving drainage from metal-mining areas may contain substantially elevated concentrations of arsenic. Sediments from the 
Cannon/Restronguet Estuary in southwest England contain $90 \mu \mathrm{g} / \mathrm{g}$ to more than $5000 \mu \mathrm{g} / \mathrm{g}$ arsenic (Thornton et al. 1975). Sediments from other estuaries in England and Whales contain 7 to $950 \mu \mathrm{g} / \mathrm{g}$ arsenic (Langston 1980). Concentrations of arsenic in sediments from Commencement Bay and the Tacoma Waterways, Washington, contain 11 to $288 \mu \mathrm{g} / \mathrm{g}$ total arsenic (Schults et al. 1987).

Concentrations of arsenic in pore water of marine sediments generally are similar to those in the overlying water, though the species may be different. Sediment pore water from Corpus Christi Harbor, Texas, after anaerobic incubation of the sediment for $45 \mathrm{~d}$, contained $3.3 \mu \mathrm{g} / \mathrm{L}$ total arsenic, including $1.4 \mu \mathrm{g} / \mathrm{L}$ each of As III and organic arsenic, and $0.5 \mu \mathrm{g} / \mathrm{L} \mathrm{As} \mathrm{V} \mathrm{(Brannon} \mathrm{and} \mathrm{Patrick}$ 1987). Pore water of sediments from Seattle Harbor, Washington, treated similarly, contained 1.1 $\mu \mathrm{g} / \mathrm{L} \mathrm{As} \mathrm{V}, 1.7 \mu \mathrm{g} / \mathrm{L}$ As III, and $1.0 \mu \mathrm{g} / \mathrm{L}$ organic arsenic. However, in most of the nearshore and deep-ocean sediments analyzed by Andreae (1979), the ratio of arsenite to arsenate was less than unity. Riedel et al. (1987) measured the distribution of arsenic species in pore water of a vertical core of sediment from Chesapeake Bay. Arsenite was barely detectable in pore water from the upper $2 \mathrm{~cm}$, indicating that it had been oxidized to arsenate. Below $2 \mathrm{~cm}$, arsenite concentrations in pore water increased with depth. Arsenate concentrations in sediment pore water showed a sharp increasing concentration gradient with depth from about $2 \mu \mathrm{g} / \mathrm{L}$ at $0.5 \mathrm{~cm}$ to about $23 \mu \mathrm{g} / \mathrm{L}$ at 4.5 $\mathrm{cm}$. Arsenite was more abundant than arsenate (arsenite:arsenate ratio greater than one) only at the greatest depth measured. No methylarsenic species were detected at any depth.

\subsubsection{Selenium}

Selenium may occur in seawater in four valency states, selenate $(+6)$, selenite $(+4)$, elemental selenium ( $\left.\mathrm{Se}^{\circ}\right)$, and selenide (-2) (Cutter and Bruland 1984, Cooke and Bruland 1987). As with arsenic, selenate and selenite usually are present as the oxyanions, $\mathrm{SeO}_{4}^{-2}$ and $\mathrm{SeO}_{3}^{-2}$, respectively. Elemental selenium, which is insoluble, has been detected in colloidal form in estuarine water, but probably is quite rare in seawater (Takayanagi and Wong 1984). Selenide, usually as biselenide ( $\mathrm{HSe}^{-}$), may occur in a variety of organic forms, including seleno amino acids and their derivatives, methylselenides, methylselenic esters, methylselenones, and methylselenonium ions (Cooke and Bruland 1987).

The different forms of selenium are interconverted in seawater and sediments by abiotic and biotic oxidation/reduction reactions (Figure 3.3). Selenite, and to a much lesser extent selenate, are bioaccumulated by phytoplankton (Wrench and Measures 1982) and marine bacteria (Foda et al. 1983). In the phytoplankton cells, the selenate and selenite are reduced to selenide and incorporated 
into a variety of organoselenide compounds (Cooke and Bruland 1987). The phytoplankton either depurate the organoselenides or, upon death, release them to the water column where they are oxidized first to selenite, then selenate. The marine bacterium, Pseudomonas marina, can accumulate selenite, but not selenate, from solution (Foda et al. 1983). The selenite is incorporated into bacterial proteins and amino acids. The latter may be excreted by the bacteria to the ambient medium. The biogeochemical cycle of selenium in the ocean is similar to those of silicon and phosphorous. Therefore, there is a good correlation in the ocean between the concentration of Se IV and silica and between Se VI and phosphorous.

The oxidation of selenite to selenate is slow, allowing the coexistence in seawater of both species, despite the fact that thermodynamic considerations would predict that only selenate should be present in oxic surface waters (Cutter and Bruland 1984). The relative proportion of the different forms of selenium in seawater and sediments is dependent upon redox conditions as well as abundances and species composition of phytoplankton (Cooke and Bruland 1987). Dimethylselenide and dimethyldiselenide are not very soluble in seawater and are quite volatile (Cooke and Bruland 1987). Therefore, they are lost rapidly from seawater to the atmosphere. The concentration of total selenium in the water column of the eastern tropical Pacific Ocean increases from $75 \mathrm{ng} / \mathrm{L}$ at the surface to $192 \mathrm{ng} / \mathrm{L}$ at $3000 \mathrm{~m}$ (Cutter and Bruland 1984). Concentrations of both Se VI and Se IV increase with depth to maxima of about 117 and $73 \mathrm{ng} / \mathrm{L}$, respectively, at $3000 \mathrm{~m}$. In the surface oxic waters, organic selenide compounds account for about $79 \%$ of the total selenium. Selenate accounts for $14 \%$ and selenite accounts for $7 \%$ of the total selenium in surface waters. Concentrations of organoselenides decrease with depth and are undetectable below $1750 \mathrm{~m}$. In surface waters of the central North Pacific Ocean, concentrations of both selenate and selenite range from less than $8 \mathrm{ng} / \mathrm{L}$ to $54 \mathrm{ng} / \mathrm{L}$ (Cutter and Bruland 1984). Cutter (1978) reported concentrations of selenate and selenite of 7.1 and $50.85 \mathrm{ng} / \mathrm{L}$, respectively, in water from Penasquitos Marsh, Delmar, California. Earlier, However, surface water from Scripps Pier, La Jolla, California, contains 58 to $80 \mathrm{ng} / \mathrm{L}$ selenate and less than $5 \mathrm{ng} / \mathrm{L}$ selenite (Cutter 1978).

A typical background concentration of total selenium in uncontaminated marine sediment is about $0.4 \mu \mathrm{g} / \mathrm{g}$ (Bowen 1979). The concentration of selenium in surficial sediment from the lower Saint Lawrence River Estuary, Canada, is about $0.76 \mu \mathrm{g} / \mathrm{g}$ (Takayanagi and Belzile 1988).

Under oxic conditions, selenite adsorbs very strongly to hydrous iron oxides, but not to humic acids (Howard 1972, Robberecht and Van Grieken 1982). In anoxic sediment, selenium may be 
precipitated as ferroselite $\left(\mathrm{FeSe}_{2}\right.$ ) or incorporated into iron sulfide minerals (Howard 1977, Huang et al. 1983). Only about $8 \%$ of the total selenium in surficial sediments from the Saint Lawrence River Estuary is in an oxalate-leachable form (adsorbed to iron and manganese oxides and labile organoselenium complexes) (Takayanagi and Belzile 1988). Below $2 \mathrm{~cm}$, only about $1 \%$ of the total selenium is leachable. Cutter (1985) reported similar results for lake sediments. Less than $10 \%$ of the total selenium is present as leachable selenate and selenite. The remainder is probably elemental selenium, nonlabile organoselenium compounds, ferroselite, and the selenium minerals (e.g., various metal sulfides, tiemannite, and naumanite: Raptis et al. 1983).

The concentration of dissolved selenium in the pore water of sediment from the Saint Lawrence River Estuary increases from about $166 \mathrm{ng} / \mathrm{L}$ at the surface to about $600 \mathrm{ng} / \mathrm{L}$ at $12-\mathrm{cm}$ depth in the sediment (Takayanagi and Belzile 1988). The concentration of selenium in pore water at the surface of the sediment is about twice that of selenium in the overlying water (about $87 \mathrm{ng} / \mathrm{L}$ ). Vertical profiles of selenium and iron in sediment pore water are similar, suggesting that iron diagenesis controls the distribution of selenium in the sediment. In oxidized sediment, selenium adsorbs to iron hydrous oxides. In suboxic sediment, iron hydrous oxides are reduced, releasing adsorbed selenium into solution in the pore water. In deeper anoxic sediment, dissolved selenium is precipitated as ferroselite or with iron sulfides, or it is reduced to insoluble elemental selenium.

\subsection{DESORPTION OF METALS FROM MARINE SEDIMENTS}

Marine sediments, even anoxic sediments rich in sulfides, are not necessarily irreversible sinks for metals. The wide variety of diagenic reactions occurring in sediments, particularly in the vicinity of the redox potential discontinuity, can result in transfer or transformation of metals from various solid forms to soluble forms that can migrate by diffusion or convection in the pore water back into the overlying water column (Salomons 1985, Salomons et al. 1987). The most important diagenic reactions resulting in dissolution and mobilization of metals in sediments are:

- Reductive dissolution of amorphous and poorly crystalline iron and manganese hydrous oxides

- Biological oxidation and degradation of sediment organic matter

- Formation of metal polysulfides or oxidation of recently precipitated metal sulfides, and

- Biomethylation of certain metals.

In laboratory experiments performed by Lu and Chen (1977a, b), cadmium, copper, nickel, lead, and 
zinc were released from sediments primarily under oxidizing conditions. Iron and manganese were preferentially released under reducing conditions and little or no silver, chromium, and mercury were released under either oxidizing or reducing conditions. The postulated mechanisms for mobilization of metals from sediments under oxidizing conditions included:

- Diffusion or convection of dissolved metals from sediment pore water.

- Oxidation of reduced metallic sulfide solids, which usually are very insoluble, to more soluble oxidized species.

- Formation of soluble metal complexes in pore water due to an increase of metal ligands in the soluble phase (e.g., chloride and dissolved organic matter).

- Oxidation and decomposition of organic compounds leading to release of adsorbed or complexed metals.

- Desorption of metals from clay minerals or other solids.

- Ion exchange.

Under reducing conditions, iron and manganese hydrous oxides dissolve, releasing any adsorbed metals. If not trapped by precipitation with sulfide (formation of metal sulfides or co-precipitation with iron sulfide), the metals may diffuse upward into the overlying water column (Förstner and Wittmann 1981). Similar observations have been made for arsenic (e.g., Riedel et al. 1987), lead (e.g., Harada and Tsunogai 1988), and other metals.

Some metals, such as copper, zinc, silver, cadmium, and lead, form not only solid sulfides under reducing conditions, but also strong complexes with sulfides (e.g., bisulfides, polysulfides, organic thio complexes) (Salomons et al. 1987). As the sulfide concentration in sediments increases, the concentration of these metals in apparent solution in sediment pore water increases. These soluble metal sulfide complexes may diffuse upward to less reduced sediment layers where they may precipitate as sulfides or be oxidized to other metal salts or complexes, some of which are soluble.

Mercury also forms soluble metal sulfide complexes that may diffuse through sediment pore water. However, at very high sulfide concentrations, mercury is virtually immobile (Berman and Bartha 1986). Bothner et al. $(1980 \mathrm{a}, \mathrm{b})$ reported that the concentration of mercury in pore water of heavily contaminated anoxic sediment from Bellingham Bay, Washington, is as high as $3.5 \mu \mathrm{g} / \mathrm{L}, 126$ times the concentration in the overlying water. By comparison, the concentration of mercury in pore water of nearby contaminated, oxidized sediment is 0.01 to $0.06 \mu \mathrm{g} / \mathrm{L}$. The estimated flux rate of 
soluble mercury from the anoxic sediment is 1.2 to $2.8 \times 10^{-5} \mathrm{ng} / \mathrm{cm}^{2} / \mathrm{s}$; no mercury is released from the oxidized sediment. The species of dissolved mercury in the pore water of the anoxic sediment probably is $\mathrm{HgS}_{2}^{2}$.

In Corpus Christi Harbor and Matagorda Bay, Texas, the development of anoxic bottom water during the summer results in precipitation of cadmium, zinc, and mercury sulfides (Holmes 1986). During the winter, the bottom waters become oxygenated and the metals dissolve and are remobilized into the water column. When polluted sediments from the Providence River, Rhode Island, were isolated from sources of organic matter, they became oxic, resulting in the release to the overlying water column of copper and lead. Bioturbation seemed to increase the rate of metal release from the sediments. Metal mobilization could have been due to oxidation of metal sulfides or biodegradation of sediment organic matter.

Diagenesis of organic matter is the most important factor affecting the distribution of copper, lead, and zinc in the relatively uncontaminated sediments of Loch Etive, Scotland (Ridgeway and Price 1987). The three metals are present at elevated concentrations in the surficial layers of the sediments and their concentrations decrease sharply with depth in the sediment to background concentrations in deeper horizons of the core (Figure 3.4). The thin surface oxidized zone of the sediment has relatively uniform metals concentrations. The gradient of decreasing metals concentrations extends from the depth of the redox potential discontinuity to the depth at which metal concentrations reach apparent background concentrations. The gradient of decreasing metals concentrations parallels gradients of decreasing oxygen and sulfate concentrations. It is also paralleled by a decrease in the concentration ratio of iodine to organic carbon, indicating that metals and iodine are being released by diagenic breakdown of organic carbon coupled to reduction of sulfate. The metals released to the sediment pore water migrate upward and are redeposited in surficial sediments, or released to the overlying water. Thus, vertical profiles of metal enrichment in sediments are not always a historic record of metal contamination. This mechanism of metal mobilization may be particularly important in sediments relatively low in sulfur for those metals, such as cadmium, chromium, copper, and mercury, that tend to be associated primarily with organic phases in sediments (see Table 3.1). 


\begin{tabular}{|c|c|c|c|c|c|}
\hline${ }^{2} S^{\ominus} d$ & $\mathrm{O}_{\mathrm{d}} \mathrm{d}$ & $S L^{\prime} 0-t^{\prime} 0$ & 009-09I & 06-09 & un!̣uə|əS \\
\hline${ }^{\varepsilon} S^{2} S H$ & 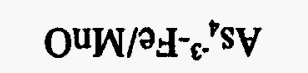 & SI-S & $000^{\prime} \varepsilon \tau-000^{\circ} \varepsilon$ & $000^{`} E-000^{`} I$ & गฺUUes.IV \\
\hline $\mathbf{s}$ & OUW/aH & $0 L-\tau$ & $000^{\circ}+8-000^{\circ} \mathrm{L}$ & $000^{\circ} S-L$ & ou!Z \\
\hline $\mathbf{S}$ & Wo 'OPA & $90^{\circ} 0$ & $000^{6} 101$ & 01 & 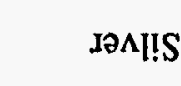 \\
\hline$S$ & $\mathrm{O}_{\mathrm{d}}$ & os & $000 ` s z-009$ & $0 \varepsilon Z-00 \mathrm{I}$ & |әxग!N \\
\hline${ }^{\varepsilon} \mathrm{OJ}^{-6} \mathrm{HO}^{-6} \mathrm{~S}-\mathrm{Ig} \mathrm{L}$ & 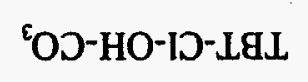 & $z$ & - & $0 I-I$ & $* * * \mathrm{U} ! \mathrm{L}$ \\
\hline $\mathbf{S}$ & wo & $\varepsilon \cdot 0-\tau^{*} 0$ & $009^{\circ} \varepsilon-0 I$ & $t \varepsilon-t$ & KunosəW \\
\hline$S$ & OuW/OH & $0 \varepsilon-\varsigma$ & $000^{\circ} \mathcal{E}-00 z$ & $09-\varsigma$ & peəT \\
\hline $\mathbf{S}$ & OuW/ad 'WO & OS-0I & $000^{\circ} t-000^{c} \mathrm{I}$ & OSI-OE & ‘əddo ગ \\
\hline 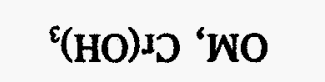 & oəม 'พo & $00 \mathrm{I}-0 \mathrm{~S}$ & $00 t-0 s$ & 00S-00I & 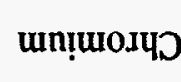 \\
\hline$s$ & No ${ }^{\circ} \mathrm{O}_{\mathrm{H}}$ & $9 \cdot 0-I^{\circ} 0$ & $000^{\circ} \mathrm{L}-\tau$ & $0 z-t$ & unțupeJ \\
\hline ग!xout & ग!खण & 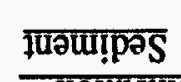 & IDIEM गIOd & IJIEMEOS & एहाकर \\
\hline
\end{tabular}

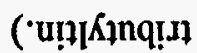

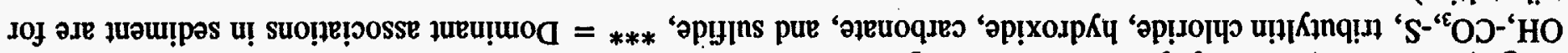

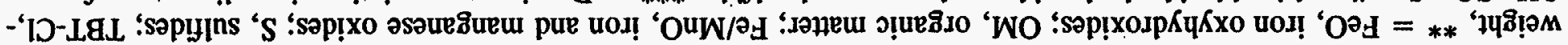

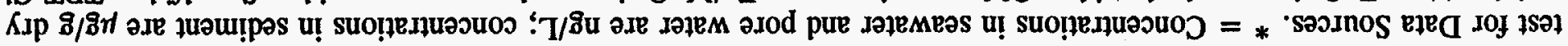

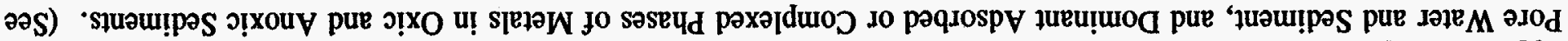
ұนәu!p 
Table 3.2. A Comparison of the Range of Binding Capacities for Several Substrates in Typical Estuarine Sediments (From Luoma and Davis 1983) $(\mathrm{a}=$ Assume acid ammonium oxylate extract includes a fraction of more crystalline iron oxide, while hydroxylamine hydrochloride extracts only highly amorphous iron oxide; $b=$ Assume binding capacity of geothite; $c=$ Assume all manganese is manganese oxide-a liberal estimate; $d=$ Assume half of total organic carbon is plant residue with a very low density of binding sites, as observed for cellulose and lignins.)

Substrate

Amorphous iron oxide

Crystalline iron oxide ${ }^{b}$

Manganese oxide

Extractable organic matter

Unextractable organic residue

\section{Apparent Binding}

Capacity of Substrate (M/g)

$1 \times 10^{-3}$

$5 \times 10^{-3}$

$1 \times 10^{-4}$

$2.5 \times 10^{-3}$

$1 \times 10^{-3}$

$1 \times 10^{-4}$
Abundance of Substrate in Sediment

Method of

Estimation

Concentration

$(\mu \mathrm{g} / \mathrm{g})$

2000-28000

Acid ammonium

oxylate

Hydroxylamine

hydrochloride

Unextracted Fe

$10000-40000$

Concentrated $\mathrm{HNO}_{3}$ reflux

$\mathrm{NaOH}$

$400-15000$

$2000-60000$
$1.0-4.0$

1.4-15

Binding

Capacity

in Sediment

$(\mu \mathrm{g} / \mathrm{g})$

$2.0-28$

1.0-14

1.4-15

$0.2-6.0$ 


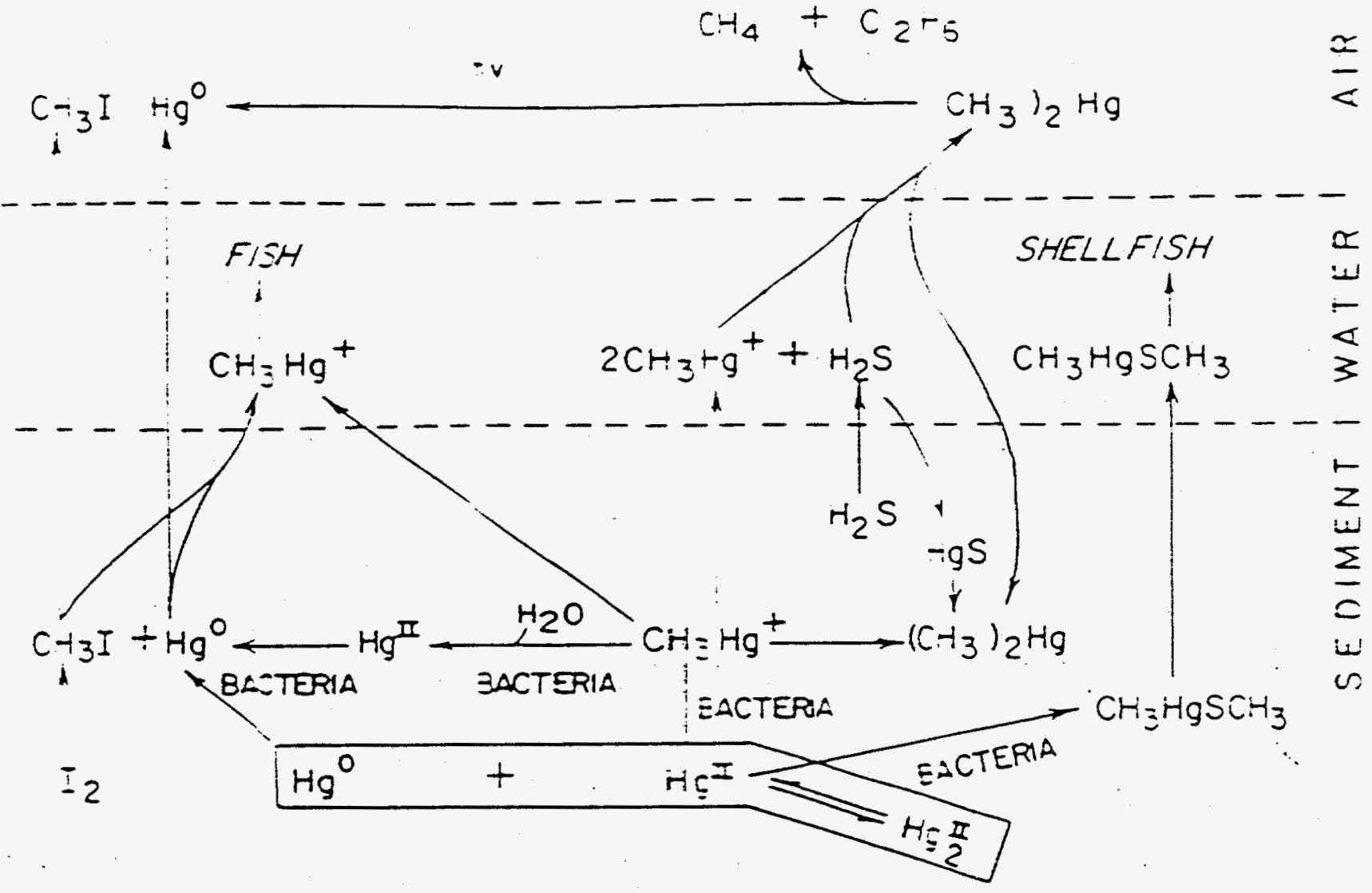

FIGURE 3.1. The Mercury Cycle in Marine and Freshwater Ecosystems (From Wood 1987) 


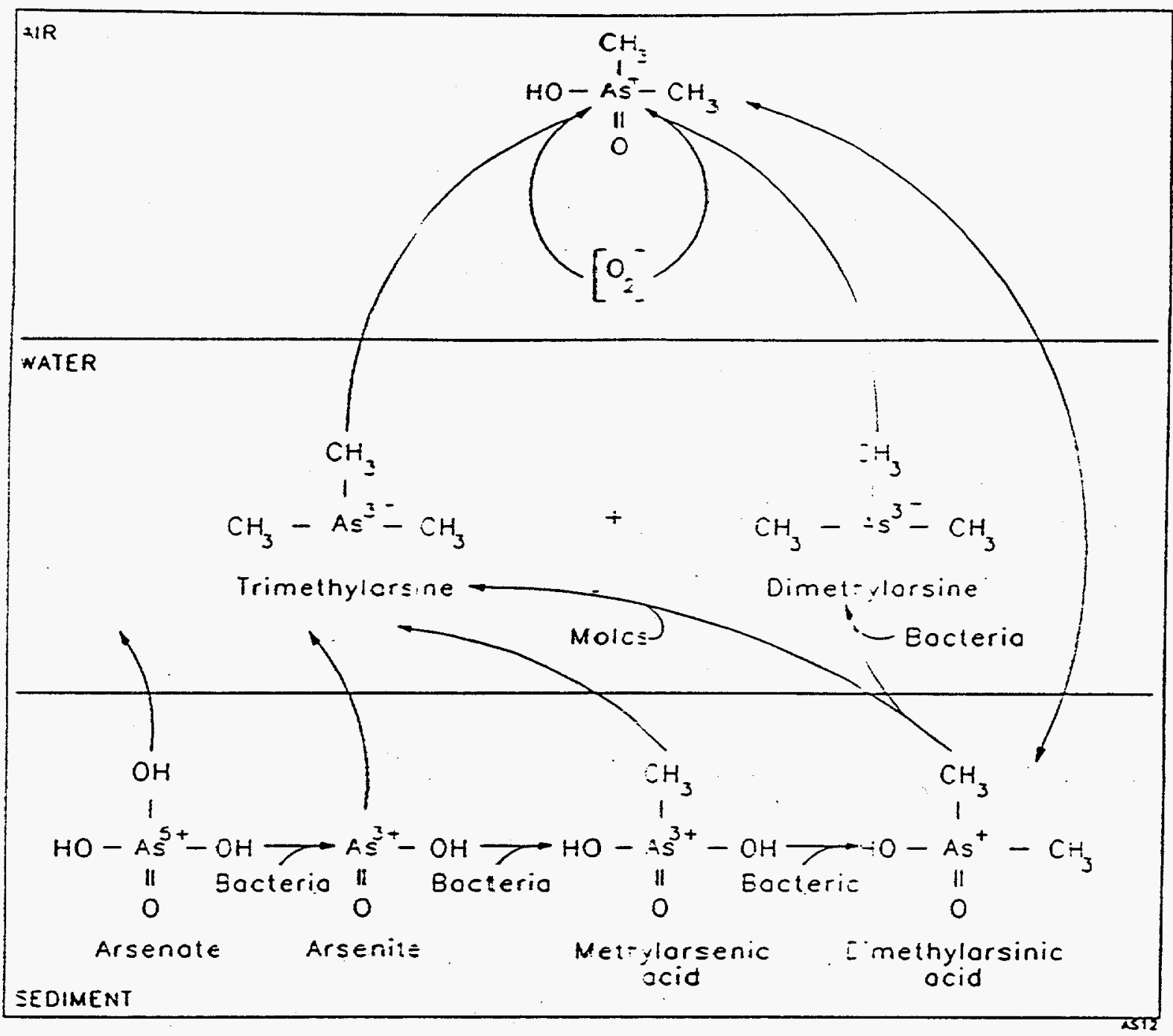

FIGURE 3.2. The Arsenic Cycle in Marine and Freshwater Ecosystems (From Wood 1987) 


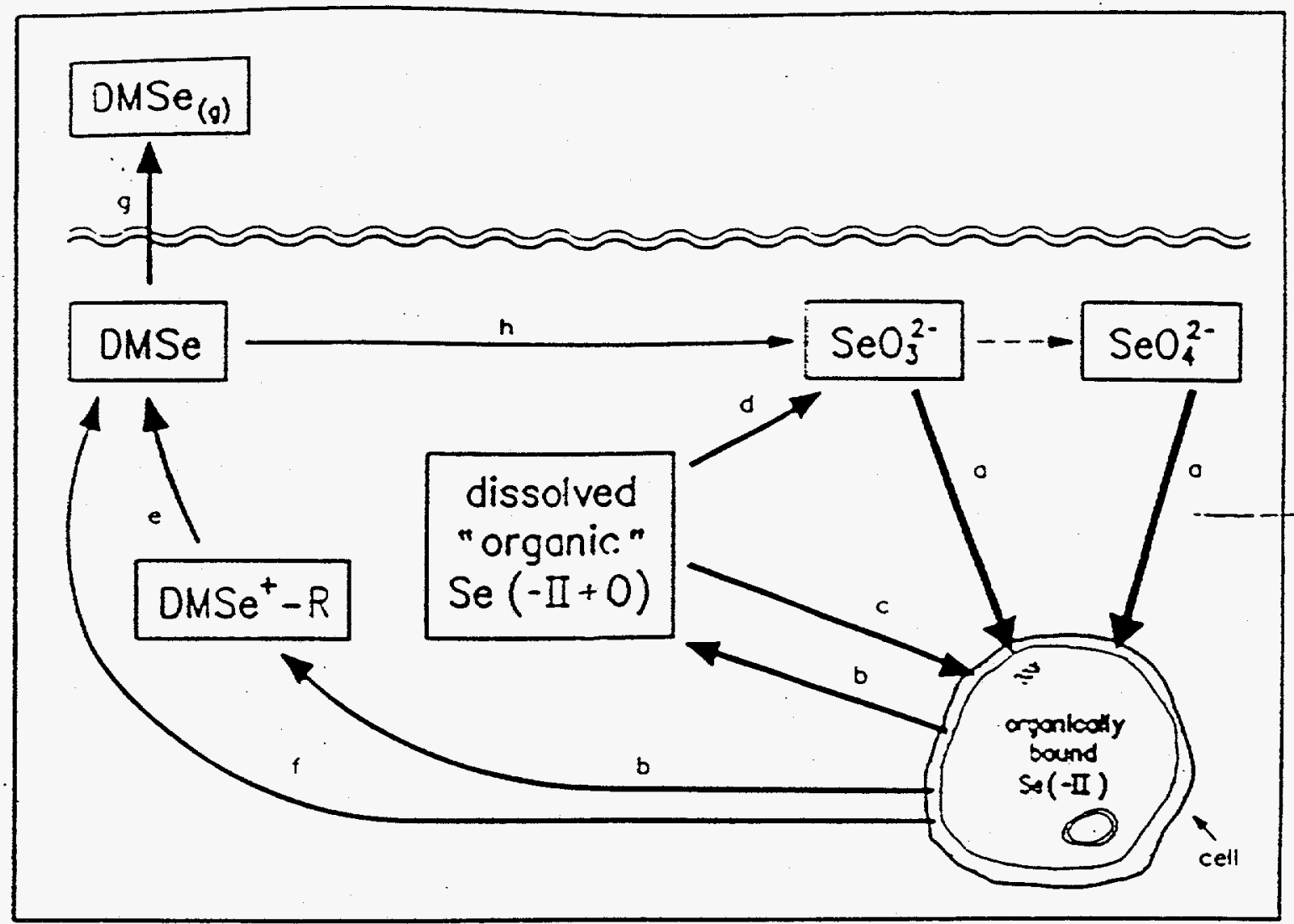

FIGURE 3.3. The Biogeochemical Cycle of Selenium in Natural Waters. Lower case letters correspond to the following processes; (a) reductive assimilation of selenite and selenite into organically bound selenide in organisms; (b) release of organically bound selenide back into solution; (c) assimilation of dissolved organic selenide by organisms; (d) oxidation of dissolved organic selenide to selenite; (e) conversion of dissolved dimethylselenonium ion (DMSe ${ }^{+}-\mathrm{R}$ ) to dimethylselenide; (f) direct release of dimethylselenide into solution; ( $g$ ) degassing of dimethylselenide to the atmosphere; (h) oxidation of dimethylselenide to selenite and/or selenite (From Cooke and Bruland 1987). 


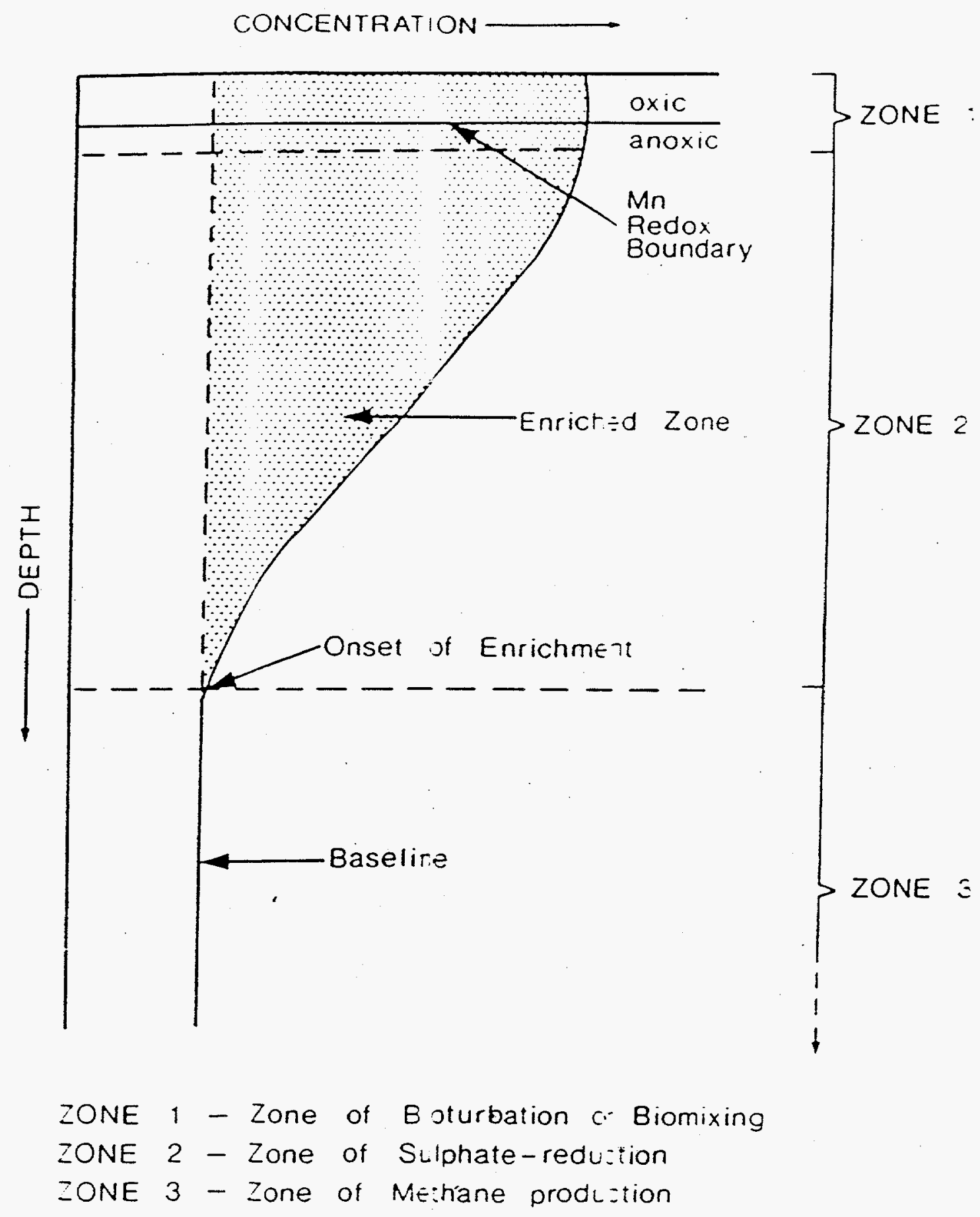

FIGURE 3.4. Schematic Diagram of a Typical Metal-Enriched Sediment Profile Exhibiting Metal Migration Caused by Diagenic Reactions and Bioturbation (From Ridgway and Price 1987) 


\subsection{ORGANIC CONTAMINANTS IN MARINE SEDIMENTS}

\subsection{INTRODUCTION}

Unlike the metals discussed in Chapter 3, a majority of the organic chemicals with potential to be serious marine pollutants are synthetic materials manufactured by humans. The most important exception to this generalization is aromatic hydrocarbons, which may be derived from fossil fuels, incomplete combustion of organic matter, and direct biosynthesis (Neff 1979a,b). Because most organic contaminant chemicals of concern in the marine environment are not natural products, there is no natural background concentration for these chemicals. Any contamination detected is derived directly or indirectly from human activities.

The number of organic chemicals with a strong potential, through abundance, use/disposal patterns, and persistence/toxicity, to be important marine pollutants is vast. There are several hundred aromatic hydrocarbons and related heterocyclics in petroleum and pyrogenic assemblages (Neff 1988a,b). In addition, approximately 100,000 different organic chemicals have been synthesized, with approximately 60,000 of these commonly used and about 1000 new organic compounds synthesized each year (Maugh 1978). Many of these organic compounds may enter the marine environment through accidental spills, unintentional releases during normal usage, and intentional discharges (Farrington and Westall 1986). Among this multitude of organic compounds, those of major environmental concern have one or more of the following properties: persistence, high mobility, and short- or long-term adverse biological activity (Miller 1984).

Several physical/chemical properties of organic contaminants affect their behavior and fate in the marine environment. Two of the most important properties are aqueous solubility and polarity. Organic compounds of environmental concern span a very wide range of aqueous solubility. Most, but not all, of these compounds are less soluble in seawater than in freshwater (e.g., Whitehouse 1984).

The solubility of an organic chemical in a polar medium, such as seawater, is determined in large part by the ability of the chemical to interact electrochemically through hydrogen bonding or ion-dipole interactions (Olsen et al. 1982). A neutral, nonpolar organic compound (one that is not charged and, therefore, unable to engage in electrostatic interactions) in aqueous solution will tend to force the water molecules around it into an energetically unfavorable, ice-like ordered configuration (Voice and Weber 1983). Because of the unfavorable entropy of the solution, the solute can be 
driven readily from solution, even at concentrations below apparent aqueous solubility. Low molecular weight polar or ionized organic compounds, on the other hand, can interact electrochemically with the water molecules. As a result, the distribution of the water molecules around the polar solute is more densely packed, but less ordered. The water can accommodate a large amount of these compounds in stable solution.

\subsection{NEUTRAL, NONPOLAR ORGANIC CHEMICALS}

Nonpolar organic chemicals, because of their low affinity for the water phase, tend to have a strong affinity for phase boundaries, such as the surface microlayer of the ocean and the surface of particles (Olsen et al. 1982). They also have a high affinity for poorly soluble organic phases. For example, the solubility of DDT in an organic solvent such as benzene is $10^{7}$-fold higher than its solubility in water (National Academy of Sciences 1971). Because of the strong affinity of dissolved, nonpolar organic chemicals for solid or liquid organic phases, they tend to partition out of the water and sorb to any available organic phase, such as tissues of aquatic organisms, organic coatings on sediment particles, and organic particles (e.g., humic materials and organic detritus) (Clayton et al. 1977, Karickhoff et al. 1979, Knezovich et al. 1987).

Sorption is used in this context to describe any accumulation of dissolved substances from the aqueous phase onto particles, including living particles (Voice and Weber 1983). This definition includes adsorption, the binding of the solute molecule at a two-dimensional interface or surface, and absorption, the partitioning of the solute into the three-dimensional bulk of the sorbing phase (Farrington and Westall 1986). Irrespective of whether the solid phase is a living organism or a particle, the same physical process is responsible for the initial binding of the solute molecule to the solid surface (Herbes 1977, Hiraizumi et al. 1979, Pavlou and Dexter 1979). As the solute molecule approaches the solid sorbent, the electron distributions of the solute and sorbent interact to induce additional dipole and quadrupole moments and distort the distribution to achieve an optimal energy state (Voice and Weber 1983). The resulting van der Waals interactions are generally of the order of one to a few $\mathrm{kcal} / \mathrm{mol}$. However, this small bonding energy is amplified for nonpolar organic molecules by the substantial thermodynamic gradient driving the solute molecules out of solution. When the sorbent is an organic particle, living or nonliving, the adsorbed molecules may then partition into the interior of the particle. 
The distribution of an organic chemical between the dissolved and the sorbed phase can be described by an equilibrium partition coefficient, $\mathrm{K}_{\mathrm{p}}$. Sorption can be defined in terms of the Freundlich equation (Moore and Ramamoorthy 1984b) as follows:

$$
\mathrm{C}_{\mathrm{s}}=\mathrm{K}_{\mathrm{p}} \mathrm{C}_{\mathrm{w}}{ }^{1 / \mathrm{n}} \text {, }
$$

where

$\mathrm{K}_{\mathrm{p}}=$ sediment/water partition coefficient (mass of water per unit mass of sediment

$\mathrm{C}_{\mathrm{s}}=$ amount of chemical sorbed per unit mass of sediment

$\mathrm{C}_{\mathrm{w}}=$ amount of chemical in "solution" per unit mass of solution

$1 / n=$ exponential factor dependent on the abundance of binding sites on the sorbent relative to the abundance of sorbate molecules. It is an indication of the intensity of the sorptive reaction (Weber 1972).

For low molecular weight, nonpolar organic solutes with low aqueous solubilities, at low aqueous concentrations (less than $10^{-5} \mathrm{M}$ or half their aqueous solubilities, whichever is lower), the term, $1 / \mathrm{n}$, approximates unity. Under these conditions, a plot of $C_{s}$ versus $C_{w}$ yields a straight line (a linear isotherm), the slope of which is $\mathrm{K}_{\mathrm{p}}$. The equation can be rewritten as follows:

$$
\mathrm{K}_{\mathrm{p}}=\mathrm{C}_{\mathrm{s}} / \mathrm{C}_{\mathrm{w}}
$$

Ideally, this ratio is a measure of the distribution at equilibrium of the organic contaminant between the particulate and dissolved phases. However, the distinction between dissolved and particulate phases usually is defined operationally (e.g., passage through a $0.45-\mu \mathrm{m}$ pore size filter) (Olsen et al. 1982). Particles smaller than $0.45 \mu \mathrm{m}$ and colloidal material may be present in the filtrate and bind the chemical, contributing to the mass of chemical measured as being in solution. Some of the dissolved chemical may sorb to the filter and be measured as solid phase chemical.

Four factors that complicate the measurement of $\mathrm{K}_{\mathrm{p}}$ for organic chemicals in natural water systems are as follows:

- Uncertainty about the amount of time required for the chemical to reach a true equilibrium distribution between dissolved and sorbed phases

- Binding of the "dissolved" chemical to dissolved or colloidal organic matter in the water column 
- Effects of particle abundance and apparent irreversible binding of a fraction of the sorbate to the particles, and

- Chemical composition and particle size of the sorbent particles.

The time required to reach true equilibrium is poorly understood. It may vary from a few minutes to several days, depending on the organic compound (Moore and Ramamoorthy 1984b), and the relative concentrations of the chemical and sorbent (Di Toro et al. 1985). In addition, the method of measusing equilibrium kinetics may influence the estimate of time required to reach equilibrium (Podoll and Mabey 1987). Wu and Gschwend (1986) predicted, based on a model of desorption kinetics, that for very hydrophobic compounds, such as the more highly chlorinated polychlorinated biphenyls, sorbed to silt particles containing about $2 \%$ organic carbon, the $90 \%$ release time for the sorbed chemical is on the order of $280 \mathrm{~d}$. Less hydrophobic compounds will reach sorption equilibrium in much less time, in a matter of hours to days. However, Karickhoff (1980) proposed that sorption of a nonpolar organic chemical to sediment particles is a two-phase process: adsorption of the chemical on the particle surface and absorption within the pore structure or organic phase of the sediment particle. The first phase is rapid with a half-time on the order of a few minutes. Absorption is slower, requiring several hours.

Growing evidence indicates that the rate of sorption of most nonpolar organic contaminants is much more rapid than the rate of desorption of the sorbate from the sorbent particle. This hysteresis complicates predictions of equilibrium distributions of the nonpolar chemical and, therefore, values for $K_{p}$.

The term $\mathrm{C}_{\mathrm{w}}$ includes not only the organic contaminant in true solution, but also the contaminant complexed with dissolved and colloidal organic matter in the water column or sediment pore water. Presumably, only that portion of the aqueous phase contaminant that is in true solution will participate in equilibration with the sorbed component. Organic matter, primarily dissolved humic substances and colloidal organic material with molecular weights in the range of about 500 to 10,000 daltons (Wijayaratne and Means 1984, Whitehouse 1985a,b), tends to complex reversibly with dissolved nonpolar organic chemicals, increasing their apparent solubilities (Chiou et al. 1987; Shinozuka et al., 1987) and decreasing sorption to solid phases (Caron et al. 1985) and bioavailability to marine organisms (Servos et al. 1989).

Theoretically, complexation of a dissolved nonpolar organic compound with dissolved or colloidal organic matter is completely reversible. The slope of the sorption isotherm should be the 
same as the slope of the dissociation isotherm. McCarthy and Jiminez (1985a) reported that this is the case for benzo(a)pyrene and its association with dissolved humic material following association times of up to seven days and dissociation times of up to four days. However, Johnsen (1987) reported that when polycyclic aromatic hydrocarbons are incubated with natural aquatic humic substances for periods of up to 70 days, desorption of the hydrocarbons from the humic substance decreases with time. The extent of irreversible binding increases with increasing hydrophobicity and decreasing solubility of the aromatic hydrocarbons.

The concentration of dissolved organic matter in open ocean waters and even in coastal waters away from the immediate influence of major riverine inputs is generally quite low. Whitehouse $(1985 \mathrm{a}, \mathrm{b})$ reported concentrations of dissolved organic matter in open ocean samples of 0.64 to 5.2 $\mathrm{mgC} / \mathrm{L}$. Salt marsh water and terrestrial runoff contained more than $10 \mathrm{mg} / \mathrm{L}$ dissolved organic matter. At these low ambient concentrations, complexation of nonpolar organic contaminants to dissolved organic matter is not important quantitatively (Whitehouse 1985a,b). However, the type of dissolved organic matter is important. Oceanic dissolved organic matter at ambient concentrations binds little polycyclic aromatic hydrocarbons, whereas terrestrial dissolved organic matter at concentrations characteristic of coastal waters and runoff does bind significant amounts of polycyclic aromatic hydrocarbons (Whitehouse 1985a,b). Solubilization of DDT and PCB increases with increasing concentrations of freshwater and terrestrial dissolved humic materials at concentrations above about $5 \mathrm{mg} / \mathrm{L}$ (Chiou et al. 1987). Solubility enhancement seems to be minimal below this concentration. Concentrations of dissolved organic matter in pore water of fine-grained sediments often are much higher than their concentrations in the overlying water column. Therefore, in sediments, particularly fine-grained sediments containing high concentrations of organic material, dissolved organic matter in the pore water may play a major role in determining the distribution of nonpolar organic contaminants among different phases in the sediment (Brownawell and Farrington 1986).

O'Connor and Connolly (1980) and Voice et al. (1983) have reported that the partition coefficient for different nonpolar organic chemicals decreases as the concentration of sorbing particles increases. The concentrations of particles in these partitioning experiments were quite high ( $10^{1}$ to $10^{4} \mathrm{mg} / \mathrm{L}$ ) indicating that particle-particle interactions could have affected the results. However, the effect was also observed for microalgal cells at concentrations ranging from about 5 to $110 \mu \mathrm{g} / \mathrm{L}$ (Voice et al. 1983). Voice et al. (1983) proposed that the observed inverse relationship between the 
concentration of particles and the partition coefficient can be attributed to a transfer of sorbing, or solute-binding material from the solid phase to the liquid phase during the course of the partition experiment. This explanation would imply that dissolved organic matter, present in the pore water of the intact sediment or organic matter desorbing from the sediment particles when they are dispersed in water for the partition experiment, complexes with the solute decreasing the apparent $C_{s} / C_{w}$ ratio. This conclusion is supported by experiments of Gschwend and Wu (1985), who showed that if precautions are taken to eliminate or account for nonsettling (or nonfilterable) microparticles or organic macromolecules that remain in the aqueous phase during laboratory sorption experiments, the observed partition coefficients for model nonpolar organic chemicals remain constant over a wide range of solid-to-solution ratios.

However, Mackay and Powers (1987) suggested that the effect of particle concentration on partition coefficients was due to a particle-induced desorption mechanism. At high particle concentrations, sorbate molecules are desorbed into the aqueous phase, decreasing the apparent $C_{k} / C_{w}$. Equilibrium is never reached in their model. Lande (1988) criticized the particle-induced desorption model and concluded that the phenomenon may be due to differences in ground state energy between the sorbed and dissolved solute.

The concept of an equilibrium partition coefficient and linear isotherms implies that sorption of a solute to a surface is fully reversible and that the rates of the sorption and desorption reactions are similar. However, Di Toro and his colleagues (Di Toro and Horzempa 1982, Di Toro et al. 1982, Horzempa and Di Toro 1983, Di Toro 1985) have provided evidence that for some highly hydrophobic organic chemicals, such as the more highly chlorinated polychlorinated biphenyls, sorption to particles is not completely reversible. A fraction of the sorbed chemical desorbs at a rate similar to that predicted from the linear isotherm for sorption. However, a second fraction desorbs at a substantially reduced rate (the desorption isotherm has a lower slope than the sorption isotherm ) or does not desorb at all. Gschwend and Wu (1985) explain the apparent differences in sorption and desorption rates as due to the presence in the experimental systems of a third phase consisting of microparticles or colloidal material that complexes with the solute and increases its apparent concentration in solution. The authors contend that if this third phase is taken into consideration, then sorption and desorption isotherms are indistinguishable. However, Di Toro (1985) showed that the concentration of the third colloidal or nonfilterable phase in the experimental system would have to be as high as the concentration of the solid sorbant phase, which is unlikely. Johnsen (1987) showed 
that apparently irreversible binding can take place between polycyclic aromatic hydrocarbons and dissolved natural humic substances following long contact times. In such an experimental system, there is no third phase.

The results of the different studies are consistent with the hypothesis that a fraction of the solute molecules partition into a more stable "interior" position in the solid or dissolved/colloidal sorbing phase, from which they are released only very slowly when ambient concentrations of the solute lecrease. The fraction of the solute that occupies this more stable microenvironment may increase with increasing equilibration time. A better understanding of the apparently irreversible component of sorption/desorption of nonpolar organic compounds is required, because this residual, less exchangeable fraction of organic contaminants probably is substantially less bioavailable than the more readily exchangeable fraction.

As discussed earlier in this chapter, marine sediments are an extremely heterogeneous mixture of different particle types and sizes. Because of this heterogeneity, the $K_{p}$ for a particular chemical is likely to vary substantially, depending on the chemical composition and grain size of the sediment used for the $\mathrm{K}_{\mathrm{p}}$ determination. Therefore, many attempts have been made to normalize $\mathrm{K}_{\mathrm{p}}$ values to some property of sediments that will allow effects of other properties of the sediments to be canceled out, giving a partition coefficient that does not vary with sediment type. The normalizing factor had to be the sediment property that most influences the sorption of solutes to the sediment. Lambert et al. (1965) and Lambert (1968) have shown that the sorption of a nonpolar organic compound to soils correlates well with the concentration of organic matter in the soil. This observation has been used as the basis for normalizing the linear partition coefficient to the concentration of total organic carbon in the sediment (Karickhoff et al. 1979, Karickhoff 1981, Voice and Weber 1983, Weber et al. 1983). The normalized partition coefficient, $\mathrm{K}_{\infty}$, is calculated according to the following formula:

$$
\mathrm{K}_{\mathrm{oc}}=\mathrm{K}_{\mathrm{p}} / \mathrm{f}_{\mathrm{oc}}
$$

where $f_{o c}$ is the fraction of organic carbon in the sediment. Karickhoff et al. (1981) plotted the $K_{p}$ of phenanthrene and pyrene against the fraction of organic carbon in sediment samples from a wide variety of sources and found a linear relationship between the fraction of organic carbon in the different sediments and the value for $K_{p} . K_{p}$ values showed a 20- to 30-fold variation for the group of sediments with concentrations of organic carbon ranging from $0.11 \%$ to $2.38 \%$. The corresponding values for $\mathrm{K}_{\mathrm{oc}}$ varied by only about two-fold. 
The type of organic material associated with the sorbent phase does not seem to have much effect on partitioning (Voice and Weber 1983). Pierce et al. (1974) showed that the highly insoluble and refractory humin fraction of marine sediment was responsible for most of the binding of DDT. Thus, normalization to organic carbon concentration in the sediment substantially decreases the variability of the estimated partition coefficient. This relationship seems to hold for nonpolar organic compounds with aqueous solubilities less than about $10^{-3} \mathrm{M}$ and for sediments containing more than about $0.1 \%$ organic carbon $\left(\mathrm{f}_{\alpha}>0.001\right)$.

The value of $K_{p}$ can be estimated directly, or indirectly by estimating $K_{\infty}$, which, when combined with a measurement of the concentration of total organic carbon in the sediment, can be used to calculate $K_{p}$ (Karickhoff 1981). The value for $K_{\infty}$ can be estimated easily for a particular compound if a correlation can be found between $\mathrm{K}_{\mathrm{oc}}$ and some widely measured and catalogued parameters of nonpolar organic solutes. Two possibly applicable parameters are octanol/water partition coefficient (Briggs 1973, Hansch and Leo 1979) and aqueous solubility (Karickhoff et al. 1979).

A regression of the $\log _{10}$ octanol/water partition coefficient $\left(K_{o w}\right)$ versus the $\log _{10}$ of $K_{o c}$ for organic solutes with aqueous solubilities spanning several orders of magnitude gives a straight line with a good correlation between the two partition coefficients (Karrickhoff et al. 1979, Briggs 1981, Brown and Flagg 1981, Karickhoff 1981). The equation for the regression can be written as follows:

$$
\log \mathrm{K}_{\mathrm{oc}}=\mathrm{a} \log \mathrm{K}_{\mathrm{ow}}+\mathrm{b} .
$$

The values for ' $a$ ' and ' $b$ ' vary, depending on the group of solutes being evaluated. A large number of different values for ' $a$ ' and ' $b$ ' have been reported in the literature for different groups of unionizable and ionizable nonpolar organic compounds (Farrington and Westall 1986).

The value of 'a' remains near 1.0 for groups of highly nonpolar organic compounds, suggesting that the ratio of the fugacity constants for octanol and the organic phase of sediment is relatively constant for these solutes (Karickhoff 1981). The fugacity constant ratios for more polar solutes and for compounds containing a variety of different substituents are more variable, giving lower values for ' $a$ '. The value of ' $b$ ' varies depending on the types of chemicals being evaluated. This means that the binding strength (affinity of the sorbent for the solute) of the organic phase of sediment and octanol are different and the degree of difference depends on properties of the organic solutes under investigation. 
There is a strong inverse correlation between aqueous solubility and octanol/water partition coefficient for a large number of nonpolar organic compounds with aqueous solubilities spanning several orders of magnitude (Miller et al. 1985). Therefore, it is reasonable to hypothesize that there will also be a good correlation between $\mathrm{K}_{\mathrm{c}}$ and aqueous solubility of nonpolar organic compounds. The log-log regression for a group of aromatic and chlorinated aromatic hydrocarbons examined by Karickhoff et al. (1979) gives the following equation:

$$
\log \mathrm{K}_{\mathrm{oc}}=-0.54 \log \mathrm{S}+0.44
$$

where ' $S$ ' is the aqueous solubility expressed as the mole fraction. However, solubility and partitioning behavior are affected in different ways by such factors as crystal energy (for solutes that are solids at room temperature) and molar volume. Karickhoff (1981) showed that for compounds with polar functional groups or anomalously high melting points, there is an improvement in the fit of the data to the regression if a crystal energy term is included in the equation.

Chiou et al. (1983) evaluated the inclusion of molar volume, $\nabla$, in the regression equation. Regression of a group of 12 compounds with log solubilities spanning four orders of magnitude gave the following equation:

$$
\log \mathrm{K}_{\infty}=-0.813 \log (\mathrm{S} \nabla)-0.993
$$

where ' $S$ ' is solubility in moles/liter and $\nabla$ is molar volume in liters per mole. Inclusion of molar volume in the equation did not substantially improve the fit of the data.

The difficulty with these empirical relationships between $\mathrm{K}_{\infty}$ and $\mathrm{K}_{\mathrm{ow}}$ or solubility is that there is considerable uncertainty about the true solubilities and values of $\mathrm{K}_{\mathrm{ow}}$ for highly hydrophobic, very low solubility compounds such as DDT and the more highly chlorinated polychlorinated biphenyls (Sabljic 1984, Vowles and Mantoura 1987). For example, Walters et al. (1989) showed that, for 2,3,7,8-tetrachlorodibenzo-p-dioxin (solubility $\sim 19.3 \mathrm{ng} / \mathrm{L}$, and $\log \mathrm{K}_{\infty} \sim 6.6$ ), even small amounts of nonseparable suspended particles (the dissolved and colloidal organic matter of Gschwend and $\mathrm{Wu}, 1985$ ) could produce spurious estimates of $\mathrm{K}_{\mathrm{oc}}$ and other sorption parameters.

Sabljic (1984) showed that a very good linear correlation exists between the first-order connectivity index $\left({ }^{1} \chi\right)$ and $\mathrm{K}_{\infty}$ for a large group of nonpolar organic chemicals. First-order connectivity indices are calculated from the non-hydrogen part of the molecular skeletons. Each nonhydrogen atom is described by its $\delta$ value, which is equal to the number of adjacent non-hydrogen atoms. ${ }^{1} \chi$ is calculated from the atomic $\delta$ values according to the following equation: 


$$
{ }^{t} \chi=\sum_{s=1}^{\mathbf{n}}\left(\delta_{j} \delta_{j}\right)_{s}^{-0.5}
$$

where ' $i$ ' and ' $j$ ' correspond to the pairs of adjacent non-hydrogen atoms and the summation is over all bonds between non-hydrogen atoms. The relationship between $\mathrm{K}_{\infty}$ and ${ }^{1} \chi$ is expressed by the following equation:

$$
\log \mathrm{K}_{\mathrm{oc}}=0.55^{1} \chi+0.45
$$

The ${ }^{1} \chi$ index correlates well with the molecular van der Waals surface area of solutes, lending support to the hypothesis that sorption of nonpolar organic chemicals to sediments is an adsorption process that depends on surface area of the sorbate.

Quite frequently, there is an inverse relationship between sediment particle size and sorption of nonpolar organic chemicals to the sediments (Richardson et al. 1971, Choi and Chen 1976, Hiraizumi et al. 1979). However, correlations often are poor (Voice and Weber 1983). Karickhoff et al. (1979) reported that $\mathrm{K}_{\mathrm{p}}$ for sand was $0.5 \%$ to $4 \%$ of that for silt and clay. This difference was due, in large part, to the low organic carbon concentrations of the sands compared to the silts and clays. However, $\mathrm{K}_{\mathrm{oc}}$ for sand was less than half that for silt and clay. This difference was not explained, but may be related to the much greater surface area of fine than coarse particles. Hiraizumi et al. (1979) reported that adsorption of polychlorinated biphenyls to sediments was linearly correlated to specific surface area of the sorbent. Wu and Gschwend (1986) showed that the rate of equilibration of a solute between the liquid and solid phases is slower for large than for small particles. Sorption rate is inversely related to diffusion path length into the particle (a function of particle size) and directly related to the surface area of the sorbing particles.

Sorption of nonpolar organic chemicals to sediment particles containing less than about $0.1 \%$ organic carbon is more dependent on particle surface area than on organic carbon concentration (Khan et al. 1979, Weber et al. 1983, Estes et al. 1988). The sorption capacity of low-organic clays is much less than that of organic-rich clays. Even trace amounts of organic material in the clay overshadow the effects of large differences in surface area of different clays on amounts of solute sorbed. 


\subsection{IONIZABLE, NONPOLAR ORGANIC COMPOUNDS}

Some organic chemicals of environmental concern, such as phenols, amines, and carboxylic acids, are primarily hydrophobic, but have one or more ionizable functional groups. A simple partitioning model is insufficient to describe the sorption behavior of these compounds if they are fully or partially ionized at ambient values of $\mathrm{pH}$ (Farrington and Westall 1986, Westall 1987). Processes such as ion exchange, ligand exchange, and formation of ion pairs or ion complexes in both the aqueous and nonaqueous phases must be considered in predicting the sorption of hydrophobic compounds containing ionizable functional groups (Westall et al. 1985).

The neutral form of these ionizable organic compounds will tend to ionize in the aqueous phase according to the following reaction:

$$
\mathrm{AH} \Leftrightarrow \mathrm{A}^{-}+\mathrm{H}^{+}
$$

The ratio of the ionized form to the unionized form of the compound is the acidity constant, $\mathrm{K}_{\mathrm{a}}$, also called the $\mathrm{pK}_{\mathrm{a}}$. At $\mathrm{pH}$ values lower than $\mathrm{K}_{\mathrm{a}}$ for a compound, the compound is present in the aqueous phase primarily as the neutral species. At $\mathrm{pH}$ values greater than $\mathrm{K}_{\alpha}$; the ionized form of the chemical is present, the relative amount being dependent on the magnitude of difference between the $\mathrm{pH}$ and $\mathrm{K}_{\mathrm{a}}$.

The sorption behavior of chlorinated phenols has been well-studied (Schellenberg et al. 1984, Westall et al. 1985, Farrington and Westall 1986, Westall 1987) and will be summarized here as an example of the behavior of hydrophobic, ionizable organic compounds in aqueous systems. The $\mathrm{K}_{\mathrm{a}}$ of chlorophenols ranges from 4.75 for pentachlorophenol to 8.52 for 2-chlorophenol. Log $\mathrm{K}_{\text {ow }}$ ranges from 2.17 for 2 -chlorophenol to 5.01 for pentachlorophenol. Thus, there is a tendency for $K_{a}$ to decrease and $\mathrm{K}_{\mathrm{ow}}$ to increase as the degree of chlorination increases. The relationships are not linear because of steric factors.

At concentrations up to about $0.5 \mu \mathrm{mol} / \mathrm{L}$, and at constant $\mathrm{pH}$ and ionic strength, the sorption isotherms for different chlorinated phenols in an octanol/water system are linear. However, the slopes of the regression curves are dependent on $\mathrm{pH}$ of the aqueous phase. The ratio of the unionized and ionized species in the solid phase to the unionized and ionized species in the aqueous phase (the distribution coefficient, D) increases with decreasing $\mathrm{pH}$. Three regions of partitioning behavior, dependent on $\mathrm{pH}$, are apparent. At $\mathrm{pH}$ values well below the $\mathrm{pK}_{a}$, the unionized species $\mathrm{AH}$ is predominant in both the aqueous and nonaqueous phases and $\log \mathrm{D}$ equals $\log \mathrm{K}_{\mathrm{ww}}$. At $\mathrm{pH}$ values just 
above the $\mathrm{pK}_{2}$, the most abundant species in the aqueous phase becomes the ionized form $\mathrm{A}^{-}$. In this range, $\mathrm{D}$ is inversely proportional to the $\mathrm{pH}$, and the distribution is thought to represent an equilibrium between the ionized species in the aqueous phase and the unionized species in the nonaqueous phase. At higher values of $\mathrm{pH}$, where $\mathrm{pH}$ is greater than the $\mathrm{pK}_{\mathrm{a}}$ in the nonaqueous phase, the ionized species becomes predominant in both phases and the apparent distribution coefficient is again independent of $\mathrm{pH}$. At high ionic strengths in the aqueous phase, as in seawater, the phenolate anion is associated in the nonaqueous phase with a counter ion sorbed from the medium (Weatall et al. 1985), or possibly already present in a solid sorbent such as humic material.

For highly chlorinated phenols with low $\mathrm{pK}_{\mathrm{\alpha}}$ values, such as tetrachlorophenol and pentachlorophenol, ambient $\mathrm{pH}$, especially in marine environments, is nearly always greater than the $\mathrm{pK}_{2}$. Therefore, these phenols are present in the aqueous phase and probably also in the nonaqueous phase primarily as the phenolate ions. Phenolate ions may bind to solid sorbents, such as organic coatings on particles, through both hydrophobic bonding and ligand exchange (Westall 1987).

Direct binding to the clay particle surface may also be important. Zierath et al. (1980) showed that binding of benzidine to sediments involved two components, sorption of the neutral species to the organic phase of the sediment and a surface area-dependent binding of the ionized species to the particles. For higher molecular weight ionizable organics, sorption interactions seem to predominate over ligand-exchange and other ionic reactions. Means et al. (1982) showed that the equilibrium isotherms for a series of amino- and carboxy-substituted polynuclear aromatic hydrocarbons were linear and values of $\mathrm{K}_{\mathrm{p}}$ were highly correlated with the organic carbon concentration of the sediments tested. However, when the ratio of percent organic carbon to percent montomorillonite clay in the sediment was less than 0.1 , there was a strong inverse relationship between $\mathrm{K}_{\mathrm{oc}}$ for aminoanthracene and aminochrysene and the organic carbon/montmorillonite ratio. These results may indicate an interaction between the ionized species of the two amines and the clay mineral fraction of the sediment.

\subsection{POLAR ORGANIC CHEMICALS}

Some organic compounds, such as ionic surfactants found in many detergents, contain a permanent positive or negative charge in addition to the nonpolar hydrophobic portion of the molecule. Sorption of the surfactant, linear alkylbenzenesulfonate (LAS), to alumina is controlled primarily by electrostatic interactions with the oxide surface (Westall 1987). However, for natural 
sediment particle surfaces coated with organic matter, hydrophobic interactions between the ionized species and the particle surface are also important to the sorptive process. The most important factors influencing sorption of LAS to soils are concentrations of oxidized iron species and organic carbon in the sediment (Litz et al. 1987).

Sorption of water-soluble oligomers and polymers to sediment particles is different from sorption of low molecular weight nonpolar organic compounds. At low aqueous concentrations, polymers tend to sorb very strongly and irreversibly to sediment and soil particles (Podoll et al. 1987). The irreversible sorption of high molecular weight polymers is due in large part to multisegment adsorption. Several segments of an individual polymer molecule attach to the sorbent surface. Once the multiple segments are adsorbed, it is statistically improbable that all segments will desorb simultaneously, releasing the polymer back into solution.

Lower molecular weight oligomers, such as nonionic polyethylene glycol (PEG) and cationic polyethylenimene (PEI) with molecular weights of about 3400 or less, also sorb strongly to sediments, although they are very soluble (Podoll et al. 1987). The sorption capacity of a sorbent for PEI is directly correlated with the cation-exchange capacity of the sorbent, suggesting that binding is through strong Coulombic attraction between $\mathrm{PEI}$ and the negatively-charged surface of the sediment particle. Sorption of PEI is directly related to clay content (surface area) of the sediment. Sorption of both oligomers is relatively independent of the organic carbon concentration of the sediment.

\subsection{MASS-LOADING OF ORGANIC CONTAMINANTS IN SEDIMENTS}

In the sorption studies discussed above, the organic compound under investigation was assumed to have been introduced into the water/sediment system in a dissolved form. As Karickhoff et al. (1979) pointed out, partitioning isotherms often are linear only when the concentration of the sorbate in solution in the aqueous phase is less then $10^{-5} \mathrm{M}$ or one-half the aqueous solubility of the sorbate, whichever is less. Quite frequently, nonpolar organic contaminants are introduced into the oceans in solid or liquid form or in amounts that can not be accommodated in solution in a reasonable amount of time. This situation is most obvious for a massive oil spill. Only a few percent of the hydrocarbons in a spill of crude oil actually dissolve in the water column (Payne et al. 1987). The remainder evaporates, is bio- or photo-degraded, washes ashore, or is physically deposited on the bottom (National Academy of Sciences 1985; Neff 1988a,b). 
Following an oil spill in coastal waters, some of the oil may mix with and become physically bound to suspended particles in the water column, and sink with them to the bottom. Additional oil may strand on the shore where it may mix with shoreline sediments. Subsequent shoreline erosion will carry the oily sediment into the subtidal zone.

Obviously, this oil, physically mixed with sediment particles, does not behave the same as petroleum hydrocarbons sorbed from dilute solution onto sediment particles. There is no relationship between the organic carbon concentration of the sediment before oiling and the amount of petroleum hydrocarbons accommodated in the sediment. Hydrocarbons can partition from a surface slick, oil droplets, or tar balls into the aqueous phase (water column or sediment pore water). The partitioning of a hydrocarbon from the oil phase to the aqueous phase depends on the mole fraction of the hydrocarbon in the oil phase, the oil/water partition coefficient (probably $\approx K_{\text {ow }}$ ) of the hydrocarbon, and the interphase mass transfer coefficient for the hydrocarbon (Payne and McNabb 1985). The rate of dissolution will depend primarily on the relative surface area of oil in contact with the water. Similar relationships probably also occur for other nonpolar organic compounds or mixtures, such as polychlorinated biphenyls, that may be introduced in solid/liquid form to the marine environment.

\subsection{BEHAVIOR OF SELECTED ORGANIC COMPOUNDS IN SEAWATER AND MARINE SEDIMENTS}

Of the large number of natural and synthetic organic chemicals in the environment, only a relatively few classes of organic chemicals are of major concern as potential pollutants in the marine environment. These include:

- Aromatic and polynuclear aromatic hydrocarbons

- Industrial halogenated aromatic hydrocarbons (e.g., polychlorinated biphenyls, chlorinated dioxins)

- Industrial halogenated aliphatic hydrocarbons (e.g., trichloroethylene, vinyl chloride)

- Chlorinated agricultural chemicals (e.g., insecticides, herbicides, fungicides)

- Carbamate and phosphate pesticides

- $\quad$ Phthalate ester plasticizers

- Chlorinated phenol biocides 
- Surfactants and detergents

- Organometallic pesticides, plasticizers, and industrial chemicals

Each class of organic chemicals of environmental concern has a different environmental behavior, persistence, and toxicity. Therefore, they vary substantially in their hazard to marine organisms and consumers of marine organisms, including humans. In the sections that follow, a brief overview is provided of the behavior in the marine environment of three classes of organic chemicals of major environmental concern.

\subsubsection{Polynuclear Aromatic Hydrocarbons}

The basic building block of an aromatic hydrocarbon is the benzene ring, a six-membered carbon ring in which nine carbon-carbon divalent bonds are shared equally among the six carbon atoms. Polynuclear aromatic hydrocarbons are composed of two or more fused benzene rings (Neff 1979a,b). Naphthalene $\left(\mathrm{C}_{10} \mathrm{H}_{8}\right)$, which consists of two fused aromatic rings, is the lowest molecular weight PAH. PAH with nine or more aromatic rings has been identified in the resin-asphaltene fractions of petroleum. PAH may be formed by a variety of mechanisms (Neff 1979a,b). These include:

- Very rapid, high temperature (e.g., $700^{\circ} \mathrm{C}$ ) incomplete combustion or pyrolysis of organic materials,

- Very slow (e.g., millions of years) rearrangement and transformation of organic materials at moderate temperatures of $100-300^{\circ} \mathrm{C}$ to form fossil fuels,

- The relatively rapid (days to years) transformation of certain classes of organic compounds in soils and sediments, and

- Direct biosynthesis by organisms.

A wide variety of organic compounds containing fused-ring polyaromatic systems are synthesized by organisms, particularly bacteria, fungi, higher plants, and some insects (Neff 1979a,b). Most of these compounds are not true PAH because they contain oxygen, nitrogen, or sulfur substituents. For instance, many organisms are able to synthesize a wide variety of polycyclic quinone pigments.

Vitamin $\mathrm{K}_{2}$ is a naphthoquinone. The marsh grass, Juncus roemerianus, synthesizes a pigment called juncusol which is a phenanthrene quinone. 
Under anoxic or hypoxic conditions, as may occur in freshwater and marine basin sediments, quinones, phenols, and related oxygenated aromatic compounds may be reduced to the parent PAH. A five-ring PAH, perylene, is abundant in anoxic freshwater and marine sediments, and its concentration tends to increase with depth in the sediment core (Venkatesan 1988). Concentrations as high as $4 \mathrm{mg} / \mathrm{kg}$ dry wt have been detected in unpolluted marine sediments. Diagenesis of organic matter derived from diatoms is thought to be a major source of perylene in anoxic marine sediments.

Retenc (1-methyl-7-isopropyl-phenanthrene and smaller amounts of other $C_{2}$ and $C_{3}$ alkyl phenanthrenes) is common in marine sediments, particularly adjacent to forested shorelines. These phenanthrenes are derived from the dehydrogenation of abietic and pimaric acids which are abundant in pine rosin .

Coal and petroleum are rich sources of PAH (Neff 1979a,b, 1988a,b). Coal generally is considered an aromatic material. Most of the PAH in coal is tightly bound in the coal structure and cannot be leached out. Nevertheless, a significant fraction of the total PAH in sediments of industrialized bays and estuaries may be derived from coal dust (Tripp et al. 1981). Total PAH concentrations tend to be higher in hard coal than in soft coals, like lignite and brown coal. However, peat deposits prevalent over vast areas of temperate bogs and arctic tundra, may contain high concentrations of some PAH, particularly perylene (Venkatesan 1988).

A typical crude petroleum may contain from $0.2 \%$ to more than $7 \% \mathrm{PAH}$. The abundance of aromatic hydrocarbons in petroleum usually decreases markedly with increasing molecular weight. In most cases, the one-ring (benzene) through three-ring (phenanthrene) aromatics account for at least 90\% of the aromatic hydrocarbons that can be resolved in crude petroleum by conventional analytical techniques (Neff 1979a,b).

The aromatic hydrocarbons in coal and petroleum may contain one or more methyl, ethyl, butyl, or occasionally higher alkyl substituents on one or more of the aromatic carbons. As a general rule, these alkyl aromatics are more abundant than the parent compounds in petroleum (Youngblood and Blumer 1975). Homologues with two to five alkyl carbons usually are more abundant than the less or more highly alkylated homologues.

A major source of PAH containing three or more aromatic rings in the environment is the combustion of organic matter (Neff 1979a,b). Combustion of any organic material, including fossil fuels, will generate a wide variety of PAH, particularly if combustion takes place in an oxygen- 
deficient environment (fuel-rich combustion mixture). The PAH assemblages produced by pyrolysis of organic matter are complex, and, unlike the assemblages in petroleum, are dominated by four-, five-, and six-ring PAH. In pyrogenic PAH assemblages, the dominant compound in each homologous series is the unalkylated parent compound or a homologue with only one or two alkyl substituents (Youngblood and Blumer 1975). As mentioned above, in petrogenic PAH assemblages, the relative abundance of compounds in each homologous series increases to a maximum at the homologue containing four or occasionally five alkyl carbons. These differences are useful in distinguishing between petrogenic and pyrogenic $\mathrm{PAH}$ assemblages in environmental samples.

Another important, though localized source of PAH in the marine environment is creosote and related wood preservatives (Dunn and Stich 1976, Merrill and Wade 1985, Bieri et al. 1986, Wade et al. 1986). Creosote is derived from coal tar, a high-temperature byproduct of coal. Creosote may contain as much as $93 \mathrm{~g}$ total PAH/kg (Lijinski et al. 1963).

Nearly all the airborne PAH produced by flame pyrolysis are associated with the particulate fraction produced during combustion (soots and carbon blacks). Soot is thought to be an agglomerate of pericondensed PAH. PAH associated with the soot particle is part of the particle structure or is tightly adsorbed to the particle through hydrogen bonding and is not easily desorbed. Farrington (1986) proposed that PAH of pyrogenic and petrogenic origin has a different behavior in the marine environment. The PAH of pyrogenic origin is more tightly bound to or incorporated into particles due to the high temperature formation process or to subsequent reactions forming particulate matter in the atmosphere. Crude oil or refined petroleum products enter the marine environment in soluble, colloidal, or more loosely bound particulate form, and therefore, are more mobile and available for bioaccumulation. Jones et al. (1986) showed that oil-derived aromatic hydrocarbons associated with sediments are readily degraded by sediment bacteria, whereas combustion-derived aromatic hydrocarbons in the same sediments are relatively resistant to degradation.

PAH from creosote and other coal tar derivatives seems to have behavior intermediate between that of soot-associated and petroleum-derived PAH (Bieri et al. 1986, Wade et al. 1986, Huggett et al. 1987). Solid creosote is not very mobile or bioavailable, but PAH can dissolve into the water phase from the creosote and these soluble $\mathrm{PAH}$ are quite mobile and bioavailable.

Aromatic hydrocarbons of environmental concern span a wide range of molecular weight and associated physical properties (Table 4.1). Șolubility ranges from $1790 \mathrm{mg} / \mathrm{L}$ for benzene to approximately $0.0001 \mathrm{mg} / \mathrm{L}$ for coronene. Estimated $\log \mathrm{K}_{\infty}$ ranges from 1.78 to 7.21 . It should be 
pointed out, however, that it becomes increasingly difficult to estimate aqueous solubility and partition coefficients as the molecular weight of the PAH or other nonpolar organic compounds increase. Therefore, estimates in the literature of these physical properties for very sparingly soluble nonpolar organic chemicals may vary over a range of several orders of magnitude.

The linear relationship between $\mathrm{K}_{\mathrm{ow}}$ and $\mathrm{K}_{\mathrm{oc}}$ appears to be slightly different for different homologous series of aromatic and polynuclear aromatic hydrocarbons (Vowles and Mantoura 1987). However, there is a reasonably good correlation among the five physical parameters listed in Table 4.2 for a wide range of aromatic hydrocarbons and their alkyl homologues between benzene and coronene.

Both temperature and salinity have an effect on the solubility of aromatic hydrocarbons. The solubility of PAH tends to decrease in a linear fashion with increasing salinity, though the slope of the curve is different for different PAH (Whitehouse 1985a,b, Eastcott et al. 1988). In some cases, the solubility of a PAH may be twice as high in freshwater as in seawater. The solubility of naphthalene drops from $30.6 \mathrm{mg} / \mathrm{L}$ in freshwater to $22 \mathrm{mg} / \mathrm{L}$ in full strength seawater (Eganhouse and Calder 1976). The solubility of phenanthrene in fresh and salt water is 1.18 and $0.644 \mathrm{mg} / \mathrm{L}$, respectively (Eastcott et al. 1988).

The solubility of PAH is directly correlated with temperature (May et al. 1978, Whitehouse 1984). For example, the solubility of phenanthrene in freshwater increases from $0.423 \mathrm{mg} / \mathrm{L}$ at a temperature of $8.5^{\circ} \mathrm{C}$ to $1.277 \mathrm{mg} / \mathrm{L}$ at a temperature of $29.9^{\circ} \mathrm{C}$ (May et al. 1978). Benz(a)anthracene shows an anomalous behavior. At high salinities, solubility decreases with increasing temperature (Whitehouse 1984). These salinity- and temperature-related changes in solubility of PAH will have important effects on the partitioning of PAH among dissolved and sorbed phases in marine and estuarine environments. Sorption of PAH to sediments will tend to increase as salinity of the water increases and its temperature decreases. In cold arctic or temperate winter environments, PAH in spilled oil will tend to remain with the surface slick or sorb to particles in the water column and sink with them to the bottom. Little PAH will partition into the water column.

The wide range of solubilities and partition coefficients exhibited by aromatic hydrocarbons with different molecular weights means that aromatic hydrocarbons will exhibit a wide spectrum of behavior in the marine environment. Benzene, toluene, and xylene are quite volatile and moderately soluble in water. Therefore, when introduced into the ocean, they partition primarily into the air and water, and little of these compounds sorb to suspended particles or bottom sediments (Moore and 
Ramamoorthy 1984b). Neely (1980) predicted that the distribution of toluene among the water, sediment and air in a model aquatic ecosystem would be $0.9 \%, 0.4 \%$, and $98.6 \%$, respectively. At the other extreme, more than $96 \%$ of benzo(a)pyrene (log $K_{o c}=5.57$ ) in an aquatic ecosystem will be sorbed to particles (based on calculations of Adams, 1987).

In fact, most of the benzo(a)pyrene and other high molecular weight PAH are derived from combustion sources and so are associated in a not readily exchangeable form, primarily with particles. Readman et al. (1987) used a linear free energy sediment-water exchange model to simulate the repartitioning and exchange of individual unalkylated (primarily pyrogenic) PAH between the surface mixed layer of sediment and the overlying water of the Tamar River Estuary in England. They showed that the concentrations of PAH in the sediments are between two and five orders of magnitude greater than those expected from equilibrium partitioning with concentrations of PAH in the associated water. These results indicate that the PAH in the sediments is chemically inert. Sorptive exchange with the water and, therefore, bioavailability of the PAH to marine organisms appears to be restricted by the existence of occluded and other micro-morphologically inert forms of particle-bound PAH.

PAH and their alkyl homologues are nearly ubiquitous trace components of marine sediments worldwide (Laflamme and Hites 1978). The composition and relative concentrations of different PAH in the PAH assemblages in uncontaminated sediments are relatively constant; total PAH concentrations tend to decrease with distance from human population centers. These observations are consistent with the hypothesis that combustion by man of various types of fuels is the major source of these PAH assemblages in sediments (Laflamme and Hites 1978). This hypothesis is supported further by the observation that, particularly in fine-grain sediments near anthropogenic sources of PAH, the concentration of total PAH is highest in the upper few centimeters of sediment cores and decreases to a relatively constant "background" concentration at a depth of 10 to $20 \mathrm{~cm}$ (Venkatesan et al. 1987). Sediment at this depth was laid down between the middle of the last century (the start of heavy industrial use of fossil fuels) and the present time, indicating that the fraction of the total PAH above background was probably derived from combustion of fossil fuels. Forest and brush fires probably were major sources of the "background" PAH deposited before the industrial revolution (Youngblood and Blumer 1975). Pyrogenic PAH reaches marine sediments worldwide primarily by long-range transport of soot particles in the atmosphere (Lunde and Bjøseth 1977). In near-coastal environments, surface runoff from land may also contribute substantially to the pyrogenic PAH in 
sediments (Hoffman et al. 1984, Prahl et al. 1984). Other sources of pyrogenic PAH in sediments include effluents from municipal sewage treatment plants, coal coking ovens, aluminum manufacture by the Søderberg electrode method, and municipal and industrial incinerators (Neff 1979a,b). Petrogenic PAH enters the marine environment from natural oil seeps, oil spills, discharges of treated and untreated ballast and bilge water from oil tankers and other ships, and effluents from oil refineries, oil/water separator platforms on production platforms, and municipal sewage treatment plants (Neff 1979a,b; National Academy of Sciences 1985).

Concentrations of PAH in marine sediments vary widely. Background concentrations of total PAH in sediments from the continental slope and rise off southern New England at a depth in the sediment cores of 24 to $35 \mathrm{~cm}$ are in the range of 10 to $20 \mathrm{ng} / \mathrm{g}$ dry sediment (Venkatesan et al. 1987). The surficial sediments in these cores contain about $100 \mathrm{ng} / \mathrm{g}$ total PAH. Concentrations of total PAH (naphthalene through perylene) in sediments from Georges Bank and the adjacent sedimentary basins off the Massachusetts coast range from less than 1 to $100 \mathrm{ng} / \mathrm{g}$ (Boehm and Farrington 1984). Highest PAH concentrations are associated with the finest grained sediments, containing high concentrations of total organic carbon. Total four- through six-ring PAH in sediments from the main basin of Puget Sound, Washington, ranges from 0.6 to $3.2 \mu \mathrm{g} / \mathrm{g}$ (Bates et al. 1987). Sediments of the Palos Verdes Shelf off southern California, influenced by treated wastewater discharges from the municipal sewage treatment plant for Los Angeles County, contain 1.4 to 7.3 $\mu \mathrm{g} / \mathrm{g}$ total PAH (Anderson and Gossett 1987, Southern California Coastal Water Research Project 1987). Concentrations of total PAH between phenanthrene and benzo(ghi)perylene in surficial sediments of the Elizabeth River, Virginia range from 1.4 to $326 \mu \mathrm{g} / \mathrm{g}$ (Huggett et al. 1987). This PAH was derived primarily from creosote plants. Subsurface sediments near a treatment plant were reported to contain 13,000 $\mu \mathrm{g} / \mathrm{g}$ total aromatic hydrocarbons ( $\mathrm{Lu} 1982$-- cited in Huggett et al. 1987). Concentrations of total PAH (naphthalene through benzo(a)pyrene) in sediments from Boston Harbor, Massachusetts, are in the range of 0.48 to $718.4 \mu \mathrm{g} / \mathrm{g}$ (Shiaris and Jambard-Sweet 1986). The authors suggested that the PAH in the hot spots in Boston inner harbor are derived from overflows of the municipal sewage system. Concentrations of total PAH in sediments from Havana Bay, Cuba, are as high as $2800 \mu \mathrm{g} / \mathrm{g}$ (Ramos et al. 1989). This PAH is primarily pyrogenic, derived from runoff from land and effluents from gas manufacture and electric power plants on the shores of the bay. 
PAH in sediments is degraded by marine bacteria and fungi. Microbial degradation of PAH is much more rapid under aerobic than anaerobic conditions (Ward et al. 1980; Bauer and Capone 1985; Kruse et al. 1986). Other factors that influence the rate of microbial degradation of PAH in sediments include temperature, nutrients (especially nitrogen and phosphorus), salinity, the physical state and chemical composition of the PAH assemblage, and previous history of PAH contamination of the sediments (Atlas 1981, Bartha and Atlas 1987).

The rate of PAH degradation tends to decrease with increasing PAH molecular weight (Readman et al. 1982). Lee and Ryan (1983) reported that naphthalene and phenanthrene were biodegraded fairly rapidly in water samples from the Rhode Island and Georgia-South Carolina coasts. Medium molecular weight PAH (anthracene, fluorene, benz(a)anthracene, and chrysene) was not biodegraded readily in the water column, but was degraded rapidly in sediment-water slurries. Higher molecular weight PAH (dimehtylbenz(a)-anthracene, dibenz(a,h)anthracene, and benzo(a)pyrene) was not biodegraded readily even in sediment-water slurries. PAH degradation was more rapid in sediments that had been contaminated with petroleum than in clean sediments. Benz(a)anthracene added to a sediment-water slurry from oil-contaminated Shipyard Creek, South Carolina, in August $\left(29^{\circ} \mathrm{C}\right)$ was degraded at a rate of about $95 \mathrm{ng} / \mathrm{g}$ sediment/d, whereas the rate of degradation was about $14 \mathrm{ng} / \mathrm{g}$ sediment/d in a slurry of clean sediment from the nearby Skidaway River, Georgia, at a temperature of $28^{\circ} \mathrm{C}$.

Rates of microbial degradation of PAH in sediments vary widely. Massie et al. (1985) estimated the rate of biodegradation of naphthalene and benzo(a)pyrene in sediments around several oil production platforms in the North Sea. Degradation rates of naphthalene ranged from 2 to 3120 $\mu \mathrm{g} / \mathrm{m}^{2} / \mathrm{d}$, and those of benzo(a)pyrene ranged from undetectable (most locations) to $27 \mu \mathrm{g} / \mathrm{m}^{2} / \mathrm{d}$. Similar degradation rates were reported earlier for naphthalene (135 to $2025 \mu \mathrm{g} / \mathrm{m}^{2} / \mathrm{d}$ ) in sediments near three production platforms in the North Sea (Saltzman, 1982). Kruse et al. (1986) reported slightly lower degradation rates for naphthalene (26 to $250 \mu \mathrm{g} / \mathrm{m}^{2} / \mathrm{d}$ in oil polluted sediments from a Danish estuary). Lee and Ryan (1983) estimated that the half-life of benz(a)anthracene at a concentration of $2.5 \mathrm{mg} / \mathrm{kg}$ dry wt in sediment would increase from $1100 \mathrm{~d}$ at a temperature of $15^{\circ} \mathrm{C}$ to $21,000 \mathrm{~d}$ at a temperature of $4^{\circ} \mathrm{C}$.

These rates of PAH degradation, particularly for PAH with four or more rings, are slow enough that rates of input of PAH to the sediments may exceed degradation rates and PAH may accumulate (Massie et al. 1985). For instance, the rates of accumulation of benzo(a)pyrene in 
surficial sediments off Palos Verdes, California, (Southern California Coastal Water Research Project 1987) or in Boston Harbor, Massachusetts, (Gschwend and Hites 1981) were estimated to be 7.5 and $0.47 \mu \mathrm{g} / \mathrm{m}^{2} / \mathrm{d}$, respectively. Atlas and Bronner (1981) estimated that petroleum hydrocarbons (both aliphatic and aromatic hydrocarbons) were being degraded in the upper $5 \mathrm{~cm}$ of intertidal sediments along the Brittany coast of France impacted by the Amoco Cadiz oil spill at a rate of $50 \mathrm{mg} / \mathrm{m}^{2} / \mathrm{d}$. Extrapolating to the $320 \mathrm{~km}$ of coastline affected by the spill, they estimated that it would take more than $20 \mathrm{yr}$ to biodegrade the estimated 64,000 metric tons of oil believed to have come ashore along the Brittany coast.

\subsubsection{Polychlorinated Biphenyls}

Chlorination of the diaromatic hydrocarbon, biphenyl, produces as many as 209 different chlorbiphenyl congeners with from one to ten chlorine atoms per molecule. Polychlorinated biphenyls (PCBs) with different degrees of chlorination are mixed in different proportions to produce a wide variety of products with different industrial applications (Moore and Ramamoorthy 1984b). Until the mid 1970's, when production of PCBs in the United States was stopped, Monsanto Chemical Company was the sole U.S. manufacturer of PCB mixtures, which were marketed under the trade name Aroclor. All Aroclor products were characterized by a 4-digit number. The first two digits stand for the type of molecule: 12 refers to chlorinated biphenyls and 54 -refers to chlorinated terphenyls. Aroclors 25- and 44- are mixtures of PCBs and polychlorinated terphenyls. The last two digits of the formula refer to the percent by weight of chlorine in the mixture. Thus, Aroclor 1254 contains $54 \%$ chlorine. The average mumber of chlorines per PCB molecule in this formulation is 4.96 .

Peak production of PCBs in the U.S. was 38,600 metric tons in 1970. Because of their chemical and thermal stability, inertness, and excellent dielectric properties, PCBs have multiple industrial and commercial applications. They are used as dielectric fluids in electrical transformers and capacitors, as plasticizers in paints, plastics, sealants, resins, inks, printing, copy paper, and adhesives, and as components of hydraulic fluids in gas turbines and vacuum pumps (Moore and Ramamoorthy 1984b). Several of these uses predispose their escape into the environment. However, the major sources of PCBs in the marine environment are wastewater discharges from electrical component manufacturers and users. Until the late 1960's, PCBs were considered inert, and their disposal in the environment was not regulated. 
Current-day inputs of PCBs to estuaries and coastal waters are from runoff from land, industrial and municipal waste discharges, and accidental spills, particularly from leaky electric transformers (Larsson 1984a). As industrial use of PCBs declines further, the major mechanism of global dispersal of PCBs will be atmospheric transport. $\mathrm{PCBs}$ are relatively volatile $\left(\mathrm{Cl}_{2}-\right.$ to $\mathrm{Cl}_{6}-\mathrm{PCBs}$ have vapor pressures ranging from $1.8 \times 10^{-6}$ to $2.9 \times 10^{-11}$ atmospheres: Dunnivant and Elzerman 1988) and have been detected in the atmosphere (e.g., Giam et al. 1980), in precipitation (Murphy and Rzeszutko 1977), and Iry deposition (Södergren 1972).

After dissolving in the water, PCBs tend to sorb rapidly to suspended particles or bioaccumulate in the lipids of aquatic organisms (Larsson 1984a, Larsson and Södergren 1987). Eventually much of the PCBs are deposited in bottom sediments. Once deposited in sediments, PCBs are not necessarily immobile. They may be remobilized into the overlying water column by bioturbation of sediments by benthic animals, desorption into pore water or the overlying water column, upward convection with gases produced in anaerobic sediments, or direct bioaccumulation from sediment by benthic organisms (Larsson and Södergren 1987). PCBs in solution tend to migrate and accumulate at the air/water interface (surface microlayer) from which they may enter the overlying air by evaporation or aerosol formation (Södergren and Larsson 1982). Paris et al. (1978) estimated that the half-life for evaporation of dissolved Aroclor 1016 and Aroclor 1242 in a $1-\mathrm{m}^{3}$ parcel of particle-free water is 9.9 and $11.2 \mathrm{hr}$, respectively.

Mackay and Diamond (1989) developed and applied a quantitative water, air, sediment . interaction (QWASI) fugacity model to describe the distribution of PCBs in Lake Ontario. The model predicted that the major inputs of PCBs to the lake are in the inflowing water (1329 kg/y) and deposition from the air (net $45 \mathrm{~kg} / \mathrm{y}$ ). There is a net flux of $1140 \mathrm{~kg} / \mathrm{y}$ of PCBs from the water to the sediment. The main routes of loss of PCBs from surficial sediments are burial in deeper layers (41.4\% of the total loss), sediment resuspension (40.9\%), diffusion from the sediment into the overlying water (11.6\%), and biotic and abiotic degradation in the sediment (6.1\%). Although this model described the behavior of PCBs in a freshwater ecosystem, the behavior of PCBs is likely to be qualitatively similar in estuarine and coastal marine ecosystems (Larsson 1984a).

Although much of the early research on the environmental behavior of PCBs treated brandname formulations of PCBs, such as the Aroclors and similar brands from Europe and Japan, as single compounds with "average" solubilities and $\mathrm{K}_{\mathrm{ow}}$, etc. (e.g., Paris et al. 1978), there is, in fact, a tremendous range in physical properties of the individual PCB congeners in these mixtures (Table 
4.3). Estimated solubilities span six orders of magnitude, and estimated $\mathrm{K}_{\mathrm{ow}}$ spans four orders of magnitude. As a general rule, solubility decreases and $\mathrm{K}_{\mathrm{ow}}$ increases as the degree of chlorination increases. However, within a group of positional isomers (e.g., all $\mathrm{Cl}_{4}$-PCBs), these parameters also vary to some extent due to stearic effects of the positions of the chlorine atoms on the biphenyl molecule. For example, the solubility of $2,2^{\prime}, 3,3^{\prime}-\mathrm{PCB}$ is ten times higher than that of $3,3^{\prime} .5,5^{\prime}-$ PCB. These differences in physical properties of individual PCB congeners mean that the different congeners will behave differently in the marine environment (Burkland et al. 1985). The rate of sedimentation of PCB congeners increases with increasing values of $K_{o c}$, whereas the less chlorinated congeners (highest solubility and vapor pressure) tend to remain longer in the water column or evaporate more rapidly than the more highly chlorinated congeners. The rate of release of PCBs from contaminated sediment is inversely related to the $\mathrm{K}_{\mathrm{ow}}$ of the different congeners (Wood et al. 1987), though stearic effects of chlorine position on the biphenyl molecule also affect mobility. The depth in undisturbed sediment to which mobilization of PCBs can take place also tends to decrease with an increase in the number of chlorines on the PCB molecule and with the $\mathrm{K}_{\text {ow }}$.

These observations are consistent with the observations of Brownawell and Farrington (1986) that surficial layers of a sediment core from highly contaminated New Bedford Harbor, Massachusetts, were slightly depleted in the di- and tri-chlorobiphenyls relative to deeper layers. The di-, tri-, and tetra-chlorobiphenyls were depleted with increasing depth in the core, whereas the concentrations of the penta-, hexa-, and hepta-chlorobiphenyls remained relatively unchanged with depth in the core. These profiles could be due to selective mobilization or degradation of the less chlorinated PCBs in the sediment core.

Brownawell and Farrington (1986) also reported that concentrations of PCBs in the pore water of the sediment increased with depth in the sediment core to a maximum of 0.893 to $17.1 \mu \mathrm{g} / \mathrm{L}$ at a depth of 9 to $11 \mathrm{~cm}$. These concentrations were one to three orders of magnitude higher than the concentrations of PCBs in the overlying water column $(0.01$ to $0.02 \mu \mathrm{g} / \mathrm{L})$ and were greater than the aqueous solubility of the more highly chlorinated PCB congeners (Table 4.3). Similar increments of PCB concentrations in sediment pore water have been reported for sediments from the Rhine-Meuse Estuary, the Netherlands, and for sediments from Lake Michigan.

Much of the PCBs in pore water appear to be associated with the dissolved organic carbon (DOC) in the pore water, which also increases in concentration with depth in the upper $14 \mathrm{~cm}$ of the sediment core (Figure 4.4). The affinity of the DOC for PCBs appears to be similar to or slightly 
higher than that of the organic carbon in the solid phase of the sediment. However, the more highly chlorinated PCBs are enriched in the pore water relative to their concentrations in the solid phase, suggesting that their affinity for DOC is higher than their affinity for solid phase organic matter. Beller and Simoneit (1986) reported that PCBs in contaminated sediments are associated primarily with a free lipid fraction of the sediment and not with the bound humic acid and humin fractions.

These results indicate that PCBs and probably other nonpolar organic chemicals are distributed among three phases, not two, in the sediment: an adsorbed solid phase, a dissolved phase, and a dissolved colloidal phase. The PCBs or other hydrophobic organic chemicals sorbed to colloidal or dissolved organic matter probably are substantially less bioavailable than the PCBs in true solution, but much more mobile than the PCBs sorbed to the solid phase. Thus, the distribution of nonpolar organic contaminants among all three phases must be considered.

Degradation of PCBs can occur in both aerobic and anaerobic sediments. In reducing sediments, reductive dehalogenation may be the main pathway for converting DDT $(1,1,1$-trichloro2,2-bis(dichlorophenyl)ethane) to DDD and DDD to DDE. Zora proposed that reductive dehalogenation is an abiotic chemical reaction possibly dependent on reduced iron porphyrins in sediment. PCBs can also be reductively dechlorinated in anaerobic sediments. The ease of reduction seems to increase with increasing of chlorination of the PCBs. However, Brown et al. (1987a) reported that the reactions appear to be mediated by anaerobic bacteria, and abiotic reducing agents in anaerobic sediments are unable to reductively dechlorinate aromatic chemicals. Methanogenic bacteria seem to be responsible for these reductions.

A variety of aerobic bacteria in freshwater and marine sediments are able to oxidatively degrade lower chlorinated biphenyls (Brown et al. 1987a). Species of Alcaligenes and Acinetabacter can oxidize and cleave PCBs up through trichlorobiphenyl by a dioxygenase reaction leading to diols and finally chlorobenzoic acids. Eukaryotes (fungi, protozoans, and animals) in sediments are able to degrade PCBs by a cytochrome P450 mixed function oxygenase system (Brown et al. 1987a).

The degradation products of $\mathrm{PCB}$ reductive dechlorination and oxidative transformation, although generally more soluble than the parent compounds, tend to remain associated with the sediments. Brown et al. (1987b) reported that $80 \%$ of the total DDT in marine sediments off southern California were the oxygenated metabolites, DDA and DDOH. They inferred a similar distribution for $\mathrm{PCBs}$ and their metabolites and supported this inference by showing that $90 \%$ or more 
of both DDT and PCBs in mussels, Mytilus californianus, were present as oxygenated metabolites, even though mussels have a minimal ability to metabolize aromatic compounds.

Because PCBs are man-made chemicals with no naturally-formed counterparts in the environment, there are no true background concentrations in different compartments of the marine environment. Environmental concentrations probably reached a maximum in the mid- to late 1970's and the environmental load probably is decreasing slowly as PCBs are removed from industrial usage and degrade slowly in the environment.

Measurements prior to 1976 of PCB concentrations in seawater probably are inaccurate. The range of 0.035 to $0.5 \mathrm{ng} / \mathrm{L}$, reported by Tanabe and Tatsukawa for deep waters of the western Pacific Ocean is probably a reasonable range of PCB concentrations to expect in open ocean waters. Coastal waters and estuaries may have substantially higher concentrations. Concentrations of total PCBs in water at several locations in Puget Sound ranged from 3.0 to $22 \mathrm{ng} / \mathrm{L}$ between 1973 and 1977 (Pavlou and Dexter 1979). Concentrations of individual tri- and penta-chlorobiphenyls in water from New Bedford Harbor, Massachusetts, ranged from 0.02 to $9.5 \mathrm{ng} / \mathrm{L}$. Suspended particulate matter in the water column of the New York Bight Apex contained 0.05 to $3.5 \mathrm{ng} / \mathrm{L}$ total PCBs.

Concentrations of total PCBs in a sediment core from New Bedford Harbor, Massachusetts, ranged from 1.31 to $33.0 \mu \mathrm{g} / \mathrm{g}$ dry wt in the solid phase and 1.31 to $20.1 \mu \mathrm{g} / \mathrm{L}$ in the pore water (Brownawell and Farrington 1986). Sediments from estuaries and harbors along Long Island Sound contained 1 to $736 \mathrm{ng} / \mathrm{g}$ total PCBs. The most heavily contaminated sediments in New Bedford Harbor, Massachusetts, contained in excess of $1000 \mu \mathrm{g} / \mathrm{g}$ total PCBs with some hot spots containing more than $100,000 \mu \mathrm{g} / \mathrm{g}$.

\subsubsection{Chlorinated Phenols}

Chlorinated phenols are used widely as biocides, and wood preservatives (Buikema et al. 1979). Many phenols are formed during the manufacture of paper and paper products. These may become chlorinated during the chlorine bleaching process. Chlorophenols are moderately to highly toxic and have low taste and odor thresholds and, therefore, are of concern as environmental contaminants.

Unlike the nonpolar organic compounds discussed in previous sections of this review, chlorophenols are moderately polar and are ionizable at normal levels of environmental $\mathrm{pH}$. Ionization constants $\left(\mathrm{pK}_{\mathrm{a}}\right)$ generally are less than the $\mathrm{pH}$ of seawater (Table 4.4 ), meaning that 
chlorinated phenols in brackish and seawater will be partially or completely ionized. Aqueous solubilities of chlorophenols is quite variable, but generally is in excess of $1 \mathrm{mg} / \mathrm{L}$ (Table 4.4). Values for $\log \mathrm{K}_{\mathrm{ow}}$ and $\log \mathrm{K}_{\mathrm{\alpha}}$ are in the range of two to four, indicating a relatively low affinity for simple van der Waals sorption to sediments. However, as discussed earlier, because chlorophenols are ionizable, they can react with substrates, forming chemical complexes.

The physical properties of chlorophenols render them more mobile and more readily biodegradable than the more nonpolar compounds discussed earlier. DeLaune studied the fate of pentachlorophenol (PCP) following a major spill in a Louisiana Gulf Coast estuary. In just 18 months after the spill of $11,350 \mathrm{~kg}$ of granular PCP, concentrations of PCP in sediments at the spill site had dropped to $1.6 \mu \mathrm{g} / \mathrm{g}$ dry wt or less. Most of the PCP had been dissolved or biodegraded. The investigators showed that the PCP was bound more tightly to oxidized than to reduced sediments. Microbial degradation of the PCP in sediments was rapid. Degradation rates decreased as the sediment redox potential decreased. The optimum $\mathrm{pH}$ for biodegradation was about 8.0.

In a study of the fate of chlorophenols from a pulp mill in the Gulf of Bothnia (east coast of Sweden), Xie reported that the rate of dilution of chlorophenols in the receiving waters was dependent on their partition coefficients. The compounds with higher partition coefficients tended to sorb to suspended particles, also abundant in the effluent, and sink with them to the bottom. However, the concentrations of different chlorophenols in sediments were not related to partition coefficients. Biodegradation played a major role in removing chlorophenols from the sediments. Concentrations of 2,3,4,6-tetrachlorophenol in the pulp mill effluent ranged from 5.8 to $7.5 \mu \mathrm{g} / \mathrm{L}$, those in the receiving waters from $<1$ to $100 \mathrm{ng} / \mathrm{L}$, and those in the sediments of the area from $<0.1$ to $89 \mathrm{ng} / \mathrm{g}$ dry wt. Thus, chlorophenols are not very persistent in the marine environment of the Gulf of Bothnia.

Although chlorophenols are used frequently as biocides, they are readily biodegraded by bacteria and fungi in seawater and sediments (Moore and Ramamoorthy 1984b). Chlorophenols are also metabolized by fish. Degree of chlorination and stearic effects of the positions of the chlorine atoms on the phenol molecule influence the rate of chlorophenol biodegradation. For example, chlorophenols with a chlorine atom in the meta position tend to be resistant to degradation. Microbial populations apparently must become adapted to degrade chlorophenols. Thus, in environments receiving chronic inputs of chlorophenols, such as the vicinity of the pulp mill on the Gulf of Bothnia, chlorophenol biodegradation is rapid. In pristine environments, there is a lag time before significant degradation takes place. 
Table 4.1. Regression Equations From the Literature for the Estimation of $\mathrm{K}_{\mathrm{oc}}$ From $\mathrm{K}_{\mathrm{ow}}$. Modified From Pavlou (1987) $(r=$ correlation coefficient).

Regression
$\log \mathrm{K}_{\infty}=0.544 \log \mathrm{K}_{\mathrm{ow}}+1.377$
$\log \mathrm{K}_{\infty}=0.937 \log \mathrm{K}_{\mathrm{ow}}-0.006$
$\log \mathrm{K}_{\infty}=1.00 \log \mathrm{K}_{\mathrm{ow}}-0.21$
$\log \mathrm{K}_{\infty}=0.94 \log \mathrm{K}_{\mathrm{ow}}+0.02$
$\log \mathrm{K}_{\infty}=1.029 \log \mathrm{K}_{\mathrm{ow}}-0.18$
$\log \mathrm{K}_{\infty}=0.52 \log \mathrm{K}_{\mathrm{ow}}+0.64$
$\log \mathrm{K}_{\infty}=0.82 \log \mathrm{K}_{\mathrm{ow}}+0.02$
$\log \mathrm{K}_{\infty}=0.989 \log \mathrm{K}_{\mathrm{ow}}-0.346$
$=0.834 \log \mathrm{K}_{\mathrm{ow}}+0.158$

Number of

Compounds

Considered

Chemical Class

Reference

$\log \mathrm{K}_{\mathrm{oc}}=0.544 \log \mathrm{K}_{\mathrm{ow}}+1.377$

45

0.86 Pesticides

19

0.97

Aromatics, polynuclear

aromatics, triazines, dinitroaniline herbicides

Pavlou \& Weston 1984

Brown and Flagg 1981

1.00

Aromatics, polynuclear aromatics

Karickhoff et al. 1979

Triazines and dinitroaniline herbicides

Lyman et al. 1982

Several herbicides,

insecticides and

fungicides

Substituted phenyl ureas alkyl N-phenylcarbamates, anilines, nitrobenzenes

Rao \& Davidson 1980

Aromatics, polynuclear aromatics

Briggs 1981

Karickhoff 1981 
Table 4.2. Physical Properties of Aromatic and Polynuclear Aromatic Hydrocarbons (Data From Eastcott et al. 1988) ( $a=$ Solubility is in fresh water. Solubility in seawater is lower, $b$ $=$ Calculated by the regression equation, $\mathrm{K}_{\mathrm{oc}}=0.989 \log \mathrm{K}_{\mathrm{ow}}-0.346-$ Karickhoff 1981).

\begin{tabular}{|c|c|c|c|c|c|}
\hline Compound & $\begin{array}{c}\text { Number of } \\
\text { Carbons }\end{array}$ & $\begin{array}{l}\text { Molecular } \\
\text { Weight }\end{array}$ & $\begin{array}{c}\text { Solubility } \\
\mathrm{mg} / \mathrm{L}\end{array}$ & $\log K_{\text {ow }}$ & $\underbrace{\log K_{\infty}^{b}}$ \\
\hline Benzene & 6 & 78.1 & 1790 & 2.13 & 1.78 \\
\hline Toluene & 7 & 92.1 & 579 & 2.65 & 2.27 \\
\hline p-Xylene & 8 & 106.2 & 221 & 3.18 & 2.79 \\
\hline n-Xylene & 8 & 106.2 & 160 & 3.20 & 2.82 \\
\hline $0-X y l e n e$ & 8 & 106.2 & 215 & 3.13 & 2.75 \\
\hline 1,3,5-Trimethylbenzene & 9 & 120.2 & 48.2 & 3.55 & 3.16 \\
\hline Naphthalene & 10 & 128.2 & 30.6 & 3.35 & 2.94 \\
\hline 2-Methylnaphthalene & 11 & 142.2 & 25.6 & 3.86 & 3.47 \\
\hline Dimethylnaphthalene & 12 & 156.2 & 2.0 & 4.31 & 3.91 \\
\hline Fluorene & 13 & 166.2 & 1.84 & 4.18 & 3.79 \\
\hline Phenanthrene & 14 & 178.2 & 1.18 & 4.57 & 4.08 \\
\hline Anthracene & 14 & 178.2 & 0.073 & 4.54 & 4.20 \\
\hline Pyrene & 16 & 202.3 & 0.135 & 5.18 & 4.83 \\
\hline Fluoranthene & 16 & 202.3 & 0.263 & 5.22 & 4.82 \\
\hline Chrysene & 18 & 228.3 & 0.002 & 5.79 & 5.38 \\
\hline Benz(a)anthracene & 18 & 228.3 & 0.014 & 5.91 & 5.50 \\
\hline Benzofluoranthene & 20 & 252.3 & 0.002 & 5.75 & 5.34 \\
\hline Benzo(a)pyrene & 20 & 252.3 & 0.004 & 5.98 & 5.57 \\
\hline Perylene & 20 & 252.3 & 0.0004 & 6.50 & 6.08 \\
\hline Dibenzanthracene & 22 & 276.3 & 0.0005 & 6.22 & 5.80 \\
\hline Benzo(g,h,i)perylene & 22 & 276.3 & 0.0003 & 7.10 & 6.68 \\
\hline Coronene & 24 & 300.4 & 0.0001 & 7.64 & 7.21 \\
\hline
\end{tabular}


Table 4.3. Physical Properties of Polychlorinated Biphenyls [a = Data from Dunnivant and Elzerman (1988) and Miller et al. (1985); b = Data from Hawker and Connell (1988); c $=$ Calculated by the regression equation, $\mathrm{K}_{\infty}=0.544 \log \mathrm{K}_{o w}+1.377$, proposed by Pavlou and Weston (1984) for pesticides].

Compound

$\begin{array}{ccccc}\begin{array}{c}\text { Percent } \\ \text { Chlorine }\end{array} & \begin{array}{c}\text { Molecular } \\ \text { Weight }\end{array} & \begin{array}{c}\text { Solubility } \\ \mathrm{mg} / \mathrm{L}\end{array} & \log \mathrm{K}_{\text {ow }}{ }^{b} & \log \mathrm{K}_{\infty}{ }^{c}\end{array}$

Biphenyl
$2-$
$2,2^{\prime}-$
$2,2^{\prime}, 5-$
$2,3^{\prime}, 5-$
$2,2^{\prime}, 3,3^{\prime}-$
$3,3^{\prime}, 5,5^{\prime}-$
$2,2^{\prime}, 4,5,5^{\prime}-$
$2,2^{\prime}, 4,6,6^{\prime}-$
$2,2^{\prime}, 3,3^{\prime}, 4,4^{\prime}-$
$2,2^{\prime}, 4,4^{\prime}, 5,5^{\prime}-$
$2,2^{\prime}, 3,3^{\prime}, 4,4^{\prime}, 6-$
$2,2^{\prime}, 3,3^{\prime}, 5,5^{\prime}, 6,6^{\prime}-$
$2,2^{\prime}, 3,3^{\prime}, 4,5,5^{\prime}, 6,6^{\prime}-$
Deca-PCB

$\begin{array}{cc}0 & 154.2 \\ 18.8 & 188.7 \\ 31.8 & 223.1 \\ 41.3 & 257.5 \\ 41.3 & 257.5 \\ 48.6 & 292.0 \\ 48.6 & 292.0 \\ 54.3 & 326.4 \\ 54.3 & 326.4 \\ 58.9 & 360.9 \\ 58.9 & 360.9 \\ 62.8 & 395.3 \\ 66.0 & 429.8 \\ 68.7 & 464.2 \\ 71.2 & 498.7\end{array}$

6.7

5.1

1.2

0.51

0.25

0.016

0.0012

0.0067

0.016

0.0023

0.00086

0.0022

0.00040

0.00002

0.000007
4.09

4.46

4.65

5.24

5.66

5.66

6.48

6.38

5.81

6.74

6.92

7.11

7.24

7.71

8.18
3.60

3.80

3.91

4.23

4.46

4.46

4.90

4.85

4.54

5.04

5.14

5.24

5.32

5.57

5.83

Table 4.4. Physical Properties of Selected Chlorinated Phenols $[\mathrm{a}=$ From Schellenberg et al. (1984), b = From Buikema et al. (1979)].

\begin{tabular}{|c|c|c|c|c|c|}
\hline Compound & $\begin{array}{c}\text { Molecular } \\
\text { Weight }\end{array}$ & $\mathrm{pK}$ & $\begin{array}{l}\text { Solubilityb } \\
\text { (mg/L) }\end{array}$ & $\mathrm{K}_{\text {ow }}{ }^{2}$ & $\mathrm{~K}_{\mathrm{oc}}^{\mathrm{a}}$ \\
\hline 2-Chlorophenol & 128.6 & 7.22 & $<1.0$ & 2.17 & 1.80 \\
\hline 2,3-DCP & 184.1 & 7.61 & - -(a) $^{(a)}$ & 3.15 & 2.62 \\
\hline 2,4-DCP & 184.1 & 7.85 & -- & 3.23 & 2.74 \\
\hline $2,4,6-\mathrm{TCP}$ & 197.4 & 6.15 & -- & 3.72 & 3.03 \\
\hline $3,4,5-\mathrm{TCP}$ & 197.4 & 7.73 & - & 4.41 & 3.57 \\
\hline $2,3,4,6-\mathrm{TeCP}$ & 231.9 & 5.40 & 100 & 4.42 & 3.82 \\
\hline $2,3,4,5-\mathrm{TeCP}$ & 231.9 & 6.35 & -- & 4.87 & 4.12 \\
\hline Pentachlorophenol & 266.4 & 5.25 & $20-25$ & 5.24 & 4.52 \\
\hline
\end{tabular}




\subsection{LIFE STYLES AND FEEDING HABITS OF BENTHIC ORGANISMS}

\subsection{INTRODUCTION}

The forms and physical associations of chemical contaminants in marine sediments discussed in Chapters 2, 3 and 4 are very important considerations in analysis of bioavailability of sedimentbound contaminants. Equally important are considerations of the biology and ecology of the infaunal and demersal animals as determinants of bioavailability. Among the numerous species that inhabit sediments, there exists a great diversity of morphologies, locomotory patterns, feeding strategies, modes of dispersion, and types of associations with sediments. This chapter cannot begin to cover all of this diversity, for there is enough material to fill numerous books. Our intention is to review issues relevant to bioavailability. Each of the many benthic and demersal species associated with sediments has unique ecological and biological attributes. During our review, we have looked for trends in these attributes (e.g, soft-bodied vs. hard-bodied species, mud-dwelling vs. sand-dwelling species, suspension-feeding vs. deposit-feeding, mobile vs. sedentary, etc.) and recognize that exceptions to any of our generalizations can be made.

This chapter covers many aspects of organism-sediment relationships. Associations with sediments discussed include morphology and body form, mobility patterns, feeding, and bioturbation/biodeposition. Bioturbation and biodeposition are important not only in exposing organisms to chemical contaminants, but also in altering the chemistry of the sediments.

Organisms dealt with in this chapter are the common macrofauna that live in the sediments and the demersal epifauna that live on or interact with the sediments in some way. For the purposes of discussion, macrofauna are defined as those organisms that do not pass through a $0.5-\mathrm{mm}$ sieve. Because literature on bioavailability is limited mainly to the macrofaunal taxa most commonly found, less common groups (e.g., brachiopods, ostracods, aplacophorans) are usually omitted. Discussion of the microorganisms will be restricted to their effects on the chemical processes that occur in the sediments.

\subsection{MORPHOLOGY AND BODY FORM}

Structure and function of marine organisms operate inseparably to determine the ability of these organisms to take up and metabolize chemical compounds. Morphological characteristics and body form are important determinants in this process, because they set the bounds or limits on the 
capabilities of each species. Many excellent texts have been written on morphology and body form (Meglitsch 1972, Lagler et al. 1977, McFarland et al. 1979, Barnes 1980, Nelson 1984, Pearse et al. 1987). Therefore, this section focuses on those morphological attributes relevant to bioavailability.

Morphological organization depends upon the way that muscles are attached in the body which in turn dictates the way animals move. An important requirement for the movement of animals is the means for affording muscular antagonism (Trueman 1975). The active phase of the muscles is the contraction, and an external force is required to restore them to their initial length as the muscles are incapable of active elongation. Any system that affords muscular antagonism can be called a skeleton, with its function being to ensure that muscles act on each other for restitution of their relaxed state after contraction. Animals fall into two categories of skeletal systems: (1) hard skeletons, internal or external, and (2) fluid or hydrostatic skeletons. Arthropods, vertebrates, and some echinoderms possess the first type of skeleton while all other organisms, with some exceptions, generally possess hydrostatic skeletons. The internal bony or cartilaginous skeleton of chordates, the chitinous exoskeletons of arthropods, and the calcarious endoskeleton of most echinoderms (crinoids, ophiuroids, echinoids, and asteroids) provide a means of muscular antagonism, permitting a far greater range of movements than is seen among organisms with hydrostatic skeletons. A hydrostatic skeleton depends on an incompressible fluid in a closed cavity. Contraction of the circular or longitudinal body wall musculature deforms the shape of the organism. Organisms that use hydrostatic skeletons include annelids, nemerteans, sipunculans, echiurans, pogonophorans, phoronids, holothurians, hemichordates, and enteropneusts. Infaunal bivalves use a hydrostatic skeleton in the foot, but use the shell ligament for antagonism of the adductor muscles. The skeletal system of echinoderms is internal. The development of the skeleton varies greatly from the welldeveloped test of the echinoids (covered by a thin epithelium) to scattered macroscopic plates embedded in the integument in the asteroids and ophiuroids to the sparse microscopic spicules of holothurians. Echinoderms have an ancillary means of changing body shape and viscosity. Unique to the echinoderms (Wilkie 1984), a layer of mutable collagenous tissue underlies the epidermis of echinoderms. Echinoderms are able to alter the chemical milieu of the tissue, causing the mutable collagenous tissue to radically change in viscosity. This reversible change can cause an asteroid to change from flexible to rigid in a matter of seconds. Thus, the mutable collagenous tissue is an effective substitute for an external skeleton in many echinoderms. The mutable collagenous tissue is, 
however, permeable to chemicals and, thus, this sort of skeleton affords little protection against the uptake of sediment-bound contaminants.

Table 5.1 presents the different animal phyla, their body forms, and the areas where interactions with sediment-bound contaminants are expected to occur. Areas of uptake and exposure to contaminants usually are located where soft tissues are exposed, even in shelled or spicular organisms. The Crustacea are different in that they take up contaminants over thin areas of the exoskeleton. The areas where soft tissues are usually exposed to contaminants are in the mid-gut region which is unchitinized (the fore- and hind-guts are chitinized) and over the gills, the coverings of which are permeable (Barnes 1980). During molting, however, the crustacean integument may become soft and may be a site where contaminant uptake can occur. The integument is comprised of several layers which are made of, depending on the layer, chitin, lipids, and proteins (Stevenson 1985b). Sites for uptake of or interaction with sediment-bound contaminants in soft-bodied forms are limited primarily to the epidermis, the digestive tract, and gills. The morphology and food processing abilities of a digestive tract influence the quality and quantity of material digested (Penry 1989) and, hence, the amount of exposure to sediment-bound contaminants, particularly if they are associated with digestable or absorbable matter. While molluscs achieve some protection from contaminants by withdrawing into their shells, they cannot escape these contaminants while conducting their normal activities because their soft parts are exposed during these activities. Asteroid and ophiuroid echinoderms have spicules densely embedded in their epidermis and echiuroids, and produce internal tests covered by a thin epithelium. In these organisms, uptake through the epidermis is anticipated to be minimal to nonexistent, while most uptake is anticipated to be through the tissues of the water vascular system where the tissues come in contact with the sediments and through sediments ingested into the digestive tract (Ferguson 1964a,b, Ferguson 1979). The holothuroids or sea cucumbers have spicules in the epidermis, but these spicules are not as dense as in other echinoderm classes and considerably more epidermis is exposed to sediments. While most fish do not live in the sediments, some species (e.g., the flatfish and sand eels) feed on organisms in the sediments and, in doing so, also ingest sediments. These fish spend considerable time resting on or buried in sediments, consequently being exposed to sediments epidermally. The high incidence of fin rot in these species in contaminated areas implicates epidermal exposure. The degree to which these different tissues play a role in uptake of sediment-bound contaminants will be discussed in Chapters 6 and 7 . 


\subsection{MOBILITY PATTERNS}

Marine benthic macrofauna and demersal epifauna exhibit a wide variety of locomotory styles to move through and over the sediments (Trueman 1975, Barnes 1980). Some animals are quite capable of rapidly avoiding environmentally unsuitable situations (e.g., contaminated sediments, anoxic sediments, predators), while others are stationary or move slowly, having no escape mechanisms. Classification schemes for mobility patterns of benthic animals have been proposed (e.g., Brenchley 1978, Fauchald and Jumars 1979, Lee and Swartz 1980). Depending on the species, benthic animals range from sessile to highly mobile. Often the degree of mobility in a species will depend on environmental conditions, stage of life, physiological conditions of the organisms, current food resources, or presence of competitors and/or predators. The wide diversity of morphologies of the species associated with sediments has resulted in considerable variety within the major mobility categories. These major categories of mobility are summarized briefly as follows:

Sedentary: Tube-building

Sedentary: Non-tube-building

Nonsedentary: Tube-building

Burrowing

Interstitial

Crawling

Demersal

Swimming

Both burrowing and tube building vary broadly (Barnes 1965, Mills 1967, Bonar 1972, Busch and Loveland 1975, Trueman 1975, Brenchley 1976, Aller and Yingst 1978, Kudenov 1978, Barnes 1980, Borowsky 1983, Kozloff 1983, Duncan 1987) in the way they are done and the tube or burrow that is formed. For the purposes of this discussion, a discrete tube remains on a sieve when tube builders are sieved from the sediments, while no structure remains when burrowers are sieved. The distinction between burrowing and tube building is not always clearcut. Frequently, nonsedentary tube builders are described as burrowers in the literature. Tubicolous animals form tubes in which to live either by burrowing into the sediments and then building of the tube or by building the tube on or into the sediments. Tubes can be made of particles held together by mucoid secretions from the tube builders or solely of secretions by the tube builder. A sedimentary tube is most often formed when the organism secretes mucus and attaches particles from the associated sediments either through an active selection or a passive collection process. Tubes can be one to many grains thick. Particle sizes incorporated into a tube influence tube structure such that tube thickness and density can vary 
considerably. Examples of animals that make sedimentary tubes are polychaetes, amphipods, and decapod crustaceans. In other cases, tubes consist only of that material that is secreted by the organism. Such tubes can be rigid and made of calcium carbonate or stiff, but flexible and made of mucus secretions. Examples are calcareous tubes of serpulid polychaetes and bivalve woodborers, and parchment tubes of some chaetopterid polychaetes and deep-sea pogonophorans.

Sedentary organisms that do not create tubes are generally represented by some of the bivalve species. Examples are Mercenaria mercenaria, Mya arenaria, Protothaca staminea, Ensis directus, Scrobicularia plana, Tagelus plebius, and Macoma inquinata. These animals live in sediments with their siphons extended to the surface of the sediments to filter feed from the water column and/or to collect sediments either at or below the sediment surface (Figure 5.1). Frequently, they create a deep burrow into which they can contract if the surface sediments are disturbed. In most cases, bivalves do not often migrate horizontally, usually doing so only when food supply is low (Yonge 1949, Hughes 1969). Macoma balthica, however, has been observed to migrate frequently (Brafield and Newell 1961).

Burrowing animals move through the sediments without establishing permanent or semipermanent tubes. Many of these animals do secrete mucus as they burrow, probably as lubrication for movement and protection from angular sediment particles. These burrows once vacated usually do not last long (i.e., less than a few days). These animals move intermittently, sometimes stopping to feed or defecate for a period of hours before moving on. Examples of these types of organisms are capitellid and orbiniid polychaetes, haustoriid amphipods, and protobranch bivalves. Some burrowing animals have been know to leave the sediment from time to time as a rapid means of avoiding unsuitable conditions and seeking a new location (Dean 1978a,b; Dauer et al. 1980; Brown 1982).

Some organisms live interstitially by moving between the grains of the sediments. Most of these benthic organisms are characterized by having small size and large length-to-width ratios. Many of the interstitial species would be considered meiofauna. They are often found in areas of high concentrations of organic matter (Hummon et al. 1976, Montagna 1984a,b). They are noteworthy in that they can play a role as a source of nutrition for macrofauna; they probably stimulate microorganisms by either disturbing them or feeding on them, and they bioturbate the sediments.

Epifaunal or demersal organisms come in contact with the sediments through either locomotion over or resting on the surface, or through ingestion of sediments during feeding. Species 
that commonly reside on the sediment surface include gastropods, crabs, lobsters, horseshoe crabs, starfish, brittle stars, sand dollars, and bottom fish. These animals tend to rest on the sediment surface when inactive and often disturb the sediment surface while moving. Most of these animals also feed on organisms living in the sediments and/or on the sediments themselves.

As mentioned above, numerous animals that inhabit or live on the sediments are also capable of swimming. Those that emerge from the sediments have been termed "demersal plankton." This phenomenon of emergence has not been studied well, but it is clear from emergence and settling traps, that this behavior occurs on a regular basis in certain subtidal habitats and, in shallow waters, it occurs primarily at night (Dean 1978a,b; Dauer et al. 1980). Such behavior is very important to organisms that need to avoid contaminants and search for more suitable environs. Demersal finfish, of course, are also capable of swimming and move readily over the sediments, although sometimes they do not lift far off the sediment surface while swimming.

\subsection{FEEDING}

\subsubsection{Deposit-Feeding}

As indicated in Table 5.1, organisms that feed on or near the sediment surface are exposed either through their digestive tracts, their external feeding structures, or other parts of the body to sediment particles. Feeding modes and food resources of benthic organisms are germane, therefore, to the issue of contaminant uptake and bioavailability because these modes and resources elucidate the processes through which the digestive tract becomes exposed to sediment-bound contaminants. Further, exposure pathways will be determined, at least in part, by the type of food and the method of food ingestion. Most benthic and demersal animals feed either by deposit-feeding, suspensionfeeding, predation, uptake of dissolved organic matter, herbivory, or omnivory. In this section, the major feeding modes and associated food resources are reviewed.

Deposit-feeding is defined as the ingestion of sedimentary deposits and associated detritus and microorganisms. Numerous definitions for deposit-feeding can be found in the literature. Depositfeeding, in this report, is used in a general sense and encompasses feeding on both sediments and associated matter, organic or inorganic, living or nonliving. In this sense, then, deposit-feeding includes detritivory. Making a finer distinction is not necessary for the purposes of this report. Incidence of the deposit-feeding mode among benthic organisms increases as water depth increases, 
presumably due to the reduction of suspended particles in the water column with increasing depth (Jumars and Fauchald 1977).

Numerous types of food resources exist in sedimentary deposits, the relative nutritional importance of which are not understood well. Of the few complete dietary studies for depositfeeders, most were conducted over short periods of time. Most deposit-feeders pick up sedimentary particles and move them through the digestive tract forming consolidated or unconsolidated feces. These animals often exhibit some degree of selectivity in the size classes of particles that are ingested (Whitlatch 1974, Fenchel et al. 1975, Hylleberg and Gallucci 1975, Cadée 1979, Hauksson 1979, Roberts 1979). The degree of selectivity is not necessarily fixed in all cases and can change over time (Luckenbach et al. 1988). It has been established that fine particles are associated with higher levels of microorganisms (bacteria and diatoms) and of organic matter (Dale 1974). Further, population densities of some species are positively correlated with organic matter in sediments (Longbottom 1970, Newell 1979). Taghon et al. (1979) predicted, therefore, that the preference for smaller particles is associated with a preference for the higher concentrations of organic matter that they contain. This prediction is supported in some cases (Taghon 1982, Petch 1986), but not others (Taghon 1982, Whitlatch 1980).

Particles are selected not only on the basis of grain size, but also on the basis of specific gravity, surface texture, and possible patch size of food (Self and Jumars 1978, Jumars et al. 1982, Robertson and Newell 1982). Selection of food particles may, in some cases, also depend on metabolic state of the organism, dietary history (e.g., ingestive conditioning, c.f. Wood 1968), and available nutritional resources. It is important to note that, in cases where apparent sediment selectivity is indicated, it may not be clear whether the selection reflects choice on the part of the animal or whether the selection results from limitations of the morphology of the animal and the feeding mechanism. Many organisms ingest a certain size range of particles because either they feed at a depth where a particular range of particles exists or the particle sizes these animals ingest are constrained by the feeding apparatus (Whitlatch 1974, Powell 1977, Cadée 1979, Brown 1982). However, size selection does not necessarily have to have morphological correlates (Jumars et al. 1982). In the case of tentaculate deposit-feeders, given initial contact of the tentacle and particle, adhesive strength of mucus will determine the probability of particle retention (Jumars et al. 1982). 
In cases where no size selection is demonstrated, it is often not clear whether the lack of selection is real or a result of small sample sizes and weak tests (Jumars et al. 1982).

Sediments are comprised of a diversity of particle types, only some of which have nutritional value to deposit-feeders. According to George (1964), approximately $10 \%$ to $20 \%$ of the organic matter in sediments is biologically available for feeding. Levinton and Stewart (1988) showed that $0.8 \%$ of the sediment nitrogen, $20 \%$ to $30 \%$ of the detrital nitrogen, $0.2 \%$ of the sediment carbon, and $5 \%$ of the detrital carbon was usable by an oligochaete. Johnson (1974) examined sediments to determine which particles were potential food resources for benthic infauna and which were not. In Johnson's study, in which particles $>5 \mu \mathrm{m}$ were studied, particles that were potential food resources included fungi, pennate and centric diatoms, diatom chains, Ischnia diatoms, algal cells and chains, pollen and spores, organic-mineral aggregates, encrusted mineral particles, fecal pellets and their fragments, plant fragments, chitinous molts and their fragments, nematodes, copepods, ostracodes, nauplius larvae, acoel turbellarians, polychaete larvae, and bivalves. Non-food particles in the sediments were clean mineral aggregates, foraminiferal tests and fragments, spines, spiculates, rods, shells and fragments of molluscs and ostracods, polychaete setae, calcareous polychaete tubes and fragments, capsules, framboids (microscopic aggregates of pyrite grains), and numerous types of diatom and dinoflagellate tests. Since that study, considerable effort has gone into determining the food resources of deposit-feeders. Potential food resources in the sediments can be the following:

a. Detritus (Tenore 1975, 1977a,b, Yingst 1976, Tsuchiya and Kurihara 1979, Tenore and Hanson 1980, Tenore et al. 1984)

b. Bacteria associated with detritus, sediment particles or found interstitially (Zobell and Feltham 1938, Wavre and Brinkhurst 1971, Tsuchiya and Kurihara 1979, Findlay and Tenore 1982, Phillips 1984)

c. Bacterial exudates (Hobbie and Lee 1980, Paerl 1978, Baird and Thistle 1986)

d. Diatoms (Hargrave 1970a, Wetzel 1977, Lopez and Kofoed 1980, Robertson et al. 1980, Jensen and Siegismund 1980, Levinton et al. 1984, Phillips 1984)

e. Blue-green algae (Kofoed 1975, Tsuchiya and Kurihara 1979)

f. Protozoans (Tsuchiya and Kurihara 1979, Phillips 1984, Shimek 1988)

g. Fungi (Morrison and White 1980, Smith et al. 1982)

h. Yeast 
i. Colloidal particles/flocculant aggregates (Johnson 1974, Hauksson 1979, Dauer 1985)

j. Dissolved organic matter (Stephens 1963, 1972, Ferguson 1979, Stewart 1979, Jørgensen and Kristensen 1980).

Bacteria are not expected to be the primary energy sources for macrofaunal detritus feeders because bacteria usually account for only a small fraction of the total organic carbon and nitrogen in sediments (Christian and Wetzel 1978, Rublee 1982). For deposit-feeders, assimilation efficiency of microbes is usually high, ranging between $40 \%$ and $100 \%$ (Cammen 1980a).

\subsubsection{Suspension-Feeding}

Suspension-feeding is of wide-spread occurrence and involves removing food particles from suspension in the overlying or surrounding water column. Reviews of this mode of feeding can be found in Yonge (1928), Jørgensen (1966), and Newell (1979). The large body of literature cannot be reviewed here and, instead, an overview is presented and discussed relative to biodeposition later in the chapter. Many suspension-feeders occur in hard-bottom habitats and are not germane to this discussion. Suspension-feeders of interest are those that occur in or on sediments. Occasional hardbottom dwellers are discussed where relevant.

Until recently, three main mechanisms were used to classify the way suspension-feeding is carried out: (1) mucus-bag feeding, (2) ciliary-mucus feeding, and (3) feeding using setose appendages (e.g., Newell 1979). During feeding, these animals essentially remove particles from the water column and defecate fecal pellets on or in the sediments. During suspension-feeding, bivalves also produce pseudofeces, i.e., particles deposited on the sediments after being filtered from the water and then rejected prior to feeding. This biodeposition process, as it is called, can be important in concentrating particles and contaminants at the sediment surface.

Food resources for suspension-feeders can include some or all of the following: phytoplankton, zooplankton, feces/detritus, humin, microorganisms especially bacteria, plant fragments, and associated bacteria, fungi, colloidal particles, and/or dissolved organic matter (Jørgensen 1966). Resources eaten by a species can be restricted to a few food types or include several. It is possible that the physiological state of the suspension-feeder will influence the food particles taken, while in other cases relatively little selection occurs. The rates of feeding will depend on factors such as the physiological state of the organism, the amount of food in the water column, current flow, and flow characteristics near the organism. The main effect of these activities in terms 
of bioavailability of contaminants is to concentrate particles near, at, or below the sediment surface. This activity can concentrate contaminated particles in the benthic/demersal region. In producing feces and pseudofeces, suspension-feeders transform smaller particles into larger, often more refractory, ones.

Suspension-feeders are found in muddy and sandy benthic environments. Because occurrence of suspension-feeders decreases as depth of water increases (Jumars and Fauchald 1977), biodeposition from suspension-feeding should have less significance in introducing contaminants into the sediments in deeper waters.

\subsubsection{Predation}

For the purposes of this review, predation is of importance not only to the question of bioavailability of contaminants but also to the issue of biomagnification and the real or potential transfer of contaminants from one trophic level to another. While some predators of benthic animals are clean feeders and ingest only the prey item, others are sloppy feeders. During the process of taking prey, "sloppy" predators of benthic animals also ingest variable quantities of sediments that may be contaminated. In determination of biomagnification, the source of the contaminant is important to establishing food-chain transfer. Further, differential digestion rates of different food types (e.g., small soft-bodied prey such as juvenile polychaetes being digested faster than large crustacean prey with exoskeletons or clams with thick shells) can lead to misunderstanding of prey types and food type preferences (Feller et al. 1979).

Predation can take various forms. For instance, some prey are consumed whole, others are only partially consumed and do not survive, and still others are consumed partially and survive. In all cases, the parts of the body consumed will influence the degree of transfer of contaminants. Where predation is incomplete and the prey survive, the "partial predation" can affect the health of the prey and, consequently, its resistance to stresses such as contaminants.

\subsubsection{Uptake of Dissolved Organic Matter}

It has been known for some time that marine organisms have the ability to take up dissolved organic matter (DOM) (Stephens 1963, 1972). They also can assimilate and incorporate it into protein and other pools and release dissolved organic carborn (Stephens 1972, Ferguson 1979, Stewart 1979, Jørgensen and Kristensen 1980). To date, DOM uptake has been observed in the following phyla: Porifera, Cnidaria, Platyhelminthes, Nemertea, Ectoprocta, Annelida, Mollusca, 
Echinodermata, Brachiopoda, Phornoida, Pogonophora, and Hemichordata (Stephens 1972, Stewart 1979, McDermott and Roe 1985). Other phyla such as Arthropoda or Nematoda do not readily take up DOM, apparently due to the impermeability of their exoskeletons or integuments (see for example, Tietjen and Lee 1975, Tempel and Westheide 1980). The issue of DOM uptake is of special interest relative to animals that do not have a digestive tract (e.g., pogonophorans - Southward and Southward 1972, 1982; Southward et al. 1979) or do not feed for a period of time (e.g., larvae during metamorphnsis to adults - Manahan and Crisp 1982). Uptake of DOM has been demonstrated for both epifaunal and infaunal organisms (Stephens 1972, Stewart 1979, Wright 1982).

Soft-bodied marine invertebrates, but not freshwater animals, have the capacity to absorb DOM primarily via epidermal carrier-transport systems. Uptake has been studied primarily using amino acids, but sugars and fatty acids have also received attention (Stewart 1979). Where the effects of sugars on amino-acid uptake, and vice versa, have been studied, results suggest that separate mechanisms exist for the absorption of these two types of substrate. Little information on the interactions between amino acids (or sugars) and fatty acids is available. Further, it appears that separate sites are available for neutral, basic, and acidic amino acids in cnidarians, polychaetes, bivalves, and echinoderms. Definitive kinetic data are only available for the bivalve amino-acid transport system.

DOM of importance to marine animals (sugars, amino acids, and fatty acids) is present in sufficient quantity in interstitial water to be of value to these animals (Southward and Southward 1972, Stephens 1972, Southward et al. 1979). DOM uptake by epidermal tissues of marine invertebrates takes place against considerable concentration gradients. For amino-acid uptake, tissue fluid:medium concentration gradient ratios as high as 2000:1 have been observed. DOM transport is by saturable processes reminiscent of enzyme saturation kinetics.

Because marine environments differ with respect to DOM, analysis of the potential significance of amino acid uptake must consider both the capacity of the organism to accumulate these compounds and the availability of free amino acids in the habitat (Stephens 1972, 1982). Invertebrates inhabiting sediments rich in organic matter seem able to obtain major parts of their energy requirements for body maintenance by uptake of DOM (Jørgensen 1976). Sediment-dwelling polychaetes, such as Clymenella torquata, Nereis diversicolor, and Capitella capitata, can obtain amounts of amino acid from the free amino acids of interstitial water that are comparable to their total respiratory requirements (Stephens 1963, 1972, 1975). The purpose of uptake of DOM could be to maintain 
osmotic balance, for nutrition, or just as a nutritional supplement. In most cases where uptake of DOM has been studied, insufficient information exists to assess its importance to the organism. Much of the work on DOM uptake has measured disappearance of a compound from the water and has not thoroughly examined the role microorganisms play in uptake of DOM. Further work also is necessary to separate uptake by microorganisms from uptake by the animals under study (Tietjen and Lee 1975).

Research questions remain to be answered regarding many aspects of use of DOM by marine invertebrates. The nutritional role of DOM in growth and survival of marine invertebrates is not well established. Such studies have been clouded by lack of information on the microorganisms in the experimental system. This need has led to estimates of the value of DOM based on comparison of oxygen consumption that would be supported by the whole animal (Stewart 1979). The relative nutritional importance of dissolved versus particulate organic matter has yet to be well established for most species. Factors that may affect the importance of DOM also need better definition. Accurate kinetic information is needed on DOM uptake with carefully controlled experiments. Often the uptake of only one substrate has been examined. The presence of other substrates (e.g., contaminants) that might be present in the natural environment should affect uptake rates and the interactions of these different substrates on uptake need to be ascertained.

\subsubsection{Herbivory and Omnivory}

Herbivory is one of the least common modes of feeding among benthic marine organisms. For the purposes of this report, herbivory is ingestion of living algae. It is also recognized that the distinction between living and dead algae is not always clear cut. Herbivory is important in elucidation of transfer of contaminants through food webs. A number of groups can be considered herbivores. Polychaete families that are herbivores include dorvilleids, eunicids, lumbrinerids, onuphids, syllids and paraonids (Fauchald and Jumars 1979). All but the paraonids have jaws. Some gastropod molluscs are also herbivores. Numerous species of sea urchins have been known to feed on algae.

Omnivores are those animals that demonstrate more than one type of feeding behavior (e.g., deposit-feeding and carnivory, deposit-feeding and suspension-feeding, etc.). In some cases, the distinction between two feeding modes is not entirely clear or has not always been made. For example, suspension-feeders will ingest fecal pellets that are very near the bottom or sinking through the water column to the bottom. Nonetheless, the distinction has value in determining pathways of 
nutrients and pollutants through food chains. Omnivory has been demonstrated in numerous cases for a variety of species including commercially important species such as lobsters, crabs, shrimp, and horseshoe crabs, as well as in numerous other species such as snails, clams, amphipods, isopods, and polychaetes.

As more research is conducted on feeding in different benthic organisms, the number of omnivorous species increases, indicating that omnivory is probably quite common. Relatively new techniques, such as the application of immunological methods to food web analysis, have elucidated new and more diverse food pathways (Feller et al. 1979). The use of different feeding modes by animals adds flexibility to ingestion methods and increases the probability of survival under conditions of low food supply. Changes in the environment that alter food supply (e.g., presence or absence of currents) can greatly modify the foraging behavior of surface feeding species such as spionid polychaetes that switch between suspension and deposit-feeding (Taghon et al. 1980, Dauer et al. 1981). Behaviors appearing optimal under one set of envirọmental conditions may be suboptimal under another set (Dauer 1983).

\subsection{BIOTURBATION/BIODEPOSITION}

Bioturbation and biodeposition are important factors relative to contaminants in sediments and influence deposition of these contaminants in a number of ways. This section will review bioturbation and biodeposition, mechanisms through which benthic organisms affect the sediments and their chemical sedimentary properties. Effects of sediment-bound contaminants on benthic organisms, bioaccumulation, and bioavailability will be discussed in Chapters 6 and 7 .

The ultimate fate of contaminants in sediments will depend on chemical reactions, biological effects in mediating those reactions, sedimentation rates, biodeposition/bioturbation and their effects on reconstituting or burying chemicals, and sediment-water exchange (Lee and Swartz 1980, Officer and Lynch 1989). Organisms can influence sedimentary processes in terms of both fluids and particles. Biodeposition can be defined as those biologically mediated processes that cause particles to be deposited from the water column. Bioturbation covers all other biologically mediated processes related to both benthic fluids and particles.

Reviews that provide insight into animal-sediment relations, bioturbation, and sedimentary processes have been written by Fenchel (1969), Bacesu (1971), Schafer (1972), Gray (1974), Rhoads 
(1974), Lee and Swartz (1980), Krantzberg (1982) and McCall and Tevesz (1982). Effects of bioturbation on contaminants in sediments are not well studied.

The effect of benthic organisms on their sedimentary environment depends on their feeding modes, mobility patterns, and other factors related to substrate. Benthic organisms modify sediments primarily through feeding and associated pelletization of sediments, burrowing, excavation, biodeposition, tube-building, and fluid transport. Table 5.2, modified from Lee and Swartz (1980), classifies feeding/mobility guilds and their related sediment-modifying processes. No classification scheme represents every situation and this one is no different. However, it does indicate trends. Some of the species or taxa mentioned in Table 5.2 could be classified in more than one category and the dominant category is given.

\subsubsection{Biodeposition}

Production of feces and pseudofeces by benthic filter-feeders and pelagic feeders adds new material to the sediments by collecting them from the water column. Filter-feeders such as the American oyster, Crassostrea virginica, are capable of removing particles from suspension quite efficiently for certain particle sizes (Havens and Morales-Alamo 1966) and depositing them as feces or pseudofeces at or near the sediment surface. In Cape Cod Bay (Massachusetts), suspension-feeders (e.g., the polychaete, Euchone incolor, the bivalve, Thyasira gouldi, and the amphipod Aeginnia longicornis) transport particles from the water to the sediments (Young and Rhoads 1971). There can be a significant reduction in phytoplankton concentration close to the seabed when suspension-feeders are present (Fréchette et al. 1989). In such cases, the height of the organism above the seafloor may affect the food concentration obtained by the suspension-feeders. Some of these suspension-feeders build tubes and have a secondary effect of stabilizing the sediments. Frithsen and Doering (1986) demonstrated that enhanced particle removal from the water column by tentaculate benthic polychaetes was due to activities of the polychaete, not just to the presence of tube structures projecting into the benthic boundary layer. Within ranges of food concentrations, suspension-feeding bivalves are capable of regulating the amount of food they ingest by modifying either filtration rate or pseudofeces production rate (Foster-Smith 1975). Where food concentration is low, pseudofeces production is low and as food concentration increases, generation of pseudofeces increases. In general, filtration rate increases with food concentration until some point when filtration of particles drops off, often dramatically. 
Limited information is available on the degree to which contaminants are concentrated and deposited on the bottom from the water column by benthic or pelagic feeders. Small and Fowler (1973) indicate that deposition of feces by Metanyctiphanes norvegica represents a major route for deposition of zinc to the bottom of the Ligurian Sea. Because feces often contain concentrations of fine particles and organic material, biodeposition may represent a source of energy to the benthic environment (Hibbert 1977). Feces also may be a vehicle for concentrating metals or organic pollutants on the bottom (Faust 1977; Lee and Swartz 1980). Annually, the bivalve, Geukensia demissa, contributes $71.9 \mathrm{mg} / \mathrm{m}^{2}$ of $\mathrm{Mn}, 1.8 \mathrm{mg} / \mathrm{m}^{2}$ of $\mathrm{Cu}$, and $22.9 \mathrm{mg} / \mathrm{m}^{2}$ of $\mathrm{Zn}$ to a salt marsh in Georgia (Kraeuter 1976), some of which may be recycled within the system rather than newly deposited. In contrast, the clam, Polymesoda caroliniana, from the same marsh contributes 0.4 $\mathrm{mg} / \mathrm{m}^{2}$ of $\mathrm{Mn}, 0.007 \mathrm{mg} / \mathrm{m}^{2}$ of $\mathrm{Cu}$, and $0.04 \mathrm{mg} / \mathrm{m}^{2}$ of $\mathrm{Zn}$ (Kraeuter 1976).

Organic biodeposits in sediments can also be comprised of hard parts of organisms such as calcite and opal which are precipitated by free floating plankton. Calcite is formed by coccoliths and forams and opal by diatoms and radiolarians. The distribution of calcite and opal in the ocean's sediments is not uniform (Figure 5.2) and depends on the distribution of the organisms that form them as well as other physical and chemical characteristics.

\subsubsection{Bioturbation}

\subsubsection{Particle Effects - Feeding}

Table 5.2 indicates that organisms in different feeding-mobility modes have substantially different effects on sediments. Feeding activities of most species affect the sediment surface by making it more topographically heterogeneous. Animals that ingest sediments and defecate on the surface can change the sediment grain size of the sediments if they are selective feeders (Rhoads 1974, Fenchel et al. 1975, Hylleberg and Galluci 1975, Bender and Davis 1984) and produce fecal mounds that increase topographic variability of the surface (Rhoads 1967, Rhoads and Young 1970; Rhoads and Young 1971, Cadee 1976, Kudenov 1982, Young et al. 1985). Topography can also be changed by funnel-feeders that, through pulling sediments down to their subsurface feeding areas, create pits or funnels at the sediment surface (Hylleberg and Gallucci 1975, Cadée 1976, Myers 1977b, Powell 1977, Hylleberg and Henriksen 1980). High densities of Clymenella torquata produce a local "spongy terrain through an increase in porosity" due to their feeding activities (Featherstone and Risk 1977). At these high densities, ripples are prevented from forming by the high sediment turnover of the worms. Feeding activities of subsurface deposit-feeders can create cavities and 
tunnels below the sediment surface (e.g., some polychaetes, some holothurians, or some sea urchins). Such activities enhance exchange of surface waters with subsurface sediments and can affect the chemical milieu. Many forms of mucus secretions are left in the sediments by marine animals which can affect the texture of the sediment and attract microorganisms (Riemann and Schrage 1978, Reise 1983). Egested sediments can be produced in disaggregated forms (Powell 1977, Brown 1982, Kudenov 1982) or as fecal pellets that are either small discrete units [e.g., as in capitellids (Cadée 1979, Forbes and Lopez 1987), hydrobids (Levinton and Lopez 1977), Amphitrite (Aller and Yingst 1978)] or loosely aggregated sediments [e.g., as in arenicolids (Cadée 1976, Hylleberg and Henriksen 1980) or in pseudofeces of bivalves such as Nucula, Macoma, Yoldia (Lee and Swartz 1980)]. Depending on the species, these feces can be deposited below or at the sediment surface or, in some cases, ejected into the water column.

Bottom-feeding marine mammals feed on benthic organisms and through these feeding activities can signicantly change the sediment surface. Gray whales (Eschrichtius robustus) excavate benthic prey by suction (Oliver et al. 1984), walruses (Odobenus rosmarus) by jetting water and rooting with their snouts and vibrissae (Oliver et al. 1983), and sea otters by digging with their forelimbs (Kvitek and Oliver 1987). Some of these excavations are large enough to be readily visible on side-scan sonor (Oliver and Kvitek 1984, Kvitek and Oliver 1986).

Sediment turnover rates have been calculated by numerous authors for several species that feed on sediments. Different methods of data collection and units for expressing turnover make comparisons among species difficult. However, three reviews have made reasonable attempts at comparing these different methods (Hargrave 1972, Powell 1977, Lee and Swartz 1980). These calculations show that the upper 15 to $20 \mathrm{~cm}$ of sediment can be turned over several times per year in shallow subtidal and intertidal regions. Temperature affects reworking rates and, in temperate regions, turnover rates will vary seasonally (Rhoads 1963, Gordon 1966, Rhoads 1974, Powell 1977, Cadée 1979, Dobbs 1983, Nicolaidou 1988). Many of the estimates of turnover represent sediments deposited only on the sediment surface by the species studied, even when these species also may be able to egest feces below the sediment surface. This phenomenon has not been well studied and it is conceivable that groups such as burrowing deposit-feeders (e.g., orbiniids or nereids) may use this method of defecation. Examples of species that feed at the surface and defecate below the surface are polychaetes, Polycirrus eximius, Scolelepis squamata, and Tharyx acutus (Cadée 1979). Powell (1977) demonstrated that the funnel-feeder, Leptosynapta tenuis, fed below the sediment surface and 
defecated below and on the sediment surface. In field studies, sediment reworking by feeding should be distinguished from reworking by physical processes. Grant (1983) has shown that the reworking by Saccoglossus kowalevskii which produces impressive fecal mounds constitutes $<1 \%$ of the amount reworked by physical processes. At the same site, reworking by the small polychaete, Paraonis fulgens, was up to $33 \%$ of physical reworking.

Some deposit-feeders have a demonstrated or inferred ability to remove organic matter associated with sediments as it passes through their digestive tracts (Gordon 1966, George 1964, Cadée 1976). The relationship between uptake of organic matter and that of organic contaminants has not been well explored. Further, this ability to remove organic matter from sediments is not always exhibited (Zeitzschel 1980) and the ubiquity and impact of this activity remain to be shown. Uptake and bioavailability of contaminants by marine organisms in sediments will be discussed in greater detail in Chapters 6 and 7.

\subsubsection{Particle Effects - Burrowing}

Organisms that burrow through the sediments (Table 5.2) use a variety of techniques to do so. Trueman (1975) provides details on the mechanisms that these organisms use. Mucus is produced as a lubricating agent to ease movement of the organism through the sediments and to protect soft-bodied organisms from sediments. Burrowing can result in different effects on the sediments, depending on the mechanics of burrowing. Several species move through the sediments simply by pushing them aside using relatively little mucus for lining and lubricating the burrow during locomotion (e.g., Scoloplos, Nephtys, Paraonis, Mercenaria, Yoldia, Nucula, Acanthohaustorius, Pseudohaustorius). These organisms create voids in the sediment that can result in changes in chemical properties, sediment water content, critical erosion velocities, overlying turbidity and depth of oxygenated layer of the sediments (Rhoads and Young 1970, 1971, Rhoads 1974, Grant et al. 1982, Rhoads and Boyer 1982, Bender and Davis 1984). These voids also decrease the compaction of the sediments and, hence, the stability of the sediments (Rhoads 1974, Myers 1977a, Lee and Swartz 1980, Aller 1982). Cadé (1976) noted that the presence of slow-moving, funnel-feeding arenicolids did not increase the water content of the sediments at the surface, but did increase water content at the bottom of the burrow in the feeding funnel. Burrows of some organisms can extend deep into the sediments even though the animals feed and defecate on the surface (Myers 1977b, Brown 1982, Meadows and Tait 1989). In such cases, oxygenated surface waters are brought from the sediment surface to deeper layers causing changes in the chemical milieu. Bioturbation by the burrower, Nereis virens, resulted 
in a marked increase in sediment uptake of glycine (Jørgensen et al. 1980). Mucus-lined burrows affect sediment permeability, water content and shear stress. Increasing density of Corophium volutator and Nereis diversicolor results in decreased water content and increased shear strength (Meadows and Tait 1989). Due to differences in tube structures between the two species, sediment permeability increases with increasing density of $N$. diversicolor, but decreases with increasing density of $C$. volutator. In addition, Meadows and Tufail (1986) demonstrated in laboratory studies that microorganisms also can reduce the permeability of intertidal sands.

The introduction of oxygenated water with depth in the sediment changes chemical equilibrium between compounds in the sediments and pore waters (Aller and Yingst 1978). Burrows can, in this way, also act to bring buried contaminants to the surface through their release from deep sediments followed by flushing to the surface (Lee and Swartz 1980). Tubificid oligochaetes burrow and deposit feed on sediments. The tubificid, Limnodrilus hoffmeisteri, caused a significant loss of inorganic mercury and methylmercury from contaminated sediments in a three-week period (Boddington et al. 1979). In this case, clearance rate of mercury depended linearly on worm density.

\subsubsection{Pariticle Effects - Excavation}

Numerous species found in the shallow subtidal and the intertidal region are considered excavators, i.e., they make holes or cavities by digging into or hollowing out sediments. These activities can cause destabilization of the sediments and result in surface scouring. As indicated in Table 5.2, not many of the feeding-mobility groups include excavators. In salt marsh systems, fiddler crabs, Uca, are notorious excavators that produce large burrows continuously by digging sediments and placing them on the surface. Uca burrow to depths of $50 \mathrm{~cm}$ in the sediments. The crab, Sesarma catenata, builds burrows to a depth of about $11 \mathrm{~cm}$ (Malen et al. 1988). Ghost shrimp, Callianassa and Upogebia, are also recognized as expert excavators and can work to depths of up to 1 to $2 \mathrm{~m}$ below the sediment surface (Aller and Dodge 1974, Pemberton et al. 1976, Roberts et al. 1981, Suchanek 1983). Species in genera such as Limulus, Ilyanassa, Polinices, Ocypode, and Leptosynapta dramatically impact the sediment surface through digging in or movement over the surface (Rhoads 1967, Monahan 1980, Wiltse 1980). Sting rays have been shown to excavate depressions in the sediments that are over $1 \mathrm{~m}$ in diameter and $30 \mathrm{~cm}$ in depth (Cook 1971, Howard et al. 1977). On a North Carolina tidal flat, $30 \%$ of the sediment surface was covered with sting ray pits during July (Grant 1983). Only a few new ray pits appeared each day. Despite the dramatic appearance of these pits, on a volumetric and areal basis, sediment reworking by rays amounted to 
$<1 \%$ of that amount reworked by physical processes. Bottom-feeding marine mammals (e.g., gray whales and walruses) can significantly disturb bottom sediments in their feeding activities (Oliver and Kvitek 1984, Oliver and Slattery 1985, Kvitek and Oliver 1986, 1987).

Sedimentation studies using radiotracers have been used to demonstrate bio-mediated transport and redistribution of sediments and, hence, associated contaminants (Benninger et al. 1979). Using ${ }^{210} \mathrm{~Pb},{ }^{137} \mathrm{Ce}$, and ${ }^{7} \mathrm{Be}$, Sharma et al. (1987) demonstrated that nuclides were an order of magnitude higher on creekbinks than in back-marsh areas due to intense burrowing of fiddler crabs on creekbanks. Tubificid oligochaetes through feeding at depth and excreting on the sediment surface redistribute the nuclide ${ }^{137} \mathrm{Ce}$ (Robbins et al. 1979).

\subsubsection{Particle Effects - Pelletization}

The process of pelletization is almost ubiquitous in all the feeding-mobility groups (Table 5.2). Pelletization affects sediments in a number of ways. For one, contaminants can be concentrated in fecal pellets due to selection by deposit-feeders for smaller particles on which contaminants tend to adsorb (Aller 1982). Hence, fecal pellet production can result in layering of contaminants in instances of selective feeding. Packets of contaminants in the form of fecal pellets can be transported to the sediment surface where they can be transported elsewhere by currents or released in situ. Conversely, packets of contaminants can be transported to depth in the sediment and buried, temporarily or permanently. Fecal pellet surfaces behave chemically in a manner similar to the sediment/water interface or the lining of burrows in that the external surfaces are more oxidized than the interior sediments (Aller 1982) (Figure 5.3).

The abundance of fecal pellets in an environment depends on the balance between their production and their breakdown. Fecal pellet breakdown will depend upon the hydrodynamic energy regime of the habitat, the amount of mucus in the pellet and the degree of microbial breakdown. Fecal pellet breakdown rates vary among species (Cadée 1979). The potential for fecal pellet production in muddy environments (e.g., tidalflats and marshes) probably is higher than in sandy environments because wave energy and currents are usually lower in these habitats and the number of deposit-feeders and/or epifaunal filter-feeders is higher. In sandy environments, higher wave energy prevents pellets from remaining in place or intact and, fewer species are present in these habitats that produce discrete, cohesive fecal pellets. Further, fecal pellets break up more easily in the presence of sand than without it (Cadée 1979). 
Making fecal pellets of fine particles into sand-sized particles creates particles of effective larger size. Consequently, parameters such as porosity and water content of sediments increase, which in turn increase the erodibility and permeability of the sediments (Lee and Swartz 1980).

\subsubsection{Particle Effects - Tube Building}

Tubes built by infaunal populations traditionally are considered to have a stabilizing effect on sediments in large part because they bind sediments together and act as reinforcing rods (Mills 1967, Neumann et al. 1970, Rhoads et al. 1978). Examples of such infaunal populations are the polychaete, Owenia fusiformis (Fager 1964), and the polychaete, Heteromastus filiformis (Rhoads et al. 1978). Some suspension-feeders (e.g., Euchone incolor) cohabit sediments with deposit-feeders and counter the sediment destabizing effects of the deposit-feeders by building tubes that bind and stabilize sediments (Rhoads and Young 1971). When present, the polychaete, Spiophanes wigleyi, can incorporate up to $50 \%$ of the upper $5 \mathrm{~cm}$ of sediment into tubes (Featherstone and Risk 1977). Many species have been shown to tightly bind sediments into their tubes [Diopatra cuprea (Myers 1972), sabellids (Fitzsimons 1965), Cerianthus (Rowe 1974), Amphitrite ornata (Aller and Yingst 1978)], but the effects of tube-building on sediments are not entirely clear (Lee and Swartz 1980). Some tubes are thought to alter hydrodynamics near the sediment-water interface, allowing particles to settle (Rhoads and Boyer 1982). In other cases, tubes projecting into the benthic boundary layer are thought to enhance particle resuspension (Carey 1983). Tube density, height, and diameter affect whether tubes increase or decrease susceptibility of sediments to erosion by changing turbulent flow over the sediment surface (Eckman et al. 1981). According to Rhoads et al. (1978), four mechanisms may work to increase critical erosional velocities caused by the addition of Heteromastus:

1) vertical tubes may reduce bioturbation by acting as barrier to burrowing forms

2) Heteromastus may have stimulated microbial mucus production and binding of sediments

3) feeding activities may have changed particle size and tubes or feeding may have bound the sediments

4) tube tops may have acted as point of flow detachment.

Rhoads et al. (1978) did demonstrate that tube tops acted as points of flow detachment (\#4 above), but did not provide evidence for the first three mechanisms. Woodin (1974) hypothesized that tubebuilders prevent settling and burrowing of mobile infaunal organisms. Eckman et al. (1981) conducted flume studies that indicated the sediment bed is destabilized by the presence of tubes at all 
densities tested. They suggested that other factors (mucus binding by animals, diatoms, and/or bacteria) explain the contradiction with the traditional viewpoint of stabilization by tubes.

\subsubsection{Fluid Transport}

Most of the effects discussed in the preceding sections dealt with particle transport. Fluid transport may also occur and may be of greater importance than particle transport in controlling distribution and flux of dissolved compounds (Lee and Swartz 1980 and Aller 1978). However, biogenic influences on fluid transport have received far less attention than particle transport. Molecules that might be involved with fluid transport include $\mathrm{O}_{2}, \mathrm{H}_{2} \mathrm{~S}$, nutrients, trace metals, and dissolved organics. If the biogenic diffusion coefficient is greater than the molecular diffusion coefficient, then biologic fluid transport activities will signficantly modify pore water distribution and flux rates of dissolved compounds.

Biological activities that result in fluid transport include burrowing by mobile fauna and irrigation of tubes and burrows by mobile and sedentary fauna. Available data indicate that irrigation is two to three orders of magnitude more important than burrowing in tranporting fluid (Mangum 1964, Rhoads 1967, Renfro 1973, and Foster Smith 1978). The effect of this irrigation will depend on the permeability of the tubes which can vary considerably.

While numerous authors have studied irrigation rates of infaunal species (see Lee and Swartz 1980, for a review), few have examined the influence of irrigation and burrowing on fluid transport of contaminants in the sediments. However, preliminary data indicate that burrowing and irrigation contributed to the degradation of oil in sediments (Gordon et al. 1973) and release of heavy metals into interstitial waters and from sediments (Renfro 1973; Bryan 1976). Burrowing by the polychaete, Nereis succinea, increased the effective surface area of the sediments and the diffusion of arsenic from the sediments by a factor of five (Riedel et al. 1987). N. succinea increased their body burden of arsenic by a factor of 4.6 over a 9-d period, after which no further increase occurred. $N$. succinea is not considered an important resevoir of arsenic, but is considered extremely important in mobilization of arsenic (Riedel et al. 1987).

Benthic organisms have been shown to enhance diffusive fluxes and oxygenation of the sediment (Rhoads 1974, McCaffrey et al. 1980, Aller et al. 1983). These animals also increase the porewater and water column concentrations of $\mathrm{NH}_{4}+$ due to excretion (Henriksen et al. 1980 , Kristensen et al. 1985). Regnault et al. (1988) recently examined the relative importance of benthic 
macrofauna and turbulence on the $\mathrm{NO}_{4}{ }^{+}$and $\mathrm{NO}_{3}{ }^{-}$fluxes at the sediment-water interface of an oyster bed. In the presence of macrofauna, $\mathrm{NH}_{4}{ }^{+}$in the water column and porewater increased. $\mathrm{NH}_{4}{ }^{+}$fluxes at this interface were one (winter) or two (summer) orders of magnitude higher than without them. When turbulence was simulated, content of $\mathrm{NH}_{4}{ }^{+}$in the water column increased markedly while that in the porewater decreased. $\mathrm{NO}_{3}{ }^{+}$content of the water column and porewater was not markedly modified by either turbulence or macrofauna. Riedel et al. (1987) suggest that physical resuspension can have a marked impact on flux rates at the sediment-water interface, but is not believed to be as important as impacts of benthic biota on flux rates because biological activity is continuous whereas physical resuspension is periodic. It seems the relative degree of impact of physical and biological processes will depend on the specific habitat and associated organisms that occupy that habitat.

\subsection{SEAGRASSES}

\subsubsection{Introduction}

Seagrasses are found throughout the world in shallow coastal waters. There are about 45 species of seagrasses belonging to two families. The family Potamogetonaceae has the greater diversity with 12 genera and 34 species. The family Hydrocharitaceae has but three genera and 11 species. Pollination occurs in most species underwater. Most species can tolerate only brief intertidal exposure. The mode of reproduction of seagrasses and their dependence on submergence separate them from the various high intertidal species of salt marshes [e.g., Spartina (cordgrasses), Salicornia (glassworts)]. In this review, the strict definition of seagrasses is adopted and all vascular plants other than those belonging to the Hydrocharitaceae and Potamogetonaceae are excluded.

A seagrass plant consists of an above-ground portion of leaves and seasonally flowers and a below ground portion of roots and rhizomes (Figure 3.15). The leaves are the major photosynthetic organs as well as the site of direct nutrient uptake from the seawater (McRoy and Barsdate 1970). The roots are the major site of nutrient uptake. The rhizomes are a means of vegetative propagation.

Seagrasses have major influences on nearshore marine communities. Seagrasses have a high growth rate, averaging 300 to $600 \mathrm{gm} \mathrm{dry} \mathrm{wt} / \mathrm{m}^{2} / \mathrm{yr}$ (Phillips 1979). This rate of production exceeds that of corn, rice and hayfields. Seagrasses are nurseries for a variety of fish and invertebrates, providing refuge for more vulnerable juvenile organisms. Although some turtles, fish, manatees, echinoids and gastropods eat seagrasses, most of seagrass seems to be cycled through the detritus food 
chain (Phillips 1979). Seagrasses do support large numbers of epiphytic organisms, with a total biomass approaching that of the plants themselves; a variety of invertebrate grazers depend on these epiphytes but do not remove seagrass biomass (Phillips 1979). As discussed below, seagrasses also have major effects on sedimentation and currents in marine inshore environments.

\subsubsection{Interactions Between Seagrasses and Marine Sediments}

The sediment characteristics of the sea bottom are determined in large part by the ambient water currents. In areas of high flow, smaller sediment particles will be carried away by those currents before deposition occurs. In slower currents, fine particles may settle onto the bottom. One expects a positive relationship between the strength of the currents and the average size of the sediment particles of the local bottom (Phillips 1979). Because seagrass meadows extend above the bottom, a decrease in flow through the bed is predicted which should result in finer sediments within seagrass meadows relative to adjacent unvegetated areas. As discussed below, many but not all of the available data fit this prediction.

The best analysis of the effects of seagrasses on ambient flow was based on laboratory work in a salt water flume. Bending of the shoot canopy is a mechanism for the re-direction of current flow and within-canopy reduction of current velocity. When bent over in flow, the blades of the seagrass intermesh to form a dense layer that redirects water over and under that layer, lowering current velocity below the intermeshed leaves but increasing velocity above the canopy.

Table 3.4 presents data comparing the sediment distribution within seagrass meadows to that of unvegetated bottoms. Although it is difficult to find adjacent seagrass meadows and unvegetated flats that differ only in the presence/absence of vegetation, the data in Table 3.4 suggest that the baffling effect of seagrasses is sufficient to slow flow sufficiently to allow increased deposition of fine sediments. Scoffin (1970) measured flow in and out of turtlegrass (Thalassia testudinum) meadows, finding that currents of $30 \mathrm{~cm} / \mathrm{sec}$ over unvegetated sediment were reduced to zero within the meadow. Harlin et al. (1981) showed that currents of 8 to $14 \mathrm{~cm} / \mathrm{sec}$ adjacent to eelgrass (Zostera marina) beds also fell to zero within the eelgrass beds.

The accumulation of fine sediments within seagrass meadows is not strictly a function of the baffling effect of the above-ground portion of the seagrasses on ambient flow. The roots and rhizomes of seagrasses effectively stabilize the sediments, inhibiting their removal by high currents such as those produced by storms. The effectiveness of seagrasses as sediment stabilizers is realized 
by considering that sand banks, formerly covered by Zostera marina in Great Britain, were lowered by $30 \mathrm{~cm}$ almost overnight after the plants disappeared in 1931. Fonseca et al. (1983) analyzed the sediment trapping characteristics of seagrasses and concluded that in low current regimes $(<90$ $\mathrm{cm} / \mathrm{sec}$ ), seagrass meadows function as sinks for fine sediments and organic matter, while in high current regimes, they function as sources of these materials.

In summary, from theoretical laboratory work and empirical field data, it is clear that seagrasses have greater per zentages of fine sediment particles (silts and clays) than adjacent unvegetated sediments. This increase in fines is a result of both the baffling of water currents by the canopy of the seagrasses and increased stability of the deposited fines by the below-ground portion of the seagrasses (roots and rhizomes). 
TABLE 5.1. Animal types, Body Forms, and Areas of Uptake or Interaction with the Sediments.

Taxa

NEMERTEA

ANNELIDA

MOLLUSCA

Scaphopoda

Bivalvia

Gastropoda

ARTHROPODA

Crustacea

SIPUNCULA

ECHIURA

POGONOPHORA

PHORONIDA

ECHINODERMATA

Asteroidea

Ophoiuroidea

Holothuroidea

Echinoidea

digestive tract

HEMICHORDATA
VERTEBRATA
Osteichthyes

Body Type

Soft-bodied

Soft-bodied

Shelled

Shelled

Shelled

Exoskeletal

Soft-bodied

Soft-bodied

Soft-bodied

Soft-bodied

Densely Spicular

Densely Spicular

Loosely Spicular

Articulated

Soft-bodied

Soft-bodied
Areas of Uptake or Interaction

Epidermis, digestive tract

Epidermis, digestive tract, gills

Mantle, foot, other exposed epidermis, digestive tract Mantle, foot, other exposed epidermis, siphons, gills, palps, digestive tract

Mantle, foot, other exposed epidermis, gills, digestive tract

Gills, digestive tract

Epidermis, tentacles, digestive traci

Epidermis, proboscidial surface, digestive tract, anal sacs

Epidermis, tentacles

Epidermis, tentacles, digestive tract

Water vascular system, digestive tract

Water vascular system, digestive tract

Epidermis, water vascular system, digestive tract, tentacles, cloaca

Water vascular system, peristomial Plates membrane

Epidermis, digestive tract, gills, pharyngeal clefts

Epidermis, gills, digestive tract 
TABLE 5.2. Feeding/Mobility Classifications and Associated Sediment Modifying Processes (Modified from Lee and Swartz, 1980) $(0=$ process of no or minor importance in modifying sediment, $+=$ process of moderate importance in modifying sediment, $++=$ process of high importance in modifying sediment).

Classification

$\begin{array}{cl}\begin{array}{c}\text { Representative } \\ \text { Taxa }\end{array} & \text { Feeding } \\ \text { Zone }\end{array}$

SUSPENSION FEEDERS

Filter Feeders

Mobile Infaunal

Stationary Infaunal

Stationary Epifaunal

Raptorial Feeders

in DEPOSIT-FEEDERS

Surface Deposit-Feeder

Mobile Infaunal-Vagile

Mobile Infaunal-Excavator

Stationary Infaunal

Mobile Epifaunal

Subsurface Deposit-Feeder

Mobile Infaunal-Vagile

Mobile Infaunal-Excavator

Funnel-feeders

Conveyor-belt species

$\begin{array}{ll}\text { Mya, Mercenaria } & \begin{array}{l}\text { Bottom few cm } \\ \text { of water column } \\ \text { Bottom few cm } \\ \text { sabellids }\end{array} \\ \begin{array}{l}\text { of water column } \\ \text { Brassostrea }\end{array} & \begin{array}{l}\text { Bottom to sevl } \\ \text { m into water }\end{array} \\ \text { Mytilus } & \text { column } \\ \text { cerianthids } & \text { Bottom to sevl } \\ & m \text { into water col. }\end{array}$

\begin{tabular}{cccc} 
& Processes \\
\hline Feeding Burrowing Excavation Biodeposition Pelletization & Tubes Transport
\end{tabular}

$\begin{array}{lllllll}0 & + & + & + & + & 0 & ++ \\ 0 & 0 & 0 & + & + & + & + \\ 0 & 0 & 0 & + & 0 & 0 \\ 0 & 0 & 0 & 0 & + & +\end{array}$

$m$ into water col.

\begin{tabular}{|c|c|c|c|c|c|c|c|c|c|}
\hline Mobile Infaunal-Vagile & Bivglyes nereids & $0-1 \mathrm{~cm}$ of sedmet & 1 & + & 0 & 0. & \pm & $0+1$ & + \\
\hline Mobile Infaunal-Excavator & $U_{c a}$ & $0-1 \mathrm{~cm}$ of sedmnt & ++ & 0 & $+t$ & 0 & $+t$ & 0 & $+t$ \\
\hline Stationary Infaunal & $\begin{array}{l}\text { spionids } \\
\text { onuphids }\end{array}$ & $0-1 \mathrm{~cm}$ of sedmnt & + & $\mathbf{0}$ & 0 & $0-+$ & + & + & + \\
\hline Mobile Epifaunal & $\begin{array}{l}\text { Amphitrite } \\
\text { holothurians }\end{array}$ & $0-3 \mathrm{~cm}$ of sedmnt & $t-t+$ & + & + & 0 & $+t$ & $\mathbf{0}$ & 0 \\
\hline \multicolumn{10}{|l|}{ Subsurface Deposit-Feeder } \\
\hline Mobile Infaunal-Vagile & $\begin{array}{l}\text { Yoldia, Nucula } \\
\text { Scoloplos } \\
\text { Nephtys }\end{array}$ & $\begin{array}{l}0-\geq 20 \mathrm{~cm} \text { of } \\
\text { sediment }\end{array}$ & + & ++ & $\mathbf{0}$ & 0 & $0-++$ & $\mathbf{0}$ & ++ \\
\hline Mobile Infaunal-Excavator & $\begin{array}{l}\text { Callianassa } \\
\text { Upogebia }\end{array}$ & $0->$ Im of sedmnt & $+t$ & 0 & ++ & $0-+$ & $t-t+$ & $\mathbf{0}$ & ++ \\
\hline Funnel-feeders & $\begin{array}{l}\text { Leptosynapta } \\
\text { arenicolids } \\
\text { Balanoglossus }\end{array}$ & $\begin{array}{l}\text { Predominantly } \\
\text { upper } 0-1 \mathrm{~cm} \text {, } \\
\text { down }>10 \mathrm{~cm}\end{array}$ & ++ & + & 0 & $\mathbf{0}$ & $\mathbf{0}$ & $\mathbf{0}$ & ++ \\
\hline Conveyor-belt species & $\begin{array}{l}\text { Pectinaria } \\
\text { Clymenella } \\
\text { Molpadia }\end{array}$ & $\begin{array}{l}\text { Deeper sediment } \\
3-30 \mathrm{~cm}\end{array}$ & $t-t+$ & $\mathbf{0}$ & $\mathbf{0}$ & $\mathbf{0}$ & $+?$ & + & $+-t+$ \\
\hline
\end{tabular}

Molpadia

$0-1 \mathrm{~cm}$ of sedmnt

$0-1 \mathrm{~cm}$ of sedmn

$-1 \mathrm{~cm}$ of sedmnt

$+$ 


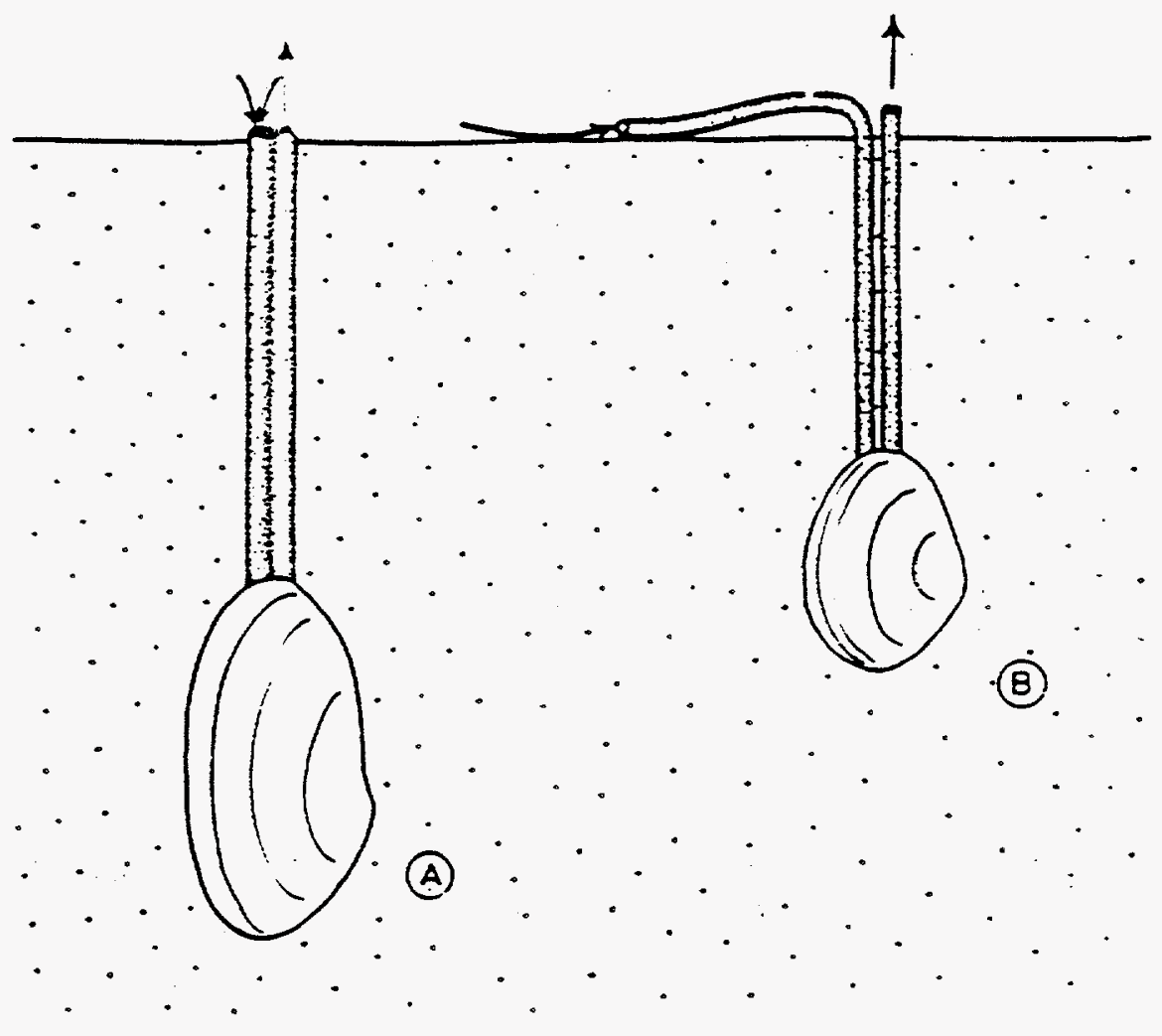

FIGURE 5.1. Use of Siphons in Feeding by Bivalves. A - suspension-feeder Mya arenaria with fused siphons, B = deposit-feeder Scrobicularia plana with seperate siphons. Arrows indicate inhalent and exhalent siphons. 

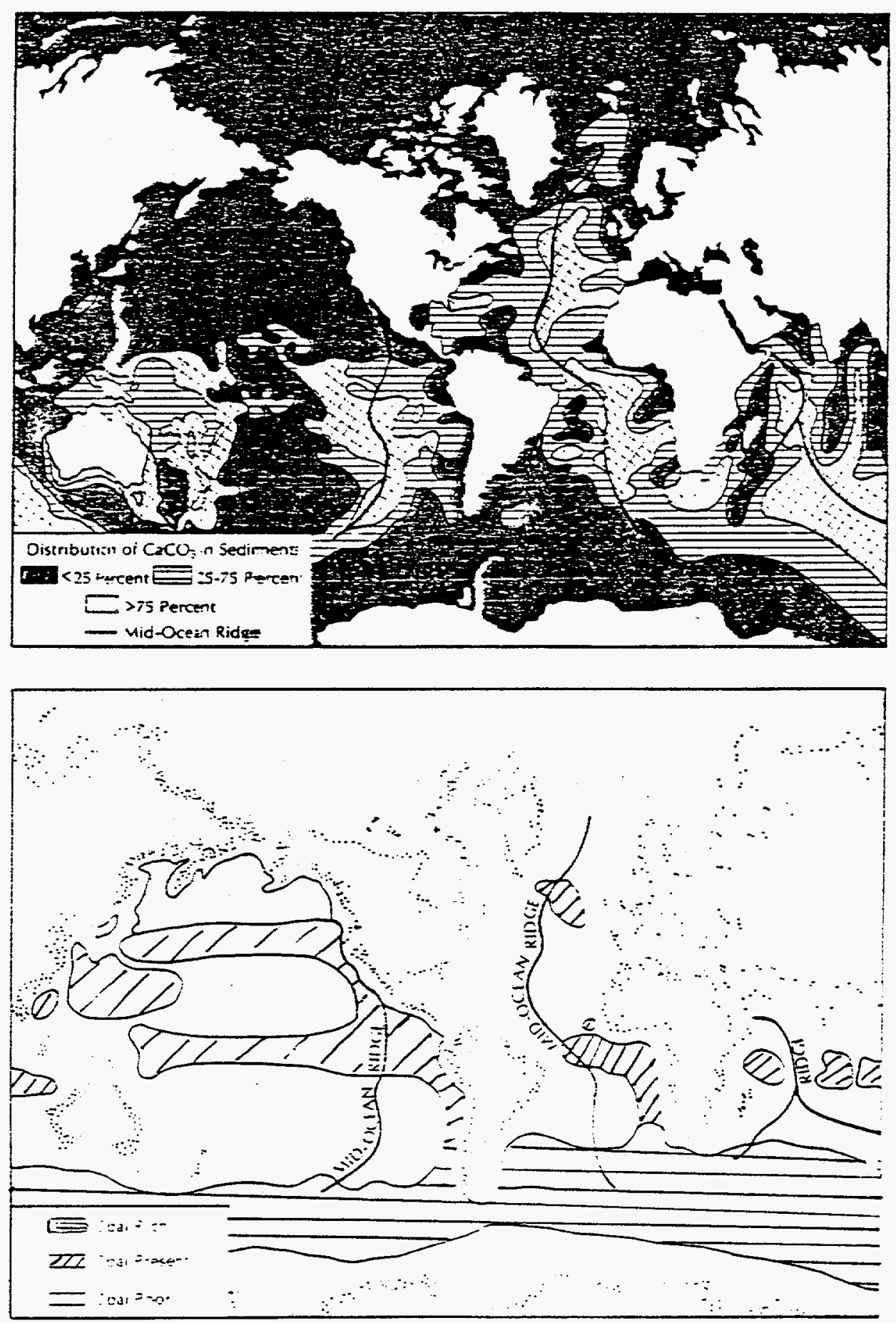

FIGURE 5.2. Distribution of Clacite (A) and Opal (B) Through Out the World's Oceans 


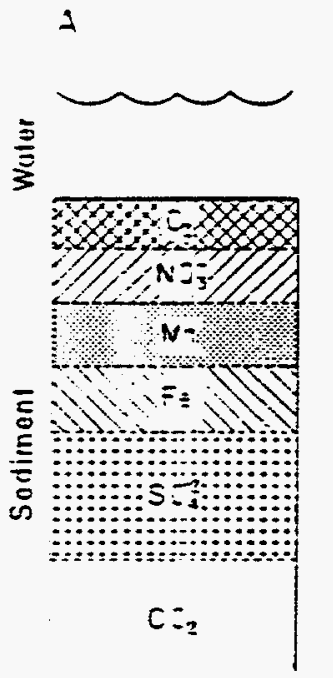

$\equiv$
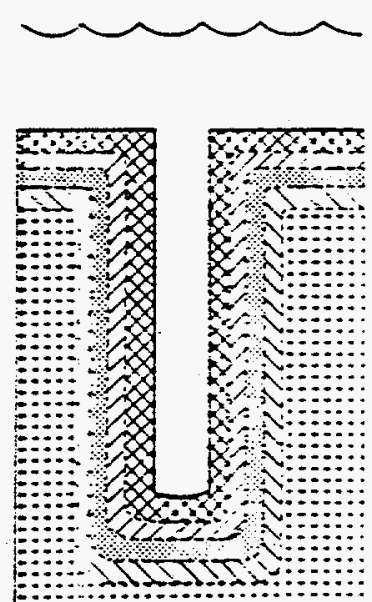

C
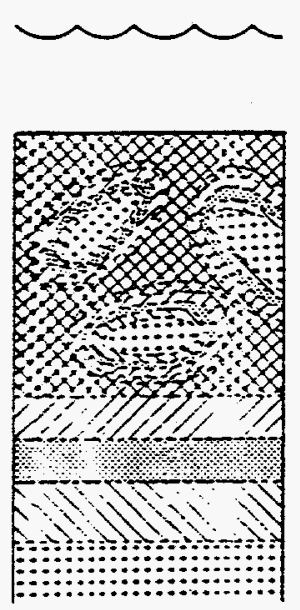

FIGURE 5.3. Zonation of Electron Acceptor Use in Sediments. $A=$ Classic vertical zonation, $B=$ Reaction zonation around irrigated burrow microenvironment, $\mathrm{C}=$ reaction zonation around fecal pellet microenvironment. 


\subsection{BIOACCUMULATION AND BIOAVAILABILITY OF SEDIMENT-BOUND METALS}

\subsection{INTRODUCTION}

As discussed in Chapters 2 and 3, numerous factors affect partitioning of metals in sediments in the marine environment. The biological importance of sediment-bound metals is complex and poorly understood. Bioaccumulation of metals by marine animals is influenced by numerous physical, chemical, and biological factors that need characterization. Metals in an aquatic environment may exist in dissolved or particulate forms (Duncan 1984, Campbell et al. 1988). Unfortunately, no current method exists for determining unambiguously the partitioning of particulate metals in natural sediments (Tessier and Campbell 1987). This empirical difficulty complicates understanding bioavailability of metals. Luoma (1985) stated, "It must be re-emphasized that our knowledge of metal bioavailability from sediments is, at best, fragmentary. Definitive studies ... have been conducted by only a few research groups, consider only a few species, and nearly all have been conducted in estuaries. Nearly all conclusions rest upon statistical evidence which has not yet been mechanistically clarified by definitive laboratory studies."

Approximately 15 to 18 metals are of interest because of their role as micronutrients (e.g., iron, copper, zinc, manganese, cobalt, molybdenum) (Engel et al. 1981). At least 50 metalloenzymes, enzymes which incorporate metal atoms into their normal structure have been identified (Duncan 1984). Some metals (e.g., copper and zinc) can act either in a stimulatory or inhibitory way, but all essential metals are toxic in excess. Nonessential metals do not play a vital role in marine animals and are considered toxins (e.g., mercury, silver, chromium, cadmium, and nickel) (Engel et al. 1981).

In general, bioavailability of most metals depends on chemical form (Engel et al. 1981). Biological response to dissolved forms of some metals (e.g., copper, cadmium, and zinc) may be a function of the free metal ion concentration (Sunda et al. 1978, Waiwood and Beamish 1978, Fowler and Heyraud 1980, Engel et al. 1981, Campbell et al. 1988, Jenkins and Mason 1988). The affinity of metals for biological materials depends on the affinity of metals for subcellular proteins and other molecules (Phillips 1980). Processes controlling uptake of metals by cells and movement of metals among tissues remain to be fully explained. In general, uptake by cells involves passive transport processes, although endocytosis may also occur (Viarengo 1985). For some metals, metal complexes 
may go through biological membranes as lipophilic compounds. Zinc is important to the structure and function of cell membranes. In the case of cadmium and lead, the metal reacts with phosphate groups of the lipid bilayer before being complexed by intracellular ligands (Viarengo 1985).

Within cells, metals can react with the cytosolic component through binding to sulfhydryl groups of proteins, chelation and salt formation. Metals bind to functional groups of proteins such as imidazole, sulfhydryl, carboxyl, amino and peptide groups (Phillips 1980, Viarengo 1985). Some metals are important constituents of enzymes or cofactors, although the physiological requirements of aquatic biota for trace metals are generally considered smaller than the actual metal content in most organisms (Phillips 1980). Numerous metals have been found associated with both metallothioneins and glutathione and both have been implicated in the detoxification of metals in cells.

Metallothioneins are a class of soluble, low molecular weight proteins with a high affinity for some metals (Viarengo 1985). Metallothioneins have been isolated from numerous marine animals. Metallothioneins usually are not saturated by a single metal. Instead, six to seven ions of copper, zinc, and cadmium; mercury and silver, when present, coexist on the metallothionein molecule (Viarengo 1985). In the cytosol, metals are found in lysosomes which are subcellular organelles that help degrade food taken up by endocytosis. Lysosomes are important in the catabolism and elimination of metallothioneins and in the elimination of metals from cells. While in cells, metals can also interact with free ribosomes and the nucleus. A schematic diagram modified from Viarengo (1985) is presented in Figure 6.1.

Elevated metal concentrations have been demonstrated many times in the tissues of marine animals that live in or on the sediments or in the water column. These metals might be accumulated by the animals directly from the water column (Lee and Jones 1979). They might be accumulated from interstitial water in the sediments or from food ingested by the animal. Animals might accumulate metals that are sorbed onto sediment particles; particles which might be in the water or on the bottom. Lastly, animals might accumulate metals which are complexed with dissolved organic matter. No studies have examined all possible sources of contaminants simultaneously, hence, the available information covers comparisons of two (or at most three) of these possibilities. Often, it is difficult to distinguish uptake from solution or food, inorganic particles, or other substances such as oil droplets. We have focused this section on uptake from sediment-bound metals and discuss the other routes only where applicable. Uptake from food is discussed in detail in Chapter 8. 


\subsection{POTENTIAL SOURCES OF METALS FOR UPTAKE}

When metals enter the marine environment, they are partitioned between solid and liquid phases (Luoma 1983). Further partitioning occurs among specific ligands depending on the strength of the metal-ligand association and ligand concentrations. Organisms that ingest or are in contact with sediment-bound metals are never exposed to a metal as a single entity; rather they encounter a variety of metal-ligand associations (Luoma 1983, 1985). Within each phase (solid or liquid), an organism is exposed to a variety of physiocochemical forms of each metal; each of which m:y differ in its bioavailability. Bioavailability of metals is also affected by (1) characteristics of the organisms and the exposed membranes, (2) metal reactivity at the membranes, (3) other cations or metals present that might antagonize or facilitate uptake by the organism, and (4) factors influencing chemical reactions (e.g., temperature) (Luoma 1983). A simplified characterization of the interface between the environment and a deposit-feeding organism is illustrated in Figure 6.2 (from Luoma 1989). Sediment-associated metals at the sediment surface are primarily associated with iron oxides, manganese oxides, and organic materials. Metals are generally in the reduced form below the sediment surface or they may enter the interstitial water. Metal transport into organisms is anticipated to be similar to that of other substances. Efflux or depuration of metals from animals also occurs, although it may be slow (Bryan 1971, 1979; Cunningham 1979). In some cases, metal concentrations never reach a steady state and life-long uptake occurs (Luoma 1983). Thus, transport rates alone cannot serve as a predictor of bioaccumulation levels.

Analysis of bioavailability of metals in sediments is fraught with many experimental difficulties. Until physicochemical relationships of metals and sediments alone are understood, the picture on bioavailability of these metals will remain unclear. As was discussed in Chapter 3 , metals occur in many states in sediments. The sedimentary milieu is more complex than that of the water column. Interstitial water tends to differ from overlying water by having higher concentrations of pollutants and organic matter. Experimentation with sediments is fraught with problems because it requires disturbance of the sediments during collection. Shifts in relative concentrations of metals in overlying water, in interstitial water, and on sediments can occur. Natural $\mathrm{eH}$ and $\mathrm{pH}$, that are important to the concentration of metals in sediments, are disturbed when sediment is collected. It cannot be realistically expected that laboratory experiments using sediments mimic the natural environment well. Confirmation of the establishment of isotopic equilibrium in experiments with radiotracers is extremely difficult due to problems in determining the specific activity of the fraction 
of the tracer in the sediment that is available to the animals (Jenne and Luoma 1977). Further, the relative importance of solute and sediment forms of metals depends both on their relative concentrations and on the relative availability of the various forms present (Jenne and Luoma 1977).

Still other problems with sediment experiments can occur. "Clean" water used in laboratory experiments causes shifts of metal equilibrium with desorption from sediments to water (Luoma 1983). Exposure of the shrimp, Pandalus danae, the clam, Macoma inquinata, and the gills of the clam, Protothaca staminea, to aged solutions of copper and seawater resulted in lower accumula.ion of copper than did exposure to unaged copper-seawater solutions (Crecelius et al. 1982). The forms of labelled metals introduced into the system are most likely not the forms predominating in the natural system. Further, addition of metals to sediments and waters may cause changes in the bioavailable fraction of metal. Use of ashed, "clean sands" in association with introduction of metal in aqueous form to the experimental system, as was the case in Pesch and Morgan (1978), does not adequately mimic the natural environment because natural complexing agents are removed and because the initial amount of the metal in sediment is zero and must build throughout the experimental period. In these cases, short-term experiments will not reflect situations where the metal has been accumulating in sediments for some time. Use of artificial substrates poses problems because they may bind contaminants in ways that do not mimic natural sediments and they may not offer particle sizes that animals will accept during feeding (Bryan 1979). Maintaining "healthy" animals throughout the long periods necessary to complete some experiments can be difficult and may limit the use of some species. Table 6.1 from Luoma (1989) provides numerous suggestions or guidelines for planning experiments on bioavailability of sediment-bound contaminants.

Bioaccumulation of metals adsorbed to sediments can come either through ingestion of the sediments and subsequent absorption of the metals into the tissues through the gut wall or absorption from interstitial water through the body wall. Infaunal deposit-feeders are especially good candidates for studies of uptake of metals from sediments because they ingest and come in contact with the sediments, whereas other groups such as suspension-feeders primarily just come in contact with the sediments. Suspension-feeders may coincidentally ingest particle-bound metals when resuspended materials are mixed with phytoplankton in the water column. Microorganisms and adsorbed organic matter can supply benthic suspension-feeders with additional nutrition (Luoma 1985).

In some cases, ingested sediments are considered the main pathway of metals accumulation in marine animals. Some evidence indicates that metal assimilation from solid forms, such as sediments, 
by detritus-ingesting organisms depends on the metal form, but occurs much slower than assimilation rate from solute forms (Jenne and Luoma 1977). They examined uptake of ${ }^{110 \mathrm{~m}} \mathrm{Ag},{ }^{65} \mathrm{Zn}$, and ${ }^{109} \mathrm{Co}$ from sediment and water by deposit-feeding clams, Macoma balthica. To estimate uptake from feeding on sediments alone, some of the clams were held in dialysis bags after which nuclide concentrations of animals enclosed in bags were subtracted from those in feeding animals. Different sediment types were used including iron oxides, mangenese oxides, organic materials and carbonates. Ingestion accounted for significant bioaccumulation of metals with differences of up to 1000 -fold among sediment types. Of the three metals, measurable bioaccumulation was noted only for ${ }^{110 \mathrm{~m}} \mathrm{Ag}$. Further, the ability of clams to assimilate zinc, silver, or cobalt from ingested sediments declined as the strength of the binding between metals and sediments increased (Luoma and Jenne 1977). Jenne and Luoma (1977) indicate that the biological importance of sediment-bound forms of metals may be due to their regulation of equilibrium solute concentrations in associated waters via sorptiondesorption and dissolution-precipitation reactions. In another study, ingestion of metal-contaminated iron oxides by Macoma balthica accounted for $89 \%$ to $99 \%$ of the total zinc uptake (Harvey and Luoma 1985). Further, $57 \%$ of the cadmium taken up by these clams feeding on unaltered estuarine sediments originated from particulates. Several reviews of field data suggest that deposit-feeding clams, Macoma balthica and Scrobicularia plana, take up metals from sediments (Bryan 1979, Luoma and Bryan 1979, Luoma 1986b). Luoma and Bryan (1978) found the concentration of lead in Scrobicularia is proportional to the concentration in the sediment as modified by the inhibitory effect of iron. Yet, it may be that the source of metal to the sediments and the organisms were the same. When the distribution of metals among tissues of Scrobicularia was analyzed, $75 \%$ of the cadmium, cobalt, nickel, lead, and zinc were found in the digestive gland indicating that sediments were the source of the metals (Bryan and Uysal 1978). Based on digestive gland metal levels, some manganese, copper, silver, and iron were also absorbed from sediments moving through the digestive tract (Bryan and Uysal 1978). Appearance of metals in digestive gland tissues does not necessarily mean the metals have been assimilated, as bivalves rely on intracellular digestion in the digestive gland. High metal concentrations associated with gills, mantle, siphon, or foot in deposit-feeding molluscs are often interpreted to indicate uptake of metals from solution (Luoma 1983). Considerable manganese and iron were interpreted to be available from solution to Scrobicularia because levels of these metals were high in the mantle and siphons (Bryan and Uysal 1978). Other field studies have been less conclusive regarding accumulation of metals. In an unusual case, arsenic levels in the polychaete, Tharyx marioni, have been found to be very high, even when levels in the associated 
sediments are low (Gibbs et al. 1983). These levels exceeded $2000 \mu \mathrm{g} / \mathrm{g}$ whole body dry wt and between 6000 and $13,000 \mu \mathrm{g} / \mathrm{g}$ palp dry wt. Based on uptake experiments, Gibbs et al. (1983) concluded that most of the arsenic is derived from the sediments rather than the water. However, the mechanisms and sites of uptake are uncertain and this instance is so unusual that results may not be generally applicable. Working in Minamata Bay and surrounding areas, Nishimura and Kumagai (1983) measured mercury levels in fish, plankton, and sediments to determine correlations in levels of mercury among the three sample types. Mercury levels in croaker, Argyrosomus argentatus, correlated fairly well with mercury levels in the sediments and even better with mercury levels in zooplankton. Levels of mercury in zooplankton and suspended particulates correlated well. Nishimura and Kumagai (1983) suggested that mercury moves from the sediments to the fish by way of suspended particulate matter and zooplankton. This correlation may have been due to common sources of mercury and more rigorous experimental approaches are needed to confirm this conclusion.

Comparisons between uptake from water-borne and sediment-bound sources of contaminants are inconclusive. In some experimental situations, water appears to be the main source of metal accumulation (Beasley and Fowler 1976a, Murray and Renfro 1976, Guary and Frazier 1977, Luoma 1977a, Ahsanullah et al. 1984, Abbe and Sanders 1990). Some metals may be selectively accumulated while others may be excluded from uptake (Abbe and Sanders 1990). Cadmium and silver are handled very differently by oysters. Silver probably binds very strongly and irreversibly to algal cell walls while cadmium is considered to be quite mobile. Some zinc appeared to be taken up from solution based on levels in the gills and labial palps. When the clam, Macoma inquinata, was exposed to copper-enriched sediments, the body burden doubled compared to that of controls (no added copper) over a two-month period (Crecelius et al. 1982). In contrast, the suspension-feeding clam, Protothaca staminea, showed no increase in body burden indicating that contact with the sediments was low and that available copper was not released from the sediments for ingestion by Protothaca. Thus, feeding type has an influence on uptake routes of metals. Feeding types are often unclear in the literature which complicates understanding the importance of ingestion of metals associated with sediments. Luoma (1977a) concluded that levels of mercury in the deposit-feeding shrimp, Palaemon debilis, were related to availability from the water rather than from contaminated sediments. Similar conclusions were reached by Fujuki (1980) who determined that red sea breams accumulated methylmercury in the dissolved form rather than from suspended solids, bottom sediments, or food. Mussels in the Forth estuary accumulated inorganic mercury from solution, 
phytoplankton, and suspended sediment in the ratios of 10:5:1 (King and Davies 1987). While inorganic mercury in solution may be more bioavailable, King and Davies (1987) point out that in the Forth estuary, the concentration of mercury on suspended sediments is one to two orders of magnitude higher than dissolved mercury so that even though inorganic mercury in suspended sediments is less bioavailable than mercury in solution, it constitutes such a large pool that it may still make a significant contribution to mercury in animals in the Forth estuary.

In some laboratory experiments, the contribution of metals taken up from sediment by tissue; appears low, but does not imply that uptake from sediments is not important given the usually much higher levels of contaminants in sediments than in water. Using the suspension-feeding cockles, Cerastoderma edule, Miramand and Germain (1985) found that transfer factors (amount of metal in the organism/amount of metal in the sediment) from sediment of ${ }^{241} \mathrm{Am}$ and ${ }^{239} \mathrm{Pu}$ were around 0.01 . Distribution of ${ }^{241} \mathrm{Am}$ in tissues of cockles in experiments with sediments was no different from the distribution in experiments in seawater only, indicating uptake from sediments was neglible under the experimental conditions (Miramand and Germain 1985). Similarly, Miramand et al. (1982) determined that uptake of ${ }^{241} \mathrm{Am}$ and ${ }^{239} \mathrm{Pu}$ from sediments was not an important pathway for the amphipod, Corophium volutator, the polychaete, Arenicola marina, and the clam, Scrobicularia plana. Ueda et al. (1977) compared accumulation of metals from sediments and water by the polychaete, Nereis japonica. They placed worms in sediment labelled with ${ }^{60} \mathrm{Co},{ }^{95} \mathrm{Zr}-{ }^{95} \mathrm{Nb},{ }^{137} \mathrm{Cs}$, and ${ }^{106} \mathrm{Ru}-{ }^{106} \mathrm{Rh}$ and in connected containers without sediment, but with free access of seawater from the sediment chamber. Uptake of radionuclides was primarily from the water with a smaller contribution from the sediments themselves. However, when Nereis japonica was exposed to ${ }^{115 m} \mathrm{Cd}$ with and without sediments, the sediments greatly enhanced the uptake of cadmium (Ueda et al. 1976). Using Neanthes arenaceodentata, Pesch (1979) found that the presence of sediments increases the uptake of copper.

Understanding of the relative importance of interstitial water and sediments as sources of metals to marine animals is hard to ascertain experimentally. Collecting interstitial water in a manner to produce realistic data on concentrations of contaminants is difficult, particularly as so many methods are disruptive (Word et al. 1987). Once clean water is added to experimental sediment, time for the concentrations in the two pools to equilibrate so that initial concentrations can be measured is often not measured. Thus, many experiments are not run under equilibrium conditions.

Redistribution of metals among different binding components in sediments is expected as the sediment 
chemistry changes (Luoma 1983) and both water and sediment concentrations need to be monitored throughout. How much activities of animals in sediments affect the bioavailability of metals in sediments is largely unexplored. Further, some studies have ignored the idea that undigested sediment in small animals may influence analyses of body burdens (Luoma and Jenne 1976a, Luoma 1983). All of these issues should be remembered in design of bioavailability experiments, but many often are not.

Sampling of interstitial water is a difficult process for other reasons. As indicated above, separating the interstitial water involves disruptive processes. When the sediment/water milieu is disrupted, the sediment chemistry can change. Consequently, knowledge of the interstitial water often comes from comparisons of animals in seawater alone and in the presence of particulates in which case the seawater results are considered comparable to those of interstitial water (see for example, Miramand et al. 1982 and Miramand and Germain 1985). This "comparability" may not be valid and direct measurements of interstitial water are needed. Speciation and concentration of metals in porewater differ from that of seawater in the overlying water column (Luoma 1989).

To further understand bioavailability, methods for manipulating concentrations of contaminants in interstitial water while maintaining constant levels adsorbed to sediments or in associated seawater are needed for uptake experiments. Kemp and Swartz (1988) have made initial strides in this direction and used their methods for toxicity studies. Their approach using peristalic pumps controlling flow-through sediments and additions of organic-rich fine particles to sandy particles resulted in greatly differing particle-bound cadmium concentrations in sediment with similar interstitial cadmium concentrations. At least, $70.2 \%$ to $87.9 \%$ of the mortality of the amphipod, Rhepoxynius abronius, appeared to be due to cadmium dissolved in interstitial water rather than cadmium associated with sediments (Kemp and Swartz 1988).

Bioavailability of contaminants in porewater appears to increase with decreases in total volatile solids. A relatively small decrease in total volatile solids from $1.72 \%$ to $1.30 \%$ in the sediments resulted in increased concentrations of zinc and mercury in interstitial water and increased sediment toxicity to the amphipod, Rhepoxynius abronius (Swartz et al. 1988). These results indicate bioavailability of metals in interstitial water increased resulting from reduced solids with which metals can complex. Similarly, Swartz et al. (1985) have determined that cadmium toxicity to Rhepoxynius results from exposure to interstitial water. 
Some work implicates interstitial water as a source of metals to marine animals. Bryan and Hummerstone (1973a) found for Nereis diversicolor that two pools of manganese exist: (1) slowly exchanging pool of the order of $10 \mu \mathrm{g} / \mathrm{g}$ dry wt which probably includes biochemically essential manganese and (2) a rapidly exchanging pool of manganese the size of which varies with several factors, the most important of which is the interstitial water concentration and salinity. Bryan and Hummerstone (1973a) suggest that manganese in Nereis diversicolor comes from ingestion, especially for the slowly exchanging pool, but that the interstitial water concentration affects the rapidly changing pool of manganese. Bryan and Hummerstone (1973b) determined that for Nereis diversicolor much of the zinc in the interstitial water was available to worms. However, the relative importance of different sources of zinc from sediments or water was not determined. Bryan and Hummerstone (1971) concluded that much of the copper in the interstitial water of sediments was available to Nereis diversicolor. In field analysis of the clam, Scrobicularia plana, zinc was taken up slowly from solution, indicating that soluble zinc is a relatively minor source of zinc for the clams compared to ingested sediments (Bryan and Uysal 1978).

\subsection{FACTORS INFLUENCING BIOAVAILABILITY OF SEDIMENT-BOUND METALS}

The relation between the concentration of a metal in an organism and that in the environment may deviate considerably from direct proportionality, depending on the environmental conditions and the ability of the organism to take up, excrete, and store the metals (Bryan 1979). Once metals have entered the marine habitat, several factors will influence whether or not they are bioavailable. In their review of bioavailability of metals to marine invertebrates, Breteler and Neff (1983) identified some of those factors that are influential as indicated in Table 6.2. Not all of these factors are of equal importance, but many need to be considered to understand bioavailability. Because so many factors exist and their relative importance is still unknown, we cannot now predict bioavailability of metals to even the best known species in the best known habitats. There can be orders of magnitude difference in the tissue metal concentrations of a species collected from two estuaries with similar concentrations of the same metal (Luoma and Bryan 1978). Individuals of the same species collected from uncontaminated and metal-contaminated sites may have similar tissue metal concentrations (Breteler and Neff 1983).

Many factors which affect the physicochemical state of metals have been discussed in detail in Chapters 2 and 3. Environmental facts such as temperature, salinity, dissolved oxygen, $\mathrm{pH}$, Eh, and 
light can influence both the form of the contaminant in the environment and the physiology of the exposed organisms. The amount of organic matter, chlorides, sulfide anions, sulfate, bicarbonate, and hydroxides will all affect the chemical state of the metals in sediments and, hence, their bioavailability. Further, the sediment type and the type of sorption encountered in binding of metals to solid particles contribute to varying degrees to bioavailability. While these factors may affect the amount of material accumulated, the influence may not be as large as expected because rates of loss ray also be affected (Bryan 1979). Many of the factors that influence bioavailability are briefly discussed below.

\subsubsection{Organic Matter}

The amount of sediment organic matter can vary considerably among different sediment types and sediment sources. In general, complexation of metals with organic matter reduces the bioavailability of the metals to marine animals (Luoma and Jenne 1976a, Crecelius et al. 1982, Langston 1982). Accumulation of mercury by benthic invertebrates was reduced by 20 to 80 times by complexation of solute $\mathrm{Hg}^{2+}$ with cysteine or protein (Jenne and Luoma 1977). In salt-marsh areas enriched with organic matter from sewage sludge, mercury uptake by both crabs, Uca pugnax, and mussels, Modiolus demissus, decreased with increasing loads of organic matter (Breteler et al. 1981a,b; Breteler and Neff 1983). In contrast to these results, Breteler and Saksa (1985) found that total organic matter of marsh sediments held in mesocosms correlated well with cadmium uptake in two species of mussels, Mytilus edulis and Modiolus demissus. Outfalls are areas with high organic loading. When metal body burdens are compared between animals collected close to and away from outfalls, conflicting results are found (Thomson et al. 1984, Brown et al. 1986). Body burden data from field collections are often difficult to explain as the history of exposure to organic matter is unknown.

Natural sediments are usually covered by an organic film and bacteria are abundant on sediments. Few studies have examined the influence of bacteria and their exopolymers on bioavailability of contaminants; some of these studies that do indicate that bacteria or their exopolymers increase bioavailability of metals (Bias 1981, Harvey and Luoma 1985a). Beasley and Fowler (1976a) suggest that the exometabolites (primarily mucus) of the animals themselves can reduce the bioavailability of metals, but conclusive experiments have yet to address this question. 


\subsubsection{Sediment Grain Size and Type}

Particle size has been related to metal concentrations in sediments. Most often, the highest concentration of metals is found in the finest fraction of sediment. Finer grains have a greater surface area for adsorption of organic matter which in turn complexes with metals (Waldichuk 1985). Metals are generally thought to be more bioavailable in coarser sediments (Breteler and Neff 1983, Luoma 1989), although some contradictions to this relationship exist (Langston 1982).

Sediment type appears to influence bioavailability. Particulate sinks for trace metals include iron and manganese oxides, carbonates, phosphates, sulfides, and oxidic aluminum and silicon (Jenne and Luoma 1977). The availability of a metal in sediments will vary with such parameters as crystallinity, surface area, coatings, mineralogy, and chemical composition. Desorption from and/or dissolution of the various sinks are controlled by these factors along with chemical and physical variables (Jenne and Luoma 1977, Harvey and Luoma 1985a). Using cockles, cadmium was readily available from biogenic calcium carbonate, less so from precipitated calcium carbonate, and unavailable from sediments of iron and manganese oxide (Cooke et al. 1979 in Duncan 1984). Availability appears to depend on the ability of cadmium to desorb from the sediment (Vangenechten et al. 1983). Luoma and Jenne (1976a) determined that cadmium associated with iron oxides was more bioavailable to Macoma balthica when the iron oxides lacked organic coatings than when the coatings were present. In a study on the influence of sediment type on bioavailability of silver, zinc, and cobalt to Macoma balthica, sediment type influenced uptake of metals over the two-week experimental period. Sediments studied included iron oxides, manganese oxides, organic detritus from a salt marsh, calcite, and biogenic calcium carbonate from crushed shells. Silver was taken up in amounts far greater than were either zinc or cobalt, with highest levels of silver uptake being associated with calcite and manganese oxide. Organic particulate-bound silver was not bioavailable in this study just as organic particulate-bound cadmium and mercury were not bioavailable in other studies (Luoma and Jenne 1977). In contrast, zinc and cobalt were most bioavailable from biogenic $\mathrm{CaCO}_{3}$ and organic particulates were least bioavailable from the hydrous oxides. Luoma and Jenne (1977) conclude that among the most abundant sinks with a given sediment mixture, metals will be selectively partitioned into those sediment types with the greatest affininty for metal sorption; i.e., there will be a tendency for metals in mixed sediments to partition into those sediment types with the lowest bioavailability. 
Metals that are associated with benthic sediments are distributed among a variety of physicochemical forms (see Chapters 2 and 3). These chemical forms have different chemical reactivities such that measurement of total concentration of a particular metal provides little indication or predictability of potential interactions with the marine animals present in the environment (Tessier and Campbell 1987).

Numerous methods of examining sediments to obtain relationships between bioaccumulation and these chemical forms have been studied. Numerous models have been developed to predict adsorption of a metal to the various phases to understand which phases of sediment exhibit the strongest binding intensity for the metal and, hence, the least bioavailability. However, most models for marine sediments are not tested even with just one metal alone. Alternatively, different methods of extracting metals from sediments have been used which vary in the amount of metal they will remove from the sediments. A thorough review of these methods can be found in Campbell et al. (1988). No one extraction method can accurately predict bioavailability of any particular metal to any particular organism (Waldichuk 1985). Some authors have used sequential extraction procedures, and while there are problems with these procedures (see Tessier and Campbell 1987, Luoma 1989), useful insights have emerged. For instance, several authors have shown that while metal body burdens in marine animals may not be related to total concentration, they may be related to the readily extractable fractions in sediments (Luoma and Jenne 1976b, Langston 1980, Luoma and Bryan 1978, Campbell et al. 1988). In other words, metal bioavailablity was related to strength of binding of metals to particulates with more weakly bound metals being more bioavailable (Luoma 1983). Examples of some types of predictors found for metal levels in organisms is shown in Table 6.3 (modified from Tessier and Campbell 1987). The main route of entry of metals into the organisms is not necessarily due to ingestion of particulate metals. It may be that the sedimentary factors controlling the adsorption of metals to particles may be the controlling mechanism.

\subsubsection{Seasons}

Changing of the seasons is most accentuated in temperate environments. Considerable research on changes in metal levels in organisms resulting from seasonal changes has been conducted and reviewed (Phillips 1980). Factors most often affected by seasonal changes include salinity, rainfall (which affects salinity), reproduction of marine organisms, size and weight changes, and temperature. Differences in metal levels in marine organisms often is reflected by the changes of these seasonally dependent factors. 
Seasonal changes in uptake of metals might be expected due to physiological changes, reproductive condition, and spawning. Burdens of metal in tissues of marine animals often change throughout the year. Copper, zinc, and cadmium varied during a year in mussels, Mytilus edulis, but not always in a regular or understandable pattern (Brown et al. 1982a). Bryan and Uysal (1978) saw seasonal trends in some metals (zinc, iron, and manganese), but not in others (copper) in Scrobicularia plana. Whole body concentrations of cobalt, zinc, and iron in oysters, Crassostrea gig. $x$, were highest in autumn and spring and lowest in summer, while the converse was true for manganese (Harrision 1979). Bryan (1973) examined seasonal variation of metals in suspensionfeeding scallops, Pecten maximus and Chlamys opercularis, from the Tamar River estuary over a three-year period. Higher whole body concentrations of cobalt, copper, iron, manganese, nickel, lead, and zinc were generally found in the autumn and winter than in spring and summer. Frenet and Alliot (1985) compared shrimp, Palaemonetes varians, over several years from two habitats, with and without seasonal pulses of metals, and determined where seasonal pulses of metals occurred, increased concentrations of copper, lead, and zinc in shrimp also appeared. Seasonal changes in tissue concentrations of metals can be related to gametogenesis, spawning, and shell deposition (Frazier 1975, 1976). During an eight-year period, concentrations of copper in field-collected clams, Macoma balthica, varied regularly, with concentrations increasing rapidly between September and November and reaching a maximum between December and March (Luoma et al. 1985, Thomson et al. 1984). The magnitude of these fluctuations varied dramatically from year to year and were influenced by salinity, discharges from local sewage treatment plants, station location, and clam body weight. Concentrations of silver in Macoma over this eight-year period followed a pattern similar to that of copper, although seasonal patterns were not consistent among all stations. In this same study, concentrations of zinc in Macoma were out of phase with copper and silver, with zinc peaks occurring later in the winter. Concentrations of zinc in Macoma were less variable than were those for copper and silver. This study indicated that many factors influence seasonal changes (e.g., weather patterns, geochemical changes, biological processes, episodic inputs, etc.) and interpretation of metal concentrations in bivalves from estuaries requires careful consideration of the processes affecting metal dynamics in these environments (Luoma et al. 1985).

\subsubsection{Salinity, Rainfall and Temperature}

Research conducted in both the field and laboratory has demonstrated that salinity affects metal bioavailability in the marine environment. Changes in salinity can alter metal bioavailability by 
changing the metal species distribution of the biologically available pool of metal. Variations in salinity can cause changes in an organism's behavior such as in feeding rates, respiration rates, etc. which in turn influences the amount of metals to which organisms are exposed. In general, uptake of metals (excluding mercury) will increase with decrease in salinity. Many examples of this increased uptake exist (Bryan and Hummerstone 1973 a,b; Amiard-Triquet 1974; Mackay et al. 1975; SchulzBaldez 1974 in Cunningham 1979; Frazier 1979). Free ion concentrations of silver, copper, and cadmium decrease with increasing salinity and pH (Engel et al. 1981), thus, decreasing the bioavailability of each metal in aqueous environments. Metal complexation with chloride varies among metals. For example, silver is more strongly complexed by chloride ion than is cadmium (Engel et al. 1981). Larval survival and egg hatch increased with decreasing free cadmium ion concentration and increasing salinity (Engel et al. 1981). Trends for extractable and total concentrations of metals (copper, iron, manganese, lead, zinc) along an estuarine gradient suggested that, except for lead, availablility will decrease from upstream to downstream (Bryan and Uysal 1978). Response of organisms to different metals at different salinities appears to be metal dependent (Phillips 1976a; Bryan and Hummerstone 1973b; Luoma 1977a; Hannerz 1968 in Phillips 1980).

Rainfall, which often changes seasonally, will change salinity of the water through dilution. Increases of metals in tissues of field collected animals have occurred at times of high rainfall, suggesting increased bioavailability due to decreased salinity (Fowler and Oregioni 1976, Frazier 1979). Luoma (1977b) correlated seasonal runoff with levels of mercury in shrimp, indicating that presumably the runoff brought more bioavailable mercury to the shrimp. As stated above, however, when exposed to increasing salinities, increases in shrimp mercury levels were not seen.

Temperature affects many physiological processes in marine animals and, thus, also affects uptake of metals (Cunningham 1979). Generally, increases in temperature up to a certain point cause increases in the availability of metals to marine organisms (Phillips 1980). Uptake and loss of metals generally will increase with increase in temperature (Fowler et al. 1978a, Abbe and Sanders 1990), but exceptions do exist (e.g., Topcuoglu et al. 1987).

\subsubsection{Age/Size/Weight/Life Stage}

Age and, thus, size and weight of animals will affect the accumulation of contaminants. The influence of age and size on metal uptake has been discussed in detail by Phillips (1980). Size and growth rate differences among individuals within a population contributes to variability of metal concentrations among individual mussels, Mytilus edulis (Strong and Luoma 1981, Lobel et al. 1989). 
Yet, size was not an important factor determining concentrations of manganese in the worms, Nereis diversicolor (Bryan and Hummerstone 1973a). Younger individuals may accumulate more metal per gram than do older ones (Cunningham and Tripp 1975a, Mackay et al. 1975, Phillips 1976a,b, Fowler et al. 1978a, Cunningham 1979, Phillips 1980, Ringwood 1989, Mauri et al. 1990). In contrast, tissue concentrations of cadmium in Scrobicularia from the field showed no increase with increases in body weight (Bryan 1976). De Wolf (1975) found higher mercury concentrations in large Mytilus edulis at one site and no trends at another site. Fowler et al. (1976) found higher concentration factors for ${ }^{237} \mathrm{Pu}$ with smaller mussels than larger ones, but found no trends with smaller and larger shrimp.

Growth will affect metal concentrations in tissues and, thus, seasonal profiles of metal concentrations (Phillips 1980). Complications in determining bioavailability of metals to organisms as they age can occur, at least in the case of molluscs. For example, Macoma balthica exhibited differential growth rates among the various years studied which altered the relationship between age and shell length (Cain et al. 1987). Accounting for these differences improved the relationship between copper in Macoma and copper concentrations in the surficial sediments. Further, the degree to which concentrations of zinc and copper fluctuated in Macoma balthica in San Francisco Bay depended on weight changes in clams over several years. These changes differed considerably among stations, among years at a single station, and between metals (Cain and Luoma 1986).

Field studies indicate inconsistency in the size to concentration relationship from site to site. Dry weight of field-collected Scrobicularia plana and total body arsenic increased linearly with increasing age regardless of the collection site (Langston 1980). For mercury in Scorbicularia collected from the same locations, the relationship of tissue concentrations and age of animal was inconsistent among the different stations (Langston 1982). In an analysis of metals in Scrobicularia from the Tamar estuary, Bryan and Uysal (1978) determined that, with the exception of smaller clams ( $<0.05 \mathrm{~g}$ dry wt of soft parts), metal concentrations were linearly related to body weight.

Concentrations of three metals (copper, manganese; and silver) decreased with increasing body size, while concentrations of cadmium, cobalt, chromium, nickel, lead, and zinc increased with increasing body size. Iron concentrations did not seem to be associated with body size. When similar analyses were conducted on Scrobicularia plana in different estuaries, conflicting results were found (Bryan and Hummerstone 1978). It appears that weight/concentration relationships vary in this species and 
variability may be due to metal loading rates, distribution of metals in different pools, populational differences among the estuaries, etc.

In crustaceans, the phase of molting is important because the permeability of the surfaces increase (Bryan 1979, Phillips 1980). Large amounts of metal in exoskeleton tissue of crustaceans have been noted (Fowler et al. 1971, Fowler and Benayoun 1976, Fowler et al. 1975, Jennings and Rainbow 1979). During molting of Carcinus maenas, the rate of absorption of ${ }^{134} \mathrm{Cs}$ increases and ${ }^{90} \mathrm{Sr}$ can be rapidly incorporated during the deposition of calcium in the new exoskeleton (Bryan 1961, Gibbs and Bryan 1972 in Bryan 1979). Molts of shrimp, Lysmata seticaudata, contained large fractions of the shrimp's ${ }^{237} \mathrm{Pu}$ content, indicating a high affinity of plutonium for surfaces (Fowler et al. 1976). However, mercury content of the exoskeleton of these shrimp was low, with lowest concentrations being in the molts (Fowler et al. 1978a). The molt of the isopod, Idothea primastica, was found to contain a high percentage of the total body ${ }^{110 \mathrm{~m}} \mathrm{Ag}$ during both the accumulation and elimination portion of the experiments (Topcuoglu et al. 1987). Whether a large or a small amount of metal is shed during molting will depend on whether the cast molt portion of the exoskeleton includes the metal (Phillips 1980).

\subsubsection{Sex or Reproductive Condition}

Differences in sex can influence the bioavailability of metals to marine animals (Phillips 1980). Considerable variability in metal concentrations is sometimes found among individuals of populations and, in some cases, sex differences account for some of that variability (e.g., see Lobel et al. 1989). However, studies on bioavailability frequently omit identification of sex of the animals being used and one is left to assume, not necessarily justifiably, that animals are distributed evenly enough in experimental treatments or field collections to negate any sexual differences in metal content of tissues that might occur. Determination of sex of unripe animals sometimes can be difficult, precluding sex determination.

Sexual differences in metal body burdens are not always clearcut (Cunningham 1979, Frenet and Alliot 1985). In some cases, females contain higher levels of metals than males (Brown et al. 1986). In other cases, males have higher levels of mercury than females (Phillips 1980). One might expect differences between sexes to be most pronounced during reproductive periods (Cunningham 1979), but more evidence is needed to determine the universality of the sexual differences in metal accumulation during or between reproduction. 
Because metals are found in reproductive tissues, decreases in whole body metal levels might be expected after spawning (Galtsoff 1964). However, Bryan (1973) demonstrated that lowest metal levels in scallops, Pecten maximus and Chlamys operularis, occurred when gonad size was largest. Apparently, other organs are better indicators of seasonal bioavailability of metals than the gonads. External eggs of shrimp, Palaemonetes varians, accumulate, on an average, considerable cadmium and lead (Frenet and Alliot 1985); levels are higher than those of the exoskeleton or the abdomen. Levels of copper and zinc in shrimp eggs are higher than levels in the abdomen, but lower than in the exoskeleton. Presumably, the metal levels in the eggs will be lost to the parents at spawning.

\subsubsection{Species Differences and Feeding Types}

Numerous authors have examined the differences in uptake of contaminants among different species. Considerable variability exists in metal levels in different species of organisms collected from the same habitat (Förstner 1980, Brown et al. 1986). Copper concentrations in the bivalve, Scrobicularia, did not change along a salinity gradient as much as they did for the polychaete, Nereis diversicolor (Bryan and Uysal 1978). Whole body arsenic concentrations in field collected animals were consistently higher for Scrobicularia than for Nereis in all habitats measured (Langston 1980). Similarly, Scrobicularia had higher concentrations of arsenic than did other animals (Nereis diversicolor, the bivalves Macoma balthica, Mytilus edulis, Ceratstoderma edule, and the gàstropods, Littorina littorea, Littorina obtusata, and Littorina saxatilis) at both contaminated and uncontaminated sites (Langston 1980).

Closely related species appear to respond similarily in some cases to metal exposure. Scallops, Pecten maximus and Chlamys opercularis, collected from the Tamar River estuary showed similar trends in metals levels (Bryan 1973), as did the scallops, Adamussium colbecki, from the Antarctic and Pecten jacobaeus from temperate seas (Mauri et al. 1990). Breteler and Saksa (1985) demonstrated that for Mytilus edulis and Modiolus demissus, uptake of mercury was similar in both species, while cadmium uptake was higher in Modiolus than in Mytilus after ten weeks of exposure to metals in salt marsh sediments. Species of bivalves not as closely related as the two scallop species or the two mussel species may not behave similarly (Harrison 1979, Vale and Mendes 1986).

Responses to different sediment treatments can be species dependent. Five species of invertebrates were exposed to chromium in layered solid phase, suspended solids phase and mud aqueous fraction preparations of a used chrome lignosulphonate drilling mud (Carr et al. 1982). The

\subsection{7}


crustaceans (brown shrimp Penaeus aztecus, crabs Portunus spinicarpus, and grass shrimp Palaemonetes pugio) accumulated chromium from all phases, but lost it again when placed in clean water indicating that the metal had not actually been assimilated. The clam, Rangia cuneata, and the worm, Nereis virens, retained some of the accumulated chromium when placed in clean seawater. Carr et al. (1982) suggest that crustaceans are probably less able to accumulate significant amounts of fine particulate or colloidal metals by pinocytosis than are worms or clams because pinocytosis generally does not occur in surface epithelia of crustaceans.

Animals of different feeding types are expected to retain different levels of metals because they use different body parts to feed on different food types (sediments, suspended matter, overlying water, interstitial water, etc.) and ingest food of different sizes. The suspension-feeding clam, Protothaca staminea, took up very little copper from copper-treated sediments while levels of copper in the deposit-feeding clam, Macoma inquinata, in the copper-enriched sediments were twice that of the control sediments (Crecelius et al. 1982). The deposit-feeding clam, Scrobicularia plana, is thought to be a good indicator of the availability of most metals in sediments (Bryan and Uysal 1978). Bryan and Uysal (1978) consider this especially true for metals in the digestive gland because most of the metals were found in this organ after the animals had cleared their guts of ingested particles.

Differences of metal uptake are found among the polychaetes. Olla et al. (1988) exposed three species of polychaetes (Glycera dibranchiata, Nereis virens, and Nephtys caeca) to sediments exposed to $\mathrm{CdCl}_{2}$ and found different uptake rates. Nereis had the highest uptake after $28 \mathrm{~d}$ (mean = $319 \mathrm{mg} / \mathrm{kg}$ ), uptake by Glycera was much lower (mean $=120 \mathrm{mg} / \mathrm{kg}$ ), and uptake by Nephtys was lowest (mean $=39 \mathrm{mg} / \mathrm{kg}$ ), and appeared to have leveled off by the end of the experimental period. Levels of cadmium in sediment, interstitial water, and overlying water were measured in these experiments. Even though cadmium levels in interstitial water in the Glycera experiments were highest, uptake was only intermediate (Olla et al. 1988). Glycera was thought to be a predator and has a digestive tract only open at the mouth. Sediments are not found in any substantial quantities in the guts of Glycera. High levels of apparent uptake in Nereis may have been undigested metals in the gut. In another study of polychaetes, Gibbs et al. (1983) compared uptake of arsenic by the polychaete, Tharyx marioni, to that of other polychaetes and found extremely high levels of As in Tharyx compared to these other species. Zinc concentrations are generally higher in subsurfacefeeding polychaetes than in polychaetes that feed at the sediment-water interface (Jenne and Luoma 1977). These results suggest that diagenetic processes in estuarine sediments may influence at least 
zinc concentrations in estuarine polychaetes and possibly those of other metals as well. Little work has been completed on bioavailability of metals as it changes with sediment depth.

Uptake of metals may vary among invertebrates and between invertebrates and vertebrates, but results are metal dependent. Fowler et al. (1976) compared uptake of ${ }^{237} \mathrm{Pu}$ by mussels, Mytilus galloprovincialis, shrimp, Lysmata seticaudata, and worms, Nereis diversicolor. Mussels accumulated more plutonium than did shrimp with most being taken up by passive adsorption on the shell. Worms readily accumulated $\mathrm{Pu}$ with concentration factors higher than those reached for mussels. Retention of plutonium in shrimp was short and related to molting. Retention of ${ }^{237} \mathrm{Pu}$ in mussels occurred for up to two years after exposure in the experiment. Methylmercury was more available to mussels and shrimp than was inorganic mercury (Fowler et al. 1978a). Influx of mercury into the polychaete, Nereis succinea, was faster than into the shrimp, Palaemon debilis (Luoma 1977b). However, the concentration was higher in the shrimp at steady state. Uptake of ${ }^{241} \mathrm{Am}$ from the sediments was low for three species (the polychaete, Hermione hystrix, the clam, Venerupis decussata, and the isopod, Cirolana borealis), and was slightly higher for Hermione (Vangenechten et al. 1983). Most of the uptake in the polychaete was in the body wall suggesting that contact with the sediments during burrowing was the major reasons for the high levels in Hermione. Differences in uptake of ${ }^{203} \mathrm{HgCl}$ were noted between the polychaete, Nereis succinea, and the shrimp, Palaemon debilis, whereby mercury uptake reached saturation level in Nereis several days prior to doing so in Palaemon (Luoma 1977a). Loss of mercury from Nereis was more rapid than from Palaemon.

The relative mobility of organisms in contact with sediment-bound contaminants seems to influence the degree of uptake of metals, such that those animals with more contact with the contaminated sediments take up more metal. The whelk, Busycon canaliculatum, accumulated appreciable amounts of silver, copper, cadmium, and zinc from a dredged material disposal site in Long Island Sound, while more mobile species including the flounder, Scophthalmus aquosus, and the crab, Cancer irroratus, did not take up metals at levels significantly higher than the organisms from the control site (Grieg et al. 1977). Similarly, the whelk, Buccinum undatum, at a contaminated sewage sludge disposal site had elevated levels of cadmium, nickel, lead, and zinc whereas more mobile crustacean species did not (Halcrow et al. 1973). Thus, one might expect lowered uptake of metals in organisms with higher ability to detect and move away from contaminated sediments to cleaner areas. 


\subsubsection{Adaptation/Evolution}

Marine animals have the capability of becoming adapted to higher levels of metals in their surrounding environment. In some cases, individuals of a species in an area of higher concentration of a metal have lower whole body metal concentrations than individuals of the same species in an area with lower concentrations of the metal (Bryan and Hummerstone 1971, 1973b). Cain and Luoma (1985) transplanted clams, Macoma balthica, from a less contaminated to a more contaminated area and compared the native clams to those transplanted to the more contaminated area. Levels of copper and silver were 6 and 60 times higher, respectively, in the native clams than in the transplanted clams at the start of the experiment. At the end of the four-month experiment, the levels of copper and silver were 2.5 and 6 times higher, respectively, in the native than in the transplanted clams. Loss of metals was slower in the transplanted clams. Loss of metals from soft tissues of native clams equalled net accumulation. The mechanisms controlling the metal accumulation could not be explained by the authors, but it appeared that the two were physiologically different. In some cases, the adaptation to higher levels of a metal can occur fairly rapidly. Klerks and Levinton (1989) demonstrated the rapid evolution of resistance to cadmium by the oligochaete, Limnodrilus hoffmeisteri, in a freshwater environment that seems to have occurred in as little as one to four generations. It would be useful to know what component of the cellular or subcellular mechanisms changed to help these animals better resist cadmium.

\subsubsection{Other Factors}

Beyond the parameters already discussed, still other factors may influence the bioavailability of metals. Uptake of zinc that has passed through biological cycles and been excreted or defecated may be less available for bioaccumulation than zinc that has been directly introduced into the marine environment in inorganic forms, presumably because the zinc is perhaps organically bound or complexed in some way (Fowler and Heyraud 1980). Several authors have predicted that due to the more reduced conditions of deeper sediments that metal in deeper sediments are less bioavailable (Luoma and Jenne 1977, Frithsen 1984). Disturbance of the sediments by bait-digging or storm events may make some metals more bioavailable by exposing buried sediments to the surface (Howell 1985). Location of individuals in the intertidal zone (high, middle, or low) may also influence the degree to which they take up metals (Bryan and Uysal 1978). 


\subsection{METAL BIOAVAILABILTY AND BIOACCUMULATION}

It has been know for some time that, in marine environments, the total concentration of a metal in sediment cannot be used to indicate its bioavailability and correlations between concentrations in organisms and total metal in the surrounding media are not always forthcoming (Rubenstein et al. 1983, Waldichuk 1985, Tessier and Campbell 1987). In some cases, correlation is lacking because an organism is regulating the metal either through control of its entry into the body or excretion of the metal at a level tu keep it at some required level (Amiard et al. 1985). Thus, in this section, we omit a review of levels of metals in tissues; a recent review can be found in Fowler (1990).

Directly measuring bioavailability of a metal associated with a particular solid phase is difficult because many different types of solids bind metals, small amounts of some phases scavenge metals in far greater proportion than their own concentration, and metals are sometimes minor constituents of these phases (Tessier and Campbell 1987). Many metals form inorganic and organic complexes with the many ligands in seawater and ion pairs in seawater. Some metals are thought to be preferentially taken up in the free ion form over other forms (Engel et al. 1981, Abbe and Sanders 1990). Adding chelating agents to solutions has reduced toxicity and uptake of metals in some cases which has led to the suggestion that the metal ion is the toxic form. Chelating agents reduce all forms of a metal so that the remaining forms are still in constant proportion to each other (Simkiss and Taylor 1989). The type of chelating agent (e.g., water-soluble vs. lipid-soluble) can influence the results of toxicity (and presumably uptake) studies (Ahsanullah and Florence 1984): Blust et al. (in Simkiss and Taylor 1989) have determined through use of a series of ligands and calculations that the bioavailable species of copper was not free copper ion, but inorganic complexes [e.g., $\mathrm{CuCO}_{3}$, $\left.\mathrm{Cu}\left(\mathrm{CO}_{3}\right)_{2}^{2-}, \mathrm{CuOH}^{+}, \mathrm{Cu}(\mathrm{OH})_{2}\right]$. Most of this work has been conducted on species in seawater without the presence of sediment. It is argued that metals taken up from sediments are those associated with pore waters in the sediments, and thus, experiments on uptake of metals in seawater are directly applicable to uptake of metals from porewater. However, the species and concentrations of porewater metals differ from those in seawater implying that sediments must be examined as entities different from seawater.

Differences in isotopic form and valency of metals may or may not affect their bioavailability to marine organisms. Beasley and Fowler (1976b) found no differences in accumulation of ${ }^{238} \mathrm{Pu}$ and ${ }^{239+240} \mathrm{Pu}$ by the polychaete worms, Nereis diversicolor, when held in natural contaminated sediments. Similarly, Fowler et al. (1976) in studying uptake of metals by shrimp, mussels, and worms found no 
differences in uptake among ${ }^{236} \mathrm{Pu},{ }^{237} \mathrm{Pu}$, and ${ }^{238} \mathrm{Pu}$. Oxidation states of the metal technetium did not influence uptake or loss of the metal by clams, Tapes decussatus (Fowler et al. 1983). Uptake of ${ }^{237} \mathrm{Pu}(\mathrm{IV})$ and ${ }^{237} \mathrm{Pu}(\mathrm{V})$ differ in the isopod, Cirolana borealis, with the more reduced ${ }^{237} \mathrm{Pu}(\mathrm{IV})$ being taken up and lost slightly slower than ${ }^{237} \mathrm{Pu}(\mathrm{V})$ (Carvalho and Fowler 1985). It should be noted that these metals may behave differently than the more commonly studied metals.

Metals may react directly with the membranes of organisms or they may pass across the membrane and affect the cytoplasm (Simkiss and Taylor 1989). It has been suggested that, in some cases, metals can enter extracellular components of animals without passing through membranes (e.g., the coelom of polychaetes) (Mason et al. 1988). In the case of metals in sediments, direct effects might occur at the epidermis, along the digestive tract, or the coelomic lining on surfaces of exposed respiratory tissues. The uptake of metals by living systems represents an interaction between the speciation of metal and the physiology of the organism. Inevitably, the entry of metals into cells involved their movement across cell membranes which may involve selectivity (Simkiss and Taylor 1989). Different types of systems exist for transport of metals into cells. Examples of such systems are presented in Figure 6.3 after Simkiss and Taylor (1989). These alternatives for transport of metals into cells are lipid permeation, complex permeation, carrier mediated transport, ion channel transport, ion pump, and endocytosis. Transport of metals across membranes of terrestrial mammals is not well understood and far less is known about membrane transport processes in marine animals. While uptake of metals has been demonstrated many times, the form of metals delivered to individual cells is not clear. Mason et al. (1988) suggest that uptake of zinc and cadmium in polychaetes, Neanthes arenaceodentata, does not require energy and that metals move across the plasma membrane via facilitative diffusion involving transport proteins, binding with ligands only after they have entered the cell. According to their model, as long as free ion activity inside the cell is lower than that outside it, then the inward bound diffusion gradient will be maintained and the metal will continue to accumulate.

The presence of some metals has been shown to enhance or limit uptake of others. For example, the rate of uptake of cadmium by Nereis diversicolor was reduced by increasing the level of zinc (Bryan and Hummerstone 1973b). Bioavailability of dissolved cadmium to Nereis is suppressed when levels of zinc and manganese are high. Jenkins et al. (1982a) indicate that cadmium will displace zinc in metallothioneins which may affect the distribution of zinc and cadmium in tissues. Similarly, the presence of copper appears to reduce the bioavailability of silver in several species 
(Bryan 1985). Silver in the snails, Littorina littoralis, is directly proportional to the silver-to-copper ratio of the food of Littorina littoralis, indicating potential competition for uptake sites (Bryan 1983). Luoma and Bryan (1982) suggested that competition between silver and copper may occur when they found concentrations of silver in the clam, Scrobicularia plana, were lower when the surrounding sediment was high in copper. Bryan and Uysal (1978) indicate that the rate of uptake of copper by Scrobicularia decreased with increasing levels of zinc. Bryan (1983) observed that cobalt and copper in Littorina littoralis were correlated with each other and suggested that cobalt might be involved in the metabolism and storage of copper. The experimental data for many studies can be confusing and sometimes contradictory (Bryan and Hummerstone 1973b; Sheline and Schmidt-Nielsen 1977; Fowler et al. 1981; Bryan 1983, 1985) and the variability in experimental techniques is probably a factor in this confusion (Simkiss and Taylor 1989). Iron oxides in sediment intluences bioavailability of other metals to marine animals, probably because these metals bind to the iron oxides. Luoma and Bryan (1982) found a negative relationship between cadmium and silver in Scrobicularia and concentrations of extractable, amorphous iron in oxidized sediments. In another study, binding of cadmium and silver to iron oxide reduced their bioavailability to deposit-feeding clams, Macoma balthica (Harvey and Luoma 1985a). These results suggest that cadmium and silver availability to deposit-feeding clams should be reduced in natural oxidized sediments rich in iron (Harvey and Luoma 1985a). Luoma and Bryan (1978) determined that the concentration of lead in the bivalve, Scrobicularia, is proportional to the concentration in the sediments as modified by the inhibitory effect of iron. That is, metal levels in the clams is proportional to the lead:iron ratio in $1 \mathrm{~N}-\mathrm{HCl}$ extracts of surface sediment. Luoma and Bryan (1978) suggest that the binding capacity of insoluble iron oxide is more important in the uptake of lead than is competition from soluble iron released into the gut. Arsenic levels in field-collected clams, Scrobicularia plana and Macoma balthica, polychaetes, Nereis diversicolor, and rockweed, Fucus vesiculosus, positively correlated with the arsenic/iron ratios of the associated sediments (Langston 1980, 1985). Arsenic enters estuaries in the particulate form, from ores such as arsenopyrite (FeAsS) and as arenite and arsenate ions which may be scavenged by hydrated iron oxides in estuarine sediments. These results imply that arsenic is complexed in some way to iron and only increases in bioavailability when iron is low or arsenic is high relative to iron.

Organic compounds that are toxic to marine organisms (e.g., polychlorinated biphenyls (PCBs), polynuclear aromatic hydrocarbons, pesticides) often co-occur with metals in sediments. Despite the high degree of co-occurrence of organic compounds in nature, analysis of the influence of 
combinations of metals and organic compounds on their uptake has received little attention. Next to nothing is known about the interaction of metals and organic compounds on bioavailability of sediment-bound metals. Animals exposed to sediment containing PCBs and metals are more likely to accumulate PCBs than metals (Rubenstein et al. 1983, Tatem 1986). In these experiments, the metals have been complexed with organic matter in sediments, becoming unavailable for bioaccumulation. Such complexation should vary with sediment type. Interactive effects of hydrocarbons and metals have also been examined. Crecelius et al. (1980) examined uptake of metals ${ }^{51} \mathrm{Cr},{ }^{60} \mathrm{Co},{ }^{152} \mathrm{Eu},{ }^{59} \mathrm{Fe}$, and ${ }^{46} \mathrm{Sc}$ ) by deposit-feeding clams, Macoma inquinata, from clean and oil-contaminated detritus. Their evidence suggests that exposure to $1000 \mathrm{ppm}$ petroleum hydrocarbons neither increased or decreased uptake of metals, except through reduction of metal intake. Thus, the petroleum hydrocarbons reduced feeding rate, but apparently did not reduce availability of metals. In another study, cadmium uptake by black sea bass, Centropristis striata, was higher in the presence of naphthalene and cadmium than in the presence of cadmium alone (Fair and Sick 1983).

Unfortunately, mechanisms explaining these differences in uptake have not been elucidated. Toxicity experiments using mixtures of sediment contaminants (combinations of zinc, mercury, Arochlor 1254 and fluoranthene) and the amphipod, Rhepoxynius abronius, indicated that contaminant effects were additive or less than additive (but, not antagonistic) when compared to the contaminants tested alone (Swartz et al. 1988). Thus, bioavailability appears to be changed when mixtures of contaminants are used, but the mechanisms of that change need to be elucidated.

Despite these pieces of information, we cannot be sure of the direct causative factors of toxicity since our knowledge of membrane-mediated events is limited, because we do not know what chemical forms are taken up at membranes, which just react on the outside of membranes, and how chemicals interact to influence uptake dynamics. Based on our current understanding, we have compiled a summary of information for some commonly studied metals.

\subsubsection{Silver}

Uptake of silver from sediments by deposit-feeders has been shown to be influenced by sediment type, seasonal biological cycles, rainfall, presence of exopolymers on sediments, population differences, and possibly salinity. In the field, degree of contamination of Macoma balthica was greatly affected by the discharge of freshwater into the bay from which they were collected (Luoma and Cain 1979). Local runoff caused the silver present either to become more bioavailable due to salinity changes or brought more silver into the bay. Thomson et al. (1984) determined that sewage 
effluent was an important source of bioavailable silver to Macoma. The amount of exopolymer adsorbed onto iron oxide particles was directly proportional to the amount of silver uptake by Macoma from ingested particles (Harvey and Luoma 1985a). Thus, binding of silver directly to iron oxides appears to reduce its availability. Cain and Luoma (1985) showed that Macoma from two different populations varied in the levels of silver in the tissues as well as loss rates of silver from the tissues, but mechanisms were not offered to explain these differences. Bioavailability of silver to Macoma varied markedly with sediment type (Luoma and Jenne 1977). That silver uptake did not vary with concentration, in this case, implies that the chemical form of silver is important. Luoma and Jenne (1977) showed that, in general, decreases in desorption coefficients of silver from different sediment types are associated with decreases in bioavailability of silver to Macoma. Little work has been conducted on the availability of the different chemical forms of silver or on uptake mechanisms at a cellular level.

\subsection{2 $\underline{\text { Arsenic }}$}

Little research on bioavailability of sediment-bound arsenic has been completed. This metal is found in most polychaetes from England at levels ranging between 26 and $202 \mu \mathrm{g} / \mathrm{g}$ dry wt (Gibbs et al. 1983). An unusual exception to this is the levels of arsenic in the polychaete, Tharyx marioni, which usually exceeds $2000 \mu \mathrm{g} / \mathrm{g}$ dry wt even in the presence of low concentrations in sediment (Gibbs et al. 1983). Most of the arsenic is thought to be derived from the sediments and much of this arsenic is contained in the palps of polychaetes used for feeding on the sediment surface (Gibbs et al. 1983). Some arsenic is bound up with copper granules, but most appears to be organically associated. About $65 \%$ of the total arsenic in Tharyx is linked to the lipid pool, while $25 \%$ is protein-bound arsenite. Arsenic in Nereis diversicolor and Scrobicularia plana from English estuaries was found to range between 6 and $87 \mu \mathrm{g} / \mathrm{g}$ dry wt and 13 and $190 \mu \mathrm{g} / \mathrm{g}$ dry wt, respectively (Langston 1980, 1985). Arsenic levels in Scrobicularia and Nereis varied proportionally with the arsenic:iron ratio, suggesting that increases of iron in sediments will make arsenic less bioavailable. Freshly precipitated Fe(oxy)hydroxide is considered to be the most effective binding substrate for arsenic (Langston 1985). An animals's size does not appear to be a factor controlling bioavailability of arsenic to Scrobicularia (Bryan and Uysal 1978, Langston 1980). In clams, Mercenaria mercenaria, most of the total arsenic was found in the visceral mass where the arsenic was in the form of monomethylarsenic (Maher 1981). Further work is needed on the processes of methylation and uptake of As in marine animals from sediments. 


\subsubsection{Cadmium}

Cadmium levels in marine animals vary among species and among collection sites. While cadmium is a frequently studied metal, it has not been analyzed frequently in relation to many benthic organisms. Early work found that Nereis does not regulate cadmium, and concentrations in worms are nearly proportional to external concentrations (Bryan and Hummerstone 1973b). Concentrations of cadmium in Nereis diversicolor and Scrobicularia plana correlated inversely with amount of carbonates and total organic carbon (TOC) in sediments (Luoma and Bryan 1982), suggesting complexation of metals with the carbonates or TOC and, hence, decreasing bioavailability of cadmium. The concentration of cadmium in the deposit-feeding, Scrobicularia and Corophium volutator, was higher in situations with low salinities than with high salinities, indicating the increased bioavailability of cadmium with decreases in salinity (Bryan and Uysal 1978, Frazier 1979, Bias 1981). The concentration of cadmium in Scrobicularia does not increase with age at low levels of exposure, but increases appreciably at higher concentrations (Bryan 1979). Scrobicularia accumulates metals as it gets larger; that is, as the animals get larger the concentration in their soft parts increases (Bryan and Uysal 1978). In contrast, cadmium levels in the suspension feeding bivalve, Adamussium colbecki, decreased with increasing size, pointing to the differences between species or in exposure levels in the environment (Mauri et al. 1990). Cadmium in Adamussium is found primarily in the cytosol of cells, bound to thioneine-like proteins (Viarengo et al. 1987). Inducible cadmium-binding proteins have also been identified for oysters, Crassostrea virginica (Frazier 1979). In contrast, cadmium in cytosol of Macoma balthica binds to high molecular weight ligands rather than to metallothionein or metallothionein-like proteins, suggesting that markediy different cadmium detoxification mechanisms probably exist for Macoma (Langston and Zhou 1987a).

The presence of cadmium in specific tissues is often used to suggest pathways of ingestion of cadmium. Because most of the cadmium in deposit-feeding, Scrobicularia plana, is located in the digestive gland, it is assumed that most of the metal is absorbed from ingested particles (Bryan and Uysal 1978). Highest levels of cadmium were also found in the digestive gland of Adamussium colbecki and of Pecten jacobaeus (Mauri et al. 1990). In contrast, in experiments exposing sedimentdwelling, detritus-feeding shrimp, Callianassa australiensis, to cadmium in water and in sediments, the shrimp did not appear to take up cadmium from the sediment (Ahsanullah et al. 1984). Amphipods, Corophium volutator, added to a system with cadmium, sediments, and water in equilibrium are less likely to take up cadmium than when the amphipods are added after the sediment 
and water are in equilibrium and before the cadmium is added to the experimental system (Bias 1981). Bias (1981) concluded that most of the cadmium in Corophium was due to uptake from water rather than from sediment. Cadmium in mussels, Mytilus edulis, appears to result from uptake from seawater rather than sediment (Szefer and Szefer 1991). Differences in uptake of cadmium have been demonstrated for three species of polychaetes. After $28 \mathrm{~d}$ of exposure to cadmium-contaminated sediments and overlying water, body burdens in Nereis virens, Glycera dibranchiata, and Nephtys caeca were 319,120 , and $39 \mu \mathrm{g} / \mathrm{g}$ dry wt (Olla et al. 1988). No effort was made in this case to ascertain mechanisms controlling these differences.

Various factors will affect bioavailability of cadmium. As with silver, the presence of exopolymers adsorbed onto iron oxide particles increased the amount of cadmium taken up by the deposit-feeding clams, Macoma balthica, from ingested particles (Harvey and Luoma 1985a). Thus, binding to iron oxide particles appeared to reduce the availability of cadmium. When iron oxides were modified with adherent bacteria, cadmium uptake was not enhanced over that with cadmium accumulated from ingestion of suspended bacteria alone (Harvey and Luoma 1985b). Harvey and Luoma (1985a) suggest that cadmium largely remained partitioned onto amorphous iron oxides when both iron oxides and bacteria were present. Binding efficiency is important in determining the total amount of cadmium taken up by clams, whether or not it is related to differences in the bioavailabiltiy of metals from ingested particles. Where metal binding is less efficient, more metal is taken up by feeding clams due to uptake from solution. Therefore, where particles bind metals less efficiently, increased metal burdens in organisms might be expected and the solute vector of uptake may be predicted to increase in importance, provided that availability of particle-associated metals and metal speciation are not altered (Harvey and Luoma 1985a). Kemp and Swartz (1988) suggest that acute toxicity, and hence bioavailability, of cadmium to the amphipod, Rhepoxynius abronius, was due to cadmium dissolved in interstitial water. These studies indicate that cadmium in solution often appears to be the bioavailable source to marine animals. More definitive work using techniques to assess the relative role of sediment type in binding cadmium should be used to differentiate between cadmium actually adsorbed to sediments and cadmium associated with the interstitial water.

As with other metals, the chemical form appears to influence the uptake of cadmium. The uptake of cadmium from seawater depends mainly on the $\mathrm{Cd}^{2+}$-ion concentration (Sunda et al. 1978). Biological accumulation of cadmium in seawater appears to be determined by free ion concentration rather than by chlorocomplexes (Enget et al. 1981). Uptake of cadmium by the polychaete, Neanthes 
arenaceodentata, was from the free ionic pool of cadmium and EDTA with EDTA-metal complexes being largely excluded from the animal (Mason et al. 1988). As discussed earlier, competition among ions can affect uptake. For Nereis diversicolor, the rate of uptake of cadmium was reduced by increasing the level of zinc present (Bryan and Hummerstone 1973b). When small amounts of sewage sludge are added to sediments with cadmium the toxicity is reduced (Swartz et al. 1985), suggesting the presence of additional ligands that form complexes with $\mathrm{Cd}$ can reduce the bioavailability of cadmium.

\subsubsection{Chromium}

Chromium has not been as well studied as some other metals. Like other metals, different chemical forms of chromium have different levels of bioavailability. For instance, hexavalent chromium (CrVI) at $100 \mu \mathrm{g} / \mathrm{L}$ adversely affected reproduction of the polychaete, Neanthes arenaceodentata, whereas trivalent chromium (CrIII) at $50,400 \mu \mathrm{g} / \mathrm{L}$ showed no adverse effects on reproduction of this polychaete (Oshida et al. 1976, 1981). It would be interesting to see how these results would have changed had the worms been reared with sediment present, rather than just in water. Beyond a certain juvenile stage, concentrations of chromium increase in Scrobicularia as animals get bigger, suggesting continuous accumulation or sequestration of the metal with increases in size (Bryan and Uysal 1978). In drilling muds, chromium associated with the soluble or fine particulate phase of the mud was more bioavailable than that associated with dense, rapidly settling particles (Carr et al. 1982).

Chromium uptake varies with the species studied. Most benthic organisms raised in mesocosms for nine months in the presence of numerous radionuclides showed no evidence of chromium uptake (Frithsen 1984). In this study, amphipods were the only group to take up chromium (measurement was $3312 \pm 2244$ counts per minute per $\mathrm{g}$ dry $w t$ ) and levels were three times higher than those of the sediments. Carr et al. (1982) found that the clam, Rangia cuneata, accumulated and lost chromium rapidly, whereas the polychaete, Nereis virens, accumulated less chromium than Rangia, but retained nearly all the chromium during the 96-h exposure to a chrome lignosulfonate drilling mud.

\subsubsection{Copper}

Although well studied in aqueous environments, copper has not often been studied in sediments. Bioavailability of copper in organisms does not appear to coincide with copper enrichment 
in the sediments (Luoma and Bryan 1982, Thomson et al. 1984). The presence of sediment appears to reduce the bioavailability of copper, at least to polychaete worms (Pesch and Morgan 1978, Pesch 1979). Bioavailability of copper in water appears to be related most to the free cupric ion concentrations (Sunda and Guillard 1976, Engel et al. 1981, Sanders et al. 1983). Most cytosolic copper in crab larvae is associated with copper-thionein (Sanders et al. 1983). Most of the copper in cytosol of three species of fish collected off California was found in the metallothionein-like pool with less being found in the enzyme-containing and glutathione-containing pools (Brown et al. 1987a). Bioavailability of $\mathrm{Cu}^{+2}$ to shrimp and clams was reduced in aged seawater as compared to unaged seawater, presumably due to slow complexation of the copper by dissolved substances present in natural seawater (Crecelius et al. 1982). In the presence of sediment, more than $50 \%$ of the added $\mathrm{Cu}^{+2}$ became bound to the organic fraction of the sediment and was unavailable to the suspensionfeeding clams while remaining available to deposit-feeding clams (Crecelius et al. 1982).

Levels of copper in tissues of marine animals varies from place to place, which is expected because of the varied biochemical conditions among sites. Thus, levels in tissues found in the field are less apt to provide information as those in laboratory accumulation experiments. However, some field situations can provide useful information. Copper availability in Macoma balthica in South San Francisco Bay was related to distance from a sewage outfall and season (Thomson et al. 1984). Levels of copper in Macoma collected in South San Francisco Bay ranged between $<50 \mu \mathrm{g} / \mathrm{g}$ dry wt and $500 \mu \mathrm{g} / \mathrm{g}$ dry wt over several years (Luoma et al. 1985). In this case, several interacting factors influenced copper levels in sediments and the factors could not be distinguished quantitatively. Luoma and Cain (1979) believed that much of the variability in copper levels in Macoma was due to temporal variation in freshwater runoff. Levels of copper in Scrobicularia plana and Nereis diversicolor collected from estuaries in England did not correlate with total sediment copper concentrations (Luoma and Bryan 1982). Further, high levels of copper in Scrobicularia at some stations appeared to be related to very anoxic conditions (Luoma and Bryan 1982). Bryan and Uysal (1978) found levels of copper in whole soft parts of Scrobicularia from the Tamar Estuary in England averaged $34 \mathrm{ug} / \mathrm{g}$ dry wt. In this study, levels of copper in Scrobicularia did not vary as widely as they did in other species, but reasons for this low variability were not clear-cut. It was thought that much of the copper was incorporated directly from solution rather than from sediment ingestion. Bryan and Uysal (1978) did find that levels of copper decreased with increasing size of specimen of Scrobicularia. Levels of copper in the cephalothorax of the shrimp, Paleomonetes varians, ranged 
between $<10$ and $75 \mu \mathrm{g} / \mathrm{g}$ dry wt and high levels were correlated with copper released during the weathering of antifouling paint in the summer (Frenet and Alliot 1985).

\subsubsection{Iron}

Experimental studies have shed some light on the uptake of iron from sediments. For the polychaete, Nereis diversicolor, Jennings and Fowler (1980) compared uptake of ${ }^{55} \mathrm{Fe}$ from two different sediment types and found that uptake was related to ${ }^{55} \mathrm{Fe}$ concentration in sediment, but not to sediment type, stable iron concentration, or the source of the contamination. The chemical form of iron when taken up is often unknown and, thus, cannot be related to bioavailability. Iron is necessary for all organisms, playing a role in enzymatic and respiratory processes (Frenet and Alliot 1985). Jennings and Fowler (1980) suggest that Nereis may regulate iron just as it does $\mathrm{Zn}$, which might explain why the concentration of stable iron remained at similar levels regardless of the sediment it was in. Considerable accumulation of iron from seawater by Mytilus edulis was located in the stomach and digestive tract and is thought to be from the particulate fraction of the water provided (Pentreath 1973a). Iron in seawater is largely particulate, most probably as $\mathrm{Fe}_{2} \mathrm{O}_{3} \mathrm{H}_{2} \mathrm{O}$ (Pentreath 1973a). These mussels became saturated with iron within a week, after which iron levels remained constant. A large portion of the loss of iron by Mytilus edulis appeared to be from the byssal threads produced by the foot (Pentreath 1973a). In contrast, uptake of ${ }^{59} \mathrm{Fe}$ in a mescosm by marine animals was neglible in most cases after nine months (Frithsen 1984).

\subsubsection{Mercury}

Mercury occurs in both organic and inorganic forms in marine waters and sediments (Niṣhimura and Kumagai 1983). Methylmercury appears to be more readily taken up than inorganic mercury (Fowler et al. 1978a). Sites of methylation of mercury in the marine environment are not well known. Methylation may occur in the sediments and water, and in the gut or liver of some animals (e.g., fish) (Pentreath 1976a,b, Bryan 1979, Nishimura and Kumagai 1983). Demethylation of mercury can also occur within some organisms (e.g., fish) (Bryan 1979). Marine mammals often have high levels of inorganic mercury in their tissues suggesting demethylation (Bryan 1979).

Selenium and mercury given simultaneously to fish resulted in increased excretion of mercury (Sheline and Schmidt-Nielsen 1977). Mercury levels in tissues tend to decrease as the amount of organic matter in sediments increases (Breteler et al. 1981b; Langston 1982, 1985; Breteler and Saksa 1985). Uptake of mercury from seawater by lobsters, Homerus americanus, increased with increased concentration of mercury in the water (Thurberg et al. 1977). 
Mercury exposure will result in differences in uptake depending upon the species used, the exposure duration, and form of metal used. Closely related mussels had markedly different uptake rates no matter what the exposure length (Breteler and Saksa 1985). Breteler and Saksa (1985) found $1 \mathrm{~N}$-extractable mercury in sediment was a good indicator of bioavailability of mercury to mussels while Langston (1982) did not. In short-term experiments with shrimp, Palaemon debilis, and polychaetes, Nereis succinea, Luoma $(1977 \mathrm{a}, \mathrm{b})$ showed rapid uptake and slow loss of mercury due to transformation of mercury to a slowly exchanging form within the organism. For these organisms, the transformation of mercury was very rapid and Luoma (1977b) suggests that susceptibility to mercury in a species will depend on transformation rates and physiological permeability of mercury. In other short-term experiments, Luoma (1977a) demonstrated that uptake of ${ }^{203} \mathrm{Hg}$ by shrimp and worms was much more rapid from labelled terrestrial sediments in water than from labelled estuarine sediments. This uptake was not due to higher levels of methylmercury in the terrestrial sediments and may have been due to higher interstitial levels of ${ }^{203} \mathrm{Hg}$. In addition, availability of mercury to the shrimp appeared to be related to inputs of freshwater into the estuary rather than to sediment levels of mercury (Luoma 1977a).

\subsubsection{Manganese}

Manganese is quite common in sediments and estuarine waters where it exists largely as amorphous hydroxides and clay colloids which are readily absorbed onto solid organic surfaces (Rice et al. 1981). Manganese in seawater is generally in a particulate form as well (Pentreath 1973a). Manganese has been found to concentrate in the kidneys of some marine animals (Ghiretti et al. 1972, Bryan 1973, Gibbs et al. 1983, Mauri et al. 1990). Unlike scallops, highest concentrations of manganese have been found in the stomach and digestive gland of mussels in seawater with radionuclides (Pentreath 1973a). Uptake of manganese from seawater by Mytilus edulis is rapid and levels off after about a week. Highest levels of manganese in Scrobicularia plana were found in the digestive gland (Bryan and Uysal 1978). Bryan and Uysal (1978) indicate bioavailability of manganese to Scrobicularia cannot be predicted. However, some factors do seem important, e.g., salinity, season, river flow rate. While season was somewhat important, factors influencing availability of manganese were not clearly spelled out (Frenet and Alliot 1985). For deposit-feeding polychaetes, Capitella capitata, availability of manganese increased with increases in ration size (Rice et al. 1981). Manganese levels in Capitella do not correlate with concentrations in detrital stocks fed the worms (Windom et al. 1982). 
For some species at least, bioavailability of manganese increases with decreasing salinity (Bryan and Hummerstone 1973a, Bryan and Uysal 1978). Manganese in Nereis diversicolor was around $5 \mu \mathrm{g} / \mathrm{g}$ dry wt of whole body tissue at the mouth of an estuary whereas it was around $30 \mu \mathrm{g} / \mathrm{g}$ dry wt in regions of lower salinity. Bryan and Hummerstone (1973a) suggest that manganese levels in Nereis in the field can be accounted for by concentrations in the surrounding liquid medium. However, no conclusive experiments were conducted. In Nereis, manganese appears to occur in two pools, one rapidly and one slowly exchanging, the latter probably involving manganese that is biochemically essential.

\section{$6.4 .9 \underline{\text { Lead }}$}

While many factors influence the bioavailability of lead in marine animals, a few have been identified as having more importance than others. The concentration of lead in Scrobicularia and Nereis diversicolor may be predicted from the lead:iron ratio in $1 \mathrm{~N}-\mathrm{HCl}$ extracts of surface sediments (Luoma and Bryan 1978, 1982; Luoma 1985). These authors suggest two factors that might influence lead uptake: competition from soluble iron released into the gut or binding capacity of insoluble iron oxide. Dissolved lead is thought by Luoma and Bryan (1978) not to be readily bioavailable to Scrobicularia. Lead in sediments is among the most refractory of metals when bound by ligands at a range of redox potentials, which may explain why increases in cadmium bioavailability to baitworms are greater than increases in lead bioavailability when subsurface sediments are brought to the surface (Howell 1985). Amiard et al. (1985) found that of the metals studied, lead in seawater was the least toxic to marine invertebrates, even though uptake of lead from seawater increased with increasing concentrations of lead. Lead accumulates outside cells, at least in invertebrates, in granules rich in carbonate (perhaps as a $\mathrm{PbCO}_{3}$ precipitate) (Luoma 1986b). Perhaps this mode of accumulation is responsible for the low toxicity.

\subsubsection{0 $\underline{\text { Zinc }}$}

Zinc is necessary for many biological reactions (e.g., as a cofactor for many enzymes) and is, therefore, considered an essential metal. Factors influencing bioavailability of zinc are not well understood. Fowler and Heyraud (1980) indicate that zinc in ionic form is much more available to marine organisms than zinc complexed with biologically derived organic matter. Bioavailability of zinc to animals cannot be predicted from total zinc in the sediments (Thomson et al. 1984). The presence of humic substances seems to decrease the availability of zinc to some marine organisms 
(Luoma and Bryan 1982). Zinc bioavailability to Macoma balthica changes with phase association of zinc in sediment as follows: organics $>$ biogenic $\mathrm{CaCO}_{3} \geq$ calcite $>$ iron and manganese oxides (Luoma and Jenne 1977). Concentration factors of zinc in these clams decrease as the desorption of the metal from the substrate decreases. Uptake of zinc may be inhibited by the presence of iron, while cadmium seems to have no competitive effect on zinc uptake (Luoma and Jenne 1977). Zinc in Scrobicularia was higher upstream in British estuaries either because animals were larger upstream or more bioavailable zinc was found upstream (Bryan and Uysal 1978). Zinc bioavailability in Macoma balthica has been shown to be related to amount of urban runoff and sewage, with availability of zinc in sewage being greater than that in urban runoff (Thomson et al. 1984). When fed detritus, uptake of zinc in Macoma balthica was higher in non-oiled detritus than in oiled detritus (Crecelius et al. 1980), either because the zinc complexed with the oil or the oil inhibited feeding on the detritus. The chemical form of zinc is not provided in most cases.

The distribution of metals in an organism suggests, but does not establish, ways that metals become bioavailable. Highest concentrations of zinc in Scrobicularia were found in the digestive gland, suggesting ingested sediments are the primary source of the zinc (Bryan and Uysal 1978). Zinc is thought to become associated with the shell of Scrobicularia due to adsorption (Bryan and Uysal 1978). In contrast to Scrobicularia, highest levels of zinc in scallops were found in the kidneys where zinc is probably associated with concretions (Mauri et al. 1990). Similarly, Macoma balthica was shown to take up most of the zinc in its tissues from sediments on which it fed (Harvey and Luoma 1985a). Highest levels of zinc in bottom-feeding fish, Platichthys flesus, were found in the skin and the gills suggesting uptake from seawater due perhaps to surface adsorption (Amiard et al. 1985).

Numerous species appear to be able to regulate zinc. Scrobicularia is thought to regulate zinc concentrations because of the low variability in tissue concentrations relative to the variability of zinc in sediments (Luoma and Bryan 1982). Using animals in seawater only with different concentrations of zinc, body burdens of zinc were constant at low doses of zinc and then increased at higher doses of zinc suggesting that bioaccumulation did not occur until toxic levels of zinc were reached, demonstrating regulation of zinc in the species studied (Nereis diversicolor, Scrobicularia plana, Crangon crangon, and Platichthys flesus) (Amiard et al. 1985). Experiments run with amphipods exposed to zinc indicated that Allorchestes compressa is capable of regulating zinc (Ahsanullah and Williams 1991). Several bivalve species in Portuguese coastal lagoons as well as worms, Nereis 
diversicolor, are also thought to regulate zinc because regardless of zinc levels in the surrounding environment, body burdens remained relatively constant (Luoma and Bryan 1982, Vale and Mendes 1986).

\subsection{METALS IN TISSUES OF MARINE ANIMALS}

Mechanisms of accumulation, storage and loss of metals comprise a variety of pathways that vary with the mode of assimilation, the species, and the chemical form of the metal (Cunningham 1979). Once metals are assimilated, they can be redistributed among the internal tissues. The apparent distribution of metals will depend on the length of time of exposure, the level of exposure to the metal, and the length of depuration. This section reviews metal distribution in tissues by major taxon. Often the distinction between the proportion of the metal bound up in tissues and that bound up on the surface of the organism (on skin, on gills, etc.) is not made. Thus, no conclusions can be drawn regarding sources of metals or their accumulation or passage through an animal.

\subsubsection{Molluscs}

One of the best studied group of organisms are the bivalve molluscs. Possible pathways of accumulation and mechanisms for loss of metals in bivalves can be seen in Figure 6.4. In the deposit-feeder, Scrobicularia plana, partitioning of metals between the digestive gland and other soft tissues suggests that uptake of cadmium, cobalt, chromium, nickel, lead, and zinc occurs mainly through ingestion of sediments (Bryan and Uysal 1978). In general, more than $75 \%$ of these metals was found in the digestive gland. Only $30 \%$ to $40 \%$ of the copper and silver, $51 \%$ to $80 \%$ of the manganese, and $3 \%$ to $20 \%$ of the iron was found in the digestive gland. In the shell of Scrobicularia, most of the manganese was incorporated into the organic matrix (presumably via the mantle) whereas copper, iron, and zinc was adsorbed onto the surface of the shell from solution (Bryan and Uysal 1978). Highest concentrations of arsenic in field-collected Scrobicularia were found in the digestive gland and in the mantle and siphons with far less being found in the gonadal or muscular feet, adductor muscle or gills (Langston 1980). These results suggest that uptake is derived primarily from the ingested sediment, although some uptake from solution also probably occurs.

Different authors choose to analyze different tissues, even among similar species, which can cause difficulties in making comparisons. Bryan (1973) sampled scallops over several years. In general, he found metals primarily located in kidneys and digestive glands. The kidneys contained most of the manganese, zinc, and lead, whereas cadmium, silver, iron, and chromium were found 
mainly in the digestive gland. Cobalt and nickel were more evenly distributed between the two organs. The kidneys are the most likely the site of excretion of metals for scallops (Bryan 1983). Bryan (1973). suggests that metals found in the kidneys are in the process of being excreted, perhaps in the form of granules, and he points out that metals in the digestive tract may also be granules in the process of being shed. The kidneys of mussels can contain high concentrations of metals (George and Coombs 1977). Like scallops, metal loss in mussels is probably facilitated through excretion via the kidneys. Mussels, Mytilus edulis, exposed to inorganic mercury had higher mercury concentrations (by at least an order of magnitude) in the gills, digestive gland, and kidneys and lower concentrations in the muscle, mantle and foot (King and Davies 1987). These authors conclude that distribution of mercury among the tissues depend on the source. Miramand and Germain (1985) demonstrated that of the ${ }^{241} \mathrm{Am}$ and ${ }^{239} \mathrm{Pu}$ found in soft tissues of cockles mostly was found in the basal cells of the gut wall and the cells of the digestive tubule wall.

After $39 \mathrm{~d}$ of exposure, cadmium concentrations in the tissues of the periwinkle gastropod, Littorina littorea, were ranked as follows: kidneys $>$ gills $>$ digestive gland $=$ mantle edge $>$ head/foot $>$ remaining tissues (Langston and Zhou 1987a). At the end of the 197-d depuration period, the concentrations in tissues were as follows: digestive gland $>$ mantle edge $>$ gills $=$ kidneys $>$ head/foot $>$ remaining tissues. In this study, cadmium decreased in the gills and kidneys after depuration, increased in the digestive gland, and remained the same in the other tissues studied. No cadmium was execreted from the animals after the 197-d depuration period.

Metals have been found in the gonads of bivalves, but the relationship between metals and gametes is unclear (Cunningham 1979). The metals may be associated with the connective tissue or the nutritive cells. However, spawning may be an important loss of metals to some species.

Shells of molluscs are potential sites of adsorption of metals (Harrison 1973, Borchardt 1983, Miramand and Germain 1985). Langston and Zhou (1987b) found cadmium uptake onto the shell of the clam, Macoma balthica, was characteristic of saturation kinetics and indicative of physical adsoprtion processes. In general, metals adsorbed to the exterior surface of shell are lost fairly quickly, whereas metals incorporated into the organic matrix of the shell are lost more slowly (Fowler et al. 1976). Sediment type does not appear to be important to the amount of uptake of metals by clam shells (Vangenechten et al. 1983).

Metal concentrations in the mantle tissue of bivalves may increase from endocytosis or from transportation of metals by amoebocytes (Cunningham 1979). Production of the shell and diapedesis 
are mechanisms for loss of metals from bivalves. Diapedesis is a continuous process involving slow migration of amoebocytes from the blood through surface epithelial tissue, where amoebocytes may be eliminated from the body (Cunningham 1979).

Bivalve gills can increase in metal concentration during exposure experiments. Surface adsorption may be a mechanism working here. Rapid loss of metals from the gills during periods of depuration would support this (Cunningham and Tripp 1975b). Diapedesis at the gills would serve as a mechanism for loss of metal at the gills (Cunninghum and Tripp 1975a).

The appearance of metals in the byssal threads of mussels actually can be considered a route of elimination of the metals. Large amounts of ${ }^{237} \mathrm{Pu}$ ended up in the byssal threads of Mytilus galloprovincialis with concentration factors as high as 4100 (Fowler et al. 1976). Iron and strontium have also been found in byssal threads of mussels (Cunningham 1979). After two weeks of accumulation, ${ }^{59} \mathrm{Fe}$ occurs in large clusters in the foot of Mytilus edulis, notably in the byssal gland area (Pentreath 1973a).

Numerous authors have demonstrated cellular deposition of metals after exposure to metals in seawater. Using X-ray techniques, mercury, cadmium, silver, lead, iron, and copper have been found in lysosomes or other membrane-bound bodies within cells from various tissues and from various species (Fowler et al. 1981). These bodies play a role in uptake and storage of metals through the process of pinocytosis (Fowler et al. 1981). Pinocytosis of lead has been shown in the digestive tract of molluscs. Such deposition is now thought to occur with a number of phyla (Fowler et al. 1981).

Distribution of metals with cellular components of different tissues will vary according to the metal. Cadmium in American oysters increased in both the digestive gland and mantle during exposure to $160 \mu \mathrm{g} \mathrm{Cd} / \mathrm{L}$ (Frazier 1979). In addition, 38\% of the cadmium in the mantle was in the cytosol, while $55 \%$ of the cadmium in the digestive gland was in the cytosol. In contrast, distribution of zinc in the cytosol in the digestive gland and mantle was equivalent -- $40 \%$ and $43 \%$, respectively. George et al. (1976) showed that particulate ferric hydroxide was phagocytized by the gill and visceral cells and stored in phagolysocomes.

A picture of the cellular distribution of metals is only beginning to emerge. Different metals appear to behave differently. Metals like zinc are natural components of bivalve biochemistry while other metals (e.g., cadmium or mercury) are not. When exposed to ${ }^{65} \mathrm{Zn}$, the subcellular fraction of 
the gills, mantle, and heart tissue of oysters, Crassostrea angulata and Ostrea edulis, showed over $50 \%$ accumulation in the nuclear and cell debris fractions while the digestive tissue showed $35 \%$ accumulation in these fractions (Cunningham 1979). Coombs (1974) has indicated that zinc is found in two compartments: a tissue residue, cell-debris bound component and a soluble component weakly complexed to small proteins. The former contained two subcomponents of the zinc complex: a firmly bound species and a less firmly bound reversible species.

\subsubsection{Crustaceans}

Metal levels will vary among the tissues of different species. While highest levels of zinc were found in the kidneys of scallops and the digestive tract of deposit-feeding clams (Bryan 1973, Bryan and Uysal 1978), highest levels of zinc in the crab, Carcinus maenas, were found in the hepatopancreas and the gills. Apparently, excess zinc in crabs can be stored in the hepatopancreas or excreted by the gills (Bryan 1966). Zinc can be that found in the blood of lobsters, Homaris vulgaris, at concentrations higher than found in the surrounding seawater, yet bound to proteins such that the gradient for unbound zinc favors diffusion over the gills (Bryan 1971). Actually, the zinc probably first adsorbs onto the cuticle covering the gills and probably attaches to protein on the gill epithelium during absorption. This process of adsorption followed by absorption probably occurs with a number of metals (Bryan 1971). Cadmium has been shown to concentrate in the hepatopancreas of the American lobster, Homaris americanus (Waldichuk 1985).

Even at very high concentrations, some metals can be absorbed very quickly from stomach

fluid. For instance, zinc, copper, and manganese are rapidly absorbed by lobsters, Homarus vulgaris, from the stomach fluid at high concentrations with no apparent control of the rate of absorption (Bryan 1971). In the case of zinc in Homarus, the absorbed metal rapidly (within $24 \mathrm{~h}$ ) appears in the urine, blood, and hepatopancreas.

For some animals, a large portion of the apparent whole body uptake is surface adsorption. When a marine isopod was exposed to ${ }^{237} \mathrm{Pu}(\mathrm{IV}),{ }^{237} \mathrm{Pu}(\mathrm{V}),{ }^{241} \mathrm{Am}(\mathrm{III})$, and ${ }^{252} \mathrm{Cf}(\mathrm{III})$ for a month, most of the radionuclides ended up in the exoskeleton while a smaller percentage ended up in the gut, digestive tract, muscle and haemolymph (Carvalho and Fowler 1985). After three months of depuration, $50 \%$ to $60 \%$ of the americium and californium were lost but the distribution among the tissues was still the same. Shrimp Palaeomonetes varians from field collections had the highest levels of metals (cadmium, copper, iron, manganese, lead, and zinc) in the exoskeleton with the remainder 
being distributed fairly evenly among the external eggs, abdomen, and cephalothorax (Frenet and Alliot 1985). Unfortunately, other tissues were not analyzed. Jennings and Rainbow (1979) demonstrated that $22 \%$ to $80 \%$ of the cadmium in the tissues of Carcinus maenas appeared in the exoskeleton after about a month. Little information exists regarding bioavailability of sediment-bound metals to marine crustaceans.

\subsubsection{Polychaetes}

Less work has been completed on polychaetes than on crustaceans and molluscs. Copper deposits in membrane-bound vescicles in the epidermis were observed in Nereis diversicolor (Bryan 1976). Presumably, these deposits serve as storage agents. When Gibbs et al. (1983) found unusually high levels of arsenic in the deposit-feeder, Tharyx marioni, they determined that a considerable amount of that arsenic was in the palps and gills and appeared to be associated with the lipid pool. Polychaetes have been shown to have low uptake of ${ }^{241} \mathrm{Am}$ in sediments with most of it ( $86 \%$ or $95 \%$ ) found in the body wall, suggesting adsorption processes influencing body burden (Vangenechten et al. 1983).

Metallothioneins have been demonstrated in polychaetes. Inducible copper-binding metallothioneins have been isolated in the fanworm, Eudistylia vancouveri, and were implicated in providing tolerance to copper over time (Young and Roesijadi 1983). Jenkins and Sanders (1986a) have demonstrated that in the polychaete, Neanthes arenaceodentata, cadmium accumulated in the metallothionein pool and the very low molecular weight ligand pool of the cells. These patterns of accumulation reflect the cadmium-induced stress.

\subsubsection{Echinoderms}

Relatively few studies have been conducted on bioavailability of metals to echinoderms. Sea urchins from southern California have been shown to detoxify metals effectively over a three-fold range of tissue concentrations (Jenkins et al. 1982a). In this case, all trace metals over levels required by the enzyme pool in sea urchin gonads are partitioned into the metallothionein pool and thereby detoxified. Metals studied in this case were cadmium, copper, and zinc (Jenkins et al. 1982a). 


\subsubsection{Vertebrates}

The liver and kidneys are often sites of concentrations of metals in fish, although mercury tends to be concentrated in fish muscle (Waldichuk 1985). Winter flounder, Pseudopleuronectes americanus, were injected with $\mathrm{CH}_{3} \mathrm{HgCl}$ and analyzed for distribution of mercury among tissues (Schmidt-Nielsen et al. 1977). Concentrations of mercury in liver, intestine, and muscle were proportional to the dose given, whereas concentrations in red blood cells, gills, and kidneys were related to time since injection indicating the transitory nuture of mercury in uptake and storage in this species (Schmidt-Nielsen et al. 1977).

Pentreath (1973b) compared levels of zinc and manganese in tissues of plaice, Pleuronectes platessa, and rays, Raja clavata. Most studies do not examine uptake from sediment-associated metals. Close correlation of mercury and selenium has been found in some fish (Bryan 1979). Black marlin, Makaira indica, contains approximately equimolar concentrations of mercury and selenium in liver and muscle tissues (Mackay et al. 1975). A low proportion of organic mercury was found in the liver and muscles of blue marlin, M. nigricans (ampla) (Rivers et al. 1972), indicating detoxification of mercury through the binding with selenium. In general, fish are thought to demethylate organic mercury, although a few studies indicate that the opposite may occur (Bryan 1979).

The presence of organic compounds seems to affect the amount of metal in tissues and the general pattern of distribution among tissues (Fair and Sick 1983). Black sea bass were exposed to cadmium alone and cadmium and naphthalene together for $336 \mathrm{~h}$. When naphthalene is absent, cadmium is stored or eliminated effectively without getting into as many tissues as it does when naphthalene is present (Fair and Sick 1983).

Relatively little work on the distribution of metals in marine mammals has been done. Cadmium metallothionein has been found in the liver and kidney of the sea lion, Zalophus californianus (Lee et al. 1977). Fish-eating mammals often contain high levels of mercury in the liver, primarily in the inorganic form (Bryan 1979). Bryan (1979) suggests that demethylation is occurring in the liver because the diet probably consists of a high level of methylmercury.

\subsubsection{Excretion and Storage of Metals}

Metals can be excreted in the urine, excreted into the gut, or lost over the body surface or gills (Bryan 1971). The particular method of loss will depend on the species. Shore crabs, Carcinus maenas, lose zinc across the gills (Bryan 1966). Barnacle larvae lose excess copper into the lumen of 
the gut (Bernard and Lane 1961) and copper and zinc are both excreted in rectal fluid of Octopus dolfeini (Potts and Todd 1965). Lobster, Homarus, does not appear to lose zinc through the gut (Bryan 1966). Crustaceans can excrete zinc, copper, cobalt, manganese, and mercury in the urine and the mollusc, Octopus, can excrete copper and zinc (Bryan 1971). As has been pointed out above in numerous cases, the kidney is frequently the site of excretion of metals in bivalves (Bryan 1973, Cunningham 1979). Cadmium loss, measured after transfer of experimentally contaminated clams, Macoma balthica, to clean seawater, was exponential and relatively slow (biological half-time of 70 d) (Langston and Zhou 1987b). Amounts of cadmium accumulated by the shell of Macoma, probably by adsorption, were low and the elimination rate was rapid compared to soft tissues (Langston and Zhou 1987b).

Storage of metals in a tissue is another way, at least temporarily, to deactivate metals. Crustaceans appear to use the hepatopancreas as a metal storeage site. In Homarus, excess zinc in the blood can be removed, at least in part, by absoprtion in the hepatopancreas from which it can be gradually released in the urine or across the body surface (Bryan 1971). Shrimp, Crangon vulgaris, can store copper in the hepatopancreas as granules (Djangmah 1970). The hepatopancreas of blue crabs, Callinectes sapidus, is known to contain intracellular calcium phosphate granules which sequester cadmium during experimental exposures (Fowler et al. 1981). In crabs, these granules are thought to function as a calcium reserve for recalcification of exoskeleton post-molting (Becker et al. 1974). Decapod crustaceans lose zinc via the feces, urine and gills and the route of loss depends on the species and level of input of zinc (Bryan 1979). Molting has been implicated as a loss of cadmium (Fowler and Benayoun 1974 in Bryan 1979) and silver (Topcuoglu et al. 1987) from crustaceans.

Molluscs can use the renal organs, leucocytes, hepatopancreas and digestive tissues to store metals. Scrobicularia plana uses stored zinc, lead, and cadmium in the hepatopancreas whereas the scallop, Chlamys opercularis, uses the renal organs for storage of zinc, manganese, copper, lead, nickel, and cobalt, but apparently not for iron (Bryan 1971). Scallops, Pecten maximus and Chlamys, and the bivalve, Pinna, have granules in their kidneys with high concentrations of manganese (Bryan 1973). Kidneys are thought to be the site of excretion of zinc and manganese for scallops and lead for mussels (Bryan 1979, 1983). Loss of metals from the kidneys appears to be in the form of granules (Bryan 1979). Intracellular calcium phosphate granules of bivalves have been shown to concentrate cadmium, zinc, and manganese from solution (Fowler et al. 1981). Deposition of byssal 
threads is another way bivalves can remove metals from the main body tissues (Fowler et al. 1976, Bryan 1979). Egg production may also be a means of loss of contaminants from bivalves (Cunningham and Tripp 1973). The digestive tissues of gastropods, Littorina littorea, accumulate cadmium during depuration indicating that these tissues are acting as storage sites (Langston and Zhou 1987a). In fact, Littorina did not lose any cadmium during the 197-d depuration period, but rather only shifted the metal among the tissues and cytosolic pools.

Half-lives for elimination of cadmium from mussels, Mytilus edulis, ranged from 96 to $109 \mathrm{~d}$ and decreased with decreasing availability of labelled algae, presumably due to slowed metabolism (Borchardt 1983). Considerable cadmium can be lost as feces when cadmium is incorporated into the food, thus accounting for the shorter half-lives. Cadmium assimilated from seawater had longer halflives. Elimination of cadmium from mussels also depends on the initial concentration of cadmium (Borchardt 1983).

Half-life for loss of manganese from Nereis ranged from 51 to $540 \mathrm{~h}$ and depended on salinity and initial concentration (Bryan and Hummerstone 1973a). Further, metals in starved animals appear to have shorter half-lives. Bryan and Hummerstone (1973a) speculate that there may also be two pools of manganese in Nereis one released slowly and one rapidly, which would account for the wide range of half-lives measured. Manganese is lost from Pecten maximus in two ways: (1) rapid loss of about $10 \%$ of the manganese and (2) then a slow loss of the remainder of the absorbed manganese (Bryan 1973). The slowly released manganese has a half-life of about $193 \mathrm{~d}$ in unfed scallops. Bryan (1973) suggests that loss rate would have been greater with stable Mn being available from food. Similarly, radionuclides $\left[{ }^{237} \mathrm{Pu}(\mathrm{IV}),{ }^{237} \mathrm{Pu}(\mathrm{V}),{ }^{241} \mathrm{Am}(\mathrm{III})\right.$, and $\left.{ }^{252} \mathrm{Cf}(\mathrm{III})\right]$ in Cirolana borealis were lost in a biphasic manner, first rapidly and then slowly (Carvalho and Fowler 1985). Half-lives for radionuclide turnover in the long-lived compartment were $60,87,261$, and $288^{\circ} \mathrm{d}$, respectively. In the clam, Tapes decussatus, exposed to technetium for approximately a month, the half-life of technetium was approximately $120 \mathrm{~d}$ (Fowler et al. 1983). The half-life of ${ }^{237} \mathrm{Pu}$ in mussels exposed to the radionuclide for just $25 \mathrm{~d}$ in water was approximately two years (Fowler et al. 1976).

Silver is lost from some crustaceans through molting of the exoskeleton as well as through fecal pellet production (Topcuoglu et al. 1987). Silver lost in pellets appears to be lost from crustaceans at two different rates reflecting a rapidly and a slowly released pool of silver (Topcuoglu et al. 1987). Half-life of silver in the rapidly released pool of the isopod, Idothea pimastica, is two 
days and from the slowly released pool it is $130 \mathrm{~d}$. However, exposures in this study only involved exposure in seawater (Topcuoglu et al. 1987).

The forms of metal will affect the half-life of the metal. Using the mussels, Mytilus galloprovincialis, Fowler et al. (1978a) determined that inorganic mercury is eliminated much more rapidly than is methylmercury. Freshwater fish exposed to higher concentrations of mercury had higher desorption rates than did fish exposed to lower concentrations (Kudo 1976). Half-life of mercury in these fish fell between 38 and $75 \mathrm{~d}$. Plaice, Pleuronectes platessa, retain organic mercury far longer than inorganic mercury with half-lives of $33 \mathrm{~d}$ for ${ }^{203} \mathrm{HgCl}_{2}$ and $163 \mathrm{~d}$ for $\mathrm{CH}_{3}{ }^{203} \mathrm{HgCl}$ (Pentreath 1976b).

Metallothioneins or metallothionein-like proteins have been identified for a number of marine animals (Noel-Lambot 1976; Howard and Nickless 1977, 1978; Lee et al. 1977; Overnell et al. 1977; Cunningham 1979; Fowler et al. 1981; Brown et al. 1987a, 1982a,b; Jenkins et al. 1982a,b). These proteins, generally found in the cytosol fraction of the cell, are thought to detoxify the effect of a metal such as cadmium or copper in a cell. These proteins are induced as levels of metal increase in cells.

\subsubsection{Regulation of Metals}

Animals combine the processes of absorption, excretion and storage to regulate the concentrations of metals in the body, even when bioavailability of metals changes in the environment. Because some metals (e.g., copper, zinc, and iron) are essential elements in nutrition, some marine organisms have developed a capability of controlling their intake (Waldichuk 1985). This regulation may obscure any relationships between metal concentrations in sediments and body burdens. Regulation is not a perfect process, that is, it does not occur in all cases. For instance, Nereis diversicolor appears to regulate copper at lower concentrations of copper in seawater, but not at higher near-lethal levels (Amiard et al. 1985). Zinc concentrations in Nereis, Scrobicularia, and Platichthys tiesus appeared to be regulated at lower concentrations and increased at higher concentrations. In addition, zinc in Crangon crangon appeared to be regulated throughout the concentration range tested which was not quite as wide as for the other species. For the essential metal zinc, four species of marine animals (the fish, Platichthys tiesus, the clam, Scrobicularia, the worm, Nereis diversicolor, and the crustacean, Crangon crangon) were all able to maintain the internal concentrations of zinc over a wide range of external concentrations including ones 
approaching the 96-h LC $\mathrm{LC}_{50}$-concentrations (Amiard et al. 1985). In the lobster, Homarus vulgaris, metals such as cobalt, manganese, and zinc are rapidly absorbed from the stomach fluid even at high concentrations indicating a lack of control of absorption at too high a concentration (Bryan 1971). As mentioned above, lobsters store metals in the hepatopancreas and eliminate them through the urine or the body surface. Similarly, crabs, Carcinus maenas, store zinc in the hepatopancreas and excrete zinc across the gills (Bryan 1966). Consequently, blood concentrations of zinc do not change much. Further, concentrations of zinc in the whole body changed only by four-fold, as compared to 500-fold concentration differences in the surrounding medium, indicating good regulation of zinc. This result is typical of those for essential metals.

Regulation of non-essential metals does not usually occur. For instance, lead concentrations in oysters, Crassostrea virginica, was proportional to that of the surrounding environment (Pringle et al. 1968 in Bryan 1971). While oysters are not eliminating lead, they may be storing it in the tissues (e.g., hepatopancreas, muscles) for release when concentrations drop. Non-essential metals such as cadmium and lead accumulate in direct proportion with the increase of metal concentration for Scrobicularia, Nereis, Crangon, and Platichthys (Amiard et al. 1985). Cadmium was not regulated in the amphipod, Allorchestes compressa, as it is not in many crustaceans. In this case, nutrient metals (chromium, copper, and zinc) showed some evidence of metabolic regulation.

Uptake, storage and excretion of metals can involve many of the potential mechanisms mentioned above including adsorption, pinocytosis, transfer to the lysosomal system, production of metal-binding proteins, accumulation in organs such as the kidney, hepatopancreas or digestive gland, and formation of excretory products, such as concretions (Fowler et al. 1981). Thus, metals can be at very high levels in the organism and, yet, be in a stable, non-toxic form. Mechanisms of uptake and storage will not only vary among organisms, but will also vary among organs within individuals.

Metal toxicity primarily results from nonspecific binding of metals to proteins and other macromolecules (Jenkins and Sanders 1986b). Most organisms regulate the distributions of essential and nonessential metals at the tissue, cellular, and subcellular levels to minimize nonspecific binding (Jenkins and Sander 1986a and references therein). Further, this regulation is mediated through soluble and insoluble metal ligands that optimize the specific binding of essential metals to appropriate macromolecules and act as sinks for excess metals (Jenkins and Sanders 1986b). Metallothioneins are cysteine-rich metal-binding proteins whose synthesis can be induced by metals such as copper, cadmium, zinc, and mercury, and they are involved in metal uptake, metabolism, and detoxification 
(Young and Roesijadi 1983, Waldichuk 1985). Binding of metals to these proteins appears to increase as exposure time increases. Thus, the apparent acclimation of marine organisms to metals may be the result of induction of these proteins.

Cadmium binding to metallothionein plays a role in determining the onset of cellular toxicity in some molluses (Fowler et al. 1981). Metallothioneins are not equally distributed throughout the bodies of marine animals (Brown et al. 1982a). In Brown et al. (1982a), metallothionein pools are relatively large in Mytilus for the cases of copper and cadmium, indicating that these enzymes are playing a role in regulation of these two metals. In mussels, Mytilus edulis, the metallothionein fraction of the cytosol to which cadmium binds is a low molecular weight fraction (Cunningham 1979). This fraction was high in cysteine. Induction of metallothionein is not a rapid process. In Crassostrea virginica, a low molecular weight, metal-binding protein has been identified which has high concentrations of aspartic and glumatic acids, but a low amount of cysteine (Cunningham 1979). Cadmium and copper metallothioneins have been identified in limpets, Patella vulgata and Patella intermedia, but zinc was not associated with the metallothionein-like protein (Howard and Nickless 1977).

In periwinkles, Littorina littorea, the high molecular weight, Cd-binding protein I (20,000 daltons) and Cd-binding protein II (10,000 daltons) pools were important in detoxification of cadmium, whereas the very low molecular weight pool was not involved in binding of cadmium (Langston and Zhou 1987a). During exposure to cadmium, CdBP-I became saturated with the metal resulting in an ever increasing build-up of cadmium associated with HMW ligands, which may in turn begin to offload cadmium on approaching saturation. The spillover of excess cadmium results in induction of the CdBP-II and in an increase in cadmium associated with CdBP-I during depuration. In contrast, no metallothioneins were found in clams, Macoma balthica, and most cytosolic cadmium was associated with the high molecular weight ligands (Langston and Zhou 1987b). The very low molecular weight fraction may be important in Macoma in regulating cadmium fluxes during uptake and elimination phases (Langston and Zhou 1987b). Macoma takes up cadmium slowly relative to other bivalves which may provide an adaptive advantage for survival in the absence of metallothioneins (Langston and Zhou (1987b). 
Metal distributions at the cellular level have also been examined for some crustaceans. Crab zoeae, Rhithropanopeus harrisii, were exposed during development to a range of free cupric ion activities regulated in seawater by use of a copper chelate buffer system (Sanders et al. 1983). In this case, most cytosolic copper was associated with metallothionein. Copper-thionein was related to free cupric ion activity and a shift in copper-thionein accumulation was correlated with inhibition of larval growth (Sanders et al. 1983). Crab larvae are able to regulate accumulation of copper (Sanders and Jenkins 1984) at concentrations found in their natural environments. Above those concentrations, the ability to regulate copper breaks down and copper is accumulated in the metallothionein and very low molecular weight pools. Thus, very low molecular weight pools are also important in detoxification of metals in marine organisms. Similarly, both pools appear to be important to detoxification in polychaetes as well (Jenkins and Sanders 1986a).

Metal-binding proteins have been found in fish. Cadmium metallothionein has been found in the liver of plaice, Pleuronectes platessa (Overnell et al. 1977). White croaker from southern California has been shown to sequester tissue trace metals in a metallothionein-containing pool (Brown et al. 1982b). These proteins are considered detoxifying agents for marine animals (Bryan 1979). Brown et al. (1987a) examined the cytosolic distribution of metals in three pools of fish livers: the high molecular weight ( $>20,000$ daltons) enżyme-containing pool (ENZ), medium molecular weight ( 3000 to 20,000 daltons) metallothionein- or metallothionein-like pool (MT), and the low molecular weight ( $<3000$ daltons) glutathione-containing (GSH) pool. Patterns of cytosolic metal distribution differed more among metals than among species or sampling locations.

Scorpionfish have been shown to have two metallothioneins in which $20 \%$ of the amino acids are cysteine and none of the amino acids are aromatic compounds (Jenkins et al. 1982b). The composition of these metallothioneins agrees well with those found in metallothioneins isolated from other fish species (e.g., eels - Noel-Lambot et al. 1978 and plaice - Overnell and Coombs 1979).

\subsection{BIOACCUMULATION FACTORS FOR METALS FROM SEDIMENTS}

Bioconcentration is the accumulation by an aquatic organism of a contaminant from the water alone. The measure of bioconcentration is the bioconcentration factor (BCF) and is the ratio of the concentration of contaminant in the tissues of the organism to the concentration of the contaminant in water. Bioaccumulation is the accumulation by an aquatic organism of the contaminant from all environmental media with which the organism comes in contact (e.g., water, sediment, food). It is 
the situation that occurs in natural populations of organisms in a marine environment. The bioaccumulation factor (BAF) usually is expressed as the ratio of the concentration of the contaminant in the tissues of the organisms to the concentration of the contaminant in the sediment. However, use of BAF rather than BCF implies that other sources of the contaminant are present. Thus, in the special case where uptake of the contaminant from sediments is being considered, BAF may be expressed as the ratio of the concentration of the contaminant in the tissues of the organism to the concentration of the contaminant in the sediment in which the organism resides or to which the organism is exposed. Many authors use the term "transfer factor" (TF) to delineate BAF for sediments. Most reported TFs do not disguish between levels of metal on the sediments and those in the porewater, such that the concentrations in sediments reflect combined concentrations of pore water and particles.

TFs have not been generated in many instances, especially when compared to the amount of literature that provides information on BCFs. Data on TFs indicate that just as body burdens of various metals change over time, so do the TFs. The length of time an experiment is conducted will influence the TFs. Beasley and Fowler (1976a) found that TFs for americium and plutonium in Nereis diversicolor held in sediments from one site (Windscale), increased as time passed indicating continuous uptake (Table 6.4). Using sediments from another site (Bikini Atoll), the same experiments were conducted, in which case TFs tended to increase over time, but less clearly so. Uptake from sediments was low, but continuous in this case. From the data provided in Bryan (1971), TFs were calculated for Nereis diversicolor for various metals in sediments of two different estuaries. As was discussed above, the concentrations of metals in sediments did not appear to reflect metal concentrations in animals. In this case, TFs varied by as much as an order of magnitude. This variability could be due to techniques used, differences in exposure routes for the worms, or differences in the populations of the worms between the two estuaries. Jennings and Fowler (1980) demonstrated that bioavailability of ${ }^{55} \mathrm{Fe}$ to the polychaete, Nereis diversicolor, depends on its concentration in the sediments more than on the sediment type, stable Fe concentration, or source of contamination. Absorption of metals into tissues and cells appears to be a passive process (Bryan 1971). Attempts to correlate concentration factors of metals in whole organisms or tissues to stabilities of complexes formed between the metals and organic ligands have failed either because concentrations of some metals (e.g., copper or zinc) are often regulated or because so many different ligands exist. 


\subsection{BIOAVAILABILITY AND BIOACCUMULATION OF METALS BY SEAGRASSES}

The interactions of seagrasses with metal contaminants is complex. Seagrasses have both a below-ground component (roots and rhizomes) and an above-ground component (leaves). Seagrasses transfer material between roots and leaves. For instance, McRoy and Barsdate (1970) showed that phosphate is taken up from the sediment by the roots and from the water column by the leaves; the phosphate is then rapidly spread to all parts of the plant. Drifmeyer (1980) showed that zinc taken up from seawater by seagrass roots is translocated to the leaf blades and that zinc taken up from seawater by the leaves is translocated to the roots and rhizomes. Brixby found strong correlations of metal concentrations for below- and above-ground portions of eelgrass, Zostera marina. It becomes patently impossible to know the source of any contaminant (sediment or water column) or that portion of the plant in which the contaminant was introduced because of rapid translocation of materials. Therefore, this section will not be restricted to uptake of sediment-bound contaminants.

The roots of seagrasses require a reducing environment while the leaves require an oxidizing environment (Phillips 1979); the potential for uptake of various species of metallic ions is high (Zieman 1975). The reduced environment around the roots and rhizomes allows for anaerobic microbial decomposition; the sulfides formed in this process create a sink for many toxic metals in the marine environment (Wood et al. 1969).

The greatest amount of information on the accumulation of metals by seagrasses is available for the widely distributed eelgrass, Z. marina. Stenner and Nickless (1975) give cadmium, copper, lead and zinc concentrations for Z. marina in contaminated areas in Portugal and Spain (Table 6.8). Wolfe et al. (1976) monitored the levels of iron, magnesium, copper and zinc in $Z$. marina as well as the levels in associated animals, algae and sediment. Manganese, copper and zinc were incorporated into eelgrass at significant concentrations (Table 6.8), while the concentrations in the associated biota was minimal. Using cadmium and manganese radionuclides, Penello and Brinkhuis (1980) showed that both of these metals may be released from roots/rhizomes into the sediment and from leaves into seawater, both from external tissue surfaces and from intercellular spaces. Manganese was released more slowly than cadmium, indicating a greater potential for biological accumulation of manganese. Faraday and Churchill (1979) and Brinkhuis et al. (1980) demonstrated uptake of cadmium by both roots/rhizomes and leaves, as well as translocation between these two portions of seagrasses.

Translocation was seen to be greater from leaves to roots/rhizomes, indicating that roots/rhizomes are a cadmium sink. Brinkhuis et al. (1980) also showed that manganese is more readily fixed by leaves, 
and hence, less mobile than cadmium which tends to diffuse into intercellular spaces. Lastly, a largescale study of metal accumulation in Z. marina in Denmark has contributed much new information (Brix and Lyngby 1982, Lyngby et al. 1982, Brix and Lyngby 1983, Brix et al. 1983, Lyngby and Brix 1984). This study involved the sampling of eelgrass at 40 stations in the Limfjord, some of which were close to major urban sources of contamination. A summary of the concentrations of four metals among these stations is given in Table 6.8. Plants were subdivided into roots, rhizomes, stems and leaves; leaves were aged. The metal concentrations in each plant fraction were determined. Metals analyzed included cadmium, copper, lead, zinc, iron, magnesium, manganese and lead; the concentrations of calcium, potassium and sodium were measured as well. Root concentrations of cadmium, copper, iron, manganese, lead and zinc were greater than concentrations in rhizomes, while manganese was more abundant in rhizomes (Brix and Lyngby 1982, 1983). For above ground metal concentrations, the age of the leaves was found to be a factor (Brix and Lyngby 1982). Cadmium, lead and zinc concentrations all increased with the age of the leaves while copper concentration declined with leaf age. Older leaves seemed to have more irreversible binding sites than younger leaves for cadmium, lead and zinc. Copper seemed to leak from older leaves. Seasonal differences in metal concentrations in the leaves were noted (Brix and Lyngby 1982) and were correlated with changes in either sediment concentrations (copper, lead, zinc) or ambient water concentrations (cadmium). Maximum metal concentrations were found in late winter when growth was at a minimum; minimum metal concentrations were found in autumn shortly after the time of maximum growth (Brix and Lyngby 1982). Brix et al. (1983) noted that for lead, copper, cadmium and zinc, the above-ground portions of $Z$. marina had greater concentrations than the below-ground portions although a correlation was seen. These authors suggest that seagrasses may be useful as a measure of trace metals in ambient and interstitial (sediment) water. From laboratory experiments, cadmium and zinc uptake was found to be greatest in stems and leaves while copper, mercury and lead uptake was greatest in roots, sometimes yielding concentrations 1850 times that of the seawater concentration (Lyngby and Brix 1984). The uptake capacity of stems, leaves and rhizomes may be given as follows: $\mathrm{Zn}>\mathrm{Cu}>\mathrm{Cd}>\mathrm{Hg}>\mathrm{Pb}$. The results of these Danish studies indicate that $\mathrm{Z}$. marina meadows play a significant role in metal cycling in the Limfjord; high concentrations of magnesium and manganese, as well as the elements calcium, potassium and sodium, are found in high concentration in eelgrass relative to sediment concentrations (Brix and Lyngby 1983). Similarly, Wolfe et al. (1976) claim that the largest metal fluxes in the Newport River estuary in North Carolina are associated with sedimentation and $Z$. marina production. For the Newport River system, 
Drifmeyer et al. (1980) claimed that eelgrass is the largest biological reservoir of manganese, iron, copper and zinc, and that growth, death and decomposition of $Z$. marina provide the major biological flux of metals in the estuary.

For turtlegrass, Thalassia testudinum, and shoal grass, Halodule wrightii, in south Texas, Parker (1962) showed that concentrations of zinc in the leaves were higher (100 ppm and $88 \mathrm{ppm}$, respectively) than the sediment concentrations (10 to $18 \mathrm{ppm}$ ) or water concentrations (8 to $15 \mathrm{ppb}$ ). The local seawater was deficient in zinc, based on the amount predicted in the water from freshwater runoff, suggesting that seagrasses are sinks for this metal. Subsequent work (Parker et al. 1963) with these two seagrasses examined the concentrations of cobalt, iron and manganese. All three metals were greatly concentrated in sediments and organisms, compared to seawater. H. wrightii accounted for much of the inventory of all three elements in the community. Concentrations of cobalt and manganese were similar between the roots and leaves of $T$. testudinum. For iron, greater concentrations were found in the roots (173 ppm in roots, $14 \mathrm{ppm}$ in leaves). Parker (1966) showed with a tracer experiment that there is a highly mobile pool of cobalt in a bay bottom community dominated by $T$. testudinum. The cobalt levels in $T$. testudinum at night were five times the noon value; cobalt is apparently readily exchanged between the sediment and the seagrass. Ragsdale and Thorhaug (1980) reviewed trace metal cycling along United States coasts and listed typical metal concentrations for $T$. testudinum (Table 6.8). They claim that cadmium is the most likely metal to be bioamplified, based on high concentration ratios (seagrass concentration/sediment concentration). Pulich (1980) examined concentrations of six metals (cadmium, zinc, copper, iron, manganese and nickel) in $H$. wrightii at seven different sites in the Corpus Christi area of Texas. Metal concentrations in both roots/rhizomes and leaves were measured. The concentration in $H$. wrightii was correlated with the sediment concentration for all six metals. Manganese, iron and zinc, all essential metals, may be concentrated because of diffusion or active uptake to meet metabolic requirements. Cadmium uptake, not an essential metal, was found to increase in seagrass tissues as a simple function of environmental concentration. Ragsdale and Thorhaug (1980) give leaf concentrations in $T$. testudinum for eight different metals, claiming that $T$. testudinum and other marine plants can serve as living filters of estuarine trace elements.

For Heterozostera tasmanica, Fabris et al. (1982) showed that cadmium concentrations in the leaves reached constant levels after eight days of exposure to a range of concentrations. Constant levels were never reached for the roots and rhizomes. These workers claimed that there is no 
translocation of cadmium between leaves and roots/rhizomes. Field measurements of cadmium concentrations in both leaves and roots/rhizomes were higher than sediment concentrations.

Summarizing the available information, the following statements can be made:

1) Metals accumulate in seagrasses from uptake by the roots in the sediment and from uptake by the leaves in the water column

2) Significant translocation of metals occurs between the below-ground (roots and rhizomes) and above-ground (leaves) portions of seagrasses

3) The concentration of metals in seagrasses is far greater than the concentration found in the sediments, water column and associated biota, making seagrasses a sink for metals

4) Different metals behave differently, where some are taken up primarily through the roots and rhizomes and others taken up through the leaves

5) Because of the tendency of seagrasses to accumulate metals, seagrasses may serve as useful bioassays of metal contamination in the near-shore marine environment. 
TABLE 6.1. Considerations for Designing Experiments on Metal Bioavailability from Sedimentary Material by Deposit Feeders (from Luoma 1989)

\section{Design Considerations}

Minimize size range within experimental population.

Animals from different populations may differ in response.

Collect allometric or other readily available biological data.

Separate influences of food and water on bioaccumulation.

Depurate undigested particulate material.

Weight specific feeding rate similar among treatments.

Organism must actually feed on experimental particulates (some benthic species are selective in choice of food).

Pre-acclimate to laboratory conditions (especially important if treatments involve changing temperature or salinity), but avoid caging stress caused by excess holding times.

Exposure Time:

-Short enough to avoid stress or behavior modification

-Long enough to achieve detectable bioaccumulation

-The closer to generation time the better the consideration of biological processes.

Geochemical gradient wide enough to test hypotheses.

Avoid or recognize changes in solution or particle chemistry caused by:

-Introduction of feeding organisms

-Equilibration within experimental systems

-Precipitation of metal

-Change in redox state of sediment

--Storage of particles for different periods of time

-Time in experimental conditions

Improvement of Sensitivity of Results

Use adequate sample size ( $>10$ individuals per sample)

Replicate experiments within treatments

Test for anomalous differences in feeding rates among individuals

Avoid growth, weight loss or change in reproductive state during experiment or between treatments

Minimize stress caused by excess exposure, caging, lack of food, etc. (Stressful conditions are

manifested by increased variability in results) 
TABLE 6.2. Factors with Potential to Affect Bioavailability of Sediment-Bound Metals to Marine Animals (Modified from Breteler and Neff 1983)

\section{Environmental Factors}

Form of metal

Particle size distribution

Sediment type

$\mathrm{pH}$ and redox status

Presence of binding agents

(e.g., Fe hydrous oxides, organic ligands)

Physical disturbance

Seasonality

(e.g., storm events, tidal wash, prop wash)

Salinity

Biological Factors

Physical Effects

Bioturbation

Biodeposition

Interspecific Differences

Detoxification

Storage and excretion

Feeding and nutrition

Metabolism

Intraspecific Differences

Size and age

Growth rate

Sex

Moulting Cycles

Reproductive condition

Location and positioning 
TABLE 6.3. Prediction of Metal Availability to Marine Benthic Organisms From Sediment Characteristics. Some examples from in situ studies. (Modified from Tessier and Campbell 1987).

Organism

Scrobicularia plana

Scrobicularia plana

Scrobicularia plana Macoma balthica Macoma balthica Modiolus demissus

Mytilus edulis $\mathrm{Hg}$
Metal Best Predictor in Sediment

$\mathrm{Pb} \quad[\mathrm{Pb}] /[\mathrm{Fe}]$ extracted with $1 \mathrm{~N} \mathrm{HCl}$

As $\quad[\mathrm{As}] /[\mathrm{Fe}]$ extracted with $1 \mathrm{~N} \mathrm{HCl}$

$\mathrm{Hg}$ [Hg] extracted with $\mathrm{HNO}_{3}$ /organic matter

$\mathrm{Hg}[\mathrm{Hg}]$ extracted with $\mathrm{HNO}_{3}$ /organic matter

$\mathrm{Cu} \quad \mathrm{Cu}]$ extracted with $1 \mathrm{~N} \mathrm{HCl}$

$\mathrm{Hg} \quad[\mathrm{Hg}]$ extracted with $1 \mathrm{~N} \mathrm{HCl}$

[Cd] extracted with $1 \mathrm{~N} \mathrm{HCl}$
Reference

Luoma \& Bryan

1978

Langston 1980

Langston 1982

Langston 1982

Luoma et al. 1985

Breteler and Saksa 1985

Breteler and Saksa 1985 
TABLE 6.4. Transfer Factors From the Literature

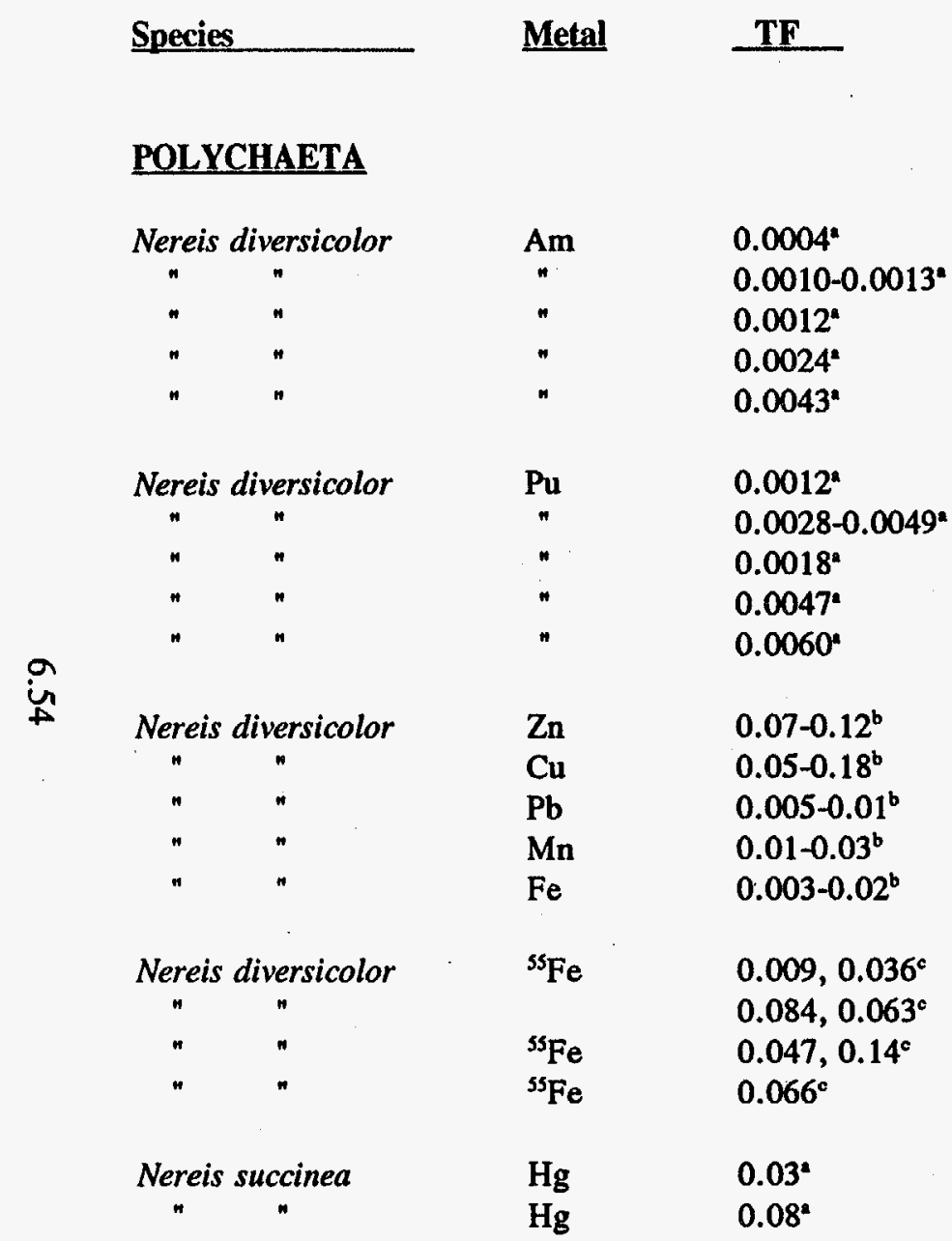

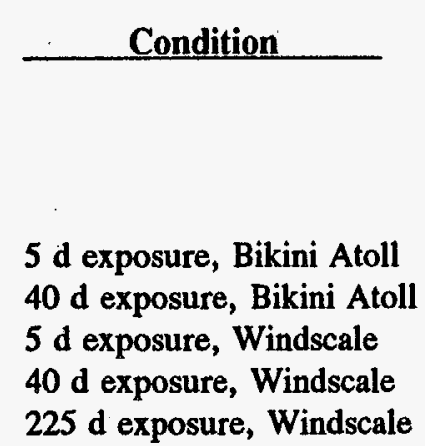

$5 \mathrm{~d}$ exposure, Bikini Atoll $40 \mathrm{~d}$ exposure, Bikini Atoll 5 dexposure, Windscale $40 \mathrm{~d}$ exposure, Windscale $225 \mathrm{~d}$ exposure, Windscale
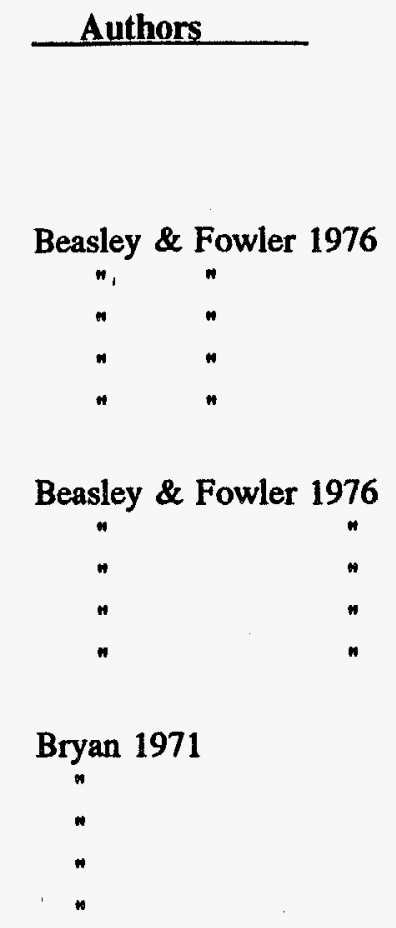

10 d, 25 d exposre, Bravo crater Jennings \& Fowler 1980 $35 \mathrm{~d}, 88 \mathrm{~d}$ exposure, Bravo crater $10 \mathrm{~d}, 25 \mathrm{~d}$ exposure, Windscale $35 \mathrm{~d}, 88 \mathrm{~d}$ exposure, Windscale

$6 \mathrm{~d}$ exposre, fed labelled sediment Luoma 1977a

$21 \mathrm{~d}$ exposre, fed labelled sediment 
Table 6.4. (contd)

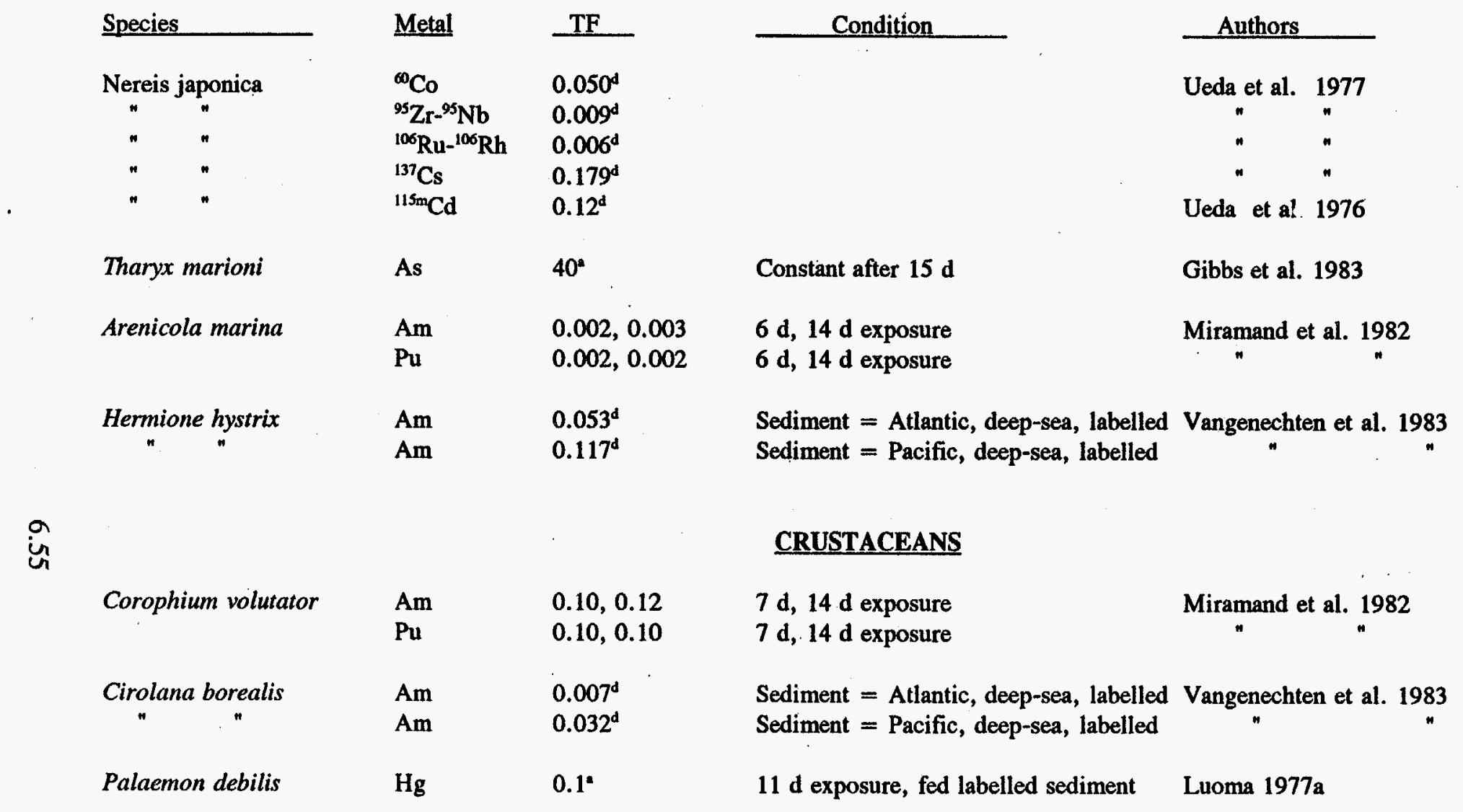


Table 6.4. (contd)

\begin{tabular}{|c|c|c|c|c|}
\hline Species & Metal & TF & Condition & Authors \\
\hline & & & BIVALVES & \\
\hline$\underset{n}{\text { Gomphina melanaegis }}$ & $\begin{array}{l}{ }^{137} \mathrm{Cs} \\
{ }^{106} \mathrm{Tu}-{ }^{106} \mathrm{Rh}\end{array}$ & $\begin{array}{l}0.045^{d} \\
0.0007^{d}\end{array}$ & & Ueda et al. 1978 \\
\hline Tapes descussatus & ${ }^{95} \mathrm{Tc}$ & $0.09-019^{c}$ & ${ }^{95} \mathrm{Tc}$ IV & Fowler et al. 1983 \\
\hline$n$ & ${ }^{95} \mathrm{Tc}$ & $0.10-0.23^{\circ}$ & ${ }^{95} \mathrm{Tc}$ VII & " " \\
\hline " & ${ }^{95} \mathrm{Tc}$ & $0.08-0.60^{c}$ & Soft Parts, ${ }^{95} \mathrm{Tc}$ IV \& VII combined & $"$ \\
\hline Scrobicularia plana & $\mathrm{Hg}$ & $0.3-7.0^{*}$ & $\begin{array}{l}\text { Calculated for various estuaries } \\
\text { from data in text }\end{array}$ & Langston 1982 \\
\hline Scrobicularia plana & $\begin{array}{l}\mathrm{Am} \\
\mathrm{Pu}\end{array}$ & $\begin{array}{l}0.007,0.009^{d} \\
0.01,0.01^{d}\end{array}$ & $7 \mathrm{~d}, 14 \mathrm{~d}$ exposure & $\underset{n}{\operatorname{Miramand}}$ et al. ${ }_{n} 1982$ \\
\hline Venerupis decussata & Am & $0.004^{d}$ & Sediment $=$ Atlantic, deep-sea, labelled & Vangenechten et al. 1983 \\
\hline & Am & $0.02^{\circ}$ & Sediment = Pacific, deep-sea, labelled & \\
\hline Macoma balthica & $\mathrm{Hg}$ & $0.4-6.4^{2}$ & $\begin{array}{l}\text { Calculated for various estuaries } \\
\text { from data in text }\end{array}$ & Langston 1982 \\
\hline Macoma balthica & Cd & $0.131^{2}$ & Sediment from San Francisco Bay & Luoma \& Jenne 1976 \\
\hline " n & Cd & $0.030^{\circ}$ & Sediment $=\mathrm{Fe}_{x} \mathrm{O}_{y} \mathrm{I}$ & " n \\
\hline " & Cd & $0.031^{*}$ & Sediment $=\mathrm{Fe}_{x} \mathrm{O}_{y} \mathrm{II}$ & $"$ \\
\hline$"$ & Cd & $0.049^{*}$ & Sediment $=\mathrm{Fe}_{x} \mathrm{O}_{y}$ III & " \\
\hline Macoma balthica & Ag & $3.7-6.1^{2}$ & Sediment $=$ Calcite & Luoma \& Jenne 1977 \\
\hline " " " & $\mathrm{Ag}$ & $0.4-0.8^{\mathrm{a}}$ & Sediment $=\mathrm{MnO}_{\mathrm{x}}$ & $"$ \\
\hline " & $\mathrm{Ag}$ & $0.04-0.15^{\mathrm{a}}$ & Sediment $=\mathrm{Fe}_{\mathrm{x}} \mathrm{O}_{\mathrm{y}}$ & $"$ \\
\hline " & Ag & $0.03-0.08^{8}$ & Sediment $=$ biogenic $\mathrm{CaCO}_{3}$ & $"$ \\
\hline n & Ag & $0.03^{\mathrm{a}}$ & Sediment $=$ organics & $"$ \\
\hline
\end{tabular}


Table 6.4. (contd)

\begin{tabular}{|c|c|c|c|c|c|c|}
\hline \multicolumn{2}{|c|}{ Species } & Metal & $\mathrm{TF}$ & Condition & \multicolumn{2}{|c|}{ Authors } \\
\hline \multicolumn{2}{|c|}{ Macoma balthica } & Ag & $-0.72^{\circ}$ & Sediment $=$ iron oxide & \multicolumn{2}{|c|}{ Harvey \& Luom } \\
\hline$n$ & " & Ag & 1.34 & $\begin{array}{l}\text { Sediment = iron oxide with } \\
68 \mathrm{mg} / \mathrm{l} \text { of exopolymer }\end{array}$ & " & $n$ \\
\hline$"$ & " & $\mathrm{Zn}$ & $0.01-0.046$ & $\begin{array}{l}\text { Sediment = iron oxide with } \\
\text { varying amounts of exopolymer added }\end{array}$ & $"$ & " \\
\hline " & " & $\mathrm{Cd}$ & $0.006-0.012$ & $\begin{array}{l}\text { Sediment }=\text { iron oxide with } \\
\text { varying amounts of exopolymer added }\end{array}$ & " & $"$ \\
\hline & & \multicolumn{5}{|c|}{ OTHER INVERTEBRATES } \\
\hline \multicolumn{2}{|c|}{ Various Invertebrates } & ${ }^{109} \mathrm{Cd}$ & $2-201^{\circ}$ & & \multicolumn{2}{|c|}{ Frithsen 1984} \\
\hline " & $n$ & ${ }^{51} \mathrm{Cr}$ & $22^{c}$ & . & $n$ & $\infty$ \\
\hline " & " & ${ }^{60} \mathrm{Co}$ & $3-35^{c}$ & & " & n \\
\hline " & " & ${ }^{59} \mathrm{Fe}$ & $6^{\circ}$ & & n & " \\
\hline " & " & ${ }^{54} \mathrm{Mn}$ & $4-11^{\circ}$ & & " & n \\
\hline " & $"$ & ${ }^{203} \mathrm{Hg}$ & $1-24^{\circ}$ & & " & " \\
\hline$"$ & " & ${ }^{113} \mathrm{Sn}$ & $1-7^{c}$ & & " & " \\
\hline$n$ & " & ${ }^{\infty} \mathrm{Zn}$ & $2-8^{c}$ & & " & n \\
\hline
\end{tabular}

* Dry wt tissues/dry wt sediments.

b Wet wt tissues/dry wt sediments.

- dpm tissues dry wt/dpm sediments dry wt.

d dpm tissues wet wt/dpm sediments wet wt.

- Based on the difference between feeding and nonfeeding clams. 
Table 6.5. Published Bioaccumulation Factors of Organic Contaminants for Marine Organisms

Species

Contaminant

Crustacea

Uca minax

U. pugilator

U. pugilator

Palaemonetes pugio

Mollusca

Mercenaria mercenaria

Protothaca staminea

Annelida

Nereis virens

Nereis virens

Nereis diversicolor

Arenicola marina
PCB

PCB

PCB

PCB

PCB

Petroleum

PCB

PCB

PCB
$<0.5$

$0.16-0.18$

4.7-10.8

0.19-0.79

$0.19-0.19$

$0.6-1.3$

0.5

$0.15-1.59$

$0.39-0.49$

$0.39-0.49$
Reference

Clark et al. 1986

Clark et al. 1986

Nimmo et al. 1971

Rubinstein et al. 1983

Rubinstein et al. 1983

Anderson et al. 1983

McLeese et al. $1980 \mathrm{~b}$

Rubinstein et al. 1983

Courtney and Langston 1978

Courtney and Langston 1978 


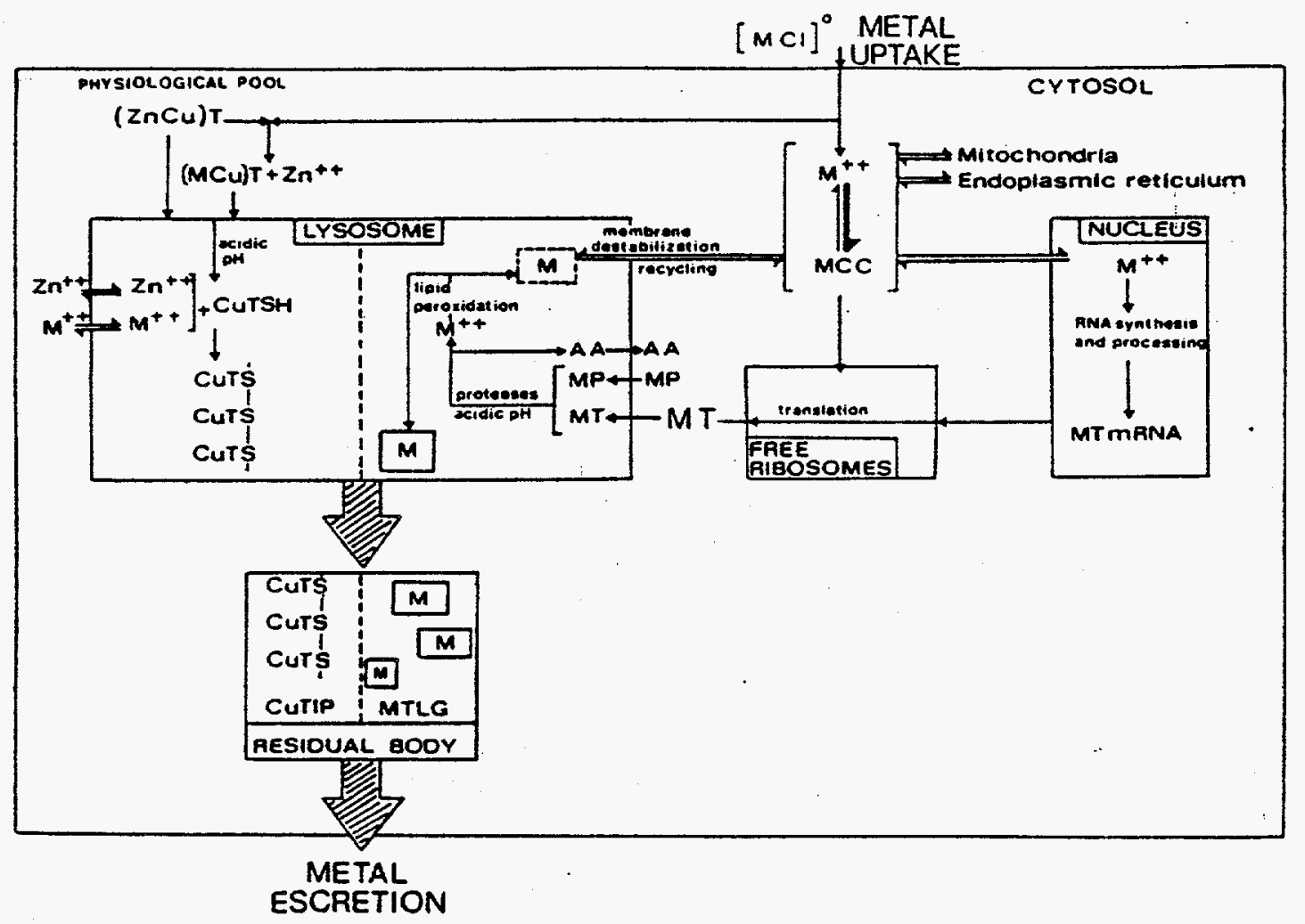

FIGURE 6.1. The Role of Metallothioneins and Lysosomes in Metal Homeostasis (After Viarengo 1986). $\mathbf{M}_{2+}=$ divalent metal cation, $\mathrm{MCC}=$ metal bound to cytosolic components, MT = metallothioneeins, $\mathrm{MP}=$ metal bound to enzymatic and structural proteins, $\mathrm{AA}=$ amino acids, $\mathrm{M}$ in dotted box = metal weakly bound to lipid peroxidation products, $M$ in solid box = metal bound to lypofuscin granules in a noninterchangeablemanner, $\mathrm{CuTiP}=\mathrm{Cu}$-thionein insluble polymer, $\mathrm{MTLG}=$ metals trapped in lypofuxcin granules. 


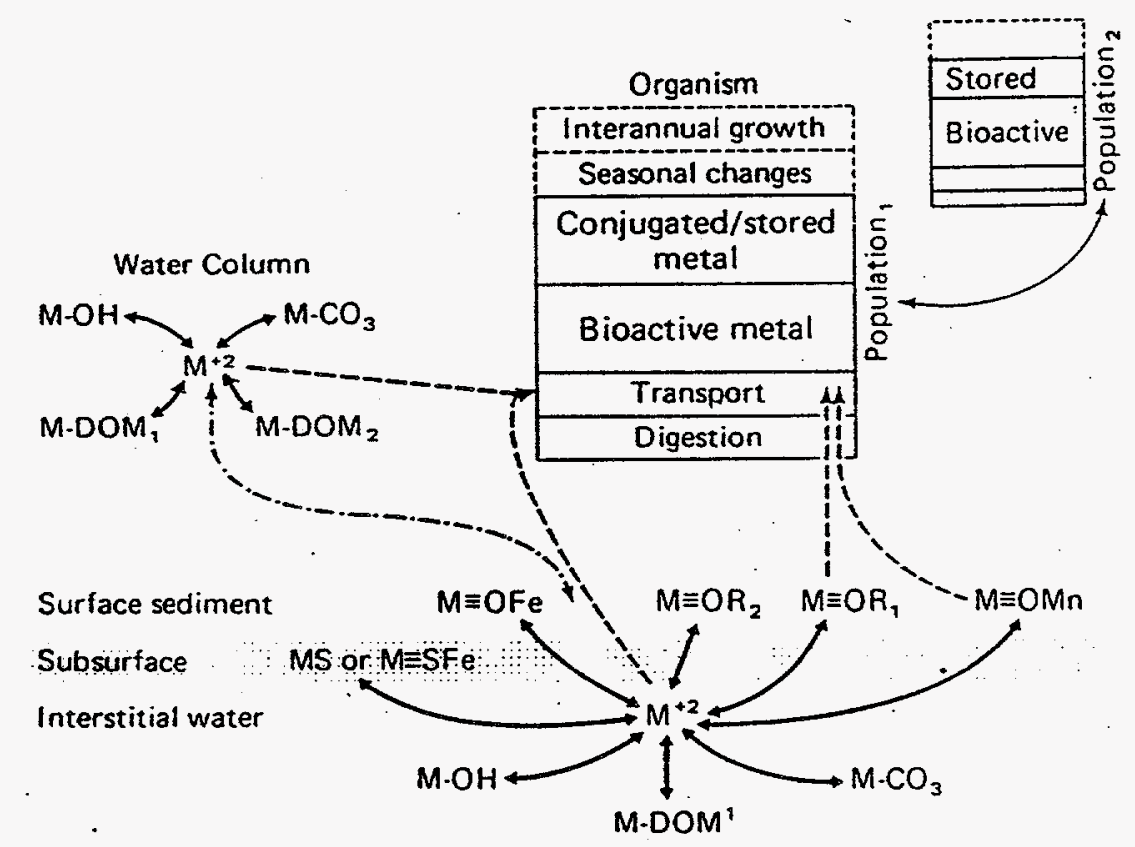

FIGURE 6.2. Metal Reactions Affecting Bioavailability to Deposit-Feeders (after Luoma 1989). Items within boxes represent biological processes that influence bioaccumulation. Dashed borders signify the importance of a process can change over time. 


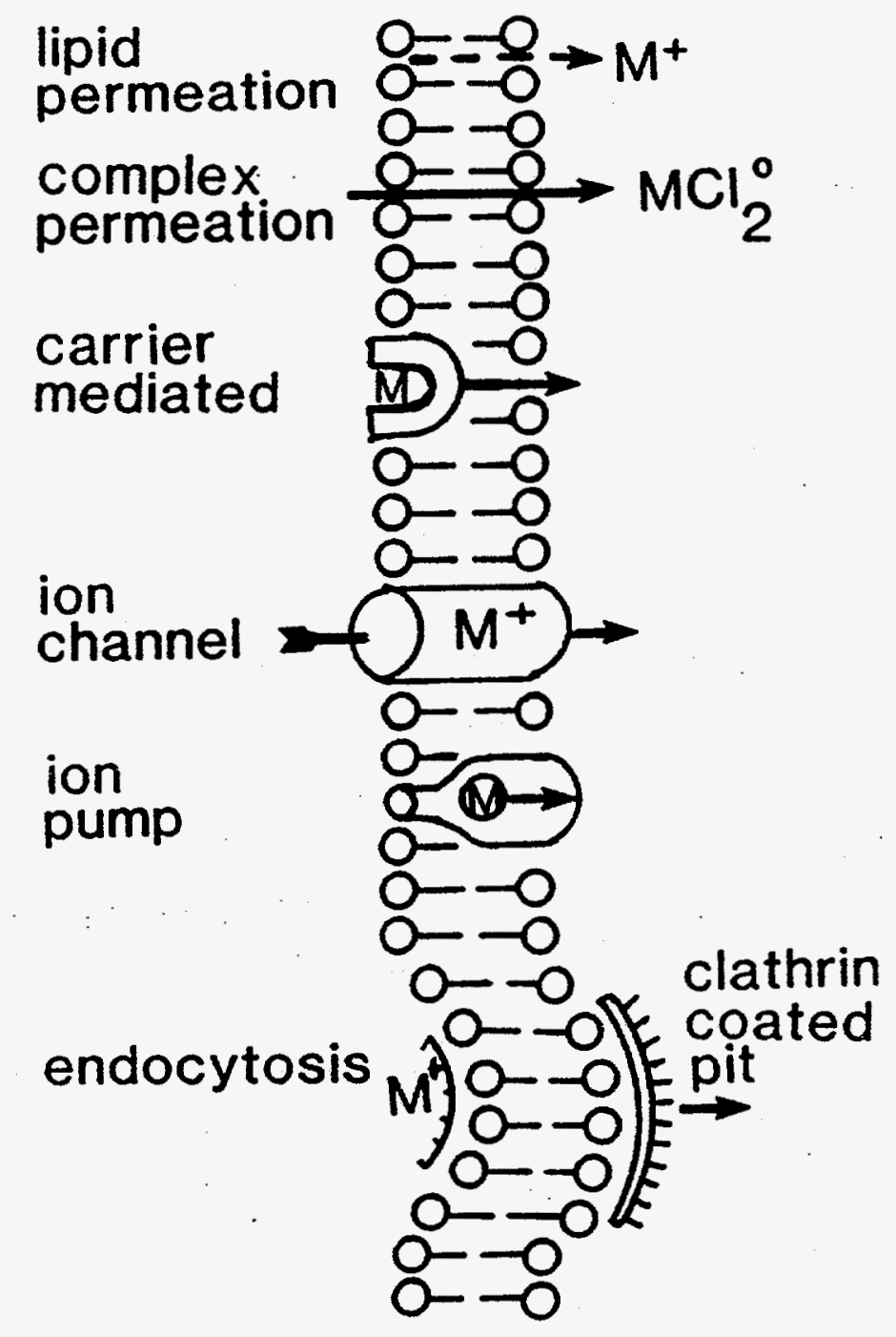

FIGURE 6.3. Possible Mechanisms Explaining Fluxes of ions Into Cells (after Simkiss and Taylor 1989). 


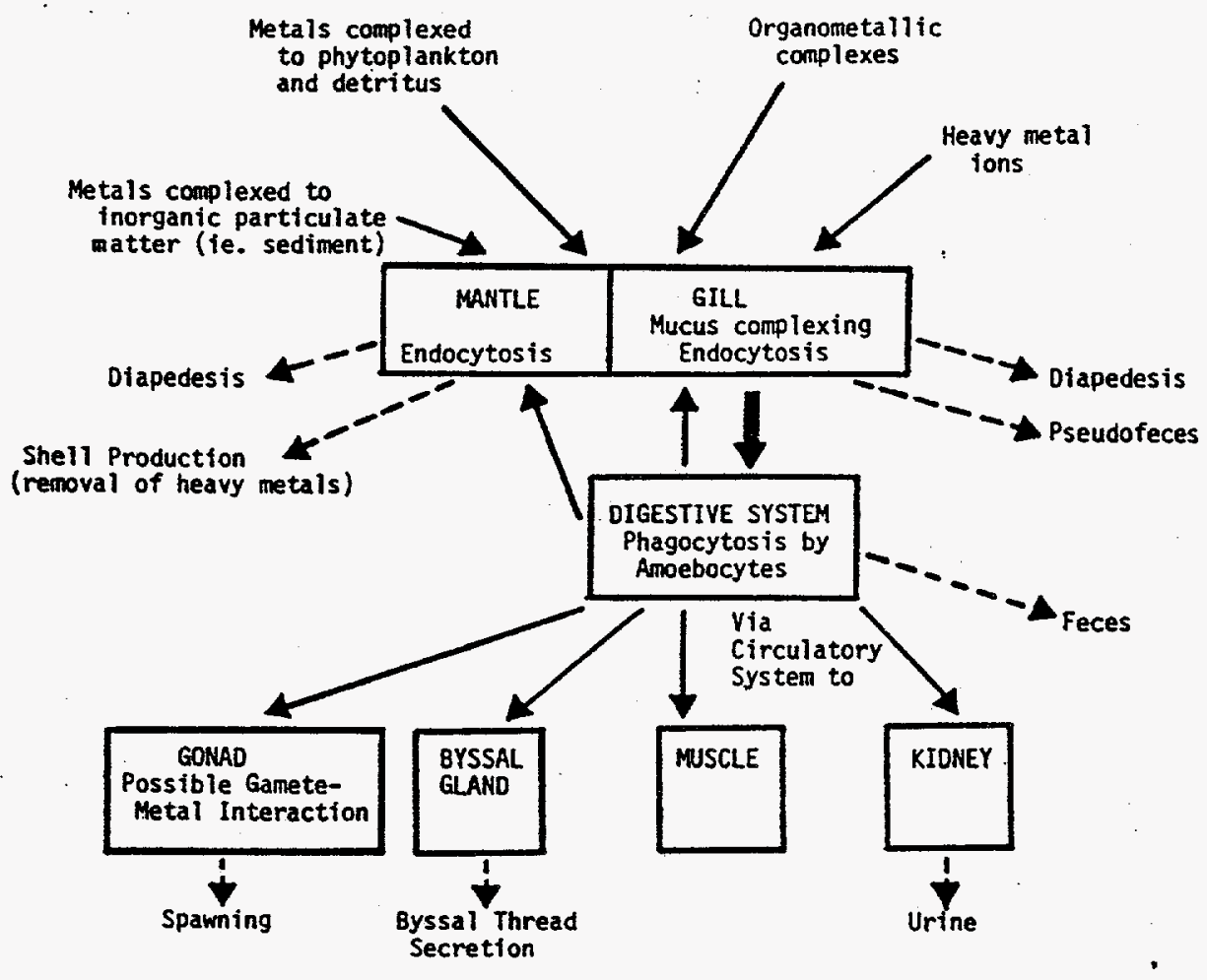

FIGURE 6.4. Possible Pathways of Accumulation of Meachanisms for Loss of Heavy Metals in Bivavles (after Cunningham 1979). 


\subsection{BIOACCUMMULATION AND BIOAVAILABILITY OF ORGANIC CONTAMINANTS}

\subsection{INTRODUCTION}

Although marine organisms contain elevated concentrations of contaminants in soft-sediment ecosystems, the source of the contamination is infrequently determined. Figure 7.1, modified from Lee and Jones (1979), presents a schematic representation of the pathways of contaminants in soft-sediment habitats to marine organisms. Five distinct sources can be identified. First, contaminants may enter organisms from the water overlying the sediment. Second, contaminants may originate from the interstitial water in the sediment. Interstitial water is formed due to the entrainment of water during the sedimentation process and is essentially isolated from the water column (Batley and Giles 1980a,b). The amount of interstitial water available depends in part on sediment porosity (determined by particle size distribution and degree of compaction). Third, contaminants sorbed to sediment particles may be taken up by organisms. Fourth, contaminants may be transferred along the food chain (a more extensive consideration of contaminant uptake via trophic transfer is the thrust of Chapter 8; limited information will be provided in this chapter). Lastly, and only recently appreciated, contaminants may bind to dissolved organic matter (DOM). It is instructive to consider these five sources of contaminants along with soft-sediment organisms as reactants in a dynamic equilibrium. To understand fully the bioavailability of sediment-bound contaminants, the relative contributions of each of the five sources of contamination for marine organisms must be quantified.

\subsection{POTENTIAL SOURCES OF ORGANIC CONTAMINANTS FOR UPTAKE}

To facilitate reading of this section, we consider three classes of organic contaminants: petroleum hydrocarbons or polycyclic aromatic hydrocarbons, including the much-studied polyaromatic hydrocarbons (PAH); polychlorinated biphenyls (PCB); and organic pesticides. For each class of compounds, we first review studies which address the importance of single sources of contaminants for marine organisms. Then, we consider studies which have compared the relative importance of two or more of these sources. Finally, we end with an overview, summarizing our present knowledge of the relative importance of the five sources of contaminants. 
There is a huge literature describing the uptake of contaminants from seawater by marine organisms (e.g., Anderson 1979, Huggett et al. 1987); for some of these studies, contaminants may have entered the water column from sediments. A review of such studies is found in Chapter 4 . In this review, we address uptake from the overlying water only for those studies where at least one other source of contaminants is compared (Figure 7.1).

\subsubsection{PAH and Other Petroleum Hydrocarbons}

Some of the most convincing data for interstitial water as a source of contamination were obtained by Di Toro (1988) who presented data on the toxic effects of various organic pollutants as a function of interstitial water concentrations. The results consistently showed greater toxic effects at higher interstitial water concentrations. Foster and Wright (1988) measured the concentrations of unsubstituted PAH in sediments, in the bivalve, Macoma inquinata, and in the polychaete, Nereis succinea, at seven sites in the Chesapeake Bay. The levels of these contaminants were directly related to corresponding concentrations in the sediment. Accumulation of contaminants was greater in coarser grained sediments compared to fine grained sediments. Because coarser sediments have greater interstitial space than fine sediments, these data suggest that the interstitial water is the source of contaminants taken up by these two infaunal organisms. Other work on interstitial water which has compared other sources of contaminants is reviewed below.

Sediment-sorbed contaminants as a source of marine organism contamination were examined by Staples et al. (1985). They presented a model predicting the influence of suspended sediments on the bioavailability of neutral organic chemicals in the water column. This study therefore examines the importance of sediment-sorbed particles in the absence of interstitial water. Parameters for their model were generated by measuring uptake of acenapthene, chrysene and the organic pesticide, dieldrin. Their model predicts that for most neutral organic chemicals to be bioavailable, the chemicals must be in solution. The data therefore strongly suggest that the accumulation of contaminants from sediment-sorbed particles is negligible.

Relevant data were presented by Fossato and Canzonier (1976) who indicated that suspension-feeding bivalves accumulated petroleum hydrocarbons by ingestion of particulate matter to which contaminants were sorbed.

Anderson et al. (1977) examined the bioavailability of petroleum hydrocarbons from Prudhoe crude oil on the sipunculan worm, Phascolosoma agassizii. The worms concentrated naphthalenes 
two to ten times the concentration in water. Oil was placed on the sediment in one treatment and mixed into the sediment in another treatment. In both treatments, the accumulation of naphthalenes was the same ( 2 to $4 \mathrm{ppm}$ in the tissues). The naphthalene concentrations of the sediments corresponded closely with the concentration in the tissues and may therefore indicate ingestion of oiled sediment. Thus, the likely source of contaminants is sediments to which naphthalene was sorbed.

Similar results were obtained by Roesijadi et al. $(1978 \mathrm{a}, \mathrm{b})$ who showed that when crude oil was strongly attached to sand by evaporation from solution in ether, its naphthalene content was not absorbed by the bivalve, Macoma inquinata, even though contaminated sediment particles were found in the gut and feces. Similarly, Anderson et al. (1977) reported that the sipunculan worm, Phascolosoma agassizii, did not concentrate naphthalenes above levels present in the exposure sediment.

Prouse and Gordon (1976) presented data for the polychaete, Arenicola marina, which showed that hydrocarbon concentrations in the fecal casts were significantly lower than concentrations in the surrounding sediment. The data suggest that contaminants were desorbed from the sediment particles. However, no samples of ingested sediment were taken. It is possible that Arenicola ingested grains that were relatively uncontaminated.

Rossi (1977) exposed the polychaete, Nereis arenaceodentata, to sediment contaminated with No. 2 fuel oil. The worms failed to accumulate naphthalenes from the sediment although sediment was ingested and passed through their guts. The clam, Rangia cuneata, accumulated naphthalenes from contaminated sediment but tissue concentrations never approached environmental concentrations (Lunsford et al. 1987). Foster et al. (1987) presented data to examine the effects of sediment-sorbed PAH (naphthalene, chrysene) in the bivalves, Macoma balthica and Mya arenaria. Macoma accumulated the labeled (deuterated) contaminants at measurable rates, in inverse proportion to the water solubilities of the sorbed chemicals. Mya did not exhibit any bioaccumulation of the sediment-sorbed chemicals.

Contamination along the trophic chain has been examined for the English sole, Parophrys vetulus. Malins et al. (1985) showed that sole from Mukilteo, Washington, had hepatic neoplasms which are associated with high PAH concentrations in the sediment. Because these fish feed at the sediment surface and hence are not likely to be exposed to interstitial water, the authors infer that 
trophic transfer is the likely source of contamination for these predators; definitive data were not provided. The inferences drawn, however, fail to agree with McCain et al. (1978) who found that English sole exposed to an artificially oiled sediment in the laboratory readily accumulated alkane and aromatic petroleum hydrocarbons in the skin, muscle and liver.

For juvenile blue crabs, Callinectes sapidus, Lee et al. (1976) demonstrated the uptake of naphthalene, methylnaphthalene, fluorene and benzo-a-pyrene (BaP) from food. Similarly, Lee (1977) showed that various species of decapod crustaceans (shrimp, crabs, and lobster were tested) rapidly take up petroleum hydrocarbons from their food. For all examples, little evidence of biomagnification through the food chain exists. A thorough treatment of the effect of feeding on bioaccumulation is given in Chapter 8. Typical data indicate that concentration factors for fish exposed to contaminants in food range between and and seven, compared to values of 61,000 to 100,000 for water (Mayer et al. 1977). Clark et al. (1990) used a mathematical model to examine dietary uptake of organic contaminants by fish, showing that uptake from the water tends to result in higher contaminant uptake than that taken up through the dietary route.

Ekelund et al. (1987) examined uptake of hexachlorobenzene by the deposit-feeding bivalve, Abra nitida. They showed that accumulation increased when suspended solids were added to the system. The contaminant apparently sorbed to the suspended solids, increasing the bioavailability for these deposit-feeding bivalves. Uptake from the water (e.g., in transfer across the gills) is contradicted because the presence of suspended particles decreases the concentration of contaminant in the water column.

Data on the importance of DOM were presented Sanborn and Malins (1977) who showed that ${ }^{14} \mathrm{C}$-naphthalene was accumulated nearly four times faster than ${ }^{14} \mathrm{C}$-naphthalene bound to bovine serum albumen. For the clam, Mercenaria mercenaria, Boehm and Quinn (1973) showed that the presence of DOM decreased the uptake of hexadecane and No. 2 fuel oil, but had no effect on the uptake of phenanthrene. McCarthy and Jimenez $(1985 \mathrm{a}, \mathrm{b})$ indicate that PAH binds to dissolved humic material with a direct relationship between the hydrophobicity of the PAH and the affinity for binding to DOM. These results strongly suggest that the presence of DOM or other sorptive components of the dissolved organic pool may affect binding to sediment or suspended particles, and thus, alter the fate and transport of organic contaminants. Specifically, data are provided which indicate that PAH bound to DOM is not bioavailable for the freshwater cladoceran crustacean, Daphnia magna (McCarthy 1983, McCarthy et al. 1985). Similarly, DOM decreased the uptake of PAH by bluegill sunfish, 
Lepomis macrochirus; the rate of uptake of PAH complexed to DOM is $0 \%$ to $10 \%$ of that for PAH dissolved without DOM present. McCarthy and Black (1987) estimated that failure to consider DOM sorbents leads to $50 \%$ to $90 \%$ errors in predictions about the exposure of aquatic organisms to contaminants. These authors show that the presence of DOM in the form of Aldrich humic acid decreased the bioavailability of benzo-[a]-pyrene which bound to the DOM particles. Such binding is particularly important for fish which pass large amounts of water across their gill membranes. Only contaminants that are freely dissolved can diffuse across gill membranes.

A number of studies demonstrate uptake of contaminants in soft-sediment habitats but fail to identify the precise source. The most common type of such studies can be characterized as failing to distinguish between the interstitial water and sediment particles to which contaminants are sorbed. From freshwater environments, Dauble et al. (1983) measured the effects of coal liquid in artificially contaminated sediments. Significant mortality of the chironomid insect larvae, Chironomus tentans, was noted but the source of the contaminant was not determined.

Augenfeld et al. (1982) placed the bivalve, Macoma inquinata, and the polychaete annelid, Abarenicola pacifica, in a fine sediment to which was added ${ }^{14} \mathrm{C}$-labeled phenanthrene, chrysene or benzo-[a]-pyrene (BaP). For Abarenicola, all of the chrysene and $\mathrm{BaP}$ and $70 \%$ of the phenanthrene was retained in the sediment, indicating that the sediment served as a source of phenanthrene, but not the other two contaminants for this polychaete. However, for Macoma, only $8 \%$ of the phenanthrene was recovered from the sediment along with $70 \%$ of the remaining two contaminants, indicating significant uptake, particularly for phenanthrene. The data clearly show risk of contamination for these organisms in sediment which has been contaminated, but the relative importance of sediment-sorbed contaminants and contaminants dissolved in the interstitial water is not known.

For the marine bivalve, Protothaca staminea, Anderson et al. (1983) showed that greater tissue contamination of PAH occurred in Sequim Bay where oil was mixed into the sediment compared to areas where oil was merely spread onto the surface of the sediment. The data cannot differentiate between contaminants sorbed onto sediment particles and those dissolved in the interstitial water as sources. Similar results for English sole were obtained by Stein et al. (1987) who examined the accumulation of PAH in the laboratory. Sole were exposed to an urban sediment for $108 \mathrm{~d}$ using sole exposed to a clean reference sediment as comparison. The concentrations of radio-labeled $\mathrm{BaP}$ reached concentrations of $4.4 \mathrm{nmole} / \mathrm{g}$ wet wt of the liver. The data indicate clearly that English sole accumulates contaminants, particularly BaP, from the sediment but the source was not identified. 
Varanasi et al. (1985) exposed two amphipod species, Rhepoxynius abronius and Eohaustorius washingtonianus, the bivalve, Macoma nasuta, the decapod prawn, Pandalus platyceros, and the English sole to an urban estuarine sediment containing $16 \mathrm{ppm}$ of PAH. Trace amounts of ${ }^{3} \mathrm{H}-\mathrm{BaP}$ were added. By measuring the rate of PAH metabolism for these species, these authors found that not all of the BaP (and presumably other PAH), extracted chemically from the sediment, was bioavailable. Once again, the relative contribution of sediment-sorbed contaminants and contaminants dissolved in interstitial water cannot be determined from this careful study.

Lake et al. (1987) conducted laboratory experiments to determine the effect of suspended sediments on accumulation of both PAH and PCBs in the blue mussel, Mytilus edulis, and the polychaete, Nereis virens. They found that lower weight compounds were accumulated at higher concentrations than heavier compounds. It was not possible to determine the dominant pathway of uptake of these contaminants from this study. The polychaetes did not feed during the course of the experiment so transfer across the gut epithelium cannot explain contaminant uptake in this species.

Several studies have explicitly attempted to determine the source of contaminants in soft-sediment environments. Roesijadi et al. (1978b) found that similar levels of hydrocarbons were accumulated by the bivalve, Macoma inquinata, placed in contaminated sediment or held in the water column above the sediment. The experiment used ${ }^{14} \mathrm{C}$-labeled phenanthrene, chrysene, dimethyl[benz]anthracene and $\mathrm{BaP}$. The authors concluded that sediment-sorbed contaminants were not as bioavailable as the chemicals leached into the interstitial water. The authors, however, failed to appreciate that the overlying water and the interstitial water are two distinct sources (Batley and Giles $1980 \mathrm{a}, \mathrm{b})$, despite limited diffusion from the interstitial water to the overlying water column. Thus, these data are best interpreted to show that uptake from the overlying water is greater than uptake from the sediment, either from contaminants sorbed to the sediment particles or dissolved in the interstitial water. Neff and Anderson (1981) interpret these data and similar results on the polychaete, Abarenicola marina (Lyes 1979), to results from contaminants desorbed from sediment particles into the interstitial water. Similar studies have been conducted using the freshwater amphipods, Gammarus pseudolimnaeus and Hyalella azteca (Lynch and Johnson 1982, Landrum and Scavia 1983). Results were similar in that amphipods accumulated contaminants to a greater degree when placed above the sediment compared to placement within the sediment.

Neff and Anderson (1981) presented data from experiments designed to measure the bioavailability of sediment-sorbed petroleum hydrocarbons to the clam, Rangia cuneata.. Four 
treatments were used. In one, clams were maintained in oil-contaminated sediment with only their siphons exposed to the overlying water. The second treatment involved the addition of grass shrimp, Palaemonetes pugio, which roiled the bottom, keeping sediment particles in suspension. The remaining two treatments involved the same sediment treatments as above, but the clams were maintained $10 \mathrm{~cm}$ above the sediment surface. Little uptake of naphthalenes was found in any treatment. The authors argue that any uptake must be attributed to water because the clams maintained within contaminated sediment accumulated no more naphthalenes than those suspended above the sediment surface. The experiment was replicated using more heavily contaminated sediment. The data again indicated that uptake from the overlying water was the main avenue of uptake but that clams have a limited ability to take up contaminants from contaminated sediments.

A careful study with the amphipod, Pontoporeia hoyi, showed that uptake of selected PAH occurs largely via the interstitial water and is kinematically controlled by desorption of sediment particles and DOM (Landrum et al. 1987, Landrum 1989). The data suggest that assimilation from ingested material may be more significant for strongly sorbed compounds such as BaP. The desorption rate of contamination from the sediment matrix appears to determine if the major sediment contaminant source is interstitial water or ingested particles. The intriguing results indicate that bioavailability of sediment-sorbed contaminants declined as contact time between the sediment and contaminant increased; and chemical extractability remained high even though bioavailability was reduced. The author points out that the relationship between chemical and biological availability needs more work.

Field studies by Pereira et al. (1988) in the vicinity of an industrial outfall in the Calcasieu River estuary, Louisiana, provided data on the roles of water, bottom sediment and suspended sediment as sources of contamination for benthic biota. The authors were unable to obtain agreement between the predicted equilibrium concentrations of contaminants with the actual concentrations of contaminants for water, suspended sediments and biota. No predictable patterns emerged in their study. Biota and sediments are obviously major sinks for PAH but there appears to be a lack of equilibrium for contaminants in the compartments shown in Figure 7.1.

The work to date has begun to provide data on the rates of exchange between marine organisms and the five sources given in Figure 7.1. No one has provided data which examines the relative importance of all the sources simultaneously for a given system. General trends which are emerging are that contamination via the food chain is likely of limited importance. The presence of 
DOM in the interstitial water is likely to reduce bioavailability as the DOM competes with organisms for the contaminants. Although sediment-sorbed contaminants can be taken up, the present data indicate that the interstitial water is likely to be the major source of contamination for sediment-associated organisms, confirming the conclusion of Neff $(1979 a, b)$. Although contaminants are generally readily taken up by organisms from the overlying water, the solubility of PAH is low and therefore concentrations of contaminants in the overlying water is low. Clearly, work to establish the strengths of the interactions in the dynamic equilibrium of Figure 7.1 is sorely needed.

The realization of thorough understanding will have to overcome several recognized complications and, doubtless, others not presently appreciated. Depuration of contaminants by marine organisms confounds measurement. It is not clear if flow-through chronic exposures or acute exposures are more biologically relevant. It would seem that flow-through systems would more accurately mimic field conditions but organisms in the field are not subjected to a constant level of contaminants as water currents shift in the field, carrying different concentrations of contaminants. Landrum's (1989) finding that chemical and biological availability are not equivalent is a particularly vexing problem to overcome. The basis for toxicity needs to be determined for contaminants before interpretation can be made. For instance, Rice et al. (1977) concluded that petroleum hydrocarbon toxicity is due to chemical toxicity of the soluble aromatics rather than the physical toxicity of dispersed oil droplets. Neff et al. (1976) claim that acute toxicity increases with increasing molecular weight, corresponding to decreasing water solubility. Taxonomic differences (reviewed below) must be accommodated. Finally, a biologically meaningful study will likely require working on smaller scales than heretofore examined. For instance, it is quite likely that a sediment particle at the sediment surface differs significantly from a particle at depth, because of differences in ages (residence times) of the sediment particles. Therefore, study at the level of millimeters or even smaller appears to be necessary.

\subsubsection{Polychlorinated Biphenyls}

As indicated for polyaromatic hydrocarbons above, there is a considerable literature on the effects of PCBs on marine organisms. Many authors have addressed single pathways of uptake but relatively few studies have sought to examine the relative importance of all the pathways depicted in Figure 7.1. As shown for PAH, uptake of PCBs from the water column is a known pathway (e.g., Hamelink et al. 1971, Scura and Theilacker 1977, Ellgehausen et al. 1980). However, these data are largely beyond the scope of this report on sediment-bound contaminants. Generally, sediment 
concentrations of PCBs are far higher than concentrations in the water column (Neff and Breteler 1983), particularly since PCBs have such a low solubility in water. In fact, Clark et al. (1986) demonstrated that PCBs from contaminated sediment did not leach into the water column at all in laboratory experiments.

Trophic transfer of PCBs by marine organisms has been well documented; this information is thoroughly reviewed in Chapter 8 . The short treatment here serves only to assess the relative importance of food as a source for contaminants in marine organisms. McLeese et al. (1980a) showed that American lobsters, Homarus americanus, accumulated tetrachlorobiphenyl and hexachlorobiphenyl in their hepatopancreas when fed blue mussels, Mytilus edulis, which had been previously contaminated with these PCBs. Diet has been implicated in a number of studies as a major source of body residues for a number of fish species (Bruggeman et al. 1981, Pizza and O'Connor 1983, Thomann and Connolly 1984). Convincing data using ${ }^{14} \mathrm{C}$-labeled Aroclor 1254 demonstrated uptake by food for the striped bass, Morone saxatilis, fed natural food, and the amphipod, Gammarus tigrinus, which had been previously contaminated (Pizza and O'Connor 1983). Two difficulties in determining the amount of contaminant transferred by diet were surmounted in this study: difficulty in quantifying secondary gill uptake of contaminants which desorb or dissolve prior to ingestion and (2) difficulty in accurately quantifying the ingested dose. In this study, the bass were fed by force-feeding. By using a mass-balance approach, Oliver and Niimi (1988) examined the accumulation of PCBs by salmonids in Lake Ontario. The authors showed that bioaccumulation was higher than that predicted from bioconcentration alone, indicating that contaminated food is a significant source of these contaminants for these fish.

Some data indicate that PCBs are bioavailable to marine organisms via the interstitial water pathway. Dexter and Pavlou (1978) argued that the predominance of lower chlorinated and more water-soluble PCB isomers in the shrimp, Crangon septemspinosa, indicate the probable source of PCBs for these epifaunal animals is from PCBs desorbed from the sediment into the interstitial water. Langston (1978a,b) evaporated PCBs onto particles of aluminum oxide and found PCBs were accumulated by the clam, Macoma balthica.

The studies described in the following paragraphs have sought to quantify the relative importance of two or more of the pathways indicated in Figure 7.1. Nimmo et al. (1971) placed the fiddler crab, Uca pugilator, and the pink shrimp, Penaeus duorarum, in aquaria with sediment substrates from contaminated areas. The animals accumulated Aroclor 1254 in their tissues by either 
ingesting contaminated sediment or by absorbing the leached chemical from either the interstitial water or the water overlying the sediment. In most cases, the concentration of PCBs in the hepatopancreas of the two crustaceans was directly related to the amount of chemical in the sediment. These data cannot distinguish the pathway of contamination, particularly for the deposit-feeding fiddler crabs.

Fowler et al. (1978b) measured the uptake of PCB from contaminated sediment and water in the polychaete, Nereis diversicolor. As expected, uptake from water was much more rapid given the low solubilities of PCBs in water and the high affinity of PCBs for sorbing to sediment particles. However, calculations based on the experimentally observed uptake and the concentrations in water and in sediments suggest that the sediments contribute the bulk of these contaminants to the worms. Unfortunately, the data do not distinguish between interstitial water and sediment-sorbed contaminants.

Boese et al. (1988) found for the bivalve, Macoma nasuta, that $63 \%$ to $84 \%$ of the uptake of hexachlorobenzene was by the gut, presumably from sediment to which the PCB was sorbed. Uptake from interstitial water ventilated across the gills accounted for $11 \%$ of the tissue residues. The data indicate that sediment-bound PCBs are bioavailable from both sediment-sorbed PCBs and PCBs dissolved in the interstitial water. Boese et al. (1988) identified the gills as the primary site of bioaccumulation of PCBs for this clam. In areas of low oxygen concentration, the bivalves may suffer to a greater degree because of the need for increased ventilation of the gills.

Shaw and Connell (1982) studied PCB uptake in Brisbane River estuary biota. They found maximum concentrations in higher order predators, namely pelicans, gulls and catfish. Biomagnification was found only in pelicans and gulls. For these two predators, accumulation through the diet may be the major source of PCB contamination. For benthic invertebrates, Shaw and Connell considered the sediment to be the major source of PCB contamination. This conclusion was based on a positive correlation between sediment concentration and organism concentration for the crab, Sesarma erythrodactyla, and the polychaete, Capitella capitata.

Working in a freshwater environment, Larsson (1984b) performed an experiment with eels, Anguilla anguilla, in which he maintained some eels in aquaria with sediment and infauna (chironomid larvae and tubificid oligochaetes). Other eels were maintained in similar aquaria except a mesh above the sediment surface prevented the eels from feeding. In both treatments, PCBs were brought into the water by the activities of the benthic organisms. No statistical difference was found 
in the body concentration of PCBs in the eels from the two treatments. These data therefore indicate that eels take up PCBs directly from the water and that the activities of benthic organisms can drive PCBs from the sediment (either sorbed to sediment particles or dissolved in the interstitial water) into the water column. The rate at which this transfer occurred was not quantified.

An excellent study was conducted by Rubinstein et al. $(1984 \mathrm{a}, \mathrm{b})$ who examined the accumulation and dietary transfer of PCBs from contaminated harbor sediments in a laboratory food chain consisting of sediments, the polychaete, Nereis virens, and spot, Leiostomus xanthurus. The experiment was conducted in two phases. In the first phase, fish and polychaetes were separately exposed to field-collected PCB-contaminated sediments in a flow-through system for $40 \mathrm{~d}$ to allow the organisms to reach steady-state concentrations. In the second phase, the dietary contribution of PCB accumulation was determined by selectively feeding contaminated polychaetes to exposed and control groups of fish. Finally, the authors examined the effect of direct sediment contact on PCB accumulation by spot. The results clearly show that contaminated sediments can serve as a source of PCBs for uptake and trophic transfer in marine systems. Fish exposed to PCB-contaminated-sediment and fed a diet of polychaetes from the same sediment accumulated more than twice the PCB whole-body residues than fish exposed to similar conditions but not fed contaminated polychaetes. The dietary contribution of PCBs accounted for $53 \%$ of the total body burden measured in fish fed for $20 \mathrm{~d}$; the percentage appeared to be increasing. The results also indicate that fish separated from direct contact with the sediment do not significantly accumulate PCBs, compared with fish allowed contact with the sediment.

Stein et al. (1987) examined the accumulation of PCBs by English sole, Parophrys vetulus, exposed in the laboratory for $108 \mathrm{~d}$ to an urban (test) sediment compared to that for English sole exposed to sediment from a reference area. The sole exposed to the test sediments had liver concentrations of PCBs that were eight times that of the reference sole. The data indicate that accumulation of PCBs from sediment by English sole is a significant route of uptake in contaminated sediments.

It should be appreciated that the work of uptake of PCBs by marine organisms in sedimentary environments has a different emphasis than the comparable work of PAHs. For PCBs, much research has been conducted on the strength of trophic transfer of PCBs. Some work has been done to explore the importance of sediment-associated PCBs in contributing to uptake by marine organisms. Little work has been done to determine whether uptake occurs via the interstitial water or via release from 
sediment particles to which contaminants have sorbed. The data clearly implicate the overlying water column, diet and sediment as sources of contamination for marine organisms living in or near soft-bottom habitats.

\subsubsection{Pesticides (Organochlorines)}

Despite the estimable literature on uptake from water (e.g., Goerke and Ernst 1980, Schimmel et al. 1983), these studies are beyond the focus of this report. The remaining pathways from Figure 7.1 will be dealt with singly and we conclude with studies which have attempted to compare these possible routes of uptake. It should be noted that much of the work on aquatic uptake of organic pesticides has been conducted in freshwater. We will draw upon these studies throughout this section.

Phillips (1980) claimed that all the available evidence to-date indicates that food is the main source of DDT residues in fish and crustaceans. This supports the prior work of Teal (1977) who considered the likelihood of contaminant accumulation of DDT, dieldrin and other non-polar compounds with low solubility in water but high solubility in lipids.

Additional support for diet as a route of uptake was provided by work in which the uptake of kepone was examined in a number of estuarine organisms (Bahner et al. 1977): oysters (Crassostrea virginica), mysid shrimp (Mysidopsis bahia), decapod grass shrimp (Palaemonetes pugio), sheepshead minnows (Cyprinodon variegatus) and spot (Leiostomus xanthurus). Bioaccumulation from the water occurred in all species. Oysters were shown to accumulate kepone when fed contaminated phytoplankton (Chlorococcum). Similarly, spot were found to accumulate kepone when they were fed mysids that had been fed kepone-contaminated brine shrimp. The authors argue that the major route of kepone transfer in this system is from the water column to phytoplankton and then on up the food chain.

McLeese et al. (1980a) demonstrated dietary accumulation of endrin in the American lobster, Homarus americanus. Lobsters were fed blue mussels, Mytilus edulis, which had been contaminated with endrin.

Relevant data from freshwater habitats were provided by Skaar et al. (1981) who showed that bluegill sunfish, Lepomis macrochirus, accumulated kepone and Mirex by eating contaminated cladocerans (Daphnia). However, greater uptake of these contaminants were obtained from the water column. It is still possible that accumulation from food may be more significant as Jarvinen and Tyo. 
(1978) argue that toxicity of a given concentration is more lethal when taken up through the diet. This finding needs more attention.

There is evidence that the sediment may be an important route of exposure for marine organisms. Indirect evidence for sediment as a source of DDT was marshaled by Varanasi et al. (1985). Noting that some fish are not able to metabolize DDT or DDE (Addison et al. 1977) while these contaminants are metabolized in sediments (Lee et al. 1978), the presence of DDT and DDE metabolites in fish is taken as an indication of uptake, by an undefined mechanism, of metabolites formed in the sediment.

A study by Adams et al. (1985) sought to differentiate between interstitial water and water overlying a mudflat as sources of kepone for the chironomid larva, Chironomus tentans, in a freshwater environment. The data clearly showed that the accumulation in a given sediment depended on the concentration of contaminant in the sediment, implicating the interstitial water as the source of kepone.

Working with oysters, Crassostrea virginica, Morales-Alamo and Haven $(1982,1983)$ demonstrated that the chlorinated pesticide, kepone, is taken up rapidly by oysters from sediment suspensions. The solubility of kepone in seawater is exceptionally low (Dawson et al. 1978), most likely making it most of it associated with sediments rather than the water column.

Ray et al. (1983) studied the uptake of DDT and chlordane in sediments from Portland, Maine. In the polychaete, Nereis virens, and clams (presumably the hard clam, Mercenaria mercenaria), they found that DDT accumulated at higher concentrations than chlordane, corresponding with the higher concentration of DDT in the sediment.

Lessening of uptake of the organochlorine Kelthane in fathead minnows, Pimephales promelas, was induced by the presence of sediment (Eaton et al. 1983). The presence of clay sediments decreased uptake of Kelthane by $35 \%$ relative to the treatment with only contaminated water present. The Kelthane sorbed to clay was apparently not bioavailable to these freshwater fish. This reduction of uptake in the presence of sediment particles was not observed by Ekelund et al. (1987) in experiments with a similar design. In this study, the deposit-feeding bivalve, Abra nitida, was exposed to lindane. The uptake of lindane was about the same in the presence and absence of sediment particles. Uptake in this case apparently occurred primarily through the dietary pathway. 
For a freshwater environment (Lake Ontario), Oliver (1984) exposed the oligochaetes, Limnodrilus hoffmeisteri and Tubifex tubifex, to contaminated sediments for $110 \mathrm{~d}$ in laboratory aquaria. Bioconcentration continued to increase for the duration of the experiment. Differences in the rate of accumulation of different organochlorine compounds were associated with differences in sediment type and with differences in the size of the organisms. Smaller worms accumulated contaminants at a higher concentration than larger animals. This finding agrees with that of McLeese et al. (1982), who showed that smaller polychaetes, Nereis virens, attained higher concentrations of organochlorine insecticides.

Foster et al. (1987) investigated the effects of sediment-sorbed DDT in the bivalves, Macoma balthica and Mya arenaria. By the use of radio-labeled DDT, they were able to show that Macoma accumulated the labeled chemicals at measurable rates while Mya did not show bioaccumulation of the sediment-sorbed chemicals. The authors did not indicate the likely pathway by which the sediment-sorbed contaminants were accumulated by Macoma.

Theoretical modeling by Staples et al. (1985) considered the influence of suspended sediments on the bioavailability of dieldrin in the water column. The results indicate that neutral organic chemicals like dieldrin must be in solution to be bioavailable.

Interstitial water has been implicated as a dominant route of exposure for some systems. For a freshwater environment, Adams (1987) examined the pathways of uptake of kepone in the midge larvae of Chironomus tentans. In this thorough study, the author showed that the interstitial water and not the overlying water, food or ingested sediment (sediment-sorbed contaminants) was the primary route of exposure. Adams et al. (1985) assert that primary exposure to interstitial water is only likely when the equilibrium interstitial water concentration reached by desorption is equal to or higher than the concentration demonstrated to cause an effect in a water exposure test. In other words, contaminant concentrations in the interstitial water pose little threat to organisms if their equilibrium concentration is below that which causes a short-term response in sediment-associated invertebrates.

The presence of dissolved organic matter may strongly influence the rate of accumulation of organochlorines. Pierce et al. (1974) found that DDT has a high affinity for humic acids in water. Thus, the amount and kind of particulate matter in a marine habitat can affect the concentrations of organic pesticides and other organic. 
The following studies have shown uptake of organic pesticides in aquatic organisms. However, the actual route of exposure is not easily determined for these studies. Uptake of five insecticides (chlordane, endosulfan, endrin, DDT and dieldrin) was shown in the polychaete, Nereis virens (McLeese et al. 1982). Worms took up insecticides from both the sediment and from the overlying water column. The authors provided no insight into the path of uptake for the sediment-associated insecticides (from molecules sorbed to sediments or molecules dissolved in the interstitial water).

The effect of DDT contamination in a North Alabama riverine system was examined by Reich et al. (1986). Very high concentrations of DDT (up to $2 \%$ ) were found in the sediments. Benthic macroinvertebrates (tubificid oligochaetes, corixid hemipterans and chironomid larvae) also had high levels of DDT. The source of the contamination (sediment-sorbed contaminants, interstitial water, overlying water) was not determined.

McLeese and Metcalfe (1980) demonstrated lethal effects of dieldrin, DDT, endosulfan and endrin on the decapod shrimp, Crangon septemspinosa. Effects were noted when these contaminants were dissolved in seawater and when sediments were spiked with the contaminants. The sediment concentration producing lethal effects was higher than the water concentration, indicating that leaching from the sediment into the water is the dominant pathway of uptake.

Markwell et al. (1989) examined the bioaccumulation of a number of different organic pesticides in the oligochaetes, Tubifex tubifex and Limnodrilus hoffmeisteri. They considered uptake to occur as a result of two dynamic equilibria: one between the sediment and the interstitial water, and the second between the oligochaete and the interstitial water. By incorporating octanol/water partition coefficients (see section below and Chapter 4), they were able to make good predictions of the amount of contaminant uptake. This approach is laudable because, as Knezovich et al. (1987) assert, attempts to predict contamination rates in sedimentary environments based on the behavior of contaminants in the water column are meaningless. The approach of Markwell et al. (1989) blends a knowledge of the field with a theoretical underpinning. Lake et al. (1990) found that consideration of the amount of organic carbon in the sediment and the lipophilic properties of the contaminants improved predictions of bioaccumulation. Ferraro et al. (1991) found that similar considerations of the lipophilic nature of contaminants could be used as a "justifiable simplification" for a first-order approximation of uptake in sediment-associated organisms. 


\subsection{FACTORS INFLUENCING BIOAVAILABILITY AND BIOACCUMULATION OF ORGANIC CONTAMINANTS}

The studies discussed in the previous section provided a diversity of results, implicating different routes of uptake (Figure 7.1) for different contaminants. It is apparent that the equilibrium concentrations for all components of the model must be known before a thorough understanding of the primary routes of exposure will be forthcoming. It is evident that equilibrium concentration for any contaminant will vary greatly, being strongly influenced by the physical, geological and chemical milieu. Furthermore, generalization is thwarted by different behaviors of various contaminants and by different physiologies of the aquatic organisms exposed to those contaminants.

\subsubsection{Feeding Types}

Lee and Schwartz (1980) showed that deposit-feeders selected particles for ingestion that were richer in organic carbon and had higher contaminant concentrations than the mean of the sediment in which they lived. Clams were more selective in a coarse sediment than in a fine sediment.

\subsubsection{Concentration and Chemical Form}

Insofar as the behavior of any molecule varies when ligands are added or when the molecule is reduced or oxidized, the chemical form of a contaminant will likely change its behavior. It is inconceivable to expect that a complete catalogue of the activity and behavior of all organic contaminants will ever be forthcoming. Environmental scientists have sought other approaches to predicting the fate and effects of organic contaminants (see section below on partition coefficients). These are described thoroughly in Chapter 4. Nevertheless, a few generalities pertaining to chemical form will be briefy described here.

An important attribute of a contaminant is the polarity of the molecule. Because many organic contaminants are nonpolar or weakly polar, they are likely to have a low solubility in water and high attraction for sorption on surfaces. Nonpolar molecules are also likely to accumulate in the lipids of organisms posing a long-term threat of a chronic exposure to resident organisms. A striking demonstration of this effect was given by Boon (1985), who demonstrated in juvenile sole, Sole solea, that the concentration of PCBs in organs depended on the lipid content of the organs.

For PCBs, a general paradigm has emerged relating the chlorine content of a given molecule to its effect on marine organisms. The solubility of PCBs is inversely proportional to chlorine content, ranging from $1 \mathrm{ppb}$ for hexachlorobiphenyl to $637 \mathrm{ppb}$ for dichlorobiphenyl (Hague and 
Schmedding 1975, Boon 1985). Similarly, the solubility of PAH varies inversely with its molecular weight and the number of aromatic rings. Roubal et al. (1977) showed that the three-ringed compound, anthracene was retained in fish longer than naphthalene (two rings) or benzene (one ring). Gossett et al. $(1982 \mathrm{a}, \mathrm{b})$ indicate that halogens greatly increase the potential for bioaccumulation and the toxicity of organic contaminants. Such differences are likely to have dramatic'effects on the equilibrium concentrations in a model, such as that presented in Figure 7.1.

Reduced and oxidized forms of organic molecules have apparently received less attention. The importance of these reactions is indicated by Harder et al. (1983), who showed that the reduced forms of toxaphene in salt marsh mud were three times more toxic than oxidized forms for mullet, Mugil curema, but about equal for spot.

The shape of the molecules of organic contaminants contributes to their behavior in the marine environment. For the polychaete, Capitella capitata, and the fish, Mugil cephalus, planar PCB molecules are efficiently absorbed (Shaw and Connell 1984). Absorption decreases as the molecule becomes less planar.

A criticism that can be leveled against many toxicological tests for organic contaminants is that contaminants are considered singly. The finding of Shaw and Connell (1982) indicated that the addition of hydrocarbons leads to reduced uptake of PCBs. Presumably, the addition of hydrocarbons to the sediments alters the equilibrium concentration of $\mathrm{PCB}$, increasing the concentration in the sediments (to a greater degree than the interstitial water concentration), resulting in lower uptake by polychaetes. Thus, the relatively high and variable concentrations of petroleum and other hydrocarbons in sediments may be an important factor affecting the rate of accumulation of PCBs by aquatic biota. By analogy, any contaminants may have synergistic effects on other contaminants. A contaminant need not be of a similar class of compounds to induce synergistic uptake of an organic contaminant. For instance, Fair and Sick (1983) administered a diet of oysters to black sea bass, Centropristis striata. The oysters were spiked with ${ }^{14} \mathrm{C}$-naphthalene, with or without ${ }^{109}$ cadmium added. The presence of cadmium resulted in reduced concentrations of naphthalene in muscle tissues but increased concentrations in the brain and kidney tissues. Similar synergistic effects were demonstrated for cadmium and several organic products used in the metallurgic industry (sodium isopropylxanthate, potassium amylxanthate and sodium diethyldithiocarbamate). All of these organics increased the uptake of cadmium by forming lipophilic complexes with cadmium. These complexes 
accumulated in lipid-rich portions of the body, particularly the kidney, liver and brain. The chemical form and behavior of each contaminant is clearly a major determinant of the nature of any synergism.

Generalities concerning the relationship between the environmental concentration of a contaminant and uptake by marine organisms have emerged as well: For both polychaetes, Nereis virens, and decapod shrimp, Crangon septemspinosa, a linear relationship between the sediment concentration and uptake was demonstrated by McLeese et al. (1980b). An ambitious four-year study of several sites in Puget Sound provided evidence of a direct link between the concentration of contaminants in bottom sediments and fish disease, particularly liver carcinomas in English sole, Parophrys vetulus. The inference was drawn that increased sediment concentrations led to increased uptake by marine organisms, resulting in increased incidence of liver carcinomas.

\subsubsection{Acquired Tolerance and Adaptation}

It is naive to expect that organisms in contaminated environments will exhibit the same response to them over time. Chronic exposure may result in an acquired tolerance by exposed organisms. If selection is strong enough, physiological adaptations may result. Such phenomena must be understood before biologically meaningful predictions of the effects of contaminants can emerge.

Most of the adaptations that have been described can be characterized as behavioral responses. For instance, Teal and Farrington (1976) showed that the killifish, Fundulus heteroclitus, from the area of an oil spill in the marshes of Wild Harbor, Massachusetts, developed the ability to discriminate against the petroleum hydrocarbons while continuing to accumulate the n-alkanes characteristic of normal marsh plants and sediment. An alternative explanation is that the mixed-function Oxygenase system of these fish became activated, permitting detoxification and excretion of these contaminants (see section on Excretion in this chapter). Garnas and Crosby (1979) showed that the gastropod, Tegula funebralis, retracts into its shell and seals its operculum when exposed to high concentrations of the organic insecticide, parathion. These authors also showed that the California mussel, Mytilus californianus, closed their valves and discontinued filtration in the presence of parathion, resulting in reduced exposure to this contaminant.

Mixed results were observed by Anderson (1979) for peracarid crustaceans. The arctic amphipod, Onismus affinis, avoided oil-tainted sediment or food. However, no preference was exhibited by the isopod, Mesidotea entomon. Anderson also showed that $50 \%$ of a laboratory 
population of the clam, Macoma nasuta, would not burrow into sediment which had been contaminated with naphthalene. In the field, such behavior could result in dispersal of the bivalves by tidal currents, carrying the bivalves away from locally contaminated sites.

From a freshwater environment, Folmar et al. (1979) examined the behavior of mayfly nymphs, Ephemerella walkeri, to different concentrations of the herbicide Roundup ${ }^{\text {th }}$. The nymphs avoided concentrations of $10 \mathrm{mg} / \mathrm{L}$ but did not respond to concentrations of $1 \mathrm{mg} / \mathrm{L}$.

Rubinstein et al. (1980) found that the effects of the organic pesticide kepone decreased the burrowing activity of the polychaete, Arenicola cristata, which potentially can reduce the resuspension of contaminated sediments. It was not reported if the reduced burrowing was due to toxicological effects or to active behavior by the polychaetes. In either case, reduced burrowing would lead to reduced availability of contaminants.

There is evidence that populations may respond genetically to chronic contamination. Rossi and Anderson (1978) found that the third generation of the polychaete, Nereis arenaceodentata, was significantly more resistant to petroleum hydrocarbons than the first generation. Lee et al. (1979) showed that the third generation of the polychaete, Capitella capitata, exhibited greater detoxification activity (see the section below on Excretion) than the second generation. Such enzyme activity was not detectable in the first generation until individuals were placed in the presence of petroleum hydrocarbons.

\subsubsection{Sediment Grain Size}

Relationships between sediment grain size and the bioavailability of contaminants have been established for some compounds. Neff (1984) showed that the bioavailability of sediment-sorbed organics is directly related to the sediment grain size; that is coarser particles are associated with greater bioavailability of contaminants, despite the fact that surface/volume ratios of coarse sediments are lower than fine sediments. Such a relationship holds particularly well for nonpolar molecules. McLeese et al. (1980b) tested the effects of the PCB, Aroclor 1254, in different sediments and found that the decapod shrimp, Crangon septemspinosa, had lower uptake in muddy sediment relative to sandier, coarser sediment. Corroborative data are provided by Clark et al. (1986) who demonstrated that the fiddler crabs, Uca minax and $U$. pugilator, picked up PCBs with bioaccumulation factors of 0.19 in a mud treatment and 0.59 to 0.79 in a treatment where mud was mixed with clean sand. 
Anderson et al. (1987) indicate that the clay content of sediments can also be important in determining the sorption of contaminants.

Augenfeld et al. (1982) conducted experiments in which the bivalve, Macoma inquinata, and the polychaete, Abarenicola pacifica, were maintained in coarse and fine sediments, respectively. Regrettably, the experimental design was incomplete; Macoma was not maintained in fine sediment nor was Abarenicola maintained in coarse sediment. Nevertheless, the authors showed that Macoma in the coarse sediment accumulated more ${ }^{14} \mathrm{C}$-labeled pherianthrene, chrysene and $\mathrm{BaP}$ than Abarenicola did in the fine sediment.

\subsubsection{Total Organic Carbon}

One of the most important determinants of the bioavailability of organic contaminants is the fraction of organic matter in the sediment (Adams 1987). In general, the sorption of these contaminants is directly related to the total organic carbon of the sediments (Chiou et al. 1977, Briggs 1981, Di Toro 1988). In carbon-rich sediments, contaminants show little mobility whereas in sandier, carbon-poor sediments, mobility is higher (Neff 1984, Lee and Jones 1987).

Empirical laboratory data have been collected by Pavlou (1980) who demonstrated that the sorption of hydrophobic chemicals on pure inorganic surfaces is negligible although inorganic particles with natural organic coatings exhibit moderate to strong binding energies. Briggs (1981) found similar results for neutral pesticides, PAH and various substituted benzenes, including PCBs. Ionizable compounds did not exhibit a direct relationship between organic content of a substrate and the sorption of those compounds.

In the field, Galassi and Migliavacca (1986) showed that there is a positive correlation between the concentration of organochlorine residues in the sediment and the organic content of the sediment for the River Po in Italy. Along a transect from the Los Angeles county municipal sewage outfall, Brown et al. (1987b) found a poor relationship between the bioaccumulation of DDT in organisms and the sediment concentration of DDT. However, when the concentration of DDT at each site was normalized to the organic content, a much better correlation was seen between organism concentration and sediment concentration.

Exacerbating the average contamination effects, deposit-feeding bivalves select particles for ingestion that are richer in organic carbon and therefore higher in contaminant concentration than the mean of the sediment in which they live (Lee and Schwartz 1980). 
Foster and Wright (1988) measured the concentration of unsubstituted PAH in sediments and compared that to the concentration in the polychaete, Nereis virens, and the bivalve, Macoma balthica. Seven sites were compared in the Chesapeake Bay. Levels of unsubstituted PAH in animal lipids was directly related to the corresponding concentration in the sediment. Coarse-grained sediments with low organic carbon content $(<0.5 \%)$ provided animal-sediment bioaccumulation factors that were much larger than fine-grained sediments.

Cunningham (1986) examined the effect of the mosquito insecticide, diflubenzuron, on estuarine crustaceans, finding that sediment and organic matter provides a substrate for adsorption that could reduce concentrations of diflubenzuron in the water column.

The empirical data above clearly demonstrate that sediments higher in organic content will accumulate higher concentrations of many contaminants than carbon-poor sediments. However, the effect of organic carbon in the sediment on bioavailability of contaminants depends on the pathway of the uptake (Figure 7.1). If the primary route of bioaccumulation is from desorption of contaminants sorbed to sediment particles or from the interstitial water, then carbon-rich sediments are likely to increase bioavailability. If the primary route of uptake is from the overlying water, carbon-rich sediments are likely to decrease bioavailability.

\subsubsection{Octanol-water Partition Coefficients}

It should be apparent that the behavior of organic compounds is difficult to predict. Even similar compounds may show strikingly different patterns of bioaccumulation. Furthermore, the behavior of any compound may vary as a function of sediment grain size, total organic carbon in the sediment and the redox conditions of the sediment. A complete catalogue of all organic contaminants is clearly out of the question.

As an alternative approach, environmental chemists have developed the notion of partition coefficients. Chapter 4 provides a thorough treatment of this theory. As a first approach, partition coefficients were formulated to describe the equilibrium of a neutral compound (including PAH, $\mathrm{PCBs}$ and organochlorine insecticides) as an equilibrium between the aqueous phase and nonaqueous phase. These partition coefficients can be expressed as:

$$
\mathrm{K}_{\mathrm{p}}=\mathrm{A}_{\mathrm{s}} / \mathrm{A}_{\mathrm{w}}
$$

where $\mathrm{K}_{\mathrm{p}}$ represents the partition coefficient for a compound at equilibrium, $\mathrm{A}_{\mathrm{s}}$ is the activity of the 
compound in the nonaqueous phase and $A_{w}$ is the activity of the compound in the aqueous or dissolved phase.

For the purposes of developing a standardized protocol to measure the partitioning behavior of a given compound between aqueous and nonaqueous states, a test system was devised. The compound is added to a mixture of octanol and water. Octanol is a nonpolar, neutral compound while water is strongly polar. The result is a partition coefficient, $K_{o w}$, where

$$
\mathrm{K}_{\mathrm{ow}}=\mathrm{A}_{\text {octanol }} / \mathrm{A}_{\text {water }}
$$

This partition coefficient can be related to the solubility $(\mathrm{S})$ of the compound under investigation as:

$$
\log \mathrm{K}_{\mathrm{ow}}=\mathrm{a}-\mathrm{b}(\log S)
$$

where $\mathrm{a}$ and $\mathrm{b}$ are determined empirically by regression analysis.

Workers have found that this relationship can be modified to account for differences in organic carbon content of the sediment (see preceding section for information on the importance of organic carbon in affecting the bioavailability of organic contaminants). The following relationship has been described:

$$
K_{o c}=\left(f_{o c}\right)\left(K_{o w}\right)
$$

where $\mathrm{K}_{\mathrm{ow}}$ is the octanol/water partition coefficient, $\mathrm{f}_{\alpha}$ is the organic carbon content of the sediment and $\mathrm{K}_{\mathrm{oc}}$ is the organic carbon normalized partition coefficient.

Finally, a relationship between $\mathrm{K}_{\mathrm{oc}}$ and $\mathrm{K}_{\mathrm{ow}}$ has been derived from the preceding equations:

$$
\log K_{\infty}=a\left(\log K_{o w}\right)+b
$$

However, this equation cannot be applied generally. The relationship only seems to hold for closely related compounds and also depends on the nature of the organic coating on the sediment (Boehm and Quinn 1973, Neely et al. 1974, Chiou et al. 1977, Schwarzenbach and Westall 1981).

In accordance with the equilibrium model of partitioning (Figure 7.1), Di Toro et al. (1982) showed that as the concentration of suspended adsorbent (sediment) increases, $K_{o w}$ decreases. This result occurs because the increased surface area for attachment of lipophilic, hydrophobic molecules increases (see Chapter 4 for a more complete discussion of this phenomenon). Because this term is in the denominator of the formula for the calculation of $\mathrm{K}_{\mathrm{ow}}$, the partition coefficient declines. This 
result agrees with the inference of Pierce et al. (1971) who stated that chemicals with relatively high octanol/water partition coefficients will be compartmentalized to sediments and other solids.

Gossett et al. (1982b) used this approach for marine organisms in the vicinity of the Los Angeles County wastewater outfall. Noting that even the 120 EPA priority pollutants are far too many to analyze individually in laboratory tests, these workers sought to discover a relationship . between the effluent and tissue concentrations of compounds and $\mathrm{K}_{\mathrm{ow}}$. Specifically, these researchers wanted to determine if $\mathrm{K}_{\mathrm{ow}}$ can be used to predict the bioaccumulation of organic contaminants. Tissues were taken from Pacific sanddab (Citharichthys xanthostigma), Dover sole (Microstomus pacificus), scorpionfish (Scorpaena guttata), white croaker (Genyonemus lineatus), ridgeback prawn (Sicyonia ingentis) and red pointer crab (Mursia gaudichaudii). For these organisms, $\mathrm{K}_{\mathrm{ow}}$ provided a good predictor of bioaccumulation.

Further data were provided by Gossett et al. (1983) by collecting sediments and animals from near the Los Angeles County outfall and analyzing them for 27 selected organic compounds. The sediment and tissue concentrations were positively correlated with each other and with $K_{o w}$, but negatively correlated with the effluent concentration. The authors concluded that $\mathrm{K}_{\mathrm{ow}}$ can be effectively used to predict the organic compounds which have the potential to bioaccumulate.

Opperhuzien and Stokkel (1988) showed that the concentration of hydrophobic chemicals by fish was dependent on the hydrophobicity of the chemicals (where low $\mathrm{K}_{\text {ow }}$ characterizes high hydrophobicity). PCBs and biphenyls were examined, spanning three orders of magnitude for $\mathrm{K}_{\mathrm{ow}}$. For the lower chlorinated benzenes and biphenyls, the amount dissolved in water were high compared with the amount in the sorbed state, and the influence of contaminated particles on their uptake by fish was negligible. For more hydrophobic chemicals which have low aqueous solubility (such as triand tetrachlorobiphenyls and penta- and hexachlorobenzene), contaminated particles can have a much greater influence on uptake by fish. Thus, sediment particles can act as a source of hydrophobic contaminants if concentrations are high and desorption rates are high.

Bierman (1990) showed that consideration of $K_{o w}$ provided a useful first approximation for uptake of organic contaminants by benthic freshwater animals if environmental data were reasonably uniform (minimal variation in physical, geological and chemical variables). He did not discuss significant variations which could be explained by individual animal-contaminant interactions, systematic variations with $\mathrm{K}_{\mathrm{ow}}$ and seasonality. 
Some evidence exists showing a relationship between $\mathrm{K}_{\mathrm{ow}}$ and bioaccumulation along a food chain. Working with PCBs in Lake Ontario, Oliver and Niimi (1988) showed that bioaccumulation increased linearly with $\mathrm{K}_{\text {ow }}$ for all trophic levels examined. The food chain involved phytoplankton, mysid crustaceans, smelt and salmonids.

The rate of bioaccumulation from a single sediment was found to be inversely proportional to the $\log \mathrm{K}_{\mathrm{ow}}$ (Landrum 1989). However, compounds with higher water solubility (lower $\mathrm{K}_{\mathrm{ow}}$ ) became unavailable more rapidly as a potential source of contaminant uptake by marine organisms. These results confirm the earlier work of Geyer et al. (1982).

Despite these successes in using $\mathrm{K}_{\text {ow }}$ as an analytical tool, some researchers have found problems with the method. Kenaga and Goring (1980) presented information on the relationship between water solubility, sediment adsorption, octanol-water partitioning and the concentration of contaminants in fish. Data were compiled for 170 organic compounds. Using only one of the four parameters above, predictions of the other three were made. The $95 \%$ confidence intervals were one to three orders of magnitude of the measured parameter. The authors claim that part of the variability is due to differences in methodology but most seem due to variability of the fish, chemicals and environments. Additional concerns were expressed by Landrum (1989) who demonstrated high variability of $\mathrm{K}_{\text {ow }}$ for $\mathrm{PAH}$ as a function of sediment grain size and other environmental parameters.

Davies and Dobbs (1984) presented evidence which indicates that $K_{\text {ow }}$ may not be a good predictor of behavior for all contaminants. They indicate that bioaccumulation of organochlorines in fish shows a good correlation with $\mathrm{K}_{\mathrm{ow}}$ and water solubility, but only for low molecular weight organochlorines. The correlations break down for heavier organochlorine contaminants. These concerns are stressed in a recent review of the utility of $\mathrm{K}_{\mathrm{ow}}$ as a predictive tool (Barron 1990). Poor predictive resolution results when $\mathrm{K}_{\mathrm{ow}}$ is low or when the molecular weight of the contaminant is high ( $\mathrm{K}_{\text {ow }}$ is high).

Complex relationships between $\mathrm{K}_{\mathrm{ow}}$ and bioaccumulation were obtained by Oliver (1984) working in Lake Ontario. Two species of oligochaetes, Limnodrilus hoffmeisteri and Tubifex tubifex were exposed to contaminated lake sediments. Differences in bioaccumulation of various organochlorines could sometimes be related to different sediment types or to different worm sizes (smaller worms had higher concentrations than larger conspecifics). There was not a straightforward relationship between $\mathrm{K}_{\mathrm{ow}}$ and bioaccumulation in these experiments. 
Some concern has been expressed that not all organic molecules with similar $\mathrm{K}_{\text {ow }}$ will show similar behavior. Pruell et al. (1986) exposed blue mussels, Mytilus edulis, to contaminated sediment from Narragansett Bay, Rhode Island. Bioaccumulation of PCBs was greater than bioaccumulation of $\mathrm{PAH}$ when compounds with similar $\mathrm{K}_{\mathrm{ow}}$ were compared. These researchers did not consider the possibility of differential depuration rates for the different populations of mussels. Di Toro (1985) expressed concern that the assumption that reactions are reversible between the particulate and dissolved phases may not be valid.

Some workers have used these empirically-derived relationships in an attempt to derive predictive models. Bruggeman et al. (1981) developed a thermodynamic model, assuming that the rate of transport of a chemical from water to the storage compartment (the lipid stores of an organism) is equal to the activity gradient between the water and the lipid, divided by the sum of the resistance factors. Blood is the major transport compartment, particularly in vertebrates. As the $\log$ $\mathrm{K}_{\mathrm{ow}}$ increases, the resistance decreases and the contaminant is quickly deposited into the lipid stores of the organism (see Chapter 8 for a detailed discussion of this phenomenon). They demonstrated a clear relationship between the bioaccumulation of related PCBs of varying molecular weight, accumulated by dietary transfer, with decreasing water solubility (increasing $\mathrm{K}_{\mathrm{ow}}$ ).

Novel insight into bioaccumulation is provided by Shaw and Connell $(1982,1984)$. They showed that bioaccumulation of PCBs in mullets, Mugil cephalus, and polychaetes, Capitella capitata, is influenced by; (1) the partition behavior of the molecule, as measured by $K_{o w}$ and, (2) the absorption coefficients of the PCBs, measured by chromatographic elution time. The combination of these two factors as $\log \left(\mathrm{K}_{\text {ow }} \mathrm{x}\right.$ elution time $)$ gives a measure which is highly correlated with bioaccumulation. Planar molecules are most efficiently adsorbed and adsorption decreases as the molecules become less planar. In their study, maximum uptake was found with penta- and hexachlorobiphenyl. Less uptake was found in di-, tri- and tetrachlorobiphenyls which have lower $\mathrm{K}_{\mathrm{ow}}$, and in hept- and octochlorobiphenyl which have lower chromatographic elution times.

Thomann (1989) presents a model for calculating the concentration of organic chemicals in a simple, generic food chain (see also Chapter 8). Chemical uptake efficiency from water, excretion rate and chemical assimilation efficiencies are variables as a function of $\mathrm{K}_{\mathrm{ow}}$. The model accounts for growth of the organism because lipid content changes with age (size). Food chain effects are not significant up to a $\log \mathrm{K}_{\mathrm{ow}}$ of about five. For $\log \mathrm{K}_{\mathrm{ow}}$ values between five and seven, the field concentrations of contaminants in top predators and the predicted concentrations based on the model 
are one to two orders of magnitude higher than the calculated Biological Concentration Factor (BCF) values.

It is apparent from the data reviewed in this section that $\mathrm{K}_{\mathrm{ow}}$ provides a useful tool to assess the bioavailability and environmental risk of organic contaminants. Certainly, there are limitations to the utility of $\mathrm{K}_{\mathrm{ow}}$. For instance, the aberrant behavior of $\mathrm{K}_{\mathrm{ow}}$ as a predictor when $\log \mathrm{K}_{\mathrm{ow}}$ values are low or the molecular weight of the contaminant is high. Nevertheless, the method seems to hold promise as a management tool. Using this method, Pavlou (1987) derived safe levels in ,ediments for 47 synthetic organic compounds in Puget Sound. Error in predicting the bioavailability of these compounds stems from; (1) lack of knowledge of toxicological synergistic or antagonistic interactions among contaminants, (2) poor understanding of the influence of environmental variables (e.g., $\mathrm{pH}$ or TOC), and (3) inability to distinguish between the bioavailable fraction and total sediment burden of the contaminant (some insight may be provided by $\mathrm{K}_{\mathrm{oc}}$ ). Nonetheless, this technique seems to provide a framework for inexpensively predicting the bioavailability of a myriad of organic contaminants.

\subsubsection{Taxonomic Differences in Organic Contaminant Uptake. Especially as Related to Life Styles and Feeding Habits}

The literature reviewed above attests to the complexity that must be dealt with to understand bioavailability of sediment-bound contaminants. Comparisons of bioaccumulation in organisms between sites are hopelessly confounded by differences in sediment (grain size, total organic carbon), synergism or antagonism of associated contaminants, hydrodynamic regime and concentrations of contaminants. A catalogue of marine organisms and their uptake of contaminants provides little insight into taxonomic differences because of the confounding effects. Furthermore, any organism will accumulate contaminants in its lipids which serve as sinks for hydrophilic compounds. All organisms will therefore accumulate organic contaminants making a list of species for which bioaccumulation of contaminants occurs a meaningless exercise. In this section, we review only those studies within a site or within a laboratory in which several species, sometimes with different feeding mechanisms, were studied.

One of the first comparative studies was conducted by Nimmo et al. (1971) using the deposit-feeding fiddler crab, Uca pugilator, and the predatory decapod shrimp, Penaeus duorarum. These crustaceans were maintained in laboratory aquaria with sediment substrates from contaminated areas. The animals accumulated the PCB, Aroclor 1254, in their tissues by either ingesting contaminated sediment or by absorbing the leached chemical from the water. Accumulation rates 
were similar implying that taxonomic affinity may be more important than diet in predicting bioaccumulation rates. However, the authors presented no independent data to demonstrate that the diets of these crustaceans were different; $P$. duorarum may, in fact, ingest detritus from the bottom and hence be similar to $U$. pugilator in feeding mode.

Anderson (1979) claims that bivalves tend to take up organic contaminants at a constant rate, with no tendency to reach asymptotic levels. On the other hand, fish and shrimp take these compounds up rapidly, reaching maximum levels in only a few hours. Longer exposures often produce lower tissue concentrations of parent compounds (Malins 1977, Varanasi and Malins 1977). These decreases are attributed to more active systems of ventilation, blood circulation, excretion and hydrocarbon metabolism of fish and shrimp as compared to bivalves.

A comparison of two polychaetes was reported by Courtney and Langston (1978a,b). The concentration factors of PCBs were calculated by exposing Arenicola marina and Nereis diversicolor to contaminated sand. Concentration factors were 0.39 and 0.49 , respectively. These values are probably not different statistically.

In the laboratory, Roesijadi et al. (1978a) exposed benthic animals to sediments contaminated with Prudhoe Bay crude oil. The deposit-feeding bivalve, Macoma inquinata, and the sipunculan worm, Phascolosoma agassizii, were compared to the suspension-feeding bivalve, Protothaca staminea. The data showed that the deposit-feeders generally accumulated hydrocarbons to a greater extent than did the suspension-feeders. In both bivalves, hydrocarbon concentrations increased during the 60-d exposure period while concentrations in the sipunculans reached an equilibrium early in the exposure. Experiments on the uptake of ${ }^{14} \mathrm{C}$-labeled phenanthrene, chrysene, dimethylbenz[a]anthracene and $\mathrm{BaP}$ by Macoma indicate that compounds directly associated with sediment were less available for uptake than those released from sediment to the surrounding seawater. The data indicate that differences in bioaccumulation are better explained by feeding type than by taxonomic affinity, since Phascolosoma and Macoma are more alike taxonomicaaly than either is to Protothaca.

Augenfeld et al. (1980) did a similar study with Protothaca and $M$. inquinata and found that 85\% of Protothaca survived $54 \mathrm{~d}$ of exposure, but Macoma had only $17 \%$ survival. These results apparently contradict the data of Roesijadi et al. (1978a) in that the suspension-feeders suffered greater mortality than the deposit-feeders. However, the amount of contaminant taken up by each 
species was not quantified. It is possible that Macoma may acquire greater concentrations of contaminants but have a greater tolerance for the toxic effects than Protothaca.

A more careful experiment was conducted by Roesijadi and Anderson (1979). They reported that exposing the surface deposit-feeding bivalve, Macoma inquinata, to oil-contaminated sediment resulted in reduced survival, reduced condition index and reduced levels of free amino acid, mainly glycine in the gills, mantle and adductor muscle. For Protothaca, the level of glycine in the mantle, gills and adductor muscle did not change significantly but the taurine level fell. The authors concluded that the deposit-feeder, Macoma, is affected more severely by oil pollution that the filter feeding, Protothaca, perhaps because the feeding activity of filter-feeders is less inhibited.

McLeese et al. (1980b) tested the uptake of PCBs from sediment in the laboratory in two species of invertebrates. The polychaete, Nereis virens, is a predator (Commito 1982, Ambrose 1984) while the decapod shrimp, Crangon septemspinosa, is a scavenger. Nereis showed greater bioaccumulation than Crangon. The calculated concentration factors varied from 10.8 for $0.6 \mathrm{~g}$ Nereis to 3.8 for $4.7 \mathrm{~g}$ Nereis. Concentration factors for Crangon ranged between 3.5 for $0.1 \mathrm{~g}$ shrimp to 1.9 for $2.9 \mathrm{~g}$ shrimp. A subsequent study with these same organisms revealed different patterns for the uptake of chlorinated organic pesticides (McLeese et al. 1982). Contaminants tested were chlordane, endosulfan, endrin, DDT and dieldrin. Bioaccumulation was tested both from the water and from sediment (with $2 \%$ organic matter). Nereis showed the same lethal concentrations in both water and sediment exposures. These concentrations were greater than the corresponding concentrations for Crangon, indicating that Nereis may be more resistant to these organic contaminants. The authors concluded that infaunal species accumulate greater amounts of PCBs from sediments than epifaunal species.

Rubinstein et al. (1980) used a microcosm approach to simulate the effects of dredging contaminated sediments. They chose the mysid crustacean, Mysidopsis (known to be very sensitive to pollutants), which spends time on the sediment surface but scavenges in the water column; the oyster, Crassostrea virginica, which is a suspension-feeder and the polychaete, Arenicola cristata, a subsurface deposit-feeder. These researchers tested the effects of the pesticide, kepone, by adding sediments (with or without kepone) periodically to the microcosms. In oysters, a bioaccumulation of $0.51 \mathrm{ppm}$, and in lugworms a bioaccumulation of $0.75 \mathrm{ppm}$ were achieved. The authors do not indicate if these means are significantly different. 
Comparative data were provided in a study of Augenfeld et al. (1982) using the surface deposit-feeding clam, Macoma inquinata, and the subsurface deposit-feeding polychaete, Abarenicola pacifica. Macoma was maintained in a coarse sediment while Abarenicola was kept in a fine sediment. Each sediment had ${ }^{14} \mathrm{C}$-labeled phenanthrene, chrysene or BaP added. For Macoma, only $8 \%$ of the phenanthrene remained in the sediment, but $70 \%$ of the remaining two contaminants was retained in the sediment. For Abarenicola, all of the chrysene and $\mathrm{BaP}$ and $70 \%$ of the phenanthrene remained in the fine sediment. Obviously, Abarenicola accumulates little phenanthrene and no chrysene or $\mathrm{BaP}$ from the sediment, while Macoma accumulates greater amounts of all three contaminants, particularly chrysene. Unfortunately, it is not known if different bioaccumulation rates result from differences between molluses and annelids, between sediment types or between feeding types.

For a freshwater environment, Oliver (1984) exposed the oligochaetes, Limnodrilus hoffmeisteri and Tubifex tubifex, to contaminated sediments from Lake Ontario for $110 \mathrm{~d}$ in laboratory aquaria. Both of these annelids are deposit-feeders. Concentration factors continued to increase over the course of the tests. Differences in bioconcentration of different chlorinated organics were found to be due to different sediment types and to different worm sizes [smaller worms have higher concentration factors as seen for the polychaete, Nereis virens, by McLeese et al. (1980b)]. These related species had similar rates of bioaccumulation.

Varanasi et al. (1985) exposed the amphipods, Rhepoxynius abronius and Eohaustorius washingtonianus, the bivalve, Macoma nasuta, the decapod shrimp, Pandalus platyceros, and Dover sole, Parophrys vetulus, to an urban estuarine sediment (16 ppm of PAH to which trace amounts of ${ }^{3} \mathrm{H}-\mathrm{BaP}$ were added). The extent of metabolism of ${ }^{3} \mathrm{H}-\mathrm{BaP}$ was generally Macoma $<$ Eohaustorius $<$ Rhepoxynius $\leq$ Pandalus $=$ Parophrys. The extent of metabolism was negatively correlated to tissue concentrations of PAH except that both amphipods accumulated higher concentrations of PAH than did clams, indicating that other factors (feeding type and rate of excretion) also influenced accumulation of PAH.

Comparative data on the uptake of PCBs were provided by Rubinstein et al. (1983) for the polychaete, Nereis virens, the bivalve, Macoma nasuta, and the shrimp, Paleomonetes pugio. The polychaetes accumulated more contaminants in their tissues and depurated them at a slower rate than either the bivalves or the shrimp. 
Some data exist on bioaccumulation in waterfowl. Llorente et al. (1987) examined the accumulation and distribution of hydrocarbons, PCBs and DDT in three species of ducks: Green-winged Teal (Anas crecca), Northern Shoveler (A. clypeata) and Red-crested Pochard (Netta runina), PCBs and DDTs showed different accumulation patterns, probably related to their different lipophilic properties and the lipid composition of each tissue. The mechanism of uptake was not known for these birds. The data indicated that these three species, nevertheless, showed similar patterns of uptake. Taxonomic relatedness is therefore a useful indicator of similar patterns of bioaccumulation.

Foster et al. (1987) described research on the effects of sediment-sorbed hydrocarbons (naphthalene, diphenyl ether, octyl phthalate, DDT, chrysene) in the bivalves, Macoma balthica and Mya arenaria. Macoma is a surface deposit-feeder while Mya is a suspension-feeder. Macoma accumulated labeled (deuterated) contaminants at measurable rates. The transfer coefficients for Macoma were inversely related to the water solubilities of the sorbed chemicals. Mya did not show bioaccumulation of the sediment-sorbed chemicals. These data corroborate the current understanding that deposit-feeders may be at greater risk to sediment-bound contaminants than suspension-feeders.

Data comparing a predator to its prey were presented by Elder and Dresler (1988). They examined the long-term accumulation of creosote wastes at a wood-preserving facility near Pensacola, Florida. Water, sediment and tissue of the predatory snail, Thais haemastoma, and one of its prey items, the oyster, Crassostrea virginica (not native), were placed in cages at test sites for six weeks. The study focused on PAH, the primary component of creosote: Very low PAH concentrations were found in the water or on the surface layer of sediment, despite heavy pollution in the sediments from the stream feeding into the study site. The primary contaminants were fluoranthene, BaP, chrysene, phenanthrene and pyrene. Bioaccumulation of fluoranthene, pyrene and phenanthrene was up to ten times greater at the test site than at the control site. No differences in bioaccumulation at the two sites was detected for naphthalene.

Spies et al. (1989a,b) found that near the Los Angeles outfall, the uptake of sewage contaminants for fish was as follows: Microstomus pacificus (Dover sole) < Citharichthys sordidus (Pacific sanddab) < Zaiolepis latipinnis (longspine combfish). The last species occupies a higher trophic position. Concentrations of chlorinated hydrocarbons on a lipid-weight basis mirrored the order above. Increases of both total DDT and Aroclor 1254 from deposit-feeding invertebrates through fish were seen in foodwebs of the outfall and references areas. These data indicate that 
higher trophic levels may have higher bioaccumulation of contaminants because trophic transfer augments uptake from abiotic sources (interstitial water, desorption of sediment-bound contaminants, overlying water; see Chapter 8 for further discussion).

We have concentrated in this section on studies in which the bioaccumulation of organic contaminants in different species was compared in controlled experiments. Confounding variables thwart efforts to make strong inferences when comparing studies using different methodologies, different sediments, different contaminant concentrations, etc. From the comparisons here, some generalities do emerge. First, for related species occupying the same trophic level, patterns of bioaccumulation are typically quite similar. This is an important observation because it allows extrapolation of results from one species to to be used to formulate accurate predictions about bioaccumulation in related species. Interspecific differences may exist, however. Neff $(1979 a, b)$ indicates a wide variation in the ability of fish to accumulate PAH from their food. The strength of predictions will be dependent on the relatedness of the species being compared: For instance, it is far more likely that congeneric species will show similar patterns of bioaccumulation than species which are merely confamilial or conordinal. Second, there seems to be consistent differences among the higher taxa. For instance, polychaetes seem to have a limited ability to accumulate PAH from their food, while crustaceans readily assimilate PAH from their food (Neff 1979a,b). Bivalve molluscs typically show the highest bioaccumulation factors for PAH (Neff 1988a,b). Teleost fish rapidly accumulate low molecular weight aromatic compounds from water; however, the body concentrations drop rapidly after a few days because of active excretion (see section below) so the net accumulation of PAH by fish is typically low. Third, deposit-feeding species seem to accumulate contaminants to a greater degree than suspension-feeders. Fourth, predators may sometimes be at greater risk than their prey because of biomagnification of contaminants (see Chapter 8).

\subsection{ORGANIC CONTAMINANTS IN TISSUES OF MARINE ANIMALS}

Most organic contaminants are nonpolar, hydrophobic molecules. As a result they are readily taken up in lipid stores throughout an organism's body. Sites of uptake such as the gills or any epithelium exposed to the environment are likely to have increased contaminant burdens, particularly for organisms which are chronically exposed to contaminants. In this section, we will review the literature comparing the internal distribution of contaminants in the various tissues of marine organisms. The coverage will be by major taxon. Basic morphology of animals vary at the level of 
phylum and class, making higher taxa an appropriate focus of review of the uptake of organic contaminants.

\subsubsection{Polychaetes}

Polychaetes are soft-bodied organisms. Therefore, it is likely that uptake of contaminants can occur anywhere along the epidermis as well as along the gut epithelium from their food. Uptake is probably most rapid through the gills, if present, because the cuticle is reduced in these regions to facilitate the exchange of oxygen and carbon dioxide between the blood and external environment.

Lyes (1979) examined the uptake of ${ }^{14} \mathrm{C}$-labeled naphthalene in the polychaete, Arenicola marina. The authors found that naphthalene accumulated in the stomach wall and in the esophageal glands. Working with the polychaete, Nereis virens, Goerke (1984) found that tissue concentrations were unequal in the anterior and posterior ends. These differences corresponded directly to differences in lipid content between the two ends of the worms.

\subsubsection{Molluses}

Oysters, Crassostrea virginica, developed pathological changes after exposure to PCBs at 5 ug PCBs/liter for six months (Nimmo et al. 1975). The normal vesicular connective tissue lost its regular cell distribution and was infiltrated by leucocytes. Atrophy of gland tubules in the hepatopancreas epithelium and an enlarged lumen occurred in exposed oysters.

Biochemical changes within tissues have been reported for some molluscs after exposure to organic contaminants. Roesijadi and Anderson (1979) reported that exposure of the bivalve, Macoma inquinata, to oil-contaminated sediment resulted in reduced levels of free amino acids, particularly glycine, in the gills, mantle and adductor muscle. Augenfeld et al. (1980) conducted a similar study with $M$. inquinata and the suspension-feeding bivalve, Protothaca staminea. For Protothaca, the level of glycine in the mantle, gills and adductor muscle did not change significantly but the taurine levels fell.

Tanacredl and Cardenas (1991) examined the uptake of PAH from bottom sediments by the hard clam, Mercenaria mercenaria. The experiments were performed in the laboratory. The bioconcentration of PAH stabilized in the clams and did not fall after $45 \mathrm{~d}$ of depuration, indicating that acute exposures may result in chronic contamination. 


\subsubsection{Crustacea}

Working with the fiddler crab, Uca pugilator, and the decapod shrimp, Penaeus duorarum, in the laboratory, Nimmo et al. (1971) found significant quantities of PCBs in the hepatopancreas of each species. The quantity of contaminant was directly related to the amount of contaminant in the sediment. A subsequent study (Nimmo et al. 1975) revealed that chronic PCB exposure was associated with tissue changes. The normal epithelial cells in the hepatopancreas had inclusions of crystal. Similar results were obtained for the American lobster (McLeese et al. 1980a). In lobiters fed two PCBs and the organochlorine insecticide, endrin, concentrations in the hepatopancreas were greater than those in the tail muscle.

\subsubsection{Fish}

In fish, the covering of scales reduces epithelial uptake. The major site of uptake appears to be the gills which are regularly ventilated by water. For species which accumulate contaminants from their food, uptake occurs along the gut epithelium.

For pink salmon, Oncorhynchus gorbuscha, Rice et al. (1977) measured the effects of the water soluble fraction of Prudhoe crude oil. The highest tissue concentrations were found in the muscle, followed by the gut, then the gills. As explained in the section on excretion, these data support the concept of excretion through the pathway of liver-gall bladder-gut. Highest tissue concentrations in other species are also found in the liver, brain and muscle (Dixit and Anderson 1977).

Chronic toxicity of the PCB, Aroclor 1254, was examined in pinfish, Lagodon rhomboides, and spot, Leiostomus xanthurus (Nimmo et al. 1975). The liver concentrated the greatest amount of PCBs, followed by the gills, heart, brain and muscle in decreasing order.

A comparative study of Aroclor 1254 uptake was conducted by Cahn et al. (1977) using various fish. They found that the highest concentrations were located in muscles and in the liver of striped bass, Morone saxatilis, bluefin tuna, Thunnus thynnus, and spiny dogfish, Squalus acanthias. For striped bass, the highest concentrations were found in the ovary and in fat tissue in pre-spawning fish with lesser concentrations in the liver. In post-spawning fish, ovary and liver concentrations were equal to the pre-spawning liver concentration while the fat concentration increased. In general, Mearns et al. (1988) found that PCB levels in fish are higher in the liver than in muscles. A similar pattern was found for DDT. 
PAH from experimentally oiled sediments readily accumulated in English sole, Parophrys vetulus (McCain et al. 1978). These contaminants were found at the highest concentrations in the skin, muscle and liver.

Some data for a freshwater salmonid are included here because of the thoroughness of the analysis. Bean et al. (1985) studied the uptake of quinoline by rainbow trout, Salmo gairdneri. After $48 \mathrm{~h}$ of exposure to quinoline in the water, the tissue concentrations could be ranked as follows: gall bladder $>$ muscle $>$ gut $>$ eyes $>$ liver $=$ gill $=$ kidney .

Phillips (1980) discussed the increase in body burdens (on a per $g$ basis) of organic contaminants for fish and other organisms as they grow larger. In many cases, the age-dependence of organochlorines is caused partly or wholly by concomitant changes in the total lipid content of organisms as they increase in age or size. Thus, many fish show considerable increases in average whole-body or tissue content of lipids as they increase in age or size, which may be related to the general increase in fecundity of these species as they become older, and hence to the increased need for storage of lipids. The increase in the size of the total lipid pool (as a percentage of tissue weight) in older animals affords a sequestration site for greater amounts of organochlorines. Hence, concentration of these compounds based on wet weights increases. Any aquatic contaminant which depends for its biological affinity on its lipophilic and hydrophobic nature may be expected to exhibit similar age dependence. In cases which do not fit this expectation, explanations may lie in age-dependent chemical changes in the lipids present. Seasonal migration to areas with different pollutant levels may induce changes in bioaccumulated loads. Dietary switches with age may change the effect (could either cause an increase or decrease in organochlorines depending on the dietary switch).

\subsubsection{Marine Birds}

Llorente et al. (1987) examined the accumulation and distribution of DDT and PCBs in three species of ducks: Red-crested Pochard, Netta runina; Green-winged Teal, Anas crecca; and Northern Shoveler, A. clypeata. PCBs and DDT show different accumulation patterns, probably related to the different lipophilicity and the different lipid compositions of each tissue. The more carnivorous Anas species had higher contaminant concentrations, with PCB concentrations greater than DDT concentrations in the liver. The pochards had a higher concentration of DDT than PCB in the liver. 


\subsubsection{Excretion of Organic Contaminants}

A thorough understanding of bioavailability of sediment-bound contaminants requires that excretory and detoxification processes of associated organisms to be understood. A static measure of contamination in an organism ignores the dynamics of exchange between the organism and the environment. Efficient excretion of contaminants may cause a researcher to mistakenly assume that uptake of contaminants is low when uptake may be high, but elimination is rapid.

Many organic contaminants are resistant to chemical and biological degradation and tend to persist in the marine environment. As indicated above, there is abundant evidence that these hydrophobic (and hence lipophilic) compounds are readily accumulated by marine organisms (see Chapter 8).

Transformation of organic contaminants to forms that are less toxic and to forms which are hydrophilic, and hence, easily excreted occurs in marine organisms via enzymatic pathways. The enzymes responsible for these biotransformations are common to all animals (Buhler and Williams 1988, 1989).

Biotransformation reactions are broken down into two classes (Buhler and Williams 1989). In phase I reactions, polar ligands are added to the organic contaminant molecules. These additions may occur via numerous pathways (oxidations, reductions, and hydrolytic reactions). In phase II reactions, contaminants or their metabolites from phase I reactions are conjugated to polar molecules in the cytoplasm of the marine organism. Common polar molecules used for these conjugation reactions are glucoronic acid, sulfate or glutathione. These reactions result in highly water-soluble conjugates which can then be easily excreted through kidneys, nephridia or gills. Phase I and phase II reactions will be discussed separately.

In phase I reactions, polar groups are conjugated with organic compounds. The primary function of such reactions is to facilitate removal of endogenous compounds such as fatty acids and endocrine products (e.g., sex hormones). Although phase I reactions may facilitate the removal of organic contaminants, these reactions do not evolve in response to selective pressure for removing such contaminants. Rather, nonpolar contaminants are serendipitously altered by phase I reactions which help regulate the internal milieu of uncontaminated organisms.

The oxidative metabolism of organic contaminants is primarily catalyzed by the mixed-function oxidase (MFO) system. This system depends on the cytochrome P-450 which is 
found in the endoplasmic reticulum of the cells of marine organisms. There are numerous classes of reaction that occur in the MFO system, affecting a variety of nonpolar compounds. In fish, the liver is the major site of the MFO system (Buhler and Williams 1989). Many data indicate that the MFO system is particularly active in the biotransformation of PAH (Bend and James 1978, Lech and Bend 1980, Stegeman 1981). The MFO system is inducible in fish, resulting in a significant increase ( $>3$ times) in activity (Lech et al. 1982, Binder et al. 1984). Reports of induced MFO systems in invertebrates are relatively rare (Lee et al. 1979, Livingstone et al. 1985). However, the evidence to date indicates that the basic MFO system is similar in all organisms that have been studied (Nemoto and Gelboin 1976, James et al. 1979a,b, Sims and Grover 1981, Wood et al. 1983, Foureman et al. 1987).

Much of the work on the role of the MFO system in affecting the bioavailability of sediment-bound contaminants has used the hydrocarbon benzo[a]pyrene. This compound is a common component of petroleum hydrocarbons. Ironically, the MFO system oxidizes benzo[a]pyrene to metabolites which have carcinogenic and mutagenic properties (e.g., Varanasi and Gmur 1980, Stegeman 1981, Malins 1982, Protic'-Sabljic' and Kurelec 1983, Milling and Mattock 1985, Nishimoto and Varanasi 1985). The particular phase I reaction of benzo[a]pyrene is catalyzed by benzo[a]pyrene-hydroxylase (BaP-hydroxylase). This enzyme is sometimes referred to as aryl hydrocarbon hydroxylase (AHH). Table 7.1 lists the activities of $\mathrm{BaP}$-hydroxylase and cytochrome P-450 activity in a number of marine organisms. Such activity has been detected in all species for which assays have been conducted; this portion of the MFO system appears to be ubiquitous. General patterns from the table include; (1) there is wide variation within a class of organisms for both cytochrome P-450 activity and BaP-hydroxylase activity, (2) on the average, elasmobranch fishes seem to have higher cytochrome P-450 activity than teleost fish, and (3) invertebrates (crustaceans and molluscs) appear to have low BaP-hydroxylase activity relative to the fish.

The primary site of BaP-hydroxylase activity (and other MFO reactions) appears to be the liver of fish, the hepatopancreas of crustaceans and the digestive gland of molluscs (Buhler and Williams 1989). However, significant activity in fish has been documented in the kidney, heart, gills, gut, spleen, testes, ovaries and muscles (Buhler and Rasmusson 1968, Lindstrom-Seppa et al. 1981, Stegeman 1981, Stegeman et al. 1982), with the kidney being the most active organ after the liver. Interestingly, the MFO system is functioning as little as four days after fertilization in fish embryos (Binder and Stegeman 1980). 
Some workers have attempted to use BaP-hydroxylase activity as a measure of environmental health (Payne and Penrose 1975). Although BaP-hydroxylase is induced by petroleum hydrocarbons in fish, the approach has not proved very successful. In most habitats that have been studied, the fish have BaP-hydroxylase levels that are characteristic of the induced state. Even background levels of petroleum hydrocarbons leading to the induction of the enzymes and hence additional increases of contaminants, such as from an oil spill, do not alter the BaP-hydroxylase activity (Stegeman 1981).

Phase II reactions further metabolize products that are produced in phase I reactions. These reactions increase the polarity of lipophilic (hydrophobic) contaminants by conjugation of the contaminant molecules with various endogenous compounds (Foureman 1989). By increasing the polarity of the molecules, excretion is facilitated.

There are four major classes of enzymes involved in phase II reactions. The first are the glutathione S-transferases (GST). The tripeptide glutathione contains a thiol group which effectively neutralizes the polar metabolites generated from PAH and other organic contaminants by phase $I$ reactions. Glutathione is of particular importance for the conjugation of epoxides, the activated intermediate metabolites of PAH.

Glutathione is maintained in high concentrations in the tissues of many animals. A thorough study by Stenersen et al. (1987) revealed that GST activity occurred in 71 of 72 animals examined, drawn from nine different phyla. Glutathione comprised $0.3 \%$ to $0.7 \%$ of all of the soluble protein (including peptides) present in these organisms. The conjugation of organic metabolites with glutathione typically proceeds to the formation of mercapturic acids which are easily excreted through the urine.

Table 7.2 presents a summary of GST activity in a number of organisms. As with the AHH system above, there is great variability among species within major taxa. For the elasmobranchs, GST activity for the Little Skate is over 60 times the activity for the Atlantic Stingray. Invertebrate GST activity is lower than that for most elasmobranch and teleost fishes.

The greatest GST activity occurs in the liver of vertebrates, in the hepatopancreas of crustaceans and in the digestive gland of molluscs (Foureman 1989). GST activity in extrahepatic tissue has been demonstrated in the kidney, gonads, gills, spiral valve, spleen, heart and pancreas of the Little Skate, Raja erinacea (Bend et al. 1977). Similar results were obtained by Bauermeister et 
al. (1983) for the rainbow trout, Salmo gairdneri. Tate and Herf (1978) demonstrated GST activity in the gills and antennal (excretory) glands of the blue crab, Callinectes sapidus.

The second major set of phase II reactions are catalyzed by epoxide hydrolase (Foureman 1989). Epoxides (alkene and arene oxides) are produced as metabolites in phase I reactions. These epoxides can be conjugated with glutathione by GSTs, described above, or converted to dihydrodiols by the action of epoxide hydrolases. Epoxide hydrolase is especially effective with the oxides of some PAH. In most instances, the dihydrodiols so formed are not toxic and may serve as substr ttes for further metabolism. This metabolic pathway provides a mechanism of detoxification of PAH oxides or oxides of other organic contaminants.

Epoxide hydrolase activity is greatest in the liver of tish, the hepatopancreas of crustaceans and the digestive gland of molluscs. Extrahepatic activity occurs as well. Bend et al. (1977) showed that the gills and egg masses of lobsters, Homarus americanus, have measurable epoxide hydrolase activity. Foureman (1989) claims that epoxide hydrolase activity has been demonstrated in every tissue that has been assayed.

A comparison of hepatic epoxide hydrolase activity in vitro is presented in Table 7.3. An oxide of benzo[a]pyrene, namely benzo[a]pyrene 4,5 oxide, was used as a substrate. The data show a trend of invertebrates, especially lobsters and spiny lobsters, to have greater activity than finfish.

A third class of phase II reactions are catalyzed by UDP-glucuronosyltransferases. These enzymes conjugate oxidized metabolites of organic contaminants to metabolically activated UDP-glycosides to form a D-giucuronide (Foureman 1989). Relatively unexplored, UDP-glucuronosyltransferases have been studied in three species of fish, vendace, Coregonus albula, roach, Rutilus rutilus and rainbow trout, Salmo gairdneri (Lindstrom-Seppa et al. 1981). The liver was a site of active catalysis although in roach, the enzymatic activity in the gills was over twice that of the liver.

The final class of phase II reactions involves sulfotransferases. For PAH, these enzymes are responsible for the conjugation of 3'-phosphoadenosine 5'-phosphosulfate to form a sulfonate monoester (Foureman 1989). These enzymes have received little attention for marine organisms. Some data are available for the southern tlounder, Paralichthys lethostigma, showing the formation of sulfonated compounds of the carcinogenic PAH metabolite, 7,8-dihydro-7,8-dihydroxybenzo[a]pyrene (Pritchard and Bend 1984). For English sole, Parophrys vetulus, Varanasi et al. (1982) showed that 
administration of benzo[a]pyrene resulted in the accumulation of sulfonate conjugates as well as glucuronides, catalyzed by UDP-glucuronosyltransferases.

In summary, the present understanding of excretory processes of organic contaminants incorporates two sets of reactions: phase I reactions involving oxidation of organic contaminants using the MFO system followed by phase II reactions involving four classes of enzymes which promote the conjugation or hydration of various chemical groups to the metabolites produced in phase I reactions. It can be argued that these enzymatic systems arose evolutionarily for the excretion of endogenously produced compounds. Their effect in removing organic xenobiotic compounds is significant but fortuitous. As shown above, metabolism of many organic contaminants results in metabolites which have enhanced carcinogenic or mutagenic properties relative to their parent compound.

It is evident that MFO systems and the various enzymes that catalyze conjugation of their by-products are ubiquitous in marine organisms. Certainly the activities of particular enzymes may vary according to major taxa (see Tables 7.1, 7.2, and 7.3). However, it would be most remarkable to find any marine animal which was not capable of metabolizing organic contaminants using the systems described above. Given the ubiquity of these systems, a catalog of all of the marine organisms which are capable of metabolizing organic contaminants is not necessary here. The interested reader should consult recent reviews by James (1989) for marine invertebrates and Varanasi et al. (1989a) for marine fish.

Despite the general distribution of these excretory mechanisms, determination of the relative health of a soft-sediment environment cannot be determined from measurement of metabolite concentrations in the environment or within the organism. Varanasi et al, (1989b) indicate that the multiple metabolic steps involved, the different metabolites produced by the phase I and II reactions and the impossibility of obtaining a complete recovery of all of these metabolites from organisms, provide little hope for mechanistic predictions of the effects of organic contaminants. Evidence exists that metabolites are retained for a much longer period of time than parent compounds in marine organisms (Lee et al. 1976, Malins 1977, Sanborn and Malins 1977), further complicating measurements and interpretation. Related species may retain metabolites in greatly different proportions (Varanasi et al. 1989b). While an understanding of phase I and II reactions is essential to understanding the cycling of organic contaminants in a soft-sediment marine environment, the effects of those contaminants will only be apparent from ecological (e.g., reduced fecundity, increased mortality, reduced growth) or morphological (e.g., presence of tumors or other abnormalities) 
measurements. Differences between organisms may be related to differences in the activities of the MFO system and the phase II enzymes. For instance, bivalves do not seem to be able to metabolize organic contaminants with the same facility as crustaceans and fish (Stegeman 1981). Crustaceans do not seem to be able to metabolize aromatic compounds with the same facility as fish (Malins 1977). However, considering the wide variation among species within a major taxon, the generalities above offer little precision in generating predictions of the effects of sediment-bound contaminants.

\subsection{SUMMARY OF BIOACCUMULATION OF ORGANIC CONTAMINANTS}

Bioaccumulation is conventionally defined as the uptake and retention in the tissues of a bioavailable chemical from all possible external sources (water, food, and substrate). The magnitude of bioaccumulation is usually measured as the bioaccumulation factor, a function of the ratio of the rate of uptake of the chemical to the rate of excretion of the chemical. Bioconcentration is a restricted case of bioaccumulation. Bioconcentration is the uptake and retention of a chemical from the water alone; uptake from food or substrate is not considered.

It is not surprising that bioconcentration values are frequently high. Most organic contaminants have very low solubility in water and hence are readily absorbed by lipophilic tissues of aquatic organisms. A typical example is provided by Risebrough et al. (1976) who measured the bioconcentration of DDT and PCBs in the blue mussel, Mytilus edulis, at four different sites in the French Mediterranean and two sites in California. For PCBs, bioconcentration ranged between 69,000 and 690,000. DDT bioconcentration ranged between 45,000 and 690,000. Neff and Giam (1977) report bioconcentration factors of 41-1298 for Aroclor, a minimally chlorinated PCB, and 23-74 for Halowax ${ }^{\mathrm{Tx}}$, a polychlorinated naphthalene. For synthetic pyrethroid insecticides, Schimmel et al. (1983) calculated bioconcentration factors of 1900 for permethrin, 4700 for fenvalerate and 222,705 for $\mathrm{AC}^{\mathrm{T} x}$.

Due to their hydrophobic nature, organic contaminants have much greater concentrations within sediments than in the water column. However, many of these molecules are tightly bound to the sediment and hence are not bioavailable. Most of the published bioaccumulation factors, which include the substrate as a possible source, are relatively low compared to bioconcentration factors. Bioaccumulation factors tend to range between 0.1 and 20 , several orders of magnitude less than published bioconcentration factors. 
A few authors have examined the dietary concentration of organic contaminants. McLeese et al. (1980a) fed American lobsters, Homarus americanus, and blue mussels, Mytilus edulis, which had been contaminated with two PCBs and the organochlorine insecticide, endrin. Concentration factors were 1.0 to 5.1 for PCBs and 2.0 for endrin.

Several caveats are in order regarding the interpretation of bioaccumulation and bioconcentration factors. First, the values will vary depending on whether the measurements are made with chronic or acute exposures to the chemical. Second, no contaminant should be studied alone. Lipophilic compounds, such as many organic contaminants, will likely compete for binding sites within organisms. Third, excretion is a highly complex process. To adequately determine bioaccumulation values, the concentration of the metabolites of the contaminants need to be measured as well. In several (perhaps many) cases, the metabolites of organic contaminants are more detrimental to the organism than the parent compound. Thus, bioconcentration factors can be useful qualitative indicators of the reactivity of organic contaminants, but lack the precision to be precise tools for assessing environmental impacts of organic contaminants.

\subsection{BIOAVAILABILITY AND BIOACCUMULATION OF ORGANIC CONTAMINANTS IN SEAGRASSES}

There is a dearth of information on the effects of organic contaminants on seagrasses (Phillips 1984). The effects of oil spills on seagrasses seems to be minimal (Phillips 1984). McRoy and Williams (1977) showed that plants exposed to low levels of kerosene and toluence showed significantly reduced rates of carbon uptake. No other information on the relationships of organic pollutants with seagrasses is available. 
Table 7.1. Compendium of Cytochrome 450 and BaP-Hydroxylase Activities for Marine Organisms. Modified after Buhler and Williams, 1989. Different techniques were used by the various workers to calculate activities.

Species $\quad$ (nmol/mg protein)

Teleost fish Scup

Sheepshead

Coho saimon

Mullet

Starry flounder

Mangrove snapper

Winter flounder

Sculpin

Black drum

Southem flounder

Eel

Elasmobranch fish

Nurse shark

Atlantic stingray

Large skate

Litule skate

Bluntnose ray

Dogfish shark

Southern stingray

Crustace

Crabs

Uca pugnax

U. minax

U. pugilator

Callinectes sapidus

Menippe mercenaria

Libinia sp.

Sesarma cinereum

Spiny lobsters

Panulirus argus

Barnacles

Balanus ebumeus

Mollusca

Gastropoda

Tegula finebralis

Littorina littore

Thais haemastoma

Bivalvia

Mytilus edulis

M. galloprovincialis
Cytochrome 450

(nmol/mg protein)
$0.14-0.23$

$0.06-0.14$

$0.09-0.16$

$0.04-0.19$

0.18

\section{-}

$$
-
$$

$0.20-1.00$

$0.36-0.56$

$0.31-0.51$

0.91

0.11

0.047

0.134

0.047

\section{BaP-hydroxylase \\ (nmol/min/mg \\ protein)}

\title{
$\underline{\text { Reference }}$
}

\author{
Stegeman \& Binder 1979 \\ Stegeman et al. 1982 \\ Stegeman et al. 1982 \\ James et al. 1979 \\ Little et al. 1981 \\ Gruger et al. 1977 \\ Schnell et al. 1980 \\ Varanasi \& Gmur 1980 \\ Little et al. 1981
}

Schoor \& Srivastava 1984

Varanasi \& Gmur 1980

James et al. 1979

Pohl et al. 1974

Bend et al. 1974

Payne and Fance 1982

James et al. 1979

James et al. 1979

Pohl et al. 1974

James et al. 1979

James et al. 1979

James et al. 1979

James et al. 1979

James et al. 1979

Pohl et al. 1974

James et al. 1979

0.043

Lee et al. 1982

James et al. 1979

James et al. 1979

Lee et al. 1982

James et al. 1979

Singer \& Lee 1977

Singer \& Lee 1977

James et al. 1979

James et al. 1979

James and Bend 1980

James et al. 1979

Stegeman \& Kaplan 1981

$\begin{array}{ll}- & 0.073\end{array}$

0.046

$<0.01$

0.054

$0.02-0.03$

0.024
Williams et al. unpublished

Livingstone et al. 1985

Livingstone 1985

Livingstone et al. 1986

Stegeman 1981

Livingstone 1985

Ade et al. 1982 
Table 7.2. Activity of in vitro Activity of Glutathione s-transferases (GSTs) in Marine Organisms. The substrate tested is benzo[a]pyrene 4,5-oxide. Data from Bend et al. 1977, Foureman and Bend 1984, Foureman 1989.

Species

GST activity

(nmol/min/mg protein)

Teleost Fish

Sheepshead Archosaugus probatocephalus

53

Black drum Pogonius cromi

9

Winter flounder Pleuropleuronectes americanus 5

Eel Anguilla rostrata

Mangrove snapper Lutjanus griseus

Elasmobranch fish

Little skate Raja erinaceus

131

Dogfish shark Squalus acanthias

8

Atlantic stingray Dasyatis sabina

2

Crustacea

American lobster Homarus americanus

3

Spiny lobster Panulirus argus

Rock crab Cancer irroratus

$<1$

$<1$

Mollusca

Blue mussel Mytilus edulis

$<1$

Soft-shell clam Mya arenaria

$<1$ 
Table 7.3. Comparison of Epoxide Hydrolase Activity of Marine Organisms Using in vitro Preparations of Liver (fish), Hepatopancreas (crustaceans) or Digestive Gland (molluscs) Extracts. The substrate used was the PAH oxide, benzo[a]pyrene 4,5-oxide. Data from Foureman (1989).

Species

Teleost fish

Winter flounder Pleuropleuronectes americanus Sheepshead Archosaugus probatocephalus

Eel Anguilla rostrata

Elasmobranch fish

Dogfish shark Squalus acanthias

Little skate Raja erinaceus

Atlantic stingray Dasyatis sabina
EH activity

(nmol $/ \mathrm{min} / \mathrm{mg}$ protein)
Crustacea

American lobster Homarus americanus

4

3

2

3

$<1$

$<1$

Spiny lobster Panulirus argus

Blue crab Callinectes sapidus

Rock crab Cancer irroratus

Mollusca

Soft-shell clam Mya arenaria
6

19

4

2

$<1$ 


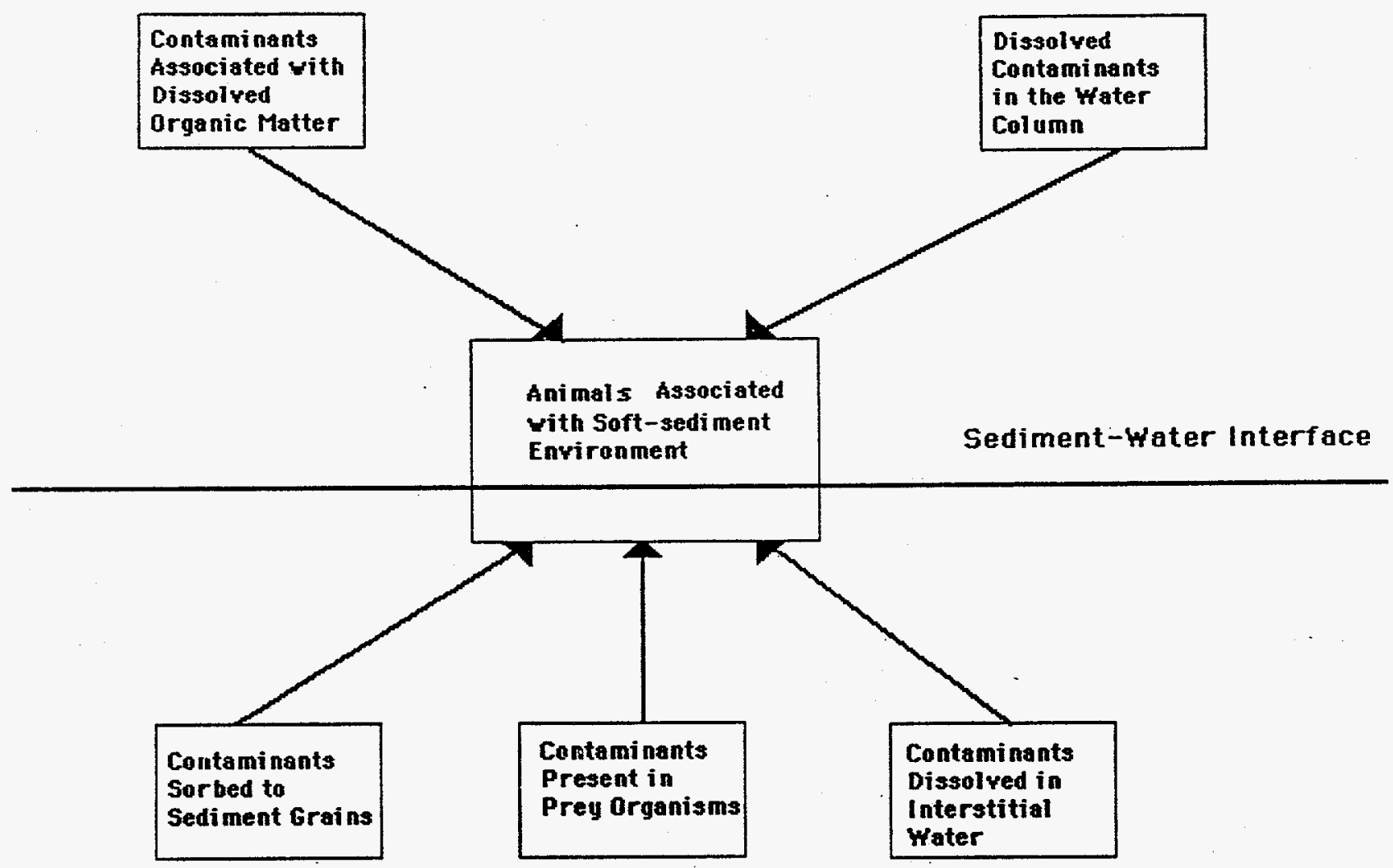

FIGURE 7.1. Schematic of Possible Sources of Organic Contaminants to Marine Animals 


\subsection{FOOD CHAIN TRANSFER AND POSSIBLE BIOMAGNIFICATION \\ OF METALS AND ORGANIC CONTAMINANTS \\ IN MARINE FOOD WEBS LEADING TO HUMANS}

\subsection{INTRODUCTION}

When a metal or organic contaminant is accumulated from sediment or sediment porewater by a benthic plant or animal, the contaminant is still part of the benthic system. However, these contaminants may be mobilized into other environmental compartments if the benthic organisms or their remains (as organic detritus or particulate organic matter) are consumed by epibenthic, pelagic, or terrestrial animals, including man. Therefore, the potential hazard to the marine environment and man of chemical contaminants is not restricted to benthic organisms alone. Marine food chains that include benthic components also may be affected by sediment contamination. In addition, the main hazard to man from marine pollution is from consumption of contaminated marine fishery products.

In Chapters 6 and 7, we discussed the bioavailability to and bioaccumulation by benthic organisms of chemical contaminants in marine and estuarine sediments. In this chapter, we discuss the transfer of chemical contaminants from sediments through marine food webs to higher trophic levels, and the possibility of food chain biomagnification of chemicals in marine food webs. The scientific literature on these topics is scanty and we have had to rely on and extrapolate, in some cases, from the published literature of food chain transfer and biomagnification in pelagic marine and freshwater food webs. When this was done, we have tried to relate the results of the studies to processes in marine sediment-based food chains to the extent possible.

\subsection{TROPHIC TRANSFER AND BIOMAGNIFICATION}

The effect mobilization has on the consumers of benthic fauna or the animals that, in turn, consume them depends on the efficiency with which the consumers can absorb the contaminants from the gut and sequester them in their tissues.

The process of accumulation of contaminants from food is called trophic transfer. Trophic transfer of contaminants in marine food webs involves many of the same physical and chemical processes that are involved in accumulation of contaminants from the water and sediments. However, bioaccumulation occurs primarily or exclusively in the unique environment of the gut of the consumer. Presumably, the contaminants introduced into the gut of the consumer sorbed or bound to 
organic components of the prey item, must be desorbed and dissolved in the gut fluids before they become bioavailable and can be absorbed across the gut wall, or incorporated into intracellular digestive vacuoles in those consumer species that rely on intracellular digestion (Pandian 1975). It is possible that highly nonpolar, lipophilic compounds sorbed to lipids of the prey may be absorbed directly into the intestinal mucosa with partially digested lipids, aided by bile salts. These lipophilic compounds may then pass with the resynthesized triacylglycerols into the abdominal lymphatic vessels and become bound to chylomicrons. Because of the abundance in the gut of organic compounds capable of binding organic and metal contaminants, decreasing their bioavailability, it is possible that the efficiency of uptake of contaminants from food may, in some cases, be less than that of uptake of contaminants from solution in water or sediment/porewater systems.

Contaminants may be spread throughout a marine food web by trophic transfer. If the trophic transfer is reasonably efficient and the consumers at each trophic level in the food web are inefficient in excreting the contaminants, it is possible that the contaminants will be biomagnified in the food web. Biomagnification is the process whereby a chemical as it is passed through the food chain or food web by trophic transfer, becomes increasingly concentrationed in tissues of organisms at each higher trophic level. There are two requirements for biomagnification. First, the efficiency of uptake of the chemical through the gut must be high. Second, once the chemical has been absorbed from the food by the consumer, it must be retained in or bound tightly to the consumer's tissues so that its rate of passive or active excretion is low. If these conditions prevail, and the food remains contaminated for a long time, the consumer will, over a long period of time, eat several times its own body weight of contaminated food and may retain the chemical in its tissues at a concentration higher than the concentration of the chemical in the food.

It may require a considerable amount of time for a predator to show significant biomagnification of a chemical contaminant that it encounters only in its food. For instance, a codfish, Gadus morhua, greater than $30 \mathrm{~cm}$ long consumes an average of $0.9 \%$ to $1.5 \%$ of its body weight in food each day (Durbin et al. 1983). If the cod's diet (a mixture of fish and benthic invertebrates) is contaminated with a contaminant, $X$, and the efficiency of assimilation of $X$ from its food is $50 \%$, the cod will accumulate in its tissues a concentration of $X$ equal to that in its food in $200 \mathrm{~d}$, assuming that none of $\mathrm{X}$ is excreted by the cod. Therefore, if no excretion of $\mathrm{X}$ occurs, it might require a year or more to convincingly demonstrate biomagnification of $\mathrm{X}$ in the cod. 
Biomagnification, particularly of highly lipophilic organic compounds, such as chlorinated pesticides and polychlorinated biphenyls, has been demonstrated in terrestrial food chains and the terrestrial component of aquatic/terrestrial food chains (Nisbet and Sarofim 1972, Peakall 1975, Shaw and Connell 1982). However, biomagnification may be less likely in strictly marine/aquatic food chains than in terrestrial food chains because marine organisms possess excretory pathways for contaminants not available to terrestrial animals.

A variety of active excretory pathways of contaminants are available to both marine and terrestrial animals. These include metabolic conversion of polar organic compounds to more watersoluble compounds followed by active excretion in the urine (Pritchard and Bend 1984) or bile (Stegeman 1981, Lee 1981), and complexation of metals with specific ligands, such as metallothionein followed by active excretion of the bound metal (Roesijadi 1981, Simkiss and Mason 1984, Shears and Fletcher 1985).

In addition, at least some of the external body surfaces of all marine animals are permeable (e.g., the gills) and contaminants can partition passively out of the animals into the surrounding water through these surfaces (equilibrium partitioning). According to equilibrium partitioning theory (Bierman 1990), when a marine animal is exposed to a nonpolar contaminant dissolved in the ambient medium (seawater or interstitial water), the contaminant partitions into the tissue lipids until an equilibrium (defined by $\mathrm{K}_{\mathrm{ow}}$ or $\mathrm{K}_{\mathrm{oc}}$ for the chemical) is reached. At equilibrium, the rates of absorption into and desorption from the lipid phase of the animal are equal. If the animal also accumulates the contaminant from its food, then a point should be reached when the concentration of the contaminant in the tissue lipids exceeds the equilibrium value and the rate of desorption will exceed the rate of absorption, returning the concentration of the contaminant in the tissue lipid towards the equilibrium value. Thus, the equilibrium concentration of a contaminant in the tissue lipids of a marine organism should be dependent on the concentration of the contaminant in the ambient medium, irrespective of any uptake from the food (Kay 1984). However, the degree to which biomagnification occurs in an aquatic food web may depend primarily on the rate at which equilibrium is reached for a particular contaminant (Addison 1976). Biomagnification may occur if the rate of uptake of a contaminant into tissue lipids is much greater than the rate of release from tissue lipids.

Passive excretion of nonpolar organic compounds, such as petroleum hydrocarbons (Neff et al. 1976, Farrington et al. 1982, Lauren and Rice 1985), polychlorinated biphenyls (Langston 
1978a,b, Calambokidis et al. 1979), and pesticides (Mason and Rowe 1976) has been demonstrated in marine bivalve molluscs that have only a limited ability to metabolically convert these compounds to soluble excretory products. Metals may behave similarly (Simkiss and Taylor 1989).

\subsubsection{Food Webs}

Demonstration of biomagnification is complicated by the fact that trophic relationships in most marine communities are very complex and only partly understood. Simple food chains, hierarchies of monophagous consumers (Paine 1980, Gray 1981), are very rare in marine ecosystems. Instead, most consumers are polyphagous, feeding on a variety of foods, often from different trophic levels. Groupings of polyphagous consumers constitute a food web. Even the concept of trophic levels in marine ecosystems is flawed. Darnell (1961), in describing the trophic relationships in coastal Louisiana, argued that most estuarine consumers derive nutrition from numerous prey categories, most of which can not readily be assigned to any particular trophic category. For instance, the grass shrimp, Palaemonetes pugio, a common estuarine species along the U.S. coasts of the Gulf of Mexico and the Atlantic, can function as a herbivore, detritivore, or carnivore, depending on prey availability (Welsh 1975). In fact, most of the consumers in estuarine food webs practice two or three different modes of feeding (Simenstad et al. 1990). For example, Paine (1980) has shown that rocky intertidal communities along the Pacific coast of the United States show marked latitudinal differences in trophic relationships, even though the species composition does not vary much over the latitudinal range of the study. Similar latitudinal patterns undoubtedly also occur in soft bottom benthic communities.

For most animals at higher trophic levels in marine food chains, actual diet at any particular time depends in large part on availability of different types of prey. For example, Adams and Brown (1989) reported that prey availability determined most of the differences in diets of four co-occurring species of penguins on sub-Antarctic Marion Island. Winter flounder, Pseudopleuronectes americanus, in Charlestown Pond, Rhode Island, consumed a wide variety of benthic prey, including crustaceans, polychaetes, tunicates, molluscs, and plant material, but diet composition varied seasonally, depending on availability of different prey items (Worobec 1984). Thus, a particular species may function at different trophic levels depending on local conditions and food availability.

Marine benthic food webs, in particular, are incompletely understood. Potential food sources for the non-predatory benthic fauna of fine-grained marine sediments include phytoplankton, benthic algae, vascular plant litter, particle-associated microorganisms, especially bacteria, fungi, and 
protozoa, a wide range of detrital organic materials, and dissolved organic matter (Lopez and Levinton 1987, Lopez 1988). Marine bacteria, yeasts, fungi, and protozoa (microautotrophs and microheterotrophs) play important roles in cycling nutrients in most estuarine, detritus-based benthic food webs (Gerlach 1978, Soule and Soule 1981, Kemp 1990). Microautotrophs use energy from sunlight or oxidized inorganic chemicals to produce new organic chemicals. Microheterotrophs convert plant detritus to organic material (bacterial biomass) that is more readily digestible by meiofauna and macrofauna.

It has been thought for several years that sediment bacteria are the main source of nutrition of deposit-feeding macrofauna, followed by meiofauna, such as polychaetes, nematodes, and harpacticoid copepods (Gerlach 1978). The relative importance of bacteria in benthic food chains depends in part on sediment type and concentration of organic matter in the sediments. Usually, bacterial biomass in marine sediments is equivalent to about $4 \%$ or less of the total organic carbon concentration in the sediment (Roublee 1982). However, the direct correlation, reported by Roublee (1982), between bacterial abundance and organic matter in sediments appears to be an oversimplification (Bird and Duarte 1989). Many factors, in addition to concentration of total organic carbon affect the abundance of bacteria in sediments. Often, bacterial biomass is similar to that of macrofaunal biomass and greater than meiofaunal biomass (Kemp 1990). However, bacterial production is always much greater than production of meiofauna and macrofauna. Therefore, most sediment organic matter is consumed by bacteria. Nevertheless, several recent studies indicate that bacterial biomass makes up only a small fraction of the nutritional requirements of deposit-feeding infauna (Lopez and Levinton 1987, Kemp 1990). For instance, Cheng and Lopez (1991) showed that the deposit-feeding bivalve, Nucula proxima, absorbed bacterial carbon more efficiently than detritus from ingested sediment. However, the animals obtained only $2 \%$ to $35 \%$ of the total organic carbon absorbed from sediment from bacteria and $65 \%$ to $98 \%$ directly from sedimentary organic matter.

On the other hand, many species of meiofauna, particularly nematodes and polychaetes, are bacteriophagous and, under some circumstances, consume a large fraction of the bacterial production (Kemp 1990). In some sediments, protozoa, particularly microflagellates, consume a large fraction of the bacterial biomass (Kemp 1990). In all but sandy benthic ecosystems, deposit-feeding macroinfauna probably graze directly on all the lower trophic levels in the sediment, including bacteria, protozoa, and meiofauna, creating a complex benthic trophic structure. 
The deposit-feeding polychaete, Nereis succinea, derives about one-fourth of its dietary carbon requirement directly from bacterial carbon (Cammen 1980). Other sources of carbon in its diet include direct digestion of plant detritus, consumption of meiofauna, and direct uptake of dissolved organic material from pore water. The deposit-feeding clam, Macoma balthica, is able to use bacteria, but not bacterial exopolymer, as a source of nutrition (Harvey and Luoma 1984). However, Bremer and Loutit (1986) found that bacterial exopolymer (polysaccharide) is an important vehicle for entry of trivalent chromium into a marine food chain.

Filter-feeders and detritivores may also use bacteria as a source of nutrition. Newell and Field (1983) reported that bacteria provide about $9 \%$ of the carbon and up to $73 \%$ of the nitrogen requirement of filter-feeders in a marine kelp community. Bacteria play an important role in degrading and converting organic matter in decaying plant material to a more easily assimilated form. Detritivores, such as the polychaete, Capitella capitata, rely for nutrition on the products of microbial degradation of plant detritus (Tenore 1977).

Most of the epibenthic macrofauna and demersal fish that prey on benthic fauna also are polyphagous. Only a few examples will be given here. The dominant food of yellowtail flounder, Limanda ferruginea, off southern New England is the polychaete, Spiophanes bombyx, and the amphipod, Unciola sp. (Langton 1983). However, the diet includes at least 22 other species of benthic or epibenthic marine animals. Winter flounder in a salt pond in Rhode Island are omnivorous, consuming a wide variety of benthic plant and animal foods, including detritus (Worobec 1984). In most seasons, the most abundant foods in winter flounder stomachs are detritus and polychaetes. However, particularly in the spring, a large part of the diet includes benthic crustaceans and grasses. Off the Oregon Coast, small English sole, Parophrys vetulus, feed primarily on polychaetes, juvenile bivalves, and harpacticoid copepods. Larger fish also feed on amphipods and cumaceans (Hogue and Carey 1982). Young Dungeness crabs in the estuaries of Washington feed on small bivalves, crustaceans (including Dungeness crabs and Crangon), and juvenile fish (Stevens et al. 1982).

The polyphagous nature of most marine animals makes it difficult to detect possible biomagnification, if it does occur. More important, because the concentrations of contaminants in tissues of marine animals vary widely from one benthic species to another (See review of Luoma $1986 \mathrm{~b}$ for lead), bioaccumulation of contaminants from the food will be related to the mean 
concentration of the contaminant in the total diet and the relative efficiencies of accumulation of the contaminants from the different food species.

\subsubsection{Methods for Documenting Biomagnification}

A variety of approaches has been used to determine if biomagnification is occurring in a marine community. Although not always done, it is important first to establish that trophic transfer of the chemical of interest is taking place in the food chain under examination. This is best performed by laboratory feeding studies. Contaminated food (preferably contaminated by bioconcentration, because then the contaminant is present in the forms in which it occurs in prey items in the environment) with known concentrations of the contaminant are fed to a consumer. Concentrations of the contaminant in the consumers are monitored over time. Concentrations of the contaminant in the ambient water in which the consumer is kept should also be monitored for the contaminant to ensure that some of the contaminant has not desorbed from the food before it is ingested by the consumer. By comparing the amount of contaminant in the food and in the feces of the consumer, it is possible to estimate the efficiency of uptake of the contaminant from the food. However, some benthic invertebrates do not produce discrete fecal pellets or they are deposited below the sediment surface where they can not be collected quantitatively. In such cases, other methods, such as use of radio-labeled food, must be used. The consumers should be allowed to void the contents of their digestive tracts before concentrations in their tissues are measured so that the unabsorbed contaminant associated with food or sediment in the gut is not counted as bioaccumulated (Lobel et al. 1991).

Circumstantial evidence for trophic transfer of a contaminant can also be gained by examining the distribution of the contaminant in a natural or artificial food chain. However, it should be kept in mind that, in a natural food chain, most of the members of the food chain are being exposed to the contaminant in both the water and food, and also, for benthic animals, the sediments. Differences in concentrations of the contaminant in animals at different trophic levels may be caused by;

(1) differences among members of the food chain in their efficiency to bioaccumulate the contaminant from the different ambient sources (water, sediment, and food), (2) differences in excretion rates of the contaminant, and (3) differences in body composition and growth rate of animals at different trophic levels. 


\subsubsection{Determination of Trophic Status}

It is essential to know the trophic position of the different members of the food web in order to study food chain transfer and biomagnification. Five trophic positions or steps can be identified in marine food webs (Mearns 1982):

Trophic Level 1

Trophic Level 2

Trophic Level 3

Trophic Level 4

Trophic Level 5
Primary producers (plants, photosynthetic bacteria, and chemoautotrophs)

Herbivores and detritivores (plant consumers)

Primary carnivores that feed on herbivores and detritivores

Secondary carnivores

Tertiary or top carnivores in the ocean.

Benthic plants, photosynthetic bacteria, and chemoautotrophs represent sediment-associated organisms at trophic level 1. Most of the benthic invertebrates are at trophic levels 2 and 3 , or both, as discussed above.

Several approaches have been used for assigning plants and animals to the different trophic levels. Plants are in trophic level 1. Some animals can be assigned by simple inspection. Hints to trophic assignment can be gained by morphology of the feeding apparatus. Fauchald and Jumars (1979), Ward et al. (1980), and others separated benthic infauna into several feeding guilds or groups, based on morphology, particularly of the feeding apparatus.

For larger marine animals, it may be possible to classify an animal based on its stomach contents (Mearns 1982). As discussed above, most marine animals are polyphagous and their diet includes representatives of more than one trophic level. Therefore, trophic assignment based on whole diet may include a whole number and a fraction (e.g., 3.4). By definition, a predator occupies a position in the food web one trophic level higher than the trophic level of its prey. Thus, the trophic level of the consumer can be defined as the trophic level of its prey plus 1.0 (Mearns 1982). To define the trophic level of a polyphagous predator, the relative importance of different prey items in the diet of the predator must be estimated. An index of relative importance of different food items in the diet of a consumer (Pinkas et al. 1971) can be calculated as:

$$
\mathrm{IRI}_{\mathrm{n}}=\% \mathrm{~F}_{\mathrm{n}}\left(\% \mathrm{~N}_{\mathrm{n}}+\% \mathrm{~V}_{\mathrm{n}}\right)
$$


where $\mathrm{IRI}_{n}$ is the Index of Relative Importance of prey item " $n$ ", $\% F_{n}$ is the frequency of occurrence of prey item " $n$ " in the diet of all predators sampled, $\% N_{n}$ is the number of prey " $n$ " in the stomachs of all predators sampled, expressed as the percent of the total number of prey items in the stomachs, and $\% V_{n}$ is the volume or weight $\left(\mathrm{cm}^{3}\right.$ or grams) of prey item " $\mathrm{n}$ ", expressed as the percent of the total volume or weight of prey items in predator stomachs. This calculation is repeated for all prey items. The IRI for each species of prey is converted to a fraction of the total IRI for the predator. Each fractional IRI is multiplied by the trophic level assignment for that prey item and the resulting values are summed to provide an estimate of the trophic level assignment for the predator. Trophic level assignments calculated in this way by Mearns (1982) for seven prominent marine animals from the Palos Verdes Shelf, California are as follows:

Mysid, Neomysis kadiakiensis

Shrimp, Heptacarpus stimpsoni

Prawn, Sicyonia ingentis

White croaker, Genyonemus lineatus

Dover sole, Microstomus pacificus

Spiny dogfish, Squalus acanthus

California scorpionfish, Scorpaena guttata

The trophic relationships of these species on the Palos Verdes coastal shelf in the southern California Bight are summarized in Figure 8.1.

Assignment of trophic level based on analysis of gut contents is laborious and may give unreliable results if some of the food items identified in the stomach contents of the predators sampled are not typical of the food items they ordinarily eat. In addition, it is difficult to account for seasonal variations in feeding habits and food preferences by this method. Therefore, chemical indicators of trophic status have been sought. The most widely used chemical indicators are the relative concentrations of different stable isotopes of carbon and nitrogen in tissues of marine organisms (Peterson and Fry 1987). Both carbon and nitrogen have more than one naturally-occurring stable isotope. The slight difference in the nuclear mass of the isotopes exerts a slight influence on their chemical and physical behaviors (Carlton and Klug 1990), and metabolic processes in plants and animals tend to enrich the heavy isotopes relative to their lighter, dominant atomic forms. There are 
two stable isotopes of carbon, ${ }^{13} \mathrm{C}$ and ${ }^{12} \mathrm{C}$, and of nitrogen, ${ }^{15} \mathrm{~N}$ and ${ }^{14} \mathrm{~N}$, the lighter isotope accounting for nearly $99 \%$ of the total in most environmental samples.

As a general rule, the ${ }^{13} \mathrm{C} /{ }^{12} \mathrm{C}$ and ${ }^{15} \mathrm{~N} /{ }^{14} \mathrm{~N}$ concentration ratios are slightly higher in the tissues of predators than in the tissues of their prey (Rau 1982, Owens 1987). These differences in isotope ratios are expressed relative to a known standard, usually belemnite carbonate from the Cretaceous PeeDee formation in South Carolina, U.S.A (Carlton and Klug 1990) for carbon and atmospheric nitrogen (Dunton et al. 1989) for nitrogen. The mathematical expression is:

$$
\delta(\mathrm{ppt})=\left[\left(\mathrm{R}_{\text {sample }} / \mathrm{R}_{\text {standard }}\right)-1\right] \times 1000
$$

where $R={ }^{13} \mathrm{C} /{ }^{12} \mathrm{C}$ or ${ }^{15} \mathrm{~N} /{ }^{14} \mathrm{~N}$. Values for $\delta$ are expressed as parts per thousand (ppt) and, because ${ }^{13} \mathrm{C}$ and ${ }^{15} \mathrm{~N}$ are nearly always depleted in the sample relative to their concentrations in the standards, usually are negative.

In plants, the value of $\delta$ is influenced by the biochemical pathway for photosynthetic fixation of carbon into organic compounds. In plants that rely on the Calvin cycle, inorganic carbon is incorporated initially into a 3-carbon acid $\left(\mathrm{C}_{3}\right.$ plants), phosphoglyceric acid, and $\delta^{13} \mathrm{C}$ usually is in the range of -25 to $-28 \mathrm{ppt}$ (Dauby 1989). In many grasses and some other plants, carbon is fixed first into a 4-carbon acid $\left(\mathrm{C}_{4}\right.$ plants), malonic or aspartic acid by the Hatch-Slack pathway, and $\delta^{13} \mathrm{C}$ usually is higher, -5 to -20 ppt. By comparison, atmospheric $\mathrm{CO}_{2}$ has a $\delta^{13}$ of -7 to $-10 \mathrm{ppt}$ (Aggarwal and Hinchee 1991). Because of these differences, it is sometimes possible to determine the source of organic carbon in the diets of herbivorous and detritivorous marine animals (Dauby 1989).

In marine animals, the value of $\delta^{13} \mathrm{C}$ often increases by about one to two at each higher trophic level (e.g., $\delta^{13} \mathrm{C}$ is 1 to $2 \mathrm{ppt}$ higher in the tissues of the consumer than in the tissues of the prey). This relationship has been observed, for example, in pelagic food webs off southern California (Rau 1982), in oil seep communities (Spies and DesMarais 1983), in estuarine benthic/pelagic communities in the northeastern United States (Gearing et al. 1991), in coastal arctic and subarctic communities of the Bering, Chukchi, and Beaufort Seas (Dunton, et al. 1989), along the Pacific coast of southern Alaska (Goering et al. 1990), and in coastal seagrass-dominated communities in the Mediterranean Sea (Dauby 1989). Schaffner and Swart (1991) demonstrated a correlation between diet and isotopic ratios of $\delta^{13} \mathrm{C}$ and $\delta^{18} \mathrm{O}$ in the egg shells of marine birds. However, in some communities, such as that of a northeastern U.S. saltmarsh, most consumers are polyphagous and 
there is not a good relationship between trophic level and $\delta^{13} \mathrm{C}$ (Peterson and Howarth 1987). Figure 8.2 from Dunton et al. (1989) illustrates the limitations of using carbon isotope ratios for trophic assignments. The range of mean $\delta^{13} \mathrm{C}$ for the nine feeding groups was greatest for the eastern Beaufort Sea (6 ppt), least in the Chukchi Sea (2 ppt), and intermediate in the southeast Bering Sea (4 ppt). The authors suggested that the Chukchi Sea benthic fauna are more tightly coupled to primary production than the benthic fauna of the other two seas.

As a general rule, $\delta^{15} \mathrm{~N}$ increases by 1 to $5 \mathrm{ppt}$ at each trophic level (Mingawa and Wada 1984, Owens 1987). Although $\delta^{15} \mathrm{~N}$ is more affected than $\delta^{13} \mathrm{C}$ by trophic transfers, it has been used less frequently then the carbon isotope ratio to identify marine food chain relationships. Broman et al. (1992) recently used $\delta^{15} \mathrm{~N}$ quite successfully to establish trophic structure of two simple food chains in the northern Baltic Sea (Broman et al. 1992).

Diagenic and biogenic alterations of organic matter in sediments may affect its $\delta^{13} \mathrm{C}$ and $\delta^{15} \mathrm{~N}$ values. Bacterial methanogenesis in anaerobic sediments produces methane that is isotopically lighter than the organic substrate (Martens et al. 1986); acetate produced by bacteria in aerobic sediments is isotopically heavier than the bacterial substrate (Blair et al. 1987). In the presence of fossil hydrocarbons, such as oil, benthic invertebrates may utilize the fossil carbon directly or indirectly (via bacteria), and, as a result, have a lower value than expected of $\delta^{13} \mathrm{C}$ (Spies and DesMarais 1983, Spies et al. 1989a,b, Aggrawal and Hinchee 1991). Values of $\delta^{13} \mathrm{C}$ and $\delta^{15} \mathrm{~N}$ in phytoplankton may increase with increasing ambient temperature because of the inverse relationship between temperature and concentration in seawater of $\mathrm{CO}_{2}$ and $\mathrm{N}_{2}$ (Rau et al. 1989, Sackett 1989, Goering et al. 1990). Because of the many factors influencing values for $\delta^{13} \mathrm{C}$ and $\delta^{15} \mathrm{~N}$, caution should be used in assigning trophic levels to marine communities based on this value alone.

\subsection{TROPHIC TRANSFER OF METALS}

\subsubsection{Natural Distribution of Metals in Marine Food Webs}

Unlike most organic contaminants, metals are important natural components of the environment of marine organisms. All the metals with the potential of becoming pollutants are present at trace or ultratrace concentrations in seawater and all are present at higher concentrations in uncontaminated marine sediments. 
Because of the ubiquity of metals in their environment, all marine organisms contain metals as normal constituents of their tissues. Several metals are essential trace nutrients required for various physiological or biochemical functions in marine organisms (Miller and Neathery 1977); some others, though apparently not essential, may be accumulated to high concentrations in the tissues of a few species of marine animals from natural sources in the environment (Simkiss and Taylor 1989). The natural biogeochemistry of metals must be kept in mind when studying the distribution and possible biomagnification of metals in marine food webs.

There are at least 11 major nutrients and 18 trace nutrients required by some terrestrial and marine organisms (Table 8.1). The major elements are required by all living organisms and are the building blocks of tissues or are major effectors of ionic regulation in celis and tissues. Many of the trace nutrients are components of bioactive proteins or are enzyme cofactors (Iyengar 1991). Some of the trace nutrients listed in Table 8.1 have been shown to be essential to only a few species of marine organisms (e.g., vanadium is present at high concentrations in some species of ascidians where it is present in organometallic pigments in the blood plasma or in special blood cells, vanadocytes: Bertrand 1950).

Several of the essential trace nutrient metals are considered important environmental contaminants because of their toxicity and potential to be mobilized by man's activities (Iyengar 1991). These include vanadium, chromium, nickel, copper, zinc, arsenic, tin, and selenium. Because they are essential micronutrients, marine organisms have evolved mechanisms for accumulating them from water and food and for regulating their forms, distribution, and concentrations in tissues and body fluids (Simkiss and Taylor 1989).

Some marine organisms accumulate apparently nonessential metals in their tissues to high concentrations or essential metals at concentrations much higher than required (Peterson 1971). In most cases, the reasons for the bioaccumulation are not known. Examples of this phenomenon include: accumulation of arsenic in the jaws of the polychaete, Tharyx marioni (Gibbs et al. 1983); deposition of barium as barium sulfate granules in several species of zooplankton (Gooday and Nott 1982, Collier and Edmond 1984a,b); accumulation of cadmium in the tissues of the oceanic hyperiid amphipod, Thermisto gaudichaudii (Rainbow 1989), and in the kidneys of several species of scallops (Coombs 1979); and the accumulation of niobium in the blood of the ascidians, Styela and Molgula (Kakubu and Hidaka 1965). Another feature of metal accumulation that must be considered in food web studies is the tendency for some metals not to reach an apparent steady state. Instead, they 
continue to accumulate for the life of the organism (Bryan 1979, Luoma 1983). Continuous accumulation of metals from apparently natural concentrations in the environment may result in a positive correlation between metal concentrations in the tissues and the size (mass) of the organism (Figure 8.3). Because the largest animals in a food web are sometimes the top predators, this concentration/size relationship can be mistaken for evidence of biomagnification. In fact, much of the metal is sequestered in tissues in the form of insoluble granules or concretions and is not biologically available to the host or to consumers.

Most metals accumulated by bivalves and herbivorous snails are sequestered (detoxified) in various tissues as insoluble granules. Carnivorous snails that consume these molluscs accumulate only very small amounts of the metals; the metal-containing granules pass through the gut and appear in the fecal pellets of the carnivorous snails (Nott and Nicolaidou 1989, 1990). Thus, the sequestered metals in bivalves appear to be relatively inert, biologically.

\subsubsection{Mechanisms for Accumulation of Metals from Food}

The mechanism of accumulation of metals from food are similar in most respects to mechanisms of uptake from water and food, discussed in Chapter 6. At least four mechanisms are available for movement of metals across the membrane of the gut of a marine animal (Figure 8.4). These include:

1. Carrier-mediated transport or facilitated diffusion across the membrane

2. Passive diffusion of nonpolar forms of the metal

3. Endocytosis, and

4. Intracellular digestion.

Most metal ions (polar) cross biological membranes of the gut by simple passive diffusion, facilitated by carrier molecules (Luoma 1983, Mason et al. 1988, Simkiss and Taylor 1989). It is probable that all the essential trace metals have specific carrier molecules in the gut epithelium to facilitate uptake from food. The carrier molecules are not completely specific and nonessential metals, such as cadmium and mercury may compete with essential metals for binding sites on carrier molecules. Bryan (1963) showed that cesium was actively transported across the gut wall of the isopod, Sphaeroma hookeri, by the potassium pump. Cadmium may compete with calcium for transmembrane transport by a calcium pump in epithelia of the crab, Carcinus maenas (Wright 1977). 
Many metal ions readily bind to organic molecules, including essential organic nutrients, and may be absorbed through the gut wall bound to the organic nutrients. Sullivan et al. (1984) showed that absorption of organically bound cadmium (in the form of lyophilized tissues of oysters that had been contaminated with radio-cadmium through a plankton food chain) in the diet of mice was more efficient than absorption of inorganic cadmium. Similarly, specific organometallic compounds, such as cobalamine, selenomethionine, and arsenobetaine, may be more readily absorbed than the corresponding inorganic metal ions (Wrench et al. 1979, Ueda et al. 1982, Cutter and Bruland 1984).

Nonpolar forms of metals may more easily penetrate biological membranes than polar, ionic forms. Cowan et al. (1986) showed that copper hydroxide species $\left(\mathrm{Cu}[\mathrm{OH}]_{2}\right.$ and $\mathrm{Cu}[\mathrm{OH}]^{+}$) are more toxic and, by implication, more bioavailable than the free copper ion $\left(\mathrm{Cu}^{+2}\right)$. Methylmercury is bioaccumulated much more rapidly than ionic mercury (Phillips and Buhler 1978).

Endocytosis and intracellular digestion are common mechanisms for digestion and assimilation of food particles in marine invertebrates (Pandian 1975). This is the primary form of digestion in bivalve molluscs (Owen 1966). Insoluble metal compounds and complexes can be accumulated in the tissues of marine animals by pinocytosis, endocytosis, and phagocytosis in the gut. George et al. $(1975,1976,1977)$ have demonstrated energy-dependent uptake of particulate iron, lead, and the metalloproteins, ferritin and transferrin, by pinocytosis in the gut epithelia of Mytilus edulis. Jenkins et al. (1989) reported direct uptake of particles of barium sulfate, probably via the gut, into tissues of bivalve molluscs exposed in the field to drilling muds (high in barite) discharged from an offshore oil well drilling platform. Metal granules accumulated by pinocytosis may be absorbed into the tissues and cells of the animal, or they may remain as insoluble concretions in vacuoles or intercellular spaces (Mason and Nott 1981, Taylor and Simkiss 1984). Although these insoluble metals have been accumulated, they have not been assimilated, and probably are biologically inert.

Following accumulation, metals bind to a variety of organic binding sites or precipitate, maintaining the inward-directed diffusion gradient and slowing efflux of the metal (Mason et al. 1988, Simkiss and Taylor 1989). Some of the accumulated metal may be sequestered more or less permanently as granules in intracellular vacuoles; the remainder may desorb from binding sites and diffuse to the ambient medium when ambient concentrations of the metal decrease. Specific metalbinding proteins, such as metallothionein, may contribute to the control of intracellular concentrations and turnover of some metals (Klaverkamp et al. 1984). 


\subsubsection{Feeding Studies}

Feeding studies have demonstrated trophic transfer of many metals in marine, estuarine, and freshwater food webs. Most of the studies did not include true benthic infaunal animals. However, mechanisms, routes, and rates of transfer probably are not markedly different for benthic than for demersal and pelagic animals. Therefore, several examples of food chain transfer not involving benthic infauna are discussed below where data for benthic food chains are lacking. A few illustrative examples of metal transfer in components of freshwater food chains also are included to illustrate important generalizations.

Because concentrations of metals are nearly always orders of magnitude higher in the tissues of marine organisms than in solution in seawater, it might be expected that the major source of metal contamination of heterotrophic organisms would be from their food. However, this is not always the case, probably because the efficiency of uptake from food usually is much lower than the efficiency of uptake from the water (Kay 1984). The efficiency of absorption of metals from food varies substantially among different taxa of marine animals and for different metals (Table 8.2).

\subsubsection{Actinides}

Gastrointestinal absorption of actinide elements (thorium, uranium, plutonium, americium, neptunium, and curium) in humans and other mammals is low (Harrison 1991). Fractional absorption factors $\left(f_{1}\right)$ from the gastrointestinal tract to the blood range from about $10^{-2}$ to $10^{-5}$, and vary with the chemical form of the actinide and age and species of the animal. Little information is available about accumulation and food chain transfer of actinides in marine food chains. The gastrointestinal absorption efficiency of americium in two marine fish is in the range of 0.007 to 0.06 (Carvalho et al. 1983). Cheng et al. (1977) measured concentrations of polonium and plutonium in beach-cast giant kelp, Macrocystis pyrifera, kelp flies, Fucilia rufitibia and $F$. separata, and predatory beetles, Cicindela sp., from the southern California shore. Concentrations of ${ }^{210} \mathrm{Po}$ and ${ }^{239.240} \mathrm{Pu}(500$ and 2 $\mathrm{pCi} / \mathrm{kg}$ dry wt, respectively) were about twice as high in the kelp as in the kelp flies, and about four times higher than in the predatory beetles. Plutonium and other actinides tend to build down, rather than biomagnify, in aquatic food chains (Guary and Fraizier 1977), indicating that food chain transfer is inefficient. 


\subsubsection{Arsenic}

Organoarsenic compounds appear to be more readily accumulated than inorganic arsenic from food. Phytoplankton readily accumulate inorganic arsenate from seawater and convert it to organic forms (Wrench et al. 1979). Primary consumers readily accumulate the organoarsenic when they consume the algae and pass it on in organic form to carnivores. The carnivores, such as the shrimp, Lysmata seticaudata, have a limited ability to accumulate inorganic arsenate from seawater; they can not convert accumulated arsenate to organic forms, but convert it largely to arsenite. In a simple model estuarine food chain consisting of phytoplankton, Artemia, and grass shrimp, Palaemonetes pugio, arsenate was accumulated from water by the phytoplankton, but not by either Artemia or grass shrimp (Lindsay and Sanders 1990). However, the brine and grass shrimp accumulated little or no arsenic from either water or food. Apparently, in this experiment, the phytoplankton had not converted accumulated arsenate to organic forms.

Concentrations of arsenic reach values in excess of $1000 \mathrm{mg} / \mathrm{kg}$ in the kidneys of giant clams, Tridacna maxima and $T$. derasa, from the Great Barrier Reef off Australia (Benson and Summons 1981). Symbiotic zooxanthellae in the clam mantle tissues accumulate arsenate from seawater, convert it to organic forms, such as trimethylarsonium lactate, and pass it on to the host. Edmonds and Francesconi (1981a, b) showed that in unpolluted waters of western Australia, the brown alga, Ecklonia radiata, accumulates inorganic arsenate from seawater and converts it to a variety of arsenosugars. The organoarsenic compounds appear to be accumulated by detritivorous polychaetes, and then by school whiting, Sillago bassensis, that feed on the polychaetes. The major form of arsenic in the fish is arsenobetaine.

Sanders et al. (1989) reported that the copepod, Eurytemora affinis, the barnacle, Balanus improvisus, and the oyster, Crassostrea virginica, did not accumulate inorganic arsenate from seawater into soft tissues. Arsenic was accumulated in shell material. Several species of phytoplankton did accumulate arsenic from the water. When the contaminated algae were fed to the invertebrates, the invertebrates accumulated arsenic in their tissues. However, the amount of arsenic accumulation from the food was small. Similarly, the snail, Lymnea sp., and the amphipod, Gammarus sp., were not able to accumulate arsenate from solution in water, but were able to accumulate arsenic from arsenic-contaminated macroalgae (Blanck et al. 1989). 
Arsenic is readily accumulated from food (the brown alga, Fucus spiralis, or the periwinkle, Littorina littoralis) by periwinkles and dogwhelks, Nucella lapillus, respectively (Klumpp 1980). Klumpp calculated that only about $0.8 \%$ of arsenic pool in the tissues of the dogwhelk would have come from direct uptake from water containing $3 \mu \mathrm{g} / \mathrm{L}$ arsenic. This could be due to more efficient uptake of organic (the primary form of arsenic in brown algae) than inorganic arsenic. Langston (1984) concluded, based on studies of the distribution of arsenic in arsenic-contaminated estuaries in southern Britain, that the periwinkles, Littorina littorea and L. littoralis, accumulated most of their body burden of arsenic from consumption of arsenic-contaminated Fucus. Crabs, Pugetta producta, fed the macroalga, Macrosystis pyrifera, retained about $6 \%$ of the arsenic, probably present as arsenosugars, in their food (Boothe and Knauer 1972).

Ünlü (1979) compared the accumulation of inorganic and organic arsenic by crabs, Carcinus maenas, fed a single meal of ${ }^{74}$ As-contaminated mussels, Mytilus galloprovinciallis. Assimilation efficiency of organic and inorganic arsenic by the crabs was $65 \%$ and $14 \%$, respectively. Organic arsenic was released more slowly from the crab tissues when the crabs were returned to a low-arsenic diet.

The dominant form of arsenic in plaice, Pleuronectes platessa, is arsenobetaine (Luten et al. 1982), probably derived from trophic transfer through a benthic/pelagic food chain of organic arsenic synthesized by primary producers. Human volunteers accumulated organo-arsenic when fed plaice filets, but excreted $69 \%$ to $85 \%$ of the administered dose in the urine within five days.

\subsubsection{Cadmium}

Harvey and Luoma $(1985 \mathrm{a}, \mathrm{b})$ showed that uptake of radio-labeled cadmium by the depositfeeding clam, Macoma balthica, was greater from the water than from suspended bacterial food. By exposing blue mussels, Mytilus edulis, to seawater containing ${ }^{115} \mathrm{Cd}$ in solution and algal food labeled with ${ }^{109} \mathrm{Cd}$, Borchardt (1983) was able to show that only $0.016 \%$ to $0.042 \%$ of the body burden of cadmium in the mussels was derived from food. Riisgard et al. (1987) estimated that the rates of uptake of cadmium by mussels from algal food and directly from water were 7.2 and 190 $\mathrm{ng} / \mathrm{mussel} / \mathrm{h}$, respectively.

Marine diatoms, Phaeodactylum tricornutum, grown in continuous culture in the presence of cadmium chloride spiked with ${ }^{109} \mathrm{Cd}$ accumulated $70 \%$ of the cadmium present (Hardy et al. 1984, Sullivan et al. 1984). Oysters, Crassostrea virginica, were able to filter $85 \%$ to $95 \%$ of the 
cadmium-contaminated diatoms from the water and retained about $61 \%$ of the cadmium supplied (Table 8.2). About $59 \%$ of the cadmium accumulated by the oysters was derived from the diatoms; the remainder was from solution in the ambient medium. Virtually all the cadmium in the oyster tissues was organically bound. When mice were fed cadmium-contaminated oysters, they retained about $0.83 \%$ of the administered dose in their tissues, most of it in liver and kidney. Very little inorganic cadmium was absorbed into the gut of the mice. Thus, trophic transfer of cadmium from a primary producer to a primary consumer was moderately efficient, but transfer to a secondary consumer, the mouse, was very inefficient.

The major source of the cadmium in the tissues of the pelagic euphausiid, Meganyctiphanes norvegica, appears to be the diet (Small et al. 1973, Benayoun et al. 1974). The crab, Pugetta producta, retained more than $86 \%$ of the cadmium in its food, the macroalgae, Macrosystis pyrifera (Boothe and Knauer 1972). However, another crab, Carcinus maenas, accumulated no more cadmium in their tissues when exposed for $20 \mathrm{~d}$ to seawater containing $0.1 \mathrm{ppm}$ cadmium and fed cadmium-contaminated brine shrimp, Artemia, than when exposed to the cadmium-contaminated water alone (Jennings and Rainbow 1979). The crabs were able to accumulate about $10 \%$ of the cadmium in their food.

Rainbow trout, Salmo gairdneri, and lake whitefish, Coregonus clupeaformis, accumulated cadmium from both water and food (Harrison and Klaverkamp 1989). Cadmium accumulated from water was retained primarily in the gills and kidney, whereas cadmium from food was retained primarily in the kidney, gut, and liver. Absorption efficiency of cadmium from water was $0.15 \%$ in rainbow trout and $0.11 \%$ for whitefish. Absorption efficiency from food was about $1 \%$ for both trout and whitefish. Food also appears to be the main source of cadmium in a marine fish, the plaice, Pleuronectes platessa (Pentreath 1977b). Less than 5\% of the cadmium in a single meal of metalcontaminated polychaetes, Nereis diversicolor, was retained by the fish.

\subsubsection{Chromium}

Preston (1971) exposed oysters, Crassostrea virginica, to radiochromium $\left({ }^{51} \mathrm{Cr}\right)$ in solution and in labeled green microalgae, Chlamydomonas sp. Uptake of ${ }^{51} \mathrm{Cr}$ was 3.5 times more rapid from the water than from the food. However, trivalent chromium was accumulated more efficiently by larvae of the sea urchin, Pseudechinus movaezealandiae, from phytoplankton (food) than from water 
(Bremer et al. 1990). Boothe and Knauer (1972) estimated that $89 \%$ of the chromium from the macroalga, Macrosystis pyrifera, ingested by crabs, Pugetta producta, was retained in the crab tissue.

Neff et al. (1989) fed juvenile winter flounder, Pseudopleuronectes americanus, and American lobster, Homarus americanus, natural food contaminated with chromium until the animals had consumed up to nine times their original body weight. The contaminated food consisted of sand worms, Nereis virens, that had been exposed for a week or longer to sediments containing the settleable fraction of an oil well drilling mud, high in chromium. The contaminated food contained slightly higher concentrations of chromium ( 0.95 to 1.6 times higher) than in uncontaminated worms. There was no statistically significant accumulation of chromium from food by either species when compared to controls. When flounder and lobsters were exposed simultaneously to drilling mudcontaminated sediment and food, they accumulated no more chromium than when they were exposed to the contaminated sediment alone. Thus, chromium in drilling muds was slightly available to the lobsters and flounder, but chromium in the food was not.

\subsubsection{Cobalt}

Uptake of cobalt by the deposit-feeding clam, Macoma balthica, was greater from bacterial food than from water (Harvey and Luoma 1985a,b). This observation is consistent with the premise that the most bioavailable form of cobalt is the bacterially-generated organic form, cyanocobalamine. Hard shell clams, Mercenaria mercenaria, fed ${ }^{60} \mathrm{Co}$-contaminated diatoms, Nitzschia, retained $22.5 \%$ to $54.4 \%$ of the ingested cobalt, depending on clam size and concentration of diatoms consumed (Nakahara and Cross 1978). Food appears to be the main source of cobalt in the tissues of plaice, Pleuronectes platessa (Pentreath 1973b).

\subsubsection{Copper}

Polychaetes, Capitella capitata, accumulated more copper from high-nitrogen foods, consisting of living or detrital algae, Gracilaria and Ascophylum (Rice et al. 1981, Windom et al. 1982). Ration size did not affect dietary accumulation of copper by the worms. Crabs, Pyugetta producta, retained only about $40 \%$ of the food in their macroalgal diet (Boothe and Knauer 1972). The concentration of copper in the feces of the crabs was about four times higher than its concentration in the food, suggesting selective absorption of other components of the diet. The 
authors concluded that food was the main source of copper in the tissues of the crabs, despite the poor absorption of copper from the food.

In a freshwater study, oligochaete worms, Tubifex sp., were fed bacteria contaminated with several concentrations of copper (Patrick and Loutit 1976). The amount of copper retained by the worms increased with increasing concentrations of copper in the bacterial food; however, concentrations of copper in worm tissue never exceeded copper concentrations in the bacteria.

\subsubsection{Lead}

Schultz-Baldes (1974) reported that mussels accumulated $23.5 \%$ of the lead provided to them in lead-contaminated algae, Dunaliella marina, compared to $29 \%$ of the lead provided in solution in the ambient seawater. The crab, Pugetta producta, retained about $25 \%$ of the lead in their macroalgal food Boothe and Knauer 1972). However, the concentration of lead was about five times higher in the feces of the crabs than in their algal food, suggesting enrichment in the gut was due to selective absorption of other food components. Abalones, Haliotis sp., derive most of their body burden of lead from their algal foods (Stewart and Schulz-Baldez 1974).

The benthic infaunal polychaete, Capitella capitata, accumulated lead from detrital and algal foods (Rice et al. 1981, Windom et al. 1982). Concentrations of lead in worm tissues increased slightly with increasing quality of the algal/detrital foods (Gracilaria and Ascophylum, and detritus prepared from these macroalgae).

\subsubsection{Mercury}

Several species of marine bacteria accumulate mercury through adsorption or absorption. Marine bacterivorous ciliates were able to accumulate ${ }^{203} \mathrm{Hg}$ from ingestion of ${ }^{203} \mathrm{Hg}$-contaminated bacteria. When ciliates, Uronema nigricans, contaminated by ingesting ${ }^{203} \mathrm{Hg}$-contaminated Vibrio sp. and Pseudomonas sp., were fed to copepods, Eurytemora affinis, the copepods retained $44 \%$ to $53 \%$ of the mercury in the ingested ciliates (Berk and Colwell 1981). In the presence of strains of Pseudomonas sp. that accumulate and reduce inorganic mercury, dissolved inorganic mercury rapidly becomes associated with particulate matter (mostly bacteria or bacterial exopolymers), and oysters accumulate the particulate mercury (Sayler et al. 1975). Although there was no biomagnification of the mercury in this trophic transfer, these studies showed that sediment bacteria play an important role in mobilizing sediment mercury into benthic/pelagic food webs. 
Polychaete worms, Capitella capitata, accumulated mercury from their algal/detrital foods (Rice et al. 1981, Windom et al. 1982). The concentration of mercury in worm tissues increased slightly with improving food quality. Food appears to be the main source of methylmercury in plaice, Pleuronectes platessa (Pentreath 1976c,d). The fish retained about $80 \%$ of the methylmercury in their food after a single meal of metal-contaminated polychaetes, Nereis diversicolor. About $5 \%$ of the ingested inorganic mercury was retained (Pentreath 1976d). Inorganic mercury was accumulated primarily from the water. The distribution of mercury in the tissues of plaice exposed to methylmercury-contaminated food, was similar to that in fish collected from the field, leading Pentreath to conclude that methylmercury was accumulated primarily from the food by feral plaice. Similar results have been obtained in freshwater feeding studies (Lock 1975, Phillips and Buhler 1978). Methylmercury, because of its very high affinity for binding with dissolved and particulate organic matter, is present in solution at only sub-ng/L concentrations, particularly in near-coastal and estuarine waters, and can not account for the body burdens of organic mercury in the tissues of marine organisms.

Pentreath (1976d) showed that methylmercury (nonpolar) readily penetrated the intestinal barrier and accumulated primarily in muscle tissue. On the other hand, most of the inorganic mercury ingested with food remained associated with the gut wall $36 \mathrm{~d}$ after a mercury-contaminated meal. Similar results were obtained with rainbow trout (Boudou and Ribeyre 1985). Inorganic mercury from food was retained primarily in the posterior intestine $30 \mathrm{~d}$ after ingesting contaminated food; only $6.4 \%$ to $14 \%$ of the ingested inorganic mercury passed the intestinal barrier and accumulated in internal tissues. However, methylmercury was readily assimilated and was distributed among liver, muscle, kidneys, spleen, blood, and posterior intestine. Between $64 \%$ and $72 \%$ of the methylmercury in the prey was retained and $76 \%$ to $86 \%$ of this was transferred from the intestine to internal tissues.

Boudou and Ribeyre (1985) estimated that in rainbow trout fed contaminated food for $30 \mathrm{~d}$, $23 \%$ of the inorganic mercury and $84 \%$ of the organic mercury in the food was accumulated. Suzuki and Hatanaka (1974) reported that an average of $88 \%$ of the methylmercury in jack mackerel, Trachurus japonicus, fed to yellowtail, Seriola quinqueradiata, was absorbed. Approximately $67 \%$ of the methylmercury in Japanese anchovies, Engraulis japonica, fed to yellowtail was absorbed by the yellowtail (Suzuki and Hatanaka (1975). Pentreath (1976d) reported that the retention of methylmercury from food by plaice, Pleuronectes platessa, varied depending on the nature of the 
contaminated food. Between $80 \%$ and $100 \%$ of the methylmercury from contaminated polychaetes was retained; $18 \%$ to $26 \%$ of the organic mercury from shrimp, Crangon vulgaris, was retained; and $7 \%$ to $42 \%$ of the methylmercury from blue mussels, Mytilus edulis, was retained.

Mussels, Mytilus galloprovincialis, accumulated twice as much and benthic shrimp, Lysmata seticaudata, accumulated ten times as much methylmercury as inorganic mercury during exposure for $35 \mathrm{~d}$ to the two forms of mercury in both the food and water (Fowler et al. 1978a,b). Small mussels accumulated slightly more of both types of mercury than large mussels. Starfish, Leptasterias polaris, accumulated methylmercury by eating contaminated mussels, Mytilus edulis (Pelletier and Larocque 1987). The starfish retained about $50 \%$ of the ingested mercury, most of it in the pyloric caeca and calcareous skeleton. However, the copepod, Acartia tonsa, did not retain significant amounts of inorganic mercury when fed mercury-contaminated algae, Croomonias salinas (Parrish and Carr 1976).

\subsubsection{Selenium}

Selenite $(+4)$ and, to a much lesser extent, selenate $(+6)$ are readily bioconcentrated from water by marine phytoplankton (Wrench and Measures 1982) and converted to various organoselenide compounds (Cooke and Bruland 1987). Zhang et al.. (1990) showed that accumulation of selenium by the clam, Puditapes philippnarum, was mainly from selenium-contaminated phytoplankton (probably present as organoselenides) with lesser uptake of inorganic selenite directly from the water. Assimilation efficiency of selenium from food by the clam was about $50 \%$. Most of the selenium accumulated from food was in soft tissues, and most of the selenium accumulated from water was in the shell.

Inorganic selenate and selenite were both accumulated readily in the gut of rainbow trout, Salmo gairdneri, (Hilton et al. 1982), and fathead minnows, Pimephales promelas, (Kleinow and Brooks 1986). However, selenomethionine was accumulated in the gut at a faster rate to a higher concentration, and persisted longer in fathead minnow tissue than inorganic selenium. Hamilton et al. (1990) fed freshwater and brackish water acclimated chinook salmon, Onchorhynchus tshawytscha, diets consisting of fish meal prepared from mosquitofish, Gambusia affinis, trom a seleniumcontaminated waterway and mosquitofish from a low-selenium environment. The latter fish meal was supplemented with selenomethionine, equivalent to the concentration of selenium in the naturallycontaminated food (up to $35.5 \mu \mathrm{g} / \mathrm{g}$ dry wt). The fish accumulated selenium in direct proportion to 
the concentration of selenium in their diet. At a dietary selenium concentration of about $35.5 \mu \mathrm{g} / \mathrm{g}$, the fish in brackish water accumulated 23.2 to $28.8 \mu \mathrm{g} / \mathrm{g}$ selenium in $120 \mathrm{~d}$. The fish fed naturally contaminated food accumulated only slightly more selenium than the fish fed the selenomethioninespiked food, suggesting that the naturally-contaminated mosquitofish contained mainly organoselenium. Although the salmon accumulated selenium from their food, they did not accumulate it to concentrations higher than those in their food (there was no biomagnification). A similar lack of biomagnification of selenium was reported for fathead minnows fed selenium-contaminated, Daphnia sp. (Bertram and Brooks 1986), or rotifers (Bennett et al. 1986).

Mallard ducks, Anas platyrhynchos, fed food containing $10 \mathrm{mg} / \mathrm{kg}$ selenomethionine accumulated 6 to $9 \mathrm{mg} / \mathrm{kg}$ wet wt Se in liver and smaller amounts in muscle tissue (Heinz et al. 1990). Equilibrium concentrations were reached in liver within $8 \mathrm{~d}$ and in muscle in about $80 \mathrm{~d}$. When selenium was removed from the diet, half times for elimination of selenium from liver and muscle were $19 \mathrm{~d}$ and $30 \mathrm{~d}$, respectively. Thus, it appears that although selenium, particularly organoselenium compounds, is readily transferred through aquatic food chains, it is not biomagnified, even in the trophic step from marine prey to terrestrial consumer.

\subsubsection{Silver}

The efficiency of trophic transfer of silver was about $50 \%$ between diatoms and the depositfeeding clam, Scrobicularia plana, and between the clams and crabs, Carcinus maenas (Amiard 1979). Polycheates, Capitella capitata, accumulated silver from detrital and algal foods; the amount of silver accumulated increased as the nutritional quality of the food increased (Rice et al. 1981, Windom et al. 1982). However, grass shrimp, Palaemonetes pugio, was not able to accumulate significant amounts of silver from either planktonic (Artemia sp.) or detrital (the bryozoan Victorella sp.) foods containing elevated concentrations of silver (Connell et al. 1991). The shrimp were able to accumulate silver from solution in the water. On the other hand, food appears to be the main source of silver in the tissues of plaice, Pleuronectes platessa (Pentreath 1977a). However, only about 5\% of the silver in the food was retained in the plaice tissues after a single meal of polychaetes, Nereis diversicolor. It appears that after silver is accumulated by marine plants or animals it binds very strongly to tissue macromolecules and is no longer in a readily bioavailable form. 


\subsubsection{Tin}

Inorganic tin is not usually considered an important marine pollutant. However, several organotin compounds, particularly tributyltin, have been widely used in antifouling paints on submerged marine structures, particularly boat hulls. Butyltin antifouling paints recently were banned for most marine uses in the United States and Europe because of their high toxicity to marine animals. Little research has been performed on the bioaccumulation and food chain transfer of or ganotins. Dog whelks, Nucella lapillus, derive slightly less than half their body burden of tributyltin (and antifoulant in boat paints) from their food (Bryan et al. 1989).

\subsubsection{Zinc}

Harvey and Luoma (1985) showed that uptake of radio-labeled zinc by the deposit-feeding clam, Macoma balthica, was greater from the water than from suspended bacterial food. The algal food of the periwinkle snail, Littorina obtusata, and the animal food of the dogwhelk, Nucella lapillus, are the major sources of zinc in their tissues (Young 1975, 1977).

Polychaete worms, Capitella capitata, accumulated several metals from their algal and detrital foods (Rice et al. 1981, Windom et al. 1982). Accumulation of zinc increased with increasing food quality (measured as nitrogen concentration) and decreased with increasing ration size of the algal foods, Gracilaria and Ascophylum.

Shrimp, Lysmata seticaudata, crabs, Carcinus maenas, and fish, Gobius sp., were exposed for three months to ${ }^{65} \mathrm{Zn}$ in water or a combination of water and food (Renfro et al. 1975). The shrimp and crabs exposed to ${ }^{65} \mathrm{Zn}$ in both water and food did not significantly accumulate more of the radionuclide than shrimp and crabs that were exposed to the radionuclide in the water alone. However, the fish accumulated 2.5 times more zinc from the combined food/water pathway than from the water pathway alone. Crabs, Pugetta producta, retained $67 \%$ of the zinc in their macroalgal food (Boothe and Knauer 1972).

In exposures lasting $120 \mathrm{~d}$, mosquitofish, Gambusia affinis, and spot, Leiostomus xanthurus, accumulated $78 \%$ and $82 \%$, respectively, of their body burdens of ${ }^{65} \mathrm{Zn}$ from food (Artemia contaminated by ingestion of ${ }^{65} \mathrm{Zn}$-labeled algae) (Willis and Sunda 1984). Similar results were obtained by Baptist and Lewis (1969) for postlarval Atlantic croakers, Micropogon undulatus, and mummichogs, Fundulus heteroclitus. Juvenile plaice, Pleuronectes platessa, accumulated zinc more efficiently from food (Artemia nauplii or polycheates, Nereis diversicolor) than from water (Pentreath 
1973a, Milner 1982). Only about $10 \%$ of the zinc in the plaice tissues was derived from the water. In a closely related flatfish, the winter flounder, Pseudopleuronectes americanus, a zinc-binding metallothionein was readily induced in intestinal cells by parenteral injections of zinc (Shears and Fletcher 1984). However, high levels of zinc metallothionein in intestinal mucosa had no effect on the rate of uptake of zinc from food, suggesting that intestinal metallothionein does not play a role in controlling absorption of metals from the gut.

\subsubsection{Field Studies}

Several investigations have been performed of the concentrations of various metals in the tissues of several species, all from a particular marine ecosystem. These studies, many of which were reviewed by Kay (1984), show wide variations in the concentrations of metals in the tissues of different species of marine plants and animals. However, in most cases, trophic relationships of the different species examined were not determined. Therefore, it is difficult in most cases to establish whether biomagnification of metals was occurring.

For example, Preston et al. (1972) measured the concentrations of silver, cadmium, copper, nickel, lead, and zinc in the tissues of the macroalgae, Fucus sp. and Porphyra sp., and the limpet, Patella sp., at different coastal locations in Great Britain. Concentrations of all the metals except zinc were higher in the limpets than in the algae, suggesting biomagnification. However, the limpets were collected from intertidal rocks where they probably were feeding on encrusting microalgae, not on the macroalgae analyzed. Therefore, the results of this study are equivocal with respect to biomagnification. All field studies designed to investigate possible biomagnification are faced with uncertainty about the history of metal contamination and taxonomic composition of the food items actually consumed at each trophic level.

As discussed above, Young and Mearns (1979), Young et al. (1980) and Schafer et al. (1982) used cesium/potassium ratios to assist in assigning trophic levels to several species of marine animals in various marine food webs from the southern California area. In the three natural food webs examined by Young and Mearns (1979) and Young et al. (1980), the Salton Sea, Newport Bay, and Palos Verdes Shelf, California, there was no relationship between trophic level and concentration in tissues of marine animals of seven of the eight metals examined (Table 8.3). Concentrations of mercury, most of which was present as organic mercury, increased from lowest to highest trophic level in all three food webs. 
In the Newport Bay and Palos Verdes food webs, the highest concentrations of chromium and copper were present in animals at the lowest trophic level. The same trend was observed for cadmium and zinc in the Palos Verdes food web.

Schafer et al. (1982) reported similar results for three marine food webs, the first inshore along the coast of the Palos Verdes Peninsula, the second an offshore pelagic food web in the southern California Bight, and the third a tropical pelagic food web in the Pacific Ocean off central America. Some of the metals, such as cadmium and zinc, showed an inverse relationship between trophic level and concentration in tissues. Others, such as chromium and copper, showed no clear relationship between trophic level and body burden. Only mercury showed evidence of biomagnification (Figure 8.5). Muscle tissues of the top or near top predators (spiny dogfish, white shark, and silky shark) contained the highest concentrations of total mercury in the Palos Verdes epibenthic food web, coastal pelagic food web, and eastern tropical food web, respectively. Between $82 \%$ and $99 \%$ of the total mercury in tissues of these three sharks was in the form of organomercury compounds. The fraction of total mercury in tissues represented by organic mercury compounds tended to increase with increasing trophic level in the food webs examined by Schafer et al. (1982). Recent studies in the tropical eastern Pacific Ocean have suggested that the high concentrations of methylmercury in large oceanic fishes and some marine mammals may be due to contamination of the oceanic food web with methylmercury derived from natural methylation of traces on natural inorganic mercury in the oxygen minimum layer below the thermocline (Mason and Fitzgerald 1991).

In most species of marine fish studied to date, more than about $80 \%$ of the total mercury in tissues is present as methylmercury (Gardner et al. 1975, May et al. 1987). The fraction of total mercury that is present as organomercury usually is much higher in muscle tissue than in liver or other organ tissues (Gardner et al. 1975). There is a general tendency for the concentration of organic mercury in fish tissues to increase with weight (age) of the fish. Less than $10 \%$ of the total mercury in marine algae is organomercury; mussels are intermediate, with $20 \%$ to $60 \%$ of total mercury in the tissues in the form of organomercury compounds (May et al. 1987). This distribution of inorganic and organic mercury in marine food webs suggests that organisms, such as plants, at lower levels in the food web accumulate primarily inorganic mercury and convert it to organic forms that are transferred efficiently to higher levels in the food web by trophic transfer. An alternative explanation is that trophic transfer and retention is much more efficient for organomercury compounds than for inorganic mercury, resulting in biomagnification of organomercury but not 
inorganic mercury. The latter explanation is gaining considerable empirical support, as discussed above, whereas there is little empirical evidence that marine plants and animals can methylate inorganic mercury.

However, Nishimura and Kumagai (1983) suggested, based on the predominance of organomercury over inorganic mercury in their tissues, that fish, particularly croaker, Argyrosomus argentatus, from Minimata Bay and the adjacent Yatushiro Sea, Japan, obtained most of their body burd ins of mercury from zooplankton and not directly from mercury-contaminated sediments. Organomercury compounds were not detected in more than 250 sediment samples from Minimata Bay and the Yatsushiro Sea. Zooplankton from the Yatsushiro Sea contained 66 to $1070 \mathrm{ng} / \mathrm{g}$ dry wt (parts per billion) total mercury; croaker contained 40 to about $220 \mathrm{ng} / \mathrm{g}$ wet wt total mercury in their tissues.

In the Derwent Estuary, Australia, heavily contaminated with mercury and several metals (see Chapter 3), there appears to be a relationship between the frequency of high concentrations of mercury in tissues and feeding habits of fish and invertebrates (Ratkowsky et al. 1975: Figure 8.6). More than $50 \%$ of the predatory fish sampled from the estuary contained $0.5 \mathrm{ppm}$ or more mercury in their tissues; $63 \%$ of the invertebrate predators sampled contained $0.3 \mathrm{ppm}$ or less total mercury; and more than $70 \%$ of the herbivorous fish sampled contained $0.2 \mathrm{ppm}$ or less total mercury. There have been several other reports of elevated concentrations of total organic mercury in tissues of top predator fish, such as sharks, tuna, and swordfish (Gardner et al. 1975, Matsunaga 1978, Ramamurthy 1979, Stoepler et al. 1979, Schafer et al. 1982). Usually, much lower concentrations of mercury were found in tisssues of forage and planktivorous fish and invertebrates from the same habitats, providing circumstantial evidence for biomagnification.

In coastal waters of Hawaii, the mean concentration of total mercury in benthic herbivores was $0.03 \mathrm{ppm}$ (Klemmer et al. 1976). Omnivores contained an average of $0.08 \mathrm{ppm}$ total mercury, and primary and secondary carnivores contained averages of 0.10 and $0.26 \mathrm{ppm}$ mercury, respectively. These results suggest very slight biomagnification of mercury in this coastal benthic food chain.

A different pattern appears to exist for plutonium and perhaps some other transuranic elements (Guary and Fraizier 1977). In the littoral ecosystem of the Bay of Ecalgrain near the nuclear fuel reprocessing plant at La Hague, France, there is a decreasing concentration of plutonium in tissues of organisms with higher trophic level. Water is the main source of plutonium in organisms 
at lower trophic levels. There appears to be little or no uptake of plutonium directly from sediments. Food chain transfer of plutonium does occur, particulariy at higher trophic levels, but does not lead to biomagnification. Concentrations of thorium, uranium, and polonium were higher in fecal pellets than in tissues of salps from the northern Mediterranean Sea, suggesting that dietary absorption of these metals was poor (Krishnaswami et al. 1985).

Amiard et al. (1980, 1983) and Metayer et al. (1980) measured the concentrations of cadmiur, copper, lead and zinc in the tissues of food web animals from two locations in the Loire Estuary, France (Table 8.4). Concentrations of cadmium were highest in the ctenophores, Mnemiopsis bachei, and tended to decrease in animals at higher trophic levels. Concentrations of cadmium were higher in crustaceans than in whole fish, including species that consume primarily crustaceans. Highest concentrations of cadmium were found in the gut (stomach and intestine) contents of the fish. Concentrations of cadmium, copper, lead, and zinc were nearly always much higher in the stomach contents than in the intestinal tract contents of the top carnivore fish in the estuary. The authors suggested that this was caused by enrichment of metals in the gut due to poor absorption of metals from the food.

The distribution of copper was similar to that of cadmium. The gut contents of fish contained higher concentrations of copper than did the fish tissues or the predominant prey items of the fish (mysid crustaceans and polychaete worms). Highest concentrations of copper were found in the mysid, Neomysis integer, the shrimp, Crangon crangon and Palaemon longirostris, and the crab, Carcinus maenas. Crustaceans often contain high concentrations of copper because of its presence in their respiratory pigment hemocyanin. Fish tissues always contained much lower concentrations of copper than did the tissues of their prey. However, Amiard-Triquet et al. (1980) demonstrated a decrease in the concentration of copper in prey items (copepods and mysids) as they passed through the gut of the fish, indicating that copper was being assimilated from the food.

Concentrations of lead also were higher in the crustaceans than in the whole tissues of the fish. Highest concentrations of lead were observed in the intestinal contents of two flatfish, the sole, Solea solea and the flounder, Platichthys flesus. The intestinal lead could have been derived from ingestion of sediments. Zinc was relatively uniformly distributed in the tissues of annelids, crustaceans, and fish from the Loire Estuary, with highest concentrations in worms and copepods.

The mean transfer factors (concentration in fish tissues/concentration in fish food) for cadmium, copper, lead, and zinc in five species of carnivorous fish from the Loire Estuary usually 
were less than one, indicating that the metals were not being biomagnified by the fish (Table 8.5). However, the top predator fish, Stizostedion lucioperca, which was consuming primarily planktivorous and omnivorous fish, contained slightly higher concentrations of cadmium and copper in its tissues than were present in its food.

The results of these investigations indicate that biomagnification of these four metals was not occurring in the food web of the Loire Estuary. The concentrations of cadmium, copper, and lead were lower in the tissues of most fish at the highest trophic levels than in prey items at lower trophic levels. Concentrations of zinc were similar in the tissues of prey items and predators. All four metals were present at higher concentrations in the gut contents and undigested prey than in the tissues of the fish (Amiard et al. 1980, Metayer et al. 1980).

Similar results were obtained by Stickney et al, (1975) for the food web of a Georgia, U.S.A. estuary. Highest concentrations of cadmium were detected in the mysid, Neomysis americana. Several species of fish that feed primarily on mysids contained in their tissues one-tenth to one-half the concentration of cadmium contained in the mysids. Copper concentrations were high in the crustaceans and low in the fish. Lead and zinc were uniformly distributed among the different species. There was no biomagnification of cadmium, copper, lead, or zinc.

However, concentrations of mercury were higher in the toad fish, Opsanus tau, the silver perch, Bairdiella chrysura, and the windowpane flounder, Scophthalmus aquosus, than in any of the crustaceans except the stone crab, Menippe mercenaria (Stickney et al. 1975). These four species contained 1.03 to $2.74 \mathrm{mg} / \mathrm{kg}$ dry wt total mercury. By comparison, mysids, the dominant prey of two of the fish contained $0.06 \mathrm{mg} / \mathrm{kg}$ dry wt total mercury. Therefore, food chain biomagnification of mercury could be occurring.

Lead is biodepleted in marine food chains relative to its biogeochemical analogue, calcium (Smith et al. 1990). Lead is passively enriched relative to calcium during accumulation of these elements from seawater by marine plants because lead is more strongly chelated on plant surfaces than is calcium, and because most marine plants have a large surface to volume ratio. However, lead is biodepleted relative to calcium during transfer from plants to primary consumers because of discrimination against lead in favor of calcium in the gut of the consumer. Lead is further depleted during transfer from the primary consumers to carnivores. 
Sea otters, Enhydra lutris, from the Aleutian Islands, Alaska, consume both benthic invertebrates and kelp bed fishes and, therefore, can be considered the top predator locally. Lead isotopic ratios in otter teeth indicate that concentrations of lead in otters have not increased due to anthropogenic inputs of lead to the environment, but the sources of lead in otter tissues have changed (Smith et al. 1990). Virtually all the lead in teeth of otters collected before industrialization was derived from weathering of pliopleistocene volcanic rocks in the Aleutian volcanic arc. Contemporary otters contain a mixture of Asian and Canadian industrial leads derived from eolian deposition of airborne lead. The lack of an increase in concentrations of lead in otter tissues despite historic increases in the flux of industrial lead to the ocean indicates that lead is not being biomagnified through the marine food chain of this remote marine environment.

Szefer (1991) examined the food chain of the southern Baltic Sea. Most organisms accumulated iron and lead primarily from the water, but accumulated very little dissolved uranium. The dominant form of uranium in seawater is the tricarbonato-uranylate anion, $\mathrm{UO}_{2}\left(\mathrm{CO}_{3}\right)_{2}^{-2}(\mathrm{Li} \mathrm{1981})$, which is not very soluble or bioavailable (Santschi and Honeyman 1989; Nozaki 1991). Plankton played an important role in translocating some metals, particularly iron, lead, and copper from the water column to the sediments. However, transfer factors (ratio of metal concentration in consumer to its concentration in food) ranged from 0.01 to 2.3. Most transfer factors were less than one, and values greater than one only occurred in one trophic transfer, indicating that biomagnification of metals was not occurring.

Marine birds and mammals often are the top predators in oceanic food chains. Because they have an impermeable integument and breathe air, any excretion of accumulated metals must be by active processes. Concentrations of metals in the tissues of these animals can be used as an indication of metal bioaccumulation and transfer through marine food chains (Thompson et al. 1990). Mean concentrations of mercury in several species of pelagic seabirds from remote areas of the Atlantic and Pacific Oceans ranged from 0.8 to $268 \mu \mathrm{g} / \mathrm{g}$ wet wt (Muirhead and Furnẹss 1988, Honda et al. 1990, Thompson et al. 1990). Most of the mercury in the bird livers was inorganic. Highest mean mercury concentrations were in livers of wandering albatross, Diomedea exulans, from the South Atlantic. Other tissues (muscle, kidney, and feathers) contained lower concentrations.

Cadmium concentrations were higher in kidneys than in livers of pelagic birds from the north Pacific and ranged from 4.4 to $68.4 \mu \mathrm{g} / \mathrm{g}$ wet wt, with highest concentrations in kidneys of blackfooted albatross, Diomedea nigripes, from coastal waters of southeastern Alaska (Honda et al. 1990). 
Liver tissue of Leach's storm-petrels, Oceanodrama leucorhoa, from coastal waters of eastern Canada contained 50 to $100 \mu \mathrm{g} / \mathrm{g}$ dry wt of selenium, a concentration often associated with pathology (Elliott et al. 1992). Liver and kidney tissues of the petrels also contained 11 to $130 \mu \mathrm{g} / \mathrm{g}$ dry wt and 76 to $334 \mu \mathrm{g} / \mathrm{g}$ of cadmium, respectively. Storm petrels feed on plankton, including euphausiids and myctophid fishes (Linton 1978). These high concentrations of selenium, mercury, and cadmium in pelagic bird tissues appear to be natural and probably are derived from various foods, such as seaskaters (gerrid insects of the genus Halobates) (Bull et al. 1977), squid (Muirhead and Furness 1988), and oceanic amphipod and euphausiid crustaceans (Rainbow 1989).

Concentrations of mercury in livers of seals, porpoises, and dolphins from waters around the British Isles ranged from 0.26 to $430 \mu \mathrm{g} / \mathrm{g}$ wet wt (Law et al. 1991). The highest concentrations were in livers of grey seals, Halichoerus grypus, from the vicinity of Liverpool Bay in the eastern Irish Sea. Seals, porpoises and dolphins from this location also had elevated concentrations of lead in their livers (1.0 to $4.3 \mu \mathrm{g} / \mathrm{g}$ ). The average concentration of mercury in livers of dolphins, Stenella attenuata, from the eastern tropical Pacific Ocean was $62.7 \mu \mathrm{g} / \mathrm{g}$ wet wt, at least six times higher than the concentration in any other organ (Andre et al. 1990). Mercury concentrations in liver and other tissues of the dolphins tended to increase with age of the animals and proximity to the equator. The dolphins probably accumulated most of their body burdens of mercury as organic mercury in their fish and cephalopod prey. As discussed above, methylmercury in the tropical Pacific food web appears to be derived from methylation of inorganic mercury by anaerobic bacteria in the oxygen minimum layer below the oceanic thermocline (Mason and Fitzgerald 1991).

Concentrations of cadmium in marine mammal livers from the vicinity of the British Isles ranged from less than 0.06 to $11 \mu \mathrm{g} / \mathrm{g}$ wet wt (Law et al. 1991). Highest concentrations were in livers of striped dolphins, Stenella coeruleoalba, from Cardigan Bay near Aberystwyth, Wales. By comparison, the average concentration of cadmium in kidneys of narwhals, Monodon monoceros, from the vicinity of Pond Inlet, Northwest Territories, Canada, was $63.5 \mu \mathrm{g} / \mathrm{g}$ wet wt; the highest concentration was $179 \mu \mathrm{g} / \mathrm{g}$ (Wageman net al. 1983). The cadmium in these whales from the remote arctic probably was derived from natural metalliferous sediments.

Polar bears, Ursus maritimus, from the high arctic of Canada had lower concentrations of cadmium in their livers than was present in their prey, mainly seals (Norstrom et al. 1986). The bear livers contained mean concentrations of 0.7 to $2.3 \mu \mathrm{g} / \mathrm{g}$ dry wt cadmium, compared to 10 to $22 \mu \mathrm{g} / \mathrm{g}$ in livers of harp and ringed seals (Wagemann and Muir 1981). This difference may be due to the 
preference of the bears for eating skin and blubber of seals, whereas most of the cadmium accumulates in the kidneys and liver.

Polar bears from the Melville Island area of northwest Canada contained more than $250 \mu \mathrm{g} / \mathrm{g}$ dry wt of mercury in their livers (Norstrom et al. 1986). Concentrations of mercury in the hair of polar bears from Greenland and Svalbard Island northeast of Greenland ranged from 1.02 to 14.19 $\mu \mathrm{g} / \mathrm{g}$ dry wt (Born et al. 1991). Livers of polar bears from eastern Greenland contained only 1 to 25 $\mu \mathrm{g} / \mathrm{g}$ total mercury. The high concentrations of mercury in Canadian polar bear livers was attributed to elevated concentrations of mercury in the ringed seal food chain resulting from high natural levels of mercury in sediments from the area. As for most marine mammals, there was a very good correlation between concentrations of mercury and selenium in livers of polar bears.

\subsection{TROPHIC TRANSFER OF ORGANIC COMPOUNDS}

\subsubsection{Mechanisms for Accumulation of Organic Contaminants from Food}

As discussed in Chapter 4 most of the organic chemicals of toxicological concern in the marine environment are man-made industrial or agricultural chemicals, or byproducts of human activities. They do not occur naturally in the environment, or occur only at trace concentrations. The exception is polycyclic aromatic hydrocarbons and related heterocyclic compounds. These chemicals are normal components of fossil fuels (gas, petroleum, and coal) and are also produced as byproducts of combustion of organic materials (Neff 1979a,b). A few are biosynthesized by bacteria, fungi, and plants or are produced by degradation of natural organic precursors, such as plant pigments. Because most organic chemicals of environmental concern are not natural constituents of the environment, there are no natural background concentrations of the chemicals in the environment as there are for metals. None of the organic chemicals of environmental concern are essential trace nutrients for marine plants and animals. However, many have become ubiquitous trace contaminants of all environmental compartments, including the marine environment.

Nonpolar (unionized) organic compounds, including most of the organic compounds of concern in the marine environment, tend to sorb to marine sediments where they may accumulate to high concentrations. As discussed in Chapter 7, these sediment-bound chemicals are not completely immobile, but are bioavailable, to varying degrees, to benthic animals living on or in the sediments. Consumers of benthic plants and animais may ingest and assimilate these chemicals with their food. 
Under certain circumstances, the organic chemicals may be passed by trophic transfer through the marine food web and accumulate at high, potentially toxic, concentrations in the top consumers.

Several conditions are required for trophic transfer and biomagnification of nonpolar organic chemicals derived from marine sediments (Gobas et al. 1988). The chemical must be present in the food in a bioavailable form (digestion may increase or decrease bioavailability). The chemical must be at least slightly soluble in the fluids in the gastrointestinal tract and it must be able to permeate the intestinal mucosa by diffusion. Orce it has moved into the cells and tissues of the digestive tract, it must partition into tissue lipids or bind to tissue macromolecules so that the rate of passive loss back to the external medium is slower than the influx. Finally, active metabolic breakdown or excretion of the chemical must be slow, so that the chemical can accumulate in tissues over time.

As with uptake from water and sediments, bioaccumulation of nonpolar organic chemicals from food is a physico-chemical partitioning process between the organism's body fat and body water (Gobas et al. 1986). Active transport across membranes probably is not important. Chemicals will tend to distribute themselves by diffusion between tissue lipid and water phases according to their relative solubilities in the two phases. This distribution has been found to be described reasonably well by the octanol/water partition coefficient $\left(\mathrm{K}_{\mathrm{ow}}\right)$ for the chemical, which is correlated with its relative lipophilicity and hydrophobicity (Opperhuizen et al. 1986). Although the rate of equilibration of nonpolar organic compounds between the external medium (water, sediment, and food) and tissue lipids is slow, equilibrium is reached rapidly among different lipid pools in aquatic animals (Gardner et al. 1990).

An alternative approach to explaining food chain transfer of nonpolar organic chemicals is fugacity (Paterson and Mackay 1985; 1987). Fugacity is equivalent to the partial pressure of a chemical in a phase; it is expressed in units of pressure $(\mathrm{Pa})$. For each phase, there is a fugacity capacity, $Z$, such that

$$
C=f Z
$$

where $\mathrm{C}$ is concentration $\left(\mathrm{mol} / \mathrm{m}^{3}\right), f$ is fugacity $(\mathrm{Pa})$, and $Z$ has units of $\mathrm{mol} / \mathrm{m}^{3} \mathrm{~Pa}$. Chemicals will tend to diffuse down fugacity gradients from phases with high fugacities to phases with lower fugacities until the gradient is abolished (equilibrium is reached). 
When a marine animal is exposed to a nonpolar organic chemical in solution in the ambient medium, the chemical accumulates in the animal tissues until the animal and water approach a state in which the fugacities or chemical potentials of the chemical in the animal and water are equal (Clark et al 1990, Clark and Mackay 1991). At equilibrium, rates of uptake and release of the chemical by the animal are equal. If the chemical also is present in the food of the animal, a similar equilibration occurs; uptake is from both the water and food. The food usually is aquatic and the chemical will have a similar fugacity in both the food and water, at least at lower trophic levels.

However, digestive processes may cause the fugacity of the chemical in the gut to increase. During digestion, the volume of material in the gut is reduced by absorption of nutrients and water, increasing the concentration (and thereby the fugacity) of the free chemical in the remaining gut contents. In the case of lipid-soluble compounds, absorption of dietary lipids, in particular, may create a positive fugacity gradient for diffusive uptake of the nonpolar compounds. In addition, hydrophobic compounds may be carried with lipid droplets transported across the gut wall by pinocytosis (Addison 1982, Bruggeman 1982). The favorable fugacity gradient drives more of the chemical through the gut wall into the tissues. Absorption is not complete and a portion of the chemical is excreted in the feces. Absorption of additional chemical from the gut creates a fugacity for the chemical in the animal that is greater than the fugacity for the chemical in the ambient water. Therefore, the net flux of the chemical through the gills and other permeable body surfaces is outward down the fugacity gradient. Under these conditions, net uptake of the chemical occurs only from the gut; the chemical is lost continuously from the animal through permeable body surfaces, by metabolism, and as unassimilated chemical in the feces. If passive (partitioning and diffusion) and active (alteration by metabolic processes) excretion of the chemical are slow relative to uptake from the gut, the chemical will tend to biomagnify in the tissues of the consumer as long as the food remains contaminated.

In fish, and possibly in invertebrates as well, the rate and efficiency of bioaccumulation of nonpolar organic chemicals from food seems to increase with weight (size) of the animal (Griesbach et al. 1982, Laake et al. 1982, cited by Ekelund 1989). The reason for this is unclear, but could be related to a lower retention efficiency of materials in the gut of smaller animals or lower contaminant elimination rate in larger animals (Ekelund 1989). A positive correlation between size and concentrations of PCBs, DDT, and hexachlorobenzene has been reported for cod (Schaefer et al. 1976), herring (Perttila et al. 1982), and salmon (Falandysz 1982). 
The potential for biomagnification of a nonpolar organic chemical increases in the trophic step from water-breathing marine animal (prey) to air-breathing animal (predator) because the predator has more limited mechanisms for passive excretion of the chemical (Paterson and Mackay 1987). Most air-breathing animals (including terrestrial animals and marine reptiles, birds, and mammals) have an impermeable integument that prevents passive diffusive efflux of complex organic chemicals except via the kidneys and gastro-intestinal tract. Most of the chemicals of concern are not sufficiently volatile to be lost via the respiratory route. The main avenues for passive loss of a nonvolatile, nonpolar organic chemical from the tissues of an air-breathing animal are by passive or facilitated excretion of the unmodified chemical in bile via the liver and gall bladder, and in urine via the kidney. Most of the chemicals of environmental concern have very low aqueous solubilities, so passive excretion is very slow by these routes.

However, most animals have metabolic systems that can convert some nonpolar organic compounds to more soluble derivatives that can be excreted more easily by passive or active mechanisms. Not all chemicals of concern are suitable substrates for these metabolic systems and the activity of the enzymes in the systems varies substantially from one taxon to another in the food chain (Boon et al. 1989). Chemicals that are metabolized more slowly at one or more trophic levels and are excreted more slowly have the greatest potential for accumulation to high concentrations in the top predators.

As with metals, not all of a nonpolar organic chemicals ingested in the food are absorbed. Some of the chemical remains in the gut and is eliminated in the feces. The relative importance of uptake from water or food in the contamination of marine food chains depends in large part on the relative efficiencies of chemical uptake by the two routes. The same physical-chemical processes govern uptake by both routes, but the environment at the uptake site (gills or general body surface for uptake from water, and gastrointestinal tract for uptake from food) are different.

Gobas et al. (1988) studied the relationship between the uptake efficiency of nonpolar organic chemicals from food $\left(E_{0}\right)$ and the octanol/water partition coefficient $\left(K_{o w}\right)$ for the chemicals (Figure 8.7). As a general rule, $E_{0}$ decreases with increasing $K_{o w}$. The Equation derived for this relationship by Gobas et al. (1988) is:

$$
1 / \mathrm{E}_{0}=5.3 \times 10^{-8} \mathrm{~K}_{\mathrm{ow}}+2.3
$$

As can be seen in Figure 8.7, there is a large amount of variability in the relationship between $E_{0}$ and 
$\log \mathrm{K}_{\mathrm{ow}}$. Factors other than hydrophobicity/lipophilicity affect absorption efficiency of nonpolar organic chemicals.

For moderately hydrophobic compounds $\left(\log \mathrm{K}_{\text {ow }}\right.$ of four to six), uptake rate constants are relatively insensitive to hydrophobicity (Gobas et al. 1986, 1989), and there is a good correlation between $\mathrm{K}_{\mathrm{ow}}$ and bioaccumulation. However, there is an inverse relationship between $\log \mathrm{K}_{\text {ow }}$ and uptake rate constant for chemicals with $\log \mathrm{K}_{\mathrm{ow}}$ greater than about six, resulting in lower absorption efficiencies for these highly hydrophobic compounds. These very hydrophobic chemicals are accumulated much more efficiently from food than from the water (Bruggeman et al. 1984). Their aqueous solubilities are so low that very little of the free, uncomplexed compound can exist at the external water/permeable membrane interface (e.g., gills) for partitioning into the animal. Higher concentrations of the chemical in gut fluid may be attained by the digestion/concentration mechanism discussed above. For super-lipophilic compounds, elimination through the gills becomes so inefficient that the main avenue of excretion is via the feces, probably as metabolites in bile (Gobas et al. 1989). These very hydrophobic chemicals usually are also very lipophilic and should partition rapidly into membrane lipids.

However, as molecular size and hydrophobicity increase further, partitioning into the tissue lipid phase decreases, due to hinderance of diffusion of the large molecules into lipid membranes or to reduced solubility of these compounds in lipids (Banerjee and Baughman 1991). Chemicals with molecular weights greater than about 600 or with a $\log \mathrm{K}_{\mathrm{ow}}$ greater than about eight to nine are absorbed very inefficiently, if at all, from the gut of fish, and so are not transferred through aquatic food chains.

Niimi and Oliver (1988) have evaluated the relationship between $E_{0}$ in fish, and molecular weight (MW) and molecular volume (MV) of several halogenated nonpolar organic chemicals (Figure 8.7). There was little relationship between molecular weight and $E_{0}$, except that most chemicals with molecular weights greater than 600 were poorly absorbed. Some chemicals with lower molecular weights, such as octachloronaphthalene (MW of 404) and dodecylcyclohexane (MW of 252) also were poorly absorbed $\left(E_{0}<0.2\right)$. Some high molecular weight compounds, such as hexabromobiphenyl (MW of 627 ) were absorbed $\left(\mathrm{E}_{0}\right.$ of 0.54$)$.

There was a slightly more consistent inverse relationship between molecular volume and $\mathrm{E}_{0}$ (Niimi and Oliver 1988). Compounds with molecular volumes greater than about $0.3 \mathrm{~nm}^{3}$ were absorbed poorly (Figure 8.7). None of the three indices, $\mathrm{K}_{\mathrm{ow}}, \mathrm{MW}$, or $\mathrm{MV}$, provide a relationship to 
$E_{0}$ that can be used to consistently estimate the absorption efficiency of nonpolar organic chemicals from food by fish. However, all three parameters affect absorption efficiency. Both MW and MV probably are poor predictors of $E_{0}$ for all but the largest chemicals because they do not consider the shape of the chemical molecules. The analysis of Niimi and Oliver (1988) suggests that chemicals with linear or planar configurations, such as n-alkanes, are absorbed more efficiently than more condensed, globular molecules with similar molecular volumes. Shaw and Connell (1984) showed, for a group of PCBs, that the distribution and positions of chlorines on the biphenyl molecule affected adsorption characteristics of PCB congeners onto biological surfaces, influencing uptake rates and efficiencies. Planar PCBs were adsorbed onto biological surfaces more efficiently than nonplanar congeners.

These empirical relationships, although not absolute, have been used as the basis for mathematical models of transfer and biomagnification of nonpolar organic chemicals in marine and freshwater food chains (e.g., Clark and Mackay 1991, Connolly, 1991). Thomann (1989) developed and evaluated a model to estimate the concentration of organic chemicals in a simple generic aquatic food chain. He showed that the $\mathrm{K}_{\text {ow }}$ of a chemical affects its uptake efficiency from water, excretion rate, and assimilation efficiency from food. Growth of the consumer may affect the uptake predicted by simple partitioning by a factor of two to five. Estimated efficiencies of uptake from water and food also have important effects on estimates of bioccumulation factors for chemicals. The model predicts that food chain effects are not significant for unionized chemicals with $\log \mathrm{K}_{\mathrm{ow}}$ up to about five. For chemicals with $\log \mathrm{K}_{\mathrm{ow}}$ between five and seven, trophic transfer is a major source of body burdens in animals at higher trophic levels and biomagnification is possible. The potential for trophic transfer and biomagnification of chemicals with $\log \mathrm{K}_{\text {ow }}$ greater than seven depends on the assimilation efficiency of the chemical from food and the ability of primary producers, particularly phytoplankton, to bioconcentrate the chemical.

\subsubsection{Polychlorinated Biphenyls}

\subsubsection{Feeding Studies}

Polychlorinated biphenyls (PCBs) are industrial chemicals containing from one to ten chlorine substituents. They range in molecular weight from 188.7 to 498.7 , the $\log \mathrm{K}_{\mathrm{ow}}$ ranges from 4.46 to 8.18 (Hawker and Connell 1988), and aqueous solubilities range from approximately 5,000 to 0.001 $\mu \mathrm{g} / \mathrm{L}$ (Opperhuizen et al. 1988). Most food chain studies with PCBs were performed with industrial mixtures (e.g., Aroclor, Phenoclor, etc.) that contained individual congeners spanning a wide 
molecular weight range. Therefore, it is not surprising that the studies have produced conflicting evidence of the importance of food chain transfer of PCBs in the contamination of marine food webs.

Several studies with commercial PCB mixtures have shown that PCBs can be accumulated from food by polychaete worms (Goerke 1984), copepods (Wyman and O'Connors 1980) and fish (Zitko 1974, Scura and Theilacker 1977, Narbonne 1979, Courtney and Langston 1980, Pizza and O’Connor 1983). However, PCBs also were accumulated from water and biomagnification was not demonstrated convincingly. Absorption efficiency $\left(E_{0}\right)$ for the commercial PCB mixtures was 0.68 in rainbow trout, Salmo gairdneri (Lieb et al. 1974), and approximately 0.85 in juvenile striped bass, Marone saxatilis (Pizza and O’Connor 1983) (Table 8.6).

In many of the laboratory studies, experimental animals were exposed to unrealistically high concentrations of PCBs in water. High exposure concentrations may have confounded the assessment of the relative importance of water and food as sources of PCB bioaccumulation. However, Spigarelli et al. (1983) exposed brown trout, Salmo trutta, to filtered water from Lake Michigan containing and average of $10.9 \mathrm{ng} / \mathrm{L}$ total PCBs (a realistic concentration). The trout also were fed alewife, Alosa pseudoharengus, from the lake containing average body burdens of $2.5 \mu \mathrm{g} / \mathrm{g}$ wet wt PCBs. Under these conditions, the trout derived only about $10 \%$ of their body burden of PCBs from the water; 90\% came from the food. A mathematical model of the Lake Michigan alewife-lake trout food chain indicated that as much as $99 \%$ of the body burden of PCBs in adult trout was from food (Thomann and Connolly 1984). However, the model, using an average $\log K_{o w}$ of 6.72 , overestimated PCB concentrations in trout by a factor of about four. Sensitivity analysis revealed that the values for estimated growth rate and absorption efficiency of PCBs by the trout had a strong influence on estimates of their concentrations in fish tissue.

Hilton et al. (1983) and Rubinstein et al. (1984a,b) showed that carnivorous fish (rainbow trout, Salmo gairdneri, and spot, Leiostomus xanthurus, respectively) could accumulate PCBs from naturally contaminated diets. Spot fed sand worms, Nereis virens, containing an average of about 0.5 $\mu \mathrm{g} / \mathrm{g}$ wet wt PCBs for $20 \mathrm{~d}$ contained average total body residues of $0.33 \mu \mathrm{g} / \mathrm{g}$ wet wt total PCBs, compared to $0.08 \mu \mathrm{g} / \mathrm{g}$ PCBs in spot fed clean worms. The rainbow trout were fed for 24 weeks with fish meal prepared from coho salmon, Onchorhynchus kisutch, from different natural populations and containing 0.1 to $3.6 \mu \mathrm{g} / \mathrm{g}$ dry wt total PCBs. At the end of the feeding period, whole body residues of PCBs in rainbow trout ranged from 0.24 to $8.69 \mu \mathrm{g} / \mathrm{g}$ dry wt and tended to increase with 
concentration of PCBs in the diet. Dietary accumulation factors ranged from 2.1 to 4.1 , and were not related to the concentration of PCBs in the food.

Mice also were fed diets containing coho salmon from different sources containing 0.004 (control chow) to $2.9 \mu \mathrm{g} / \mathrm{g}$ total PCBs (Cleland et al. 1988). After four months on these diets, the mice contained averages of 0.005 to $4.0 \mu \mathrm{g} / \mathrm{g}$ total PCBs in their livers. The PCB congener group retained at highest concentrations in the mouse livers was the 6-chlorine group, even though the diet contained nearly equal amounts of the 5-, 6-, and 7-chlorine congener groups. These results support the hypothesis of a direct relationship between $\mathrm{K}_{\mathrm{ow}}$ and absorption/retention of dietary PCBs.

McLeese et al. (1980a,b) measured the accumulation of two PCB congeners from food by American lobsters, Homarus americanus. The lobsters were fed mussels, Mytilus edulis, containing nominal concentrations of 1.7 and $17 \mu \mathrm{g} / \mathrm{g}$ each of $2,2^{\prime}, 4,5^{\prime}$ tetrachlorobiphenyl (TCBP) and $2,2^{\prime}, 4,4^{\prime}, 5,5^{\prime}$ hexachlorobiphenyl (HCBP). These compounds have a $\log \mathrm{K}_{\mathrm{ow}}$ of 5.85 and 6.92 , respectively (Hawker and Connell 1988). At low doses in the food (about $2.4 \mu \mathrm{g} /$ feeding), dietary absorption efficiency $\left(E_{0}\right)$ was $52 \%$ for TCBP and nearly $100 \%$ for HPCP. Values of $E_{0}$ decreased with increasing dose in the food. Maximum concentration factors (concentration in tissues/concentration in food) also decreased with increasing dose in the food and were 5.1 and 7.3 for TCBP and HCBP, respectively, in the hepatopancreas of the lobsters after six weeks of feeding. Both compounds were released from the hepatopancreas, tail muscle, and claw muscle when feeding with contaminated food was stopped. The TCBP was released more rapidly than HCBP.

In similar experiments, Opperhuizen and Schrap (1988) measured the accumulation from food of two unmetabolizable PCB congeners by guppies, Phoecilia reticulata. The PCB congeners were $2,2^{\prime}, 3,3^{\prime}, 5,5^{\prime}$-hexachlorobiphenyl (HCBP) and $2,2^{\prime}, 3,3^{\prime}, 4,4^{\prime}, 6^{\prime} 6^{\prime}$ - octachlorobiphenyl (OCBP), which have $a K_{o w}$ of 6.86 and 7.30 , respectively (Hawker and Connell 1988). The fish were fed for 65 to $247 \mathrm{~d}$ with fish food containing 7.1 to $1400 \mu \mathrm{g} / \mathrm{g}$ dry wt of each $\mathrm{PCB}$, the highest concentrations being environmentally unrealistic. Large numbers of fish died within $65 \mathrm{~d}$ at the two highest dietary PCB concentrations. At the three lower PCB concentrations in food (approximately $7.1,70$ and $145 \mu \mathrm{g} / \mathrm{g}$ ), equilibrium PCB concentrations in guppy tissues were approached within about $100 \mathrm{~d}$ at concentrations of 1 to $2 \mu \mathrm{g} / \mathrm{g}$ of both compounds. Dietary uptake efficiencies $\left(\mathrm{E}_{0}\right)$ of the two PCB congeners were 0.44 to 0.52 and were unaffected by concentration of the PCB in the food at the three lowest concentrations. At the two highest dietary concentrations (about 540 and $1400 \mu \mathrm{g} / \mathrm{g}$ ), which were unrealistic, $\mathrm{E}_{\mathrm{0}}$ for the two compounds was 0.24 to 0.28 . Thus, at realistic 
concentrations in food, absorption efficiency appears to be relatively insensitive to PCB concentration in the food. Dietary uptake of the two compounds apparently was little affected by the nearly ten-fold difference in their $\mathrm{K}_{\mathrm{ow}}$. Subsequently, Clark and Mackay (1991) calculated that equilibrium for OCBP in guppy tissues is reached after about $200 \mathrm{~d}$. Their model predicts that, after about $100 \mathrm{~d}$, the fugacity of OCBP in the fish exceeds that in their food and biomagnification is occurring.

Crossland et al (1987) dosed freshwater ponds with $14 \mu \mathrm{g} / \mathrm{L}$ of 2,5,4' trichlorobiphenyl (log $\mathrm{K}_{\mathrm{ow}}$ of 5.67: Hawker and Connell 1988) and studied uptake of the PCB by Asiatic grass carp, Ctenopharyngodon idella (a herbivore), and rainbow trout, Salmo gairdneri (a carnivore). After 28 $\mathrm{d}$, the grass carp and rainbow trout contained an average of 3.4 and $10.1 \mu \mathrm{g} / \mathrm{g}$ trichlorobiphenyl, respectively. At $28 \mathrm{~d}$ the pond water contained an average of $0.2 \mu \mathrm{g} / \mathrm{L}$ and pond plants and invertebrates contained average concentrations of 0.24 and $1.4 \mu \mathrm{g} / \mathrm{g}$ trichlorobiphenyl, respectively. Gut analysis of the fish revealed that the carp were feeding exclusively on plants and the trout were feeding exclusively on invertebrates. The authors concluded that the main route of PCB uptake by both species of fish was from the water for the first four days of exposure; thereafter, food became more important, especially for trout. The concentration of the PCBs in the tissues of both fish was higher than in their respective foods, suggesting biomagnification.

\section{4:2.2 Field Studies}

Field studies of PCBs in freshwater and marine food chains also provide variable results. In the Mediterranean Sea, total PCB residues range from 0.0002 to $0.0048 \mu \mathrm{g} / \mathrm{L}$ in seawater, to 800 to $26,600 \mu \mathrm{g} / \mathrm{kg}$ in the liver of the seagull, Larus ridibundus (Geyer et al. 1984). There is a trend, though inconsistent, for PCB concentrations to increase with trophic level in the marine food chain. However, the top predatory fish, tuna, contained a similar range of $\mathrm{PCB}$ concentrations to the herbivorous striped mullet, suggesting food chain transfer but not necessarily biomagnification of PCBs. Similarly, Schneider (1982) was not able to show a clear relationship between trophic level and concentration of total PCBs in tissues of food chain organisms from Kiel Bay, Germany.

Three benthic invertebrates from the Weser River estuary, Germany, contained means of 0.011 to $0.064 \mu \mathrm{g} / \mathrm{g}$ wet wt total PCBs (Goerke et al. 1979). Common sole, Solea solea, from the same estuary contained a mean of $0.206 \mu \mathrm{g} / \mathrm{g}$ total PCBs, suggesting food chain biomagnification, assuming the sole were consuming the invertebrates. Similarly, flounder, Platichthys flesus, and common gobies, Pomatoschistus microps, from Ora, Norway, which feed on benthic polychaetes and amphipods, contained an average of 0.325 and $0.217 \mu \mathrm{g} / \mathrm{g}$ wet wt total PCBs, compared to $0.10 \mu \mathrm{g} / \mathrm{g}$ 
in nereid worms from the same location (Bjerk and Brevik 1980). In two marine food webs off southern California, studied by Schafer et al. (1982), there was a general though inconsistent trend for body burdens of PCBs to increase with increasing trophic level, determined by the tissue Cs:K ratio (Figure 8.8). Highest concentrations of PCBs were in sea lions $(84.7 \mathrm{mg} / \mathrm{kg}$ lipid) in the coastal pelagic food web and in spiny dogfish $(41.9 \mathrm{mg} / \mathrm{kg}$ lipid) in the Palos Verdes epibenthic food web.

Food chain transfer and biomagnification may be more efficient from marine gill-breathing animals to air-breathing marine mammals. Muir et al. (1988) studied the distribution of PCBs in a Canadian arctic food chain consisting of arctic cod, Boreogadus saida, ringed seals, Phoca hispida, and polar bears, Ursus maritimus. Mean concentrations of total PCBs were $0.0037 \mu \mathrm{g} / \mathrm{g}$ wet wt in cod muscle, $0.68 \mu \mathrm{g} / \mathrm{g}$ in ringed seal blubber, and $4.5 \mu \mathrm{g} / \mathrm{g}$ in bear fat. The dominant PCB congener groups in the cod were the tri- and tetrachlorobiphenyls, whereas the dominant PCB congeners in the ringed seal blubber were the penta- and hexachlorobiphenyls, and the dominant congeners in bear fat were the hexa- and heptachlorobiphenyls. Highest concentrations of PCBs in bear fat (average 8.25 $\mu \mathrm{g} / \mathrm{g}$ ) were in samples collected from McLure Strait along the southern shore of Melville Island in the high arctic (Norstrom et al. 1988). Earlier studies of PCBs in tissues of ringed seals and polar bears from the Canadian arctic and subarctic indicated a similar trend, with concentrations of total PCBs in fat of ringed seals from several locations ranging from 0.006 to $1.93 \mu \mathrm{g} / \mathrm{g}$ wet wt and concenträtions in fat of polar bears from throughout their range in Canada ranging from 0.01 to $11.8 \mu \mathrm{g} / \mathrm{g}$ (Bowes and Jonkel 1975). These results indicate a high probability of PCB biomagnification, particularly of the more highly chlorinated PCBs, in this marine/terrestrial food.chain from a remote relatively uncontaminated habitat.

Oliver and Niimi (1988) and Evans et al. (1991) showed that concentrations of total PCBs increased with trophic level in the Lake Ontario and Lake Michigan ecosystems. In Lake Michigan, the average increase in total PCB concentration from plankton to fish was 12.9-fold. Chlorine content of the PCB assemblage also increased with trophic level, indicating preferential bioaccumulation of the more highly chlorinated, more hydrophobic PCB congener groups. Most of the discrimination among congener groups occurred at the lower end of the food chain (water to plankton to mysids) in the Lake Ontario food chain. Bioaccumulation factors at higher levels in the food chain increased with increasing $\mathrm{K}_{\mathrm{ow}}$ of the congeners, as predicted. However, concentrations of the more highly chlorinated PCB congener groups in the top predators studied, the salmonid fish, were higher than predicted by laboratory-derived bioconcentration factors, indicating that contaminated food was the 
main source of PCB residues in the tissues of the fish. Rasmussen et al. (1990) showed that concentrations of PCBs in lake trout increased with the length of the food chain in different glacial lakes in Ontario, Canada. Each trophic level contributed about a 3.5-fold biomagnification factor to the PCB concentrations in the trout.

Connolly (1991) modeled the distribution of PCBs in the American lobster, Homarus americanus, and winter flounder, Pseudopleuronectes americanus, food chains in New Bedford Harbor, Massachusetts, a site heavily contaminated with PCBs. PCB residues in the flounder and, to a lesser extent, the lobster were derived from contaminated sediments. Estimated dietary absorption efficiencies decreased from 0.5 to 0.8 for trichlorobiphenyls and 0.15 to 0.4 for hexachlorobiphenyls. As a result, the importance of dietary uptake in contributing to tissue residues in lobsters and flounder increased with the degree of chlorination of congener groups. Flounders had higher absorption efficiencies for all PCB congener groups than did lobsters, explaining in part the nearly ten-fold higher concentration of total PCBs in flounders than in lobsters. The differences probably also were due in part to differences in the diets of the two species.

The variability in observed patterns of distribution, trophic transfer, and biomagnification of PCBs in laboratory and natural food chains undoubtedly is due in part to interspecies variability in the capacity of marine and aquatic organisms to metabolize PCBs. PCBs are converted by the cytochrome P450 mixed function oxygenase system (MFO) to unstable arene-oxides that are converted autocatalytically or enzymatically to more soluble biphenyl-ols, dihydrodiols, and thioethers that can be excreted readily via the urine or bile (Safe 1984, Pritchard and Bend 1991). Not only does the overall capability to perform these reactions vary from one species to another, but the suitability of different PCB congeners as substrates for the MFO system also varies, depending on the positions and distribution of chlorine atoms on the ten available carbon atoms of the biphenyl molecule (Figure 8.9). The PCB congeners that possess vicinal (on adjacent carbons) $\mathrm{H}$-atoms at either a meta-para position or at an ortho-meta position on one aromatic ring with chlorine substitution being absent at both ortho-positions of that ring are more readily metabolized and excreted than PCB congeners that do not possess these structures (Boon and Eijgenraam 1988). Despite the large number of PCB congeners present in different commercial PCB formulations, only a relatively few congeners make up a majority of the $\mathrm{PCB}$ residues in the tissues of fish-eating birds and mammals (Boon et al. 1987, Borlakoglu et al. 1988). These are the congeners that are sterically hindered from facile metabolism by the mixed function oxidase system. For example, when 
expressed on a lipid basis, concentrations of unmetabolizable or not easily metabolized PCB congeners were higher in tissues of female harbor seals, Phoca vitulina, than in their food, suggesting biomagnification of the unmetabolizable PCB congeners (Boon et al. 1987).

MFO activity tends to increase as one moves up through the taxonomic hierarchy (Boon et al. 1989). As a result, PCB congeners that are readily metabolized by MFO are not transferred efficiently through aquatic food chains and do not biomagnify. However, PCB congeners, particularly the more highly chlorinated ones with high $\mathrm{K}_{\mathrm{ow}}$, that are rot readily metabolized by MFO tend to biomagnify (Figure 8.9).

Marine mammals, which often are the top carnivores in marine food chains and, because of their impermeable integument and air-breathing habits, cannot eliminate contaminants by passive diffusion, are good indicators of the potential for biomagnification of nonpolar organic compounds in marine food webs, if proper precautions are taken (Reijnders 1986, Aguilar 1987). Such factors as nutritive state, age, reproductive state, and level in the food chain have a pronounced effect on the residue leveis of organochlorines in marine mammals. Seals from the North Sea and Baltic Sea contained 28.7 to $140.8 \mu \mathrm{g} / \mathrm{g}$ blubber total PCBs as Clophen A60 (Luckas et al. 1990). By comparison, blubber of seals from Spitzbergen, Norway and Iceland contained 1.1 to $13.4 \mu \mathrm{g} / \mathrm{g}$ PCBs and seals from Antarctica contained 0.07 to $0.08 \mu \mathrm{g} / \mathrm{g}$ PCBs. The dominant PCBs in harbor seals, Phoca vitulina, from the North Sea were the more highly chlorinated congeners $(6$ chlorines or more); concentrations of less chlorinated PCB congeners were low (Beck et al. 1990).

Concentrations of total PCBs in the blubber of striped dolphins, Stenella coereoalba, from the northwest Pacific Ocean off Japan did not change significantly between 1978/79 and 1986

(Loganathan et al. 1990). In 1978/79, concentrations in blubber of adult males ranged from 15 to 46 $\mu \mathrm{g} / \mathrm{g}$ wet wt; in 1986, the range was 17 to $38 \mu \mathrm{g} / \mathrm{g}$. By comparison, concentrations of total PCBs in blubber of killer whales, Orcinus orca, from the northwest Pacific Ocean were reported to be 350 to $410 \mu \mathrm{g} / \mathrm{g}$ (Ono et al. 1987). The PCB concentrations reported in tissues of orcas are much higher than concentrations in tissues of cetaceans from the most heavily contaminated sites, such as the St. Lawrence River estuary, and may be erroneous. Concentrations of PCBs in blubber of male Dall's porpoises, Phocoenoides dalli, from the northwest Pacific Ocean ranged from 6 to $18 \mu \mathrm{g} / \mathrm{g}$ wet wt and were inversely correlated with concentrations of circulating titers of testosterone, suggesting that 
body burdens of PCBs and other organochlorines were having an adverse effect on reproduction in the porpoises (Subramanian et al. 1987).

Concentrations of total PCBs in blubber of bottlenose dolphins, Tursiops truncatus, from the Atlantic coast of the United States and the south-eastern Indian Ocean ranged from about 17 to 160 $\mu \mathrm{g} / \mathrm{g}$ lipid (De Kock and Lord 1989, Kuehl et al. 1991). Concentrations generally were lower in blubber of common dolphins, Delphinus delphis, which feed farther from shore than the bottlenosed dolphins. Average concentrations were higher in males than females, a pheno.nenon observed in other marine mammals, including fin and sei whales (Aguilar and Borrell 1991) and North Atlantic right whales, Eubalaena gracialis (Woodley et al. 1991), and is thought to be related to the ability of females to transfer nonpolar contaminants to the young in lipid-rich milk. Concentrations of PCBs were higher in blubber of bottlenose dolphins than in blubber of either common dolphins, Delphinus delphis, and white-sided dolphins, Lagenorhynchus acutus, possibly due to differences in food habits of the three species (Kuehl et al. 1991). Concentrations (0.1 to $1.9 \mu \mathrm{g} / \mathrm{g}$ wet wt) of total PCBs in blubber of North American right whales from the Bay of Funday and on Brownis-Bacara Bank, Canada, were lower than in tissues of toothed cetaceans (Woodley et al. 1991). Similar results were obtained by several of the investigators cited in this paragraph for several chlorinated hydrocarbon pesticides, particularly DDT and its metabolites. These results all lend support to the hypothesis that PCBs, particularly the more highly chlorinated congeners, and DDTs are biomagnified in marine food chains.

\subsubsection{Other Halogenated Organic Compounds}

\subsubsection{Feeding Studies}

Most other nonpolar halogenated organic compounds behave like PCBs in marine food chains. The tendency for these compounds to biomagnify in aquatic tood chains depends on their hydrophobicity/lipophilicity $\left(\mathrm{K}_{\mathrm{ow}}\right)$, absorption efficiency from the gut, and ease of metabolism by metabolic detoxification systems. A few examples will be presented here. Ellgehausen et al. (1980) studied the bioaccumulation potential of ten pesticides in a simple freshwater food chain. They concluded that transfer of pesticide residues via food chains was of lesser importance than direct uptake from the water in determining concentrations of pesticides in organisms at different levels in the food chain. This conclusion was based mainly on the poor assimilation efficiency from food of even highly lipophilic pesticides. However, several more recent studies have shown that most highly 
hydrophobic organochlorine pesticides are biomagnified in marine and freshwater food webs, particularly at the water-breathing to air-breathing trophic step.

DDT (1,1,1-trichloro-2,2-bis[p-chlorophenyl]ethane) is an extremely persistent pesticide that is still present in the marine environment despite the fact that its use was banned in most countries many years ago (Addison et al. 1984). DDT occurs in marine sediments as the parent compound and several persistent degradation products or metabolites ( $p, p^{\prime}-\mathrm{DDE}, p, p^{\prime}-\mathrm{DDD}, p, p^{\prime}-\mathrm{TDE}, o, p^{\prime}-\mathrm{DDT}$, etc.). In assessing food chain transfer of DDT, it is important to consider all the persistent forms of the pesticide.

Harding et al. (1981) examined the accumulation of DDT from phytoplankton by the copepod, Calanus finmarchicus. Dietary absorption $\left(\mathrm{E}_{0}\right)$ of DDT decreased with increasing densities of phytoplankton from 0.6 to 0.7 at a food density of $60 \mu \mathrm{g} \mathrm{C} / \mathrm{L}$ to 0.1 at a food density of about 600 $\mu \mathrm{g} \mathrm{C/L}$. The authors provided some circumstantial evidence that the copepods could pass DDT on to their progeny in the eggs.

Absorption efficiency of DDT from food by brook trout was 0.36 (Macek and Korn 1970). Rainbow trout, Salmo gairdneri, fed diets (naturally contaminated coho salmon) containing different concentrations of DDT and its metabolites accumulated total DDT to concentrations higher than the concentrations in their food (Hilton et al. 1983). At all dietary levels, the increment in total DDT between the food and the tissue residues in the trout was about two-fold. In all cases $p, p^{\prime}-D D E$ was the form of DDT accumulated to the greatest extent. When contaminated coho salmon were fed to mice, only DDE was accumulated in the mouse tissues (Cleland et al. 1988) and concentrations of DDE in the mice were lower than in their food.

Rainbow trout, Salmo gairdneri, and guppies, Phoecilia reticulata, fed a diet containing different concentrations of hexachlorobenzene (HCB) $\left(\log \mathrm{K}_{\text {ow }}\right.$ of 5.47 , solubility of $5 \mu \mathrm{g} / \mathrm{L}$ : Mackay and Paterson 1991) accumulated the chemical in their tissues (Niimi and Cho 1980, 1981, Niimi and Oliver 1988, Clark and Mackay 1991). The amount accumulated was less than the concentration in the food (in guppies, the fugacity of HCB in tissues was about ten-fold less than that of the food). The trout retained between $78 \%$ and $88 \%$ of the HCB in their food. However, dietary absorption efficiencies for HCB in salmon and guppies were zero (Zitko and Hutzinger 1976) and 0.01 (Bruggeman 1983), respectively. Because of rapid elimination by metabolism and passive efflux across the gills, HCB was not biomagnified by the fish. 
Lee et al. (1990) and Boese et al. (1990) showed that the deposit-feeding clam, Macoma nasuta, was able to select particles for ingestion that were richer in organic carbon than the bulk sediment. This selectivity affords a mechanism by which the clams can increase accumulation of nonpolar organic chemicals (usually associated primarily with the organic carbon fraction of sediments) above that predicted by equilibrium partitioning theory. They showed that efficiency of uptake of HCB from bulk sediment by the clams was $38 \%$ to $56 \%$. Uptake of HCB through the gut from high-organic sediment particles was the single most important route of accumulation, accounting for $63 \%$ to $84 \%$ of the body burden of HCB in the clam tissues (Table 8.7). These results suggest that $\mathrm{HCB}$, and perhaps other nonpolar organics with similar $\mathrm{K}_{\text {ow }}$ can be taken up readily from sediments and transferred into marine food chains.

Kepone (chlordecone) is a chlorinated polycyclic ketone closely related to another pesticide, Mirex. It is highly hydrophobic with a $\mathrm{K}_{\text {ow }}$ of 6.08 (Zaroogian et al. 1985). Bahner et al. (1977) showed that oysters, Crassostrea virginica, fed phytoplankton containing approximately $34 \mu \mathrm{g} / \mathrm{g}$ wet wt of the pesticide accumulated $0.21 \mu \mathrm{g} / \mathrm{g}$ wet wt kepone in $14 \mathrm{~d}$, but when they were returned to clean seawater, they depurated the kepone within ten days. However, kepone was passed along the food chain consisting of laboratory brine shrimp, Artemia salina, mysid, Mysidopsis bahia, and spot, Leiostomus xanthurus. After $30 \mathrm{~d}$, the average efficiency of transfer of kepone from shrimp to mysids was 0.53 and from mysid to spot it was 0.85 . Kepone was transferred but not biomagnified in this simple laboratory food chain.

Spot accumulated kepone from food (contaminated grass shrimp, Palaemonetes pugio) in direct proportion to the concentration in the food (Stehlik and Merriner 1983, Fisher et al. 1986). However, assimilation efficiency of kepone from the food was low, approximately 0.15 , regardless of ration size or kepone concentration in the food. Essentially identical results were obtained for grass shrimp, P. pugio (Fisher and Clark 1990). Assimilation efficiency of kepone from food by grass shrimp was approximately 0.21 . Somewhat different results were obtained by Connolly and Tonelli (1985), who modeled kepone in the striped bass, Marone saxatilis, food chain of the James River estuary, Virginia. The model indicated that for the upper levels of the food chain, diet was the major route of contamination, accounting for $87 \%$ to $88 \%$ of the concentrations observed in tissues of Atlantic croaker, Micropogon undulatus, and white perch, Morone americanus, and $91 \%$ of the kepone concentration in the tissues of striped bass. The model also showed that the sediments were an important source of kepone in the fish, probably through transfer from benthic invertebrates. 
Kepone derived from sediments represented about $50 \%$ of the body burden in croaker and perch and $40 \%$ of the body burden in striped bass. The model suggested that biomagnification of kepone was occurring in the striped bass food chain despite the poor absorption efficiency of kepone from food by invertebrates and fish.

Argyle et al. (1975) fed channel catfish, Ictalurus punctatus, diets containing $0.4,0.8$, and $4.0 \mu \mathrm{g} / \mathrm{g}$ dieldrin for up to $210 \mathrm{~d}$. Dietary absorption efficiency was 0.24 from the diet containing $4.0 \mu \mathrm{g} / \mathrm{g}$ dieldrin and 0.30 to $0.37 \mu \mathrm{g} / \mathrm{g}$ from the lower-dose diets. Concentrations of dieldrin in fish tissues never approached those in the diet. When the fish were fed a dieldrin-free diet, they released the dieldrin rapidly with a half-life of about ten days. Petrocelli et al. (1975) obtained similar results when they fed blue crabs, Callinectes sapidus, marsh clams, Rangia cuneata, containing 181 to 193 $\mu \mathrm{g} / \mathrm{g}$ dieldrin for ten days. Dietary absorption efficiency ranged from 0.47 to 0.68 after ten days. After ten days, the crabs contained an average of about $4.1 \mu \mathrm{g} / \mathrm{g}$ dieldrin, compared to 0.44 to 1.4 $\mu \mathrm{g} / \mathrm{g}$ in control crabs. These experiments demonstrate trophic transfer, but not biomagnification of dieldrin.

Endrin (a pesticide closely related to dieldrin) exhibited similar behavior in a mussel, Mytilus edulis, lobster, Homarus americanus, feeding study (McLeese et al. 1980a,b). The lobsters were fed mussels containing an average of $4.7 \mu \mathrm{g} / \mathrm{g}$ wet wt endrin for two weeks. At the end of two weeks, the lobsters contained an average of about $2 \mu \mathrm{g} / \mathrm{g}$ endrin in the hepatopancreas and $0.045 \mu \mathrm{g} / \mathrm{g}$ endrin in the tail muscle. Dietary absorption efficiency was estimated at about 0.71 . When the lobsters were returned to an endrin-free diet they lost endrin from their tissues with a half-life of four days. However, when rainbow trout were fed fish food prepared with field-contaminated coho salmon for 24 weeks, their whole body burden of dieldrin was about twice the concentration in their diets, suggesting limited biomagnification (Hilton et al. 1983). Because of its slow accumulation from the diet and rapid excretion, dieldrin has only a limited potential to biomagnify in freshwater and marine food webs.

Polychlorinated dibenzo-p-dioxins and polychlorinated dibenzofurans (PCDDs and PCDFs) are extremely toxic and lipophilic byproducts of various industrial processes. They have dietary absorption efficiencies in rainbow trout of 0.01 to about 0.5 , depending on molecular weight and $\mathrm{K}_{\text {ow }}$ (Muir et al. 1990, Opperhuizen and Sijm 1990). For example, 2,3,7,8-PCDD has a $K_{\mathrm{ow}}$ of 6.8 (Gobas et al, 1988) and an absorption efficiency of about 0.5 ; and octachlorodibenzodioxin has a $\mathrm{K}_{\mathrm{ow}}$ of 8.2 and an absorption efficiency of about 0.05 to 0.08 . The efficiency of dietary absorption of 
2,3,4,7,8-PCDF was 0.41 to 0.44, depending on concentration in food (Muir et al. 1990). When trout were fed clean food, they lost the dibenzofuran from their tissues at a half-life of 61 to $69 \mathrm{~d}$. Bioaccumulation factors of less chlorinated congeners of these compounds from water and food are several orders of magnitude less than would be predicted from their aqueous solubilities and $\log \mathrm{K}_{\text {ow }}$ (Muir et al. 1985, Kleeman et al. 1986, Doucette and Andren 1987, Opperhuizen and Sijm 1990), probably because of rapid metabolism and excretion. Bioaccumulation of some of the more highly chlorinated congeners is less than predicted because of poor absorption efficiency. Most of these compounds have a limited potential for biomagnification in aquatic food chains.

Trichlorobenzes (Log $\mathrm{K}_{\mathrm{ow}}$ of 3.9 to 4.4: Opperhuizen et al. 1988) were assimilated from food by rainbow trout with an efficiency of about $61 \%$ (Smith et al. 1980). However, more than $90 \%$ of the assimilated dose of trichlorobenzenes was metabolized and excreted by the fish within $174 \mathrm{~h}$, indicating little potential for biomagnification.

Bleaching of wood pulp to produce paper generates a large number of chlorinated organic compounds derived from reactions between chlorine and lignin. Polychlorinated guaiacols and catechols are particularly toxic byproducts of this process. Neilson et al. (1989) studied the transfer and transformations of 4,5,6-trichloroguaiacol ( $\log \mathrm{K}_{\mathrm{ow}}$ of 3.73, and $\mathrm{PK}_{\mathrm{a}}$ of 7.20: Xie and Dyrssen, 1984) in a Fucus-based model Baltic Sea ecosystem. At the end of the 16-month experiment most of the algae contained from 0.5 to $3.0 \mu \mathrm{g} / \mathrm{g}$ dry wt of trichloroguaiacol and its metabolites; herbivores and detritivores contained 1.0 to $7.0 \mu \mathrm{g} / \mathrm{g}$; invertebrate carnivores contained 10 to $15 \mu \mathrm{g} / \mathrm{g}$; and the fish in the mesocosm, the stickleback, Gasterosteus aculatus, contained up to $40 \mu \mathrm{g} / \mathrm{g}$ dry wt of trichloroguaiacol and its metabolites. These results strongly suggest that chlorinated guaiacols were biomagnified in this model food chain. Apparent biomagnification of trichloroguaiacol, despite its relatively low $\mathrm{K}_{\text {ow }}$, may be related to its ionizability at near-neutral $\mathrm{pH}$, allowing it to bind covalently to tissue macromolecules.

\subsubsection{Field Studies}

A large number of field studies of food chain transfer and biomagnification of DDT in freshwater and marine ecosystems have been reviewed by Kay (1984). Generally, these studies showed poor correlations between apparent trophic level of aquatic invertebrates and fish and body burdens of DDT and its metabolites. However, in some cases, there was a tendency for DDT concentrations to be highest in one or more species of top predators, particularly if that species was an air-breathing bird or mammal. For example, in the coastal pelagic food web studied by Schafer et 
al. (1982), the highest average concentration of total DDT was observed in sea lions (Figure 8.8). In the Palos Verdes epibenthic food web, spiny dogfish had the highest concentration of total DDT.

There was a strong positive relationship between trophic level (as determined by $\delta^{13} \mathrm{C}$ concentration and CS/K ratios), and concentrations of total DDT in benthic/demersal animals from the vicinity of the Palos Verdes sewage outfall in the Southern California Bight near Los Angeles and a cleaner site off Santa Barbara, CA (Figure 8.10: Spies et al. 1989b). In a pelagic food chain in the north Pacific and Bering Sea, the mean concentration of total DDT increased from $0.071 \mu \mathrm{g} / \mathrm{g}$ lipid wt in zooplankton to $9.1 \mu \mathrm{g} / \mathrm{g}$ in Dall's porpoise and $1.8 \mu \mathrm{g} / \mathrm{g}$ in thick-billed murres (Kawano et al. 1988). The $p, p^{\prime}-\mathrm{DDE}$ increased from $36.5 \%$ of the total DDT residues in zooplankton to $58.2 \%$ in Dall's porpoises, and $95.7 \%$ in murres. Similar results were reported for a Lake Ontario food web (Oliver and Niimi 1988) and epibenthic and benthic food webs in Lake Michigan (Evans et al. 1991). In the Lake Michigan food chains, DDE was the most strongly biomagnified contaminant, increasing 28.7-fold from plankton to fish.

Investigations of the distribution of dieldrin in components of natural marine food webs in the lower Medway Estuary, Kent, England, and the Wesser Estuary, Germany, indicated no trend of increasing dieldrin residues in whole animals on either a bulk or lipid basis (Warfe and van den Broek 1978, Goerke et al. 1979). However, recent investigations of top predators in arctic food chains suggest that limited biomagnification of dieldrin may occur under some circumstances, particularly at the level of the gill-breather to air-breather trophic transfer. Arctic cod from Admiralty Inlet and Barrow Strait, northern Canada contained about $0.001 \mu \mathrm{g} / \mathrm{g}$ wet wt dieldrin in muscle tissues (Muir et al. 1988). However, ringed seals (males and females combined) contained mean concentrations of dieldrin in their blubber of about 0.075 to $0.085 \mu \mathrm{g} / \mathrm{g}$, and polar bears contained mean concentrations of dieldrin in their body fat of 0.375 to $0.381 \mu \mathrm{g} / \mathrm{g}$. The difference in dieldrin concentration in cod muscle and seal blubber is decreased substantially if both concentrations are expressed on a lipid basis $(0.067 \mu \mathrm{g} / \mathrm{g}$ lipid in cod and 0.083 to $0.094 \mu \mathrm{g} / \mathrm{g}$ lipid in seal blubber). However, there is a large jump in dieldrin concentration, even on a lipid basis, between seal blubber and bear fat $(0.47$ to 0.48 $\mu \mathrm{g} / \mathrm{g}$ lipid in bear fat).

Chlordane, a pesticide containing more than 45 different isomers and congeners, has a $K_{o w}$ of about 6.0 and a dietary absorption efficiency of 0.42 to 0.52 (Gobas et al. 1988). Various chlordane isomers have been detected in marine food webs. Muir et al. (1988) measured chlordane in the tissues of arctic cod, ringed seals, and polar bears from the Canadian arctic. Arctic cod muscle from 
Admiralty Inlet and Barrow Strait contained 0.002 to $0.003 \mu \mathrm{g} / \mathrm{g}$ wet wt $(0.13$ to $0.2 \mu \mathrm{g} / \mathrm{g}$ lipid) total chlordane; ringed seal blubber contained about 0.375 to $0.405 \mu \mathrm{g} / \mathrm{g}(0.417$ to $0.45 \mu \mathrm{g} / \mathrm{g}$ lipid) chlordane; and polar bear fat contained about 2.67 to $2.97 \mu \mathrm{g} / \mathrm{g}$ (3.33 to $3.73 \mu \mathrm{g} / \mathrm{g}$ lipid), suggesting substantial biomagnification between ringed seals and polar bears, but not between arctic cod and ringed seals. Concentrations of chlordane in tissue lipids of polar bears from throughout the Canadian arctic in 1982-1984 ranged from 1.81 to $7.09 \mu \mathrm{g} / \mathrm{g}$ (Norstrom et al. 1988). Chlordane concentrations in polar bear fat increased by more than four-fold between 1969 and 1983-84.

Kawano et al. (1988) examined the distribution of the major chlordane congeners in marine food chains of the north Pacific ocean, Bering Sea and the Antarctic Ocean. In the north Pacific/Bering food chain, the concentration of total chlordane increased from an average of 0.054 $\mu \mathrm{g} / \mathrm{g}$ lipid in zooplankton to $2.82 \mu \mathrm{g} / \mathrm{g}$ lipid in Dall's porpoises and $0.098 \mu \mathrm{g} / \mathrm{g}$ in thick billed murres (Figure 8.11). In the Antarctic food web, the average total chlordane concentration increased from $0.002 \mu \mathrm{g} / \mathrm{g}$ lipid in $\mathrm{krill}$ to $0.069 \mu \mathrm{g} / \mathrm{g}$ lipid in Weddell seals and $0.034 \mu \mathrm{g} / \mathrm{g}$ lipid in Adele penguins. The most abundant chlordane congener in north Pacific zooplankton was cis-chlordane; and transnanochlor was the most abundant chlordane congener in north Pacific Dall's porpoises. These congeners were present at low concentrations in murres; the dominant congener in murres, representing nearly $85 \%$ of the total chlordane in the bird's tissues, was oxychlordane. A roughly similar pattern of chlordane congener distribution was observed in the Antarctic food chain. Oxychlordane is a metabolite of other chlordanes. Therefore, the authors concluded that the murre, and possibly the penguin, metabolized chlordanes and nanochlors more efficiently than the porpoise and seal. These studies indicate that metabolic detoxification abilities have an important influence on biomagnification of nonpolar organic chemicals at top trophic levels in marine food webs.

Knutzen and Oehme (1989) measured concentrations of PCDD and PCDF in mussels, crabs, and fish from a fjord in southern Norway receiving a contaminated wastewater discharge from a magnesium production plant. There was a steeply decreasing gradient of body burdens of both types of contaminants in all species with distance from the outfall. However, chlorinated dioxins and dibenzofurans were present at higher concentrations in muscle tissue of mussels and crabs than in filets of codfish, flounder, and eels, suggesting an inverse relationship between trophic level (or taxonomic rank) and body burdens. On the other hand, cod liver contained higher concentrations of total PCDD and PCDF than crab hepatopancreas (both higher than muscle in fat content). The highest concentrations of PCDD and PCDF in cod liver were 20.6 and $192 \mathrm{ng} / \mathrm{g}$ wet wt, respectively. 
Concentrations of total PCDD and PCDF were similar, on a lipid basis, in tissues of salmon, Salmo salar, cod, Gadus morhua, ringed seals, Phoca hispida, and grey seals, Halochoerus grypus, from the Baltic Sea (Koistinen 1990), suggesting a lack of significant biomagnification of these compounds. Concentrations of selected PCDD/PCDF congeners in blubber of ringed seals from Spitzbergen and the Canadian arctic and blubber of harbor seals, Phoca vitulana, from Oslofjord, Norway ranged from less than 2 to $23 \mathrm{ng} / \mathrm{Kg}$ lipid (Oehme et al. 1990), suggesting little biomagnification. Ono et al. (1987) reported concentrations of total PCDF in blubber of three killer whales from the northwest Pacific Ocean of 300 to $480 \mathrm{ng} / \mathrm{Kg}$. No PCDD was detected, suggesting that the PCDF is more widespread or more persistent in the environment than PCDD. The composition of the PCDF assemblage in the killer whale blubber indicated that selected isomers of penta-, hexa-, and hepta-chloro-PCDFs may biomagnify to some degree, supporting the conclusions from the subsequent food chain studies of Broman et al. (1992).

Broman et al. (1992) studied the distribution in two natural food chains from the northern Baltic Sea of several PCDD and PCDF congeners with different molecular configurations and toxicities. They identified different trophic levels by relative concentrations of stable isotopes of nitrogen in organisms in the food chains. The littoral food chain consisted of phytoplankton, seston, mussels and eider ducks; and the pelagic food chain consisted of phytoplankton, seston, zooplankton, herring, and cod. Results were similar for both food chains. There was an inverse relationship between trophic level and concentrations in tissues of 2,3,7,8-substituted PCDD and PCDF that also had chlorine substitution in the 1,4 and/or 6,9 positions (Figure 8.12). However, there was a direct relationship between trophic level and concentrations in tissues (biomagnification was occurring) of 2,3,7,8-substituted PCDD and PCDF with no chlorine substitution in the 1,4 and/or 6,9 positions. Octachloro-PCDD and PCDF were not accumulated well at any trophic level and their concentrations in tissues of food chain organisms decreased with increasing trophic level. The authors suggested that 2,3,7,8-substituted PCDD and PCDF with chlorine substitution in the 1,4 and/or 6,9 positions were accumulated less efficiently from food and water by food chain organisms than the PCDD and PCDF without these substituents because they had larger molecular cross-sections $(>0.95 \mathrm{~nm})$ than the latter. Juvenile eider ducks, which feed almost exclusively on mussels, retained more of the most toxic PCDD and PCDF (those without vicinal chlorine substitution) than the less toxic, larger isomers. 
Chlorinated hydrocarbon pesticides tend to accumulate in natural marine food chains. However, the extent of biomagnification is highly variable, depending on the physical/chemical properties of the chemicals, the facility with which they are metabolized in animals at different trophic levels, and the relative concentrations in the ambient water. For example, Hargrave et al. (1992), in a summary presentation of published data, showed that six chlorinated hydrocarbon pesticides tended to bioconcentrate in some species in the Canadian polar marine food chain (Figure 8.13). Demersal amphipods and arctic cod, which are important food items of ringed seals, beluga whales, and polar bears in Canada, generally contained lower body burdens of pesticides than the marine mammals. Concentrations of total DDT and PCB were higher in amphipods than in seals and polar bears. Hexachlorocyclohexane $(\mathrm{HCH})$ and its isomers, chlorinated benzenes, and dieldrin, were biomagnified less than the other chlorinated hydrocarbons investigated. Among the marine mammals studied, polar bears contained the highest concentrations of chlordane (including isomers and degradation products) and total PCB in their fats; beluga whales contained the highest concentration of total DDT.

Biomagnification factors (concentration in lipids of predator/concentration in lipids of food) for chlorinated pesticides often are quite high in the transfer from a gill-breathing marine animal to an air-breathing marine mammal (Muir et al. 1988). In a Canadian Arctic marine food chain, arctic cod to ringed seal and arctic cod to polar bear biomagnification factors were higher than seal to polar bear biomagnification factors (Figure 8.14). However, this may be somewhat misleading, because arctic cod are not the preferred food of either ringed seals or polar bears (Lowry et al. 1980, Muir et al. 1988); polar bears often prefer other parts to the blubber of ringed seals.

\subsubsection{Polycyclic Aromatic Hydrocarbons}

\subsubsection{Feeding Studies}

Several laboratory studies have demonstrated that marine and freshwater animals can accumulate polycyclic aromatic hydrocarbons (PAH) and saturated hydrocarbons from their food (Neff 1979a,b). However, there have been very few investigations of food chain transfer and possible biomagnification of PAH and saturates. This is surprising, considering the great public concern expressed after large oil spills about possible food chain contamination with petroleum hydrocarbons, especially the more toxic PAH, from the spilled oil. In an oil spill situation, marine organisms at all trophic levels are exposed to a common source of hydrocarbons dissolved or dispersed in the water column, or deposited in nearshore sediments (Gundlach et al. 1983, Neff 1991). Under these 
conditions, the distribution of hydrocarbons in the food web reflects the different capabilities of organisms at different trophic levels to accumulate hydrocarbons from the water, food, and sediments, and to excrete them by active and passive means.

Rossi (1977) fed young polychaete worms, Neanthes arenaceodentata, powdered alfalfa (their diet in laboratory culture) contaminated with $10-15 \mu \mathrm{g} / \mathrm{g}{ }^{14} \mathrm{C}$-methylnaphthalene for $16 \mathrm{~d}$.

Radioactivity was detected in the worms after they had consumed contaminated food for 8 to $16 \mathrm{~d}$. However, when worms were fed uncontaminated food for $24 \mathrm{~h}$ to allow purging of unassimilated food from the gut, no radioactivity was detected in the worm tissues. All radioactivity in the aquarium water was associated with unmetabolized methylnaphthalene. It is probable that the 24-h period, allowed for purging the gut of unassimilated food, was sufficient to allow the worms to depurate most of the methylnaphthalene. When sand worms, Nereis virens, were fed lyophilized mussels containing an average of $17.8 \mu \mathrm{g} / \mathrm{g}$ dry $\mathrm{wt}^{14} \mathrm{C}$-benz[a]anthracene, they accumulated approximately $0.46 \mu \mathrm{g} / \mathrm{g}$ benz[a]anthracene radioactivity (parent compound and metabolites) in their tissues (McElroy et al. 1990). The maximum flux of radioactivity to the water occurred $24 \mathrm{~h}$ after the labeled meal (about 2 $\mathrm{ng} / \mathrm{h}$ ) was administered, indicating rapid release of dietary benz[a]anthracene and its metabolites by the worms.

The differences between the two experiments in the food chain accumulation of two PAHs by polychaete worms may be related to solubility-and partition coefficient-related differences in the uptake and release rates of the two compounds. Naphthalene (solubility of $30.6 \mathrm{mg} / \mathrm{L}$, and $\mathrm{K}_{\text {ow }}$ of 3.35: Eastcott et al. 1988) is accumulated and released much more rapidly than benz[a]anthracene (solubility of $0.014 \mathrm{mg} / \mathrm{L}$, and $\mathrm{K}_{\mathrm{ow}}$ of 5.91 ). Naphthalene is released so rapidly that there is no observable net accumulation from food, while benz[a]anthracene is accumulated and released more slowly, so there is a net accumulation for a brief time after feeding.

When larvae of the hard shell clam, Mercenaria mercenaria, were fed for up to eight days with diatoms, Thalassiosira pseudonana, containing 37.8 to $40.4 \mu \mathrm{g} / \mathrm{g}$ dry wt of ${ }^{14} \mathrm{C}$-benzo[a]pyrene (solubility of $0.004 \mathrm{mg} / \mathrm{L}$, and $\mathrm{K}_{\mathrm{ow}}$ of 5.98: Eastcott et al. 1988), they accumulated up to about 16 $\mu \mathrm{g} / \mathrm{g}$ dry wt of the PAH (Dobroski and Epifanio 1980). At all times up to eight days, the larvae were able to release approximately $44 \%$ of the accumulated radioactivity in $24 \mathrm{~h}$ after returning to clean food. A large decrease in the rate of release of accumulated radioactivity coincided with the onset of metamorphosis of the larvae on day nine of the experiment. The accumulation efficiency for benzo[a]pyrene by the algae was 0.19 ; and the efficiency of assimilation of henzo[a]pyrene from the 
diet by the clam larvae was 0.054 . The poor efficiency of assimilation of benzo[alpyrene from the food and relatively rapid release of the PAH following cessation of feeding of contaminated food indicates that even for this relatively hydrophobic PAH, the likelihood of significant food chain transfer and biomagnification is small.

Marine crustaceans are able to accumulate PAH from their food, but assimilation efficiency varies in different species. The copepod, Calanus helgolandicus, was able to accumulate naphthalene from food (living and dead nauplii of the copepod, Elminius sp., or living cells of the alga, Bidulphia sinensis) that had been labeled with ${ }^{14} \mathrm{C}$-naphthalene (Corner et al. 1976a, Harris et al. 1977). Accumulation of naphthalene from food was more efficient than from water. Efficiency of absorption of naphthalene from the diet was approximately 0.60 . Approximately $35 \%$ of the radioactivity accumulated from the food was lost during depuration for $24 \mathrm{~h}$ in clean seawater. Most of the naphthalene remaining in the copepod tissues was present as the unmetabolized hydrocarbon, whereas most of the radioactivity recovered from the water was in the form of naphthalene metabolites.

Lee et al. (1976) showed that juvenile blue crabs, Callinectes sapidus, were able to accumulate naphthalene, methylnaphthalene, fluorene, and benzo[a]pyrene from contaminated food. From $7 \%$ to $10 \%$ of the ingested hydrocarbon was transferred from the stomach to other tissues of the crabs in $24 \mathrm{~h}$. Most of the remainder was lost in the feces within two days of the meal. Most of the accumulated PAH was released rapidly as polar metabolites. O'Connor and Squibb (1989) obtained slightly different results. Male and female blue crabs assimilated about $70 \%$ and $11 \%$, respectively, of an ingested dose of phenanthrene within three hours. Peak concentrations of. phenanthrene in hepatopancreas were reached in three hours in males and in six hours in females. Phenanthrene was metabolized rapidly in tissues of both sexes and little phenanthrene accumulated in non-hepatic tissues. Males produced metabolites more rapidly and accumulated them in the hepatopancreas at greater concentrations than did the females. Both males and females released phenanthrene and its metabolites rapidly. These results suggest that there is little potential for biomagnification of aromatic hydrocarbons in food chains containing crustaceans.

In a similar experiment, Dillon (1982) fed grass shrimp, Palaemonetes pugio, brine shrimp nauplii containing an average of $0.24 \mu \mathrm{g} / \mathrm{g}$ wet wt 2,6-dimethylnaphthalene for $32 \mathrm{~d}$. At the end of the feeding period, the grass shrimp maintained under a constant temperature regime contained an average of $5.26 \mu \mathrm{g} / \mathrm{g}$ wet wt dimethylnaphthalene; and grass shrimp, maintained under a fluctuating temperature regime, contained an average of $7.20 \mu \mathrm{g} / \mathrm{g}$ dimethylnaphthalene. These results seem to 
suggest biomagnification (Kay 1984). However, close examination of the experimental methods revealed that the grass shrimp were fed approximately $0.05 \mathrm{~g}$ of food each day for $32 \mathrm{~d}$. The estimated total amount of dimethylnaphthalene in the $32-\mathrm{d}$ ration is $0.38 \mu \mathrm{g}$. Thus, there was not enough of the PAH in the total diet to account for the concentrations in the shrimp tissues at $32 \mathrm{~d}$, assuming an average weight for grass shrimp of about $0.1 \mathrm{~g}$. The results presented by Dillon (1982) do, however, demonstrate that this PAH with a $\log \mathrm{K}_{\mathrm{ow}}$ of about 4.3 (Eastcott et al. 1988) was assimilated from food by a marine crustacean. Biomagnification was not demonstrated.

When gulf killifish, Fundulus similis, were administered ${ }^{14} \mathrm{C}$-naphthalene in solution by stomach tube, they assimilated approximately $12 \%$ of the administered dose in $2 \mathrm{~h}$ (Dixit and Anderson 1977). After $8 \mathrm{~h}, 79 \%$ of the radioactivity remaining in the fish was present in the gall bladder, presumably as polar metabolites, indicating rapid metabolism and excretion of PAH assimilated from the gut. However, larval Pacific herring, Clupea harengus pallasi, did not accumulate any ${ }^{14} \mathrm{C}$-naphthalene when fed ${ }^{14} \mathrm{C}$-naphthalene-contaminated food for up to $28 \mathrm{~d}$ (Carls 1987).

Similar results were obtained in the American eel, Anguilla rostrata (Nava and Engelhardt 1980), and rainbow trout, Salmo gairdneri (Niimi and Dookhran 1989). In rainbow trout, dietary absorption efficiencies for six PAHs ranged from 0.01 for methylanthracene to 0.32 for acenaphthylene. Half-times for elimination of the PAH ranged from one day for acenaphthylene to 25 $\mathrm{d}$ for phenyl naphthalene. Niimi and Dookhran (1989) concluded that PAH was not accumulated by trout through dietary exposure because of the combined effects of poor absorption efficiency and rapid elimination rates.

Corner et al. (1976b) and Whittle et al. (1977) fed young cod, Gadus morhua, and juvenile Atlantic herring, Clupea harengus, squid contaminated with ${ }^{14} \mathrm{C}$-benzo[a]pyrene. Forty-eight hours after feeding, $96 \%$ of the radioactivity was present in the stomach and intestinal contents of the cod (Table 8.8). After $96 \mathrm{~h}, 73 \%$ of the radioactivity still was associated with the stomach and intestines, apparently in an unassimilated form, possibly bound to macromolecules in the gut contents or in the gut wall. Most of the rest was present in the aquarium water, mainly as feces. About $2 \%$ was present in bile fluid as polar metabolites, and only about $4 \%$ of the benzo[a]pyrene and its metabolites was retained in the tissues of the cod. In herring, nearly $80 \%$ of the recovered radioactivity remained in the lipid-soluble fraction (unmetabolized benzo[a]pyrene) in the stomach $43 \mathrm{~h}$ after ingestion of the labeled squid. Most of the remaining radioactivity was present as unmetabolized benzo[a]pyrene and 
its metabolites in the lower gut. Although the digestive tract of fish represents the major site of both uptake and excretion of hydrocarbons from food, the fact that more than $98 \%$ of the radioactivity recovered from the fish $48 \mathrm{~h}$ after feeding was in the digestive tract strongly suggests that there was little assimilation of ingested PAH, and that the small amount assimilated was metabolized rapidly and excreted via the gall bladder into the intestine. The authors concluded that retention of benzo[a]pyrene in the stomach implies strong adsorption or binding to the stomach wall. This binding prevents subsequent absorption and assimilation of the ingested PAH.

Berry and Fisher (1979) showed that bluegill sunfish did not assimilate ${ }^{14} \mathrm{C}$-toluene from contaminated food (mosquito larvae). All the radioactivity in the fish at 1,4 , and $8 \mathrm{~h}$ after feeding was associated with the stomach and intestines. Thomas and Rice (1986) found that dolly varden, Salvelinus malma, assimilated less toluene and naphthalene from food when they were in freshwater than when they were in seawater. Twelve hours after feeding of freshwater-acclimated fish, about $60 \%$ of the toluene and $75 \%$ of the naphthalene administered in the diet were still in the stomach; in the seawater-acclimated fish, about $38 \%$ of the dietary toluene and $18 \%$ of the dietary naphthalene were still in the gut. These differences may be related to the fact that fish in seawater drink and absorb water from the gut, increasing the fugacity of chemicals in solution in the gut fluids, whereas fish in freshwater drink very little water.

O'Connor et al. (1988) fed rainbow trout, Salmo gairdneri, gelatin capsules containing benzo[a]pyrene or 7,12-dimethylbenz[a]-anthracene in corn oil. The fish assimilated between $2 \%$ and $12 \%$ of the two PAHs between 6 and $72 \mathrm{~h}$ after the feeding. Most of the accumulated PAH was metabolized rapidly to polar metabolites and excreted via the bile into the gut. Niimi and Palazzo (1986) fed rainbow trout oil containing eight PAHs. All the PAH was absorbed poorly by the fish. The authors estimated dietary absorption efficiencies of 0.14 for fluoranthene, 0.04 for phenanthrene, and less than 0.01 for anthracene, fluoranthene, benz[a]anthracene, and benzo[a]pyrene. Chrysene and pyrene were not absorbed at all. The authors estimated half-lives for assimilated PAH in fish tissues ranging from nine days for phenanthrene to less than two days for benzo[a]pyrene and benz[a]anthracene.

About $18 \%$ of an ingested dose of dodecylcyclohexane was assimilated by rainbow trout (Cravedi and Tulliez 1986a). Only $25 \%$ of the ingested dose remained in the fish tissues after one week; much of this was oxidized to cyclohexyldodecanoic acid and incorporated into normal tissue phospholipids and neutral lipids. At least $90 \%$ of a single ingested dose of the normal alkane, 
heptadecane, was absorbed by rainbow trout (Cravedi and Tulliez 1986b). About $50 \%$ of the absorbed dose was excreted within one week. Some of the alkane retained by the fish was oxidized to the fatty acid, heptadecanoic acid and incorporated into phospholipids and neutral lipids. Approximately $60 \%$ of an ingested dose of the branched alkane, pristane, was absorbed by rainbow trout (Le Bon et al. 1987). However, only about $17 \%$ of the administered dose remained in the fish tissues after three days. A small fraction of the assimilated pristane apparently was oxidized to fatty acids.

Twenty-four hours after fingerling coho salmon, Onchorhynchus kisutch, were fed food containing ${ }^{14} \mathrm{C}$-naphthalene and ${ }^{14} \mathrm{C}$-anthracene, 0.03 and 0.17 , respectively, of the administered dose was assimilated and was associated with the various internal tissues (Roubal et al. 1977). Anthracene and its metabolites were retained longer than naphthalene and its metabolites in fish tissues. Fair and Sick (1983) and Fair and Fortner (1987) fed black sea bass, Centropristis striata, oysters containing 0.40 or $0.47 \mu \mathrm{g} / \mathrm{g}$ wet ${ }^{2}{ }^{14} \mathrm{C}$-naphthalene for up to $14 \mathrm{~d}$ or shrimp muscle containing $0.2 \mu \mathrm{g} / \mathrm{g}{ }^{14} \mathrm{C}$ benzo[a]pyrene for ten days. Assimilation efficiency of naphthalene from the food was not calculated, but it was low. The assimilated radioactivity (naphthalene plus metabolites) was distributed among several tissues. At $24 \mathrm{~h}$, most of the assimilated radioactivity was associated with the gall bladder (probably as metabolites) and blood. The assimilation efficiency for benzo[a]pyrene also was low. After ten days, the highest concentrations of benzo[a]pyrene and its metabolites were associated with the bile. Lower concentrations of radioactivity were present in the liver and kidneys. Only traces of radioactivity were detected in muscle tissue. These results are consistent with those of other investigators in showing low assimilation efficiency of PAH from food and rapid metabolism and excretion of any assimilated PAH.

When mallard ducks, Anas americana, were fed crayfish, Procambarus spp., that had accumulated ${ }^{14} \mathrm{C}$-naphthalene from water contaminated with a water soluble fraction of No. 2 fuel oil, the ducks accumulated the radioactivity in several tissues (Tarshis and Rattner 1982). Highest mean concentrations of radioactivity (naphthalene and metabolites) were in the gall bladder and fats of the ducks. Kidney, liver, and blood also contained some of the radioactivity. Radioactivity increased in all tissues of the ducks, except fat, during the three days of feeding on contaminated craytish. When glaucous-winged gulls, Larus glaucescens, and mallard ducks were fed radiolabled crude and refined oils, they accumulated radioactivity primary in the kidney and liver, with lesser amounts in fats (McEwan and Whitehead 1980). Between 52\% and 64\% of the administered doses apparently were 
assimilated, though much of the apparently assimilated doses, particularly of bunker $\mathrm{C}$ residual oil, remained associated with the gut. Radioactivity dropped to background levels in all tissues except the gut of bunker $\mathrm{C}$-fed birds within $24 \mathrm{~h}$. Mallard ducks assimilated n-alkanes and aromatic hydrocarbons from ingested south Louisiana crude oil in direct proportion to the concentration of oil in their food (Lawler et al. 1978). There was evidence that both the saturated and aromatic petroleum hydrocarbons were metabolized and excreted rapidly. These studies show that petroleum hydrocarbons can be accumulated to a limited extent from food by aquatic birds.

Ringed seals, Phoca hispida, accumulated small amounts of aromatic hydrocarbons from ingested crude oil (Engelhardt 1978). Only small amounts of hydrocarbons accumulated in liver and kidney of the seals; larger amounts accumulated in blubber. The hydrocarbons were excreted rapidly in the urine and little remained in the blood after $16 \mathrm{~d}$.

PAH metabolites may also be transferred through marine food chains (McElroy and Sisson 1989, McElroy et al. 1991). When sand worms, Nereis virens, containing ${ }^{14} \mathrm{C}$-benzo[a]pyrene alone or a mixture of benzo[a]pyrene and its naturally-produced metabolites were fed to winter flounder, Pseudopleuronectes americanus, a small amount of the isotope accumulated in the fish tissues. Absorption efficiency for the parent PAH was greater than for the metabolites. About $5 \%$ of the dose of benzo[a]pyrene and about $3 \%$ of the dose of metabolites were present in the bile and liver of the flounder $24 \mathrm{~h}$ after the meal. About $13 \%$ of the parent compound and $2 \%$ of the metabolites in the food remained in the intestines of the fish $24 \mathrm{~h}$ after the meal. No other tissues contained detectable radioactivity in the first experiment. In a second experiment in which fish were dosed with food containing ${ }^{3} \mathrm{H}$-benzo[a]pyrene or metabolites, small amounts of the parent compound or metabolites accumulated in muscle tissue. Dietary assimilation efficiencies for ${ }^{3} \mathrm{H}$-benzo[a]pyrene and metabolites in flounder were 0.23 and 0.05 , respectively. When flounder were fed worms containing ${ }^{14} \mathrm{C}$-labeled benzo[a]pyrene-7,8-dihydrodiol (a major pre-carcinogen metabolite of benzo[a]pyrene), they assimilated $15.4 \%$ of the radioactivity in the food. Most of the metabolite was in the bile.

\subsubsection{Field Studies}

Broman (1990) and Broman et al. (1990) studied the distribution of PAH in a simple food chain from the Baltic Sea consisting of seston (nonliving suspended particles $>0.045 \mu \mathrm{m}$ ), blue mussels, Mytilus edulis, and common eider ducks, Somateria mollissima. The composition and relative concentrations of different PAHs in the assemblage studied, consisting of 19 PAHs of pyrogenic origin, changed from one trophic level to another (Figure 8.15). These changes were 
attributed to the different metabolic capabilities of mussels and ducks to metabolize and excrete different PAHs. Approximately $80 \%$ of the PAH accumulated by the mussels and virtually all the PAH accumulated by the ducks were accumulated from the food, demonstrating the importance of trophic transfer in accumulation of PAH. However, concentrations of all PAH decreased between seston and tissues of the ducks, indicating that biomagnification was not occurring.

There are very limited data on the concentrations of PAH in the tissues of marine mammals. Hellou et al. (1990) measured concentrations of total PAH by ultraviolet fluorescence (subject to multiple interferences in tissue matrices) in muscle tissues of several species of seals and cetaceans from the northwest Atlantic off Canada. Concentrations of total PAH (as chrysene equivalents) in tissues of seals ranged from 0.1 to $0.80 \mu \mathrm{g} / \mathrm{g}$ dry wt; the highest concentration was for a female harbor seal from southeastern Newfoundland. Concentrations of total PAH in muscle tissues of cetaceans ranged from $0.21 \mu \mathrm{g} / \mathrm{g}$ in a minke whale from southeast Newfoundland to $1.21 \mu \mathrm{g} / \mathrm{g}$ in a harbor porpoise collected offshore east of Newfoundland (Hellou et al. 1990). In a subsequent study, Hellou et al. (1991) measured total PAH concentrations in muscle tissues of 28 harp seals, Phoca groenlandica, from coastal waters of northeastern Canada. Concentrations ranged from 0.03 to 0.73 $\mu \mathrm{g} / \mathrm{g}$ dry $w t$ in male seals and below detection limits to $0.58 \mu \mathrm{g} / \mathrm{g}$ in females. Lowest concentrations were found in foetal tissues, but there was no evidence of increasing concentrations with age of the seals. Seals with highest body burdens of total PAH may have been from the St. Lawrence River herd, a contaminated area. Aduit male and female and subadult male harp seals from the northeastern Atlantic feed primarily on amphipods and decapod crustaceans; subadult females feed primarily on fish (Lyderson et al. 1991). These results strongly suggest very limited trophic transfer and no biomagnification of PAH in marine food chains.

\subsection{SUMMARY OF TROPHIC TRANSFER AND BIOMAGNIFICATION}

Metals can be accumulated from food by marine animals. The efficiency of trophic transfer of metals in laboratory studies seems to depend on several chemical and biological factors.

Absorption efficiencies of metals from the gut vary widely in different phyla and for different metals, but usually is less efficient in invertebrates than in fish. The type of food and the chemical form of the metal in the food also are important. Metals in the form of organometallic compounds are absorbed more efficiently than the corresponding inorganic metal species. Of the metals evaluated in 
feeding studies, only methylmercury seems to be biomagnified under some circumstances. Other metals, including organo-arsenic and selenium compounds do not appear to be biomagnified.

As a general rule, soft-bodied marine invertebrates obtain most of their body burdens of metals from the water or sediment, and not from food. On the other hand, most marine fish obtain more metals from food than from water or sediments. Many metals tend to "build down". That is their concentrations are highest in tissues of organisms at lower trophic levels in the food chain and tend to decrease at high trophic levels.

Food chain studies performed to date consistently show that inorganic forms of metals do not biomagnify in marine food webs. The lack of biomagnification of inorganic metals was attributed by Fowler (1982) to incomplete absorption of metals across the gut, rapid excretion, and dilution in muscle, which represents a large part of the total body weight of most marine animals. Organometallic compounds, such as methylmercury, may biomagnify to a limited extent in marine food webs; probably because of the more efficient absorption, stronger binding to tissue macromolecules, and slower excretion of organic than inorganic forms of metals. Organic compounds of essential metals such as arsenic and selenium probably are regulated to some extent and do not appear to biomagnify. However, air-breathing marine birds and mammals that depend on marine foods obtain most of their body burdens of metals from their food. In some cases, metals accumulate in these top consumers to high concentrations.

The efficiency of absorption of nonpolar organic contaminants from the gut varies widely among marine animals. The main determinant of dietary absorption efficiency seems to be hydrophobicity, measured as the octanol/water partition coefficient, $\mathrm{K}_{\mathrm{ow}}$. The food is quantitatively the most important source of most nonpolar organic contaminants in the tissues of marine animals in both comparative laboratory feeding studies and in field food web investigations. The sediment pore water and water column routes usually are less important because the concentrations in dissolved, bioavailable forms of these very sparingly soluble compounds usually are very low, compared to concentrations in the food.

Most organic contaminants with values of $\log \mathrm{K}_{\mathrm{ow}}$ greater than about four tend to show evidence of biomagnification in marine food webs. However, high molecular weight compounds, such as the most highly chlorinated PCBs, and compounds that are rapidly metabolized in and excreted from the tissues of marine animals, such as PAH, do not biomagnify. Among similar organic contaminants, such as congeneric PCBs, the extent of biomagnification is inversely related to 
the ease of metabolism of the compound. Organic compounds with a flat, planar configuration tend to be more readily metabolized and excreted than more globular compounds.

Several nonpolar organic compounds that are metabolized inefficiently, if at all, by marine animals at different trophic levels, are biomagnified efficiently at the water-breather to air-breather trophic transfer. These compounds, such as some PCB congeners, DDT (and some of its degradation products) and chlordane (and its degradation products), may be present at very high concentrations in the lipids of marine birds and mammals, even from remote areas.

Marine sediments are a quantitatively very important environmental compartment for the cycling of metal and organic contaminants through marine and terrestrial environments.

Concentrations of metal and organic contaminants from a wide variety of anthropogenic and natural sources often are many orders of magnitude higher than the concentrations in solution in the overlying water column. Chemical contaminants. in sediments can be accumulated by marine animals that live or feed in or on the sediments. The contaminants, originally derived from the sediments, may be passed throughout the marine food chain by trophic transfer. A few compounds, because they are absorbed efficiently and excreted poorly, may biomagnify in marine food chains to very high, potentially toxic concentrations in the top predators, including marine birds and mammals, and man. 
TABLE 8.1. Essential Elements Known to Have Biochemical or Physiological Functions in Plants or Animals

Major Elements

Hydrogen

Carbon

Nitrogen

Oxygen

Sodium

Magnesium

Phosphorus

Sulfur

Chlorine

Potassium

Calcium

\section{Trace Nutrients}

Boron

Aluminum

Silicon

Vanadium

Chromium

Manganese

Iron

Cobalt

Nickel

Copper

Zinc

Arsenic

Selenium

Bromine

Molybdenum

Iodine 
TABLE 8.2. Efficiency of Absorption of Metals From Food by Marine Non-Marine Animals

\begin{tabular}{|c|c|c|c|}
\hline Metal & Species & $\begin{array}{l}\text { Absorption } \\
\text { Efficiency }\end{array}$ & Reference \\
\hline Americium & Two marine fish. & $0.007-0.06$ & Carvalho et al. 1983 \\
\hline \multirow[t]{2}{*}{ Arsenic (I) } & Carcinus maenas & 0.14 & Ünlü 1979 \\
\hline & Pugetta producta & 0.68 & Boothe and Knauer 1972 \\
\hline Arsenic (O) & Carcinus maenas & 0.65 & Ünlü 1979 \\
\hline \multirow[t]{4}{*}{ Cadmium } & Crassostrea virginica & 0.59 & Hardy et al. 1984 \\
\hline & Carcinus maenas & 0.10 & Jennings and Rainbow 1979 \\
\hline & Pugetta producta & 0.87 & Boothe and Knauer 1972 \\
\hline & Pleuronectes platessa & $<0.05$ & Pentreath $1977 b$ \\
\hline Chromium & Pugetta producta & 0.89 & Booth and Knauer 1972 \\
\hline Cobalt & Mercenaria mercinaria & $0.22-0.54$ & Nakahara and Cross 1978 \\
\hline Copper & Pugetta producta & 0.40 & Boothe and Knauer 1972 \\
\hline \multirow[t]{2}{*}{ Lead } & Mytilus edulis & 0.24 & Schultz-Baldes 1974 \\
\hline & Pugetta producta & 0.25 & Boothe and Knauer 1972 \\
\hline Mercury (I) & Pleuronectes platessa & 0.05 & Pentreath $1976 d$ \\
\hline \multirow[t]{6}{*}{ Mercury (O) } & Leptasterias polaris & 0.5 & Pelletier and Larocque 1987 \\
\hline & Pleuronectes platessa & $0.80-1.0$ & Pentreath $1976 \mathrm{~d}$ \\
\hline & Pleuronectes platessa & $0.18-0.26$ & Pentreath 1976d \\
\hline & Pleuronectes platessa & $0.07-0.42$ & Pentreath $1976 d$ \\
\hline & Seriola quinqueradiata & 0.88 & Suzuki and Hatanaka 1974 \\
\hline & Seriola quinqueradiata & 0.67 & Suzuki and Hatanaka 1975 \\
\hline Selenium & Puditapes philippnarum & 0.5 & Zhang et al. 1990 \\
\hline \multirow[t]{3}{*}{ Silver } & Scrobicularia plana & 0.5 & Amiard 1979 \\
\hline & Carcinus maenas & 0.5 & Amiard 1979 \\
\hline & Pleuronectes platessa & $<0.05$ & Pentreath $1977 \mathrm{a}$ \\
\hline Zinc & Pugetta producta & 0.67 & Boothe and Knauer 1972 \\
\hline
\end{tabular}


TABLE 8.3. Concentrations of Several Metals in Muscle Tissues of Marine Animals at Different Trophic Levels in Three Southern California Food Chains. Trophic level assignments are based on Cs/K concentration ratios in tissues. Data from Young et al. (1980).

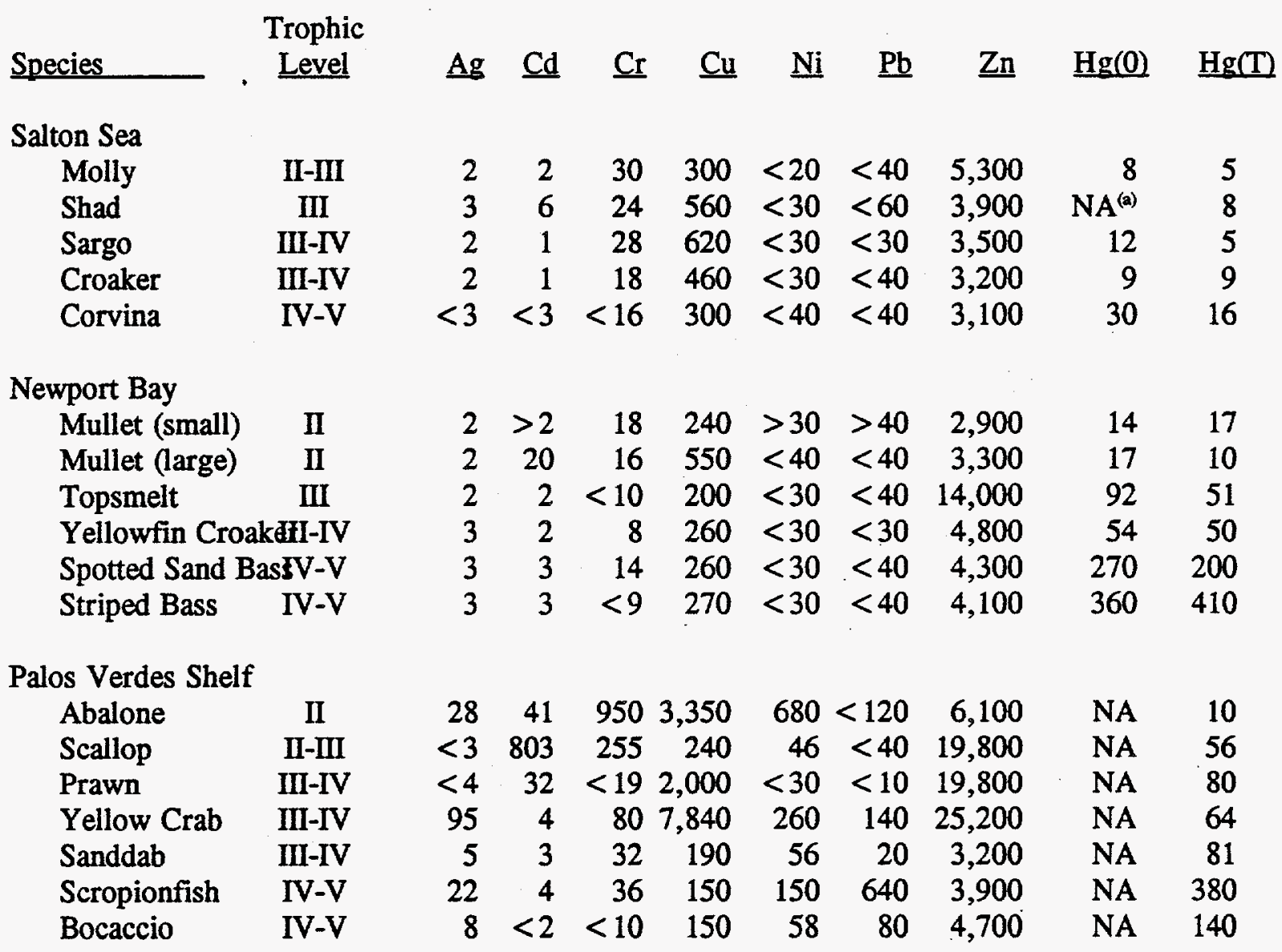

(a) NA Not analyzed. 
TABLE 8.4. Mean Concentrations of Several Metals in Whole Tissues of Marine Animals From a Loire Estuary, France, Food Chain. Data From Amiard et al. (1980)

\begin{tabular}{|c|c|c|c|c|c|}
\hline \multirow[b]{2}{*}{ Species } & \multirow[b]{2}{*}{$\begin{array}{l}\text { Feeding } \\
\text { Habits }\end{array}$} & \multicolumn{4}{|c|}{$\begin{array}{c}\text { Concentrations in Tissues } \\
(\mu \mathrm{g} / \mathrm{kg} \text { Dry Weight })\end{array}$} \\
\hline & & $\underline{\mathrm{Cd}}$ & $\underline{\mathrm{Pb}}$ & $\underline{\mathrm{Cu}}$ & $\underline{\mathrm{Zn}}$ \\
\hline \multicolumn{6}{|l|}{ Ctenophores } \\
\hline Mnemiopsis bachei & Planktivore & 496 & 368 & 687 & 47,900 \\
\hline \multicolumn{6}{|l|}{ Crustaceans } \\
\hline Neomysis integer & Carnivore & 69 & 4,652 & 20,492 & 47,800 \\
\hline Mesopodopsis slabberi & - & 142 & 5,748 & 7,370 & 62,800 \\
\hline Crangon crangon & Omnivore & 103 & 2,520 & 22,425 & 39,000 \\
\hline Carcinus maenas & Omnivore & 289 & 662 & 30,835 & 68,500 \\
\hline
\end{tabular}

Fish

Solea solea

Platichthys flesus

Benthos

$\begin{array}{llll}47 & 711 & 3,739 & 57,800\end{array}$

Dicentrarchus labrax

Benthos

$39 \quad 1,411$

$\mathrm{NA}^{(\mathbf{a})} \quad 114,500$

Gobius microps

Omnivore

116

584

3,306

81,500

Ominvore

44

360

$1,203 \quad 58,000$

Osmorus eperlanus (sm)

Planktivore

$9 \quad 1,929$

2,243

53,500

Osmorus eperlanus (Ig)

Planktivore

22

1,385

892

81,500

Sprattus sprattus (sm)

Planktivore

139

238

$3,542 \quad 119,600$

Sprattus sprattus (1g)

Engraulis incrusicolus

Syngnathus rostellatus

Merlangius merlangus

Planktivore

25

Planktivore

1,133

$1,444 \quad 68,500$

Plankivore

68

746

3,237

81,300

Top Carnivore

123

1,616

1,576

90,000

37

693

1,261

50,000

(a) NA Not Analyzed. 
TABLE 8.5. Transfer Factors (Concentration in Fish Tissues/Concentration in Fish Food) for Metals in Five Species of Fish From the Loire Estuary, France. Data from Metayer et al. (1980)

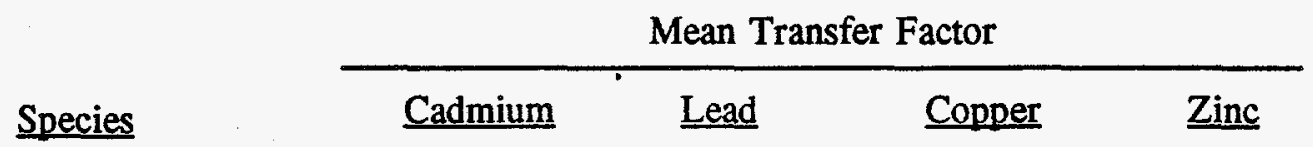

Dicentrarchus labrax

0.59

0.09

0.16

0.97

Gobius microps

0.15

0.21

0.07

1.14

Merlangius merlangus

0.37

0.30

0.16

0.74

Gadus luscus

0.08

0.42

0.48

0.81

Stizostedion lucioperca

1.63

0.37

1.32

1.05 
TABLE 8.6. Efficiency of Absorption of Nonpolar Organic Chemicals From Food by Marine and Freshwater Animals. Additional Values for Absorption Efficiences in Freshwater Fish Can Be Found in Gobas et al. (1988), Niimi and Oliver (1988), and Opperhuizen and Sijm (1990)

\begin{tabular}{|c|c|c|c|}
\hline Compound & Species & $\begin{array}{l}\text { Absorption } \\
\text { Efficiency }\end{array}$ & Reference \\
\hline \multirow[t]{2}{*}{ PCB mixture } & Salmo gairdneri & 0.68 & Lieb et al. 1974 \\
\hline & Marone saxatilis & 0.85 & Pizza and O'Connor 1983 \\
\hline $2,2^{\prime}, 4,5^{\prime}-\mathrm{PCB}$ & Homarus americanus & 0.52 & McLeese et al. 1980 \\
\hline $2,2^{\prime} 4,4^{\prime} 6-\mathrm{PCB}$ & Nereis virens & $0.68-0.80$ & Goerke 1984 \\
\hline $2,2^{\prime}, 3,3^{\prime}, 5,5^{\prime}-\mathrm{PCB}$ & Poecelia reticulata & 0.44 & Opperhuizen and Schrap 1988 \\
\hline $2,2^{\prime}, 4,4^{\prime}, 5,5^{\prime}-\mathrm{PCB}$ & Homarus americanus & 1.00 & McLeese et al. 1980 \\
\hline $\begin{array}{l}2,2^{\prime}, 3,3^{\prime}, 4,4^{\prime}, \\
6,6^{\prime}-\mathrm{PCB}\end{array}$ & Phoecelia reticulata & 0.52 & Opperhuizen and Schrap 1988 \\
\hline \multirow[t]{2}{*}{ DDT } & Calanus finmarchicus & $0.6-0.7$ & Harding et al. 1981 \\
\hline & Brevoortia tyrannus & 0.62 & Warlen et al. 1977 \\
\hline \multirow[t]{2}{*}{ Hexachlorobenzene } & Macoma nasuta & $0.38-0.56$ & Lee et al. 1990 \\
\hline & Phoecelia reticulata & 0.01 & Bruggeman 1983 \\
\hline \multirow[t]{5}{*}{ Kepone } & Mysidopsis bahia & 0.53 & Bahner et al. 1977 \\
\hline & Palaemonetes pugio & 0.21 & Fisher and Clark 1990 \\
\hline & Leiostomus xanthurus & 0.85 & Bahner et al. 1977 \\
\hline & & 0.31 & Stehlik and Merriner 1983 \\
\hline & & 0.15 & Fisher et al. 1986 \\
\hline \multirow[t]{2}{*}{ Dieldrin } & Calinectes sapidus & $0.47-0.68$ & Petrocelli et al. 1975 \\
\hline & Ictalurus punctatus & $0.24-0.37$ & Argyle et al. 1975 \\
\hline Endrin & Homarus americanus & 0.71 & McLeese et al. 1980 \\
\hline
\end{tabular}




\section{TABLE 8.6. (contd)}

\begin{tabular}{|c|c|c|c|}
\hline Compound & Species & $\begin{array}{l}\text { Absorption } \\
\text { Efficiency }\end{array}$ & Reference \\
\hline $\begin{array}{l}2,3,7,8 \text {-Tetra- } \\
\text { chlorodibenzo- } \\
\text { p-dioxin }\end{array}$ & Salmo gairdneri & 0.5 & Muir et al. 1990 \\
\hline $\begin{array}{l}\text { Octachlorodibenzo- } \\
p \text {-dioxin }\end{array}$ & Salmo gairdneri & $0.05-0.08$ & Muir et al. 1990 \\
\hline $\begin{array}{l}2,3,4,7,8 \text {-Penta- } \\
\text { chlorodibenzo- } \\
\text { furan }\end{array}$ & Salmo gairdneri & $0.41-0.44$ & Muir et al. 1990 \\
\hline Trichlorobenzenes & Salmo gairdneri & 0.61 & Smith et al. 1990 \\
\hline Dodecylcyclohexane & Salmo gairdneri & 0.18 & Cravedi and Tulliez 1986a \\
\hline Heptadecane & Salmo gairdneri & 0.90 & Cravedi and Tulliez 1986b \\
\hline Pristane & Salmo gairdneri & 0.60 & LeBon et al. 1987 \\
\hline \multirow[t]{3}{*}{ Naphthalene } & Calanus helgolandicus & 0.60 & Corner et al. 1976 \\
\hline & Fundulus similis & 0.12 & Dixit and Anderson 1977 \\
\hline & Onchorhynchus kisutch & 0.03 & Roubal et al. 1977 \\
\hline Acenaphthylene & Salmo gairdneri & 0.32 & Niimi and Dookhran 1989 \\
\hline Fluorene & Salmo gairdneri & 0.14 & Niimi and Palazzo 1986 \\
\hline Phenanthrene & Calinectes sapidus (M) & 0.74 & O'Connor and Squibb 1989 \\
\hline \multirow[t]{2}{*}{ Squibb 1989} & & (F) & O'Connor and \\
\hline & Salmo gairdneri & 0.04 & Niimi and Palazzo 1986 \\
\hline Anthracene & Salmo gairdneri & $<0.01$ & Niimi and Palazzo 1986 \\
\hline Anthracene & Onchorhynchus kisutch & 0.17 & Roubal et al. 1977 \\
\hline 2-Methylanthracene & Salmo gairdneri & 0.14 & Niimi and Dookhran 1989 \\
\hline
\end{tabular}


TABLE 8.6. (contd)

\begin{tabular}{|c|c|c|c|}
\hline Compound & Species & $\begin{array}{l}\text { Absorption } \\
\text { Efficiency }\end{array}$ & Reference \\
\hline 9-Methylanthracene & Salmo gairdneri & 0.01 & Niimi and Dookhran 1989 \\
\hline Phenyl naphthalene & Salmo gairdneri & 0.15 & Niimi and Dookhran 1989 \\
\hline Pyrene & Salmo gairdneri & 0.00 & Niimi and Palazzo 1986 \\
\hline Fluoranthene & Salmo gairdneri & $<0.01$ & Niimi and Palazzo 1986 \\
\hline Benz(a)anthracene & Salmo gairdneri & $<0.01$ & Niimi and Palazzo 1986 \\
\hline $\begin{array}{l}\text { 7,12-dimethylbenz } \\
\text { (a)anthracene }\end{array}$ & Salmo gairdneri & $0.02-0.12$ & O'Connor et al. 1988 \\
\hline Triphenylene & Salmo gairdneri & 0.04 & Niimi and Dookhran 1989 \\
\hline Chrysene & Salmo gairdneri & 0.00 & Niimi and Palazzo 1986 \\
\hline Perylene & Salmo gairdneri & 0.02 & Niimi and Dookhran 1989 \\
\hline \multirow[t]{4}{*}{ Benzo(a)pyrene } & Mercenaria mercenaria & 0.054 & Dobroski and Epifanio 1980 \\
\hline & Gadus morrhua. & 0.06 & Corner et al. 1976 \\
\hline & Salmo gairdneri & $0.02-0.12$ & O'Connor et al. 1988 \\
\hline & $\begin{array}{l}\text { Pseudopleuronectes } \\
\text { americanus }\end{array}$ & 0.23 & McElroy et al. 1991 \\
\hline $\begin{array}{l}\text { Benzo(a)pyrene } \\
\text { aimetabolites }\end{array}$ & $\begin{array}{l}\text { Pseudopleuronectes } \\
\text { americanus }\end{array}$ & 0.05 & McElroy et al. 1991 \\
\hline $\begin{array}{l}\text { Benzo(a)pyrene- } \\
\text { 7,8-dihydrodiol }\end{array}$ & $\begin{array}{l}\text { Pseudopleuronectes } \\
\text { americanus }\end{array}$ & 0.15 & McElroy et al. 1991 \\
\hline Severäl PAH & Calinectes sapidus & $0.07-0.10$ & Lee et al. 1976 \\
\hline \multirow[t]{2}{*}{$\begin{array}{l}\text { Crude and refined } \\
\text { oils }\end{array}$} & Anas americanus & $0.52-0.64$ & McEwan and Whitehead 1980 \\
\hline & Larus glaucescens & $0.52-0.64$ & McEwan and Whitehead 1980 \\
\hline
\end{tabular}


TABLE 8.7. Contribution of Various Sources to the Bioaccumulation of Hexachlorobenzene by the Deposit-Feeding Clam, Macoma nasuta. Data From Boese et al. (1990)

\section{Bulk Sediment}

\section{Uptake Route}

Overlying water fluxed across gills

Overlying water for pseudofeces production

Interstitial water passed through gut

Interstitial water at gills with pseudofeces

Interstitial/interfacial water at gills \& residues desorbed from particles at gills

Sorbed from interstitial water by non-gill tissues

Ingested sediment particles
Calculated

Residues in

Tissues $(\mu \mathrm{g})$
Ingested sediment particles

residues desorbed from particles at gills

Sorbed from interstitial water by non-gill tissues

Fine Sediment II

Overlying water fluxed across gills

Overlying water for pseudofeces production

Interstitial water passed through gut

Interstitial water at gills with pseudofeces

Interstitial/interfacial water at gills \& residues desorbed from particles at gills

Sorbed from interstitial water by non-gill tissues

Ingested sediment particles
88-187

9.6-20.4

0.8

2.0-9.1

274

224

1,732

$0-62$

$0-5.7$

1.6

7.8-34.5

216

99

1,659

Percent of Total

Residues in

Tissues

3.9-8.3

$0.4-0.9$

$<0.1$

$0.1-0.4$

12.2

11

78.2

$0-3.1$

$0-0.3$

0.1

$0.4-2.0$

10.9

5

83.8

57-71

5.0-6.2

9.6-11.8

0.8-1.0

0.5

$<0.1$

3.9-16.1

0.3-1.4

123

10.7

58

5

727

63.2 
TABLE 8.8. Distribution of ${ }^{14} \mathrm{C}$ Activity (As \% of Total Activity Recovered) at Intervals After Feeding Squid Containing ${ }^{14} \mathrm{C}-\mathrm{BaP}$ and ${ }^{14} \mathrm{C}$-hexadecane to Young Codfish Gadus morrhua. Data From Corner et al. (1976b).

\begin{tabular}{|c|c|c|c|}
\hline \multirow[b]{2}{*}{ Sample } & \multicolumn{3}{|c|}{ Percent ${ }^{14} \mathrm{C}$ Activity Recovered After: } \\
\hline & $48 \mathrm{~h}$ & $\underline{72 \mathrm{~h}}$ & $\underline{96 \mathrm{~h}}$ \\
\hline Stomach & 83.5 & 32.9 & 37.1 \\
\hline Liver & 2.2 & 3.6 & 3.4 \\
\hline Bile Fluid & 0.6 & 12.5 & 1.9 \\
\hline Intestinal Contents & 12.9 & $8.6^{(\mathrm{a})}$ & 36.3 \\
\hline Urine & 0 & trace & 0.03 \\
\hline Aquarium Residue (mainly feces) & 0.5 & 41.4 & 20.7 \\
\hline Aquarium Water & 0 & 0.2 & 0.12 \\
\hline Plasma $^{(\mathfrak{b})}$ & 0.03 & 0.08 & 0.05 \\
\hline Blood $^{(\mathbf{b})}$ & 0 & 0.06 & 0.04 \\
\hline Gills & 0.2 & 0.5 & 0.4 \\
\hline Spleen & 0.06 & 0.1 & 0.1 \\
\hline
\end{tabular}

(a). A loss of at least $50 \%$ occurred during dissection

(b) Expressed on a per gram basis 


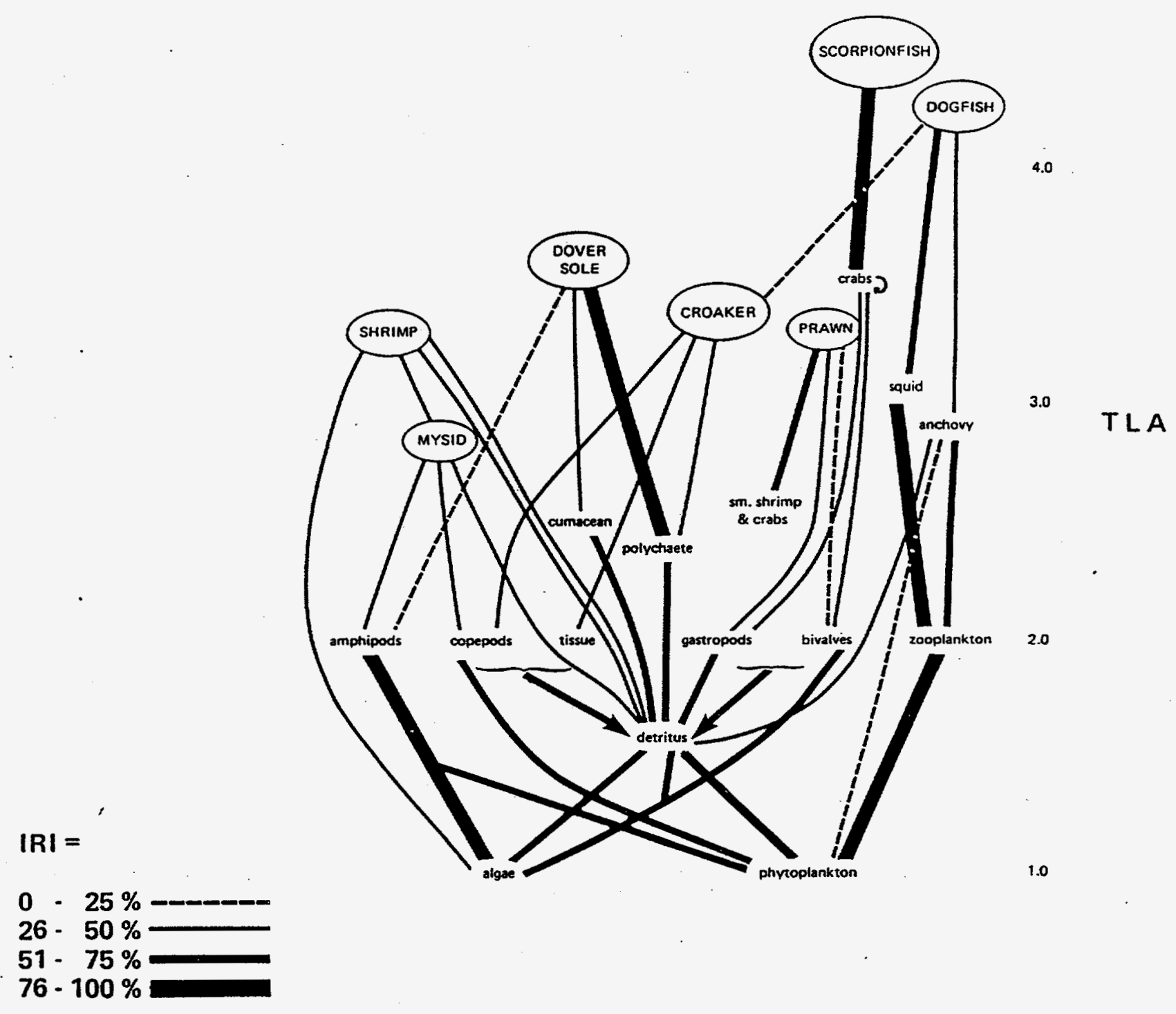

FIGURE 8.1. Summary of Trophic Relationships on the Palos Verdes Shelf, California. Width of connecting lines is proportional to the percent index of relative importance (IRI), based on stomach content analysis. Vertical position approximates trophic level assignment (TLA) as indicated by IRI. From Mearns (1982). 


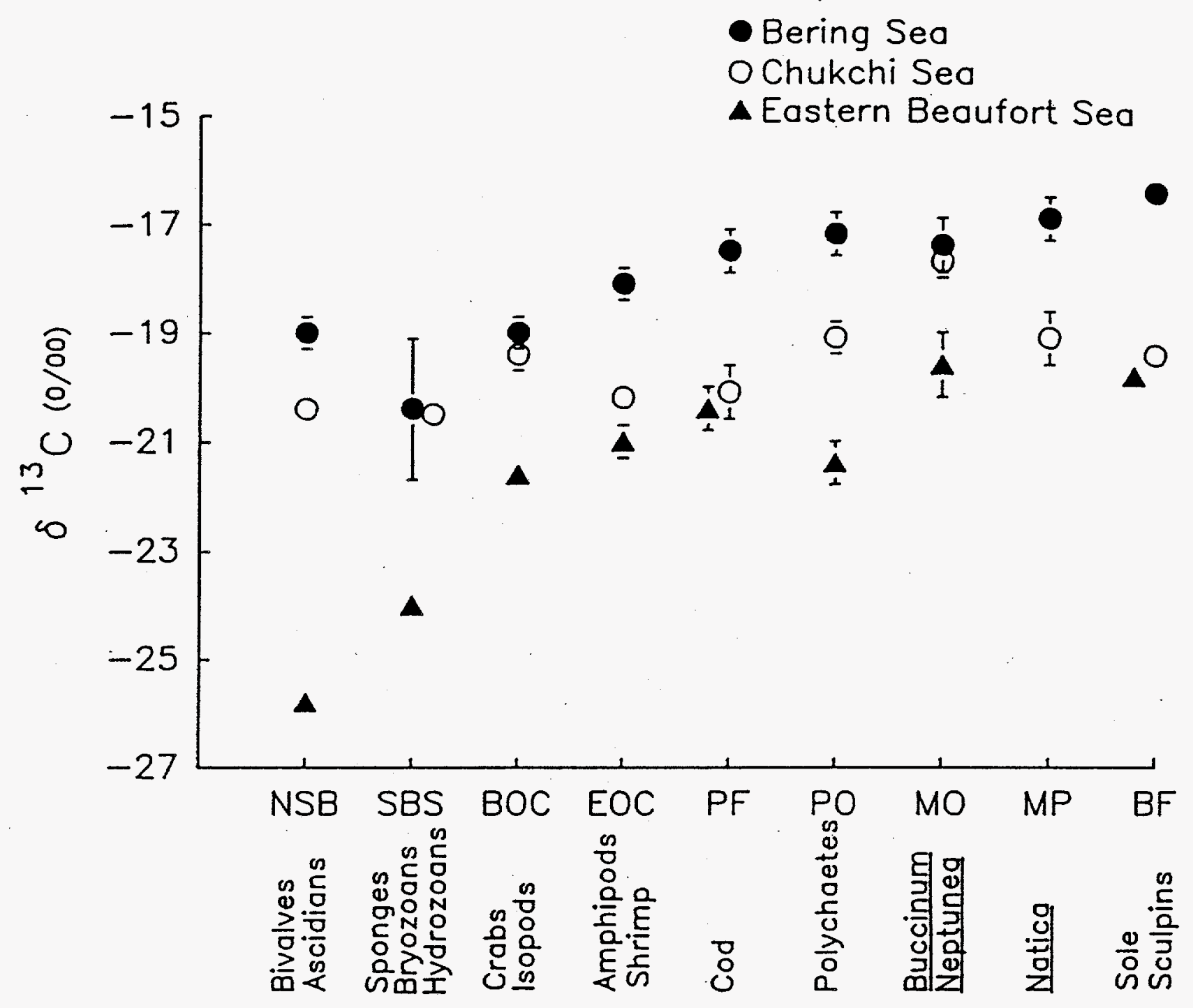

FIGURE 8.2. Values for $\delta_{12} C$ (mean $\pm S E, n=4$ ) in Tissues of Alaskan Fauna From the Southwest Bering, Chukchi, and Eastern Beaufort Seas. Animals are grouped according to feeding strategy and presumed trophic status. NSB, nonselective benthic feeder; SBS, selective benthic suspension feeder; BOC, benthic omnivorous crustaceans; EOC, epibenthic omnivorous crustaceans; PF, pelagic fish; PO, polychaete omnivorous; $\mathrm{MO}$, molluscan omnivorous; $\mathrm{MP}$, molluscan predators; $\mathrm{BF}$, demersal fish. From Dunton et al 1989. 

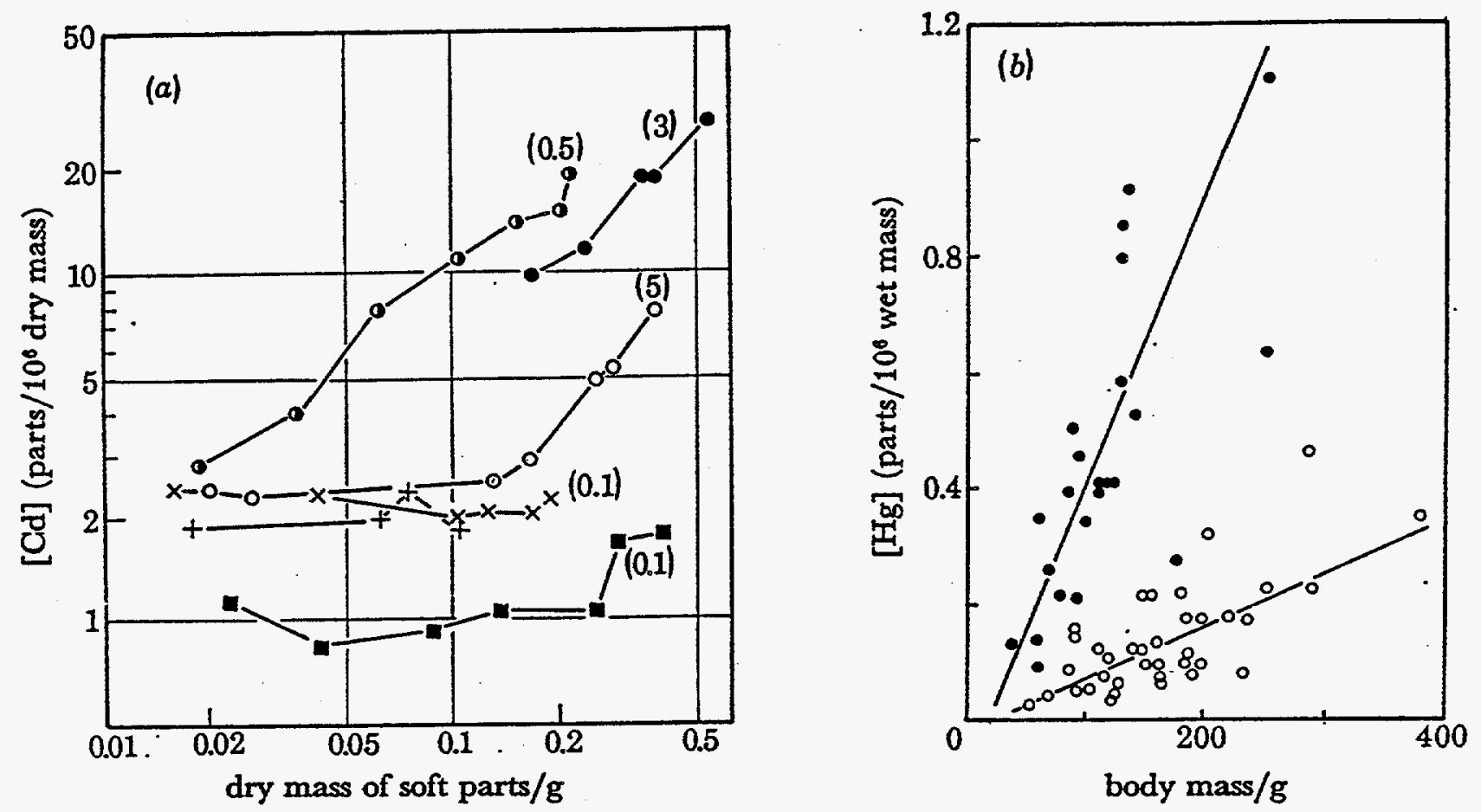

FIGURE 8.3. Relationship Between Body Mass and Concentrations of Cadmium in Tissues of the Clam, Scrobicularia plana, From Five British Estuaries (a) and Mercury in Muscle Tissue of the Cottid Fish, Myoxocephalus quadricornis From a Contaminated (Filled Circles) and Uncontaminated (Unfilled Circles) Area of the Baltic Sea. Numbers in parentheses in (a) are approximate concentrations of cadmium in sediments from which the clams were collected. From Bryan (1979). 


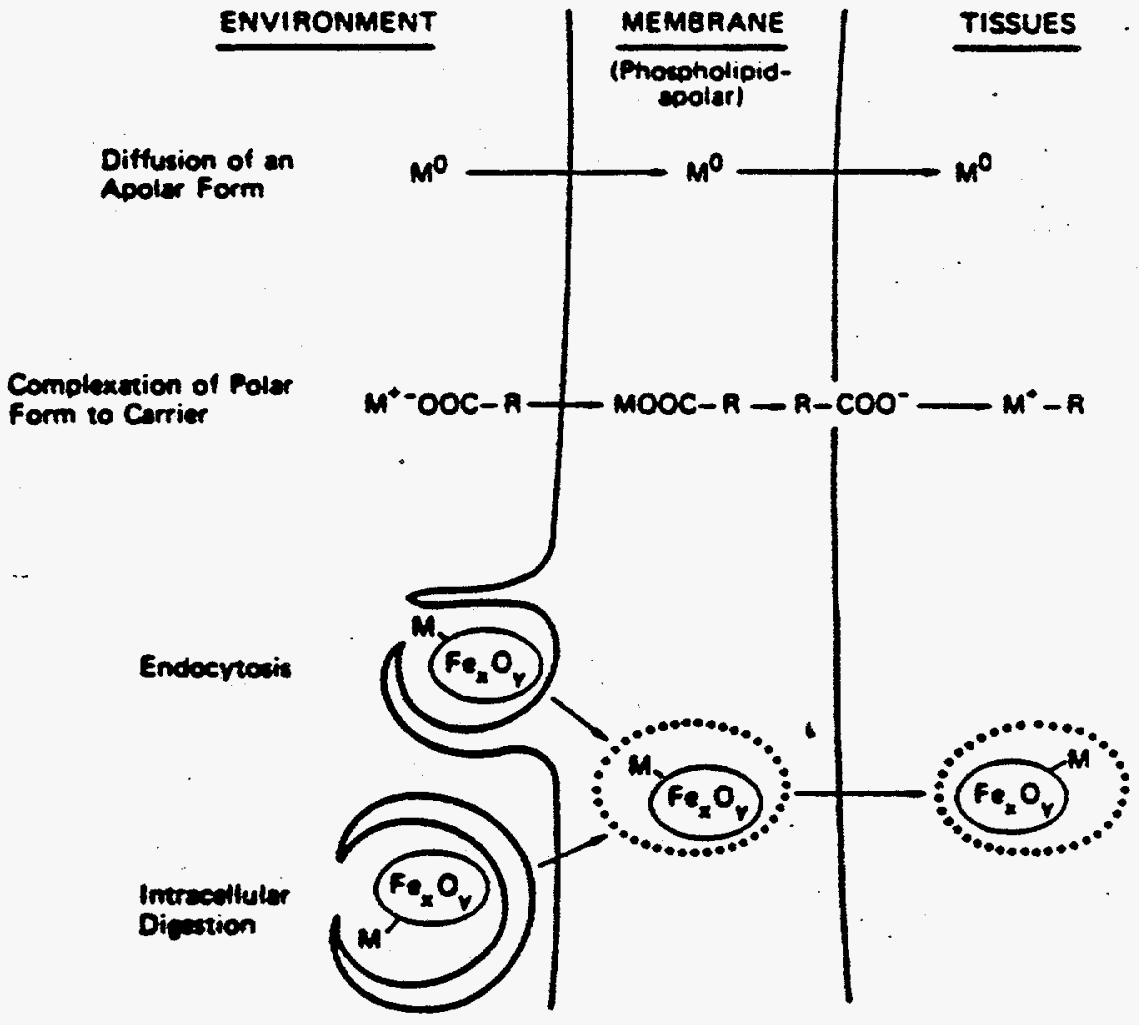

FIGURE 8.4. Simplified Schematic Representation of the Mechanisms of Uptake of Metals Through Membranes into Tissues of Marine Animals. From Luoma (1983). 

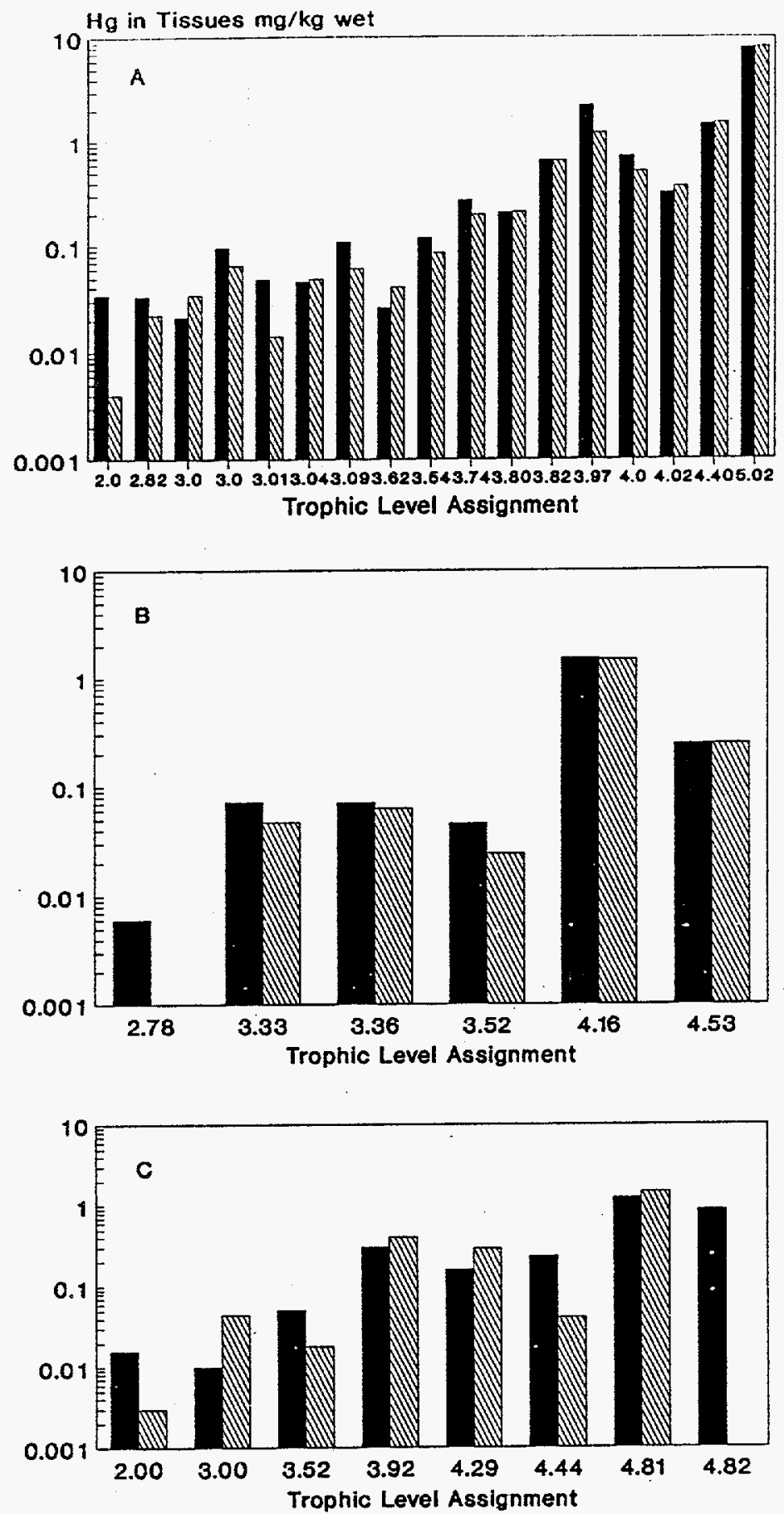

Total Mercury Organic Mercury

FIGURE 8.5. Concentrations of Total and Organic Mercury in Tissues of Marine Animals From Three Marine Food Webs of the Pacific: (a) the Coastal Pelagic Food Web of the Southern California Bight, (b) the Palos Verdes Shelf, California, Epibenthic Food Web, and (c) the Eastern Tropical Pacific Open Ocean Food Web. From Schafer et al. 1982). 

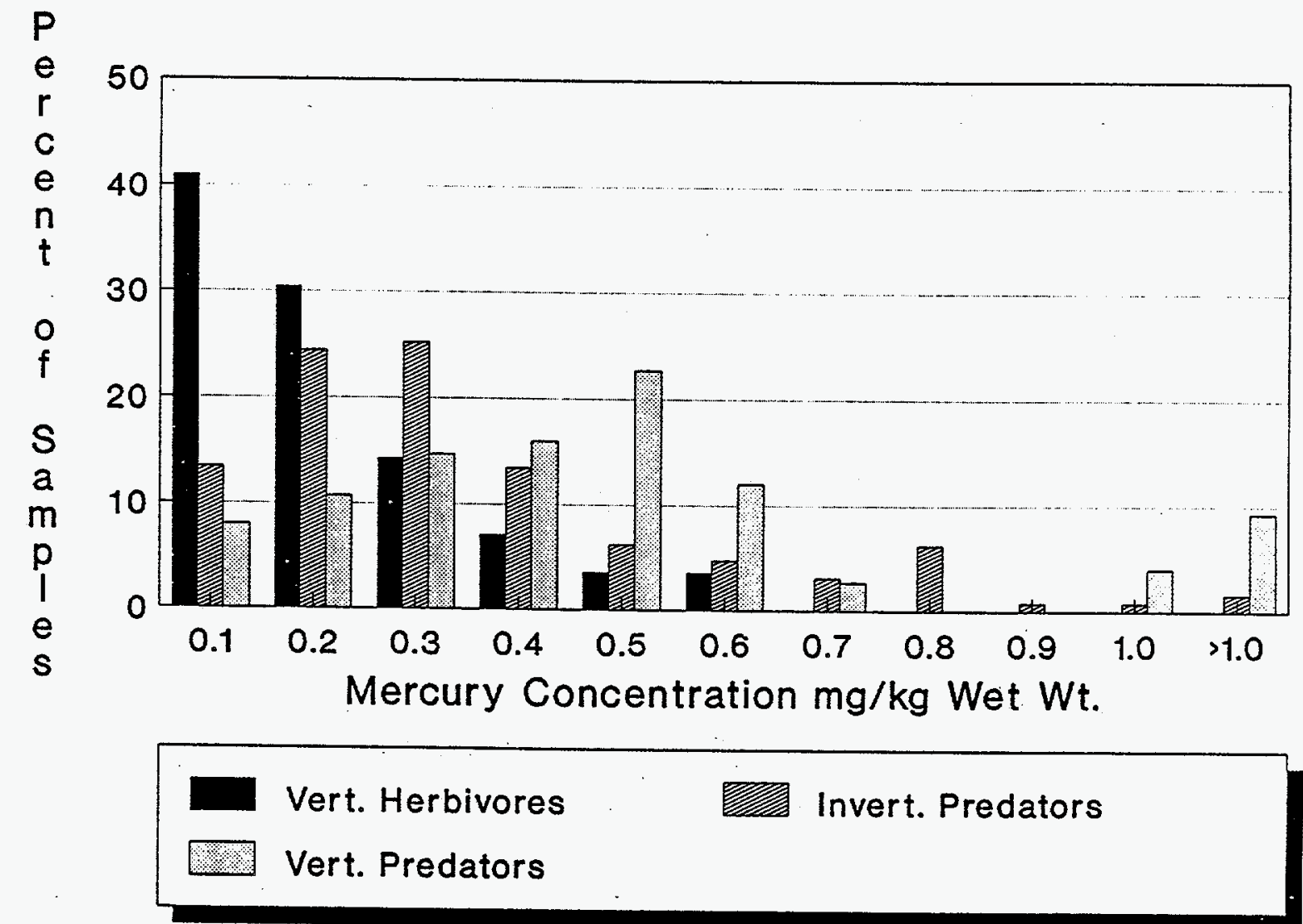

FIGURE 8.6. The Distribution of Total Mercury Concentrations in the Tissues of Major Consumer Groups of the Derwent Estuary, Australia, Food Web. From Ratkowsky et al. (1975). 


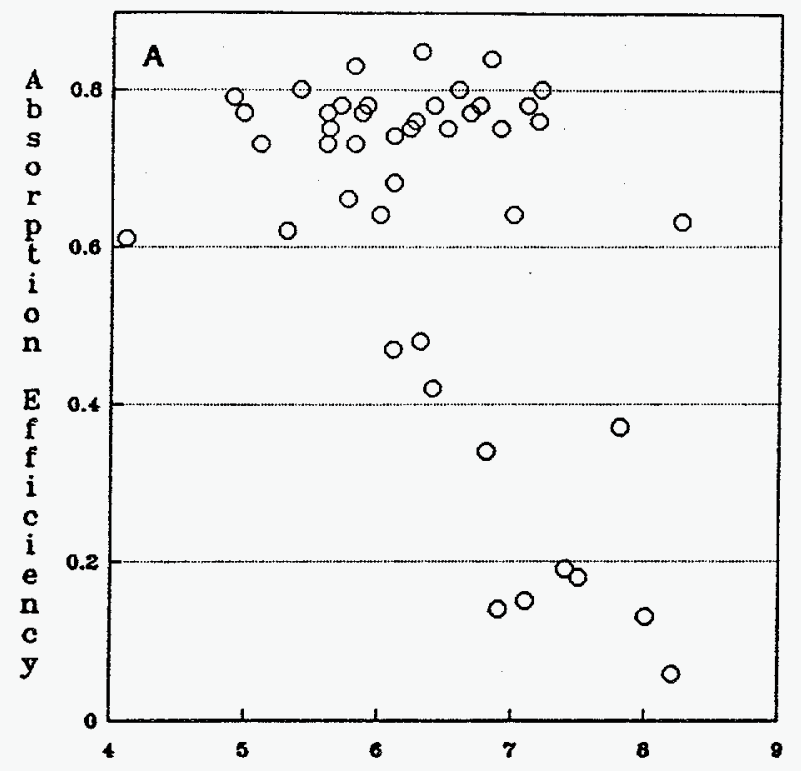

Log Kow
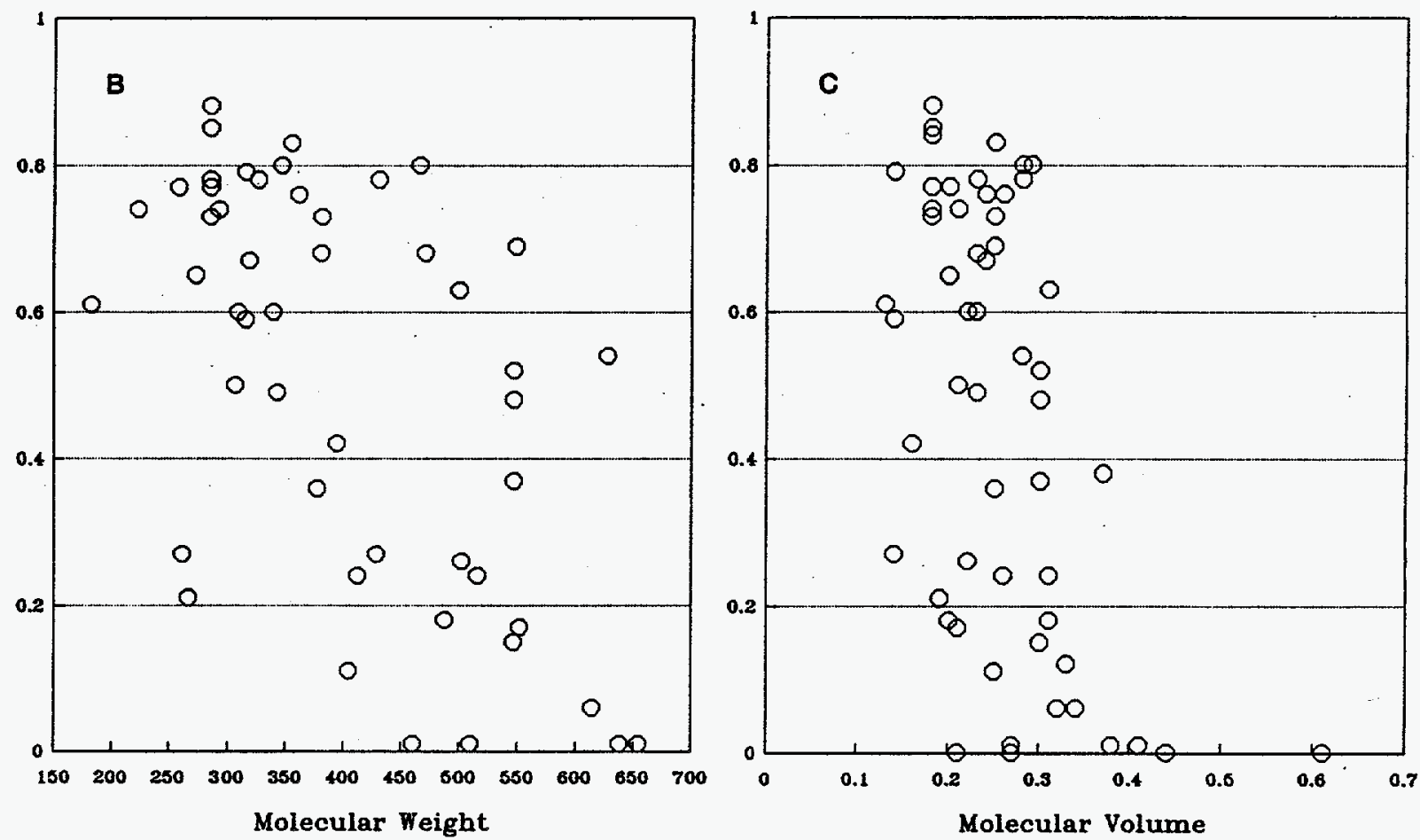

FIGURE 8.7. The Relationship Between Log $\mathrm{K}_{\mathrm{ow}}$ (a), Molecular Weight (b), and Molecular Volume, (c) of Nonpolar Organic Chemicals and the Efficiency of Absorption From the Gut of Salmonid Fish. From Gobas et al, 1988), Niimi and Oliver (1988), and Clark et al. (1990). 

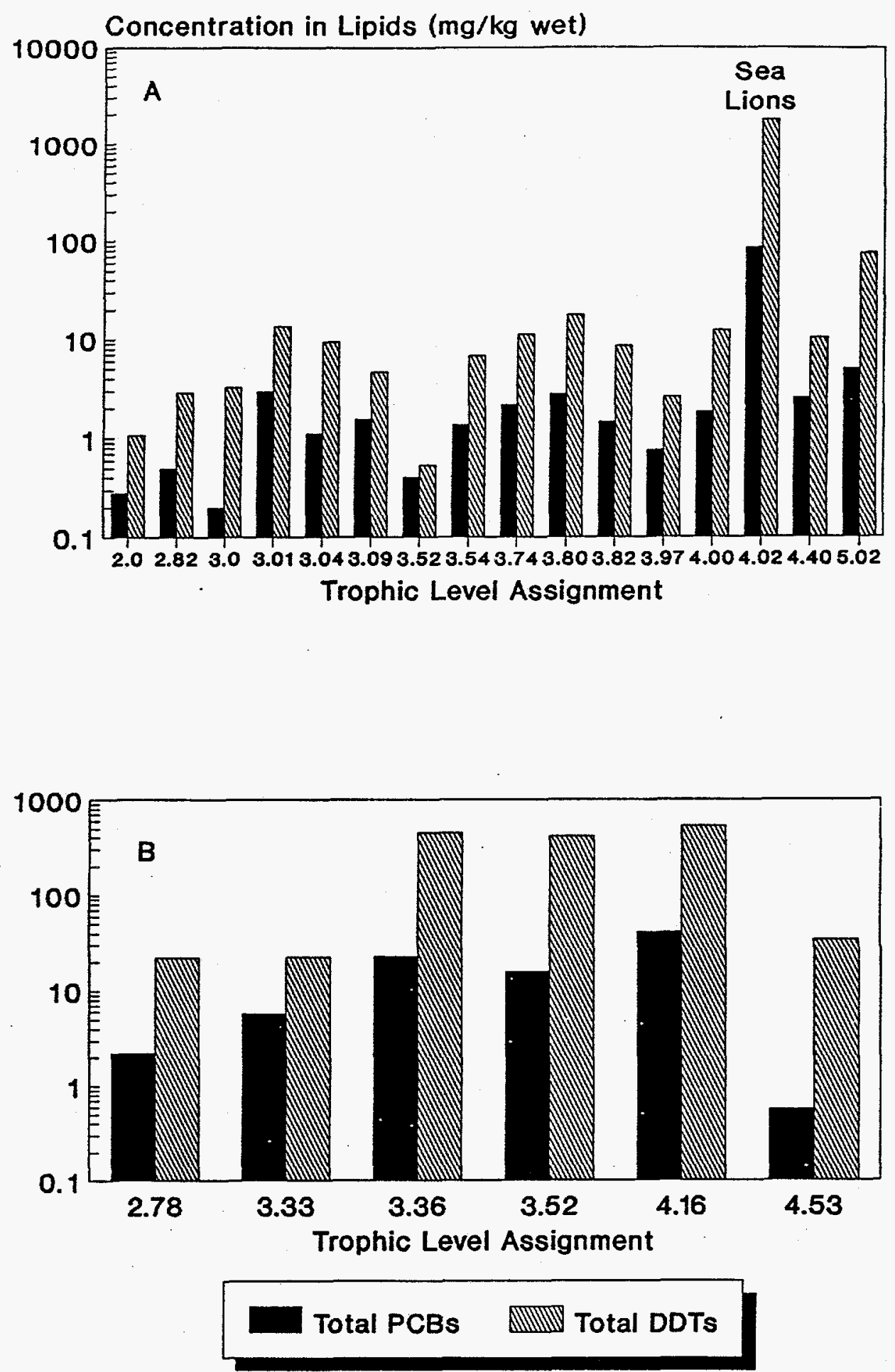

FIGURE 8.8. Concentrations of Total PCBs and DDTs in Lipids of Marine Animals at Different Trophic Levels in the Coastal Pelagic Food Web of the Southern California Bight (a) and the Palos Verdes Shelf, California, epibenthic Food Web (b). From Schafer et al. (1982). 

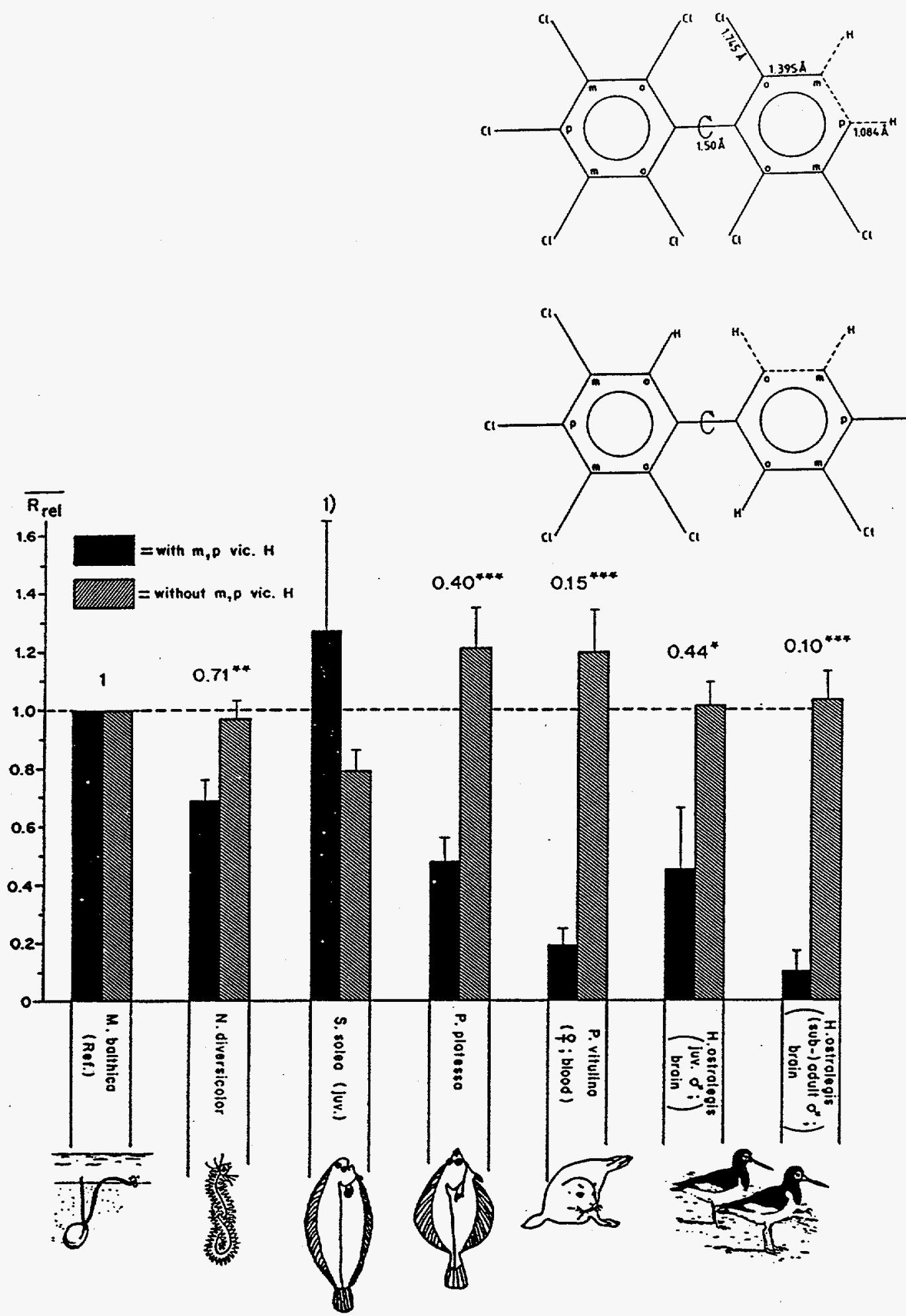

FIGURE 8.9. Mean Concentrations ( \pm SEM) Relative to the Concentrations in the Clam, Macoma balthica, or Group I and Group II PCB Congeners in a Simple Baltic Sea Food Chain. Group I Congeners (a) have vicinal H-Atoms in the meta, para Position; Group II Congeners (b) Have Vicinal $\mathrm{H}$-atoms in the ortho, meta Position. The Quotient of the Mean Relative Value of Group I and Group II Congeners and Their Levels of Significance are Given for Each Species. , $\mathrm{P}<0.05 ; * *, \mathrm{P}<0.01 ; * * *, \mathrm{P}<0.001$. From Boon et al. (1989). 


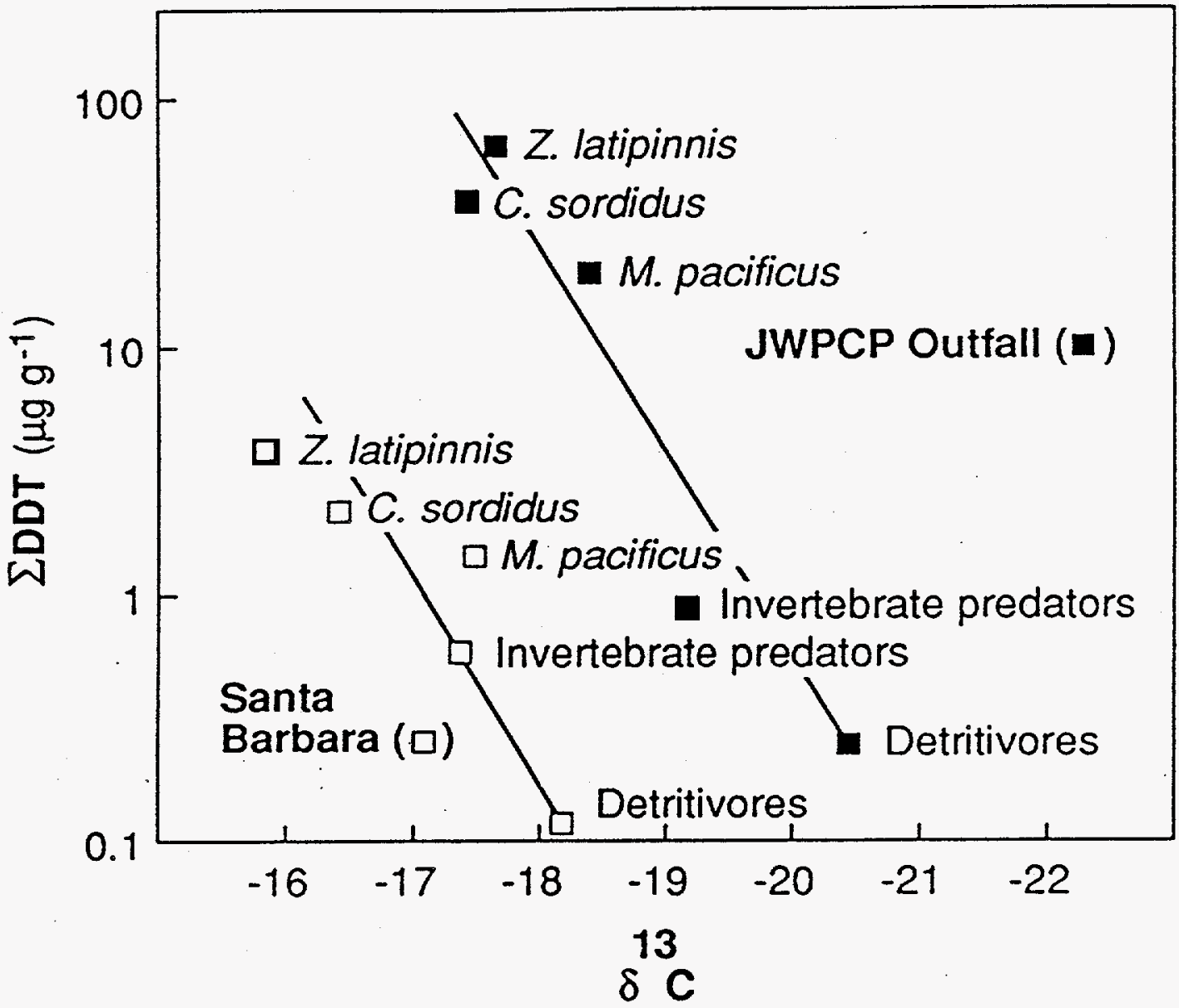

FIGURE 8.10. Relationship Between Trophic Level, as Indicated by $\delta^{13} \mathrm{C}$, and Mean Concentrations of Total DDTs in Tissues of Marine Animals From Food Chains Adjacent to the Santa Barbara Wastewater Treatment Plant Outfall and the Joint Water Pollution Control Plant (JWPCP: Lost Angles County) Outfall in the Southern California Bight. From Spies et al. (1989). 

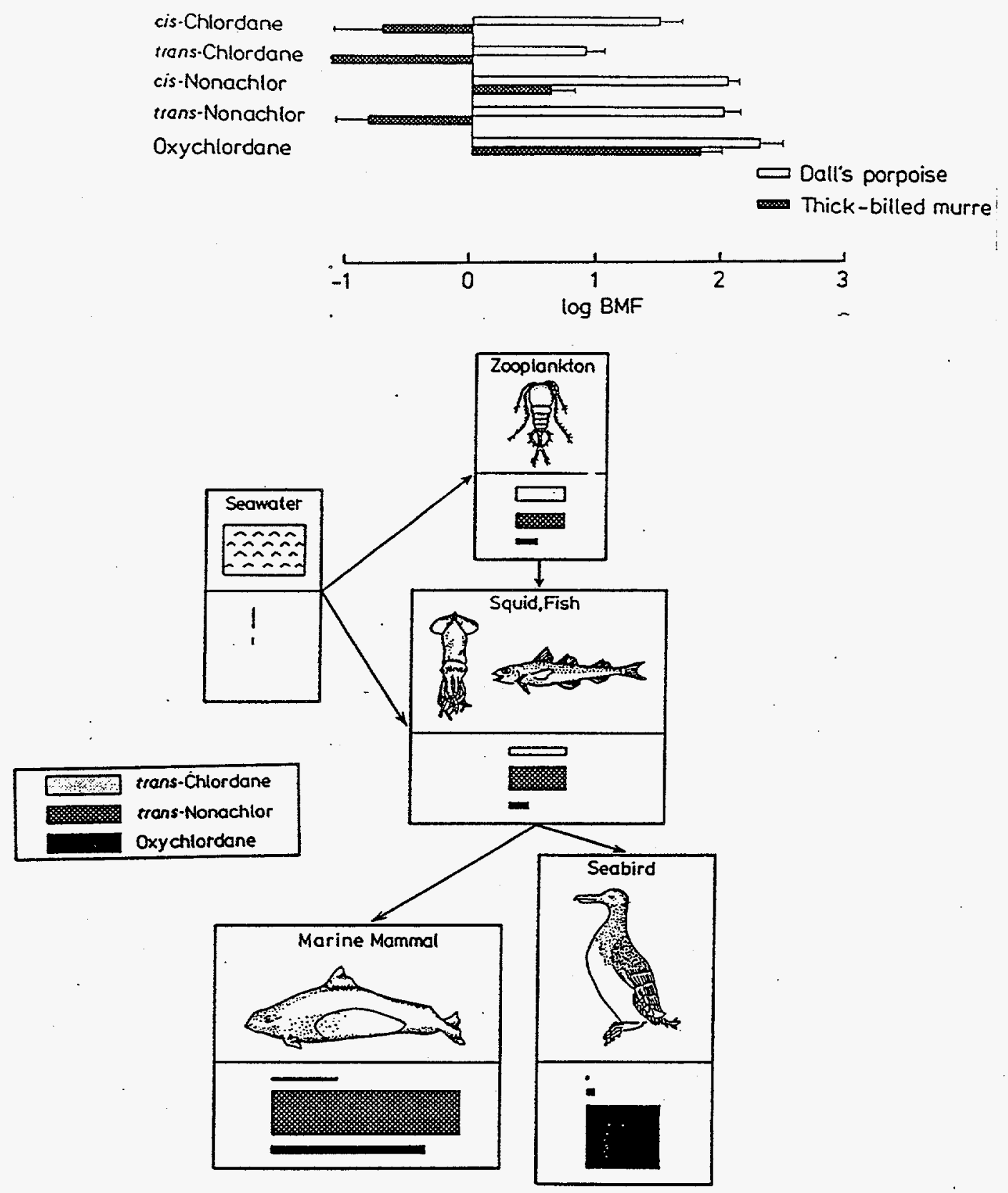

FIGURE 8.11. Biomagnification Factors (Concentrations in Predator/Concentration in Food) of Chlordane Isomers in Dall's Porpoise Phocoenoides dalli and Thick-Billed Murre Uria lomvia From the North Pacific Ocean and Bering Sea (a). Conceptual Diagram of the Distribution of Chlordanes in Different Compartments of a Marine Food Chain (b). The Width of the Bars Shows the Relative Abundance, the Length of the Bars Shows the Accumulation Capacities of the Different Animals in the Food Chain. From Kawano et al. (1988). 

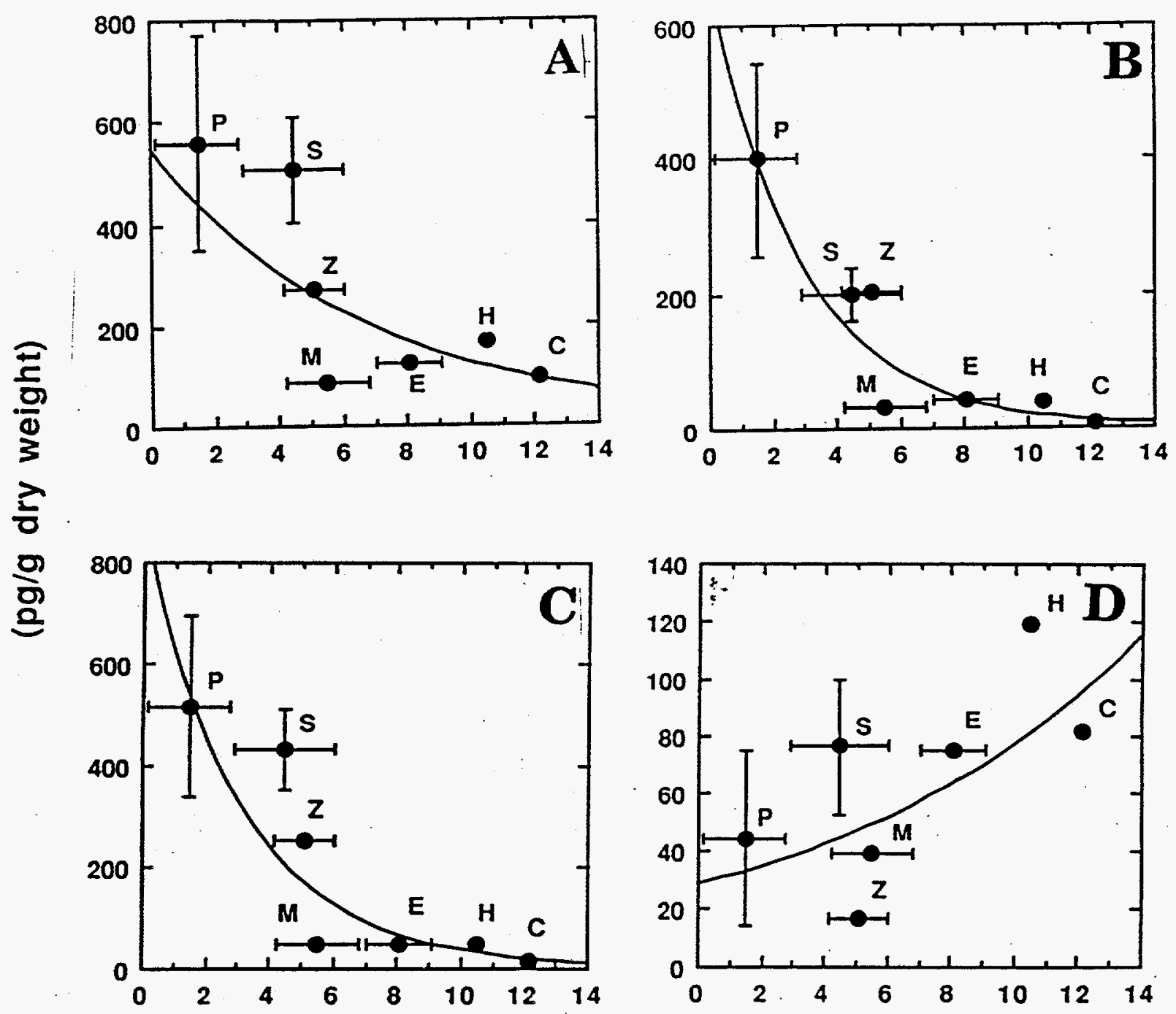

$\delta^{15} \mathrm{~N}$

FIGURE 8.12. Relationship Between Trophic Level, as Indicated by $\delta^{15} \mathrm{~N}$, and Concentrations of Polychlorinated Dibenzodioxins and Polychlorinated Dibenzofurans. (a) total 2378substituted PCDD/PCDFs; (b) Octachloro-dibenzodioxins/Dibenzofurans; (c) 2378Substituted PCDD/PCDFs With Chlorine Substitution in the 1,4 and/or 6,9 Positions; (d) 2378-Substituted PCDD/PCDFs With no Chlorine Substitution in the 1,4 and/or 6,9 Positions. P, Phytoplankton; S, Seston; Z, Zooplankton; M, Mussels; E, Eider Ducks; h, Herring; C, Cod. From Broman et al. (1992). 


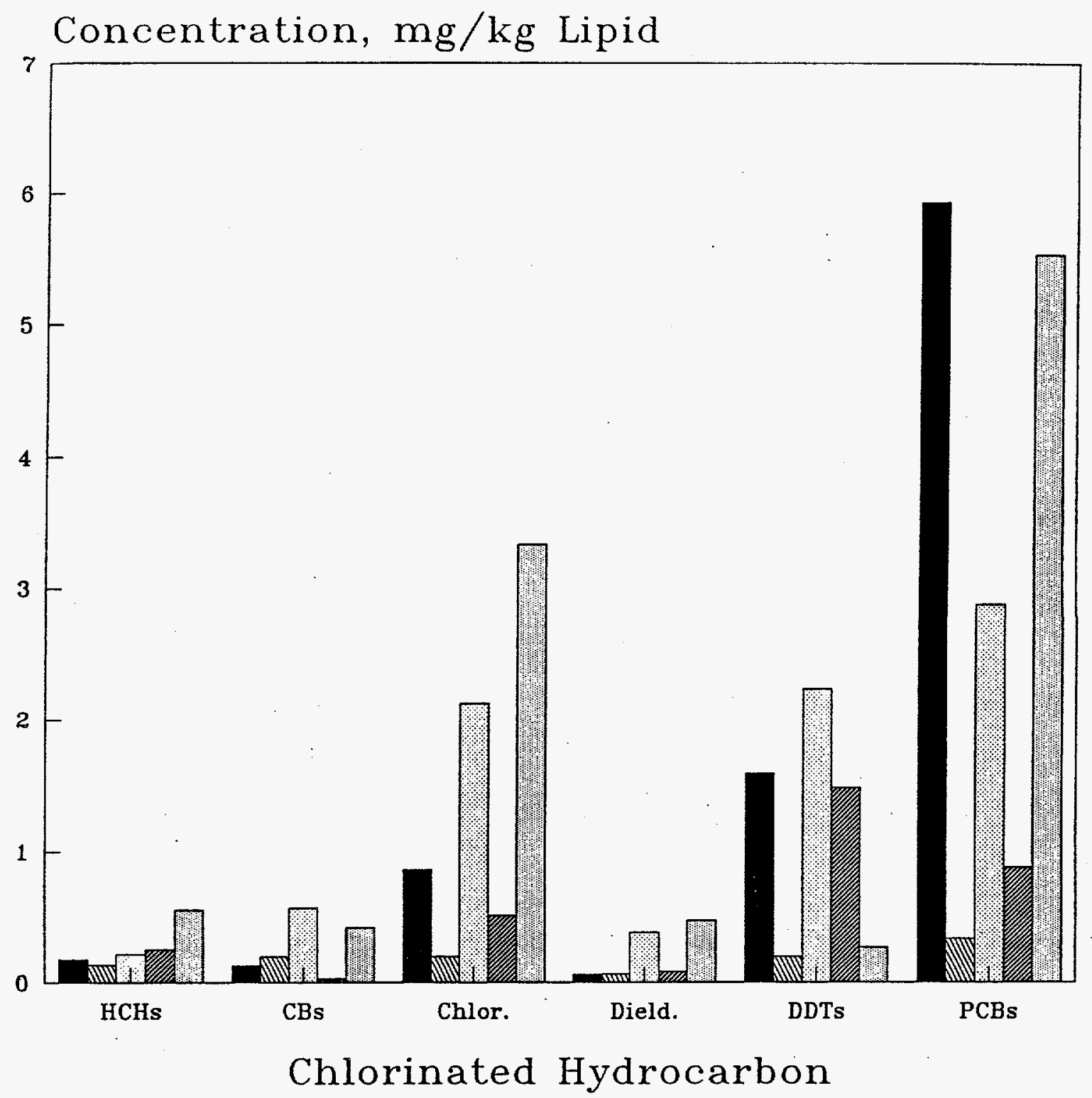

\begin{tabular}{lll}
\hline Amphipods & Arctic Cod \\
WIII & Seal & Peluga
\end{tabular}

FIGURE 8.13. Mean Concentrations of Several Chlorinated Hydrocarbons in the Tissues of Two Marine Animals and Three Marine Mammals from the Canadian Arctic. From Hargrave et al. (1992). 


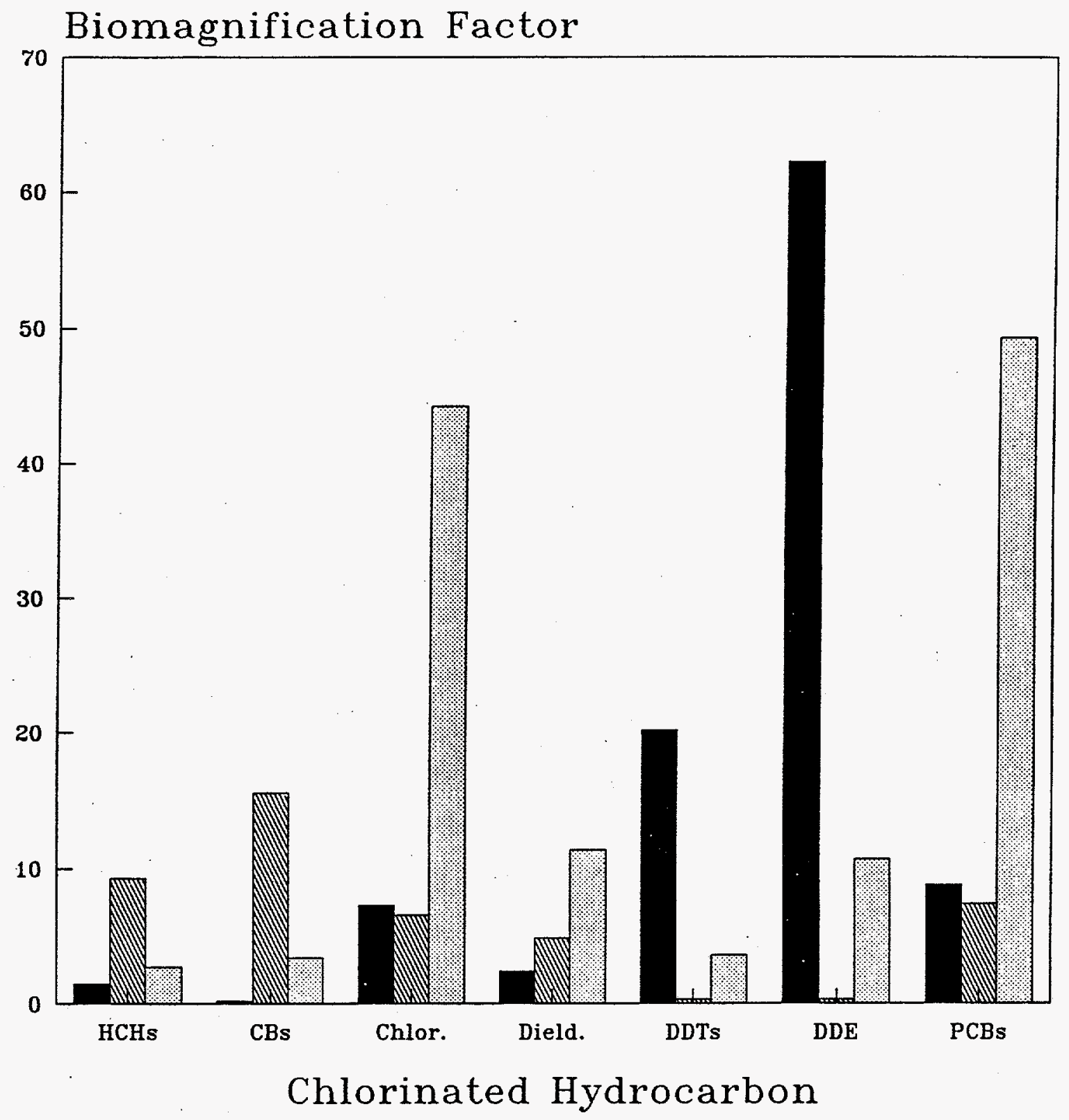

FIGURE 8.14. Mean Biomagnification Factors (Concentration in Predator Lipids/Concentration in Prey Lipids) of Several Chlorinated Hydrocarbons for Three Trophic Steps in a Canadian Arctic Marine Food Chain. From Muir et al. (1988). 


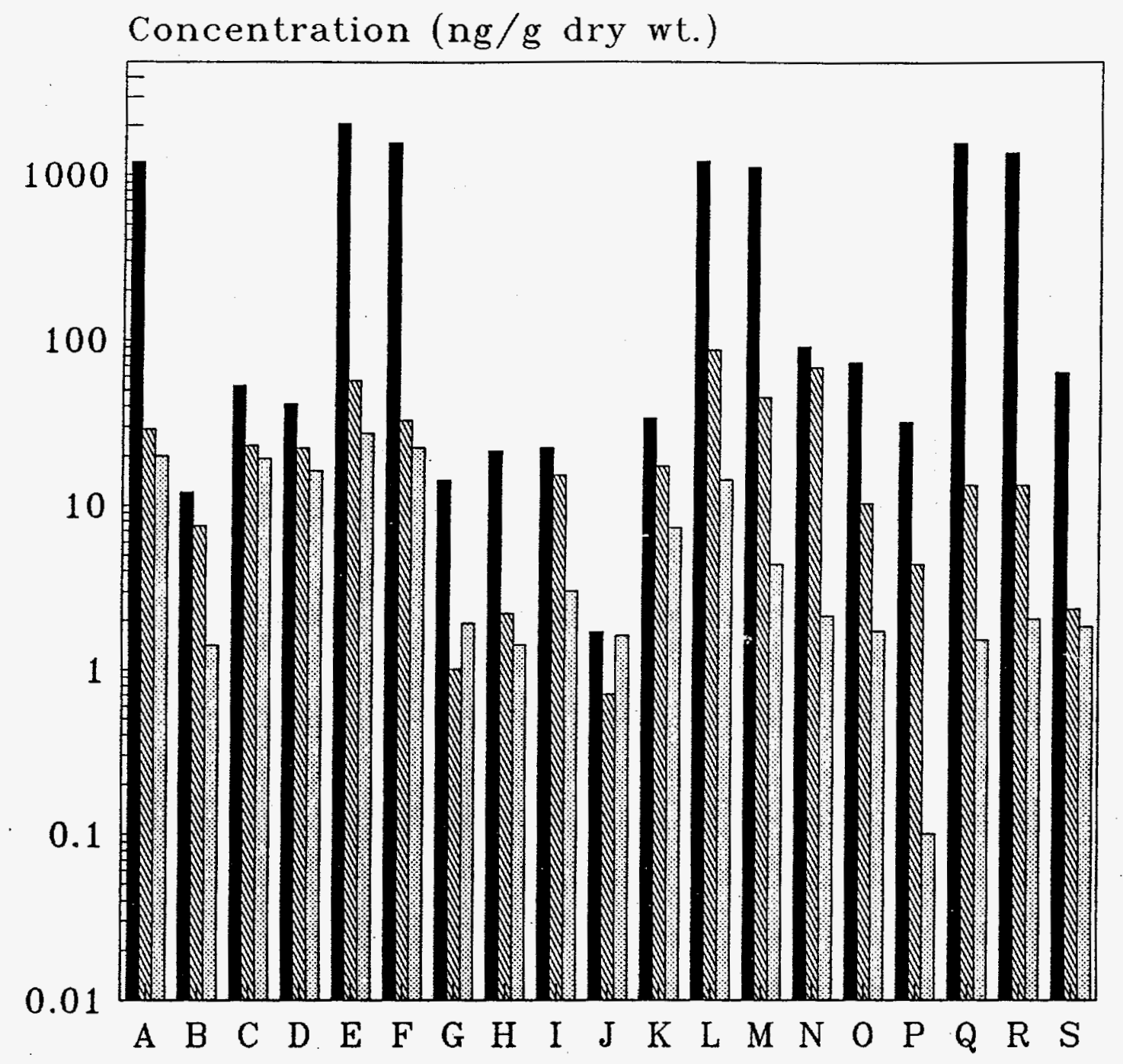

\section{Polycyclic Aromatic Hydrocarbon}

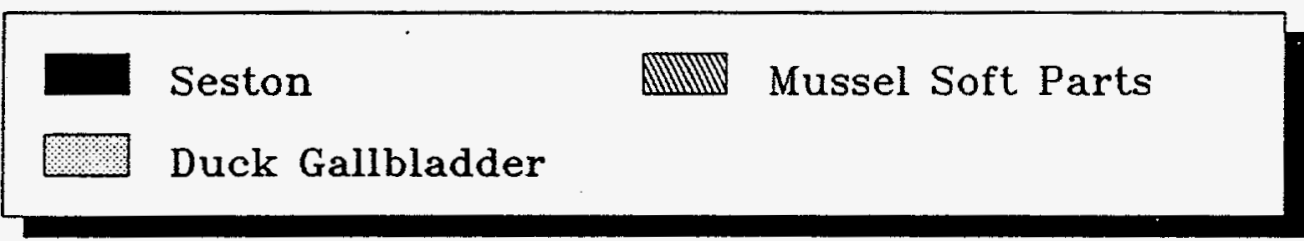

FIGURE 8.15. Mean Concentration of Several Polycyclic Aromatic Hydrocarbons in Three Components of a Simple Marine Food Chain From the Baltic Sea: Seston, Blue Mussel, and Eider Dick. A, phenanthrene; B, anthracene; C, 3-methylphenanthrene; D, 1-methylphenanthrene; E, fluoranthene; F, pyrene; G, 2-methylpyrene; H, 1methylpyrene; I, benzo(g,h,i)fluoranthene; J, cyclopenta(c,d)pyrene; $\mathrm{K}$, benzo(a)anthracene; $\mathrm{N}$, benzo(e)pyrene; $\mathrm{O}$, benzo(a)apyrene; $\mathrm{R}$, benzo( $\mathrm{g}, \mathrm{h}, \mathrm{i})$ perylene; S, coronene. From Browman et al. (1990). 


\subsection{SUMMARY AND CONCLUSIONS}

\subsection{INTRODUCTION}

For a long time, it was assumed by many scientists that chemical contaminants associated with marine and estuarine sediments are tightly bound to the sediment particles and making them practically inert biologically. The sediments serve as a sink for chemical contaminants that enter the marine environment from various sources. However, it has become increasingly evident in recent years that metal and organic contaminants in sediments may, under some conditions, desorb from the sediment particles into the sediment pore water and overlying water column. The desorbed chemicals may be present in the water in forms that are bioavailable and potentially toxic to marine plants and animals. Thus, the sediments are not only a sink, but also a source for chemical contaminants in the marine environment (Salomons et al. 1987).

A variety of physical/chemical properties of marine sediments and of chemical contaminants themselves influence the extent to which the contaminants in marine sediments desorb or change to forms that are bioavailable to marine plants and animals associated with the sediments. Benthic plants and animals vary widely in their ability to accumulate metal and organic compounds from sediments, due in part to species-specific differences in the nature and extent of the interface between sediment particles and pore water on one hand and living tissues on the other. Finally, contaminants can be exported from the sedimentary ecosystem by passive desorption from particles and dissolution in the overlying water column or by food chain transfer through benthic-feeding animals to higher trophic levels, including human consumers of fishery products.

In this review, we have discussed the physical/chemical properties of sediments (Chapter 2), chemical characteristics that affect the ability of the contaminants to be bioaccumulated (Chapters 3 and 4), and the aspects of the morphology, life styles, and feeding habits of benthic animals that affect their ability to accumulate contaminants from sediments (Chapter 5). We then reviewed the rapidly growing scientific literature on the bioaccumulation of metals (Chapter 6) and organic contaminants (Chapter 7) from marine sediments, and food chain transfer and biomagnification of contaminants from sediments to higher trophic levels in marine ecosystems (Chapter 8 ). This chapter provides a summary and integration of the earlier chapters. 


\subsection{THE BENTHIC ENVIRONMENT}

Several physical properties of sediments affect the presence and distribution in of both chemical contaminants and benthic plants and animals. The most important is sediment grain size or texture. Fine silt/clay sediments have a much larger surface area per unit mass and so are able to adsorb higher amounts of organic material and chemical contaminants than coarse sand/gravel sediments. Fine grained sediments usually contain higher concentrations of organic matter and often support a more abundant and diverse benthic fauna than coarse sediments. Many of the fauna in fine, organic-rich sediments are deposit-feeders that ingest sediments and remove living and dead organic particles and dissolved organic matter from it as a source of nutrition.

Sediment texture affects porosity and permeability, and as a general rule, there is a roughly inverse relationship between sediment grain size and porosity, the fraction of total sediment volume that is pore space. However, the porosity of clay sediments ranges from about $90 \%$ to $20 \%$, depending on the degree of compaction. As a rule, mixed-textured sediments composed of a range of sediment sizes, are less porous than well sorted sediments. Permeability increases with increasing sediment grain size. Clays, although they have high porosities, often have low permeabilities because of inhibition of water movement through the fine pore spaces by friction, sorption, and capillary forces.

Sediment porosity and permeability affect the rates of adsorption/desorption reactions of metal and organic contaminants in sediments. They also affect the rate of exchange of chemicals between pore water and overlying water. More important, permeable sediments usually remain oxidized to a greater depth than impermeable sediments, affecting many of the chemical reactions that control mobility of chemical contaminants in sediments, and favoring habitation by the larger, more diverse obligate aerobic fauna.

A variety of biotic and abiotic chemical reactions in sediments alter the chemical forms and phase associations (particulate, colloidal, or dissolved) of many inorganic and organic constituents of sediments. These chemical reactions include a variety of oxidation and reduction reactions that change the chemical species of inorganic compounds and mineralize organic matter to varying degrees, leading to release of inorganic nutrients. These reactions change the oxidation-reduction (redox) potential of the sediment, often leading to precipitation or dissolution of various mineral phases in the sediments. For example, oxidation of titanium, vanadium, and chromium increases 
their aqueous solubilities. However, reduction of manganese, iron, cobalt, nickel, and copper increases their aqueous solubilities.

The most important of these oxidation-reduction reactions involve iron and manganese. Iron and manganese hydrous oxides form colloidal precipitates in estuarine and marine waters and are deposited as coatings on suspended inorganic particles, particularly clays. These iron and manganese oxide coatings on particles have a high affinity for binding dissolved organic compounds and divalent metal ions in the water, forming labile contaminant/particle complexes. When iron and manganese hydrous oxide particles or coatings encounter reducing conditions in sediments, organic matter is oxidized and the the hydrous oxide particles are reduced and go into solution, releasing any adsorbed organic compounds or metal ions into the pore water. The released metals and organic contaminants may migrate upward to oxidized layers of the sediment where they would be available for bioaccumulation by aerobic benthic fauna.

The other major chemical reaction in marine sediments is the reduction of sulfur. Under oxygen-poor reducing conditions, inorganic sulfur in sediments is reduced to sulfide in microbiallymediated reactions involving the oxidation of organic matter. Several metals in sediments form stable, extremely insoluble metal sulfides under reducing conditions in the sediments.

Most of the oxidation/reduction reactions in marine sediments are mediated by bacteria, fungi, and protists. Organic matter accumulating from the water column in oxidized surficial sediments is oxidized by sediment microbes, and to a lesser extent by meiofauna and macrofauna, resulting in a decrease in the concentration of oxygen in the sediments. When oxygen in the sediment is depleted, sulfate-reducing bacteria take over and continue oxidizing organic matter, producing a variety of reduced sulfur species. In a generally well-mixed marine ecosystem, the depth in the sediment of the redox potential discontinuity (where oxygen is replaced by sulfate as the reducible substrate for oxidation of organic matter) depends on the quantity and quality of oxidizable organic substrates in the sediment, and the activities of any resident macroinfauna. All the oxidation/reduction reactions in oxidized and reduced sediment layers, except oxidation of organic matter, are fully reversible.

Benthic animals both affect and are affected by the porosity, permeability, and chemistry of sediments. Benthic organisms modify the physical and chemical properties of sediments by feeding on and pelletizing sediment particles, burrowing, excavation, biodeposition, tube-building, and fluid transport. Many feeding behaviors of benthic and demersal animals result in sorting and aeration of sediment layers. Selective deposit-feeders, some of which feed at depth and defecate on the surface 
and others of which feed at the surface and defecate at depth, change the texture of the surface and deep deposits. Because most deposit-feeders selectively ingest the finer, organic-rich particles in the sediments, their fecal pellets usually are composed of finer particles than the average for the sediments upon which they are feeding.

During passage of sediment particles through the gut of a deposit-feeder, the quality and quantity of sediment organic matter changes. Fecal pellets often consist of sediment particles bound together with mucus. They may be depleted of many of the labile organic compounds found in the sediment and enriched in microbial organic carbon. Some fecal pellets are refractory to further biodegradation; others have a higher food quality than the original sediment. Some benthic fauna selectively feed on the fecal pellets produced by other species.

Suspension-feeding benthic animals, although they collect their food from the water column or the sediment/water interface, also modify the physical and chemical properties of the sediments in which they reside. Suspension-feeders convert living and dead organic particles in the water column into fecal pellets and pseudofeces on the sediment surface or in surficial sediment layers. Many suspension-feeders produce water currents that carry oxygenated water containing nutrients and suspended particles over the sediment/water interface and down into tubes or burrows. These water currents may substantially increase the rate of exchange or flushing between sediment pore water and the overlying water column. Mucus net and string feeders bind sediment particles together and move particles from the surface flocculent layer into the sediment column.

The burrows and tubes of infauna allow convective mixing of oxygenated water at depth in sediments and so usually cause the redox potential discontinuity to move deeper in the sediment column. This process is aided by active irrigation of the tubes or burrows by the resident infaunal invertebrates. Tubes and mucus-lined burrows also tend to bind and stabilize sediments.

Feeding excavations of many large benthic-feeding animals, such as crustaceans (e.g., fiddler crabs, lobsters, and ghost shrimp), fish (e.g., tile fish, mullet, and many flatfish), and marine mammals (e.g., gray whales, walruses, and sea otters) mix and aerate the upper layers of the sediment. Benthic and epibenthic predators and detritivores often mix and resuspend surficial sediments while seeking preferred foods. In a diverse, productive shallow marine or estuarine ecosystem, the upper twenty or so centimeters of sediment may be turned over several times each year by the activities of infaunal burrowers and epifaunal excavators. This sediment mixing increases the depth of the redox potential discontinuity in the sediment column and may increase the rate of flux 
of chemical contaminants to or from the sediments, depending on the forms and concentrations of the chemicals in the sediments and overlying water column.

Most benthic fauna have a fairly narrow preferred range of sediment texture and organic carbon content. Deposit-feeders, in particular, require specific combinations of sediment texture (fine grained sediments usually are preferred) and sediment organic carbon concentration (usually a few percent). Most benthic fauna, particularly macrofauna, also have specific requirements for oxygen, and many have a very limited tolerance of hydrogen sulfide. Meiofauna seen to be more eurytolerant and many are facultative or even obligate anaerobes. The most diverse marine benthic macrofaunal communities are found in fine, mixed-texture sediments where organic carbon concentrations are not too high, oxygen is abundant, and reducing conditions with elevated concentrations of hydrogen sulfide are deep in the sediments (Pearson and Rosenthal 1978). Benthic communities may be dominated or made up entirely by vast numbers of one or a few opportunistic species, such as the polychaete, Capitella capitata, where sediment organic carbon concentrations are high and the redox potential discontinuity is near or at the sediment surface.

\subsection{BINDING OF CONTAMINANTS TO SEDIMENTS}

\subsubsection{Metals}

A large fraction of most of the metals of environmental concern in sediments is part of the mineral matrix of the sediment particles and is not bioavailable. The remaining fractions of metals in oxidized fine-grained sediments may be bioavailable, depending on physical, chemical, and biological conditions in the sediment column. Potentially exchangeable and bioavailable metals in oxidized sediments are adsorbed to or complexed with hydrous oxides of iron, aluminum, and manganese, clay minerals, carbonates, and organic matter. The dominant associations vary for different metals. For example, chromium, copper, and mercury have a strong affinity for sorption to organic phases of oxidized sediments. Cadmium, lead, nickel, silver, zinc, and selenium are preferentially sorbed to iron and manganese hydrous oxides. Arsenate may be coprecipitated with hydrous iron and manganese oxide fractions.

In anoxic marine sediments, most metals are present as immobile metal sulfides. Chromium does not form sulfides and remains associated with sediment organic matter. However, under highly reducing conditions in the presence of high concentrations of sulfides, cadmium, copper, lead, mercury, and zinc may form soluble complexes with bisultides, polysulfides, and organic thiols.

\section{5}


These soluble sulfides may diffuse upward and precipitate as insoluble sulfides in less reduced sediment layers or sorb to iron and manganese oxides and organic matter in oxidized layers.

From an environmental perspective, the most important forms of metals in sediments are those that are directly bioavailable to benthic organisms and those that can readily be transformed by natural abiotic and biological processes in sediments to bioavailable forms. The complexity of metal/solid interactions in oxidized surficial sediments precludes direct measurement of the distribution of metals among different adsorbed and solid phases. Sequential extrac.ion and leaching schemes have been used extensively to partially characterize the phase associations of metals in marine sediments and to identify the fraction of the total metal that is or could become bioavailable. Although no single extraction can adequately describe the bioavailable fraction of metals in sediments, dilute hydrochloric or nitric acid is the most widely accepted extractant for the "bioavailable fraction" of metals in sediment.

The most important diagenic reactions resulting in dissolution and mobilization of metals in marine sediments are: reductive dissolution of hydrous iron and manganese oxides; biological oxidation and degradation of sediment organic matter; formation of metal polysulfides or oxidation of recently-precipitated metal sulfides; and biomethylation of certain metals (mercury, arsenic, and selenium). In addition, oxidation of complex organic compounds in sediments produces a variety of soluble low molecular weight organic compounds, some of which form stable, soluble complexes with metal ions. The dissolved organic matter in sediment pore water may bind a large fraction of the total labile metals in the sediment. These soluble metal complexes are readily released to the overlying water column by sediment flushing and bioturbation.

\subsubsection{Organic Chemicals}

Organic contaminants in sediments can be divided into two classes, depending on their binding properties: nonpolar (unionizable), and polar (ionizable). Nonpolar organic compounds generally have low aqueous solubilities and high affinities for sorption to phase boundaries, such as sediment particles, and poorly soluble organic phases. Because of the strong affinity of dissolved, nonpolar organic chemicals for solid or liquid organic phases, they have a strong tendency to partition out of the water and sorb to any available organic phase, such as tissues of marine organisms, organic coatings on sediment particles, and organic particles. The avidity with which a nonpolar organic compound sorbs to sediment organic matter is defined by the sediment organic carbon/water partition 
coefficient, $\mathrm{K}_{\mathrm{x}}$, the ratio of the amount of the chemical sorbed per unit mass of the organic phase of sediment to the amount of the chemical in solution per unit mass of water at equilibrium.

The value of $\mathrm{K}_{\infty}$ for a particular nonpolar organic chemical is directly proportional to the aqueous solubility and octanol/water partition coefficient $\left(\mathrm{K}_{\text {ow }}\right)$ for that chemical. The octanol/water partition coefficient also is a good predictor, under some circumstances, of the tendency of an organic chemical to bioaccumulate in the tissues of a marine organism. Therefore, if aqueous solubility, $\mathrm{K}_{\mathrm{oc}}$, or $\mathrm{K}_{\mathrm{ow}}$ for a chemical is known or determined empirically, it should be possible to predict the distribution of the chemical at equilibrium among the solid organic carbon fraction of sediment, solution in sediment pore water, and the tissues of marine organisms living in close association with the sediments. However, several factors affect the accuracy and precision of such extrapolations. These factors include: the wide range of published values for $\mathrm{K}_{\mathrm{ow}}$ and aqueous solubility for nonpolar organic chemicals of environmental concern; variation in the avidity of binding of nonpolar organic chemicals to different forms of sediment organic matter; uncertainty about the amount of time required for chemicals to reach a true equilibrium distribution between dissolved and sorbed phases; irreversible binding or very slow desorption of chemicals from some types of sediment organic matter; complexation of the dissolved chemical with dissolved or colloidal organic matter; and the abundance, size, and chemical composition of the sediment particles. Nevertheless, equilibrium partitioning theory gives a good first approximation of the distribution of nonpolar organic compounds among phases in most marine sediments.

Sorption of ionizable compounds to marine sediments is more complex than sorption of nonpolar organic compounds. Most ionizable organic compounds of environmental concern, such as phenols and detergents, contain both polar and nonpolar portions. At values of $\mathrm{pH}$ below the $\mathrm{pK}_{\mathrm{a}}$ of the ionizable group(s), the compound is present in the aqueous phase primarily as the neutral species and partitions in a manner similar to a nonpolar organic compound. At $\mathrm{pH}$ values greater than the $\mathrm{pK}_{\mathrm{a}}$, the ionized form of the chemical is present in variable amounts depending on the difference between $\mathrm{pH}$ and $\mathrm{pK}_{\mathrm{a}}$. Under these conditions, the chemical may bind to sediment particles by ion exchange, ligand exchange, and formation of ion pairs or ion complexes, in addition to hydrophobic interactions. 


\subsection{BIOACCUMULATION AND BIOMAGNIFICATION OF CONTAMINANTS FROM SEDIMENTS}

\subsubsection{Bioavailability and Bioaccumulation}

A fraction of the metal and organic contaminants in sediments may be present in forms that are bioavailable to marine plants and animals that live or feed in close association with the sediments. A chemical is bioavailable if it can interact chemically with or penetrate biological membranes of organisms. Bioavailable chemicals may bioaccumulate in the tissues of benthic marine animals if their rate of influx is greater than their rate of loss from the tissues of the organism. The routes of bioaccumulation of sediment-associated chemicals by benthic marine animals are the general external body surface, especially permeable epithelia such as gills, and the digestive tract. Most bioavailable forms of chemical contaminants in marine sediments and pore water can be accumulated both directly from the ambient medium across permeable outer body surfaces and from the food through the gut epithelium. The relative importance of the ambient medium (water and sediment) and food as sources of chemical contaminants in the tissues of marine animals depends on the physical/chemical properties and forms of the chemicals themselves, environmental conditions during uptake, the relative concentrations of the chemicals in water, sediment, and food, and the anatomy, life style, and feeding behavior of the animals.

It is generally thought that sediment-bound chemicals must desorb from the particulate phase and go into solution in the pore water before they can be accumulated by benthic marine animals. However, it is possible that some chemicals, particularly nonpolar organic chemicals, may partition directly from the sediment organic carbon phase to the tissue membrane lipid phase.

\subsubsection{Metals}

Metals may move across the membranes of gills, gut, or general body surface by at least four mechanisms: carrier-mediated transport or facilitated diffusion across the membrane; passive diffusion of nonpolar forms of the metal; endocytosis; and intracellular digestion. Dissolved metal ions or ion complexes are polar and move across biological membranes by passive diffusion, facilitated in some cases, particularly for the 15 or 16 essential trace nutrient metals, by specific carrier molecules. Metal ion/organic complexes and many organometallic compounds are relatively nonpolar and readily partition across lipid bilayer membranes. For this reason, organic compounds of some metals, such as methylmercury, arsenobetaine, cobalamine, and selanomethionine, are bioaccumulated more rapidly than the inorganic, ionic forms of the metals by most marine organisms. 
In intracellular digestion and endocytosis, epithelial cells of the gills, some other tissues, and particularly the gut of marine invertebrates ingest particulate metals by pinocytosis or phagocytosis. The particulate metals usually are retained in vacuoles and do not actually enter the interior of the cells. However, the metal-containing vacuoles may be transported throughout the body and may be sequestered in certain storage tissues, often in the kidneys or digestive glands.

Many physical, chemical, and biological factors affect the bioavailability of sediment-bound metals to benthic marine animals. The most important physical/chemical factor is the $\mathrm{r}$ slative abundance of major binding sites on sediment particles. As discussed above, the most important sorption/complexation substrates for most metals are hydrous iron and manganese oxides, organic matter, and sulfide. As the relative concentrations of each of these binding substrates increase, the fraction of total metal in sediment that is bioavailable decreases. Several environmental factors, such as salinity, sediment grain size, and sediment redox potential, affect bioavailability indirectly by affecting binding of metals to the three major binding phases. Biological factors, such as age, size, sex, and biochemical composition of tissues of benthic marine animals also affect the rates of uptake and release, and capacity of the animals to accumulate metals from sediments. However, the relationships are not clear-cut or well understood.

There are large interspecies differences in the rate and magnitude of bioaccumulation of metals from sediments. These differences are related to feeding methods and food types, and morphological differences in the nature and extent of direct exposure of permeable epithelia to sediments and pore waters. As a general rule, deposit-feeders accumulate more metals from sediments than suspension-feeders or predators. However, much of the metals in deposit-feeders may be present in unassimilated forms in the gut contents or in phagocytotic vacuoles in gut epithelia or kidneys.

Empirically determined transfer factors (concentration in animal tissues/concentration in sediments) for most metals and most benthic invertebrates are less than one. There are a few notable exceptions, such as uptake of mercury (possibly present in sediments as methylmercury) and silver in calcitic sediments by deposit-feeding bivalves.

Uptake and release of some of the essential micronutrient metals are regulated by marine animals. Other metals are detoxified and either stored in an inert form or excreted. Metallothionein and related low molecular weight metal binding proteins may bind metals that enter cells, preventing the metals from binding to essential cellular macromolecules, such as enzymes and DNA. The metal- 
binding proteins also are thought to aid in the active excretion of accumulated metals. In addition, many invertebrates detoxify metals by incorporating them as insoluble concretions in vacuoles.

Metal-containing vacuoles may be sequestered in various storage tissues more or less permanently or they may be excreted. Accumulated metals also may be excreted passively through permeable body surfaces, such as the gills and gut epithelia.

The ability of benthic marine invertebrates and demersal fish to accumulate metals from their food also varies widely. The efficiency of trophic transfer of metals in laboratory studies seen.s to depend on several chemical and biological factors. Absorption efficiencies of metals from the gut vary widely in different marine taxa and for different metals. Metal uptake via the gut generally is more efficient in fish than in invertebrates. The type of food and the chemical form of the metal in the food also are important. Organometallic compounds, such as arsenobetaine, methylmercury, and selanomethionine, are absorbed more efficiently than the corresponding inorganic metal species. As a general rule, soft-bodied marine invertebrates obtain most of their body burdens of metals from the water or sediment, not from food. However, most fish obtain more metals from food than from water or sediments.

All metals except methylmercury tend to build down in natural marine food webs (concentration decreases at higher trophic levels) or show no relationship to trophic level. The lack of biomagnification of inorganic metals in marine food webs is attributed to incomplete absorption of metals across the gut, rapid excretion, and dilution in muscle, which represents a large part of the total body weight of most marine animals. Organo-mercury compounds may biomagnify to a limited extent in marine food webs, probably because of the more efficient absorption, stronger binding to tissue macromolecules, and slower excretion of organic than inorganic forms of mercury. Selective uptake and food chain transfer of organic over inorganic mercury may explain the observation that the fraction of total mercury in tissues that is organo-mercury tends to increase at higher trophic levels.

Some air-breathing marine animals, such as marine birds and mammals, that obtain most of their body burdens of metals from their food, may contain high concentrations of the metals. This may be due to the slower rate of excretion of metals by air-breathing than by water-breathing animals.

\subsubsection{Organic Compounds}

Most of the organic chemicals of major environmental concern are nonpolar at the $\mathrm{pH}$ and salinity of seawater. Bioaccumulation of nonpolar organic chemicals from water, sediments, and food 
is a physico-chemical partitioning process between the organism's body fat and body water. Organic chemicals will tend to distribute themselves by diffusion between water and tissue lipid phases according to their relative solubilities in the two phases. This distribution is described reasonably well by the octanol/water partition coefficient $\left(\mathrm{K}_{\mathrm{ow}}\right)$ for the chemical. It is uncertain whether nonpolar organic chemicals can partition directly from the sediment organic carbon phase to the membrane lipid phase of an animal in close contact with the sediment. Irrespective of whether or not direct transfer can take place, the distribution of a nonpolar organic chemical among the particulate, pore water, and tissue phases will depend on the relative affinity of the chemical for the three phases.

As a general rule, the affinity of most nonpolar organic chemicals for sediment organic carbon is slightly less than the affinity of the chemical for tissue lipids. Values for $\mathrm{K}_{\mathrm{oc}}$ are slightly lower than values for $\mathrm{K}_{\mathrm{ow}}$ for nonpolar organic chemicals. Therefore, marine animals in close contact with sediments and sediment pore water will tend to accumulate nonpolar organic compounds from the sediment. At equilibrium, concentrations of the chemical in the tissue lipids of the benthic animals should be similar to or slightly higher than the concentration in the sediment organic carbon phase. However, when expressed on a bulk residue basis, bioaccumulation factors or transfer factors (concentration of chemical in tissues/concentration of chemical in sediments) usually are in the range of 0.1 to about 10. Bioaccumulation factors of nonpolar organic chemicals from sediments tend to increase as values of $\mathrm{K}_{\mathrm{ow}}$ increase.

However, these generalizations are complicated by many chemical and biological factors. The bioavailability of nonpolar organic chemicals from sediments is inversely proportional to the concentration of total (dissolved and particulate) organic carbon in the sediment. Because the sediment organic carbon concentration often is inversely correlated with sediment grain size, the relative bioavailability of nonpolar organic chemicals from sediments tends to increase as mean sediment grain size increases. However, the binding capacity and strength of different forms of solid or dissolved organic carbon for nonpolar organic chemicals varies widely, affecting partitioning behavior. Values for empirically-determined $K_{o c}$ may vary by several orders of magnitude for the same chemical, depending on the source and chemistry of the sediment organic matter. In some cases, dissolved organic matter in sediment pore water has a substantially higher affinity than particulate-phase organic matter for binding nonpolar organic contaminants. The relative importance of the forms and relative concentrations of different types of dissolved and particulate organic carbon 
on the rate of equilibration and distribution at equilibrium of nonpolar organic chemicals among the solid, pore water, and biotic phases of the sediment system are poorly understood.

Deposit-feeding benthic invertebrates usually accumulate sediment-sorbed nonpolar organic chemicals to higher concentrations than suspension-feeders and predators. This difference probably is related to the fact that the food of deposit-feeders (detritus, microbes, meiofauna), being at equilibrium with chemical residues in the bulk sediment, often contains higher concentrations of nonpolar organic chemicals than the food of suspension feeders or predators.

Accumulation of nonpolar organic compounds from food as well as water and sediments can, under some circumstances, lead to biomagnification of the chemical in marine food webs. When a marine animal is exposed to a nonpolar organic chemical in solution in the ambient pore water or overlying water, the chemical accumulates in the animal tissues until the rates of influx and efflux of the chemical from the animal tissues are equal. If the chemical also is present in the food of the animal, a similar equilibrium occurs; uptake is from both water and food. The food usually is marine; therefore, the food should have an equilibrium concentration associated with that of the tissues of the consumer. However, digestive processes may cause the apparent concentration of the chemical in the gut fluids to increase through digestion of organic substrates to which the chemical was bound and absorption of fluids. More of the chemical partitions from the gut contents into the tissues of the consumer. Accumulation of the chemical from the food increases the concentration of the chemical in the tissues to a level higher than the tissue/water equilibrium concentration, causing the chemical to diffuse outward through permeable body surfaces down its partitioning gradient. If passive and active excretion of the chemical are slow relative to the rate of uptake from the gut, the chemical will tend to biomagnify in tissues of the consumer as long as the food remains contaminated. The potential for biomagnification of nonpolar organic chemicals increases in the trophic step from water-breathing marine animal (prey) to air-breathing marine animal (predator) because the predator has more limited mechanisms for passive excretion of accumulated chemicals.

The efficiency of dietary absorption of nonpolar organic chemicals from the gut varies widely among marine animals. The main determinant of dietary absorption efficiency seems to be hydrophobicity, measured as $\mathrm{K}_{\mathrm{ow}}$. Absorption efficiency from the gut ranges from less than $10 \%$ to more than $90 \%$ for different nonpolar organic chemicals in different species. Dietary absorption efficiency tends to increase with increasing values of $\mathrm{K}_{\mathrm{cm}}$. However, high molecular weight compounds (molecular weight greater than about 600) or compounds with log $\mathrm{K}_{\mathrm{ow}}$ greater than about 
seven are not readily absorbed across the gut wall. The food is quantitatively the most important source of most nonpolar organic contaminants in the tissues of marine animals. The sediment pore water and water column routes usually are less important because concentrations of dissolved, bioavailable forms of these sparingly soluble compounds usually are very low, compared to concentrations in food.

Most organic contaminants with values of $\log \mathrm{K}_{\mathrm{ow}}$ greater than about four tend to show evidence of biomagnification in marine food webs. However, high molecular weight compounds, such as the most highly chlorinated PCBs, and compounds that are rapidly metabolized in and excreted from the tissues of marine animals, such as PAH, do not biomagnify. Among similar organic contaminants, such as congeneric PCBs, the extent of biomagnification is inversely related to the ease of metabolism of the compound. Organic compounds with a flat, planar configuration are bioaccumulated more rapidly but tend to be more readily metabolized and excreted than more globular compounds. Non-coplanar PCB congeners tend to biomagnify more efficiently than coplanar congeners. Therefore, for most nonpolar organic chemicals of environmental concern, the occurrence and magnitude of biomagnification in marine food webs depends more on the rate of active and passive metabolism and excretion of accumulated residues than on the rate of uptake from food, water, and sediments.

Marine animals have several mechanisms for passive or active excretion of nonpolar organic contaminants. As concentrations of these chemicals in the ambient water, sediments, and food decrease, the chemicals will tend to partition passively outward into the external medium down their partitioning gradients. This is quantitatively the most important mechanism of excretion for several major marine taxa, including molluscs, coelenterates, and echinoderms, that have very low activity of enzyme systems involved in active conversion and excretion of nonpolar organic contaminants.

All or nearly all marine animals examined to date have an enzyme system, called the cytochrome P450 mixed function oxygenase (MFO) system, that is capable of oxidizing various nonpolar organic chemicals to more polar, water soluble metabolites that can be excreted more readily by active (via the kidneys, gall bladder, or equivalent organs) or passive means. Often, enzymes in the system conjugate the initial polar metabolite with sulfate, sugar, or other polar substrates to make the compound even more polar and easily excreted. Suitable substrates for MFO include PAH, 
PCBs, chlorinated dioxins, and dibenzofurans, and several chlorinated hydrocarbon pesticides, such as DDT.

The activity of this system and its importance in excretion of nonpolar organic contaminants increases as one moves up the phylogenetic hierarchy. Molluscs have very little MFO activity; crustaceans have a moderately active MFO system, components of which are involved in the molt cycle; fish and higher vertebrates, including marine reptiles, birds, and mammals, have a very active, highly inducible MFO system. Among the marine vertebrates, the inducible MFO system plays a critical, though not exclusive, role in excretion of accumulated nonpolar organic compounds.

Several nonpolar organic compounds that are metabolized inefficiently, if at all, by marine animals at different trophic levels, are biomagnified efficiently at the water-breather to air-breather trophic transfer. These compounds, such as some PCB congeners, DDT (and some of its degradation products), and chlordane (and its degradation products), may be present at very high concentrations in the lipids of marine birds and mammals, even from remote areas. This may be due to the inability of air-breathing marine vertebrates to use passive excretory routes available to water-breathing marine animals to contribute to elimination of accumulated nonpolar organic chemicals.

Marine sediments are a quantitatively very important environmental compartment for the cycling of metal and organic contaminants through marine and terrestrial environments. Concentrations of metal and organic contaminants from a wide variety of anthropogenic and natural sources often are many orders of magnitude higher in sediments than in solution in the overlying water column. Chemical contaminants in sediments can be accumulated by marine animals that live or feed in or on the sediments. The contaminants, originally derived from the sediments, may be passed throughout the marine food chain by trophic transfer. A few compounds, because they are absorbed efficiently and excreted poorly, may biomagnify in marine food chains to very high, potentially toxic concentrations in the top predators, including marine birds and mammals, and man.

\subsection{RECOMMENDATIONS FOR ADDITIONAL RESEARCH}

There has been a tremendous amount of progress in the last decade in our understanding of the physical, chemical, and biological factors that influence the bioavailability of chemical contaminants associated with marine and estuarine sediments. The growing awareness that sediments often are a source of chemical contaminants to the overlying water column and its biota has led to requests by environmental managers and regulators to develop methods for determining threshold 
concentrations for contaminants in sediments, above which sediment-associated contaminants could pose a hazard to users of the overlying water column. Identification of generic threshold concentrations (that may later become sediment quality criteria and standard) applicable to all or most environmental settings is extremely difficult, because the processes controlling the bioavailability of sediment-bound contaminants are complex and our understanding of them is incomplete.

\subsubsection{Bioavailability}

It is reasonable to postulate that, in order for a metal or organic contaminant that is sorbed to sediments to produce toxic effects in marine plants and animals, it must be bioavailable. However, little work has been performed on the relationship between bioavailability, bioaccumulation, and toxicity of sediment-sorbed contaminants. Most work to date on development of sediment quality criteria, particularly evaluation of equilibrium partitioning theory, has relied on physical/chemical models and laboratory evaluations of the toxicity of bulk sediments spiked with different contaminants.

Little research has been performed on bioaccumulation of the chemicals by representative benthic marine organisms from the sediment/pore water system. The effects of the species of benthic animal used in the study and the quality and relative abundance of different forms (dissolved, sorbed, and particulate) of organic matter on the toxicity and bioavailability of the sediment-sorbed chemicals have not been evaluated. Both laboratory and field studies of this sort are needed if we are to extrapolate results and resulting threshold or criterion values to all types of marine sediment systems.

In most cases, bioaccumulation is a better indication than toxicity of the relative hazard of a sediment-sorbed chemical to marine ecosystems. Results of toxicity tests can be confounded by many difficult-to-control variables in standard solid phase bioassays. Chemicals other than the one under investigation or physical/chemical conditions in sediments may cause or contribute to the observed toxicity of the sediments. Interpretation of the accumulation of the target chemical is more straightforward.

A particularly valuable field study would involve collection of natural marine sediments by box corer. The Eh profile of the sediment would be recorded to a depth of at least $20 \mathrm{~cm}$. Particulate and pore water fractions of the sediment would be coilected from different depth intervals in the sediment column. Pore water and sediment particles would be analyzed separately for total organic carbon, sulfides, and the contaminants of interest. Sediment grain size distribution would be 
determined. Infauna would be collected from the box core if enough biomass was available, or from a benthic dredge sample collected at the same location and time as the core. If possible, benthic infauna would either be allowed to depurate for $24 \mathrm{~h}$ in clean seawater or be dissected to remove the gut and its contents. Statistical correlations would be made among contaminant concentrations (on a bulk basis and normalized for sediment and pore water organic carbon and tissue lipids) in sediments, pore water, and animal tissues. The role of particulate and dissolved organic matter, sulfides, pore water salinity, and sediment grain size on the distribution of the contaminants among the three phases would be determined. A relationship would also be sought between contaminant concentrations in tissues of different species of benthic infauna and feeding type, morphology (particularly as it relates to the relative area of direct contact between permeable body surfaces and sediments), and size of animal.

Heavily contaminated sediments may not support a diverse infauna. To extrapolate the field studies to sediments that may actually need regulatory attention, it may be necessary to perform laboratory studies with contaminated sediments from the field and representative infaunal organisms, such as polychaetes and amphipods, introduced to tanks containing the sediments. Relationships between physical/chemical properties of the sediments, as discussed above, and bioaccumulation of selected contaminants in the tissues of the test species would be determined.

The role of sediment microbiota and meiofauna in mobilization and bioaccumulation by macrofauna of metal and organic contaminants is incompletely understood. The important role of sediment microbiota in oxidation/reduction reactions in sediments is widely recognized. However, the effects of uptake, transformation, or binding of chemical contaminants by sediment microbes or their exudates on availability of the contaminants to meiofauna and macrofauna are poorly understood. Additional research is needed on the role of bacteria, fungi, and protists in cycling of metal and organic contaminants in marine sediments, and particularly on the effects of sediment microbiota on the bioavailability of contaminants to macrofauna.

The tendency of some metals, particularly organo-mercury compounds, and nonpolar organic chemicals to biomagnify at the trophic step from water-breather (prey) to air-breather (predator) to a much greater extent than in any of several trophic steps between water-breathers has not been fully explained. It appears to be related in part to the inability of air-breathing animals to passively excrete accumulated chemicals, particularly those with very low aqueous solubilities, through permeable body surfaces. Most of the air-breathers have active enzymatic detoxification and excretion systems that 
should allow them to rapidly excrete accumulated contaminants. It appears that some populations of marine mammals and birds are being adversely affected by methylmercury and certain nonpolar organic chemicals, particularly PCBs and DDT, in marine waters and sediments. Additional experimental studies are needed on uptake from food, metabolism, and excretion, especially methylmercury, and nonpolar organic chemicals by marine mammals and birds.

\subsubsection{Metals}

A large and variable fraction of the total metal in sediment is part of the mineral matrix of the sediment particles or is irreversibly complexed to the particles and is not bioavailable. The potentially bioavailable forms of metals are sorbed or complexed to hydrous iron and manganese oxides, organic matter, and labile sulfides. However, the relative importance of these different forms of sorbed metals to the bioavailability of metals from sediments is poorly understood.

Natural sediments from different marine habitats, containing a wide range and combination of organic matter, labile sulfides, and sorbed iron and manganese oxides, should be evaluated in controlled laboratory exposure experiments with different species of infaunal animals. Attempts should be made to correlate bioaccumulation of different metals from the contaminated sediments to the physical/chemical forms of the sorbed chemicals in the sediments, and to other environmental variables, such as sediment grain size, relative concentrations and forms of dissolved and particulate organic carbon, salinity, Eh, and infaunal species.

Most attention has been placed on the potential bioavailability of metals introduced to marine sediment/water systems in soluble or complexed forms. A fraction of these metals sorb to various particulate fractions in sediments and remain somewhat bioavailable. Little is known, however, about physical/chemical processes that affect the bioavailability of metals introduced into marine ecosystems in tightly bound or highly insoluble forms (e.g., mine tailings, coal fly ash, and metallic sulfide impurities in drilling mud barite). It is unclear if natural biogeochemical processes in marine sediments can convert supposedly inert forms of metals, such as mercuric sulfide in the form of cinnabar, to mobile, bioavailable forms at rates fast enough to allow the immobile metal species to pose a hazard to marine ecosystems. Studies should be performed of biogeochemical processes and rates of transformation of highly insoluble mineralogic forms of metals to bioavailable forms. 
Several species of marine animals tend to convert accumulated metals to insoluble forms that are either excreted or stored more or less permanently in a bound form in various tissues. The sequestered metals appear to be completely nontoxic to the host animals. A few studies indicate that they also are inert to predators of the host animals. The role of precipitation and sequestration of metals in benthic animals in the cycling of metals in benthic ecosystems needs to be better understood. The fate and effects of metal concretions in sediment-based marine food webs should be investigated.

\subsubsection{Organic Contaminants}

The theoretical basis of equilibrium partitioning theory to explain the distribution of nonpolar organic contaminants among sediment particles, pore water, and the tissues of benthic fauna is well established. The theory explains quite well the distribution of nonpolar contaminants in carefully controlled laboratory microcosms and in some natural marine ecosystems. However, a large number of factors influences the accuracy of extrapolations from concentrations of organic contaminants in bulk sediments to actual bioaccumulation and toxicity to marine organisms.

Empirically determined values for $\mathrm{K}_{\mathrm{ow}}$ for a single nonpolar organic chemical may vary by several orders of magnitude, depending on the methods used to measure $K_{o w}$. Values for $K_{o c}$ usually are derived from values for $\mathrm{K}_{\mathrm{ow}}$ or aqueous solubility by regression equations. Many regression equations have been published, most of which produce fairly good estimates for a small group of chemicals with similar structures. All these mathematical derivations are based on the invalid assumption that all sediment organic matter has a similar affinity for nonpolar organic compounds. Actually, natural dissolved and particulate organic matter in sediments may vary over several orders of magnitude in its affinity, as measured empirically by $\mathrm{K}_{\mathrm{o}}$, for nonpolar organic contaminants. The coupled imprecision of estimates of $\mathrm{K}_{\mathrm{ow}}$ and $\mathrm{K}_{\propto}$ may yield predictions of the equilibrium distribution of nonpolar organic chemicals among sorbed, pore water, and biotic phases that are in error by several orders of magnitude. Values for $\mathrm{K}_{\mathrm{ow}}$ and $\mathrm{K}_{\mathrm{oc}}$ for nonpolar organic chemicals of major environmental concern should be determined empirically for a wide variety and sources of natural sediment organic carbon, and environmental variables, such as salinity and temperature. Equilibrium partitioning theory should be tested based on measurements of bioavailability and bioaccumulation of nonpolar organic chemicals from pore water in equilibrium with the solid phase of sediments, not just on the basis of the toxicity of bulk sediments to benthic fauna. 
Rates of equilibration of nonpolar organic chemicals with different sorptive phases in sediments are poorly understood. Possible hysteresis (different rates of absorption and desorption of chemicals at the sediment/water interface) in equilibration has been identified a few times but not explored thoroughly. If the rate of desorption of chemicals from various sorption substrates is very slow, particularly following very long (months or years) equilibration times, then conventional equilibrium partitioning theory can not be used to predict the fraction of total nonpolar organic chemical in sediment that is in a bioavailable form. Carefully controlled laboratory and field experiments should be performed to determine the rates of sorption and desorption of nonpolar organic contaminants to and from natural sorption substrates in marine sediments. Relative rate kinetics for sorption/desorption from different types of natural dissolved and particulate organic substrates should be examined.

Very little is known about the relationships between the forms of sorbed or complexed nonpolar organic compounds, and their distribution between soluble and particulate phases on the one hand, and their efficiency of absorption through the gut wall of benthic animals. It is possible that some complexes between dissolved organic matter in pore water and nonpolar organic chemicals are directly bioavailable through the gut wall and integument, including the gills. Alternatively these soluble organic matter/contaminant complexes may have a very low bioavailability. It is probable that nonpolar organic chemicals sorbed or complexed to digestible organic matter are more bioavailable than chemicals sorbed or complexed to highly refractory organic matter, such as humic material. Carefully controlled laboratory studies are needed on the effects of the chemical and physical forms of natural organic matter in sediments on the bioavailability via the gut and pore water of sedimentassociated nonpolar organic matter to benthic marine animals.

Mixed function oxygenases and related metabolic systems are important in controlling bioaccumulation and biomagnification of nonpolar organic compounds in marine food webs. However, MFO may produce metabolites of some nonpolar organic chemicals that are more toxic than the parent compound. Some of the metabolites are carcinogenic, mutagenic, or teratogenic. Therefore, MFO is both a detoxification and a toxification system. More information is needed on the relative roles of MFO in protecting benthic marine animals and their consumers from adverse effects of certain nonpolar organic chemicals and in increasing the tuxicity of contaminants associated with sediments to benthic animals. Several chemicals in sediments, including some metals, may stimulate or inhibit MFO in benthic animals and fish. The relationship between concentrations in 
sediments of these chemicals and food chain transfer and biomagnification of chemicals in sedimentbased food chains should be explored. 


\subsection{REFERENCES}

Abbe, G.R. and J.G. Sanders. 1990. "Pathways of Silver Uptake and Accumulation by the American Oyster (Crassostrea virginica) in Chesapeake Bay." Est. Coast. Shelf Sci. 31:113-123.

Abdullah, M.I. and B. Reusch-Berg. 1981. "Metal Species in Sediments and Interstitial Water." In Proceedings of an International Conference on Heavy Metals in the Environment, pp. 669-673. CEP Consultants Ltd., Edinburgh.

Adams, N.J. and C.R. Brown. 1989. "Dietary Differentiation and Trophic Relationships in the SubAntarctic Penguin Community at Marion Island." Mar. Ecol. Prog. Ser. 57:249-258.

Adams, W.J. 1987. "Bioavailability of Neutral Lopophilic Organic Chemicals Contained in Sediments: A Review." In Fate and Effects of Sediment-bound Chemicals in Aquatic Systems, eds. K.L. Dickson, A.W. Maki, and W.A. Brungs, pp. 219-244. Pergamon Press, New York.

Adams, W.J., R.A. Kimerle, and R.G. Mosher. 1985. "Aquatic Safety Assessment of Chemicals Sorbed to Sediments." In Aquatic Toxicology and Hazard Assessment, eds. R.D. Cardwell, R. Purdy and R. Comotto, pp. 429-453. ASTM Special Publication 854, Philadelphia.

Addison, R.F. 1976. "Organochlorine Compounds in Aquatic Organisms: Their Distribution, Transport and Physiological Significance." In Effects of Pollutants on Aquatic Organisms. Society for Experimental Biology Seminar Series, Volume 2, ed. A.P.M. Lockwood, pp. 124-143. Cambridge University Press, Cambridge, England.

Addison, R.F. 1982. "Organochlorine Compounds and Marine Lipids." Prog. Lipid Res. 21:47-71.

Addison, R.F., P.F. Brodie, M.E. Zinck, and D.E. Sergeant. 1984. "DDT has Declined More Than PCBs in Eastern Canadian Seals During the 1970s." Environ. Sci. Technol. 18:935-937.

Addison, R.R., M.F. Zinck, and D.E. Willis. 1977. "Mixed Function Oxidase Enzymes in Trout (Salvelinus fontinalis) Liver: Absence of Induction Following Feeding of p,p'-DDT or p,p'-DDE." Comp. Biochem. Physiol. 57C:39-43.

Aggarwal, P.K. and R.E. Hinchee. 1991. "Monitoring In Situ Biodegradation of Hydrocarbons by Using Stable Carbon Isotopes." Environ. Sci. Technol. 25:1178-1180.

Aguilar, A. 1987. "Using Organochlorine Pollutants to Discriminate Marine Mammal Populations: A Review and Critique of the Methods." Mar. Mamm. Sci. 3:242-262.

Aguilar, A. and A. Borrell. 1991. "Heterogeneous Distribution of Organochlorine Contaminants in the Blubber of Baleen Whales: Implications for Sampling Procedures." Mar. Environ. Res. 31:275286.

Ahsanullah, M. and T.M. Florence. 1984. "Toxicity of Copper to the Marine Amphipod Allorchestes compressa in the Presence of Water and Lipid Soluble Ligands." Mar. Biol. 84:41. 
Ahsanullah, M., M.C. Mobley, and D.S. Negilski. 1984. "Accumulation of Cadmium from Contaminated Water and Sediment by the Shrimp Callianassa australiensis."

Ahsanullah, M. and A.R. Williams. 1991. "Sublethal Effects and Bioaccumulation of Cadmium, Chromium, Copper, and Zinc in the Marine Amphipod Allorchestes compressa." Mar. Biol. 108:5965.

Aiken, G.R., D.M. McKnight, R.L. Wershaw, and P. MacCarthy. 1985. "An Introduction to Humic Substances in Soil, Sediment, and Water." In Humic Substances in Soil, Sediment, and Water. Geochemistry, Isolation, and Characterization, eds. G.R. Aiken, D.M. McKnight, R.L. Wershaw, and P. MacCarth, pp. 1-9. John Wiley and Sons, New York.

Aislabie, J. and M.W. Loutit. 1986. "Accumulation of $\mathrm{Cr}$ (III) by Bacteria Isolated From Polluted Sediment." Marine Environmental Research 20:221-232.

Aller, R.C. 1978. "The Effects of Animal-Sediment Interactions on Geochemical Processes Near the Sediment-Water Interface." In: Esttuarine Interaction, M.L. Wiley, ed. Academic Press, New York. pp157-172.

Aller, R.C. 1982. "The Effects of Macrobenthos on Chemical Properties of Marine Sediment and Overlying Water." In Animal-Sediment Relations, eds. P.L. McCall and M.J.S. Tevesz, Vol. 2. pp. 53-102. Topics in Geobiology, Plenum Press.

Aller, R.C. and R.E. Dodge. 1974. "Animal-Sediment Relations in a Tropical Lagoon, Discovery Bay, Jamaica." J. Mar. Res. 32:209-232.

Aller, R.C. and P.D. Rude. 1988. "Complete Oxidation of Solid Phase Sulfides by Manganese and Bacteria in Anoxic Marine Sediments." Geochimica et Cosmochimica Acta 52:751-766.

Aller, R.C. and J.Y. Yingst. 1978. "Biogeochemistry of Tube-Dwellings: A Study of the Sedentary Polychaete Amphitrite ornata (Leidy)." J. Mar. Res. 36:201-254.

Aller, R.C., J.Y. Yingst, and W.J. Ullman. 1983. "Comparative Biogeochemistry of Water in Intertidal Onuphis (Polychaeta) and Upogebia (Decapoda) Burrows: Temporal Pattern and Causes." J. Mar. Res. 41:571-604.

Alzieu, C., J. Sanjuan, J.P. Deltreil, and M. Borel. 1986. "Tin Contamination in Arcachon Bay: Effects on Oyster Shell Anomalies." Marine Pollution Bulletin 17:494-498.

Ambrose Jr., W.G. 1984. "Influences of Predatory Polychaetes and Epibenthic Predators on the Structure of a Soft-Bottom Community in a Maine Estuary." J. Exp. Mar. Biol. Ecol. 81:115-145.

Amdurer, M., D. Adler, and P.H. Santschi. 1983. "Studies of the Chemical Forms of Trace Elements in Sea Water Using Radiotracers." In Trace Metals in Sea Water, eds. C.S. Wong, E. Boyle, K.W. Bruland, J.D. Burton, and E.D. Goldberg, pp. 537-562. Plenum Press, New York. 
Amiard, J.-C. 1979. "Modalités de la Contamination d'une Chaine Trophique Marine Benthique Par L'argent 110m. II - Transfert du Radionucléide Dans La Chaine Alimentaire (1)." Cah. Biol. Mar. 20:189-199.

Amiard, J.C., C. Amiard-Triquet, and C. Métayer. 1985. "Experimental Study of Bioaccumulation, Toxicity, and Regulation of Some Trace Metals in Various Estuarine and Coastal Organisms." In Heavy Metals in Water Organisms, ed. J. Salanki, pp. 313-324. Symposia Biologica Hungarica, Akademiai Kiado, Budapest.

Amiard, J.C., C. Amiard-Triquet, C. Metayer, and R. Ferré. 1983. "Etude du Transfert de Quelques Oilgo-élements Métaliques Entre Le Milieu Sédimentaire Estuarien et Les Poissons Plats Mangeurs de Sediments'." Mar. Environ. Res. 10:159-171.

Amiard, J.-C., C. Amiard-Triquet, C. Metayer, J. Marchand, and R. Ferre. 1980. Etude du Transfery de $\mathrm{Cd}, \mathrm{Pb}, \mathrm{Cu}$, et $\mathrm{Zn}$ Dans Les Chaines Trophiques Neritiques et Estruariennes-I. Etat Dans L'estuaire Interne Del La Loire (France) au Cours De l'ete 1978." Wat. Res. 14:665-673.

Amiard-Triquet, C. 1974. "Influence de la Salinité et de l'équilibre Ionique Sur la Contamination d'Arenicola marina L. (Annelide: Polychete) Par le Caesium-137." J. Exp. Mar. Biol. Ecol. 15:159-164.

Amiard-Triquet, C., C. Metayer, J.-C. Amiard, and R. Ferre. 1980. "Study of the Transfer of Cadmium, Lead, Copper and Zinc in Neritic Trophic Chains and Estuaries." Wat. Res. 14:13271332.

Anderson, J.W, 1979. "An Assessment of Knowledge Concerning the Fate and Effects of Petroleum Hydrocarbons in the Marine Environment." In Marine Pollution: Functional Responses, pp. 3-21. Academic Press, New York.

Anderson, J.W. and R.W. Gossett. 1987. Polynuclear Aromatic Hydrocarbon Contamination in Sediments From Coastal Waters of Southern California. Final Report to California State Water Resources Control Board, C-212, Southern California Coastal Water Research Project, Long Beach, California.

Anderson, J. W. Birge, J. Gentile, J. Lake, J. Rodgers, Jr., and R. Swartz. 1987. "Biological Effects, Bioaccumulation and Ecotoxicology of Sediment-Associated Chemicals." In Fate and Effects of Sediment-bound Chemicals in Aquatic Systems, eds. K.L. Dickson, A.W. Maki and W.A. Brungs, pp. 267-291. Pergamon Press, Elmsford, New York.

Anderson, J.W., L.J. Moore, J.W. Blaylock, D.L. Woodruff, and S.L. Kiesser. 1977. "Bioavailability of Sediment-Sorbed Naphthalenes to the Sipunculid Worm, Phascolosoma agassizii." In Fate and Effects of Petroleum Hydrocarbons in Marine Ecosystems and Organisms, eds. D.A. Wolfe, J.W. Anderson, D.K. Button, D.C. Malins, T. Roubal and U. Varanasi, pp. 276-285. Pergamon Press, New York. 
Anderson, J.W., R.G. Riley, S.L. Kiesser, B.L. Thomas, and G.W. Fellingham. 1983. Natural Weathering of Oil in Marine Sediments: Tissue Contamination and Growth of the Littleneck Clam, Protothaca staminea." Can. J. Fish. Aquat. Sci. 40(2):70-77.

André, J.M., R. Ribeyre, and A. Boudou. 1990. "Mercury Contamination Levels and Distribution in Tissues and Organs of Delphinids (Stenella attenuata) From the Eastern Tropical Pacific, in Relation to Biological and Ecological Factors." 'Mar. Environ. Res. 30:43-72.

Andreae, M.O. 1979. "Arsenic Speciation in Seawater and Interstitial Waters: The Influence of Biological-Chemical Interactions on the Chemistry of a Trace Element." Limnology and Oceanography 24:440-452.

Andreae, M.O., J.T. Byrd, and P.N. Froelich, Jr. 1983. "Arsenic, Antimony, Germanium, and Tin in the Tejo Estuary, Portugal: Modeling a Polluted Estuary." Environmental Science and Technology 17:731-737.

Argyle, R.L., G.C. Williams, and C.B. Daniel. 1975. "Dieldrin in the Diet of Channel Catfish, (Ictalurus punctatus): Uptake and Effect on Growth." J. Fish. Res. Bd. Can. 32:2197-2204.

Arrhenius, G. 1963. Pelagic Sediments. In The Sea, Vol. 3, eds. M.N. Hill, pp. 655-727. Interscience, New York.

Arthur D. Little, Inc. 1987. An Overview of Sediment Quality in the United States. Report to the U.S. Environmental Protection Agency, Monitoring and Data Support Division, Office of Water Regulations and Standards, Washington, D.C.

Atlas, R.M. 1981. "Microbial Degradation of Petroleum Hydrocarbons. An Environmental Perspective." Microbiological Reviews 45:180-209.

Atlas, R.M. and A. Bronner. 1981. "Microbial Hydrocarbon Degradation Within Intertidal Zones Impacted by the amoco Cadiz Oil Spillage." In amoco Cadiz Consequences d'une Pollution Accidentelle par les Hydrocarbures. Fates and Effects of the Oil Spill, pp. 251-256. CNEXO, Paris.

Augenfeld, J.M., J.W. Anderson, R.G. Riley, and B.L. Thomas. 1982. "The Fate of Polyaromatic Hydrocarbons in an Intertidal Sediment Exposure System: Bioavailability to Macoma inquinata (Mollusca: Pelecypoda) and Abarenicola pacifica (Annelida: Polychaeta)." Mar. Environ. Res. 7:31-50.

Augenfeld, J.M., J.W. Anderson, D.L. Woodruff, and J.L. Webster. 1980. "Effects of Prudhoe Bay Crude Oil-Contaminated Sediments on Protothaca staminea (Mollusca: Pelecypoda):

Hydrocarbon Content, Condition Index, Free Amino Acid Level. Mar. Environ. Res. 4:135-143.

Bacesu, M.C. 1971. "Substratum: 7.3 Animals." In Marine Ecology, Vol. 1, Part 3, ed. O. Kinne. John Wiley and Sons, London. 
Bahner, L.H., A.J. Wilson, Jr., J.M. Sheppard, J.M. Patrick, Jr., L.R. Goodman, and G.E. Walsh. 1977. "Kepone ${ }^{\oplus}$ Bioconcentration, Accumulation, Loss, and Transfer Through Estuarine Food Chains." Chesapeake. Sci. 18:299-308.

Baird, B.H. and D. Thistle. 1986. "Uptake of Bacterial Extracellular Polymer by a Deposit-Feeding Holothurian (Isostichopus badionotus)." Mar. Biol. 92:183-187.

Baker, G. 1962. "Detrital Heavy Metals in Natural Accumulations. Institute of Marine Metals." Cited in Warren, op. cit. Melbourne, Australia.

Baldi, F. and R. Bargagli. 1982. "Chemical Leaching and Specific Surface Measurements of Marine Sediments in the Evaluation of Mercury Contamination Near Cinnabar Deposits." Marine Environmental Research 6:69-82.

Baldi, F. and R. Bargagli. 1984. "Mercury Pollution in Marine Sediments Near a Chloralkali Plant: Distribution and Availability of the Metal." Science of the Total Environment 39:15-26.

Balistrieri, L., P.G. Brewer, and J.W. Murray. 1981. "Scavanging Residence Times of Trace Metals and Surface Chemistry in Sinking Particles in the Deep Ocean." Deep-Sea Research 28A:101121.

Balzer, W. 1982. "On the Distribution of Iron and Manganese at the Sediment/Water Interface." Geochimica et Cosmochimica Acta 46:1153-1161.

Banerjee, S. and G.L. Baughman. 1991. "Bioconcentration Factors and Lipid Solubility." Environ. Sci. Technol. 25:536-539.

Baptist, J.P. and C.W. Lewis. 1969. "Transfer of ${ }^{65} \mathrm{Zn}$ and ${ }^{51} \mathrm{Cr}$ Through an Estuarine Food Chain." In Proceedings of the 2nd National Symposium on Radioecology, eds. D.J. Nelson and F.C. Evans, pp. 420-430. Atomic Energy Commission (CONF-670503).

Barcelona, M.J. 1980. "Dissolved Organic Carbon and Volatile Fatty Acids in Marine Sediment Pore Waters." Geochimica et Cosmochimica Acta 44:1977-1984.

Barnes, R.D. 1965. "Tube-Building and Feeding in Chaetopterid Polychaetes." Biol. Bull. 129:217-233.

Barnes, R.D. 1980. Invertebrate Zoology. Fourth Edition, Saunders College Publishing,a Philadelphia.

Barron, M.G. 1990. "Bioconcentration." Environ. Sci. Technol. 24:1612-1618.

Barron, E.J. and J.M. Whitman. 1981. "Oceanic Sediments in Space and Time." In The Oceanic Lithosphere, Vol. 7 of The Sea, ed. C. Emiliani, pp. 689-732. John Wiley and Sons, New York. 
Bartha, R. and R.M. Atlas. 1987. "Transport and Transformations of Petroleum: Biological Processes." In Long-Term Environmental Effects of Offshore Oil and Gas Development, eds. D.F. Boesch and N.N. Rabalais, pp. 287-341. Elsevier Applied Science Publishers, London.

Bartlett, P.D. and P.J. Craig. 1981. "Total Mercury and Methyl Mercury Levels in British Estuarine Sediments-II." Water Research 15:37-47.

Bates, T.S., P.P. Murphy, H.C. Curl, Jr., and R.A. Feely. 1987. "Hydrocarbon Distribution and Transport in an Urban Estuary." Environmental Science and Technology 21:193-198.

Batley, G.E. and M.S. Giles. 1980a. "A Solvent Displacement Technique for the Separation of Sediment Interstitial Waters." In Contaminants in Sediments ed. R.A. Baker. Vol. 2, pp. 101-117. Ann Arbor Science Press, Michigan.

Batley, G.E. and M.S. Giles. 1980b. " "Sources of Contaminants in Aquatic Systems." In Contaminants and Sediment, Vol. 2, Analysis, Chemistry, Biology, ed. R.A. Baker, pp. 101-117. Ann Arbor Science Publishers, Ann Arbor, Michigan.

Bauer, J.E. and D.G. Capone. July 1985. "Degradation and Mineralization of the Polycyclic Aromatic Hydrocarbons Anthracene and Naphthalene in Intertidal Marine S Sediments." Applied Environmental Microbiology, pp. 81-90.

Bauermeister, A., A. Lewenoon, P.I.N. Ramage, and I.A. Nimmo. 1983. "Distribution and Some Properties of the Glutathione S-Transferase and Gamma-Glutamyl Transpeptidase Activities or Rainbow Trout." Comp. Biochem. Physiol. 74C:89-94.

Bean, R.M., D.D. Dauble, B.L. Thomas, R.W. Hane, Jr., and E.K. Chess. 1985. "Uptake and Biotransformation of Quinoline by Rainbow Trout." Aquat. Toxicol. 7:221-239.

Beasley, T.M. and S.W. Fowler. 1976a. "Plutonium and Americium: Uptake From Contaminated Sediments by the Polychaete Nereis diversicolor." Mar. Biol. 38:95-100.

Beasley, T.M. and S.W. Fowler. 1976b. "Plutonium Isotope Ratios in Polychaete Worms." Nature 262:813-814.

Beck, H., E.M. Breuer, A. Drob, and W. Mathar. 1990. "Residues of PCDDs, PCDFs, PCBs and Other Organochlorine Compounds in Harbour Seals and Harbour Porpoise." Chemosphere 20:10271034.

Becker, G.L., C.-H. Chen, J.W. Greenawalt, and A.L. Lehninger. 1974. "Calcium Phosphate Granules in the Hepatopancreas of the Blue Crab Callinectes sapidus." J. Cell. Biol. 61:316-326.

Benayoun, G., S.W. Fowler, and B. Oregioni. 1974. "Flux of Cadmium Through Euphausiids." Mar. Biol. 27:205-212. 
Bend, J.R. and M.O. James. 1978. "Xenobiotic Metabolism in Marine and Freshwater Species." In Biochemical and Biophysical Perspectives in Marine Biology, eds. D.C. Malins and J.R. Sargent, pp. 101-117. Academic Press, New York.

Bend, J.R., M.O. James, and P.M. Dansette. 1977. "In vitro Metabolism of Xenobiotics in Some Marine Animals." Ann. N.Y. Acad. Sci. 298:505-523.

Bender, K. and W.R. Davis. 1984. "The Effect of Feeding of Yoldia limatula on Bioturbation." Ophelia. 23:91-100.

Benjamin, M.M., K. Hayes, and J.O. Leckie. 1982. "Removal of Toxic Metals From PowerGeneration Waste Streams by Absorption and Co-Precipitation." Journal of the Water Pollution Control Federation 54:1472-1481.

Bennett, W.N., A.S. Brooks, and M.E. Boras. 1986. "Selenium Uptake and Transfer in an Aquatic Food Chain and its Effects on Fathead Minnow Larvae." Arch. Environ. Contam. Toxicol. 15:513517.

Benninger, L.K., R.C. Aller, J.K. Cochran, and K.K. Turekian. 1979. "Effects of Biological Sediment Mixing on the ${ }^{210} \mathrm{~Pb}$ chronology and Trace Metal Distribution in a Long Island Sound Sediment Core." Earth Planet. Sci. Lett. 43:241-259.

Benson, A.A. and R.E. Summons. 1981. "Arsenic Accumulation in Great Barrier Reef Invertebrates." Sci. 211:482-483.

Berk, S.G. and R.R. Colwell. 1981. "Transfer of Mercury Through a Marine Microbial Food Web." J. Exper. Mar. Biol. Ecol. 52:157-172.

Berman, M. and R. Bartha. 1986. "Control of the Methylation Process in a Mercury-Polluted Aquatic Sediment." Environmental Pollution (Series B) 11:41-53.

Bernard, F.J. and C.E. Lane. 1961. "Absorption and Excretion of Copper Ions During Settlement and Metamorphosis for the Barnacle Balanus amphitrite niveus." Biol. Bull. 121:438-448.

Bernhard, M., E.D. Goldberg, and A. Piro. 1975. "Zinc in Seawater - An Overview 1975." In The Nature of Seawater, ed. E.D. Goldberg, pp. 43-68. Dahlem Konferenzen, Physical and Chemical Sciences Report 1.

Berry, W.O. and J.W. Fisher. 1979. "Transfer of ${ }^{14} \mathrm{C}$-toluene From Mosquito Larvae to Bluegill Sunfish." Bull. Environ. Contam. Toxicol. 23:733-736.

Bertram, P.E. and A.S. Brooks. 1986. "Kinetics of Accumulation of Selenium From Food and Water by Fathead Minnows." Wat. Res. 20: 877-884.

Bertrand, D. 1950. "Biogeochemistry of Vanadium." Bull. Amer. Mus. Nat. Hist. 94:18-27. 
Bias, V.R. 1981. "Kinetik der Cadmium-akkumulation in Euryhalinen Amphipoden des ElbeAestuars: Experimente mit Corophium volutator (Pallas) (Amphipoda, Corophiidae. Arch. Hydrobiol./Suppl. 61:84-152.

Bieri, R.H., C. Hein, R.J. Huggett, P. Shou, H. Slone, C. Smith, and C.-W. Su. 1986. "Polycyclic Aromatic Hydrocarbons in Surface Sediments From the Elizabeth River Subestuary." International Journal of Environmental Analytical Chemistry 26:97-113.

Bierman, Jr., V.J. 1990. "Equilibrium Partitioning and Biomagnification of Organic Chemicals in Benthic Animals." Environ. Sci. Technol. 24:1407-1412.

Binder, R.L., M.J. Melancon, and J.J. Lech. 1984. "Factors Influencing the Persistence and Metabolism of Chemicals in Fish." Drug. Metab. Rev. 15:697-724.

Binder, R.L. and J.J. Stegeman. 1980. "Induction of Aryl Hydrocarbon Hydroxylase Activity in Embryos of an Estuarine Fish." Biochem. Pharmacol. 29:949-955.

Bird, D.F. and C.M. Duarte. 1989. "Bacteria-Organic Matter Relationship in Sediments: A Case of Spurious Correlation." Can. J. Fish. Aquat. Sci. 46:904-908.

Bjerk, J.E. and E.M. Brevik. 1980. "Organochlorine Compounds in Aquatic Environments." Arch. Environ. Contam. Toxicol. 7:743-750.

Blair, N.E. C.S. Martens, and D.J. Des Marais 1987. "Natural Abundances of Carbon Isotopes in Acetate From a Coastal Marine Sediment." Sci. 236:66-68.

Blanck, H., K. Holmgren, L. Landner, H. Norin, M. Notini, A. Rosmarin, and B. Sundelin. 1989. "Advanced Hazard Assessment of Arsenic in the Swedish Environment." In Chemicals in the Aquatic Environment. Advanced Hazard Assessment, ed. L. Landner, pp. 256-328. Springer-Verlag, Berlin.

Bloom, H. and G.M. Ayling. 1977. "Heavy Metals in the Derwent Estuary." Environmental Geology 2:3-22.

Boddington, M.J., A.S.W. DeFreitas, and D.R. Miller. 1979. "The Effect of Benthic Invertebrates on the Clearance of Mercury From Sediments." Exotoxicol. Environ. Safety. 3:236-244.

Boehm, P.D. and J.W. Farrington. 1984. "Aspects of the Polycyclic Aromatic Hydrocarbon Geochemistry of Recent Sediments in the Georges Bank Region." Environmental Science and Technology 18:840-845.

Boehm, P.D. and J.G. Quinn. 1973. "Solubilization of Hydrocarbons by Dissolved Organic Matter in Seawater." Geochim. Cosmochim. Acta 37:2459-2461.

Boese, B.L., H. Lee II, and D.T. Specht. 1988. "Efficiency of Uptake of Hexachlorobenzene From Water by the Tellinid Clam, Macoma nasuta." Aquat. Toxicol. 12:345-356. 
Boese, B.L., H. Lee II, D.T. Specht, R.C. Randall, and M.H. Winsor. 1990. "Comparison of Aqueous and Solid-Phase Uptake for Hexachlorobenzene in the Tellinid Clam Macoma nasuta (Conrad): A Mass Balance Approach." Environ. Toxicol. Chem. 9:221-231.

Bolton, H.S., R.J. Breteler, B.W. Vignon, J.A. Scanlon, and S.L. Clark. 1985. National Perspective on Sediment Quality. Report to U.S. Environtmental Protection Agency, Criteria and Standards Division, Office of Water Regulations and Standards, Washington, D.C.

Bonar, D.B. 1972. "Feeding and Tube Construction in Chone mollis Bush (Polychaeta, Sabellidae)." J. Exp. Mar. Biol. Ecol. 9:1-18.

Bonatti, E. 1981. Metal Deposits in the Ocean Lithosphere. In The Sea. Vol. 7 of The Oceanic Lithosphere, ed. E. Emiliani, pp. 639-686. John Wiley and Sons, New York.

Boon, J.P. 1985. "Uptake, Distribution, and Elimination of Selected PCB Components of Clophen A40 in Juvenile Sole (Solea solea) and Effects on Frowth." In Marine Biology of Polar Regions and Effects of Stress on Marine Organisms, eds. J.S. Gray and M.E. Christiansen, pp. 101-117. John Wiley \& Sons, Inc., New York.

Boon, J.P. and F. Eijgenraam. 1988. "The Possible Role of Metabolism in Determining Patterns of PCB Congeners in Species of the Dutch Wadden Sea." Mar. Environ. Res. 24:3-8.

Boon, J.P., F. Eijgenraam, J.M. Everaarts, and J.C. Duinker. 1989. "A Structure-Activity Relationship (SAR) Approach Towards Metabolism of PCBs in Marine Animals From Different Trophic Levels." Mar. Environ. Res. 27:159-176.

Boon, J.P. P.J.H. Reijnders, J. Dols, P. Wensvoort, and M.T.J. Hillebrand. 1987. "The Kinetics of Individual Polychlorinated Biphenyl Congeners in Female Harbour Seals (Phoca vitulina), with Evidence for Structure-Related Metabolism." Aquat. Toxicol. 10:307-324.

Boothe, P.N. and G.A. Knauer. 1972. "The Possible Importance of Fecal Material in the Biological Amplification of Trace and Heavy Metals." Limnol. Oceanogr. 17:270-274.

Borchardt, T. 1983. "Influence of Fod Qantity on the Knetics of Cadmium Uptake and Loss Via Food and Seawater in Mytilus edulis." Mar. Biol. 76:67-76.

Borlakoglu, J.T., J.P.G. Wilkins, and C.H. Walker. 1988. "Polychlorinated Biphenyls in FishEating Sea birds - Molecular Features and Metabolic Interpretations." Mar. Environ. Res. 24:15-19.

Born, E.W., A. Renzoni, and R. Dietz. 1991. "Total Mercury in Hair of Polar Bears (Ursus maritimus) From Greenland and Svalbard." Polar Res. 9:113-120.

Borowsky, B. 1983. "Behaviors Associated with Tube-Sharing in Microdeutopus gryllotalpa (Costa) (Crustacea:Amphipoda)." J. Exp. Mar. Biol. Ecol. 68:39-51. 
Bothner, M.H., P.J. Aruscavage, W.M Ferrebee, and P.A. Baedecker. 1980a. "Trace Metal Concentrations in Sediment Cores From the Continental Shelf Off the South-Eastern United States." Estuarine and Coastal Marine Science 10:523-541.

Bothner, M.H., R.A. Jahnke, M.L. Peterson, and R. Carpenter. 1980b. Rates of Mercury Loss From Contaminated Estuarine Sediments." Geochimica et Cosmochimica Acta 44:273-285.

Bothner, M.H., R.R. Rendigs, E. Campbell, M.W. Doughten, C.M. Parmenter, C.H. O'Dell, G.P. DiLisio, R.G. Johnson, and J.R. Gillison, and N. Rait. 1985. The Georges Bank Monitoring Program 1985: Analysis of Trace Metals in Bottom Sediments During the Third Year of Monitoring. U.S. Geological Survey Circular 988, U.S. Geological Survey, Woods Hole, Massachusetts.

Boudou, A. and F. Ribeyre. 1985. "Experimental Study of Trophic Contamination of Salmo gairdneri by Two Mercury Compounds $-\mathrm{HgCl}_{2}$ and $\mathrm{CH}_{3} \mathrm{HgCl}-$ Analysis at the Organism and Organ Levels." Wat. Air Soil Pollut. 26:137-148.

Boulègue, J. 1983. "Trace Metals (Fe, Cu, Zn, Cd) in Anoxic Environments." In Trace Metals in Sea Water, eds. C.S. Wong, E. Boyle, K.W. Bruland, J.D. Burton, and E.D. Goldberg, pp. 563578. Plenum Press, New York.

Boulègue, J., C.J. Lord III, and T.M. Church. 1982. "Sulfur Speciation and Associated Trace Metals (Fe, Cu) in the Pore Waters of Great Marsh, Delaware." Geochimica et Cosmochimica Acta 46:453-464.

Bowen, H.J.M. 1979. Environmental Chemistry of the Elements. Academic Press, New York.

Bowes, G.W. and C.J. Jonkel. 1975. "Presence and Distribution of Polychlorinated Biphenyls (PCB) in Arctic and Subarctic Marine Food Chains." J. Fish. Res. Bd. Can. 32:2111-2123.

Boyle, E.A., F.R. Sclater and J.M. Edmond. 1977. "The Distribution of Dissolved Copper in the Pacific." Earth and Planetary Science Letters 37:38-54.

Brafield, A.E. and G.E. Newell. 1961. "The Behaviour of Macoma balthica (L.)." J. Mar. Biol. Ass. U.K. 41:81-87.

Brannon, J.M. and W.H. Patrick, Jr. 1987. "Fixation, Transformation, and Mobilization of Arsenic in Sediments." Environmental Science and Technology 21: 450-459.

Brannon, J.M., J.R. Rose, R.M. Engler, and I. Smith. 1977. The Distribution of Heavy Metals in Sediment Fractions From Mobile Bay, Alabama. In Chemistry of Marine Sediments, ed. T.F. Yen, pp. 125-149. Ann Arbor Science Publishers, Ann Arbor, Michigan.

Bremer, P.J., M.F. Barker, and M.W. Loutit. 1990. "A Comparison of the Roles of Direct Absorption and Phytoplankton Ingestion in Accumulation of Chromium by Sea Urchin Larvae." Mar. Environ. Res. 30:233-241. 
Bremer, P.J. and M.W. Loutit. 1986. "Bacterial Polysaccharide as a Vehicle for Entry of $\mathrm{Cr}$ (III) to a Food Chain." Marine Environmental Research 20:235-248.

Brenchley, G.A. 1976. "Predator Detection and Avoidance: Ornamentation of Tube-Caps of Diopatra spp. (Polychaeta:Onuphidae)." Mar. Biol. 38:179-188.

Brenchley, G.A. 1978. On the Regulation of Marine Infaunal Assemblages at the Morphological Level: A Study of the Interactions Between Sediment Stabilizers, Destabilizers, and Their Sedimentary Environment. Ph.D. Dissertation, Johns Hopkins University.

Breteler, R.J. and J.M. Neff. 1983. "Waste Disposal in the Marine Environment. 1. Biological Availability of Heavy Metals to Marine Invertebrates." In Proceedings Oceans 83, Vol. II., pp. 905910. Marine Technology Society, Washington, D.C.

Breteler, R.J. and F.I. Saksa. 1985. "The Role of Sediment Organic Matter on Sorption-Desorption Reactions and Bioavailability of Mercury and Cadmium in an Intertidal Ecosystem." In Aquatic Toxicology and Hazard Assessment: Seventh Symposium, eds. R.D. Cardwell, R. Purdy, and R.C. Bahner, pp. 905-910. ASTM STP 854, Amer. Soc. Testing Materials, Philadelphia.

Breteler, R.J., J.M. Teal, and I. Valiela. 1981a. "Retention and Fate of Experimentally Added Mercury in a Massachusetts Salt Marsh Treated with Sewage Sludge." Mar. Env. Res. 5:211-225.

Breteler, R.J., I. Valiela, and J.M. Teal. 1981b. "Bioavailability of Mercury in Several NorthEastern U.S. Spartina Ecosystems." Est. Coast. Shelf. Sci. 12:155-166.

Briggs, G.G. 1973. "A Simple Relationship Between Soil Sorption of Organic Chemicals and Their Octanol-Water Partition Coefficients." In Proceedings of the 7th British Insect and Fungi Control Symposium 11:475-478.

Briggs, G.G. 1981. "Theoretical and Experimental Relationships Between Soil Adsorption, OctanolWater Partition Coefficients, Water Solubilities, Bioconcentration Factors, and the Parachor." Journal of Agricultural and Food Chemistry 29:1050-1059.

Brinkhuis, B.H., Pennela, W.F. and A.C. Churchill. 1980. "Cadmium and Manganese Flux in Eelgrass Zostera marina. II. Metal Uptake by Leaf and Root-Rhizome Tissues." Mar. Biol. 58:187196.

Brix, H. and J.E. Lyngby. 1982. "The Distribution of Cadmium, Copper, Lead and Zinc in Eelgrass (Zostera marina L.)." Sci. Total Environ. 24:51-63.

Brix, H. and J.E. Lyngby. 1983. "The Distribution of Some Metallic Elements in Eelgrass (Zostera marina L.) and in Sediment in the Limfjord, Denmark." Est. Coast. Shelf Sci. 16:455-467.

Brix, H., Lyngby, J.E. and H.-H. Schierup. 1983. "Eelgrass (Zostera marina L.) as an Indicator Organism of Trace Metals in the Limfjord, Denmark." Mar. Environ. Res. 8:165-181. 
Broman, D. 1990. Transport and Fate of Hydrophobic Organic Compounds in the Baltic Aquatic Environment - Polycyclic Aromatic Hydrocarbons, Polychlorinated Dibenzodioxins and Dibenzofurans. Doctoral Thesis, Dept. of Zoology, University of Stockholm, Stockholm, Sweden.

Broman, D., C. Näf, I. Lundbergh, and Y. Zebühr. 1990. "An In Situ Study on the Distribution, Biotransformation and Flux of Polycyclic Aromatic Hydrocarbons (PAHs) in an Aquatic Food Chain (seston-Mytilus edulis L.-Somateria mollissima) from the Baltic: An Ecotoxicological Perspective." Environ. Toxicol. Chem. 9:429-442.

Broman, D., C. Näf, C. Rolff, Y. Zebühr, B. Fry, and J. Hobbie. 1992. "Using Ratios of Stable Nitrogen Isotopes to Estimate Bioaccumulation and Flux of Polychlorinated Dibenzo-p-dioxins (PCDDs) and Dibenzofurans (PCDFs) in Two Food Chains From the Northern Baltic." Environ. Toxicol. Chem. 11:331-345.

Brown, B. 1982. Intraspecific Interactions and Feeding Biology of the Deposit-Feeding Polychaete, Scoloplos fragilis. Ph.D. Dissertation, University of Delaware.

Brown, D.A., E.M. Perkins, K.D. Jenkins, P.S. Oshida, S.M. Bay, J.F. Alfafara, and V. Raco. 1982a. "Seasonal Changes in Mussels." In: Southern California Coastal Water Research Project 1981-1982. W. Bascom (ed.), Long Beach, CA. pp179-192.

Brown, D.A., K.D. Jenkins, E.M. Perkins, R.W. Gossett, and G.P. Hershelman. 1982 b. "Detoxification of Metals and Organic Compounds in White Croakers. In: Southern California Coastal Water Research Project 1981-1982. W. Bascom (ed.), Long Beach, CA. pp157-172.

Brown, D.A., S.M. Bay, D.J. Greenstein, P. Szalay, G.P. Hershelman, C.F. Ward, A.M. Westcott and J.N. Cross. 1987a. "Municipal WasteWater Contamination in the Southern Caiifornia Bight. Part II. Cytosolic Distribution of Contaminants and Biochemical Effects in Fish Livers." Mar. Environm. Res. 21:135-161.

Brown, D.A., R.W. Gossett, G.P. Hershelmann, C.F. Ward, A.M. Westcott, and J.N. Cross. 1986. Municipal wastewater contamination in the southern California Bight: Part I-Metal and organic contaminants in sediments and organisms. Mar. Env. Res. 18:291-310.

Brown, D.A., R.W. Gossett, and S.R. McHugh. 1987b. "Oxygenated Metabolites of DDT and PCBs in Marine Sediments and Organisms." In Oceanic Processes in Marine Pollution, Vol. I, eds. J. M. Capuzzo and D.R. Kester, pp. 905-910. Robert E. Krieger Publ. Co., Malabar, Florida.

Brown, D.A., K.D. Jenkins, E.M. Perkins, R.W. Gossett, and G.P. Hershelman. 1982b. "Detoxificiation of Metals and Organic Compounds in White Croakers." In Southern California Coastal Water Research Project 1981-1982, ed. W. Bascom, pp. 905-910. Long Beach, California.

Brown, D.A., E.M. Perkins, K.D. Jenkins, P.S. Oshida, S.M. Bay, J.F. Alfafara, and V. Raco. 1982a. "Seasonal Changes in Mussels." In Southern California Coastal Water Research Project 1981-1982, ed. W. Bascom, pp. 905-910. Long Beach, California. 
Brown, D.S. and E.W. Flagg. 1981. "Empirical Prediction of Organic Pollutant Sorption in Natural Sediments." Journal of Environmental Quality 10:382-386.

Brownawell, B.J. and J.W. Farrington. 1986. "Biogeochemistry of PCBs in Interstitial Waters of a Coastal Marine Sediment." Geochimica et Cosmochimica Acta 50:157-169.

Brownlee, D.E. 1981. "Extraterrestrial Components." In The Sea, Vol. 7 of The Oceanic Lithosphere, ed. C. Emiliani, pp. 733-762. John Wiley and Sons, New York.

Bruggeman, W.A. 1982. "Hydrophobic Iteractions in the Aquatic Environment." In Handbook of Environmental Chemistry. Vol. 2, Part B, ed. O. Hutzinger, pp. 29-49. Springer, Berlin.

Bruggeman, W.A. 1983. Bioaccumulation of Polychlorinated Biphenyls and Related Hydrophobic Chemicals by Fish. Doctoral Thesis, University of Amsterdam, RIZA, Lelystad, Netherlands.

Bruggeman, W.A., L.B.J.M. Martron, D. Kooiman, and O. Hutzinger. 1981. "Accumulation and Elimination Kinetics of Di-, Tri-, and Tetrachlorobiphenyls by Goldfish After Dietary and Aqueous Exposure." Chemosphere 10:811-832.

Bruggeman, W.A., A. Opperhuizen, A. Wijbenga, and O. Hutzinger. 1984. "Bioaccumulation of Super-Lipophilic Chemicals in Fish." Toxicol. Environ. Chem.

7:173-189.

Bruland, K.W. 1980. "Oceanographic Distributions of Cadmium, Zinc, Nickel and Copper in the North Pacific." Earth and Planetary Science Letters 47:176-198.

Bruland, K.W. and R.P. Franks. 1983. "Mn, Zn, and Cd in the Western North Atlantic." In Trace Metals in Sea Water, eds. C.S. Wong, E. Boyle, K.W. Bruland, J.D. Burton, and E.D. Goldberg, pp. 395-414. Plenum Press, New York.

Brumsack, H.J. and J. M. Gieskes. 1983. "Interstitial Water Trace-Metal Chemistry of Laminated Sediments From the Gulf of California, Mexico." Marine Chemistry 14:89-106.

Bryan, G.A. 1961. "The Accumulation of Radioactive Caesium in Crabs." J. Mar. Biol. Ass. U.K. 41:551-575.

Bryan, G.W. 1963. "The Accumulation of ${ }^{137} \mathrm{Cs}$ by Brackish Water Invertebrates and Its Relation to Regulation of Potassium and Sodium." J. Mar. Biol. Assoc. U. K. 43:541-565.

Bryan, G.W. 1966. "The Metabolism of Zinc and ${ }^{65} \mathrm{Zn}$ in Crabs, Lobsters, and Freshwater Crayfish." Presented for Symp. Radioecological Concentration Processes, Stockholm, Sweden, Pergamon Press, Oxford.

Bryan, G.W. 1971. "The Effects of Heavy Metals (Other Than Mercury) on Marine and Estuarine Organisms." Proc. Roy. Soc. Lond. B. 177:389-410. 
Bryan, G.W. 1973. "The Occurrence and Seasonal Variation of Trace Metals in the Scallops Pecten maximus (L.) and Chlamys opercularis (L.)." J. Mar. Biol. Ass. U.K. 53:145-166.

Bryan, G.W. 1976. "Some Aspects of Heavy Metal Tolerance in Aquatic Organisms." In Effects of Pollution on Aquatic Organisms, ed. A.P.M. Lockwood, pp. 905-910. Cambridge Univ. Press, London.

Bryan, G.W. 1979. "Bioaccumulation of Marine Pollutants." Phil. Trans. Roy. Soc. Lond. 286:483-505.

Bryan, G.W. 1983. "Brown Seaweed, Fucus vesiculosus, and the Gastropou, Littorina littoralis, as Indicators of Trace-Metal Availability in Estuaries." The Science of the Total Environment 28:91104.

Bryan, G.W. 1985. "The Use of Multi-Estuary Comparisons to Elucidate Factors Governing the Bioaccumulation and Effects of Heavy Metals in Benthic Organisms." Estuaries 8(2B):99A.

Bryan, G.W:, P.E. Gibbs, L.G. Hummerstone, and G.R. Burt. 1989. "Uptake and Transformation of ${ }^{14} \mathrm{C}$-labelled Tributyltin Chloride by the Dog-Whelk, Nucella lapillus: Importance of Absorption From the Diet." Mar. Environ. Res. 28:241-245.

Bryan, G.W. and L.G. Hummerstone. 1971. "Adaptation of the Polychaete Nereis diversicolor to Estuarine Sediments Containing High Concentrations of Heavy Metals. 1. General Observations and Adaptation to Copper." J. Mar. Biol. Ass. U.K. 51:845-863.

Bryan, G.W. and L.G. Hummerstone. 1973a. "Adaptation of the Polychaete Nereis diversicolor to Manganese in Estuarine Sediments." J. Mar. Biol. Ass. U.K. 53:859-872.

Bryan, G.W. and L.G. Hummerstone. 1973b. "Adaptation of the Polychaete Nereis diversicolor to Estuarine Sediments Containing High Concentrations of Zinc and Cadmium." J. Mar. Biol. Ass. U.K. 53:839-857.

Bryan, G.W. and L.G. Hummerstone. 1978. "Heavy Metals in the Burrowing Bivalve Scrobicularia plana From Contaminated and Uncontaminated Estuaries." J. Mar. Biol. Ass. U.K. 58:401-419.

Bryan, G.W. and H. Uysal. 1978. "Heavy metals in the burrowing bivalve Scrobicularia plana from the Tamar Estuary in relation to environmental levels." J. Mar. Biol. Ass. U.K. 58:89-108.

Buhler, D.R. and M.E. Rasmusson. 1968. "The Oxidation of Drugs by Fishes." Comp. Biochem. Physiol. 25:223-226.

Buhler, D.R. and D.E. Williams. 1988. "The Rrole of Biotransformation in the Toxicity of Chemicals." Aquat. Toxicol. 11:19-28. 
Buhler, D.R. and D.E. Williams. 1989. "Enzymes Involved in Metabolism of PAH by Fishes and Other Aquatic Animals: Oxidative Enzymes (or phase I enzymes)." In Metabolism of Polycyclic Aromatic Hydrocarbons in the Aquatic Environment, ed. U. Varanasi, pp. 905-910. CRC Press, Boca Raton, Florida.

Bull, K.R., R.K. Murton, D. Osborn, P. Ward, and L. Cheng. 1977. "High Levels of Cadmium in Atlantic Seabirds and Sea-Skaters." Nature, Lond. 269:507-509.

Burkland, L.P., D.E. Armstrong, and A.W. Andren. 1985. "Partitioning Behavior of Polychlorinated Biphenyls." Chemosphere 14:1703-1716.

Burns, R.G. and V.M. Burns. 1981. "Authigenic Oxides." . In The Sea, Vol. 7 of The Oceanic Lithosphere, ed. E. Emiliani, pp. 875-914. John Wiley and Sons, New York.

Busch, D.A. and R.E. Loveland. 1975. "Tube-Worm-Relationships in Populations of Pectinaria gouldii (Polychaeta:Pectinariidae) from Barnegat Bay, New Jersey, USA." Mar. Biol. 33:255-264.

Byrd, J.T. 1988. "The Seasonal Cycle of Arsenic in Estuarine and Nearshore Waters of the South Atlantic Bight." Marine Chemistry 25:383-394.

Cadee, G.C. 1976. "Sediment Reworking by Arenicola marina on Tidal Flats in the Dutch Wadden Sea. Netherlands J. Sea Res. 10:440-460.

Cadee, G.C. 1979. "Sediment Reworking by the Polychaete Heteromastus filiformis on a Tidal Flat in the Dutch Wadden Sea.". Netherlands J. Sea Res. 13:441-456.

Cahn, P.H., J. Foehrenbach, and W. Guggino. 1977. "PCB Levels in Certain Organs of Some Feral Fish From New York State." In Physiological Mechanisms of Marine Pollution Toxicity, eds. W.B. Vernberg, A. Calabrese, F.P. Thurberg and F.J. Vernberg, pp. 905-910. Academic Press, New York.

Cain, D.J. and S.N. Luoma. 1985. "Copper and Silver Accumulation in Transplanted and Resident Clams (Macoma balthica) in South San Francisco Bay." Mar. Environ. Res. 15:115-135.

Cain, D.J. and S.N. Luoma. 1986. "Effect of Seasonally Changing Tissue Weight on Trace Metal Concentrations in the Bivalve Macoma balthica in San Francisco Bay." Mar. Ecol. Prog. Ser. 28:209-217.

Cain, D.J., J.K. Thompson, and S.N. Luoma. 1987. "The Effect of Differential Growth on Spatial Comparisons of Copper Content of a Bivalve Indicator." In Heavy Metals in the Environment. Vol. 2., pp. 905-910. CEP Consultants, Ltd., Edinburgh, UK,

Calambokidis, J., J. Mowrer, M.W. Beug, and S.H. Herman. 1979. "Selective Retention of Polychlorinated Biphenyl Components in the Mussel, Mytilus edulis." Arch. Environ. Contam. Toxicol. 8:299-308. 
Callister, S.M. and M.R. Winfrey. 1986. "Microbial Methylation of Mercury in Upper Wisconsin River Sediments." Water, Air, and Soil Pollution 29:453-465.

Cammen, L.M. 1980a. "The Significance of Microbial Carbon in the Nutrition of the Deposit Feeding Polychaete Nereis succinea." Mar. Biol. 61:9-20.

Cammen, L.M. 1980b. "A Method for Measuring Ingestion Rate of Deposit Feeders and Its Use with the Polychaete Nereis succinea. Estuaries 3:55-60.

Campbell, J.H. and R.D. Evans. 1987. "Inorganic and Organic Ligand Binding of Lead and Cadmium and Resultant Implications for Bioabailability." Science of the Total Environment 62:219227.

Campbell, P.G.C., A.G. Lewis, P.M. Chapman, A.A. Crowder, W.K. Fletcher, B. Imber, S.N Luoma, P.M. Stokes, and M. Winfrey. 1988. Biologically Available Metals in Sediments, National Research Council of Canada Publication No. NRCC 27694, Ottawa, Canada.

Capelli, R., V. Contardi, and G. Zanicchi. 1976. "Enquete Explorative Sur la Teneur en Metaux Lourds (Cd-Co-Cu-Cr-Mn-Ni-Pb) Dans Les Echantillons de Moules (Mytilus galloprovincialis L.)." Journal d'Etudes de Pollution Marine. XXV Congress of the International Commission for the Scientific Exploration of the Sea.

Capuzzo, J.D. and F.E. Anderson. 1973. "The Use of Modern Chromium Accumulations to Determine Estuarine Sedimentation Rates." Marine Geology 14:225-235.

Carey, D.A. 1983. "Particle Resuspension in the Benthic Boundary Layer Induced by Flow Around Polychaete Tubes." Can. J. Fish. Aquat. Sci. 40:301-308.

Carls, M.G. 1987. "Effects of Dietary and Water-Borne Oil Exposure on Larval Pacific Herring (Clupea harengus pallasi)." Mar. Environ. Res. 22:253-270.

Carlton, R.G. and M.H. Klug. 1990. "Spatial and Temporal Variations in Microbial Processes in Aquatic Sediments: Implications for the Nutrient Status of Lakes." In Sediments: Chemistry and Toxicity of In-Place Pollutants, eds. R. Baudo, J. Giesy, and H. Muntau, pp. 107-130. Lewis Publishers, Inc. Chelsea, Michigan.

Caron, G., I.H. Suffet, and T. Belton. 1985. "Effect of Dissolved Organic Carbon on the Environmental Distribution of Nonpolar Organic Compounds." Chemosphere 14:993-1000.

Carr, R.S., W.L. McCulloch and J.M. Neff. 1982. "Bioavailability of Chromium From a Used Chrome Lignosulfonate Drilling Mud to Five Species of Marine Invertebrates." Mar. Environm. Res. 6:189-203.

Carvalho, F.P. and S.W. Fowler. 1985. "Biokinetics of Plutonium, Americium, and Californium in the Marine Isopod Cirolana borealis, with Observations on its Feeding and Molting Behavior." Mar. Biol. 89:173-181. 
Carvalho, F.P. S.W. Fowler, and J. La Rosa. 1983. "Assimilation, Interorgan Transfer and Excretion of Americium in Two Teleost Fish." Mar. Biol. 77:59-66.

Cauwet, G. 1987. "Influence of Sedimentological Features on the Distribution of Trace Metals in Marine Sediments." Marine Chemistry 22:221-234.

Champ, M.A. and W.L. Pugh. 1987. "Tributyltin Antifouling Paints: Introduction and Overview." In Proceedings of the Oceans '87 Conference: The Ocean "An International Workplace" pp. 12961309. Marine Technology Society, Washington, D.C.

Chang, C.C.Y., J.A. Davis, and J.S. Kuwabara. 1987. "A Study of Metal Ion Adsorption at Low Suspended-Solid Concentrations." Estuarine, Coastal and Shelf Science 24:419-424.

Cheng, I.J. and G.R. Lopez. 1991. "Contributions of Bacteria and Sedimentary Organic Matter to the Diet of Nucula proxima, a Deposit-Feeding Protobranchiate Bivalve." Ophelia 34:157-170.

Cheng, L., V.F. Hodge, and R.A. Lewin. 1977. "Polonium and Plutonium in an Intertidal Food Chain." Nature, Lond. 269:795-796.

Chester, R., A. Thomas, F.J. Lin, A.S. Basaham, and G. Jacinto. 1988. "The Solid State Speciation of Copper in Surface Water Particles and Oceanic Sediments." Marine Chemistry 24:261292.

Chiou, C.T., D.E. Kile, T.I. Brinton, R.L. Malcolm, J.A. Leenheer, and P. MacCarthy. 1987. "A Comparison of Water Solubility Enhancements of Organic Solutes by Aquatic Humic Materials and Commercial Humic Acids." Environmental Science and Technology 21:1231-1234.

Chiou, C.T., V.H. Freed, D.W. Schmedding, and R.L. Kohnert. 1977. "Partition Coefficient and Bioaccumulation of Selected Organic Chemicals." Environ. Sci. Technol. 11:475-478.

Choi, W.-W. and Y. Chen. 1976. "Associations of Chlorinated Hydrocarbons with Fine Particles and Humic Substances in Nearshore Surficial Sediments." Environmental Science and Technology 10:782-786.

Christensen, D. 1984. "Determination of Substrates Oxidized by Sulfate Reduction in Intact Cores of Marine Sediments." Limnology and Oceanography 29:189-192.

Christian, R.R. and R.L. Wetzel. 1978. "Interactions Between Substrate, Microbes, and Consumers of Spartina in Estuaries." In Estuarine Interactions, ed. M.L. Wiley, pp. 93-114. Academic Press, New York.

Clark, K.E., F.A.P.C. Gobas, and D. Mackay. 1990. "Model of Organic Chemical Uptake and Clearance by Fish From Food and Water." Environ. Sci. Technol. 24:1203-1213.

Clark, K.E. and D. Mackay. 1991. "Dietary Uptake and Biomagnification of Four Chlorinated Hydrocarbons by Guppies." Environ. Toxicol. Chem. 10:1205-1217. 
Clark, J.R., J.M. Patrick, Jr. , J.C. Moore, and J. Forester. 1986. "Accumulation of Sediment-Bound PCBs by Fiddler Crabs." Bull. Environ. Contam. Toxicol. 36:571-578.

Clark, R. B. 1967. "Dynamics of Metazoan Evolution." Clarendon Press, Oxford, England. 313pp.

Clayton, J.R., S.P. Pavlou, and N.F. Breitner. 1977. "Polychlorinated Biphenyls in Coastal Marine Zooplankton: Bioaccumulation by Equilibrium Partitioning." Environmental Science and Technology 11:676-682.

Cleary, J.J. and A.R.D. Stebbing. 1987. "Organotin in the Surface Microlayer and Subsurface Waters of Southwest England." Marine Pollution Bulletin 18:238-246.

Cleland, G.B., B.G. Oliver, and R.A. Sonstegard. 1988. "Bioaccumulation of Halogenated Aromatic Hydrocarbons in C57B1/6 and DBA/2 Mice Following Consumption of Great Lakes Coho Salmon (Onchorhynchus kisutch)." Chemosphere 17:405-420.

Collier, R.W. and J.M. Edmond. 1984a. "Plankton Deposition and Trace Element Fluxes From the Surface Ocean." In Trace Metals in Seawater, ed. E.D. Goldberg, pp. 789-809. Plenum Press, New York.

Collier, R.W. and J. Edmond. 1984b. "The Trace Element Geochemistry of Marine Biogenic Particulate Matter." Progress in Oceanography 13:113-199.

Commito, J.A. 1982. "Importance of Predation by Infaunal Polychaetes in Controlling the Structure of a Soft-Bottom Community in Maine, USA." Mar. Biol. 68:77-81.

Compeau, D. and R. Bartha. 1984. "Methylation and Demethylation of Mercury Under Controlled Redox, pH, and Salinity Conditions." Applied and Environmental Microbiology 48:1203-1207.

Compeau, D. and R. Bartha. 1985. "Sulfate-Reducing Bacteria: Principal Methylators of Mercury in Anoxic Estuarine Sediments." Applied and Environmental Microbiology 50:498-502.

Connell, D.B., J.G. Sanders, G.F. Riedel, and G.R. Abbe. 1991. "Pathways of Silver Uptake and Trophic Transfer in Estuarine Organisms." Environ. Sci. Techn. 25:921-924.

Connolly, J.P. 1991. "Application of a Food Chain Model to Polychlorinated Biphenyl Contamination of the Lobster and Winter Flounder Food Chains in New Bedford Harbor." Environ. Sci. Technol. 25:760-770.

Connolly, J.P. and R. Tonelli. 1985. "Modelling Kepone in the Striped Bass Food Chain of the James River Estuary." Estuar. Cstl. Shelf Sci. 20:349-266.

Cook, D. 1971. "Depressions in Shallow Marine Sediments Made by Benthic Fish." J. Sed. Petrol. 41:577-602. 
Cooke, T.D. and K.W. Bruland. 1987. "Aquatic Chemistry of Selenium: Evidence of Biomethylation." Environmental Science and Technology 21:1214-1219.

Coombs, T.L. 1974. "The Nature of Zinc and Copper Complexes in the Oyster, Ostrea edulis." Mar. Biol. 28:1-10.

Coombs, T.L. 1979. "Cadmium in Marine Organisms." In The Chemistry, Biochemistry, and Biology of Cadmium, ed. M. Webb, pp. 93-139. Elsevier/North Holland Biomedical Press, Amsterdam.

Corner, E.D.S., R.P. Harris, C.C. Kilvington, and S.C.M. O'Hara. 1976a. "Petroleum Compounds in the Marine Food Web: Short-Term Experiments on the Fate of Naphthalene in Calanus." J. Mar. Biol. Assoc. U.K. 56:121-133.

Corner, E.D.S., R.P. Harris, K.J. Whittle, and P.R. Mackie. 1976b. "Hydrocarbons in Marine Zooplankton and Fish." In Effects of Pollutants on Aquatic Organisms, ed. A.P.M. Lockwood, pp. 71-106. Cambridge University Press, Cambridge, England.

Courtney, W. and W. Langston. 1978. "Uptake of Polychlorinated Biphenyl (Aroclor 1254) From Sediment and From Sea Water in Two Intertidal Polychaetes." Environ. Poll. 15:303-315.

Courtney, W.A.M. and W.J. Langston. 1980. "Accumulation of Polychlorinated Biphenyls in Turbot (Scophthalmus maximus) From Seawater and Food." Helg. Meeresunters 33:333-339.

Cowan, C.E., E.A. Jenne, and R.R. Kinnison. 1984. "A Methodology for Determining the Toxic Chemical Species of Copper in Toxicity Experiments and Natural Waters." In Trace Substances in Environmental Health - XVIII, ed. D.D. Hemphill, pp. 78-91. University of Missouri, Columbia, Missouri.

Cowan, C.E., E.A. Jenne, and R.R. Kinnison. 1986. "Methodology for Determining the Relationship Between Toxicity and Aqueous Speciation of a Metal." In Aquatic Toxicology and Environmental Fate: Ninth Volume, eds. T.M. Poston and R. Purdy, pp. 463-478. ASTM STP 921. American Society for Testing and Materials, Philadelphia.

Craig, P.J. 1980. "Metal cycles and biological methylation." In The Natural Environment and Biogeochemical Cycles, ed. O. Hutzinger, pp. 169-227. Springer-Verlag, New York.

Craig, P.J. and P.A. Moreton. 1984. "The Role of Sulfide in the Formation of Dimethyl Mercury in River and Estuary Sediments." Marine Pollution Bulletin 15:406-408.

Craig, P.J. and S. Rapsomanikis. 1984. "Formation of Tetramethyltin From Trimethyltin Precursors in Sediment Environments." Environmental Technology Letters 5:407-416.

Craig, P.J. and S. Rapsomanikis. 1985. "Methylation of Tin and Lead in the Environment: Oxidative Methyl Transfer as a Model for Environmental Reactions." Environmental Science and Technology 19:726-730. 
Cranston, R.E. and J.W. Murray. 1980. "Chromium Species in the Columbia River and Estuary." Limnology and Oceanography 25:1104-1112.

Cravedi, J.-P. and J. Tulliez. 1986a. "Metabolites of the Naphthenic Hydrocarbon Dodecylcyclohexane in Rainbow Trout Liver and Their Incorporation into Lipids." Arch. Environ. Contam. Toxicol. 15:207-213.

Cravedi, J.-P. and J. Tulliez. 1986b. "Metabolism of n-alkanes and Their Incorporation Into Lipids in the Rainbow Trout." Environ. Res. 39:180-187.

Crecelius, E.A. 1982. "The Significance of Atmospheric Input on Metal Concentrations in Oceanic Surface Water and Suspended Matter." Paper presented at the NATO Advanced Research Institute Symposium on Trace Metals in Sea Water, Erice, Italy.

Crecelius, E.A., J.M. Augenfeld, D.L. Woodruff, and J.W. Anderson. 1980. "Uptake of Trace Metals by the Clam Macoma inquinata From Clean and Oil-Contaminated Detritus." Bull. Environm. Contam. Toxicol. 25:337-344.

Crecelius, E.A., M.H. Bothner, and R. Carpenter. 1975. "Geochemistries of Arsenic, Antimony, Mercury, and Related Elements in Sediments of Puget Sound." Environmental Science and Technology 9:325-333.

Crecelius, E.A., J.T. Hardy, C.I. Gibson, R.L. Schmidt, C.W. Apts, J.M. Gurtisen, and S.P. Joyce. 1982. "Copper Biovavailability to Marine Bivalves and Shrimp: Relationship to Cupric Ion Activity." Mar. Envionm. Res. 6:13-26.

Crosby, S.A., D.R. Glasson, A.H. Cuttler, I. Butler, D.R. Turner, M. Whitfield, and G.E. Millward. 1983. "Surface Areas and Porosities of Fe (III)- and Fe(II)-Derived Oxyhydroxides." Environmental Science and Technology 17:709-713.

Crossland, N.O., D. Bennett, and C.J.M. Wolff. 1987. "Fate of 2,5,4'-Trichlorobiphenyl in Outdoor Ponds and its Uptake via the Food Chain Compared with Direct Uptake via the Gills in Grass Carp and Rainbow Trout." Ecotoxicol. Environ. Safe. 13:225-238.

Cunningham, P.A. 1979. "The Use of Bivalve Molluscs in Heavy Metal Pollution Research." In Marine Pollution: Functional Responses, eds. Vernberg, W.B., F.P. Thurberg, A. Calabrese, and F.J. Vernberg, pp. 905-910. Academic Press, New York.

Cunningham, P.A. 1986. "A Review of Toxicity Testing and Degradation Studies Used to Predict the Effects of Diflubenzuron (Dimilin ${ }^{\mathrm{Tx}}$ ) on Estuarine Crustaceans." Environ. Poll. 40(A):63-86.

Cunningham, P.A. and M.R. Tripp. 1973. "Accumulation and Depuration of Mercury in the American Oyster Crassostrea virginica." Mar. Biol. 20:14-19.

Cunningham, P.A. and M.R. Tripp. 1975a. "Factors Affecting Accumulation and Removal of Mercury From Tissues of the American Oyster, Crassostrea virginica." Mar. Biol. 31:311-319. 
Cunningham, P.A. and M.R. Tripp. 1975b. "Accumulation, Tissue Distribution, and Elimination of ${ }^{203} \mathrm{HgCl}$ in the Tissues of the American Oyster, Crassostrea virginica." Mar. Biol. 31:321-334.

Cutter, G.A. 1978. "Species Determination of Selenium in Natural Waters." Analytica Chimica Acta 98:59-66.

Cutter, G.A. 1985. "Determination of Selenium Speciation in Biogenic Particles and Sediments." Analytical Chemistry 57:2951-2955.

Cutter, G. A. and K.W. Bruland. 1984. "The Marine Biogeochemistry of Selenium: A ReEvaluation." Limnology and Oceanography 29:1179-1192.

Dale, N.G. 1974. "Bacteria in Intertidal Sediments: Factors Related to Their Distribution." Limnol. Oceanogr. 19:509-518.

Dales, N.C. 1974. "Bacteria in Intertidal Sediments: Factors Related to Their Destribution." Limnology and Oceanography 19:509-518.

Dalland, C., E. Schumacher, and M.L. Sohn. 1986. "The Adsorption of Organomercury Compounds from Seawater onto Sedimentary Phases. In Organic Marine Geochemistry, pp. 369-381. American Chemical Society, Washington, D.C.

Darnell, R.M. 1961. "Trophic Spectrum of an Estuarine Community, Based on Studies of Lake Pontchartrain, Louisiana." Ecol. 42:553-568.

Dauble, D.D., W.E. Fallon, R.M. Bean, R.H. Gray, and L.J. Felice. 1983. "Retention and Toxicity of a Coal Liquid in Artificially Contaminated Sediments." Water Air Soil Poll. 20:391-399.

Dauby, P. 1989. "The Stable Carbon Isotope Ratios in Benthic Food Webs of the Gulf of Calvi, Corsica." Cont. Shelf Res. 9:181-195.

Dauer, D.M. 1983. "Functional Morphology and Feeding Behavior of Scolelepis squamata (Polychaeta:Spionidae)." Mar. Biol. 77:279-285.

Dauer, D.M. 1985. "Functional Morphology and Feeding Behavior of Paraprionospio pinnata (Polychaeta: Spionidae)." Mar. Biol. 85:143-151.

Dauer, D.M., R.M. Ewing, G.H. Tourtellotte, and H.R. Barker, Jr. 1980. "Nocturnal Swimming of Scolecolepides viridis (Polychaeta: Spionidae)." Estuaries 3:142-149.

Dauer, D.M., C.A. Maybury, and R.M. Ewing. 1981. "Feeding Behavior and General Biology of Several Spionid Polychaetes From the Chesapeake Bay." J. Exp. Mar. Biol. Ecol. 54:21-38.

Davies, R.P. and A.J. Dobbs. 1984. "The Prediction of Bioconcentration in Fish." Water Res. 18:1253-1264. 
Davies-Colley, R.J., P.O. Nelson, and K.J. Williamson. 1984. "Copper and Cadmium Uptake by Estuarine Sediment Phases." Environmental Science and Technology 18:491-499.

Davies-Colley, R.J., P.O. Nelson, and K.J. Williamson. 1985. "Sulfide Control of Cadmium and Copper Concentrations in Anaerobic Estuarine Sediments." Marine Chemistry 16:173-186.

Davis, J.A. and J.O. Leckie. 1980. "Surface Ionization and Complexation at the Oxide/Water Interface. III. Adsorption of Anions." Journal of Colloid and Interface Science 74:32-43.

Dawson, G.W., J.A. McNeese, M.J. Schneider, G.E. Pierce, and B.S. Ausmus. 1978. "Properties of Kepone." In The Feasibility of Mitigating Kepone Contamination in the James River Basin (Appendix A), ed. G.W. Dawson, pp. 905-910. Pacific Northwest Laboratory, Battelle Memorial Institute to the U.S. Environmental Protection Agency,

Dean, D. 1978a. "Migration of the Sandworm Nereis virens During Winter Nights." Mar. Biol. 45:165-173

Dean, D. 1978b. "The Swimming of Bloodworms (Glycera spp.) at Night with Comments on Other Species." Mar. Biol. 48:99-104.

De Kock, A.C. and D.A. Lord. 1989. "Predicting the Fate and Effects of Chlorinated Hydrocarbons in a Coastal Marine System - South-East Indian Ocean." Intern. J. Environ. Anal. Chem. 36:133138.

De Wolf, P. 1975. "Mercury Content of Mussels from West European Coasts." Mar. Pollut. Bull. 6:61-63.

Dexter, R. and S. Pavlou. 1978. "Mass Solubility and Aqueous Activity Coefficients of Stable Organic Chemicals in the Marine Environment.: Polychlorinated Biphenyls." Mar. Chem. 6:41-48.

Dillon, T.M. 1982. "Dietary Accumulation of Dimethylnaphthalene by the Grass Shrimp Palaemonetes pugio under Stable and Fluctuating Temperatures." Bull. Environ. Contam. Toxicol. 28:149-153.

Di Toro, D.M. 1985. "A Particle Interaction Model of Reversible Organic Chemical Sorption." Chemosphere 14:1503-1538.

Di Toro, D.M. 1988. A Review of the Data Supporting the Equilibrium Partitioning Approach to Establishing Sediment Quality Criteria. Proc. Nat. Res. Council Marine Board Symposium: Workshop on Contaminated Marine Sediments.

Di Toro, D.M. and L.M. Horzempa. 1982. "Reversible and Resistant Components of PCB Adsorption-Desorption: Isotherms." Environmental Science and Technology 16:594-602.

Di Toro, D.M., L.M. Horzempa, M.M. Casey, and W. Richardson. 1982. "Reversible and Resistant Components of PCB Adsorption-Desorption: Adsorbent Concentration Effects." Journal of Great Lakes Research 8:336-349. 
Di Toro, D.M., J.S. Jeris, and D. Claria. 1985. "Diffusion and Partitioning of Hexachlorobiphenyl in Sediments." Environmental Science and Technology 19:1169-1176.

Dixit, D. and J.W. Anderson. 1977. "Distribution of Naphthalenes Within Exposed Fundulus similis and Correlations with Stress Behaviour." In Proceeding 1977 Oil Spill Conference Prevention, Behavior, Control, Cleanup), pp. 633-636. American Petroleum Institute, Washington, D.C.

Djangmah, J.S. 1970. "The Effects of Feeding and Starvation on Copper in the Blood and Hepatopancreas and on the Blood Proteins of Crangon vulgaris (Fabricius)." Comp. Biochem. Physiol. 32:709-731.

Dobbs, F.C. 1983. "Monitoring Defecation Activity of Infaunal Deposit Feeders." Mar. Ecol. Progr. Ser. 12:47-50.

Dobroski, C.J. and C.E. Epifanio. 1980. "Accumulation of Benzo[a]pyrene in a Larval Bivalve via Trophic Transfer." Can. J. Fish. Aquat. Sci. 37:2318-2322.

Donard, O.F.X. and J.H. Weber. 1985. "Behavior of Methyltin Compounds Under Simulated Estuarine Conditions." Environmental Science and Technology 19:1104-1110.

Dossis, P. and L.J. Warren. 1980. "Distribution of Heavy Metals Between the Minerals and Organic Debris in a Contaminated Marine Sediment." In Contaminants and Sediments, ed. R.A. Baker, pp. 119-139. Ann Arbor Science Publishers, Ann Arbor, MI.

Doucette, W.J. and A.W. Andren. 1987. "Correlation of Octanol/Water Partition Coefficients and Total Molecular Surface Area for Highly Hydrophobic Polyaromatic Compounds." Environ. Sci. Technol. 21:699-707.

Douglas, G.S., G.L. Mills, and J.G. Quinn. 1986. "Organic Copper and Chromium Complexes in the Interstitial Waters of Narragansett Bay Sediments." Marine Chemistry 19:161-174.

Drifmeyer, J.E. 1980 . "Uptake of ${ }^{65_{\mathrm{Zn}}}$ by Eelgrass Zostera marina L." Sci. Total Environ. 16:263-266.

Drifmeyer, J.E., Thayer, G.W., Cross, F.A. and J.C. Zieman. 1980. "Cycling of Mn, Fe, Cu and Zn by Eelgrass, Zostera marina L." Amer. J. Bot. 67:1089-1096. 
Duncan, D.B. 1987. "Burrow Structure and Burrowing Activity of the Funnel-Feeding Enteropneust Balanoglossus aurantiacus in Bogue Sound, North Carolina." Mar. Ecol. 8:75-95.

Duncan, M.J. 1984. "Levels of Contaminants in Bivalve Molluscs in British Columbia. Regional Program Rept. 83-18. Dept. of Environ., Environ. Protection Serv., Pac. Reg., Canada.

Dunn, B.P. and H.F. Stich. 1976. "Release of the Carcinogen Benzo(a)pyrene From Environmentally Contaminated Mussels." Bulletin of Environmental Contomination and Toxicology 14:398-401.

Dunnivant, F.M. and A.W. Elzerman. 1988. "Aqueous Solubility and Henry's Law Constant Data for PCB Congeners for Evaluation of Quantitative Structure-Property Relationships (QSPRs)." Chemosphere 17:525-541.

Dunton, K.H., S.M. Saupe, A.N. Golikov, D.M. Schell, and S.V. Schonberg. 1989. "Trophic Relationships an Isotopic Gradients Among Arctic and Subarctic Marine Fauna." Mar. Ecolo. Prog. Ser. 56:89-97.

Durbin, E.G., A.G. Durbin, R.W. Langton, and R.E. Bowman. 1983. "Stomach Contents of Silver Hake, Merluccius bilinearis, and Atlantic Cod, Gadus morhua, and Estimation of Their Daily Rations." Fish. Bull. U.S. 83:437-454.

Eary, L.E. and D. Rai. 1987. "Kinetics of Chromium (III) Oxidation to Chromium (VI) by Reaction with Manganese Dioxide." Environmental Science and Technology 21:1187-1193.

Eary, L.E. and D. Rai. 1988. "Chromate Removal from Aqueous Wastes by Reduction with Ferrous Iron." Environmental Science and Technology 22:972-977.

Eastcott, L., W.Y. Shiu, and D. Mackay. 1988. "Environmentally Relevant Physical-Chemical Properties of Hydrocarbons: A Review of Data and Development of Simple Correlations." Oil \& Chemical Pollution 4:191-216.

Eaton, A. 1976. "Marine Geochemistry of Cadmium." Marine Chemistry 4:141-154.

Eaton, J.G., V.R. Mattson, L.H. Mueller, and D.K. Tanner. 1983. "Effects of Suspended Clay on Bioconcentration of Kelthane ${ }^{\mathrm{Tx}}$ in Fathead Minnows." Arch. Environ. Contam. Toxicol. 12:439-445.

Eckman, J.E., A.R.M. Nowell, and P.A. Jumars. 1981. "Sediment Destabilization by Animal Tubes." J. Mar. Res. 39:361-374.

Edmonds, J.S. and K.A. Francesconi. 1981a. "Arseno-Sugars From Brown Kelp (Ecklonia radiata) as Intermediates in Cycling of Arsenic in a Marine Ecosystem." Nature Lond. 289:602-604.

Edmonds, J.S. and K.A. Francesconi. 1981b. "The Origin and Chemical Form of Arsenic in the School Whiting." Mar. Pollut. Bull. 12:92-96. 
Eganhouse, R.P. and J.A. Calder. 1976. "The Solubility of Medium Molecular Weight Aromatic Hydrocarbons and the Effects of Hydrocarbon Co-Solutes and Salinity." Geochimica et Cosmochimica Acta 40:555-561.

Eganhouse, R.P., D.R. Young, and J.N. Johnson. 1978. "Geochemistry of Mercury in Palos Verdes Sediments." Environmental Science and Technology 12:1151-1157.

Ekelund, R. 1989. "Bioaccumulation and Biomagnification of Hydrophobic Persistent Compounds as Exemplified by Hexachlorobenzene." In Chemicals in the Aquatic Environment. Advanced Hazard Assessment, ed. L. Landner, pp. 128-149. Springer Verlag, Berlin.

Ekelund, R., A. Gromo, M. Bergren, L. Renberg, and C. Wahlberg. 1987. "Influence of Suspended Solids on Bioavailability of Hexachlorobenzene and Lindane to the Deposit-Feeding Marine Bivalve, Abra nitida (Muller)." Bull. Environ. Contam. Toxicol. 38:500-508.

Elder, J.F. and P.V. Dresler. 1988. "Accumulation and Bioconcentration of Polycyclic Aromatic Hydrocarbons in a Nearshore Estuarine Environment Near a Pensacola (Florida) Creosote Contamination Site." Environ. Poll. 49:117-132.

Elderfield, H. 1970. "Chromium Speciation in Seawater." Earth and Planetary Science Letters 9:10-16.

Elderfield, H., R.J. McCaffrey, N. Luedtke, M. Bneder, and V.W. Truesdale. 1981. "Chemical Diagenesis in Narragansett Bay Sediments." American Journal of Science 281:1021-1055.

Ellgehausen, H., J.A. Guth, and H.O. Esser. 1980. "Factors Determining the Bioaccumulation Potential of Pesticides in the Individual Compartments of Aquatic Food Chains." Ecotoxicol. Environ. Safety 4:134-150.

Elliott, J.E., A.M. Scheuhammer, F.A. Leighton, and P.A. Pearce. 1992. "Heavy Metal and Metallothionein Concentrations in Atlantic Canadian Seabirds." Arch. Environ. Contam. Toxicol 22:63-73.

Emerson, R.R., D.F. Soule, M. Oguri, K.Y. Chen, and J. Lu. 1976. "Heavy Metal Concentrations in Marine Organisms and Sediments Collected Near an Industrial Waste Outfall. In Proceedings of the International Conference on Environmental Sensing and Assessment, Vol. 1, pp. 1-5. Las Vegas, Nevada.

Eng, G., O. Bathersfield, and L. May. 1986. "Mössbauer Studies of the Speciation of Tributyltin Compounds in Seawater and Sediment Samples." Water, Air, and Soil Pollution 27:191-197. 
Engel, D.W., W.G. Sunda, and B.A. Fowler. 1981. "Factors Affecting Trace Metal Uptake and Toxicity to Estuarine Organsisms. I. Environmental Parameters." In Biological Monitoring of Marine Pollutants, eds. Vernberg, F.J., A. Calabrese, F.D. Thurberg, and W.B. Vernberg, pp. 905910. Academic Press, New York.

Engelhardt, F.R. 1978. "Petroleum Hydrocarbons in Ringed Seals, Phoca hispida, Following Experimental Oil Exposure." In Proceedings of the Conference on Assessment of Ecological Impacts of Oil Spills, pp.614-628: American Institute of Biological Sciences, Washington, D.C.

Estes, T.J., R.V. Shah, and V.L. Vilker. 1988. "Adsorption of Low Molecular Weight Halocarbons by Montmorillonite." Environmental Science and Technology 27:377-381.

Evans, D.W., N.H. Cutshall, F.A. Cross, and D.A. Wolfe. 1977. "Manganese Cycling in the Newport River Estuary, North Carolina." Estuarine and Coastal Marine Science 5:71-80.

Evans, M.S., G.E. Noguchi, and C.P. Price. 1991. "The Biomagnification of Polychlorinated Biphenyls, Toxaphene, and DDT Compounds in a Lake Michigan Offshore Food Web." Arch. Environ. Contam. Toxicol. 20:87-93.

Fabris, G.J., Harris, J.E. and J.D. Smith. 1982. "Uptake of Cadmium by the Seagrass Heterozostera tasmanica from Corio Bay and Western Port, Victoria." Aust. J. Mar. Freshw. Res. 33: 829-836.

Fager, E. 1964. "Marine Sediments: Effects of a Tube-Building Polychaete." Science. 143:356359.

Fagerstrom, R. and A. Jernelov. 1971. "Formation of Methyl Mercury From Pure Mercuric Sulfide in Aerobic Organic Sediment." Water Research 5:121-122.

Fagerstrom, R. and A. Jernelov. 1972. "Some Aspects of the Quantitative Ecology of Mercury." Water Reaearch 6:1193-1202.

Fair, P.H. and A.R. Fortner. 1987. "Effect of Ingested Benzo[a]pyrene and Cadmium on Tissue Accumulation, Hydroxylase Activity, and Intestinal Morphology of the Balck Sea Bass, Centropristis striata." Environ. Res. 42:185-195.

Fair, P.H. and L.V. Sick. 1983. "Accumulation of Naphthalene and Cadmium After Simultaneous Ingestion by Black Sea Bass, Centropristis striata." Arch. Environ. Contam. Toxicol. 12:551-557.

Falandysz, J. 1982. "Chlorinated Hydrocarbons in Salmon Netted in Gdansk Bay, Baltic Sea (Poland)." Meeresforsch 29:219-224.

Fallon, R.D. 1987. "Sedimentary Sulfides in the Nearshore Georgia Bight." Estuarine, Coastal and Shelf Science 25:607-619.

Faraday, W.E. and A.C. Churchill. 1979. "Uptake of Cadmium in the Eelgrass Zostera marina." Mar. Biol. 53: 293-298. 
Farrington, J.W. 1986. "Fossil Fuel Aromatic Hydrocarbon Biogeochemistry in the Marine Environment." In Strategies and Advanced Techniques for Marine Pollution Studies: Mediterranean Sea, eds. C.S. Giam and H.J.-M. Dou, pp. 113-142. NATO ASI Series Vol. G9. Springer-Verlag, Berlin.

Farrington, J.W., A.C. Davis, N.M. Frew, and K.S. Rabin. 1982. "No. 2 Fuel Oil Compounds in Mytilus edulis. Retention and Release After an Oil Spill." Mar. Biol.

66:15-26.

Farrington, J.W. and J. Westall. 1986. "Organic Chemical Pollutants in the Oceans and Groundwater: A Review of Fundamental Chemical Properties and Biogeochemistry." In The Role of the Oceans as a Waste Disposal Option, ed. G. Kullenberg, pp. 361-425D. Reidel Publishing Co., New York.

Fauchald, K. and P.A. Jumars. 1979. "The Diet of Worms: A Study of Polychaete Feeding Guilds." Oceanogr. Mar. Biol. Ann. Rev. 17:193-284.

Faust, S.D. 1977. "Chemical Mechanisms Affecting the Fate of Organic Pollutants in Natural Aquatic Environments." In Fate of Pollutants in the Air and Water Environments, ed. J. Suffed, pp.317-365. John Wiley \& Sons, New York.

Featherstone, R.P. and M.J. Risk. 1977. "Effect of Tube-Building Polychaetes on Intertidal Sediments of the Minas Basin, Bay of Fundy." J. Sed. Petrol. 47:446-450.

Feijtel, T.C., R.D. DeLaune, and W.H. Patrick, Jr. 1988. "Biogeochemical Control on Metal Distribution and Accumulation in Louisiana Sediments." Journal of Environmental Quality 17:88-94.

Feller, R.J., G.L. Taghon, E.D. Gallagher, G.E. Kenny, and P.A. Jumars. 1979. "Immunological Methods for Food Web Analysis in a Soft-Bottom Benthic Community." Mar. Biol. 54:61-74.

Fenchel, T. 1969. "The Ecology of Marine Microbenthos IV: Structure and Function of the Benthic Ecosystem, Its Chemical and Physical Factors, and the Microfauna Communities with Special Reference to the Ciliated Protozoa." Ophelia. 6:1-182.

Fenchel, T., L.H. Kofoed, and A. Lappalainen. 1975. "Particle Size-Selection of Two DepositFeeders: The Amphipod Corophium volutator and the Prosobranch Hydrobia ulvae." Mar. Biol. 30:119-128.

Ferguson, J.C. 1964a. "Nutrient Transport in Starfish. I. Properties of the Coelomic Fluid." Biol. Bull. 126:33-53.

Ferguson, J.C. 1964b. " Nutrient Transport in Starfish. II. Uptake of Nutrients by Isolated Organs." Biol. Bull. 126:391-406.

Ferguson, J.C. 1979. "Ingestion and Assimilation of Dissolved Amino Acids by a Starfish." Comp. Biochem. Physiol. 62A:343-346. 
Ferraro, S.P., H. Lee II, L.M. Smith, R.J. Ozretich, and D.T. Specht. 1991. "Accumulation Factors for Eleven Polychlorinated Biphenyl Congeners." Bull. Environ. Contam. Toxicol. 46:276-283.

Findlay, S. and K. Tenore. 1982. "Nitrogen Source for a Detritivore: Detritus Substrate Versus Associated Microbes." Science 218:371-373.

Fisher, D.J. and J.R. Clark. 1990. "Bioaccumulation of Kepone by Grass Shrimp (Palaemonetes pugio): Importance of Dietary Accumulation and Food Ration." Aquat. Toxicol. 17:167-186.

Fisher, D.J., J.R. Clark, M.H. Roberts, Jr., J.P. Connolly, and L.H. Mueller. 1986. "Bioaccumulation of Kepone by Spot (Leiostomus xanthurus): Importance of Dietary Accumulation and Ingestion Rate." Aquat. Toxicol. 9:161-178.

Fitzsimons, Gail. 1965. "Feeding and Tube-Building in Sabellastarte magnifica (Shaw) (Sabellidae: Polychaeta)." Bull. Mar. Sci. 15:642-671.

Foda, A. J.H. Vandermeulen, and J.J. Wrench. 1983. "Uptake and Conversion of Selenium by a Marine Bacterium." Canadian Journal of Fisheries and Aquatic Science 40 (Supplement), pp. 215220.

Folmar, L.C., H.O. Sanders, and A.M. Julin. 1979. "Toxicity of the Glyphosate and Several of its Formulations to Fish and Aquatic Invertebrates." Arch. Environ. Contam. Toxicol. 8:269-278.

Forbes, T.L. and G.R. Lopez. 1987. "The Allometry of Deposit Feeding in Capitella Species I (Polychaeta:Capitellidae): The Role of Temperature and Pellet Weight in the Control of Egestion." Biol. Bull. 172:187-201.

Förstner, U. 1980. "Inorganic Pollutants, Particularly Heavy Metals in Estuaries." In Chemistry and Biogeochemistry of Estuaries, eds. E. Olausson and I. Cato, pp. 905-910. John Wiley \& Sons Ltd.

Förstner, U. and P. Stoffers. 1981. "Chemical Fractionation of Transition Elements in Pacific Pelagic Sediments." Geochimica et Cosmochimica Acta 45:1141-1146.

Förstner, U. and G.T.W. Wittmann. 1981. Metal Pollution in the Aquatic Environment. Second Revised Edition. Springer-Verlag, Berlin.

Fossato, V.U. and W.J. Canzonier. 1976. "Hydrocarbon Uptake and Loss by the Mussel Mytilus edulis." Mar. Biol. 36:243-250.

Foster, G.D., S.M. Baksi, and J.C. Means. 1987. Bioaccumulation of Trace Organic Contaminants From Sediment by Baltic Clams (Macoma balthica) and Soft-Shell Clams (Mya arenaria)." Environ. Toxicol. Chem. 6:969-976.

Foster, G.D. and D.A. Wright. 1988. "Unsubstituted Polynuclear Aromatic Hydrocarbons in Sediments, Clams, and Clam Worms from Chesapeake Bay." Mar. Poll Bull. 19:459-465. 
Foster-Smith, R.L. 1975. "The Effect of Concentration of Suspension on the Filtration Rates and Pseudofaecal Production for Mytilus edulis L., Cerastoderma edule (L.) and Venerupis pullastra." J. Exp. Mar. Biol. Ecol. 17:1-22.

Foster-Smith, R.L. 1978. "The Effect of Concentration of Suspension on the Filtration Rates and Pseudofaecal Production for Mytilus edulis L., Cerastoderma edule (L.) and Venerupis pullastra." J. Exp. Mar. Biol. Ecol. 17:1-22.

Foureman, G.L. 1989. "Enzymes Involved in Metabolism of PAH by Fishes and Other Aquatic Animals: Hydrolysis and Conjugation Enzymes (or Phase II Enzymes)." In Metabolism of Polycyclic Aromatic Hydrocarbons in the Aquatic Environment, ed. U. Varanasi, pp. 905-910. CRC Press, Boca Raton, Florida.

Foureman, G.L., O. Hernandez, A. Bhatia, and J.R. Bend. 1987. "The Stereoselectivity of Four Hepatic Glutathione-S-Transferases Purified From a Marine Elasmobranch with Several K-Region Polycyclic Arene Oxide Substrates." Biochim. Biophys. Acta 914:217-219.

Fowler, B.A., N.G. Carmichael, and K.S. Squibb. 1981. "Factors Affecting Trace Metal Uptake and Toxicity to Estuarine Organisms. II. Cellular Mechanisms." In Biological Monitoring of Marine Pollutants, eds. F.J. Vernberg, A. Calabrese, F.P. Thornberg, W.B. Vernberg, pp. 905-910. Academic Press, New York.

Fowler, B.A., D.A. Wolfe, and W.F. Hettler. 1975. Mercury and Iron Uptake by Cytosomes in Mantle Epithelial Cells of Quahog Clams (Mercenaria mercenaria) Exposed to Mercury." J. Fish. Res. Bd. Canada. 32:1767-1775.

Fowler, S.W. 1982. "Biological Transfer and Transport Processes." In Pollutant Transfer and Transport in the Sea. Vo. II, ed. G. Kullenberg, pp. 1-65. CRC Press, Boca Ratan, Florida.

Fowler, S.W. 1990. "Critical Review of Selected Heavy Metals and Chlorinated Hydrocarbon Concentrations in the Marine Environment." Mar. Environ. Res. 29:1-64.

Fowler, S.W., S.R. Aston, G. Benayoun, and P. Parsi. 1983. "Bioavailability of Technetium From Artificially Labelled North-East Atlantic Deep-Sea Sediments." Mar. Environ. Res. 8:87-100.

Fowler, S.W. and G. Benayoun. 1976. "Selenium Kinetics in Marine Zooplankton." Mar. Sci. Comm. 2:43-67.

Fowler, S.W. and M. Heyraud. 1980. "Biologically-Transformed Zinc and its Availability for Bioaccumulation by Marine Organisms." In Management of Environment, ed. B. Patel, pp. 905-910. Wiley Eastern Limited, New Delhi, India.

Fowler, S., M. Heyraud, and T.M. Beasley. 1976. Experimental Studies on Plutonium Kinetics in Marine Biota, No. 54, pp. 905-910. Internatl. Atomic Energy Agency, Vienna.

Fowler, S.W., M. Heyraud, and J. La Rosa. 1978a. "Factors Affecting Methyl and Inorganic Mercury Dynamics in Mussels and Shrimp." Mar. Biol. 46:267-276. 
Fowler, S.W., M. Heyraud, and J. La Rosa. 1978a. "Factors Affecting Methyl and Inorganic Mercury Dynamics in Mussels and Shrimp." Mar. Biol. 46:267-276.

Fowler, S.W. and B. Oregioni. 1976. "Trace Metals in Mussels From the North-West Mediterranean." Mar. Poll. Bull. 7:26-29.

Fowler, S.W., G.G. Polikarpov, D.L. Elder, P. Parsi, and J.-P. Villeneuve. $1978 b$.

"Polychlorinated Biphenyls: Accumulation From Contaminated Sediments and Water by the Polychaete Nereis diversicolor." Mar. Biol. 48:303-309.

Fowler, S.W., L.F. Small, and J.M. Dean. 1971. "Experimental Studies on Elimination of Zinc-65, Cesium-137 and Cerium-144 by Euphausiids." Mar. Biol. 8:224-231.

Frazier, J.M. 1975. "Dynamics of Metals in the American Oyster, Crassostrea virginica. I. Seasonal Effects." Ches. Sci. 16:162-187.

Fréchette, M., C.A. Butman, and W.R. Geyer. 1989. "The Importance of Boundary-Layer Flows in Supplying Phytoplankton to the Benthic Suspesnion Feeder, Mytilus edulis L. Limnol. Oceanogr. 34:19-36.

Frazier, J.M. 1976. "Dynamics of Metals in the American Oyster, Crassostrea virginica. II. Environmental Effects." Ches. Sci. 16:188-197.

Frazier, J.M. 1979. "Bioaccumulation of Cadmium by Marine Organisms." Environ. Health Persp. 28:75-79.

Freeman, M.C., J. Aggett, and G. O'Brien. 1986. "Microbial Transformation of Arsenic in Lake Ohakuri, New Zealand." Water Research 20:283-294.

Freidman, G.M., and J.E. Sanders. 1978. Principles of Sedimentology. John Wiley \& Sons, New York.

Frenet, M. and A. Alliot. 1985. "Comparative Bioaccumulation of Metals in Palaemonetes varians in Polluted and Non-Polluted Environments." Mar. Environ. Res. 17:19-44.

Frithsen, J.B. 1984. "Metal Incorporation by Benthic Fauna: Relationships to Sediment Inventory." Est. Coast. Shelf Sci. 19:523-539.

Frithsen, J.B. and P.H. Doering. 1986. "Active Enhancement of Particle Removal From the Water Column by Tentaculate Benthic Polychaetes." Ophelia. 25:169-182.

Froelich, P.N., G.P. Klinkhammer, M.I. Bender, N.A. Luedke, B. Hartmann, and V. Maynard. 1979. "Early Oxidation of Organic Matter in Pelagic Sediments of the Eastern Equitorial Atlantic: Suboxic Diagenesis." Geochimica et Cosmochimica Acta 43:1075-1090.

Fukai, R.M. 1969. "Valency State of Chromium in Sea Water." Nature (London) 213:901 
Fujuki, M. 1980. "Methylmercury Accumulation in Plankton and Fish." In Contaminants and Sediments. Vol. II: Analysis, Chemistry, Biology, ed. R.A. Baker, pp. 905-910. Ann Arbor, Michigan.

Gaillard, J.-F., C. Jeandel, G. Michard, E. Nicolas, and D. Renard. 1986. "Interstitial Water Chemistry of Villefranche Bay Sediments: Trace Metal Diagenesis." Marine Chemistry 18: 233-247.

Galassi,, S. and M. Migliavacca. 1986. "Organochlorine Residues in River Po sediment: Testing the Equilibrium Condition with Fish." Ecotoxicol. Environ. Safety 12:120-126.

Galtsoff, P. 1964. "The American Oyster, Crassostrea virginica." Fish. Bull. Fish. Wildl. Serv. U.S. $64: 1-480$.

Gapon, J.N. 1947. "Specific Surface Area of Soil Humus." Kolloid Zeitschrift 9:329-334.

Gardiner, J. 1974. "The Chemistry of Cadmium in Natural Water - II. The Adsorption of Cadmium on River Muds and Naturally Occurring Solids." Water Research 8:157-164.

Gardner, D. 1975. "Observations on the Distribution of Dissolved Mercury in the Ocean." Marine Pollution Bulletin 6:43-46.

Gardner, L.R. 1974. Organic Versus Inorganic Trace Metal Complexes in Sulfidic Marine Waters Some Speculative Calculations Based on Available Stability Constants." Geochimica et Cosmochimica Acta 38:1297-1302.

Gardner, L.R. 1979. "A Preliminary Comprehensive Model for the Chemistry of Sulfidic Marine Sediments." In Chemical Modelling in Aqueous Systems. Speciation, Sorption, Solubility, and Kinetics, ed. E.A. Jenne, pp. 795-814. ACS Symposium Series 93, American Chemical Society, Washington, D.C.

Gardner, W.S., P.F. Landrum, and J.F. Cavaletto. 1990. "Lipid Partitioning and Distribution of Benzo[a]pyrene and Hexachlorobiphenyl in Lake Michigan Pontiporeia hovi and Mysis relicta." Environ. Toxicol. Chem. 9:1269-1278.

Gardner, W.S., H.L. Windom, J.A. Stephens, F.E. Taylor, and R.R. Stickney. 1975. "Concentrations of Total Mercury and Methyl Mercury in Fish and Other Coastal Organisms: Implications to Mercury Cycling." In Mineral Cycling in Southeastern Ecosystems, Proceedings of a Symposium, ed. F.G. Howell, J.B. Gentry, and M.H. Smith, pp. 268-278. Technical Information Center, Office of Pollution Assessment, U.S. Energy Research and Development Administration, Washington, DC.

Garnas, R.L. and D.G. Crosby. 1979. "Comparative Metabolism of Parathion by Intertidal Invertebrates." In Marine Pollution: Functional Responses, eds. W.B. Vernberg, F.P. Thurberg, A. Calabrese, and F.J. Vernberg, Academic Press, New York. 
Gavis, J. and J.F. Ferguson. 1972. "The Cycling of Mercury Through the Environment." Water Research 6:989-1008.

Gearing, P.J., J.N. Gearing, J.T. Maughan, and C.A. Oviatt. 1991. "Isotopic Distribution of Carbon From Sewage Sludge and Eutrophication in the Sediments and Food Web of Estuarine Ecosystems." Environ. Sci. Technol: 25:295-301.

George, J.D. 1964. "Organic Matter Available to the Polychaete Cirriformia tentaculata (Montagu), Living in an Intertidal Mudflat." Limnol. Oceanogr. 9:452-454.

George, S.G. and T.L. Coombs. 1977. "The Effects of Chelating Agents on the Uptake and Accumulation of Cadmium by Mytilus edulis." Mar. Biol. 39:261-268.

George, S.G., B.J.S. Pirie, and T.L. Coombs. 1975. "Absorption, Accumulation, and Excretion of Iron-Protein Complexes by Mytilus edulis (L.)." In Proceedings of the Conference on Heavy Metals in the Environment, pp. 887-900. Toronto, Ontario, Canada.

George, S.G., B.J.S. Pirie, and T.L. Coombs. 1976. "The Kinetics of Accumulation and Excretion of Ferric Hydroxide in Mytilus edulis (L.) and its Distribution in the Tissues." J. Exp. Mar. Biol. Ecol. 23:71-84

George, S.G., B.J.S. Pirie, and T.L. Coombs. 1977. "Metabolic Characteristics of Endocytosis of Ferritin by the Gills of a Marine Bivalve Mollusc." Bioch. Soc. Trans. 5:136-137.

Gerlach, S.A. 1978. "Food-Chain Relationships in Subtidal Silty sand Marine Sediments and the Role of Meiofauna in Stimulation Bacterial Productivity." Oecologia 33:55-69.

Geyer, H. D., Freitag, and F. Korte. 1984. "Polychlorinated Biphenyls (PCBs) in the Marine Environment, Particularly in the Mediterranean." Ecotoxicol. Environ. Safe. 8:129-151.

Geyer, H., P. Sheehan, D. Kotzias, D. Freitag, and F. Korte. 1982. "Prediction of Ecotoxicological Behaviour of Chemicals: Relationship Between Physico-Chemical Properties and Bioaccumulation or Organic Chemicals in the Mussel Mytilus edulis." Chemosphere 11:1121-1134.

Ghiretti, F., B. Salvato, S. Carlucci, and R. de Pieri. 1972. "Manganese in Pinna nobilis." Experentia 28:232-233.

Giam, C.S., E. Atlas, H.S. Chan, and G.S. Neff. 1980. "Phthalate Esters, PCB, and DDT Residues in the Gulf of Mexico Atmosphere." Atmospheric Environment 14:65-69.

Gibbs, P.E. and G.W. Bryan. 1972. "A Study of Strontium, Magnesium and Calcium in the Environment and Exoskeleton of Decapod Crustaceans, with. Special Reference to Uca burgersi on Barbuda, West Indies." J. Exp. Mar. Biol. Ecol. 9:97-110.

Gibbs, P.E., W.J. Langston, G.R. Burt, and P.L. Pascoe. 1983. Tharyx marioni (Polychaeta): A Remarkable Accumulator of Arsenic.". J. Mar. Biol. Ass. U.K. 63:313-325. 
Giblin, A.E. and R.W. Howarth. 1984. "Porewater Evidence for a Dynamic Sedimentary Iron Cycle in Salt Marshes." Limnology and Oceanography 29:47-63.

Gilmour, C.C., J.H. Tuttle, and J.C. Means. 1985. "Tin Methylation in Sulfide Bearing Sediments." In Estuarine and Marine Geochemistry, eds. A.H. Hattori and A.C. Sigeleo, pp. 239258. Lewis Publications, Chelsea, Michigan.

Gobas, F.A.P.C., K.E. Clark, W.Y. Shiu, and D. Mackay. 1989. "Bioconcentration of Polybrominated Benzenes and Biphenyls and Related Superhydrophobic Chemicals in Fish: Role of Bioavailability and Elimination into Feces." Environ. Toxicol. Chem. 8:231-246.

Gobas, F.A.P.C., D.C.G. Muir, and D. Mackay. 1988. "Dynamics of Dietary Bioaccumulation and Faecal Elimination of Hydrophobic Organic Chemicals in Fish." Chemosphere 17:943-962.

Gobas, F.A.P.C., A. Opperhuizen, and O. Hutzinger. 1986. "Bioconcentration of Hydrophobic Chemicals in Fish: Relationship with Membrane Permeation." Environ. Toxicol. Chem. 5:637-646.

Goering, J., V. Alexander, and N. Haubenstock. 1990. "Seasonal Variability of Stable Carbon and Nitrogen Isotope Ratios of Organisms in a North Pacific Bay." Estuar. Coast. Shelf Sci. 30:239-260.

Goerke, H. 1984. Temperature-Dependent Elimination of $2,4,6,2^{\prime}, 4^{\prime}$-pentachloro $\left[\mathrm{U}^{1}{ }^{14} \mathrm{C}\right]$ Biphenyl in Nereis virens -(Polychaeta)." Arch. Environ. Contam. Toxicol. 13:347-355.

Goerke, H., G. Eder, K. Weber, and W. Ernst. 1979. "Patterns of Organochlorine Residues in Animals of Different Trophic Levels From the Weser Estuary." Mar. Pollut. Bull. 10:127-133.

Goerke, H., and W. Ernst. 1980. "Accumulation and Elimination of 14C- -HCH (lindane) in Nereis virens (Polychaeta) with Consideration of Metabolites." Helgo. wiss. Meeres. 33:313-326.

Goldberg, E.D. 1954. "Marine Geochemistry. Chemical scavengers of the sea." Journal of Geology 62:249-266.

Goldberg, E.D. 1964. "The Oceans as a Geological System." Transactions of the New York Academy of Sciences, Series 11, 27:7-19.

Gooday, A.J. and J.A. Nott. 1982. "Intracellular Barite Crystals in Two Xenophyophores, Aschemonella ramuliformis and Galatheammina sp. (Protozoa: Rhizopoda) with Comments on the Taxonomy of A. ramuliformis." J. Mar. Biol. Assoc. U. K. 62:595-605.

Gordon, D.C. 1966. "The Effects of the Deposit Feeding Polychaete Pectinaria gouldii on the Intertidal Sediments of Barnstable Harbor." Limnol. Oceanogr. 11:327-332.

Gordon, D.C., Jr., J. Dale, and P.D. Keizer. 1973. "Importance of Sediment Working by the Deposit-Feeding Polychaete Arenicola marina on the Weathering Rate of Sediment-Bound Oil." $J$. Fish. Res. Bd. Can. 35:591-603. 
Gossett, R.W., D.A. Brown, and D.R. Young. 1982a. "Predicting the Bioaccumulation and Toxicity of Organic Compounds." In SCCWRP Bien. Rep. 1981-1982, ed. W. Bascom, pp. 149-146. Long Beach, California.

Gossett, R.W., D.A. Brown, and D.R. Young. 1983. "Predicting the Bioaccumulation of Organic Compounds in Marine Organisms Using Octanol/Water Partition Coefficients." Mar. Poll. Bull. 14:387-392.

Gossett, R.W., H.W. Puffer, R.H. Arthur, J.F. Alfafara, and D.R. Young. 1982b. "Levels of Trace Organic Compounds in Sportfish From Southern California." In SCCWRP Bien. Rep. 1981-1982, ed. W. Bascom, pp. 29-37. Long Beach, California.

Grant, J. 1983. "The Relative Magnitude of Biological and Physical Sediment Reworking in an Intertidal Community." J. Mar. Res. 41:673-689.

Grant, W.D., L.F. Boyer, and L.P. Sanford. 1982. " The Effects of Bioturbation on the Initiation of Motion of Intertidal Sands." J. Mar. Res. 40:659-677.

Gray, J.S. 1974. "Animal-Sediment Relationships." Oceanogr. Mar. Biol. Ann. Rev. 12:223-261.

Gray, J.S. 1981. The Ecology of Marine Sediments. Cambridge University Press, Cambridge, England.

Grieg, R.A., D.R. Wenzloff, A. Adams, B. Nelson and C. Shelpuk. 1977. "Trace Metals in Organisms From Ocean Disposal Sites of the Middle Eastern United States." Arch. Envir. Contam. Toxicol. 6:395-409.

Griesbach, S., R.H. Peters, and S. Youakim. 1982. "An Allometric Model for Pesticide Bioaccumulation." Can. J. Fish. Aquat. Sci. 39:727-735.

Grieve, D.A. and W.K. Fletcher. 1976. "Heavy Metals in Deltaic Sediments of the Fraser River, British Columbia." Canadian Journal of Earth Sciences 13:1683-1693.

Griffin, J.J., H. Windom, and E.D. Goldberg. 1968. "The Distribution of Clay Minerals in the World Ocean." Deep-Sea Research 15:433-459.

Gschwend, P.M. and R.A. Hites. 1981. "Fluxes of Polycyclic Aromatic Hydrocarbons to Marine and Lacustrian Sediments in the Northeastern United States." Geochimica et Cosmochimica Acta 45:2359-2367.

Gschwend, P.M. and S.-C. Wu. 1985. "On the Constancy of Sediment-Water Partition Coefficients of Hydrophobic Organic Pollutants." Environmental Science and Technology 19:90-96.

Guard, H.E., A.B. Cobet, and W.M. Coleman III. 1981a. "Methylation of Trimethyltin Compounds by Estuarine Sediments." Science 213:770-771. 
Guard, H.E., W.M. Coleman III, and A.B. Cobet. 1981b. Speciation of Tributyltin Compounds in Seawater and Estuarine Sediments. Extended Abstract presented before the Division of Environmental Chemistry, American Chemical Society, Las Vegas, Nevada, pp. 180-183, March 1982.

Guary, J.C. and A. Fraizier. 1977. "Influence of Trophic Level and Calcification on the Uptake of Plutonium Observed, In Situ, in Marine Organisms." Health Physics 32:21-28.

Gundlach, E.R., P.D. Boehm, M. Marchand, R.M. Atlas, D.W. Ward, and D.A. Wolfe. 1983. "The Fate of Amoco Cadiz Oil." Sci. 221:122-129.

Hague, R. and D. Schmedding. 1975. "A Method of Measuring the Water Solubility of Hydrophobic Chemicals: Solubility of Five Polychlorinated Fiphenyls." Bull. Environ. Contam. Toxicol. 14:13-18.

Halbach, P. 1984. "Deep-Sea Metallic Deposits." Ocean Mamagement 9:35-60.

Halcrow, W., D.W. Mackay, and I. Thornton. 1973. "The Distribution of Trace Metals and Fauna in the Firth of Clyde in Relation to the Disposal of Sewage Sludge." J. Mar. Biol. Ass. U.K. 53:721-739.

Hall, L.W., Jr. 1988. "Tributyltin Environmental Studies in Chesapeake Bay." Marine Pollution Bulletin 19:431-438.

Hall, L.W.; Jr., M.J. Lenkevich, W.S. Hall, A.E. Pinkney, and S.J. Bushong. 1987. "Evaluation of Butyltin Compounds in Maryland Waters of Chesapeake Bay." Marine Pollution Bulletin 18:78-83.

Hamelink, J.L., R.C. Waybrand, and R.C. Ball. 1971. "A Proposal: Exchange Equilibria Control the Degree Chlorinated Hydrocarbons are Biologically Magnified in Lentic Environments." Trans. Am. Fish. Soc. 100:207-213.

Hamilton, S.J., K.J. Buhl, N.L. Faerber, R.H. Wiedmeyer, and F.A. Bullard. 1990. "Toxicity of Organic Selenium in the Diet of Chinook Salmon." Environ. Toxicol. Chem. 9:347-358.

Hansch, C. and A.J. Leo. 1979. Substituent Constants for Correlation Analysis in Chemistry and Biology. John Wiley and Sons, New York.

Hanson, A.K., Jr. and J.G. Quinn. 1983. "The Distribution of Dissolved and Organically Complexed Copper and Nickel in the Middle Atlantic Bight." Canadian Journal of Fisheries and Aquatic Sciences 40(2):151-161.

Harada, K. and S. Tsunogai. 1988. "Is Lead Soluble at the Surface of Sediments in Biologically Productive Seas?" Continental Shelf Research 8:387-396.

Harder, H.W., T.V. Cater, and T.F. Bidleman. 1983. "Acute Effects of Toxaphene and its Sediment-Degraded Products on Estuarine Fish." Can. J. Fish. Aquat. Sci. 40:2119-2125. 
Harding, G.C.H., W.P. Vass, and K.F. Drinkwater. 1981. "Importance of Feeding, Direct Uptake from Seawater, and Transfer From Generation to Generation in the Accumulation of an Organochlorine (p,p'-DDT) by the Marine Planktonic Copepod Calanus finmarchicus." J. Fish. Res. Bd. Can. 38:101-119.

Hardy, J.T., M.F. Sullivan, E.A. Crecelius, and C.W. Apts. 1984. "Transfer of Cadmium in a Phytoplankton-Oyster-Mouse Food Chain." Arch. Environ. Contam. Toxicol. 13:419-425.

Hargrave, B.T. 1970a. "The Utilization of Benthic Microflora by Hyalella azteca (Amphipoda)." $J$. Anim. Ecol. 39:427-437.

Hargrave, B.T. 1970b. "The Effect of a Deposit-Feeding Amphipod on the Metabolism of Benthic Microflora." Limnol. Oceanogr. 15:21-30.

Hargrave, B.T. 1972. "Prediction of Egestion by the Deposit-Feeding Amphipod Hyalella azteca." Oikos. 23:116-124.

Hargrave, B.T., G.C. Harding, W.P. Vass, P.E. Erickson, B.R. Fowler, and V. Scott. 1992. "Organochlorine Pesticides and Polychlorinated Biphenyls in the Arctic Ocean Food Web." Arch. Environ. Contam. Toxicol. 22:41-54.

Harris, J.E.W. and J.J. Cleary. 1987. "Particle Water Partitioning and Organotin Dispersal in an Estuary." In Proceedings of the Oceans 87 Conference: The Ocean "an International Workplace," pp. 1370-1374. Marine Technology Society, Washington, D.C.

Harris, R.P., V. Berdugo, E.D.S. Corner, C.C. Kilvington, and S.C.M. O'Hara. 1977. "Factors Affecting the Retention of Petroleum Hydrocarbons by Marine Planktonic Copepods." In Fate and Effects of Petroleum Hydrocarbons in Marine Organisms and Ecosystems, ed. D.A. Wolfe, pp. 268304. Pergamon Press, New York.

Harrison, F.L. 1973. "Accumulation and Loss of Cobalt and Caesium by the Marine Clam, Mya arenaria, Under Laboratory and Field Conditions." In Symposium on Interaction of Radioactive Contaminants with the Constituents of the Marine Environment, pp. 453-748. Seattle, Washington, July 10-14, 1972, IAEA Vienna.

Harrison, F.L. 1979. "Effect of the Physiochemical Form of Trace Metals on Their Accumulation by Bivalve Molluscs." In Chemical Modeling in Aqueous Systems: Speciation, Sorption, Solubility, and Kinetics, ed. E.A. Jenne, pp. 611-634. ACS Symp. Ser. 93, Amer. Chem. Soc., Washington, D.C.

Harrison, J.D. 1991. "The Gastrointestinal Absorption of the Actinide Elements." Sci. Tot. Environ. 100:43-60.

Harrison, S.E. and J.F. Klaverkamp. 1989. "Uptake, Elimination and Tissue Distribution of Dietary and Aqueous Cadmium by Rainbow Trout (Salmo gairdneri Richardson) and Lake Whitefish (Coregonus clupeaformis Mitchill)." Environ. Toxicol. Chem. 8:87-97. 
Harvey, G.R. and D.A. Boran. 1985. "Geochemistry of Humic Substances in Seawater." In Humic Substances in Soil, Sediment, and Water. Geochemistry, Isolation, and Characterization, eds. G.R Aiken, D.M. McKnight, R.L. Wershaw, and P. MacCarthy, pp. 233-247. John Wiley and Sons, New York.

Harvey, R.W. and S.N. Luoma. 1984. "The Role of Bacterial Exopolymer and Suspended Bacteria in the Nutrition of the Deposit-Feeding Clam, Macoma balthica." J. Mar. Res. 42:957-968.

Harvey, R.W. and S.N. Luoma. 1985a. "Effect of Adherent Bacteria and Bacterial Extracellular Polymers Upon Assimilation of Macoma balthica of Sediment-Bound Cd, Zn, and Ag." Mar. Ecol. Progr. Ser. 22:281-289.

Harvey, R.W. and S.N. Luoma. 1985b. "Separation of Solute and Particulate Vectors of Heavy Metal Uptake in Controlled Suspension-Feeding Experiments with Macoma balthica." Hydrobiologia 121:97-102.

Hatcher, P.G., I.A. Breger and M.A. Mattingly. 1980. "Structural Characteristics of Fulvic Acids From Continental Shelf Sediments." Nature (London) 285:560-562.

Hauksson, E. 1979. "Feeding Biology of Stichopus tremulus a Deposit-Feeding Holothurian." Sarsia. 64:155-160.

Havens, D.S. and R. Morales-Alamo. 1966. "Aspects of Biodeposition by Oysters and Other Invertebrate Filter Feeders." Limnol. Oceanogr. 11:487-498.

Hawker, D.W. and D.W. Connell. 1988. "Octanol-Water Partition Coefficients of Polychlorinated Biphenyl Congeners." Environ. Sci. Technol. 22:382-387.

Heinz, G.H., G.W. Pendleton, A.J. Krynitsky, and L.G. Gold. 1990. "Selenium Accumulation and Elimination in Mallards." Arch. Environ. Contom. Toxicol. 19:374-379.

Hellou, J., G. Stenson, I.-H. Ni, and J.F. Payne. 1990. "Polycyclic Aromatic Hydrocarbons in Muscle Tissue of Marine Mammals from the Northwest Atlantic." Mar. Pollut. Bull. 21:469-473.

Hellou, J., C. Upshall, I.-H. Ni, J.F. Payne, and Y.S. Huang. 1991. "Polycyclic Aromatic Hydrocarbons in Harp Seals (Phoca groenlandica) From the Northwest Atlantic." Arch. Environ. Contam. Toxicol. 21:135-140.

Helz, G.R. 1976. "Trace Element Inventory for the Northern Chesapeake Bay with Emphasis on the Influence of Man." Geochimica et Cosmochimica Acta 40:573-580.

Henriksen, K., J.I. Hansen, and T.H. Blackburn. 1980. "The Influence of Benthic Infauna on Exchange Rates of Inorganic Nitrogen Between Sediment and Water." Ophelia. 19 Suppl. 1:249256. 
Herbes, S.E. 1977. "Partitioning of Polycyclic Aromatic Hydrocarbons Between Dissolved and Particulate Phases in Natural Waters." Water Research 11:493-496.

Hershelman, G.P., H.A. Schafer, T.-K. Jan, and D.R. Young. 1981. "Metals in Marine Sediments Near a Large California Municipal Outfall." Marine Pollution Bulletin 12:131-134.

Hibbert, C.J. 1977. "Energy Relations of the Bivalve Mercenaria mercenaria on an Intertidal Mudflat." Mar. Biol. 44:77-84.

Hilton, J.W., P.V. Hodson, H.E. Braun, J.L. Leatherland, and S.J. Slinger. 1983. "Contaminant Accumulation and Physiological Response in Rainbow Trout (Salmo gairdneri) Reared on Naturally Contaminated Diets." Can. J. Fish. Aquat. Sci. 40:1987-1994.

Hilton, J.W., P.V. Hodson, and S.J. Slinger. 1982. "Absorption, Distribution, Half-Life and Possible Routes of Elimination of Dietary Selenium in Juvenile Rainbow Trout (Salmo gairdneri)." Comp. Biochem. Pharmacol. 71C:49-55.

Hiraizumi, Y., M. Takahashi, and H. Nishimura. 1979. "Adsorption of Polychlorinated Biphenyl Onto Sea Bed Sediment, Marine Plankton, and Other Adsorbing Agents." Environmental Science and Technology 13:580-584.

Hobbie, J. and C. Lee. 1980. "Microbial Production of Extracellular Material: Importance in Benthic Ecology." In Marine Benthic Dynamics, eds. K.R. Tenore and B.C. Coull, pp. 341-346. USC Press, Columbia, South Carolina.

Hoffman, E.J., G.L. Mills, J.S. Latimer, and J.G. Quinn. 1984. "Urban Runoff as a Source of Polycylic Aromatic Hydrocarbons to Coastal Waters." Environmental Science and Technology 18:580-587.

Hogue, E.W. and A.G. Carey, Jr. 1982. "Feeding Ecology of 0-Age Flatfishes at a Nursery Ground on the Oregon Coast." Fish. Bull. U.S. 80:555-565.

Holmes, C.W. 1986. "Trace Metal Seasonal Variations in Texas Marine Sediments." Marine Chemistry 20:13-27.

Holmes, C.W., E.A. Slade, and C.J. McLerran. 1974. "Migration and Redistribution of Zinc and Cadmium in a Marine Estuarine System." Environmental Science and Technology 8:255-259.

Honda, K. J.E. Marcovecchio, S. Kan, R. Tatsukawa, and H. Ogi. 1990. "Metal Concentrations in Pelagic Seabirds From the North Pacific Ocean." Arch. Environ. Contam. Toxicol. 19:704-711.

Hopkinson, C.S., Jr. 1987. "Nutrient Regeneration in Shallow-Water Sediments of the Estuarine Plume Region of the Nearshore Georgia Bight, U.S.A." Marine Biology 94:127-142.

Horzempa, L.M. and D.M. Di Toro. 1983. "The Extent of Reversibility of Polychlorinated Biphenyl Adsorption." Water Research 17:851-859. 
Hou-Pan, H.S. and N. Imura. 1982. "Involvement of Mercury Methylation in Microbial Detoxification." Archives of Microbiology 131:176-178.

Howard, A.G. and G. Nickless. 1977. "Heavy Metal Complexation in Polluted Molluscs. I. Limpets (Patella vulgata and Patella intermedia)." Chem.-Biol. Interactions. 16:107-114.

Howard, A.G. and G. Nickless. 1978. "Heavy Metal Complexation in Polluted Molluscs. III. Periwinkles (Littorina littorea), Cockles (Cardium edule) and Scallops (Chlamys opercularis)." Chem.-Biol. Interactions. 23:227-231.

Howard, J.D., T.V. Mayoll, and R.W. Heard. 1977. "Biogenic Sedimentary Structures Formed by Rays." J. Sed. Petrol. 47:339-346.

Howard, J.H.,III. 1972. "Control of Geochemical Behavior of Selenium in Natural Waters by Adsorption on Hydrous Ferric Oxides." In Trace Substances in Environmental Health.-V, ed. D.D. Hemphill, pp. 485-495. University of Missouri, Columbia.

Howard, J.H.,III. 1977. "Geochemistry of Selenium: Formation of Ferroselite and Selenium Behavior in the Vicinity of Oxidizing Sulfide and Uranium Deposits." Geochimica et Cosmochimica Acta 41:1665-1678.

Howarth, R.W. and J.M. Teal. 1979. "Sulfate Reduction in a New England Salt Marsh." Limnology and Oceanography 24:999-1013.

Howell, R. 1985. "The Effect of Bait-Digging on the Bioavailability of Heavy Metals From Surficial Intertidal Marine Sediments." Mar. Poll. Bull. 16:292-295.

Huang, P.M., D.W. Oscarson, U.T. Hammer, N.G. Lipinski, and W.K. Leaw. 1983. "Dynamics and Certain Redox Reactions of Selenium in Freshwater Sediments." Canadian Technical Reports in Fisheries and Aquatic Science 1163:97-103.

Huggett, R.J., M. Bender, and D.H. Slone. 1972. "Mercury in Sediments From Three Virginia Estuaries." Chesapeake Science 12:280-282.

Huggett, R.J., M. Bender, and M.A. Unger. 1987. "Polynuclear Aromatic Hydrocarbons in the Elizabeth River, Virginia." In Fate and Effects of Sediment-Bound Chemicals in Aquatic Systems, eds. K.L. Dickson, A.W. Maki, and W.A. Brungs, pp. 327-341. Pergamon Press, New York.

Hughes, R.N. 1969. "A Study of Feeding in Scrobicularia plana." J. Mar. Biol. Assoc. U. K. 49:805-823.

Hummon, W.D., J.W. Fleeger, and M.R. Hummon. 1976. "Meiofauna-Macrofauna Interactions. I. Sand Beach Meiofauna Affected by Maturing Limulus eggs." Mar. Biol. 34:77-83.

Hylleberg, J. and V.F. Gallucci. 1975. "Selectivity in Feeding by the Deposit-Feeding Bivalve Macoma nasuta." Mar. Biol. 32:167-178. 
Hylleberg, J. and K. Henriksen. 1980. "The Central Role of Bioturbation in Sediment Mineralization and Element Re-Cycling." Ophelia. Suppl. 1:1-16.

Iyengar, G.V. 1991. "Milestones in Biological Trace Element Research." Sci. Tot. Environ. 100:115.

James, M.O. 1989. "Biotransformation and Disposition of PAH in Aquatic Invertebrates." In Metabolism of Polycyclic Aromatic Hydrocarbons in the Aquatic Environment, ed. U. Varanasi, pp. 152-184. CRC Press, Boca Raton, Florida.

James, M.O., E.R. Bowen, P.M. Dansette, and J.R. Bend. 1979a. "Epoxide Hydrase and Glutathione S-Transferase Activities with Selected Alkene and Arene Oxides in Several Marine Species." Chem. Biol. Interact. 25:321-337.

James, M.O., M.A.Q. Khan, and J.R. Bend. 1979b. "Hepatic Microsomal Mixed-Function Oxidase Activities in Several Marine Species Common to Coastal Florida." Comp. Biochem. Physiol.

$62 \mathrm{C}: 155-158$.

Jarvinen, A.W. and R.M. Tyo. 1978. "Differential Effects of Organic Contaminants: Diet Versus Absorption." Arch. Environ. Contam. Toxicol. 7:409-418.

Jednacak-Biscan, J. and M. Juracic. 1987. "Organic Matter and Surface Properties of solid Particles in the Estuarine Mixing Zone." Marine Chemistry 22:257-263.

Jenkins, K.D., D.A. Brown, and P. Oshida. 1982a. "Detoxification of Metals in Sea Urchins." In Southern California Coastal Water Research Project 1981-1982, ed. W. Bascom, pp. 173-178. Long Beach, California.

Jenkins, K.D., J.W. Conner, X. Torres, and W.C. Meyer. 1982b. "Characteristics of Scorpionfish Metallothioneins." In Southern California Coastal Water Research Project 1981-1982, ed. W. Bascom, pp. 225-230. Long Beach, California.

Jenkins, K.D., S. Howe, B.M. Sanders, and C. Norwood. 1989. "Sediment Deposition, Biological Accumulation and Subcellular Distribution of Barium Following Drilling of an Exploratory Well." In Drilling Wastes, eds. F.R. Engelhardt, J.P. Ray, and A.H. Gillam, pp. 587-608. Elsevier Applied Sciences, London.

Jenkins, K.D. and A.Z. Mason. 1988. "Relationships Between Subcellular Distributions of Cadmium and Perturbations in Reproduction in the Polychaete Neanthes arenaceodentata." Aquat. Tox. 12: 229-244.

Jenkins, K.D. and B.M. Sanders. 1986a. "Relationships Between Free Cadmium Ion Activity in Sea Water, Cadmium Accumulation and Subcellular Distribution, and Growth in Polychaetes." Environm. Health Persp. 65:205-210. 
Jenkins, K.D. and B.M. Sanders. 1986b. "Assessing Biological Effects of Contaminants In Situ." In Urban Runoff Quality - Impact and Quality Enhancement Technology, Proc. Engineering Foundation Conf., Amer. Soc. Civil Engineers, New York, pp. 170-181.

Jenne, E.A. 1977. "Trace Element Sorption by Sediments and Soils - Sites and Processes." In Symposium on Molybdenum in the Environment, eds. W. Chappel and K. Petersen, pp. 425-553. Marcel Dekker, New York.

Jenne, E.A. and S.N. Luoma. 1977. "Forms of Trace Elements in Soils, Sediments, and Associated Waters: An Overview of Their Determination and Biological Availability." In Biological Implications of Metals in the Environment, eds. R.E. Wildung and H. Drucker, pp. 110-143. CONF-750929, NTIS, Springfield, Virginia.

Jennings, C.D. and S.W. Fowler. 1980. "Uptake of ${ }^{55}$ Fe From Contaminated Sediments by the Polychaete Nereis diversicolor." Mar. Biol. 56:277-280.

Jennings, J.R. and P.S. Rainbow. 1979. "Studies of the Uptake of Cadmium by the Crab Carcinus maenas in the Laboratory. I. Accumulation From Seawater and a Food Source." Mar. Biol. 50:131139.

Jensen, K.T. and H.R. Siegismund. 1980. "The Importance of Diatoms and Bacteria in the Diet of Hydrobia-species." Ophelia. Suppl. 1:193-199.

Johnsen, S. 1987. "Interactions Between Polycyclic Aromatic Hydrocarbons and Natural Aquatic Humic Substances. Contact time relationship." Science of the Total Environment 67:269-278.

Johnson, D.L. and M.E.Q. Pilson. 1972. "Arsenate in the Western North Atlantic and Adjacent Regions." Journal of Marine Research 30:140-149.

Johnson, I., N. Flower, and M.W. Loutit. 1981. "Contribution of Periphytic Bacteria to the Concentration of Chromium in the Crab Helice crassa." Microbial Ecology 7:245-252.

Johnson, R.G. 1974. "Particulate Matter at the Sediment-Water Interface in Coastal Environments." J. Mar. Res. 32:313-330.

Jonasson, I.R. 1977. "Geochemistry of Sediment/Water Interactions of Metals, Including Observations on Availability. In The Fluvial Transport of Sediment-Associated Nutrients and Contaminants, eds. H. Shear and A.P. Watson, pp. 255-271. International Joint Commission, Windsor, Ontario.

Jonasson, I.R. and R.W. Boyle. 1972. "Geochemistry of Mercury and Origins of Natural Contamination of the Environment." CIM Transactions 75:8-15.

Jones, P.G.W. and D.F. Jeffries. 1983. "The Distribution of Selected Trace Metals in United Kingdom Shelf Waters and the North Atlantic." Canadian Journal of Fisheries and Aquatic Sciences 40(2):124-131. 
Jørgensen, C.B. 1966. "The Biology of Suspension-Feeding." Pergamon Press, Oxford. 357pp.

Jørgensen, N.O.G. 1976. "Uptake of L-Valine and Other Amino Acids by the Polychaete Nereis virens." Mar. Biol. 52:45-52.

Jørgensen, N.O.G. and E. Kristensen. 1980. "Uptake of Amino Acids by Three Species of Nereis (Annelida: Polychaeta). I. Transport Kinetics and Net Uptake From Natural Concentrations." Mar. Ecol. Progr. Ser. 3:329-340.

Jørgensen, N.O.G., K. Mopper, and P. Lindroth. 1980. "Occurrence, Origin, and Assimilation of Free Amino Acids in an Estuarine Environment." Ophelia. Suppl. 1:179-192.

Jumars, P.A. and K. Fauchald. 1977. "Between-Community Contrasts in Successful Polychaete Feeding Strategies." In Ecology of Marine Benthos, pp. 1-20. Univ. of South Carolina Press.

Jumars, P.A., R.F.L. Self, and A.R.M. Nowell. 1982. "Mechanics of Particle Selection by Tentaculate Deposit-Feeders." J. Exp. Mar. Biol. Ecol. 64:47-70.

Kakubu, N. and T. Hidaka. 1965. "Vanadium and Niobium in Ascidians." Nature, Lond. 205:1028-1029.

Kalinowski, E. and R. Blondeau. 1988. "Characterization of Sedimentary Humic Acids Fractionated by Hydrophobic Interactions Chromatography." Marine Chemistry 24:29-37.

Karickhoff, S.W. 1980. "Sorption Kinetics of Hydrophobic Pollutants in Natural Sediments." In Contaminants and Sediments, ed. R.A. Baker, pp. 193-205. Ann Arbor Science Publishers, Ann Arbor, Michigan.

Karickhoff, S.W. 1981. "Semi-Empirical Estimation of Sorption of Hydrophobic Pollutants on Natural Sediments and Soils." Chemosphere 10:833-846.

Karickhoff, S.W., D.S. Brown, and T.A. Scott. 1979. "Sorption of Hydrophobic Pollutants on Natural Sediments." Water Research 13:241-248.

Kastner, M. 1981. "Authigenic Silicates in Deep-Sea Sediments: Formation and Diagenesis." In The Sea, Vol. 7 of The Oceanic Lithosphere, ed. C. Emiliani, pp. 915-980. John Wiley and Sons, New York.

Kaufman, R. 1986. "Nodules, Crusts and Polymetallic Sulfides in the EEZ." In Proceedings Exclusive Economic Zone Symposium. Exploring the New Ocean Frontier, eds. M. Lockwood and G. Hill, pp. 149-164. U.S. Dept of Commerce, National Oceanic and Atmospheric Administration, National Ocean Service, Rockville, MD.

Kawano, M. T. Inoue, T. Wada, H. Hidaka, and R. Tatsukawa. 1988. "Bioconcentration and Residue Patterns of Chlordane Compounds in Marine Animals: Invertebrates, Fish, Mammals, and Seabirds." Environ. Sci. Technol. 22:792-797. 
Kay, S.H. 1984. Potential for Biomagnification of Contaminants Within Marine and Freshwater Food Webs. Technical Report D-84-7. Department of the Army, Waterways Experiment Station, Corps of Engineers, Vicksburg, Mississippi.

Kemp, P.F. 1990. "The Fate of Benthic Bacterial Production." Rev. Aquat. Sci. 2:109-124.

Kemp, P.F. and R.C. Swartz. 1988. "Acute Toxicity of Interstitial and Particle-Bound Cadmium to a Marine Infaunal Amphipod." Mar. Environ. Res. 26:135-153.

Kenaga, E.E. and C.A.I. Goring. 1980. "Relationship Between Water Solubility, Soil Sorption, Octanol-Water Partitioning, and Concentration of Chemicals in Biota." In Aquatic Toxicology, eds. J.G. Eaton, P.R. Parrish and A.C. Hendricks, pp. 78-115. American Society for Testing and Materials, Philadelphia.

Kerdijk, H.N. and W. Salomons. 1981. "Heavy Metal Cycling in the Scheldt Estuary." Delft Hydraulics Report M1640/M1736. Cited in W. Salomons and U. Förstner. 1984. Metals in the Hydrocycle. Springer Verlag, New York.

Kersten, M. and U. Förstner. 1986. "Chemical Fractionation of Heavy Metals in Anoxic Estuarine and Coastal Sediments." Water Science and Technology 18:121-130.

Khan, A., J.J. Hassett, and W.L. Banwart. 1979. "Sorption of Acetophenone by Sediments and Soils." Soil Science 128:297-302.

King, D.G. and I.M. Davies. 1987. "Laboratory and Field Studies of the Accumulation of Inorganic Mercury by the Mussel Mytilus edulis (L.)." Mar. Poll. Bull. 18:40-45.

Kitamura, S. 1968. "Determination of Mercury Content in Bodies of Inhabitants, Cats, Fishes, and Shells in Minimata District and in the Mud of Minimata Bay." Minimata Disease, pp. 257-266.

Klaverkamp, J.F., W.A. Macdonald, D.A. Duncan, and R. Wagemann. 1984. "Metallothionein and Acclimation to Heavy Metals in Fish: A Review." In Contaminant Effects on Fisheries, eds. V.W. Cairns, P.V. Hodson, and J.O. Nriagu, pp. 99-113. John Wiley \& Sons, New York.

Kleeman, J.M., J.R. Olson, S.M. Chen, and R.E. Peterson. 1986. "Metabolism and Disposition of 2,3,7,8-tetrachlorodibenzo-p-dioxin in Rainbow Trout." Toxicol. Appl. Pharmacol. 83:391-401.

Kleinow, K.M. and A.S. Brooks. 1986. "Selenium Compounds in the Fathead Minnow (Pimephales promelas)-I. Uptake, Distribution, and Elimination of Orally Administered Selenate, Selenite, and Lseleniomethionine." Comp. Biochem. Pharmacol. 83C:61-69.

Klemmer, H.W., C.S. Unninayer, and W.I. Okubo. 1976. "Mercury Content of Biota in Coastal Waters in Hawaii." Bull Environ. Contam. Toxicol. 15:454-457.

Klerks, P.L. and J.S. Levinton. 1989. "Rapid Evolution of Metal Resistance in a Benthic Oligochaete Inhabiting a Metal-Polluted Site." Biol. Bull. 176:135-141. 
Klumpp, D.W. 1980. "Accumulation of Arsenic From Water and Food by Littorina littoralis and Nucella lapillus." Mar. Biol. 58:265-274.

Klumpp, D.W. and P.J. Peterson. 1979. "Arsenic and Other Trace Elements in the Waters and Organisms of an Estuary in SW England." Environmental Pollution 19:11-20.

Knezevic, M.Z. and K.Y. Chen. 1977. "Organometallic Interactions in Recent Sediments." In Chemistry of Marine Sediments, ed. T.F. Yen, pp. 223-241. Ann Arbor Science Publishers, Ann Arbor, Michigan.

Knezovich, J.P., F.L. Harrison, and R.G. Wilhelm. 1987. "The Bioavailability of Sediment-Sorbed Organic Chemicals: a Review." Water, Air, and Soil Pollution 32:233-245.

Knutzen, J. and M. Oehme. 1989. "Polychlorinated Dibenzofuran (PCDF) and Dibenzo-p-dioxin (PCDD) Levels in Organisms and Sediments From the Frierfjord, Southern Norway." Chemosphere 19:1897-1909.

Kofoed, L.H. 1975. "The Feeding Biology of Hydrobia ventrosa (Montagu). I. The Assimilation of Different Components of the Food." J. Exp. Mar. Biol. Ecol. 19:233-241.

Koistinen, J. 1990. "Residues of Planar Polychloroaromatic Compounds in Baltic Fish and Seal." Chemosphere 20:1043-1048.

Kozloff, E.N. 1983. Seashore Life of the Northern Pacific Coast. Univ. Washington Press.

Kraeuter, J.N. 1976. "Biodeposition by Salt-Marsh Invertebrates. Mar. Biol. 35:215-223.

Krantzberg, G. 1982. "The Influence of Bioturbation on Physical, Chemical and Biological Parameters in Aquatic Environments: A Review." Environ. Poll. (Ser. A) 39:99-122.

Krishnaswami, S., M. Baskaran, S.W. Fowler, and M. Heyraud. 1985. "Comparative Role of Salps and Other Zooplankton in the Cycling and Transport of Selected Elements and Natural Radionuclides in Mediterranean Waters." Biogeochem. 1:353-360.

Kristensen, E., M.H. Jensen, and T.K. Andersen. 1985. "The Impact of Polychaete (Nereis virens Sars) Burrows on Nitrification and Nitrate Reduction in Estuarine Sediments." J. Exp. Mar. Biol. Ecol. 85:75-91.

Krom, M.D., K.K. Turekian, and N.H. Cutshall. 1985. "Fate of Metals in Sediments of the New York Bight." In Wastes in the Ocean, of Vol. 6 Nearshore Waste Disposal, eds. B.H.K. Ketchum, J.M. Capuzzo, W.V. Burt, I.W. Duedall, P.K. Park, and D.R. Kester, pp. 209-234. John Wiley and Sons, New York.

Krumbein, W.C. 1936. "Application of Logarithmic Moments to Size Frequency Distribution of Sediments." Journal of Sedimentary Petrology 6:35-47. 
Kruse, B., B.K. Jensen, S.K. Jensen, and K. Jensen. 1986. "Degradation of a Petroleum Hydrocarbon in Coastal Sediments." Ophelia 26:285-292.

Kudenov, J.D. 1978. "The Feeding Ecology of Axiothella rubrocincta (Johnson) (Polychaeta: Maldanidae)." J. Exp. Mar. Biol. Ecol. 31:209-221.

Kudenov, J.D. 1982. "Rates of Seasonal Sediment Reworking in Axiothella rubrocincta (Polychaeta: Maldanidae)." Mar. Biol. 70:181-186.

Kudo, A. 1976. "Mercury Transfer from Bed Sediments to Freshwater Fish (Guppies). J. Environ. Qual. 5:427-430.

Kudo, A. S. Miyahara, and D.R. Miller. 1980. "Movement of Mercury From Minimata Bay into Yatsushiro Sea." Progress in Water Technology 12:509-524.

Kuehl, D.W., R. Haebler, and C. Potter. 1991. "Chemical Residues in Dolphins From the U.S. Atlantic Coast Including Atlantic Bottlenose Obtained During the 1987/88 Mass Mortality." Chemosphere 22:1071-1084.

Kvitek, R.G. and J.S. Oliver. 1986. "Side-Scan Sonar Estimates of the Utilization of Gray Whale Feeding Grounds Along Vancouver Island, Canada." Con. Shelf Res. 6:639-654.

Kvitek, R.G. and J.S. Oliver. 1987. "Sea Otter Foraging Habits and Effects on Prey Populations and Communities in Soft-Bottom Environments." In The Community Ecology of Sea Otters, eds. G.R. VanBlaricom and J.A. Estes, pp, 22-47. Springer-Verlag, New York.

Laake, M., P.E. Bergner, N. Hansen, K. Ingebrigtsen, L.A. Kirkerud, L. Landner, N. Nyholm, L. Renberg, H.U. Riisgård, I.U.S. Skåre, O. Svanberg, M. Tarkpea, T. Viktor, and U. Wahlgren. 1982. "Bioakkumulering Ved Opptak Fra Føde." - In Ekotoxikologiska Metoder for Akvatisk Miljo, pp. 96-100. Nordforsk. Miljövårdsser 1982:2. Cited by Ekelund 1989.

Lagler, K.F., J.E. Bardach, R.R. Miller, and D.R.M. Passino. 1977. Icthyology. John Wiley and Sons, New York.

Lake, J.L., N.I. Rubinstein, H. Lee II, C.A. Lake, J. Heltshe, and S. Pavignano. 1990.

"Equilibrium Partitioning and Bioaccumulation of Sediment-Associated Contaminants by Infaunal Organisms." Environ. Toxicol. Chem. 9:1095-1106.

Lake, J.L., N. Rubinstein, and S. Pavignano. 1987. "Predicting Bioaccumulation: Development of a Simple Partitioning Model for Use as a Screening Tool for Regulating Ocean Disposal of Wastes." In Fate and Effects of Sediment-Bound Chemicals in Aquatic Systems, eds. K.L. Dickson, A.W. Maki and W.A. Brungs, pp. 151-166. Pergamon Press, Elmsford, New York.

Lambert, S.M. 1968. "Omega (8) a Useful Index of Soil Sorption Equilibria." Journal of Agricultural and Food Chemistry 16:340-343. 
Lambert, S.M., P.E. Porter, and H. Schieferstein. 1965. "Movement and Sorption of Chemicals Applied to Soil." Weeds 13:185-190.

Laflamme, R.E. and R.A. Hites. 1978. "The Global Distribution of Polycyclic Aromatic Hydrocarbons in Recent Sediments." Geochimica et Cosmochimica Acta 42:289-303.

Lande, S.S. 1988. "Application of Steady-State Kinetics to Explain Partitioning Behavior of Hydrophobic Organic Chemicals: A Critique of "Particle-Induced" Desorption." Chemosphere 17:1085-1088.

Landrum, P.F. 1989. "Bioavailability and Toxicokinetics of Polycyclic Aromatic Hydrocarbons Sorbed to Sediments for the Amphipod Pontoporeia hoyi." Environ. Sci. Technol. 23:588-595.

Landrum, P.F., S.R. Nihart, B.J. Eadie, and L.R. Herche. 1987. "Reduction in Bioavailability of Organic Contaminants to the Amphipod Pontoporeia hoyi by Dissolved Organic Matter of Sediment Interstitial Waters." Environ. Toxicol. Chem. 6:11-20.

Landrum, P.F. and D. Scavia. 1983. "Influence of Sediment on Anthracene Uptake, Depuration, and Biotransformation by the Amphipod Hyalella azteca." Can. J. Fish. Aquat. Sci. 40:298-305.

Langton, R.W. 1983. "Food Habits of Yellowtail Flounder, Limanda ferruginea (Storer), From Off the Northeastern United States." Fish. Bull. U.S. 81:15-22.

Langston, W.J. 1978a. "Persistence of Polychlorinated Bophenyls in Marine Bivalves." Mar. Biol. 46:35-40.

Langston, W.J. 1978b. "Uptake of Organic Contaminants by the Bivalve, Macoma balthica." Mar. Biol. 45:265-269.

Langston, W.J. 1980. "Arsenic in U.K. Estuarine Sediments and Its Availability to Benthic Organisms." Journal of the Marine Biological Society of the United Kingdom 60:869-881.

Langston, W.J. 1982. "The Distribution of Mercury in British Estuarine Sediments and Its Availability to Deposit-Feeding Bivalves." Journal of the Marine Biological Society of the United Kingdom 62:667-684.

Langston, W.J. 1984. "Availability of Arsenic to Esturaine and Marine Organisms: A Field and Laboratory Evaluation." Mar. Biol. 80:143-154.

Langston, W.J. 1985. "Assessment of the Distribution and Availability of Arsenic and Mercury in Estuaries." In Estuarine Management and Quality Assessment, eds. J.G. Wilson and W. Halcrow, pp. 131-146. Plenum Press, New York.

Langston, W.J. and M. Zhou. 1987a. "Cadmium Accumulation, Distribution and Metabolism in the Gastropod Littorina littorea: The Role of Metal-Binding Proteins." J. Mar. Biol. Ass. U.K. 67:858601. 
Langston, W.J. and M. Zhou. 1987b. "Cadmium Accumulation, Distribution and Elimination in the Bivalve Macoma balthica : Neither Metallothioein nor Metallothioein-Like Proteins are Involved. Mar. Environ. Res. 21:225-237.

Larsson, P. 1984a. "Sedimentation of Polychlorinated Biphenyls (PCBs) in Limnic and Marine Environments." Water Research 18:1389-1394.

Larsson, P. 1984b. "Uptake of Sediment Released PCBs by the Eel Anguilla anguilla in Static Model Systems." Ecol. Bull. 36:62-67.

Larsson, P. and A. Södergren. 1987. "Transport of Polychlorinated Biphenyls (PCBs) in Freshwater Mesocosms From Sediment to Water and Air." Water, Air, and Soil Pollution 36:33-46.

Laughlin, R.B., Jr., H.E. Guard, and W.M. Coleman, III. 1986. "Tributyltin in Seawater:

Speciation and Octanol-Water Partition Coefficient." Environmental Science and Technology 20:201204.

Lauren, D.J. and S. Rice. 1985. "Significance of Active and Passive Depuration in the Clearance of Naphthalene From the Tissues of Hemigrapsus nudus (Crustacea: Decapoda)." Mar. Biol. 88:135142.

Law, R.J., C.F. Fileman, A.D. Hopkins, J.R. Baker, J. Harwood, D.B. Jackson, S. Kennedy, A.R. Martin, and R.J. Morris. 1991. "Concentrations of Trace Metals in the Livers of Marine Mammals (seals, porpoises and dolphins) From Waters Around the British Isles." Mar. Pollut. Bull. 22:183191.

Lawler, G.C., J.P. Holmes, B.J. Fiorito, J. Laseter, and R.C. Szaro. 1978. "Quantification of Petroleum Hydrocarbons in Selected Tissues of Male Mallard Ducklings Chronically Exposed to South Louisiana Crude Oil." In Proceedings of the Conference on Assessment of Ecological Impacts of Oil Spills, pp. 584-613. American Institute of Biological Sciences, Washington, D.C.

Le Bon, A.-M., J.-P. Cravedi, and J. Tulliez. 1987. "Fate of the Isoprenoid Hydrocarbon, Pristane, in Rainbow Trout." Ecotoxicol. Environ. Saf. 13:274-281.

Lech, J.J. and J.R. Bend. 1980. "Relationship Between Biotransformation and the Toxicity and Fate of Xenobiotic Chemicals in Fish." Environ. Health Perspect. 34:115-122.

Lech, J.J., M.J. Vodicnik, and C.R. Elcombe. 1982. "Induction of Monooxygenase Activity in Fish." In Aquatic Toxicology, ed. L.J. Weber, pp. 107-137. Raven Press, New York.

Leckie, J.O., M. Benjamin, K. Hayes, G. Kaufman, and S. Altman. 1980. Adsorption/CoPrecipitation of Trace Elements From Water with Iron Oxyhydroxide. Final Report. EPRI RP-910, Electric Power Research Institute, Palo Alto, California.

Lee, F.Y. and J.A. Kittrick. 1984. "Elements Associated with the Cadmium Phase in a Harbor Sediment as Determined with the Electron Beam Microprobe." Journal of Environmental Quality 13:337-340. 
Lee, G.F. and R.A. Jones. 1979. "Role of Biotransformation in Environmental Hazard Assessment." In Biotransformation and Fate of Chemicals in the Aquatic Environment, eds. A.W. Maki, K.L. Dickson and J. Cairns, Jr., pp. 8-21. Amer. Soc. for Microbiol., Washington, D.C.,

Lee, G.F. and R.A. Jones. 1987. "Water Quality Significance of Contaminants Associated with Sediments: An Overview." In Fate and Effects of Sediment-Bound Chemicals in Aquatic Systems, eds. K.L. Dickson, A.W. Maki and W.A. Brungs, pp. 3-34. Pergamon Press, Elmsford, New York.

Lee, H., II, B.L. Boese, R.C. Randall, and J. Pelletier. 1990. "A Method for Determining Gut Uptake Efficiencies of Hydrophobic Pollutants in a Deposit-Feeding Clam." Environ. Toxicol. Chem. 9:215-219.

Lee H, II, and R.C. Swartz. 1980. "Biological Processes Affecting the Distribution of Pollutants in Marine Sediments. Part II. Biodeposition and Bioturbation." In Contaminants and Sediments, ed. R.A. Baker, pp. 555-606. Ann Arbor Sci. Publ., Inc., Ann Arbor, Michigan.

Lee, R.F. 1977. "Accumulation and Turnover of Petroleum Hydrocarbons in Marine Organisms." In Fate and Effects of Petroleum Hydrocarbons in Marine Ecosystems and Organisms, eds. D.A. Wolfe, J.W. Anderson, D.K. Button, D.C. Malins, T. Roubal and U. Varanasi, pp. 60-70. Pergamon Press, New York.

Lee, R.F. 1981. "Mixed Function Oxygenases (MFO) in Marine Invertebrates." Mar. Biol. Lett. 2:87-105.

Lee, R.F., W.S. Gardner, J.W. Anderson, J.W. Blaylock, and J. Barwell-Clarke. 1978. "Fate of Polycyclic Aromatic Hydrocarbons in Controlled Ecosystem Enclosures." Environmental Science and Technology 12:832-838.

Lee, R.F. and C. Ryan. 1983. "Microbial and Photochemical Degradation of Polycyclic Aromatic Hydrocarbons in Estuarine Waters and Sediments." Canadian Journal of Fisheries and Aquatic Sciences 40:86-94.

Lee, R.F., C. Ryan, and M.L. Neuhauser. 1976. "Fate of Petroleum Hydrocarbons Taken Up From Food and Water by the Blue Crab, Callinectes sapidus." Mar. Biol. 37:363-370.

Lee, R.F., S.C. Singer, K.R. Tenore, W.S. Gardner, and R.M. Philpot. 1979. "Detoxification System in Polychaetee Worms: Importance in the Degradation of Sediment Hydrocarbons." In Marine Pollution: Functional Responses, eds. W.B. Vernberg, F.P. Thurberg, A. Calabrese and F.J. Vernberg, pp. 23-37. Academic Press, New York.

Lee, S.S., B.R. Mate, K.T. Von Der Trenck, R.A. Rimerman, and D.R. Buhler. 1977. "Metallothionein and the Subcellular Localization of Mercury and Cadmium in the California Sea Lion." Comp. Biochem. Physiol. 57C:45-53.

Levinton, J.S. and G.R. Lopez. 1977. "A Model of Renewable Resources and Limitation of Deposit-Feeding Benthic Populations." Oecologia. 31:177-190. 
Levinton, J.S., T.S. Bianchi, and S. Stewart. 1984. "What is the Role of Particulate Organic Matter in Benthic Invertebrate Nutrition?" Bull. Mar. Sci. 35:270-282.

Levinton, J.S. and S. Stewart. 1988. "Effects of Sediment Organics, Detrital Input, and Temperature on Demography, Production, and Body Size of a Deposit Feeder." Mar. Ecol. Progr. Ser. 49:259-266.

Li, Y.-H. 1981. "Ultimate Removal Mechanisms of Elements From the Ocean." Geochim. Cosmochim. Acta 45:1659-1664.

Li, Y.-H., L. Burkhardt, and H. Teraoka. 1984. "Desorption and Coagulation of Trace Elements During Estuarine Mixing." Geochimica et Cosmochimica Acta 48:1879-1884.

Lieb, A.J., D.D. Bills, and R.O. Sinnhuber. 1974. "Accumulation of Dietary Polychlorinated Biphenyls (Aroclor 1254) by Rainbow Trout (Salmo gairdneri)." J. Agric. Food Chem. 22:638-642.

Lijinsky, W., I. Domsky, G. Mason, H.Y. Ramahi, and T Safavi. 1963. "The Chromatographic Determination of Trace Amounts of Polynuclear Aromatic Hydrocarbons in Petroleum, Mineral Oil, and Coal-Tar." Analytical Chemistry 35:952-956.

Lindberg, S.E., A.W. Andren, and R.C. Harriss. 1975. "Geochemistry of Mercury in the Estuarine Environment." In Estuarine Research, ed. L.E. Cronin, Vol. I, pp. 64-107. Academic Press, New York.

Lindberg, S.E. and R.C. Harriss. 1974. "Mercury-Organic Matter Interactions in Estuarine Sediments and Interstitial Water." Environmental Science and Technology 8:459-462.

Lindberg, S.E. and R.C. Harriss. 1977. "Release of Mercury and Organics From Suspended NearShore Sediments." Journal of the Water Pollution Control Federation 49:2479-2487.

Lindsay, D.M. and J.G. Sanders. 1990. "Arsenic Uptake and Transfer in a Simplified Estuarine. Food Chain." Environ. Toxicol. Chem. 9:391-395.

Lindstrom-Seppa, P., U. Koivussaari, and O. Hanninen. 1981. "Extrahepatic Xenobiotic Metabolism in North-European Freshwater Fish." Comp. Biochem. Physiol. 69C:259-263.

Linton, A. 1978. The Food and Feeding Habits of Leach's Storm-Petrel (Oceanodroma leucorhoa) at Pearl Island N.S. and Middle Lawn Island, Newfoundland. M.Sc Thesis, Dalhousie University, Halifax, Nova Scotia, Canada.

Lion, L.W., R.S. Altmann, and J.O. Leckie. 1982. "Trace-Metal Adsorption Characteristics of Estuarine Particulate Matter: Evaluation of Contributions of Fe/Mn Oxide and Organic Surface Coatings." Environmental Science and Technology 16:660-666.

Litz, N., H.W. Doering, M. Thiele, and H.-P. Blume. 1987. "The Behavior of Linear Alkylbenzenesulfonate in Different Soils: A Comparison Between Field and Laboratory Studies." Ecotoxicology and Environmental Safety 14:103-116. 
Livingstone, D.R., M.N. Moore, D.M. Loew, C. Nasci, and S.V. Farrar. 1985. "Responses of the Cytochrome P-450 Monooxygenase System to Diesel Oil in the Common Mussel, Mytilus edulis L., and the Periwinkle, Littorina littorea L." Aquat. Toxicol. 7:79-88.

Llorente, G.A., A. Farrna, X. Ruiz, and J. Albaiges. 1987. "Accumulation and Distribution of Hydrocarbons, Polychlorobiphenyls, and DDT in Tissues of Three Species of Anatidae from the Ebro Delta (Spain)." Arch. Environ. Contam. Toxicol. 16:563-572.

Lobel, P.B., S.P. Belkhode, S.E. Jackson, and H.P. Longerich. 1989. "A Universal Method for Quantifying and Comparing the Residual Variability of Element Concentrations in Biological Tissues Using 25 Elements in the Mussel Mytilus edulis as a Model." Mar. Biol. 102:513-518.

Lobel, P.B., S.P. Belkhode, S.E. Jackson, and H.P. Longerich. 1991. "Sediment in the Intestinal Tract: A Potential Serious Source of Error in Aquatic Biological Monitoring Programs." Mar. Environ. Res. 31:163-174.

Lock, R.A.C. 1975. "Uptake of Methylmercury by Aquatic Organisms From Water and Food." In Sublethal Effects of Toxic Chemicals on Aquatic Animals, eds. J.H. Koeman and J.J.T.W.A. Strik, pp. 61-80. Elsevier Scientific Publishers, Amsterdam.

Lockwood, R.A. and K.Y. Chen. 1973. "Adsorption of Hg (II) by Hydrous Manganese Oxides." Environmental Science and Technology 7:1028-1034.

Loganathan, B.G., S. Tanabe, H. Tanaka, S. Watanabe, N. Miyazaki, M. Amano, and R. Tatsukawa. 1990. "Comparison of Organochlorine Residue Levels in the Striped Dolphin From Western North Pacific, 1978-79 and 1986." Mar. Pollut. Bull. 21:435-439.

Longbottom, M.R. 1970. "The Distribution of Arenicola marina (L.) with Particular Reference to the Effects of Particle Size and Organic Matter of the Sediments." J. Exp. Mar. Biol. Ecol. 5:138157.

Lopez, G.R. 1988. "Comparative Ecology of the Macrofauna of Freshwater and Marine Muds." Limnol. Oceanog. 33:946-962.

Lopez, G.R. and L.H. Kofoed. 1980. "Epipsammic Browsing and Deposit-Feeding in Mud Snails (Hydrobiidae)." J. Mar. Res. 38:585-599.

Lopez, G.R. and J.S. Levinton. 1987. "Ecology of Deposit-Feeding Animals in Marine Sediments." Quart. Rev. Biol. 62:235-260.

Loring, D.H. 1982. "Geochemical Factors Controling the Accumulation and Dispersal of Heavy Metals in the Bay of Fundy Sediments." Canadian Journal of Earth Sciences 19:930-944.

Loutit, M.W., J. Aislabie, P. Bremer, and C. Pillidge. 1988. "Bacteria and Chromium in Marine Sediments." In Advances in Microbial Ecology, ed. K.C. Marshall, Vol. 10, pp. 415-437. Plenum Press, New York. 
Loutit, M., P. Bremer, and J. Aislabie. 1988. "The Significance of the Interactions of Chromium and Bacteria in Aquatic Habitats." In Chromium in the Natural and Human Environments, eds. J.O. Nriagu and E. Nieboer, pp. 317-334. John Wiley and Sons, Inc., New York.

Loutit, M. and C.J. Pillidge. 1986. "Sediment Bacteria and Mobilization of Chromium (III). In Proceedings of the 4th International Congress of Microbial Ecology, pp. 225-230. Ljubljana, Yugoslavia.

Lowry, L.F., K. Frost, and J.J. Burns. 1980. "Variability in the Diet of Ringed Seals, Phoca hispida, in Alaska." Can. J. Fish. Aquat. Sci. 37: 2254-2261.

Lu, J.C.S. and K.Y. Chen. 1977a. "Migration of Trace Metals in Interfaces of Seawater and Polluted Surficial Sediments." Environmental Science and Technology 11:174-182.

Lu, J.C.S. and K.Y. Chen. 1977b. "Migration of Chemical Constituents in Sediment-Seawater Interfaces." In Chemistry of Marine Sediments, ed. T.F. Yen, pp. 181-221. Ann Arbor Science Publishers, Inc., Ann Arbor, Michigan.

Luckas, B., W. Vetter, P. Fischer, G. Heidmann, and J. Plötz. 1990. "Characteristic Chlorinated Hydrocarbon Patterns in the Blubber of Seals From Different Marine Regions." Chemosphere 21:1319.

Luckenbach, M.W., D.W. Huggett, and E.C. Zobrist. 1988. "Sediment Transport, Biotic Modifications, and Selection of Grain Size in a Surface Deposit-Feeder." Estuaries 11:134-139.

Lunde, G. and A. Bjørseth. 1977. "Polycyclic Aromatic Hydrocarbons in Long-Range Transported Aerosols." Nature 268:518-519.

Lunsford, C.A., M.P. Weinstein, and L. Scott. 1987. "Uptake of Kepone $e^{\mathrm{Tx}}$ by the Estuarine Bivalve Rangia cuneata, During the Dredging of Contaminated Sediments in the James River, Virginia."

Wat. Res. 21:411-416.

Luoma, S.N. 1977a. "The Dynamics of Biologically Available Mercury in a Small Estuary." Est. Coastal Mar. Sci. 5:643-652

Luoma, S.N. 1977b. "Physiological Characteristics of Mercury Uptake by Two Estuarine Species." Mar. Biol. 41:269-273.

Luoma, S.N. 1983. "Bioavailability of Trace Metals to Aquatic Organisms - A Review." Science of the Total Environment 28:1-22.

Luoma, S.N. 1985. "Biological Availability of Sediment-Bound Trace Metals." In La Baie de Seine (Greco-Manche), IFREMER, Actes de Colloques No. 4, pp. 347-362.

Luoma, S.N. 1986a. "A Comparison of Two Methods for Determining Copper Partitioning in Oxidized Sediments." Marine Chemistry 20:45-59. 
Luoma, S.N. 1986b. Cycling of Lead into Food Webs in Aquatic Environments. Report for the Commission on Lead in the Environment, Royal Society of Canada, pp. 146-161. Ottawa, Ontario.

Luoma, S.N. 1989. "Can We Determine the Biological Availability of Sediment-Bound Trace Elements?" Hydrobiologia 176/177:379-396.

Luoma, S.N. and G.W. Bryan. 1978. "Factors Controlling the Availability of Sediment-Bound Lead to the Estuarine Bivalve Scrobicularia plana." J. Mar. Biol. Ass. U.K. 58: 793-802.

Luoma, S.N. and G.W. Bryan. 1979. "Trace Metal Bioavailability: Modeling Chemical and Biological Interactions of Sediment-Bound Zinc." In Chemical Modeling in Aqueous Systems: Speciation, Sorption, Solubility, and Kinetics, ed. E.A. Jenne, pp. 577-509. ACS Symp. Ser. 93, Amer. Chem. Soc., Washington, D.C.

Luoma, S.N. and G.W. Bryan. 1981. "A Statistical Assessment of the Form of Trace Metals in Oxidized Estuarine Sediments Employing Chemical Extractions." Science of the Total Environment 17:165-196.

Luoma, S.N. and G.W. Bryan. 1982. "A Statistical Study of Environmental Factors Controlling Concentrations of Heavy Metals in the Burrowing Bivalve Scrobicularia plana and the Polychaete Nereis diversicolor." Est. Coast. Shelf Sci. 15:95-108.

Luoma, S.N. and D.J. Cain. 1979. "Fluctuations of Copper, Zinc, and Silver in Tellinid Clams as Related to Freshwater Discharge-South San Francisco Bay." In San Francisco Bay: The Urbanized Estuary, pp. 231-246. Pacific Div., Amer. Assoc. Adv. Sci.

Luoma, S.N., D. Cain, and C. Johansson. 1985. "Temporal Fluctuations of Silver, Copper and Zinc in the Bivalve Macoma balthica at Five Stations in South San Francisco Bay." Hydrobiologia 129:109-120.

Luoma, S. N. and J.A. Davis. 1983. "Requirements for Modeling Trace Metal Partitioning in Oxidized Estuarine Sediments." Marine Chemistry 12:159-181.

Luoma, S.N. and E.A. Jenne. 1976a. "Factors Affecting the Availability of Sediment-Bound Cadmium to the Estuarine, Deposit-Feeding Clam, Macoma balthica." In Radioecology and Energy Resources: Proc. Fourth Natl. Symp. on Radioecology, ed. C.E. Cushing, pp. 283-291.

Luoma, S.N. and E.A. Jenne. 1976b. "Estimating Bioavailability of Sedient-Bound Trace Metals with Chemical Extractants." In Trace Substances in Environmental Health - X. A Symposium, ed. D.D. Hemphill, pp. 343-351. Univ. of Missouri, Columbus.

Luoma, S.N. and E.A. Jenne. 1977. "The Availability of Sediment-Bound Cobalt, Silver, and Zinc to a Deposit-Feeding Clam." In Biological Implications of Metals in the Environment, eds. R.E. Wildung and H. Drucker, pp. 213-230. CONF-750929, NTIS Springfield, Virginia.

Luoma, S.N. and D.J.H. Phillips. 1988. "Distribution, Variability, and Impacts of Trace Elements in San Francisco Bay." Marine Pollution Bulletin 19:413-425. 
Luten, J.B., G. Riekwel-Booy, and A. Rauchbaar. 1982. "Occurrence of Arsenic in Plaice (Pleuronectes platessa), Nature of Organo-Arsenic Compound Present and Its Excretion by Man." Environ. Hlth. Persp. 45:165-170.

Luther, G.W., III, A.E. Giblin, and R. Varsolona. 1985. "Polorographic Analysis of Sulfur Species in Marine Porewaters." Limnology and Oceanography 30:727-736.

Luther, G.W. III, Z. Wilk, R.A Ryans, and A.L. Meyerson. 1986. "On the Speciation of Metals in the Water Column of a Polluted Estuary." Marine Pollution Bulletin 17:535-542.

Lyman, W.J., W.F. Reehl, and D.H. Rosenblatt. 1982. Handbook of Chemical Property Estimation Methods: Environmental Behavior of Organic Compounds. McGraw-Hill Book Co., New York.

Lyderson, C., L.A. Angantyr, Ø. Wiig, and T. Øritsland. 1991. "Feeding Habits of Northeast Atlantic Harp Seals (Phoca groenlandica) Along the Summer Ice Edge of the Barents Sea." Can. J. Fish. Aquat. Sci. 48: 2180-2183.

Lyes, M.C. 1979. "Bioavailability of a Hydrocarbon from Water and Sediment to the Marine Worm Arenicola marina." Mar. Biol. 55:121-127.

Lynch, T.R. and H.E. Johnson. 1982. "Uptake of Contaminants by the Amphipods Gammarus pseudolimnaeus and Hyalella azteca." In Aquatic Toxicology and Hazard Assessment: Fifth

Conference, eds. J.G. Pearson, R.B. Foster and W.E. Bishop, pp. 273-287. ASTM STP 766, Amer. Soc. for Testing and Materials, Philadelphia.

Lyngby, J.E. and Brix H. 1984. "The Uptake of Heavy Metals in Eelgrass Zostera marina and Their Effect on Growth." Ecol. Bull. 36: 81-89.

Lyngby, J.E., Brix, H. and H.-H. Schierup. 1982. "Absorption and Translocation of Zinc in Eelgrass (Zostera marina L.)." J. Exp. Mar. Biol. Ecol. 58: 259-270.

Lynn, D.C. and E. Bonatti. 1965. "Mobility of Manganese in Diagenesis of Deep-Sea Sediments." Marine Geology 3:457-474.

Lyons, W.B. and W.F. Fitzgerald. 1983. "Trace Metals Speciation in Nearshore Anoxic and Suboxic Pore Waters." In Trace Metals in Sea Water, eds. C.S. Wong, E.Boyle, K.W. Bruland, J.D. Burton, and E.D. Goldberg, pp. 621-642. Plenum Press, New York.

Macek, K.J. and S. Korn. 1970. "Significance of the Food Chain in DDT Accumulation in Fish." J. Fish. Res. Bd. Can. 27:1496-1498.

Mackay, D. and M. Diamond. 1989. "Application of the QWASI (Quantitative Water Air Sediment Interaction) Fugacity Model to the Dynamics of Organic and Inorganic Chemicals in Lakes." Chemosphere 18:1343-1365.

Mackay, D. and S. Paterson. 1991. "Evaluating the Multimedia Fate of Organic Chemicals: A Level III Fugacity Model." Environ. Sci. Technol. 25:427-436 
Mackay, D. and B. Powers. 1987. "Sorption of Hydrophobic Chemicals From Water: A Hypothesis for the Mechanism of the Particle Concentration Effects." Chemosphere 16:745-757.

Mackay, N.J., R.J. Williams, J.L. Kacprzac, A.J. Collins, and E.H. Auty. 1975. "Heavy Metals in Cultured Oysters, Crassostrea commercialis From the Estuaries of New South Wales." Aust. Mar. Freshwat. Res. 26:31-46

Maguire, R.J. 1984. "Butyltin Compounds and Inorganic Tin in Sediments in Ontario." Environmental Science and Technology 18:291-294

Maguire, R.J., J.H. Carey, and E.J. Hale. 1983. "Degradation of the Tri-n-butyltin Species in Water." Journal of Agricultural and Food Chemistry 31:1060-1065.

Maguire, R.J. and R.T. Tkacz. 1985. "Degradation of Tri-n-butyltin Species in Water and Sediment from Toronto Harbor." Journal of Agricultural and Food Chemistry 33:947-953.

Maher, W.A. 1981. "Determination of Inorganic and Methylated Arsenic Species in Marine Organisms and Sediments." Analytica Chimica Acta 126:157-165.

Maher, W.A. 1984. "Mode of Occurrence and Speciation of Arsenic in Some Pelagic and Estuarine Sediments." Chemical Geology 47:333-345.

Makkar, N.S., A.T. Kronick, and J.J. Cooney. 1989. "Butyltins in Sediments From Boston Harbor, USA." Chemosphere 18:2043-2050.

Malcolm, R.L. 1985. "Geochemistry of Stream Fulvic and Humic Substances." In Humic Substances in Soil, Sediment, and Water. Geochemistry, Isolation, and Characterization, eds. G.R. Aiken, D.M. McKnight, R.L. Wershaw, and P. MacCarthy, pp. 181-209. John Wiley and Sons, New York.

Malen, D.E., T. Erasmus, and D. Baird. 1988. "Aspects of Sesarma catenata (Grapsidae, Crustacea) Burrows and Its Implications in the Event of an Oil Spill." Est. Coast. Shelf Sci. 26:95104.

Malins, D.C. 1977. "Metabolism of Aromatic Compounds in Marine Organisms." Ann. N.Y. Acad. Sci. 298:482-496.

Malins, D.C. 1982. "Alterations in the Cellular and Subcellular Structure of Marine Teleosts and Invertebrates Exposed to Petroleum in the Laboratory and Field: A Critical Review." Can. J. Fish. Aquat. Sci. 39:877-890.

Malins, D.C. 1988. Sediment Contamination and Marine Ecosystems: Potential Risks to Human Health. Position paper for Symposium/Workshop on Contaminated Marine Sediments, Tampa, Florida, May 31 through June 2, 1988. National Research Council, Washington, D.C.

Malins, D.C., M.M. Krahn, D.W. Brown, L.D. Rhodes, M.S. Myers, B.B. McCain, and S.-L. Chan. 1985. "Toxic Chemicals in Marine Sediment and Biota from Mukilteo, Washington: 
Relationships with Hepatic Neoplasms and Other Hepatic Lesions in English Sole (Parophrys vetulus)." J. Nat. Cancer Inst. 74:487-493.

Manahan, D.T. and D.J. Crisp. 1982. "The Role of Dissolved Organic Material in the Nutrition of Pelagic Larvae: Amino Acid Uptake by Bivalve Veligers." Amer. Zool. 22;635-646.

Mangum, C. 1964. "Activity Patterns in Metabolism and Ecology of Polychaetes." Comp. Biochem. Physiol. 11:239-256.

Mantoura, R.F.C., A. Dickson, and J.P. Riley. 1978. "The Complexation of Metals in Natural Waters." Estuarine and Coastal Marine Science 6:387-408.

Markwell, R.D., D.W. Connell, and A.J. Gabric. 1989. "Bioaccumulation of Lipophilic Compounds From Sediments by Oligochaetes." Wat. Res. 23:1443-1450.

Mart, L., Nürnberg, and H. Rützel. 1984. "Comparative Studies on Cadmium Levels in the North Sea, Norwegian Sea, Barants Sea and the Eastern Arctic Ocean." Fresenius Zeitschrift fur Analytische Chemie 317:201-209.

Mart, L., H. Rützel, P. Klahre, L. Sipos, U. Platzek, P. Valenta, and H.W. Nürnberg. 1982. "Comparative Studies on the Distribution of Heavy Metals in the Oceans and Coastal Waters." Science of the Total Environment 26:1-17.

Martens, C.S. N.E. Blair, C.D. Green, and D.J. Des Marais. 1986. "Seasonal Variations in the Stable Carbon Isotope Signature of Biogenic Methane in a Coastal Sediment." Sci. 233:1300-1303.

Mason, A.Z., K.D. Jenkins, and P.A. Sullivan. 1988. "Mechanisms of Trace Metal Accumulation in the Polychaete Neanthes arenaceodentata." J. Mar. Biol. Ass. U.K. 68:61-80.

Mason, A.Z. and J.A. Nott. 1981. "The Role of Intracellular Biomineralization Granules in the Regulation and Detoxification of Metals in Gastropods with Special Reference to the Marine Prosobranch Littroina littorea." Aquat. Toxicol. 1:239-256.

Mason, J.W. and D.R. Rowe. 1976. "The Accumulation and Loss of Dieldrin and Endrin in the Eastern Oyster." Arch. Environ. Contam. Toxicol. 4:349-360.

Mason, R.P. and W.F. Fitzgerald. 1991. "Mercury Speciation in Open Ocean Waters." Wat. Air Soil Pollut. 56:779-789.

Massie, L.C., A.P. Ward, and J.M. Davies. 1985. "The Effects of Oil Exploration and Production in the Northern North Sea: Part 2 - Microbial Degradation of Hydrocarbons in Water and Sediments, 1978-1981." Marine Environmental Research 15:235-262.

Matsunaga, K. 1978. "Concentrations of Mercury in Marine Animals." Bull Fac. Fish. Hokkaido Univ. 29:70-74.

Maugh. T.H., II. 1978. "Chemicals: How Many Are There?" Science 199:162. 
Mauri, M., E. Oriando, M. Nigro, and F. Regoli. 1990. "Heavy Metals in the Antarctic Scallop Adamussium colbecki." Mar. Ecol. Progr. Ser. 67:27-33.

May, K., M. Stoeppler, and K. Reisinger. 1987. "Studies in the Ratio Total Mercury/Methylmercury in the Aquatic Food Chain." Toxicol. Environ. Chem. 13:153-159.

May, W.E., S.P. Wasik, and D.H. Freeman. 1978. "Determination of the Solubility Behavior of Some Polycyclic Aromatic Hydrocarbons in Water." Analytical Chemistry 50:997-1000.

Mayer, F.L., P.M. Mehrle, and H.O. Sanders. 1977. "Residue Dynamics and Biological Effects of Polychlorinated Biphenyls in Aquatic Organisms." Arch. Environ. Contam. 5:501-511.

Mayer, L.M. 1985. "Geochemistry of Humic Substances in Estuarine Environments." In Humic Substances in Soil, Sediment, and Water, eds. G.A. Aiken, D.M. McKnight, R.L. Wershaw, and P. MacCarthy, pp. 211-232. Geochemistry, Isolation, and Characterization. John Wiley and Sons, New York.

Mayer, L.M. 1988. "Geochemistry of Chromium in the Oceans." In Chromium in the Natural and Human Environments, eds. J.O. Nriagu and E. Nieboer, pp. 173-187. John Wiley and Sons, New York.

Mayer, L.M. and K.J.R. Fink. 1980. "Granulometric Dependance of Chromium Accumulation in Estuarine Sediments in Maine." Estuarine and Coastal Marine Science 11:491-503.

Mayer, L.M., S.A. Macko, and L. Cammen. 1988. "Provenence, Concentrations and Nature of Sedimentary Organic Nitrogen in the Gulf of Maine." Marine Chemistry 25:291-304.

Mayer, L.M. and L.L. Schick. 1981. "Removal of Hexavalent Chromium From Estuarine Waters by Model Substrates and Natural Sediments." Environmental Science and Technology 15:1482-1484.

McCaffrey, R.J., A.C. Myers, E. Davey, G. Morrison, M. Bender, N. Luedtke, D. Cullen, P. Froelich, and G. Klinkhammer. 1980. "The Relation Between Pore Water Chemistry and Benthic Fluxes of Nutrients and Manganese in Narragansett Bay, Rhode Island." Limnol. Oceanogr. 25:3144.

McCain, B.B., H.O. Hodgins, W.D. Bronlund, J.W. Hawkes, D.W. Brown, and M.S. Myers. 1978. "Bioavailability of Crude Oil from Experimentally Oiled Sediments to English Sole (Parophrys vetulus), and Pathological Consequences." J. Fish. Res. Bd. Can. 35:657-664.

McCall, P.L. and M.J.S. Tevesz, eds. 1982. Animal-Sediment Relations: The Biogenic Alteration of Sediments, Vol. 2 of Topics in Geobiology, ed. F.G. Stehli, Series Editor. Plenum Press, New York.

McCarthy, J.F. 1983. "Role of Particulate Organic Matter in Decreasing Accumulation of Polynuclear Aromatic Hydrocarbons by Daphnia magna." Arch. Environ. Contam. Toxicol. 12:559-568. 
McCarthy, J.F. and M.C. Black. 1987. "Partitioning Between Dissolved Organic Macromolecules and Suspended Particulates: Effects on Bioavailability and Transport of Hydrophobic Organic Chemicals in Aquatic Systems." In Tenth Symposium on Aquatic Toxicology and Hazard Assessment, eds. R.D. Cardwell, R. Purdy, and R. Comooto, pp. 146-161. Amer. Soc. for Testing and Materials, Philadelphia.

McCarthy, J.F. and B.D. Jiminez. 1985a. "Interactions Between Polycyclic Aromatic Hydrocarbons and Dissolved Humic Material: Binding and Dissociation." Environmental Science and Technology 19:1072-1076.

McCarthy, J.F. and B.D. Jimenez. 1985b. "Reduction in Bioavailability to Bluegills of Polycyclic Aromatic Hydrocarbons Bound to Dissolved Humic Material." Environ. Toxicol. Chem. 4:511-521.

McCarthy, J.F., B.D. Jimenez, and T. Barbee. 1985. "Effect of Dissolved Humic Material on Accumulation of Polycyclic Aromatic Hydrocarbons: Structure-Activity Relationships." Aquat. Toxicol. 7:15-24.

McDermott, J.J. and Roe, P. 1985. "Food, Feeding Behavior and Feeding Ecology of Nemerteans." Amer. Zool. 25:113-126.

McElroy, A.E., J.M. Cahill, J.D. Sisson, and K.M. Kleinow. 1991. "Relative Bioavailability and DNA Adduct Formation of Benzo[a]pyrene and Metabolites in the Diet of the Winter Flounder." $J$. Comp. Biochem. Physiol. (in press).

McElroy, A.E., J.W. Farrington, and J.M. Teal. 1990. "Influence of Mode of Exposure and the Presence of a Tubiculous Polychaete on the Fate of Benz[a]anthracene in the Benthos." Environ. Sci. Technol. 24:1648-1654.

McElroy, A.E. and J.D. Sisson. 1989. "Trophic Transfer of Benzo[a]pyrene Metabolites Between Benthic Marine Organisms." Mar. Environ. Res. 28:265-269.

McEwan, E.H. and P.M. Whitehead. 1980. "Uptake and Clearence of Petroleum Hydrocarbons by the Glaucous-Winged Gull (Larus glaucescens) and Mallard Duck (anas platyrhynchos)." Can. J. Zool. 58:723-730.

McFarland, W.M., F.H. Pough, T.J. Cade, and J.B. Heiser. 1979. Vertebrate Life. Macmillan Publ. Co., Inc., New York and Collier Macmillan Publ., London. 875 pp.

McLeese, D.W., L.E. Burridge, and J.V. Dinter. 1982. "Toxicities of Five Organochlorine Compounds in Water and Sediment to Nereis virens." Bull. Environ. Contam. Toxicol. 28:216-220.

McLeese, D.W. and C.D. Metcalfe. 1980. "Toxicities of Eight Organochlorine Compounds in Sediment and Seawater to Crangon septemspinosa." Bull. Environ. Contam. Toxicol. 25:921-928.

McLeese, D.W., C.D. Metcalfe, and D.S. Pezzack. 1980a. "Bioaccumulation of Chlorobiphenyls and Endrin From Food by Lobsters (Homarus americanus)." Bull. Environ. Contam. Toxicol. 25:161-168. 
McLeese, D.W., C.D. Metcalfe, and D.S. Pezzack. 1980b. "Uptake of PCBs From Sediment by Nereis virens and Crangon septemspinosa." Arch. Environ. Contam. Toxicol. 9:507-518.

McRoy, C.P. and R.J. Barsdate. 1970. "Phosphate Absorption in Eelgrass." Limnol. Oceanogr. 15:6-30.

McRoy, C.P and S.L. Williams. 1977. Sublethal Effects of Hydrocarbons on Seagrass

Photosynthesis. Final Rep. to NOAA Outer Continental Shelf Environ. Assessment Prog. Contract 03-5-022-56:1-35.

Meadows, P.S. and J. Tait. 1989. "Modification of Sediment Permeability and Shear Strength by Two Burrowing Invertebrates. Mar. Biol. 101:75-82.

Meadows, P.S. and A. Tufail. 1986. "Bioturbation, Microbial Activity and Sediment Properties in an Estuarine Ecosystem." Proc. R. Soc. Edinb. (Sect. B). 90:1-14.

Means, J.C., S.G. Wood, J.J. Hassett, and W.L. Banwart. 1982. "Sorption of Amino- CarboxySubtituted Polynuclear Aromatic Hydrocarbons by Sediments and Soils." Environmental Science and Technology 16:93-98.

Mearns, A.J. 1982. Assigning Trophic Levels to Marine Animals. Coastal Water Research Project. Biennial Report 1981-1982. Southern California Coastal Water Research Project, Long Beach California.

Mearns, A.J., M.B. Matta, D. Simecek-Beatty, M.F. Buchman, G. Shigenaka, and W.A. Wert. 1988. "PCB and Chlorinated Pesticide Contamination in U.S. Fish and Shellfish: A Historical Assessment Report." NOAA Techn. Memorandum NOS OMA 39:1-140.

Meglitsch, P.A. 1972. Invertebrate Zoology. 2nd Ed., Oxford Univ. Press, New York.

Merrill, E.G. and T.L. Wade. 1985. "Carbonized Coal Products as a Source of Aromatic Hydrocarbons to Sediments From a Highly Industrialized Estuary." Environmental Science and Technology 19:597-603.

Metayer, C., J.-C. Amiard, C. Amiard-Triquet, and J. Marchand. 1980. "Etude du Transfert de Quelques Oilgo-éléments Dans Les Chaînes Trophiques Néritique et Estuariennes: Accumulation Biologique Chez Les Poissons Omnivores et Super-Carnivores." Helg. Meeresunters. 34:179-191.

Mikac, N. and M. Picer. 1985. "Mercury Distribution in a Polluted Marine Area. Concentrations of Methyl Mercury in Sediments and Some Marine Organisms." Science of the Total Environment 43:27-39.

Miller, D.R. 1984. "Chapter 2." In Effects of Pollutants at the Ecosystem Level, Scope 22, ed. P.J. Sheehan. John Wiley and Sons, New York.

Miller, D., C.M. Brown, T.H. Pearson, and S.O. Stanley. 1979. "Some Biologically Important Low Molecular Weight Organic Acids in the Sediments of Loch Eil." Marine Biology 50:375-383. 
Miller, M.M., S.P. Wasik, G.-L. Huang, W.-Y. Shiu, and D. Mackay. 1985. "Relationships Between Octanol-Water Partition Coefficients and Aqueous Solubility." Environmental Science and Technology 19:522-529.

Miller, W.J. and M.W. Neathery. 1977. "Newly Recognized Trace Mineral Elements and Their Role in Animal Nutrition." BioSci. 27:674-679.

Milling, D.M. and M.B. Maddock. 1985. "Activation of Polycyclic Aromatic Measures, C.I., B.C. Grant, B.J. Mangum, and J.M. Edmond. 1983. "The Relationship of the Distribution of Dissolved Selenium IV and VI in Three Oceans to Physical and Biological Processes. In Trace Metals in Sea Water, eds. C.S. Wong, E. Boyle, K.W. Bruland, J.D. Burton, and E.D. Goldberg, pp. 73-83. Plenum Press, New York.

Millero, F.J. 1980. "Chemical Speciation of Ionic Components in Estuarine Systems." In River Inputs to Ocean Systems, eds. J.M. Martin, J.D. Burton, and D. Eisma, pp. 116-131. UNEP/SCOR, Rome.

Mills, E.L. 1967. "The Biology of an Ampeliscid Amphipod Crustacean Sibling Species Pair." J. Fish. Res. Bd. Can. 24:305-355.

Mills, G.L. and J.G. Quinn. 1984. "Dissolved Copper and Copper-Organic Complexes in the Narraganestt Bay Estuary." Marine Chemistry 15:151-172.

Millward, G.E. and J.D. Burton. 1975. "Association of Mercuric Ions and Humic Acid in Sodium Chloride Solution." Marine Science Communications 1:15-26.

Milner, N.J. 1982. "The Accumulation of Zinc by O-Group Plaice, Pleuronectes platessa (L.), From High Concentrations in Sea Water and Food." J. Fish Biol. 21:325-336.

Mingawa, M. and E. Wada. 1984. "Stepwise Enrichment of ${ }^{15} \mathrm{~N}$ Along Food Chains: Further Evidence and the Relation Between $\delta^{15} \mathrm{~N}$ and Animal Age." Geochim. Cosmochim. Acta 48:11351140 .

Miramand, P. and P. Germain. 1985. "Sea Water Uptake, Sediment Transfer and Histoautoradiographic Study of Plutonium $\left({ }^{239} \mathrm{Pu}\right)$ and Americium $\left({ }^{241} \mathrm{Am}\right)$ in the Edible Cockle Cerastoderma edule." Mar. Ecol. Progr. Ser. 22:59-88.

Miramand, P., P. Germain, and H. Camus. 1982. "Uptake of Americium and Plutonium from Contaminated Sediments by Three Benthic Species: Arenicola marina, Corophium volutator, and Scrobicularia plana." Mar. Ecol. Progr. Ser. 7:59-65.

Miyake, Y. and Y. Suzuki. 1983. "The Concentration and Chemical Forms of Mercury in Waters of the Western North Pacific." Deep-Sea Research 30:615-627.

Monahan, R. 1980. The effect of biologically-derived sediment disturbance on the dominant infauna of Cape Henlopen, Delaware. M.S. Thesis, University of Delaware. 75 pp. 
Montagna, P.A. 1984a. "In Situ Measurement of Meiobenthic Grazing Rates on Sediment Bacteria and Edaphic Diatoms." Mar. Ecol. Progr. Ser. 18:119-130.

Montagna, P.A. 1984b. "Competition for Dissolved Glucose Between Meiobenthos and Sediment Microbes." J. Exp. Mar. Biol. Ecol. 76:177-190.

Moore, J.N., W.H. Ficklin, and C. Johns. 1988. "Partitioning of Arsenic and Metals in Reducing Sulfidic Sediments." Environmental Science and Technology 22:432-437.

Moore, J.W. and S. Ramamoorthy. 1984a. Heavy Metals in Natural Waters. Applied Monitoring and Risk Assessment. Springer Verlag, New York.

Moore, J.W. and S. Ramamoorthy. 1984b. Organic Chemicals in Natural Waters. Applied Monitoring and Impact Assessment. Springer Verlag, New York.

Morales-Alamo, R. and D.S Haven. 1982. "Uptake of Kepone From Sediments in Suspension by the Oyster Crassostrea virginica (Gmelin) and the Wedge Clam Rangia cuneata (Sowerby) in Laboratory and Field Studies." J. Shellfish. Res. 2:103-104.

Morales-Alamo, R. and D.S Haven. 1983. "Uptake of Kepone From Sediment Suspensions and Subsequent Loss by the Oyster Crassostrea virginica." Mar. Biol. 74:187-201.

Morel, F., R.E. McDuff, and J.J. Morgan. 1973. "Interactions and Chemostasis in Aquatic Chemical Systems: Role of $\mathrm{pH}, \mathrm{pE}$, Solubility, and Complexation." In Trace metals and MetalOrganic Interactions in Natural Waters, ed. P.C. Singer, pp. 157-200. Ann Arbor Science Publishers, Ann Arbor, Michigan.

Morris, A.W., A.J. Bale, and R.J.M. Howland. 1982. "The Dynamics of Estuarine Manganese Cycling." Estuarine, Coastal and Shelf Science 14:175-192.

Morris, R.J. and G. Eglinton. 1977. "Fate and Recycling of Carbon Compounds." Marine Chemistry 5:559-572.

Morrison, S.J. and D.C. White. 1980. "Effects of Grazing by Estuarine Gammaridean Amphipods on the Microbiota of Allochthonous Detritus." Appl. Environ. Microbiol. 40:659-671.

Mueller-Harvey, I. and R.J. Parkes. 1987. "Measurement of Volatile Fatty Acids in Pore Water From Marine Sediments by HPLC." Estuarine, Coastal and Shelf Science 25:567-579.

Muir, D.C.G., W.K. Marshall, and G.R.B. Webster. 1985. "Bioconcentration of PCDDs by Fish: Effects of Molecular Structure and Water Chemistry." Chemosphere 14:829-833.

Muir, D.C.G., R.J. Norstrom, and M. Simon. 1988. "Organochlorine Contaminants in Arctic Marine Food Chains: Accumulation of Specific Polychlorinated Biphenyls and Chlordane-Related Compounds." Environ. Sci. Technol. 22:1071-1078. 
Muir, D.C.G., A.L. Yarechewski, D.A. Metner, W.L. Lockhart, G.R.B. Webster, and K.J. Friesen. 1990. "Dietary Accumulation and Sustained Hepatic Mixed Function Oxidase Enzyme Induction by 2,3,4,7,8-pentachlorodibenzofuran in Rainbow Trout." Environ. Toxicol. Chem. 9:1463-1472.

Muirhead, S.J. and R.W. Furness. 1988. "Heavy Metal Concentrations in the Tissues of Seabirds From Gough Island, South Atlantic Ocean." Mar. Pollut. Bull. 19:278-283.

Mukheriji, P. and D.R. Kester. 1979. "Mercury Distribution in the Gulf Stream." Science 204:6466.

Müller, M.D., L. Renberg, and G. Rippen. 1989. "Tributyltin in the Environment - Sources, Fate and Determination. An Assessment of Present Status and Research Needs." Chemosphere 18:20152042.

Murphy, T.J. and C.P. Rzeszutko. 1977. "Precipitation Inputs of PCBs to Lake Michigan." Journal of Great Lakes Research 3:305-312.

Murray, C.N. and W. Renfro. 1976. "Uptake of Plutonium From Seawater and Sediment by a Marine Polychaete Worm." J. Oceanogr. Soc. Japan. 32:249-252.

Murray, J.W., B. Spell, and B. Paul. 1983. "The Contrasting Geochemistry of Manganese and Chromium in the Eastern Tropical Pacific Ocean." In Trace Metals in Seawater, eds. C.S. Wong, E. Boyle, K.W. Bruland, J.D. Burton, and E.D. Goldberg, pp. 643-668. Plenum Press, New York.

Myers, A.C. 1972. "Tube-Worm-Sediment Relationships of Diopatra cuprea (Polychaeta: Onuphidae)." Mar. Biol. 17:350-356.

Myers, A.C. 1977a. "Sediment Processing in a Marine Subtidal Sandy Bottom Community: I. Physical Aspects. J. Mar. Res. 35:609-632.

Myers, A.C. 1977b. "Sediment Processing in a Marine Subtidal Sandy Bottom Community: II. Biological Consequences." J. Mar. Res. 35:633-647.

Nakahara, M. and F.A. Cross. 1978. "Transfer of Cobalt-60 From Phytoplankton to the Clam (Mercenaria mercenaria)." Bull. Jap. Soc. Sci. Fish. 44:419-425.

Nakayama, E., T. Kuwamoto, S. Tsurubo, and T. Fujinaga. 1981b. "Chemical Speciation of Chromium in Sea Water. Part 2. Effects of Manganese Oxides and Reducible Organic Materials on the Redox Processes of Chromium." Analytica Chimica Acta 130:401-404.

Nakayama, E., T. Kuwamoto, S. Tsurubo, H. Tokoro, and T. Fujinaga. 1981a. "Chemical Speciation of Chromium in Sea Water. Part 1. Effect of Naturally Occurring Organic Materials on the Complex Formation of Chromium (III)." Analytica Chimica Acta 130:289-294.

Narbonne, J.F. 1979. "Accumulation of Polychlorinated Biphenyl (Phenoclor DP6) by Estuarine Fish." Bull. Environ. Contam. Toxicol. 18:60-64. 
National Academy of Sciences. 1971. Marine Environmental Quality. National Academy Press, Washington, D.C.

National Academy of Sciences. 1985. Oil in the Sea. Inputs, Fates and Effects. National Academy Press, Washington, D.C.

National Oceanic and Atmospheric Administration (NOAA). 1988. Federal Plan For Ocean Pollution Research, Development, and Monitoring: Fiscal Years 1988-1992. U.S. Dept. of Commerce.

Nava, M.E. and F. R. Engelhardt. 1980. "Compartmentalization of Ingested Labelled Petroleum in Tissues and Bile of the American Eel (Anguilla rostrata)." Bull. Environ. Contam. Toxicol. 24:879885.

Neal, C., H. Elderfield, and R. Chester. 1979. "Arsenic in Sediments of the North Atlantic and the Eastern Mediterranean Sea." Marine Chemistry 7:207-219.

Neely, W., D. Branson, and G. Blau. 1974. "Partition Coefficient to Measure Bioconcentration Potential of Organic Chemicals to Fish." Environ. Sci. Technol. 8:1113-1115.

Neff, J.M. 1979a. Polycyclic Aromatic Hydrocarbons in the Aquatic Environment: Sources, Fates, and Biological Effects. Applied Sciences Publishers, Barking Essex, England.

Neff, J.M. 1979b. Polycyclic Aromatic Hydrocarbons in the Aquatic Environment. Applied Science Publishers Ltd., London.

Neff, J.M. 1984. "Bioaccumulation of Organic Micropollutants From Sediments and Suspended Particulates by Aquatic Animals." Fresenius Z. Anal. Chem. 319:132-136.

Neff, J.M. 1988a. Bioaccumulation and Biomagnification of Chemicals From Oil Well Drilling and Production Wastes in Marine Food Webs: A Review. Rept. for Amer. Petroleum Inst., New York.

Neff, J.M. 1988b. "Composition, Sources, and Fate of Petroleum and Oil Spill Treatment Agents in the Marine Environment." In Effects of Oil on Marine Mammals, eds. J. Geraci, D. St. Aubin, and J. Neff, OCS Study, MMS 88-0049. U.S. Dept. of the Interior Minerals Management Service, Herndon, Virginia.

Neff, J.M. 1991. Water Quality in Prince William Sound and the Gulf of Alaska. Report to Exxon Company, USA. Arthur D. Little, Inc., Cambridge, Massachusetts.

Neff, J.M. and J.W. Anderson. 1981. Response of Marine Animals to Petroleum and Specific Petroleum Hydrocarbons. Applied Science Publishers Ltd., London.

Neff, J.M., J.W. Anderson, B.A. Cox, R.B. Laughlin, Jr., S.S. Rossi, and H.E. Tatem. 1976. " Effects of Petroleum on Survival, Respiration and Growth of Marine Animals." In Sources, Effects and Sinks of Hydrocarbons in the Aquatic Environment, Amer. Inst. of Biol. Sci., Washington, D.C. 
Neff, J.M. and R.J. Breteler. 1983. "Waste Disposal in the Marine Environment: 2. Biological Availability of Organic Contaminants to Marine Invertebrates." In Proceedings Oceans '83, pp. 970-972. Mar. Tech. Soc., Washington, D.C.

Neff, J.M., R.J. Breteler, and R.S. Carr. 1989. "Bioaccumulation, Food Chain Transfer, and Biological Effects of Barium and Chromium From Drilling Muds by Flounder (Pseudopleuronectes americanus) and Lobster (Homarus americanus)." In Drilling Wastes, eds F.R. Engelhardt, J.P. Ray, and A.H. Gillam, pp. 439-460. Elsevier Applied Science Publishers, London.

Neff, J.M., B.A. Cox, D. Dixit, and J.W. Anderson. 1976. "Accumulation and Release of Petroleum-Derived Aromatic Hydrocarbons by Marine Animals." Mar. Biol. 38:279-289.

Neilson, A.H., H. Blanck, L. Förlin, L. Landner, P. Pärt, A. Rosmarin, and M. Söderström. 1989. "Advanced Hazard Assessment of 4,5.6-trichloroguaiacol in the Swedish Environment." In Chemicals in the Aquatic Environment: Advanced Hazard Assessment, ed. L. Landner, pp. 29-374. Springer-Verlag, Berlin.

Nelson, A., and P. Donkin. 1985. "Processes of Bioaccumulation: The Importance of Chemical Speciation." Marine Pollution Bulletin 16:164-169.

Nelson, J.S. 1984. Fishes of the World. 2nd ed., John Wiley and Sons, New York.

Nelson, P.O., A.K. Chung, and M.C. Hudson. 1981. "Factors Affecting the Fate of Heavy Metals in the Activated Sludge Process." Journal of the Water Pollution Control Federation 53:1323-1333.

Nemoto, N. and H.V. Gelboin. 1976. "Enzymatic Conjugation of Benzo[a]pyrene Oxides, Phenols and Dihydrodiols with UDP-Glucuronic Acid." Biochem. Pharmacol. 25:1221-1234.

Neumann, A.C., C.D. Gebelein, and T.P. Scoffin. 1970. "The Composition, Structure and Erodibility of Subtidal Mats, Abaco, Bahamas." J. Sediment. Petrol. 40:274-297.

Newell, R.C. 1965. "The Role of Detritus in the Nutrition of Two Marine Deposit Feeders, the Prosobranch Hydrobia ulvae and the Bivalve Macoma balthica." Proceedings of the Zoological Society of London 144:25-45.

Newell, R.C. 1979. Biology of Intertidal Animals, Third Edition. Marine Ecological Surveys Ltd., Faversham, Kent, England.

Newell, R.C. and J.G. Field. 1983. "The Contribution of Bacteria and Detritus to Carbon and Nitrogen in a Benthic Community." Mar. Biol. Lett. 4:23-36.

Nicolaidou, A. 1988. "Notes on the Behaviour of Pectinaria koreni." J. Mar. Biol. Ass. U.K. 68:55-59.

Niimi, A.J, and C.Y. Cho. 1980. "Uptake of Hexachlorobenzene (HCB) From Feed by Rainbow Trout (salmo gairdneri)." Bull. Environ. Contam. Toxicol. 24:834-839. 
Niimi, A.J. and C.Y. Cho. 1981. "Elimination of Hexachlorobenzene (HCB) by Rainbow Trout (Salmo gairdneri), and an Examination of its Kinetics in Lake Ontario Salmonids." Can. J. Fish. Aquat. Sci. 38:1350-1356.

Niimi, A.J. and G.P. Dookhran. 1989. "Dietary Absorption Efficiencies and Elimination Rates of Polycyclic Aromatic Hydrocarbons (PAHs) in Rainbow Trout (Salmo gairdneri)." Environ. Toxicol. Chem. 8:719-722.

Niimi, A.J. and B.G. Oliver. 1988. "Influence of Molecular Weight and Molecular Volume on Dietary Absorption Efficiency of Chemicals by Fishes." Can. J. Fish. Aquat. Sci. 45:222-227.

Niimi, A.J. and V. Palazzo. 1986. "Biological Half-Lives of Eight Polycyclic Aromatic Hydrocarbons (PAHs) in Rainbow Trout (Salmo gairdneri)." Wat. Res. 20:503-507.

Nimmo, D.R., D.J. Hansen, J.A. Couch, N.R. Cooley , P.R. Parrish, and J.J. Lowe. 1975. "Toxicity of Aroclor 1254 and its Physiological Activity in Several Estuarine Organisms." Arch. Environ. Contam. Toxicol. 3:22-39.

Nimmo, D.R., P.D. Wilson, R.R. Blackman, and A.J. Wilson, Jr. 1971. "Polychlorinated Biphenyl Absorbed From Sediments by Fiddler Crabs and Pink Shrimp." Nature 231:50-52.

Nisbet, C.T. and A.F. Sarofim. 1972. "Rates and Routes of Transport of PCBs in the Environment." Environ. Hlth. Persp. 4:21-38.

Nishimoto, M. and U. Varanasi. 1985. Benzo[a]pyrene Metabolism and DNA Adduct Formation Mediated by English Sole Liver Enzymes." Biochem. Pharmacol. 34:263-271..

Noel-Lambot, F. 1976. "Distribution of Cadmium, Zinc, and Copper in the Mussel, Mytilus edulis. Existence of Cadmium Binding Proteins Similar to Metallothioneins." Experientia 32:324-326.

Nishimura, H. and M. Kumagai. 1983. "Mercury Pollution of Fishes in Minamata Bay and Surrounding Water: Analysis of Pathway of Mercury." Water, Air, and Soil Pollution. 20:401-411.

Nissenbaum, A., and D.J. Swaine. 1976. "Organic Matter-Metal Interaction in Recent Sediments: The Role of Humic Substances." Geochimica et Cosmochimica Acta 40:809-816.

Noel-Lambot, F. 1976. "Distribution of Cadmium, Zinc, and Copper in the Mussel,

Norstrom, R.J., R.E. Schweinsberg, and B.T. Collins. 1986. "Heavy Metals and Essential Elements in Livers of the Polar Bear (Ursinus maratimus) in the Canadian Arctic." Sci. Tot. Environ. 48:195212.

Norstrom, R.J., M. Simon, D.C.G. Muir, and R.E. Schweinsburg. 1988. "Organochlorine Contaminants in Arctic Marine Food Chains: Identification, Geographical Distribution, and Temporal Trends in Polar Bears." Environ. Sci. Technol. 22:1063-1070. 
Nott, J.A. and A. Nicolaidou. 1989. "Metals in Gastropods - Metabolism and Bioreduction." Mar. Environ. Res. 28:201-205.

Nott, J.A. and A. Nicolaidou. 1990. "Transfer of Detoxification Along Marine Food Chains." $J$. Mar. Biol. Assoc. U.K. 70:905-912.

Nozaki, Y. 1991. "The Systematics and Kinetics of U/Th Decay Series in Ocean Water." Rev. Aquat. Sci. 4:75-105.

Nürnberg, H.W. 1983. "Voltammetric Studies on Trace Metal Speciation in Natural Water. Part II: Application and Conclusions for Chemical Oceanography and Chemical Limnology." In Trace Element Speciation in Surface Waters and Its Ecological Implications, ed. G.G. Leppard, pp. 211230. Plenum Press, New York.

Nürnberg, H.W. and P. Valenta. 1983. "Potentailities and Applications of Voltammetry in Chemical Speciation of Trace Metals in the Sea." In Trace Metals in Sea Water, eds. C.S. Wong, E. Boyle, K.W. Bruland, J.D. Burton, and E.D. Goldberg, pp. 671-698. Plenum Press, New York.

Oakley, S.M., P.O. Nelson, and K.J. Williamson. 1981. "Model of Trace-Metal Partitioning in Marine Sediments." Environmental Science and Technology 15:474-480.

O'Connor, D.J. and J.P. Connolly. 1980. "The Effect of Concentration of Adsorbing Solids on the Partition Coefficient." Water Research 14:1517-1523.

O'Connor, J.M., A.R. Schnitz, and K.A. Squibb. 1988. "In vivo Kinetics of Benz[a]pyrene and 7,12-dimethylbanz[a]anthracene Assimilation and Metabolism in Rainbow Trout." Mar. Environ. Res. 24:63-67.

O'Connor, J.M. and K.S. Squibb. 1989. Bioaccumulation of Polycyclic Aromatic Hydrocarbons and Metals in Estuarine Organisms. API Publication 4473. American Petroleum Institute, Washington, D.C.

Oehme, M., M. Ryg, P. Fürst, C. Fürst, H.A. Meemken, and W. Groebel. 1990. "Re-Evaluation of Concentration Levels of Polychlorinated Dibenzo-p-dioxins and Dibenzofurans in Arctic Seal From Spitzbergen." Chemosphere 21:519-523.

Officer, C.B. and D.R. Lynch. 1989. "Bioturbation, Sedimentation, and Sediment-Water Exchange." Est. Coast. Shelf Sci. 28:1-12.

Olafsson, J. 1983. "Mercury Concentrations in the North Atlantic in Relation to Cadmium, Aluminum and Oceanographic Parameters." In Trace Metals in Sea Water, eds. C.S. Wong, E. Boyle, K.W. Bruland, J.D. Burton, and E.D. Goldberg, pp. 475-486. Plenum Press, New York.

Oliver, B.G. 1984. "Uptake of Chlorinated Organics From Anthropogenically Contaminated Sediments by Oligochaete Worms." Can. J. Fish. Aquat. Sci. 41:878-883. 
Oliver, B.G. and A.J. Niimi. 1988. "Trophodynamic Analysis of Polychlorinated Biphenyl Congeners and Other Chlorinated Hydrocarbons in the Lake Ontario Ecosystem." Environ. Sci. Technol. 22:388-397.

Oliver, J.S. and R.G. Kvitek. 1984. "Side-Scan Sonar Records and Diver Observations of Gray Whale (Eschrichtius robustus) Feeding Grounds." Biol. Bull. 167:264-269.

Oliver, J.S. and P.N. Slattery. 1985. "Destruction and Opportunity on the Sea floor: The Effects of Gray Whale Feeding." Ecology 66:1965-1975.

Oliver, J.S., P.N. Slattery, E.F. O'Connor, and L.F. Lowry. 1983. "Walrus, Odobenus rosmarus, Feeding in the Bering Sea: A Benthic Perspective." Fish. Bull. 81:501-512.

Oliver, J.S., P.N. Slattery, L.W. Hurlberg, and J.W. Nybakken. 1984. Gray whale feeding on dense ampeliscid amphipod communities near Bamfield, British Columbia. Can. J. Zool. 62:41-49.

Olla, B.L., V.B. Estelle, R.C. Swartz, G. Braun, and A.L. Studholme. 1988. "Responses of Plychaetes to Cadmium-Contaminated Sediment: Comparison of Uptake and Behavior." Environ. Toxicol. Chem. 7:587-592.

Olsen, C.R., N.H. Cutshall, and I.L. Larsen. 1982. "Pollutant-Particle Associations and Dynamics in Coastal Marine Environments: A Review." Marine Chemistry 11:501-533.

Olson, B.H., T. Barkay, D. Nies, J.M. Bellama, and R.R. Colwell. 1979. "Plasmid Mediation of Mercury Voltailization and Methylation by Estuarine Bacteria." Developments in Industrial Microbiology 20:275-284.

Olson, B.H. and R.C. Cooper. 1976. "Comparison of Aerobic and Anaerobic Methylation of Mercuric Chloride by San Francisco Bay Sediments." Water Research 10:113-116.

Olson, G.J. and F.E. Brinkman. 1986. "Biodegradation of Tributyltin by Chesapeake Bay Microorganisms." In Proceedings of the Oceans 86 Conference: Science-Engineering-Adventure, pp. 1196-1201. Marine Technology Society, Washington, D.C.

Ono, M., N. Kannan, T. Wakimoto, and R. Tatsukawa. 1987. "Dibenzofurans a Greater Global Pollutant Than Dioxins? Evidence From Analysis of Open Ocean Killer Whale." Mar. Pollut. Bull. 18:640-643.

Opperhuizen, A., F.A.P.C. Gobas, J.M.D. Van der Steen, and O. Hutzinger. 1988. "Aqueous Solubility of Polychlorinated Biphenyls Related to Molecular Structure." Environ. Sci. Technol. 22:638-646.

Opperhuizen, A., E.W. Van der Velde, F.A.P.C. Gobas, A.K.D. Liem, J.M.D. Van der Steen, and O. Hutzinger. 1986. "Relationship Between Bioconcentration in Fish and Steric Factors of Hydrophobic Chemicals." Chemosphere 14:1071-1096. 
Opperhiuzen, A. and S.M. Schrap. 1988. "Uptake Efficiencies of Two Polychlorobiphenyls in Fish After Dietary Exposure to Five Different Concentrations." Chemosphere 17:253-262.

Opperhuizen, A. and D.T.H.M. Sijm. 1990. "Bioaccumulation and Biotransformation of Polychlorinated Dibenzo-p-dioxins and Dibenzofurans in Fish." Environ. Toxicol. Chem. 9:175-186.

Opperhuizen, A. and R.C.A.M. Stokkel. 1988. "Influence of Contaminated Particles on the Bioaccumulation of Hydrophobic Organic Micropollutants in Fish." Environ. Poll. 51:165-177.

Oppenheimer, C.H. 1966. "pH and Eh of Marine Sediments." In The Encyclopedia of Oceanography, ed. R.W. Fairbridge, pp. 699-705. Reinhold Publishing Corporation, New York.

Oppenheimer, C.H. and L Kornicker. 1958. "Effect of Microbial Production of Hydrogen Sulfide and Carbon Dioxide on the pH of Recent Sediments." Publications of the Institute of Marine Sciences, University of Texas 5:5-15.

Oshida, P.S., A.J. Mearns, D.J. Reish, and C.S. Word. 1976. The Effects of Hexavalent and Trivalent Chromium on Neanthes arenaceodentata (Polychaeta: Annelida). S. Calif. Coastal Water Res. Proj. TM 225.

Oshida, P.S., L.S. Word, and A.J. Mearns. 1981. "Effects of Hexavalent and Trivalent Chromium on the Reproduction of Neanthes arenaceodentata (Polychaeta)." Mar. Environ. Res. 5:41-49.

Overnell, J. and T.L. Coombs. 1979. "Purification and Properties of Plaice Metallothionein, a Cadmium-Binding Protein from the Liver of the Plaice (Pleuronectes platessa). J. Biochem. 183:277283.

Overnell, J., I.A. Davisdon, and T.L. Coombs. 1977. "A Cadmium-Binding Glycoprotein From the Liver of the Plaice (Pleuronectes platessa)." Biochem. Soc. Trans. 5:267-269.

Owen, G. 1966. "Digestion." In Physiology of Mollusca, Volume II, eds. K.M. Wilbur and C.M. Yound, pp. 52-96. Academic Press, New York.

Owens, N.J.P. 1987. "Natural Variations in $15_{\mathrm{N}}$ in the Marine Environment." $A d v$. Mar. Biol. 24:390-451.

Paerl, H.W. 1978. "Microbial Organic Carbon Recovery in Aquatic Ecosystems." Limnol. Oceanogr. 23:297-935.

Paine, R.T. 1980. "Food Webs: Linkage, Interaction Strength and Community Infrastructure. The Third Tansley Lecture." J. Anim. Ecol. 49:667-685.

Pandian, T.J. 1975. "Mechansims of Heterotrophy." In Marine Ecology. A Comprehensive, Integrated Treatixe on Life in Oceans and Coastal Waters. Volume II, Physiological Mechanisms, Part 1.O, ed. Kinne, pp. 61-249. John Wiley and Sons, New York.

Parker, P.L. 1962. "Zinc in a Texas Bay." Publ. Inst. Mar. Sci. Univ. Texas 8:75-79. 
Parker, P.L. 1966. "Radio-Tracer studies of Cobalt and Manganese in a Texas Bay." Publ. Inst. Mar. Sci. Univ. Texas 11:102-107.

Parker, P.L., Gibbs, A. and R. Lowler. 1963. "Cobalt, Iron, and Manganese in a Texas Bay." Publ. Inst. Mar. Sci. Univ. Texas 9: 28-32.

Parrish, K. and R.A. Carr. 1976. "Transport of Mercury Through a Laboratory Two-Level Marine Food Chain." Mar. Pollut. Bull. 7:90-91.

Paterson, S. and D. Mackay. 1985. "The Fugacity Concept in Environmental Modeling." In The Handbook of Environmental Chemistry. Vol. 2, Part C, ed. O. Hutzinger, pp. 121-140. SpringerVerlag, Heidelberg.

Paterson, S. and D. Mackay. 1987. "A Steady-State Fugacity-Based Pharmacokinetic Model with Simultaneous Multiple Exposure Routes." Environ. Toxicol. Chem. 6:395-408.

Patrick, F.M. and M. Loutit. 1976. "Passage of Metals in Effluents Through Bacteria to Higher Organisms." Wat. Res. 10:333-335.

Patterson, C.C. and D.M. Settle. 1987. "Review of Data on Eolian Fluxes of Industrial and Natural Lead to the Lands and Seas in Remote Regions on a Global Scale." Marine Chemistry 22:137-162.

Pavlou, S.P. 1987. "The Use of the Equilibrium Partitioning Approach in Determining Safe Levels of Contaminants in Marine Sediments." In Fate and Effects of Sediment-Bound Chemicals in Aquatic Systems, eds. K.L. Dickson, A.W. Maki, and W.A. Brungs, pp. 388-412. Pergamon Press, New York.

Pavlou, S.P. and R.N. Dexter. 1979. "Distribution of Polychlorinated Biphenyls (PCB) in Estuarine Ecosystems. Testing the Concept of Equilibrium Partitioning in the Marine Environment." Environmental Science and Technology 13:65-71.

Payne, J.R. and G.D. McNabb, Jr. 1985. "Weathering of Petroleum in the Marine Environment." Marine Technology Society Journal 18:1-19.

Payne, J.F. and W.R. Penrose. 1975. "Induction of Aryl Hydrocarbon Benzo[a]pyrene Hydroxylase in Fish by Petroleum." Bull. Environ. Contam. Toxicol. 14:112-121.

Payne, J.R., C.R. Phillips, and W. Hom. 1987. "Transport and Transformations:

Water Column Processes. In Long-Term Environmental Effects of Offshore Oil and Gas

Development, eds. D.F. Boesch and N.N. Rabalais, pp. 175-231. Elsevier Applied Science Publishers, London.

Peakall, D.B. 1975. "PCB's and Their Environmental Effects." CRC Crit. Rev. Environ. Contr. 5:469-508.

Pearse, V., J. Pearse, M. Buchsbaum, and R. Buchsbaum. 1987. Living Invertebrates. Blackwell Sci. Publ., Palo Alto, California and the Boxwood Press, Pacific Grove, California. 
Pelletier, E. and R. Larocque. 1987. "Bioaccumulation of Mercury in Starfish From Contaminated Mussels." Mar. Pollut. Bull. 18:482-485.

Pemberton, G., M. Risk and D. Buckley. 1976. "Supershrimp: Deep Bioturbation in the Strait of Canso, Nova Scotia." Science 192:790-791.

Penello, W.F. and B.H. Brinkhuis. 1980. "Cadmium and Manganese Flux in Eelgrass Zostera marina. I. Modelling Dynamics of Metal Release From Labelled Tissues." Mar. Biol. 58:181-186.

Penry, D.L. 1989. "Tests of Kinematic Models for Deposit-Feeders' Guts: Patterns of Sediment Processing by Parastichopus californicus (Stimpson) (Holothuroidea) and Amphicteis scaphobranchiata Moore (Polychaeta)." J. Exp. Mar. Biol. Ecol. 128:127-146.

Pentreath, R.J. 1973a. "The Accumulation and Retention of ${ }^{59} \mathrm{Fe}$ and ${ }^{58} \mathrm{Co}$ by the Plaice, Pleuronectes platessa L." J. Exper. Mar. Biol. Ecol. 12:315-326.

Pentreath, R.J. 1973b. "The Accumulation From Water of ${ }^{65} \mathrm{Zn},{ }^{54} \mathrm{Mn},{ }^{58} \mathrm{Co}$ and ${ }^{59} \mathrm{Fe}$ by the Mussel Mytilius edulis." J. Mar. Biol. Ass. U.K. 53:127-143.

Pentreath, R.J. 1976a. "Some Further Studies on the Accumulation and Retention of ${ }^{65} \mathrm{Zn}$ and ${ }^{54} \mathrm{Mn}$ by the Plaice, Pleuronectes platessa L." J. Exper. Mar. Biol. Ecol. 21:179-189.

Pentreath, R.J. 1976b. "The Accumulation of Inorganic Mercury From Seawater by the Paice, Pleuronectes platessa L." J. Exper. Mar. Biol. Ecol. 24:103-119.

Pentreath, R.J. 1976c. "The Accumulation of Mercury From Food by the Plaice, Pleuronectes platessa L." J. Exper. Mar. Biol. Ecol. 25:51-65.

Pentreath, R.J. 1976d. "The Accumulation of Organic Mercury From Seawater by the Paice, Pleuronectes platessa L." J. Exper. Mar. Biol. Ecol. 24:121-132.

Pentreath, R.J. 1977a. "The Accumulation of $110 \mathrm{~m} \mathrm{Ag}$ by the Plaice, Pleuronectes platessa L., and the Thornback Ray, Raja clavata L." J. Exper. Mar. Biol. Ecol. 29:315-325.

Pentreath, R.J. 1977b. "The Accumulation of Cadmium by the Plaice, Pleuronectes platessa L., and the Thornback Ray, Raja clavata L." J. Exper. Mar. Biol. Ecol. 30:223-232.

Pereira, W.E., C.E. Rostad, C.T. Chiou, T.I. Brinton, L.B. Barber, II, D.K. Demcheck, and C.R. Demas. 1988. "Contamination of Estuarine Water, Biota, and Sediment by Halogenated Organic Compounds: A Field Study." Environ. Sci. Technol. 22:772-778.

Perttila, M., V. Tervo, and R. Parmanne. 1982. "Age Dependence of the Concentration of Harmful Substances in Baltic Herring Clupea harengus." Chemosphere 11:1019-1026.

Pesch, C.E. 1979. "Influence of Three Sediment Types on Copper Toxicity to the Polychaete Neanthes arenaceodentata." Mar. Biol. 52:237-245. 
Pesch, C.E. and D. Morgan. 1978. "Influence of Sediment in Copper Toxicity Tests with the Polychaete Neathes arenaceodentata." Water Res. 12:747-751.

Petch, D.A. 1986. "Selective Deposit-Feeding by Lumbrineris cf. latreilli (Polychaeta:Lumbrineridae), with a New Method for Assessing Selectivity by Deposit-Feeding Organisms." Mar. Biol. 93:443-448.

Peterson, B.J. and B. Fry. 1987. "Stable Isotopes in Ecosystem Studies." Ann. Rev. Ecol. Syst. 18:293-320.

Peterson, B.J. and R.W. Howarth. 1987. "Sulfur, Carbon and Nitrogen Isotopes Used to Trace Organic Matter Flow in the Salt-Marsh Estuaries of Sapelo Island, Georgia." Limnol. Oceanog. 32:1195-1213.

Peterson, P.J. 1971. "Unusual Accumulations of Elements by Plants and Animals." Sci. Prog. 59:505-526.

Petrocelli, S.R., J.W. Anderson, and A.R. Hanks. 1975. "Biomagnification of Dieldrin Residues by Food Chain Transfer From Clams to Blue Crabs Under Controlled Conditions." Bull. Environ.

Contam. Toxicol. 13:108-116.

Phillips, D.J.H. 1976a. "The Common Mussel, Mytilus edulis as an Indicator of Pollution by Zinc, Cadmium, Lead, and Copper. I. Effects of Environmental Variables on Uptake of Metals." Mar. Biol. 38:59-69.

Phillips, D.J.H. 1976b. "The Common Mussel, Mytilus edulis as an Indicator of Pollution by Zinc, Cadmium, Lead, and Copper. II. Relationship of Metals in the Mussel to Those Discharged by Industry." Mar. Biol. 38:71-80.

Phillips, D.J.H. 1980. Quantitative Aquatic Biological Indicators: Their Use to Monitor Trace Metal and Organochlorine Pollution. Appl. Sci. Publ. Ltd., Essex, England.

Phillips, G.R. and D.R. Buhler. 1978. "The Relative Contributions of Methylmercury From Food and Water to Rainbow Trout (Salmo gairdneri) in a Controlled Laboratory Environment." Trans. Amer. Fish. Soc. 107:853-861.

Phillips, N.W. 1984. "Role of Different Microbes and Substrates as Potential Suppliers of Specific Essential Nutrients to Marine Detritivores." Bull. Mar. Sci. 35:283-298.

Phillips, R.C. 1979. "Role of Seagrasses in Estuarine Systems." Proc. Gulf of Mexico Coastal Ecosyst. Workshop, U.S. Fish and Wildlife Service, Publ. FWS/OBS-80/30:67-96.

Phillips, R.C. 1984. The Ecology of Eelgrass Meadows in the Pacific Northwest: A Community Profile. U.S. Fish and Wildlife Service. FWS/OBS-84/24:1-85.

Pierce, R.H., Jr., C.E. Olney, and G.T. Felbeck. 1971. "Pesticide Adsorption in Soils and Sediments." Environ. Letter 1:157-172. 
Pierce, R.H., Jr., C.E. Olney, and G.T. Felbeck, Jr. 1974. "pp-DDT Adsorption to Suspended Particulate Matter in Sea Water." Geochimica et Cosmochimica Acta 38:1061-1073.

Pinkas, L., M.S. Oliphant, and I.L.K. Iverson. 1971. "Food Habits of Albacore, Bluefin Tuna and Bonito in California Waters." Fish. Bull. Calif. Dept. Fish Game 152:1-105.

Pizza, J.C. and J.M. O’Connor. 1983. "PCB Dynamics in Hudson River Striped Bass. II. Accumulation From Dietary Sources." Aquat. Toxicol. 3:313-327.

Pocklington, R. 1977. "Chemical Processes and Interactions Involving Marine Organic Matter." Marine Chemistry 5:479-496.

Podoll, R.T., K.C. Irwin, and S. Brendinger. 1987. "Sorption of Water-Soluble Oligomers on Sediments." Environmental Science and Technology 21:562-568.

Podoll, R.T. and W.R. Mabey. 1987. "Factors to Consider in Conducting Laboratory Sorption/Desorption Tests. In Fate and Effects of Sediment-Bound Chemicals in Aquatic Systems, eds. K.L. Dickson, A.W. Maki, and W.A. Brungs, pp. 99-108. Pergamon Press, New York.

Potts, W.T.W. and M. Todd. 1965. "Kidney Function in the Octopus." Comp. Biochem. Physiol. 16:479-489.

Poutanen, E.-L. and R.J. Morris. 1985. "Comparison of the Structures of Humic Acids From Marine Sediments and Degraded Field Diatoms by ${ }^{13} \mathrm{C}$ and ${ }^{\mathrm{H}_{-N M R}}$ Spectroscopy." Marine Chemistry 17:115-126.

Powell, E.N. 1977. "Particle Size Selection and Sediment Reworking in a Funnel Feeder, Leptosynapta tenuis (Holothuroidea, Synaptidae)." Int. Revue ges. Hydrobiol. 62:385-408.

Prahl, F.G., E. Crecelius, and R. Carpenter. 1984. "Polycyclic Aromatic Hydrocarbons in Washington Coastal Sediments: An Evaluation of Atmospheric and Riverine Routes of Introduction." Environmental Science and Technology 18:687-693.

Preston, A., D.f. Jefferies, J.W.R. Dutton, B.R. Harvey, and A.K. Steele. 1972. "British Isles Coastal Waters: the Concentrations of Selected Heavy Metals in Sea Water, Suspended Matter and Biological Indicators - A Pilot Survey." Environ. Pollut. 3:69-82.

Preston, E.M. 1971. "The Importance of Ingestion in Chromium-51 Accumulation by Crassostrea virginica (Gmelin)." J. Exper. Mar. Biol. Ecol. 6:47-54.

Pritchard, J.B. and J.R. Bend. 1984. "Mechanisms Controlling the Renal Excretion of Xenobiotics in Fish: Effects of Chemical Structure." Drug Metab. Rev. 15:655-680.

Prohic, E. and G. Kniewald. 1987. "Heavy Metal Distribution in Recent Sediments of the Krka River Estuary - An Example of Sequential Extraction Analysis." Marine Chemistry 22:279-297. 
Protic'-Sabljic', M. and B. Kurelec. 1983. "High Mutagenic Potency of Several Polycyclic Aromatic Hydrocarbons Induced by Liver Postmitochondrial Fractions From Control and Xenobiotic-Treated Immature Carp." Mutation Res. 118:177-184.

Prouse, N.J. and D.C. Gordon, Jr. 1976. "Interactions Between the Deposit-Feeding Polychaete Arenicola marina and Oiled Sediment." In Sources, Effects and Sinks of Hydrocarbons in the Aquatic Environment, pp. 407-422. Amer. Inst. of Biol. Sci., Washington, D.C.

Pruell, R.J., J.L. Lake, W.R. Davis, and J.G. Quinn. 1986. "Uptake and Depuration of Organic Contaminants by Blue Mussels (Mytilus edulis) Exposed to Environmentally Contaminated Sediment." Mar. Biol. 91:497-507.

Pulich, Jr., W.M. 1980. "Heavy Metal Accumulation by Selected Halodule wrightii Asch. Populations in the Corpus Christi Bay Area." Contr. Mar. Sci. 23:89-100.

Ragsdale, H.L. and A. Thorhaug. 1980. "Trace Metal Cycling in the U.S. Coastal Zone: A Synthesis." Amer. J. Bot. 67:1102-1112.

Rainbow, P.S. 1989. "Copper, Cadmium and Zinc Concentrations in Oceanic Amphipod and Euphausid Crustaceans, as a Source of Heavy Metals to Pelagic Seabirds." Mar. Biol. 103:513-518.

Ramamurthy, V.D. 1979. "Baseline Study of the Level of Concentration of Mercury in the Food Fishes of Bay of Bengal, Arabian Sea and Indian Ocean." Bull. Jap. Soc. Sci. Fish. 45:1405-1407.

Ramos, I., M. Fuentes, R. Mederos, J.O. Grimalt, and J. Albaigés. 1989. Dissimilar Microbial Hydrocarbon Transformation Processes in the Sediment and Water Column of a Tropical Bay (Havana Bay, Cuba)." Marine Pollution Bulletin 20:262-268.

Rapin, F. 1983. "Speciation of Heavy Metals in a Sediment Core From Baie de Nice (Mediterranean Sea)." In Proceedings of International Conference on Heavy Metals in the Environment, pp. 1005-1008. CEP Consultants, Edinburgh, Scotland.

Rapin, F., G.P. Nembrini, U. Förstner, and J.I. Garcia. 1983. "Heavy Metals in Marine Sediment Phases Determined by Sequential Chemical Extraction and Their Interaction with Interstitial Water." Environmental Technology Letters 4:387-396.

Rapin, F., A. Tessier, P.G.C. Campbell, and R. Caregnan. 1986. "Potential Artifacts in the Determination of Metal Partitioning in Sediments by a Sequential Extraction Procedure." Environmental Science and Technology 20:836-840.

Raptis, S.E., G. Kaiser, and G. T. Tölg. 1983. "A Survey of Selenium in the Environment and a Critical Review of Its Determination at Trace Levels." Fresenius Zeitschrift fur Analytische Chimie 316:105-123.

Rasmussen, J.B., D.J. Rowan, D.R.S. Lean, and J.H. Carey. 1990. "Food Chain Structure in Ontario Lakes Determines PCB Levels in Lake Trout (Salvelinus namaycush) and Other Pelagic Fish." Can. J. Fish. Aquat. Sci. 47:2030-2038. 
Ratkowsky, D.A., T.G. Dix, and K.C. Wilson. 1975. "Mercury in Fish in the Derwent Estuary, Tasmania, and its Relation to the Position of the Fish in the Food Chain." Austral. J. Mar. Freshw. Res. 26:223-231.

Rau, G.H. 1982. "The Relationship Between Trophic Level and Stable Isotopes of Carbon and Nitrogen." In Coastal Water Research Project. Biennial Report 1981-1982, Southern California Coastal Water Research Project, Long Beach California.

Rau, G.H., T. Takahashi, and D.J. Des Marais. 1989. "Latitudinal Variations in Plankton $\delta^{13} \mathrm{C}$ : Implications for $\mathrm{CO}_{2}$ and Productivity in Past Oceans." Nature Lond. 341:516-518.

Ray, L.E., H.E. Murray, and C.S. Giam. 1983. "Organic Pollutants in Marine Samples From Portland, Maine." Chemosphere 12:1031-1038.

Readman, J.W., R.F.C. Mantoura, and M.M. Rhead. 1987. "A Record of Polycyclic Aromatic Hydrocarbon (PAH) Pollution Obtained From Accreting Sediments of the Tamar Estuary, U.K.: Evidence for Non-Equilibrium Behabiour of PAH." The Science of the Total Environment 66:73-94.

Readman, J.W., R.F.C. Mantoura, M.M. Rhead, and L. Brown. 1982. "Aquatic Distribution and Heterotrophic Degradation of Polycyclic Aromatic Hydrocarbons in the Tamar Estuary." Estuarine, Coastal and Shelf Science 14:369-389.

Regnault, M., R. Boucher-Rodoni, G. Boucher, and P. Lasserre. 1988. "Effects of Macrofauna Excretion and Turbulence on Inorganic Nitrogenous Exchanges at the Water-Sediment Interface. Experimental Approach in Microcosms." Cah. Biol. Mar. 29:427-444.

Reich, A.R., J.L. Perkins, and G. Cutter. 1986. "DDT Contamination of a North Alabama Aquatic Ecosystem." Environ. Toxicol. Chem. 5:725-736.

Reijnders, P.J.H. 1986. "Perspectives for Studies of Pollution in Cetaceans." Mar. Pollut. Bull. 17:58-59.

Reise, K. 1983. "Biotic Enrichment of Intertidal Sediments by Experimental Aggregates of the Deposit-Feeding Bivalve Macoma bäthica." Mar. Ecol. Progr. Ser. 12:229-236.

Renfro, W.C. 1973. "Transfer of ${ }^{65} \mathrm{Zn}$ from Sediments by Marine Polychaete Worms. Mar. Biol. 21:305-316.

Renfro, W.C., S.W. Fowler, M. Heyroud, and J. La Rosa. 1975. "Relative Importance of Food and Water in Long-Term Zinc ${ }^{-65}$ Accumulation by Marine Biota." J. Fish. Res. Bd. Can. 32:1339-1345.

Rhoads, D.C. 1963. "Rates of Sediment Reworking by Yoldia limatula in Buzzards Bay, Massachusetts and Long Island Sound." 'J. Sediment. Petrol. 33:723-727.

Rhoads, D.C. 1967. "Biogenic Reworking of Intertidal and Subtidal Sediments in Barnstable Harbor and Buzzards Bay, Massachusetts." J. Geol. 75:461-476. 
Rhoads, D.C. 1974. "Organism-Sediment Relations on the Muddy Sea Floor." Oceanogr. Mar. Biol. Ann. Rev. 12:263-300.

Rhoads, D.C. and L.F. Boyer. 1982. "The Effects of Marine Benthos on Physical Properties of Sediments: A Successional Perspective." In Animal-sediment Relations: The Biogenic Alteration of Sediments, eds. P.L. McCall and M.J.S. Tevesz, pp. 3-52. Plenum Press, New York.

Rhoads, D.C., J.Y. Yingst, and W.J. Uliman. 1978. "Seafloor Stability in Central Long Island Sound: Part I. Temporal Change in Erodibility of Find-Grained Sediment." In Estuarine Interactions, ed. M.L. Wiley, pp. 221-244. Academic Press, New York.

Rhoads, D.C. and D.K. Young. 1970. "The Influence of Deposit-Feeding Organisms on Sediment Stability and Community Trophic Structure." J. Mar. Res. 28:150-178.

Rhoads, D.C. and D.K. Young. 1971. "Animal-Sediment Relations in Cape Cod Bay, Massachusetts II. Reworking by Molpadia oolitica (Holothuroidea)." Mar. Biol. 11:255-261.

Rice, D.L., K.R. Tenore, and H.L. Windom. 1981. "The Effect of Detritus Ration on Metal Transfer to Deposit-Feeding Benthos." Mar. Ecol. Progr. Ser. 5:135-140.

Rice, S.D., R.E. Thomas, and J.W. Short. 1977. "Effect of Petroleum Hydrocarbons on Breathing and Coughing Rates and Hydrocarbon Uptake-Depuration in Pink Salmon Fry. In Physiological Mechanisms of Marine Pollution Toxicity, eds. W.B. Vernberg, A. Calabrese, F.P. Thurberg, and F.J. Vernberg, pp. 259-277. Academic Press, New York.

Richardson, E.M. and E. Epstein. 1971. "Retention of Three Insecticides on Different Size Soil Particles Suspended in Water." Soil Science Society Symposium Proceedings 35:884-887.

Ridgway, I.M. and N.B. Price. 1987. "Geochemical Associations and Post-Depositional Mobility of Heavy Metals in Coastal Sediments: Loch Etive, Scotland." Marine Chemistry 21:229-248.

Riedel, G.F., J.G. Sanders, and R.W. Osman. 1987. "The Effect of Biological and Physical Disturbances on the Transport of Arsenic From Contaminated Estuarine Sediments." Esuarine, Coastal and Shelf Science 25:693-706.

Riemann, F. and M. Schrage. 1978. "The Mucus-Trap Hypothesis of Feeding of Aquatic

Nematodes and Implications for Biodegradation and Sediment Texture." Oecologia. 35:75-88.

Riisgård, H.U., E. Bjørnstad, and F. Møhlenberg. 1987. "Accumulation of Cadmium in the Mussel Mvtilus edulis: Kinetics and Importance of Uptake Via Food and Sea Water." Mar. Biol. 96:349-353.

Ringold, P. 1978. "Burrowing, Root Mat.Density, and the Distribution of Fiddler Crabs in the Eastern United States." J. Exp. Mar. Biol. Ecol. 36:11-21.

Ringwood, A.H. 1989. "Accumulation of Cadmium by Larvae and Adults of the Hawaiian Bivalve, Isognomon californicum, During Chronic Exposure." Mar. Biol. 102:499-504. 
Risebrough, R.W., B.W. DeLappe, and T.T. Schmidt. 1976. "Bioaccumulation Factors of Chlorinated Hydrocarbons Between Mussels and Seawater." Mar. Poll. Bull. 7:225-228.

Rivers, J.B., J.E. Pearson, and C.D. Schultz. 1972. "Total and Organic Mercury in Marine Fish." Bull. Environm. Contam. Toxicol. 8:257-266.

Robberecht, H. and R. Van Grieken. 1982. "Selenium in Environmental Waters: Determination, Speciation and Concentration Levels." Talanta 29:823-844.

Robbins, J.A., P.L. McCall, J.B. Fisher, and J.R. Krezoski. 1979. "Effect of Deposit Feeders on Migration of ${ }^{137}$ Ce in Lake Sediments." Earth Planet. Sci. Lett. 42:277-287.

Roberts, D. 1979. "Deposit-Feeding Mechanisms and Resource Partitioning in Tropical Holothurians." J. Exp. Mar. Biol. Ecol. 37:43-56.

Roberts, H.H., T.H. Suchanek, and W.J. Wiseman. 1981. "Lagoon Sediment Transport: the Significant Effect of Callianassa Bioturbation." Proc. Fourth Internatl. Coral Reef Symp., Manila. $1: 459-465$.

Robertson, J.R., K. Bancroft, G. Vermeer, and K. Plaisier. 1980. "Experimental Studies on the Foraging Behavior of the Sand Fiddler Crab Uca pugilator (Bosc, 1802)." J. Exp. Mar. Biol. Ecol. 45:67-83.

Robertson, J.R. and S.Y. Newell. 1982. "Experimental Studies of Particle Ingestion by the Sand Fiddler Crab Uca pugilator (Bosc)." J. Exp. Mar. Biol. Ecol. 59:1-21.

Roesijadi, G. 1981. "The Significance of Low Molecular Weight Metallothionein-like Proteins in Marine Invertebrates: Current Status." Mar. Environ. Res. 4:167-179.

Roesijadi, G. and J.W. Anderson. 1979. "Condition Index and Free Amino Acid Content of Macoma inquinata Exposed to Oil-Contaminated Marine Sediments." In Marine Pollution, Functional Responses, eds. W.B. Vernberg, F.P. Thurberg, A. Calabrese, and F.J. Vernberg, pp. 164-187. Academic Press, New York.

Roesijadi, G., J.W. Anderson, and J.W. Blaylock. 1978a. "Uptake of Hydrocarbons From Marine Sediment Contaminated with Prudhoe Bay Crude Oil: Influence of Feeding Type of Test Species and Availability of Polycylic Aromatic Hydrocarbons." J. Fish. Red. Bd. Can. 35:608-614.

Roesijadi, G., D.L. Woodruff, and J.W. Anderson. 1978b. "Bioavailability of Naphthalenes From Marine Sediments Artificially Contaminated with Prudhoe Bay Crude Oil." Environ. Poll. 15:223-229.

Rona, P.A. 1983. "Hydrothermal Mineralization at Seafloor Spreading Centers: Atlantic Ocean and Indian Ocean," In Proceedings Oceans '83 Conference, pp. 817-824.

Rosental, R., G.A. Eagle, and M.J. Orren. 1986. "Trace Metal Distribution in Different Chemical Fractions for Nearshore Marine Sediments." Estuarine, Coastal and Shelf Science 22:303-324. 
Rossi, S.S. 1977. Bioavailability of Petroleum Hydrocarbons From Water, Sediments and Detritus to the Marine Annelid, Neanthes arenaceodentata. In Proc. 1977 Oil Spill Conference (Prevention, Behavior, Control, Cleanup), API Publication No. 4284, pp. 621-625. American Petroleum Institute, Washington, D.C.

Rossi, S.S. and J.W. Anderson. 1978. "Petroleum Hydrocarbon Resistance in the Marine Worm Neanthes arenaceodentata (Polychaeta: Annelida) Induced by Chronic Exposure to No. 2 Fuel Oil." Bull. Environ. Contam. Toxicol. 20:513-521.

Roubal, W.T., T.K. Collier, and D.C. Malins. 1977. "Accumulation and Metabolism of Carbon-14 Labeled Benzene, Naphthalene, and Anthracene by Young Coho Salmon (Onchorhynchus kisutch)." Arch. Environ. Contam. Toxicol. 5:513-529.

Roublee, P.A. 1982. "Bacteria and Microbial Distribution in Marine Sediments." In Estuarine Comparisons, ed. V.S. Kennedy, pp. 159-182. Academic Press, New York.

Rowe, G.T. 1973. "The Effects of the Benthic Infauna on the Physical Properties of Deep-Sea Sediments." In: Deep-Sea Sediments: Physical and Mechanical Properties, A.L Inderbitzen (ed.), Plenus Press, New Yourk, NY. pp 381-400.

Rubenstein, J.I., E. Lores, and N.R. Gregory. 1983. "Accumulation of PCBs, Mercury and Cadmium by Nereis virens, Mercenaria mercenaria and Palaemonetes pugio From Contaminated Harbor Sediments." Aquatic Toxicology 3:249-260.

Rubinstein, N.I., C.N. D'Asaro, C. Sommers, and F.G. Wilkes. 1980. "The Effects of Contaminated Sediments on Representative Estuarine Species and Developing Benthic Communities." In Contaminants and Sediments, Vol. I: Fate and Transport, Case Studies, Modeling, Toxicity, ed. R.A. Baker, pp. 445-461. Ann Arbor Science Publishers, Ann Arbor, Michigan.

Rubinstein, N.I., W.T. Gilliam, and N.R. Gregory. 1984a. Dietary Accumulation of PCBs From a Contaminated Sediment Source by a Demersal Fish Species (Leiostomus xanthurus). Technical Report D-84-6 to the Dept. of the Army, U.S. Corps of Engineers, Washington, DC.

Rubinstein, N.I., W.T. Gilliam, and N.R. Gregory. 1984b. "Dietary Accumulation of PCBs From a Contaminated Sediment Source by a Demersal Fish (Leiostomus xanthurus)." Aquat. Toxicol. 5:331-342.

Rubinstein, N.I., E. Lores, and N.R. Gregory. 1983. "Accumulation of PCBs, Mercury and Cadmium by Nereis virens, Mercenaria mercenaria and Palaemonetes pugio From Contaminated Harbor Sediments." Aquat. Toxicol. 3:249-260.

Rublee, P.A. 1982. "Bacteria and Microbial Distribution in Estuarine Sediments." . In Estuarine Comparisons, ed. M.L. Wiley, pp. 159-182. Academic Press, New York.

Sabljic, A. 1984. "Predictions of the Nature and Strength of Soil Sorption of Organic Pollutants by Molecular Topology." Journal of Agricultural and Food Chemistry 32:243-246. 
Sackett, W.M. 1989. "Stable Carbon Isotope Studies of Organic Matter in the Marine Environment." In Handbook of Environmental Isotope Geochemistry. Vol. 3. The Marine Environment, pp. 142-169. Elsevier, Amsterdam.

Safe, S. 1984. "Polychlorinated Biphenyls (PCBs) and Polybrominated Biphenyls (PBBs): Biochemistry, Toxicology and Mechanism of Action." CRC Crit. Rev. Toxicol. 13:319-393.

Saliot, A., M. Brault, and C. Boussuge. 1988. "The Lipid Geochemistry of Interstitial Waters of Recent Marine Sediments." Geochimica et Cosmochimica Acta 52:839-850.

Salomons, W. 1985. "Sediments and Water Quality." Environmental Technology Letters 6:315-326.

Salomons, W., N.M. de Rooij, H. Derdijk, and J. Bril. 1987. "Sediments as a Source for Contaminants?" Hydrobiologia 149:13-30.

Salomons, W. and U. Förstner. 1980. "Trace Metal Analysis of Polluted Sediments. II. Evaluation of Environmental Impact." Environmental Technology Letters 1:506-517.

Salomons, W. and U. Förstner. 1984. Metals in the Hydrosphere. Springer-Verlag, Berlin. 349 pp.

Saltzman, H.A. 1982. "Biodegradation of Aromatic Hydrocarbons in Marine Sediments of Three North Sea Oil Fields." Marine Biology 72:17-26.

Sanborn, H.R. and D.C. Malins. 1977. "Toxicity and Metabolism of Naphthalene: A Study with Marine Larval Invertebrates." Proc. Soc. Exp. Biol. Med. 154:151-167.

Sanders, B.M. and K.D. Jenkins. 1984. "Relationship Between Free Cupric Ion Concentrations in Seawater and Copper Metabolism and Growth in Crab Larvae." Biol. Bull. 167:704-712.

Sanders, B.M., K.D. Jenkins, W.G. Sunda, and J.D. Costlow. 1983. "Free Cupric Ion Activity in Seawater: Effects on Metallothionein and Growth in Crab Larvae." Science 222:53-55.

Sanders, J.G. 1983. "Role of Marine Phytoplankton in Determining the Chemical Speciation and Biogeochemical Cycling of Arsenic." Canadian Journal of Fisheries and Aquatic Sciences 40(2):192196.

Sanders, J.G. 1985. "Arsenic Geochemistry in Chesapeake Bay: Dependence Upon Anthropogenic Inputs and Phytoplankton Species Composition." Marine Chemistry 17:329-340.

Sanders, J.G., R.W. Osman and G.F. Riedel. 1989. "Pathways of Arsenic Uptake and Incorporation in Estuarine Phytoplankton and the Filter-Feeding Invertebrates Eurytemora affinis, Balanus improvisus and Crassostrea virginica." Mar. Biol. 103:319-325.

Sansone, F.J. 1986. "Depth Distribution of Short-Chain Organic Acid Turnover in Cape Lookout Bight Sediments." Geochimica et Cosmochimica Acta 50:99-105. 
Santschi, P.H. and B.D. Honeyman. 1989. "Redionuclides in Aquatic Environments." Radiat. Phys. Chem. 34:213-240.

Sayler, G.S., J.D. Nelson, Jr., and R.R. Colwell. 1975. "Role of Bacteria in Bioaccumulation of Mercury in the Oyster Crassostrea virginica." Appl. Microbiol.

30:91-96.

Schaefer, R.G., W. Ernst, H. Goerke, and G. Eder. 1976. "Resisdues of Chlorinated Hydrocarbons in North Sea Animals in Relation to Biological Parameters." Ber. Dtsch. Wiss. Kommun.

Meeresforsch. 24:225-233.

Schafer, H.A., G.P. Hershelman, D.R. Young, and A.J. Mearns. 1982. "Contaminants in Ocean Food Webs. In Coastal Water Research Project. Biennial Report for the Years 1981-1982, ed. W. Bascom, pp. 17-28. Southern California Coastal Water Research Project, Long Beach, California.

Schafer, W. 1972. Ecology and Palaeoecology of Marine Environments, Univ. of Chicago Press, Chicago.

Schaffer, F. and P. Schachtschabel. 1966. Lehrbuch der Bodenkunde. Enke, Stuttgart.

Schaffner, F.C. and P.K. Swart. 1991. "Influence of Diet and Environmental Water on the Carbon and Oxygen Isotopic Signatures of Seabird Eggshell Carbonate." Bull. Mar. Sci. 48: 23-38.

Schaule, B.K. and C.C. Patterson. 1978. "The Occurrence of Lead in the Northeast Pacific and the Effects of Anthropogenic Inputs." In Proceedings of the International Experts Discussion on Lead: Occurrence, Fate, and Pollution in the Marine Environment, ed. M. Branica. Pergamon Press, Oxford, England.

Schaule, B.K. and C.C. Patterson. 1981. "Lead Concentrations in the Northeast Pacific: Evidence for Global Anthropogenic Perturbations.". Earth and Planetary Science Letters 54:97-116.

Scheidegger, A.E. 1957. The Physics of Flow Through Porous Media. Macmillan Company, New York.

Schellenberg, K., C. Leuenberger, and R.P. Schwarzenbach. 1984. "Sorption of Chlorinated Phenols by Natural Sediments and Aquifer Materials." Environmental Science and Technology 18:652-657.

Schindler, P.W. and W. Stumm. 1987. "The Surface Chemistry of Oxides, Hydroxides, and Oxide Minerals." In Aquatic Surface Chemistry. Chemical Processes at the Particle-Water Interface, ed. W. Stumm, pp. 83-110. John Wiley \& Sons, New York.

Schmidt-Nielsen, B., J. Sheline, D.S. Miller, and M. Deldonno. 1977. "Effect of Methylmercury Upon Osmoregulation, Cellular Volume, and Ion Regulation in Winter Flounder, Pseudopleuronectes americanus." In Physiological Responses of Marine Biota to Pollutants, eds. Vernberg, W.B., A. Calabrese, F.P. Thurberg, and F.J. Vernberg, pp. 105-117. Academic Press, New York. 
Schimmel, S.C., R.L. Garnas, J.M. Patrick, Jr., and J.C. Moore. 1983. "Acute Toxicity, Bioconcentration, and Persistence of AC 222,705, Benthiocarb, Chlorpyrifon, Fenvalerate, Methyl Parathion, and Permethrin in the Estuarine Environment." J. Agric. Food Chem. 31:104-113.

Schneider, R. 1982. "Polychlorinated Biphenyls (PCBs) in Cod Tissues From the Western Baltic: Significance of Equilibrium Partitioning and Lipid Composition in the Bioaccumulation of Lipophilic Pollutants in Gill-Breathing Animals." Meeresforsch.

29:69-79.

Schnitzer, M. and S.U. Khan. 1972. Humic Substances in the Environment. Marcel Dekker, New York.

Schoer, J. 1985. "Iron-Oxo-Hydroxides and Their Significance to the Behaviour of Heavy Metals in Estuaries." Environmental Technology Letters 6:189-202.

Schroeder D.C. and G.F. Lee. 1975. "Potential Transformations of Chromium in Natural Waters." Water, Air and Soil Pollution 4:355-365.

Schults, D.W., S.P. Ferraro, G.R. Ditsworth, and K.A. Sercu. 1987. "Selected Chemical Contaminants in Surface Sediments of Commencement Bay and the Tacoma Waterways, Washington, USA." Marine Environmental Research 22:271-295.

Schulz-Baldez, M. 1974. "Lead Uptake From Sea Water and Food, and Lead Loss in the Common Mussel Mytilus edulis." Mar. Biol. 25:177-193.

Schwarzenbach, R.P. and J. Westall. 1981. "Transport of Nonpolar Organic Compounds From Surface Water to Groundwater. Laboratory Sorption Studies." Environ. Sci. Technol. 15:1360.

Sclater, F.R., E.A Boyle, and J.M. Edmond. 1976. " "On the Marine Geochemistry of Nickel." Earth and Planetary Science Letters 31:119-128.

Scura, E.D. and G.H. Theilacker. 1977. "Transfer of the Chlorinated Hydrocarbon PCB in a Laboratory Food Chain." Mar. Biol. 40:317-325.

Self, R.F.L. and P.A. Jumars. 1978. "New Resource Axes for Deposit Feeders?" 'J. Mar. Res. 36:627-641.

Seligman, P.F., A.O. Valkirs, and R.F. Lee. 1986. "Degradation of Tributyltin in Marine and Estuarine Waters." In Proceedings of the Oceans 86 Conference: Science-Engineering-Adventure, pp. 1189-1185. Marine Technology Society, Washington, D.C.

Serne, R.J. 1977. "Geochemical Distribution of Selected Trace Metals in San Francisco Bay Sediments." In Biological Implications of Metals in the Environment. ERDA Symposium Series No. 42, eds. H. Drucker and R.E. Wildung, pp. 280-286. Energy Research and Development Administration, Washington, D.C. 
Servos, M.R. D.C.G. Muir, and G.R.B. Webster. 1989. "The Effect of Dissolved Organic Matter on the Bioavailability of Polychlorinated Dibenzo-p-dioxins." Aquatic Toxicology 14:169-184.

Sharma, P., L.R. Gardner, W.S. Moore, and M.S. Bollinger. 1987. "Sedimentation and Bioturbation in a Salt Marsh as Revealed by ${ }^{210} \mathrm{~Pb},{ }^{137} \mathrm{Cs}$, and ${ }^{7} \mathrm{Be}$ Studies." Limnol. Oceanogr. 32:313-326.

Shaw, G.R. and D.W. Connell. 1982. "Factors Influencing Concentrations of Polychlorinated Biphenyls in Organisms From an Estuarine Ecosystem." Aust. J. Mar. Freshw. Res. 33:1057-1070.

Shaw, G.R. and D.W. Connell. 1984. "Physicochemical Properties Controlling Polychlorinated Biphenyl (PCB) Concentrations in Aquatic Organisms." Environ. Sci. Technol. 18:18-23.

Shea, D. and G.R. Helz. 1988. "The Solubility of Copper in Sulfidic Waters: Sulfide and Polysulfide Complexes in Equilibrium with Covellite." Geochimica et Cosmochimica Acta 52:18151825 .

Shea, D. and W.A. MacCrehan. 1988a. "Determination of Hydrophobic Thiols in Sediment Porewater Using Ion-Pair Liquid Chromatography Coupled to Electrochemical Detection." Analytical Chemistry 60:1449-1454.

Shea, D. and W.A. MacCrehan. 1988b. "Role of Biogenic Thiols in the Solubility of Sulfide Minerals." Science of the Total Environment 73:135-141.

Shears, M.A. and G.L. Fletcher. 1984. "The Relationship Between Metallothionein and Intestinal Zinc Absorption in the Winther Flounder." Can. J. Zool. 62:2211-2220.

Shears, M.A. and G.L. Fletcher. 1985. "Hepatic Metallothionein in the Winter Flounder (Pseudopleuronectes americanus)." Can. J. Zool. 63:1602-1609.

Sheline, J. and B. Schmidt-Nielsen. 1977. "Methylmercury-Selenium: Interaction in the Killifish, Fundulus heteroclitus." In Physiological Responses of Marine Biota to Pollutants, eds. Vernberg, W.B., A. Calabrese, F.P. Thurberg, and F.J. Vernberg, eds, pp. 119-130. Academic Press, New York.

Shiaris, M.P. and D. Jambard-Sweet. 1986. "Polycyclic Aromatic Hydrocarbons in Surficial Sediments of Boston Harbor, Massachusetts, USA." Marine Pollution Bulletin 17:469-472.

Shieh, C.-S. and I.W. Duedall. 1988. "Role of Amorphous Ferric Oxyhydroxide in Removal of Anthropogenic Vanadium From Seawater." Marine Chemistry 25:121-139.

Shimek, R.L. 1988. "The Functional Morphology of Scaphopod Captacula." The Veliger. 30:213221.

Shinozuka, N., C. Lee, and S. Hayano. 1987. "Solubilizing Action of Humic Acid From Marine Sediment." Science of the Total Environment 62:311-314. 
Sibley, T.H. and J.J. Morgan. 1977. "Equilibrium Speciation of Trace Metals in Fresh Water: Sea Water Mixtures." Proceedings of the International Conference on Heavy Metals in the Environment. Toronto, Canada 1:319-338.

Simenstad, C.A. L.F., Small, and C.D. McIntire. 1990. "Consumption and Food Web Structure in the Columbia River Estuary." Prog. Oceanog. 25:271-297.

Simkiss, K. and A.Z. Mason. 1984. "Cellular Responses of Molluscan Tissues to Environmental Metals." Mar. Environ. Res. 14:103-118.

Simkiss, K. and M.G. Taylor. 1989. "Metal Fluxes Across the Membranes of Aquatic Organisms." Reviews in Aquatic Sciences 1:173-188.

Sims, P. and P.L. Grover. 1981. "Involvement of Dihydrodiols and Diol Epoxides in the Metabolic Activation of Polycyclic Hydrocarbons Other Than Benzo[a]pyrene." In Polycyclic Hydrocarbons and Cancer, Vol. 3, eds. H.V. Gelboin and P.O.P. Ts'o, pp. 117-137. Academic Press, New York.

Skaar, D.R., B.T. Johnson, J.R. Jons, and J.N. Huckins. 1981. " Dietary Uptake of the Isecticides Kepone and Mirex by Bluegill Sunfish." Can. J. Fish. Aquat. Sci. 38:931-943.

Skei, J.M., N.B. Price, S.E. Calvert, and E. Hogdahl. 1972. "The Distribution of Heavy Metals in Sediments of Sörfjord, West Norway." Water, Air, and Soil Pollution 1:452-461.

Small, L.F. and S.W. Fowler. 1973. "Turnover and Vertical Transport of Zinc by the Euphausiid Meganyctiphanes norvegica in the Ligurian Sea." Mar. Biol. 18:284-290.

Small, L.F., S.W. Fowler, and S. Keckes. 1973. "Flux of Zinc Through a Macroplanktonic Crustacean." In Radioactivity in the Sea, No. 34, pp. 437-452. International Atomic Energy Commission, Vienna.

Smith, A.D., T.J. Griffith, D.E. Orr, and G.W. Ozburn. 1980. "Assimilation Efficiency and Clearance of Trichlorobenzenes in Rainbow Trout." In Aquatic Toxicology, ASTM STP 707, eds. J.G. Eaton, P.R. Parrish, and A.C. Hendricks, pp. 216-223. American Society for Testing and Materials, Philadelphia.

Smith, D.R., S. Niemeyer, J.A. Estes, and A.R. Flegal. 1990. "Stable Lead Isotopes Evidence Anthropogenic Contamination in Alaskan Sea Otters." Environ. Sci. Technol. 24:1517-1521.

Smith, G.A., J.S. Nickels, W.M. Davis, R.F. Martz, R.H. Findley, and D.C. White. 1982. "Perturbations of the Biomass, Metabolic Activity, and Community Structure of the Estuarine Detrital Microbiota: Resource Partitioning in Amphipod Grazing." J. Exp. Mar. Biol. Ecol. 64:125-143.

Smith, J.D. and J.D. Burton. 1972. "The Occurence and Distribution of Tin with Particular Reference to Marine Environments." Geochimica et Cosmochimica Acta 36:621-633.

Snodgrass, W.J. 1980. "Distribution and Behavior of Nickel in the Aquatic Environment." In Nickel in the Environment, ed. J.O. Nriagu, pp. 303-274. John Wiley and Sons, New York. 
Snoeij, N.J., A.H. Penninks, and W. Seinen. 1987. "Biological Activity of Organotin Compounds An Overview." Environmental Research 44:335-353.

Södergren, A. 1972. "Chlorinated Hydrocarbon Residues in Airborne Fallout." Nature 236:395397.

Södergren, A. and P. Larsson. 1982. "Transport of PCBs in Aquatic Laboratory Model Ecosystems From Sediment to the Atmosphere Via the Surface Microlayer." Ambio 11:41-45.

Sorensen, J., D. Christensen, and B.B. Jorgensen. 1981. "Volatile Fatty Acids and Hydrogen as Substrates for Sulfate Reducing Bacteria in Anaerobic Marine Sediment." Applied and Environmental Microbiology 42:5-11.

Soule, D.F. and J.D. Soule. 1981. "The Importance of Non-Toxic Urban Wastes in Estuarine Detrital Food Webs." Bull. Mar. Sci. 31:786-800.

Southern California Coastal Water Research Project. 1987. "Polynuclear Aromatic Hydrocarbons in Waste Effluent and Sediments." In SCCWRP Annual Report, pp. 21-26. Southern California Coastal Water Research Project, Long Beach, CA.

Southward, A.J. and E.C. Southward. 1972. "Observations on the Role of Dissolved Organic Compounds in the Nutrition of Benthic Invertebrates. III. Uptake in Relation to the Organic Content of the Habitat." Sarsia. 50:29-46.

Southward, A.J. and E.C. Southward. 1982. "The Role of Dissolved Organic Matter in the Nutrion of Deep-Sea Benthos." Amer. Zool. 22:647-658.

Southward, A.J., E.C. Southward, T. Brattegard, and T. Bakke. 1979. "Further Experiments on the Value of Dissolved Organic Matter as Food for Siboglinum fiordicum (Pogonophora)." J. Mar. Biol. Ass. U.K. 59:133-148.

Spies, R.B., J.E. Bauer, and D. Hardin. 1989a. "Stable Isotope Study of Sedimentary Carbon Utilization by Capitella spp.: Effects of Two Carbon Sources and Geochemical Conditions During Their Diagenesis." Mar. Biol. 101:69-74.

Spies, R.B. and D.J. DesMarais. 1983. "Natural Isotope Study of Trophic Enrichment of Marine Benthic Communities by Petroleum Seepage." Mar. Biol. 73:67-71.

Spies, R.B., H. Kruger, R.Ireland, and D.W. Rice, Jr. 1989b. "Stable Isotope Ratios and Contaminant Concentrations in a Sewage-Distorted Food Web." Mar. Ecol. Prog. Ser. 54:157-170.

Spigarelli, S.A., M.M. Thommes, and W. Prepejchal. 1983. "Thermal and Metabolic Factors Affecting PCB Uptake by Adult Brown Trout." Environ. Sci. Technol. 17:88-94.

Stallard, M., V. Hodge, and E.D. Goldberg. 1987. "TBT in California Coastal Waters: M Monitoring and Assessment." Environmental Monitoring and Assessment 9:195-220. 
Stang, P.M. and P.F. Seligman. 1986. "Distribution and Fate of Butyltin Compounds in the Sediment of San Diego Bay." In Proceedings of the Oceans 86 Conference: Science-EngineeringAdventure, pp. 1256-1261. Marine Technology Society, Washington D.C.

Staples, C.A., K.L. Dickson, J.H. Rodgers, Jr., F.Y. Saleh. 1985. "A Model for Predicting the Influence of Suspended Sediments on the Bioavailability of Neutral Organic Chemicals in the Water Compartment." In Aquatic Toxicology and Hazard Assessment, ASTM Special Publication 854, eds. R.D. Cardwell, R. Purdy and R. Comotto, pp. 417-427. Philadelphia.

Stegeman, J.J. 1981. "Polynuclear Aromatic Hydrocarbons and Their Metabolism in the Marine Environment." In Polycyclic Hydrocarbons and Cancer, Vol. 3, eds. H.V. Gelboin and P.O.P. Ts'o, pp. 1-46. Academic Press, New York.

Stegeman, J.J., B.R. Woodin, A.V. Klotz, R.E. Wolke, and N.R. Orme-Johnson. 1982. "Cytochrome P-450 and Monooxygenase Activity in Cardiac Microsomes From the Fish Stenotomus chrysops." Mol. Pharmacol. 21:517-521.

Stehlik, L.L. and J.V. Merriner. 1983. "Effects of Accumulated Dietary Kepone on Spot (Leiostomus xanthurus).". Aquat. Toxicol. 3:345-358.

Stein, J.E., T. Hom, E. Casillas, A. Friedman, and U. Varanasi. 1987. "Simultaneous Exposure of English Sole (Parophrys vetulus) to Sediment-Associated Xenobiotics: Part 2 - Chronic Exposure to an Urban Estuarine Sediment with Added 3H-benzo[a]pyrene and 14C-polychlorinated Biphenyls." Mar. Environ. Res. 22:123-149.

Steinberg, S.M., M.I. Venkatesan, and I.R. Kaplan. 1987. "Organic Geochemistry of Sediments From the Continental Margin Off Southern New England, U.S.A. Part I. Amino Acids, Carbohydrates and Lignin." Marine Chemistry 21:249-265.

Stenersen, J., S. Kobro, M. Bjerk, and U. Arenal. 1987. "Glutathione Transferases in Aquatic and Terrestrial Animals From Nine Phyla." Comp. Biochem. Physiol. 86C:73-76.

Stenner, R.D. and G. Nickless. 1975. "Heavy Metals in Organisms of the Atlantic Coast of SouthWest Spain and Portugal." Mar. Poll. Bull. 6: 89-92.

Stephens, G.C. 1963. "Uptake of Organic Material by Aquatic Invertebrates-II. Accumulation of Amino Acids by the Bamboo Worm, Clymenella torquata." Comp. Biochem. Physiol. 10:191-202.

Stephens, G.C. 1972. "Amino Acid Accumulation and Assimilation in Marine Organisms." In Nitrogen Metabolism and the Environment, eds. J.W. Campbell and L. Goldstein, pp. 156-184. Academic Press, New York.

Stephens, G.C. 1975. "Uptake of Naturally Occurring Amines by Marine Annelids." Biol Bull. 149:397-407.

Stephens, G.C. 1982, "Recent Progress in the Study of "Die Ernährung der Wassertiere und der Stoffhaushalt der Gewässer." Amer. Zool. 22:611-621. 
Stevens, B.G., D.A. Armstrong, and R. Cusimano. 1982. "Feeding Habits of the Dungeness Crab Cancer magister as Determined by the Index of Relative Importance." Mar. Biol. 72:135-145.

Stevenson, F.J. 1982. Humus Chemistry: Genesis, Composition, Reactions. Wiley-Interscience, New York.

Stevenson, F.J. 1985a. "Geochemistry of Soil Humic Substances." In Humic Substances in Soil, Sediment, and Water. Geochemistry, Isolation, and Characterization, eds. G.R. Aiken, d.M. McKnight, R.W. Wershaw, and P. MacCarthy, pp. 13-52. John Wiley and Sons, New York.

Stevenson, J.R. 1985b. "Ch. 1. Dynamics of the Integument." In The Biology of Crustacea. Volume 9: Integument, Pigments, and Hormonal Processes. eds. D.E. Bliss and L.H. Mantel, pp. 142. Academic Press, New York.

Stewart, J. and M. Schulz-Baldes. 1976. "Long-Term Lead Accumulation in Abalone (Haliotis spp.) Fed on Lead-Treated Brown Algae (Egregia laevigata)." Mar. Biol.

36:19-24.

Stewart, M.G. 1979. "Absorption of Dissolved Organic Nutrients by Marine Invertebrates." Oceanogr. Mar. Biol. Ann. Rev. 17:163-192.

Stickney, R.R., H.I.. Windom, D.B. White, and F.E. Taylor. 1975. "Heavy Metal Concentrations in Selected Georgia Estuarine Organisms with Comparative Hood-Habit Data." In Mineral Cycling in Southeastern Ecosystems, eds. F.G. Howell, J.B. Gentry, and M.H. Smith, pp. 257-267. Technical Information Center, Office of Pollution Assessment, U.S. Energy Research and Development Administration, Washington, DC.

Stockman, K.W., R.N. Ginsberg, and E.A. Shinn. 1967. "The Production of Lime Mud by Algae in South Florida." Journal of Sedimentary Petrology 37:633-648.

Stoepler, M., M. Bernard, F. Backaus, and E. Schulte. 1979. "Comparative Studies on Trace Metal Levels in Marine Biota. I. Mercury in Marine Organisms From Western Italian Coast, the Strait of Gibraltar and the North Sea." Sci. Tot. Environ. 13:209-223.

Stoffers, P., C. Summerhayes, U. Förstner, and S.R. Patchineelum. 1977. "Copper and Other Heavy Metal Contamination in Sediments From New Bedford Harbor, Massachusetts: A Preliminary Note." Environmental Science and Technology 11:819-821.

Stone, A.T. and J.J. Morgan. 1987. "Reductive Dissolution of Metal Oxides." In Aquatic Surface Chemistry. Chemical Processes at the Particle-Water Interface, ed. W. Stumm, pp. 221-254. John Wiley and Sons, New York.

Strong, C.R. and S.N. Luoma. 1981. "Variations in the Correlation of Body Size with Concentrations of $\mathrm{Cu}$ and $\mathrm{Ag}$ in the Bivalve Macoma balthica." Can. J. Fish. Aquat. Sci. 38:10591064. 
Stumm, W. and P. Baccini. 1978. "Man-Made Perturbation of Lakes." In Lakes - Chemistry, Geology, Physics, ed. A. Lerman, pp. 91-126. Springer Verlag, New York.

Subramanian, A.N., S. Tanabe, R. Tatsukawa, S. Saito, and N. Miyazaki. 1987. "Reduction in the Testosterone Levels by PCBs and DDE in Dall's Porpoises of Northwestern North Pacific." Mar. Pollut. Bull. 18:643-646.

Suchanek, T.H. 1983. "Bioturbation by Callianassid Shrimp: Redistribution of Radioactive Falloutat. Enewetak and Bikini Atolls. Amer. Zool. 23:1003.

Sullivan, M.F., J.T. Hardy, B.M. Miller, R.L. Buschbom, and T.C. Siewidki. 1984. "Absorption and Distribution of Cadmium in Mice Fed Diets Containing Either Inorganic or Oyster-Incorporated Cadmium." Toxicol. Appl. Pharmacol. 72:210-217.

Summerhayes, C.P., J.P. Ellis, P. Stoffers, S.R. Briggs, and M.G. Fitzgerald. 1977. Fine-Grained Sediment and Industrial Waste Distribution and Dispersal in New Bedford Harbor and Western Buzzards Bay, Massachusetts. Report 76-115, Woods Hole Oceanographic Institution, Woods Hole, Massachusetts.

Summers, A.O. 1985. "Bacterial Resistances to Toxic Elements." Trends in Biotechnology 3:122125.

Summers, A.O. and S. Silver. 1978. "Microbial Transformation of Metals." Annual Review of Microbiology 32:637-672.

Sunda, W.G., D.W. Engel, and R.M. Thuotte. 1978. "Effect of Chemical Speciation on Toxicity of Cadmium to Grass Shrimp, Palaemonetes pugio: Importance of Free Cadmium Ion." Environ. Sci. Technol. 12:409-413.

Sunda, W.G. and R.R.L. Guillard. 1976. "The Relationship Between Cupric Ion Activity and the Toxicity of Copper to Phytoplankton." J. Mar. Res. 34:511-529.

Suzuki, T. and M. Hatanaka. 1974. "Experimental Investigation on the Biological Concentration of Mercury-I. On the Rate of Mercury Transfer Through the Food Chain From Jack Mackerel to Young Yellowtail." Bull. Sci. Soc. Sci. Fish. 40:1173-1178.

Suzuki, T. and M. Hatanaka. 1975. "Experimental Investigation on the Biological Concentration of Mercury-II. On the Origin of Mercury Found in the Body of Young Yellowtail." Bull."Jap. Soc. Sci. Fish. 41:225-231.

Swartz, R.C., G.R. Ditsworth, D.W. Schults, and J.O. Lamberson. 1985. "Sediment Toxicity to a Marine Infaunal Amphipod: Cadmium and its Interaction with Sewage Sludge." Mar. Environ. Res. 18:133-153.

Swartz, R.C., P.F. Kemp, D.W. Schults, and J.O. Lamberson. 1988. "Effects of Mixtures of Sediment Contaminants on the Marine Infaunal Amphipod, Rhepoxynius abronius." Environ. Toxicol. Chem. 7:1013-1020. 
Szefer, P. 1991. "Interphase and Trophic Relationships of Metals in a Southern Baltic Ecosystem." Sci. Tot. Environ. 101:201-215.

Szefer, P. and K. Szefer. 1991. "Concentration and Discrimination Factors for $\mathrm{Cd}, \mathrm{Pb}, \mathrm{Zn}$, and $\mathrm{Cu}$ in Benthos of Puck Bay, Baltic Sea." The Science of the Total Environment 105:127-133.

Taghon, G.L. 1982. "Optimal Foraging by Deposit-Feeding Invertebrates: Roles of Particle Size and Organic Coating." Oecologia. 52:295-302.

Taghon, G.L., A.R.M. Nowell, and P.A. Jumars. 1980. "Induction of Suspension Feeding in Spionid Polychaetes by High Particulate Fluxes." Science 210:562-564.

Taghon, G.L., R.F.L. Self, and P.A. Jumars. 1979. "Predicting Particle Selection by Deposit Feeders: A Model and its Implications." Limnol. Oceanogr. 23:752-759.

Takayanagi, K. and N. Belzile. 1988. "Profiles of Dissolved and Acid-Leachable Selenium in a Sediment Core From the Lower St. Lawrence Estuary." Marine Chemistry 24:307-314.

Takayanagi, K. and G.T. Wong. 1984. "Organic and Colloidal Selenium in Southern Chesapeake Bay and Adjacent Waters." Marine Chemistry 14:141-148.

Tanacredl, J.T. and R.R. Cardenas. 1991. "Biodepuration of Polynuclear Aromatic Hydrocarbons from a Bivalve Mollusc Mercenaria mercenaria." L. Environ. Sci. Technol. 25:1453-1461.

Tarshis, I.B. and B.A. Rattner. 1982. "Accumulation of ${ }^{14} \mathrm{C}$-naphthalene in the Tissues of Redhead Ducks Fed Oil-Contaminated Crayfish." Arch. Environ. Contam. Toxicol.

11:155-159.

Tate, L.G. and D.A. Herf. 1978. "Characterization of Glutathione S-Transferase Activity in Tissues of the Blue Crab, Callinectes sapidus." Comp. Biochem. Physiol. 61C:165-168.

Tatem, H.E. 1986. "Bioaccumulation of Polychlorinated Biphenyls and Metals From Contaminated Sediment by Freshwater Prawns, Macrobrachium rosenbergii and Clams, Corbicula fluminea." Arch. Environ. Contom. Toxicol. 15:171-183.

Taylor, M.G. and K. Simkiss. 1984. "Inorganic Deposits in Invertebrate Tissues." Environ. Chem. 3:102-138.

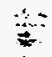

Teal, J.M. 1977. "Food Chain Transfer in Hydrocarbons." In Fate and Effects of Petroleum Hydrocarbons in Marine Ecosystems and Organisms, eds. D.A. Wolfe, J.W. Anderson, D.K. Button, D.C. Malins, T. Roubal and U. Varanasi, pp. 71-77. Pergamon Press, New York.

Teal, J.M. and J.W. Farrington. 1976. "A Comparison of Hydrocarbons in Animals and Their Benthic Habitats." In Petroleum Hydrocarbons in the Marine Environment, eds. A.D. McIntyre and K. White, Rapp. pp. 171-188. P.-c. Reun. Cons. Int. Expl, Mar., New York. 
Tempel, D. and W. Westheide. 1980. "Uptake and Incorporation of Dissolved Amino Acids by Interstitial Turbellaria and Polychaeta and Their Dependence on Temperature and Salinity." Mar. Ecol. Progr. Ser. 3:41-50.

Tenore, K.R. 1975. "Detrital Utilization by the Polychaete Capitella capitata." J. Mar. Res. 33:261-274.

Tenore, K.R. 1977a. "Growth of the Polychaete Capitella capitata Cultured in Different Levels of Detritus From Various Sources." Limnol. Oceanogr. 22:936-941.

Tenore, K.R. 1977b. "Utilization of Aged Detritus Derived From Different Sources by the Polychaete Capitella capitata." Mar. Biol. 44:51-55.

Tenore, K.R. and R.B. Hanson. 1980. "Availability of Detritus of Different Types and Ages to a Polychaete Macroconsumer, Capitella capitata." Limnol. Oceanogr. 25:553-558.

Tenore, K.R., R.B. Hanson, J. McClain, A.E. MacCubbin and R.E. Hodson. 1984. "Changes in Composition and Nutritional Value to a Benthic Deposit Feeder of Decomposing Detritus Pools."

Bull. Mar. Sci. 35:299-311.

Tenore, K.R. 1977. "Utilization of Aged Detritus Derived From Different Sources by the Polychaete Capitella capitata." Mar. Biol. 44:51-55.

Tessier, A. and P.G.C. Campbell. 1987. "Partitioning of Trace Metals in Sediments: Relationships with Bioavailability:" Hydrobiologia 149:43-52.

Thayer, J.S. and F.E. Brinckman. 1982. "The Biological Methylation of Metals and Metalloids." Advances in Organometallic Chemistry 20:313-356.

Thomann, R.V. 1989. "Bioaccumulation Model of Organic Chemical Distribution in Aquatic Food Chains." Environ Sci. Technol. 23:699-707.

Thomann, R.V. and J.P. Connolly. 1984. "Bioaccumulation of Organic Contaminants in Aquatic Organisms." Environ. Sci. Technol. 18:65-71.

Thomas, J.F., M. Mukai, and B.D. Tebbens. 1968. "Fate of Airborne Benzo(a)pyrene." Environmental Science and Technology 2:33-39.

Thomas, R.E. and S.D. Rice. 1986. "The Effects of Salinity on Uptake and Metabolism of Toluene and Naphthalene by Dolly Varden, Salvelinus malma." Mar. Environ. Res. 18:203-214.

Thompson, D.R., F.M. Stewart, and R.W. Furness. 1990. "Using Seabirds to Monitor Mercury in Marine Environments. The Validity of Conversion Ratios for Tissue Comparisons." Mar. Pollut. Bull. 21:339-342. 
Thomson, E.A., S.N. Luoma, C.E. Johansson, and D.J. Cain. 1984. "Comparison of Sediments and Organisms in Identifying Sources of Biologically Available Trace Metal Contamination." Water Res. 18:755-765.

Thomson-Becker, E.A. and S.N. Luoma. 1985. "Temporal Fluctuations in Grain Size, Organic Materials and Iron Concentrations in Intertidal Surface Sediment of San Francisco Bay." Hydrobiologia 129:91-107.

Thornton, I., H. Watling, and A. Darracott. 1975. "Geochemical Studies in Several Rivers and Estuaries Used for Oyster Rearing." Science of the Total Environment 4:325-345.

Thurberg, F.P., A. Calabrese, E. Gould, R.A. Grieg, M.A. Dawson, and R.K. Tucker. 1977. "Response of Lobster, Homarus americanus, to Sublethal Levels of Cadmium and Mercury." In Physiological Responses of Marine Biota to Pollutants, eds. Vernberg, W.B., A. Calabrese, F.P. Thurberg, and F.J. Vernberg, pp. 185-197. Academic Press, New York.

Tietjen, J.H. and J.J. Lee. 1975. "Axenic Culture and Uptake of Dissolved Organic Substances by the Marine Nematode, Rhabditis marina Bastian." Cah. Biol. Mar. 16:685-694.

Topcuoglu, S., E. Birol, and M.Y. Ünlü. 1987. "Factors Affecting the Accumulation and Elimination of Silver $(110 \mathrm{~m} \mathrm{Ag})$ in Marine Isopods." Mar. Environ. Res. 21:189-198.

Trefry, J.H. and B.J. Presley. 1976. "Heavy Metals in Sediments From San Antonio Bay and the Northwest Gulf of Mexico." Environmental Geology 1:283-294.

Trefry, J.H., R.P. Troune, S. Metz, and M.A. Sisler. 1986. Forms, Reactivity, and Availability of Trace Metals in Barite. Final report to the Offshore Operators Committee, Taskforce, on Environmental Science, New Orleans.

Tripp, B.W., J.W. Farrington, and J.M. Teal. 1981. "Unburned Coal as a Source of Hydrocarbons in Surface Sediments." Marine Pollution Bulletin 12:122-126.

Trudinger, P.A. 1979. "The Biological Sulfur Cycle." In Biogeochemical Cycling of MineralForming Elements, eds. P.A. Trudinger and D.J. Swain. Elsevier, New York.

Trueman, E.R. 1975. The Locomotion of Soft-bodied Animals. American Elsevier, New York.

Tsuchiya, M. and Y. Kuihara. 1979. "The Feeding Habits and Food Sources of the Dêposit-Feeding Polychaete, Neanthes japonica (Izuka)." J. Exp. Mar. Biol. Ecol. 36:79-89.

Tunnicliffe, V. and M.J. Risk. 1977. "Relationships Between the Bivalve Macoma balthica and Bacteria in Intertidal Sediments: Minas Basin, Bay of Fundy." Journal of Marine Research 35:449509.

Ueda, T., R. Nakamura, and Y. Suzuki. 1976. "Comparison of $115 \mathrm{~m}_{\mathrm{Cd}}$ Accumulation From Sediments and Sea Water by Polychaete Worms." Bull. Japanese Soc. Sci. Fish. 42:299-306. 
Ueda, T., R. Nakamura, and Y. Suzuki. 1977. "Comparison of Influences of Sediments and Sea Water on Accumulation of Radionuclides by Worms." J. Radiat. Res. 18:84-92.

Ueda, T., Y. Suzuki, R. Nakamura, and M. Nakahara. 1982. "Accumulation of Co by Bivalve Tridacna cricea." Bull. Jap. Soc. Sci. Fish. 48:993-997.

Unger, M.A., W.G. MacIntyre, and R.J. Huggett. 1988. "Sorption Behavior of Tributyltin on Estuarine and Freshwater Sediments." Environmental Toxicology and Chemistry 7:907-916.

Ünlü, M.Y. 1979. "Chemical Transformation and Flux of Different Forms of Arsenic in the Crab Carcinas maenas." Chemosphere 5:269-275.

Vale, C. and R. Mendes. 1986. "Zinc Levels in Bivalves: Evidence for a Regulator Ability in Clams (Venerupis spp.) and Cockles (Cerastroderm edule)." In Proceedings of the International Conference on Chemicals in the Environment, eds. Lester, J.N., R. Perry, R.M. Sterrett, pp. 199204. Selper, Ltd, London.

Valenta, P., R. Breder, L. Mart, H. Rützel. 1987. "Distribution of Cd and Pb Between Dissolved and Particulate Phases in Estuaries." Toxicological and Environmental Chemistry 14:129-141.

Valkirs, A.O., M.O Stallard, and P.F. Selligman. 1987. "Butyltin Partitioning in Marine Waters." In Proceedings of the Oceans 87 Conference: The Ocean "an International Workplace," pp. 13741380. Marine Technology Society, Washington D.C.

Vandenbroucke, M., R. Pelet, and Y. Debyser. 1985. "Geochemistry of Humic Substances in Marine Sediments." In Humic Substances in Soil, Sediment, and Water. Geochemistry, Isolation, and Characterization, eds. G.R. Aiken, D.M. McKnight, R.L. Wershaw, and P. MacCarthy, pp. 249273. John Wiley and Sons, New York.

Van der Weijden, C.H. and M. Reith. 1982. "Chromium (III) - Chromium (VI) Interconversions in Seawater." Marine Chemistry 11:565-572.

Vangenechten, J.H.D., S.R. Aston, and S.W. Fowler. 1983. "Uptake of Americium-241 From Two Experimentally Labelled Deep-Sea Sediments by Three Benthic Species: A Bivalve Mollusc, a Polychaete and an Isopod." Mar. Ecol. Progr. Ser. 13:291-228.

Varanasi, U. and D.J. Gmur. 1980. "Metabolic Activation and Covalent Binding of Benzo[a]pyrene to Deoxyribonucleic Acid Catalyzed by Liver Enzymes of Marine Fish." Biochem. Phărmacol. 29:753-759.

Varanasi, U. and D.C. Malins. 1977. "Metabolism of Petroleum Hydrocarbons: Accumulation and Biotransformation in Marine Organisms." In Effects of Petroleum on Arctic and Subarctic Marine Environments and Organisms, Vol. II, Biological Effects, ed. D.C. Malins, pp. 175-270. Academic Press, New York.

Varanasi, U., M. Nishimoto, W.M. Baird, and T.A. Smolarek. 1989b. "Metabolic Activation of PAH in Subcellular Fractions and Cell Cultures From Aquatic and Terrestrial Species." In 
Metabolism of Polycyclic Aromatic Hydrocarbons in the Aquatic Environment, ed. U. Varanasi, pp. 203-251. CRC Press, Boca Raton, Florida.

Varanasi, U., W.L. Reichert, J.E. Stein, D.W. Brown, and H.R. Sanborn. 1985. "Bioavailability and Biotransformation of Aromatic Hydrocarbons in Benthic Organisms Exposed to Sediment From an Urban Estuary." Environ. Sci. Technol. 19:836-841.

Varanasi, U., J.E. Stein, and M. Nishimoto. 1989a. "Biotransformation and Disposition of PAH in Fish." In Metabolism of Polycyclic Aromatic Hydrocarbons in the Aquatic Environment, ed. U. Varanasi, pp. 93-150. CRC Press, Boca Raton, Florida.

Varanasi, U., J.E. Stein, M. Nishimoto, and T. Hom. 1982. "Benzo[a]pyrene Metabolites in Liver, Muscle, Gonads, and Bile of Adult English Sole (Parophrys vetulus)." In Polynuclear Aromatic Hydrocarbons, eds. M.W. Cooke and A.J. Dennis, pp. 1221-1247. Battelle Press, Columbus, Ohio.

Venkatesan, M.I. 1988. "Occurence and Possible Sources of Perylene in Marine Sediments - A Review." Marine Chemistry 25:1-27.

Venkatesan, M.I., E. Ruth, S. Steinberg, and I.R. Kaplan. 1987. "Organic Geochemistry of Sediments From the Continental Margin Off Southern New England, U.S.A. Part II. Lipids." Marine Chemistry 21:267-299.

Viarengo, A. 1985. "Biochemical Effects of Trace Metals." Mar. Poll. Bull. 16:153-158.

Viarengo, A., M.N. Moore, G. Mancinelli, A. Mazzucotelli, K. Piper, and S.V. Farrar. 1987. "Metallothioneins and Lysosomes in Metal Toxicity and Accumulation in Marine Mussels: The Effect of Cadmium in the Presence and Absence of Phenanthrene." Mar. Biol. 94:251-257.

Vincent, E. and W.H. Berger. 1981. "Planktonic Foraminifera and Their Use in Paleooceanography:" In The Oceans, Vol. 7 in The Oceanic Lithosphere, ed. C. Emiliani, pp. 10251120. John Wiley and Sons, New York.

Voice, T.C., C.P. Rice, and W.J. Weber, Jr. 1983. "Effect of Solids Concentration on the Sorptive Partitioning of Hydrophobic Pollutants in Aquatic Systems." Environmental Science and Technology 17:513-518.

Voice, T.C. and W.J. Weber, Jr. 1983. "Sorption of Hydrophobic Compounds by Sediments, Soils and Suspended Solids-I. Theory and Background." Water Research 17:1433-1441.

Vowles, P.D. and R.F.C. Mantoura. 1987. "Sediment-Water Partition Coefficients and HPLC Retention Factors of Aromatic Hydrocarbons." Chemosphere 16:109-116.

Wade, T.L., M.C. Kennicott II, and E.G. Merrill. 1986. "Fate of Carbonized Coal Hydrocarbons in a Highly Industrialized Estuary." In Organic Marine Geochemistry, pp. 215-228 
Wagemann, R. and D.C.G. Muir. 1981. Assessment of Heavy Metals and Organochlorine Concentrations in Marine Mammals of Northern Waters. ICES Marine Environmental Quality Committee, C.M. 1981/N:9.

Wagemann, R., N.B. Snow, A. Lutz, and D.P1 Scott. 1983. "Heavy Metals in Tissues and Organs of the Narwhal (Monodon monoceros)." Can. J. Fish. Aquat. Sci. 40(2):206-214.

Waiwood, K.G. and F.W.H. Beamish. 1978. "Effects of Copper, pH and Hardness on the Critical Swimming Performance of Rainbow Trout Salmo gairdneri Richardson." Wat. Res. 12:611-619.

Waldichuk, M. 1985. "Biological Availability of Metals to Marine Organisms." Mar. Poll. Bull. 16:7-11.

Waldock, M.J., M.E. Waite, and J.E. Thain. 1987. Changes in Concentrations of organotins in U.K. rivers and estuaries following legislation in 1986. Pages 1352-1356 In: Proceedings of the Oceans 87 Conference: The Ocean "an International Workplace." Marine Technology Society, Washington, D.C.

Waiters, R.W., S.A. Ostazeski, and A. Guiseppi-Elle. 1989. " "Sorption of 2,3,7,8 tetrachlorodibenzo-p-dioxin From Water by Surface Soils." Environmental Science and Technology 23:480-484.

Ward, D.M. R.M. Atlas, P.D. Boehm, and J.A. Calder. 1980. "Biodegradation and Chemical Evolution of Oil From the Amoco Cadiz Oil Spill." Ambio 9:277-283.

Warfe, J.R. and W.L.F. van den Broek. 1978. "Chlorinated Hydrocarbons in Macroinvertebrates and Fish From the Lower Medway Estuary, Kent." Mar. Pollut. Bull. 9:76-79.

Warren, L.J. 1981. "Contamination of Sediments by Lead, Zinc and Cadmium: A Review." Environmental Pollution (Series B) 2:401-436.

Watson, P.G., P.E. Frickers, and C.M. Goodchild. 1985. "Spatial and Seasonal Variations in the Chemistry of Sediment Interstitial Waters in the Tamar Estuary." Estuarine, Coastal and Shelf Science 21:105-119.

Wavre, M. and R.O. Brinkhurst. 1971. "Interactions Between Some Tubificid Oligochaetes and Bacteria Found in the Sediments of Toronto Harbour, Ontario." J. Fish. Res. Bd. Canada. 28:335341.

Weber, J.H., K. Reisinger, and M. Stoeppler. 1985. "Methylation of Mercury (II) by Fulvic Acid." Environmental Technology Letters 6:203-208.

Weber, W.J., Jr., T.C. Voice, M. Pirbazari, G.E. Hunt, and D.M. Ulanoff. 1983. Sorption of Hydrophobic Compounds by Sediments, Soils and Suspended Solids-II. Sorbent Evaluation Studies." Water Research 17:1443-1452.

Welsh, B.L. 1975. "The Role of Grass Shrimp Palaemonetes pugio in a Tidal Marsh Ecosystem." Ecol. 56:513-530. 
Wentworth, C.K. 1922. "A Scale of Grade and Class Terms for Clastic Sediments." Journal of Geology 30:377-392.

Westall, J.C. 1987. "Adsorption Mechanisms in Aquatic Surface Chemistry." In Aquatic Surface Chemistry. Chemical Processes at the Particle-Water Interface, ed. W. Stumm, pp. 3-32. John Wiley and Sons, New York.

Westall, J.C., C. Leuenberger, and R.P. Schwarzenbach. 1985. "Influence of pH and Ionic Strength on the Aqueous-Nonaqueous Distribution of Chlorinated Phenols." Environmental Science and Technology 19:193-198.

Wetzel, R.L. 1977. "Carbon Resources of a Benthic Salt Marsh Invertebrate, Nassarius obsoletus." In Estuarine Proceeses, Volume 2, ed. M.L. Wiley, pp. 293-308. Academic Press, New York.

Whitehouse, B.G. 1984. "The Effects of Temperature and Salinity on the Aqueous Solubility of Polynuclear Aromatic Hydrocarbons." Marine Chemistry 14: 319-332.

Whitenouse, B.G. 1985a. "The Effects of Dissolved Organic Matter on the Aqueous Partitioning of Polynuclear Aromatic Hydrocarbons." Estuarine, Coastal and Shelf Science 20:393-402.

Whitehouse, B.G. 1985b. "Observation of Abnormal Solubility Behavior of Aromatic Hydrocarbons in Seawater." Marine Chemistry 17:277-284.

Whittle, K.J., J. Murray, P.R. Mackie, R. Hardy, and J. Farmer. 1977. "Fate of Hydrocarbons in Fish." In Petroleum Hydrocarbons in the Marine Environment. Cons. Intern. Explor. Mer. Vol. 171, ed. A.D. McIntyre and K.J. Whittle, pp.139-142. Charlottenlund Slot, Denmark.

Whitlatch, R.B. 1974. "Food-Resource Partitioning in the Deposit Feeding Polychaete Pectinaria gouldii." Biol. Bull. 147:227-235.

Whitlatch, R.B. 1980. "Foraging in the Deposit-Feeding Polychaete Pectinaria gouldii: Testing the Energy-Optimization Hypothesis." Am. Zool. 20:920.

Wijayaratne, R.D. and J.C. Means. 1984. "Affinity of Hydrophobic Pollutants for Natural Estuarine Colloids in Aquatic Environments." Environmental Science and Technology 18:121-123.

Wilkie, I.C. 1984. "Variable Tensility in Echinoderm Collagenous Tissues: A Review:" Mar. Behav. Physiol. 11:1-34.

Willis, J.N. and W.G. Sunda. 1984. "Relative Contributions of Food and Water in the Accumulation of Zinc by Two Species of Marine Fish." Mar. Biol. 80:273-279.

Wiltse, W.I. 1980. "Effects of Polinices duplicatus (Gastropoda: Naticidae) on Infaunal Community Structure at Barnstable Harbor, Massachusetts, USA. Mar. Biol. 56:301-310. 
Windom, H.L., K.T. Tenore, and D.L. Rice. 1982. "Metal Accumulation by the Polychaete Capitella capitata: Influences of Metal Content and Nutritional Quality of Detritus." Can. J. Fish. Aquat. Sci. 39:191-196.

Windom, H., G. Wallace, R. Smith, N. Dudek, M. Maeda, R. Dulmage, and F. Sorti. 1983. "Behavior of Copper in Southeastern United States Estuaries." Marine Chemistry 12:183-193.

Winfrey, M.R. and D.M. Ward. 1983. "Substrates for Sulfate Reduction and Methane Production in Intertidal Sediments." Applied Environmental Microbiology, 3/83:193-199.

Wolfe, D.A., Thayer, G.W. and S.M. Adams. 1976. "Manganese, Iron, Copper and Zinc in an Eelgrass (Zostera marina L.) Community." In Radioecology and Energy Resources, Proc. Fourth Ecological Soc. Amer., Spec. Publ. 1:256-270.

Wood, A.W., R.L. Chang, W. Levin, D.E. Ryan, P.E. Thomas, R.E. Lehr, S. Kumar, M. Schaefer-Ridder, U. Englehardt, H. Yagik, D.M. Jerina, and A.H. Conney. 1983. "Mutagenicity of Diol-Epoxides and Tetrahydroepoxides of Benz(a)acridine and Benz(c)acridine in Bacteria and in Mammalian Cells." Cancer Res. 43:1656-1669.

Wood, E.J., Odum, W.E. and J.C. Zieman. 1969. "Influence of Seagrasses on the Productivity of Coastal Lagoons." In Coastal Lagoons, eds. Ayala Castanares, A. and F.B. Phleger, pp. 495-902. Universidad Nacional Autonoma de Mexico, Ciudad Universitaria.

Wood, J.M. 1987. "Biological Processes Involved in the Cycling of Elements Between Soil or Sediments and the Aqueous Environment." Hydrobiologia 149:31-42.

Wood, L. 1968. "Physiological and Ecological Aspects of Prey Selection by the Marine Gastropod Urosalpinx cinerea (Prosobranchia: Muricidae)." Malacologia. 6:267-320.

Wood, L.W., G.-Y. Rhee, B. Bush, and E. Barnard. 1987. "Sediment Desorption of PCB Congeners and Their Bio-Uptake by Dipteran Larvae." Water Research 21:875-884.

Woodin, S.A: 1974. "Polychaete Abundance Patterns in a Marine Soft-Sediment Environment: the Importance of Biological Interactions." Ecol. Monogr. 44:171-187.

Woodley, T.H., M.W. Brown, S.D. Kraus, and D.E. Gaskin. 1991. "Organochlorine Levels in North Atlantic Right Whale (Eubalaena gracialis) Blubber." Arch. Environ. Contam. Toxicol. 21:141-145.

Word, J.Q. 1980. "Classification of Benthic Invertebrates Inot Infaunal Trophic Index Feeding Groups." In Southern California Coastal Water Research Project. Annual Report for 1979, ed. W.Bascom, pp. 103-121. SCCWRP, El Segundo, California.

Word, J. Q., J. A. Ward, L. M. Franklin, V. I. Cullinan, S. L. Kiesser. 1987. Evaluation of the Equilibrium Partitioning Theory for Estimating the toxicity of the Nonpolar Organic Compound DDT to the Sediment Dwelling Amphipod Rhepoxynius abronius. Prepared for the Criteria and Standards Division of the U.S. Environmental Protection Agency, Washington, D.C., by Battelle, Pacific 
Northwest Laboratory, Richland, Washington, Submitted by Battelle, Washington Environmental Program Office, Washington D.C.

Worobec, M.N. 1984. "Field Estimates of the Daily Ration of Winter Flounder, Pseudopleuronectes americanus (Walbaum), in a Southern New England Salt Pond."

J. Exp. Mar. Biol. Ecol. 77:183-196.

Wrench, J., S.W. Fowler, and M.Y. Ünlü. 1979. "Arsenic Metabolism in a Marine Food Chain." Mar. Pollut. Bull. 10:18-20.

Wrench, J.J. and C.I. Measures. 1982. "Temporal Variations in Dissolved Selenium in a Coastal Ecosystem." Nature 299:431-433.

Wright, D.A. 1977. "The Effect of Calcium on Cadmium Uptake by the Shore Crab Carcinus maenus." J. Exper. Biol. 67:173-173.

Wright, S.H. 1982. "A Nutritional Role for Amino Acid Transport in Filter-Feeding Marine Invertebrates." Amer. Zool. 22:621-634.

Wu, S.-C. and P.M. Gschwend. 1986. Sorption Kinetics of Hydrophobic Organic Compounds to Natural Sediments and Soils." Environmental Science and Technology 20:717-725.

Wyman, K.d. and H.B. O'Connors, Jr. 1980. "Implications of Short-Term PCB Uptake by Small Estuarine Copepods (genus Acartia) From PCB-Contaminated Water, Inorganic Sediments and Phytoplankton." Estuar. Cstl. Mar. Sci. 11:121-131.

Xie, T.M. and D. Dyrssen. 1984. "Simultaneous Determination of Partition Coefficients and Acidity Constants of Chlorinated Phenols and Guaiacols by Gas Chromatography." Anal. Chim. Acta 160:2130 .

Yingst, J.Y. 1976. "The Utilization of Organic Matter in Shallow Marine Sediments by an Epibenthic Deposit-Feeding Holothurian." J. Exp. Mar. Biol. Ecol. 23:55-69.

Yonge, C.M. 1928. "Feeding Mechanisms in Invertebrates." Biol. Rev. 3:21-76.

Yonge, C.M. 1949. The Sea Shore. Collins, London.

Young, D.K., W.H. Jahn, M.D. Richardson, and A.W. Lohanick. 1985. "Photographis of Deep-Sea Lebensspuren: A Comparison of Sedimentary Provinces in the Venezuela Basin, Caribbean Sea." Mar. Geol. 68:269-301.

Young, D.K. and D.C. Rhoads. 1971. "Animal-Sediment Relations in Cape Cod Bay, Massachusetts. 1. A Transect Study." Mar. Biol. 11:242-254.

Young, D.R. and A.J. Mearns. 1979. "Pollutant Flow Through Food Webs." In Coastal Water Research Project. Annual Report for the Year. 1978, ed. W. Bascom, pp. 185-202. Southern California Coastal Water Research Project, El Segundo, California. 
Young, D.R., A.J. Mearns, T.-K. Jan, T.C. Heesen, M.D. Moore, R.P. Eganhouse, G.P. Hershelman, and R.W. Gossett. 1980. "Trophic Structure and Pollutant Concentrations in Marine Ecosystems of Southern California." CalCOFI Rep. 21:197-206.

Young, J.S. and G. Roesijadi. 1983. "Reparatory Adaptation to Copper-Induced Injury and Occurrence of a Copper-Binding Protein in the Polychaete, Eudistylis vancouveri." Mar. Poll. Bull. 14:30-32.

Young, M.L. 1975. "The Transfer of ${ }^{65} \mathrm{Zn}$ and ${ }^{59} \mathrm{Fe}$ Along a Fucus serratus (L.) - Littorina obtusata (L.) Food Chain." J. Mar. Biol. Assoc. U.K. 55:583-610.

Young, M.L. 1977. "The Roles of Food and Direct Uptake From Water in the Accumulation of Zinc and Iron in the Tissues of the Dogwhelk, Nucella lapillus (L.)."

J. Exper. Mar. Biol. Ecol. 30:315-325.

Youngblood, W.W. and M. Blumer. 1975. "Polycyclic Aromatic Hydrocarbons in the Environment: Homologous Series in Soils and Recent Marine Sediments." Geochimica et Cosmochimica Acta 39:1303-1314.

Zaroogian, G.E., J.F., and M. Johnson. 1985. "Estimation of Bioconcentration in Marine Species Using Structure-Activity Models." Environ. Toxicol. Chem. 4:3-12.

Zeitzschel, B. 1980. "Sediment-Water Interactions in Nutrient Dynamics." In Marine Benthic Dynamics, eds. K.R. Tenore and B.C. Coull, pp. 195-218. University of South Carolina Press, Columbia, South Carolina.

Zhang, G.H., M.H. Hu, Y.P. Huang, and P.J. Harrison. 1990. "Se Uptake and Accumulation in Marine Phytoplankton and Transfer of Se to the Clam Puditapes philippnarum." Mar. Environ. Res. 30:179-190.

Zieman, J.C. 1975. "Tropical Seagrass Ecosystems and Pollution." In Tropical Marine Pollutions, eds. E.J.F. Wood and R.C. Johannes. Elsevier Oceanogr. Ser., Vol. 12:63-74.

Zierath, D.L., J.J. Hassett, W.L. Banwart, S.G. Wood, and J.C. Means. 1980. "Sorption of Benzidine by Sediments and Soils." Soil Science 129:277-281.

Zirino, A. and S. Yamamoto. 1972. "A pH-Dependent Model for the Chemical Speciation of Copper, Zinc, Cadmium, and Lead in Seawater." Limnology and Oceanography 17:66 I-671.

Zitko, V. 1974. "Uptake of Chlorinated Paraffins and PCB from Suspended Solids and Food by Juvenile Atlantic Salmon." Bull. Environ. Contam. Toxicol. 12:406-412.

Zitko, V. and O. Hutzinger. 1976. "Uptake of Chloro- and Bromo-Biphenyls and Hexachloro- and Hexabromo-Benzenes by Fish." Bull. Environ. Contam. Toxicol. 16:665-673. 
Zobell, C.E. 1938. "Studies on the Bacterial Flora of Marine Bottom Sediments." Journal of Sedimentary Petrology 8:10-18.

Zobell, C.E. and C.B. Feltham. 1938. "Bacteria as Food for Certain Marine Invertebrates." $J$. Mar. Res. 1:312-327.

Zuehlke, R.W. and D.R. Kester. 1983. "Copper Speciation in Marine Waters." In Trace Metals in Sea Water, eds. C.S. Wong, E. Boyle, K.W. Bruland, J.D. Burton, and E.D. Goldberg, pp. 773788. Plenum Press, New York. 


\section{DISTRIBUTION}

No. of

Copies

\section{OFFSITE}

2 DOE/Office of Scientific and Technical Information

25 Mr. W. Lawrence Pugh

National Ocean Pollution Program Office

NOAA

1825 Connecticut Avenue, NW

Room 518

Washington, DC 20235

$5 \quad$ Betsy Brown

Department of Biology

Colby College

Mayflower Hill Drive

Waterville, ME 04901

5 Jerry Neff

Battelle Ocean Sciences Laboratory

397 Washington Street

P.O. Box AH

Duxbury, MA 02332-0601
No. of

Copies

ONSITE

1 DOE Richland Operations Office

P. J. Kruger

14 Pacific Northwest Laboratory

E. A. Crecelius

R. M. Ecker

M. R. Finney

R. M. Thom

J. A. Trelstad (2)

J. Q. Word

Publishing Coordation

Technical Report Files (5)

Routing

M. J. Graham

P. M. Irving

R. L. Skaggs

C. S. Sloane

P. C. Hays

Distr. 1 